The Principle of Loyalty in EU Law

Marcus Klamert

\title{
EUROP:
}


This is an open access version of the publication distributed under the terms of the Creative Commons Attribution-NonCommercial-NoDerivs licence (http://creativecommons.org/licenses/by-nc-nd/3.0/), which permits non-commercial reproduction and distribution of the work, in any medium, provided the original work is not altered or transformed in any way, and that the work is properly cited. For commercial re-use, please contact academic.permissions@oup.com 


\title{
OXFORD STUDIES IN EUROPEAN LAW
}

Series Editors

PAUL CRAIG

Professor of English Law at St John's College, Oxford

\author{
GRÁINNE DE BÚRCA
}

Professor of Law at New York University School of Law

\section{The Principle of Loyalty in EU Law}

This is an open access version of the publication distributed under the terms of the Creative Commons Attribution-NonCommercial-NoDerivs licence (http://creativecommons.org/licenses/by-nc-nd/3.0/), which permits non-commercial reproduction and distribution of the work, in any medium, provided the original work is not altered or transformed in any way, and that the work is properly cited. For commercial re-use, please 


\title{
OXFORD STUDIES IN EUROPEAN LAW
}

\author{
Series Editors \\ Paul Craig, Professor of English Law at St John's College, Oxford and \\ Gráinne de Búrca, Professor of Law at New York University School of Law
}

The aim of this series is to publish important and original research on EU law. The focus is on scholarly monographs, with a particular emphasis on those which are interdisciplinary in nature. Edited collections of essays will also be included where they are appropriate. The series is wide in scope and aims to cover studies of particular areas of substantive and of institutional law, historical works, theoretical studies, and analyses of current debates, as well as questions of perennial interest such as the relationship between national and EU law and the novel forms of governance emerging in and beyond Europe. The fact that many of the works are interdisciplinary will make the series of interest to all those concerned with the governance and operation of the EU.

\section{OTHER TITLES IN THIS SERIES}

Constitutional Pluralism in the EU Klemen Jaklic

EU Consumer Law and Human Rights Iris Benöhr

The Principle of Mutual Recognition in EU Law Christine Janssens

The Coherence of EU Free Movement Law

Constitutional Responsibility and the Court of Justice Niamh Nic Shuibhne

European Law and New Health Technologies Edited by Mark L Flear, Anne-Maree Farrell, Tamara K Hervey, and Thérèse Murphy

The Legal Effect of EU Agreements Mario Mendez

The Enforcement of EU Law

The Role of the European Commission Stine Andersen

European Agencies

Law and Practice of Accountability Madalina Busuioc

The Foundations of European Union Competition Law

The Objective and Principles of Article 102

Renato Nazzini

The Emergence of EU Contract Law

Exploring Europeanization Lucinda Miller

Participation in EU Rule-making A Rights-Based Approach Joana Mendes
Regulating Cartels in Europe Second Edition

Christopher Harding, Julian Joshua

Religion and the Public Order of the European Union Ronan McCrea

Governing Social Inclusion

Europeanization through Policy Coordination Kenneth A. Armstrong

Judicial Control in the European Union

Reforming Jurisdiction in the Intergovernmental Pillars Alicia Hinarejos

EU Counter-Terrorist Policies and Fundamental Rights

The Case of Individual Sanctions Christina Eckes

From Dual to Cooperative Federalism The Changing Structure of European Law Robert Schütze

Conflicts of Rights in the European Union A Theory of Supranational Adjudication Aida Torres Pérez

Judicial Deliberations

A Comparative Analysis of Transparency and Legitimacy

Mitchel de S-O-l'E Lasser

Racism and Equality in the European Union Mark Bell

Constitutional Principles of EU External Relations Geert De Baere

This is an open access version of the publication distributed under the terms of the Creative Commons Attribution-NonCommercial-NoDerivs licence (http://creativecommons.org/licenses/by-nc-nd/3.0/), which permits non-commercial reproduction and distribution of the work, in any medium, provided the original work is not altered or transformed in any way, and that the work is properly cited. For commercial re-use, please contact academic.permissions@oup.com 


\title{
The Principle of Loyalty in EU Law
}

\author{
MARCUS KLAMERT
}

\section{OXFORD \\ UNIVERSITY PRESS}

This is an open access version of the publication distributed under the terms of the Creative Commons Attribution-NonCommercial-NoDerivs licence (http://creativecommons.org/licenses/by-nc-nd/3.0/), which permits non-commercial reproduction and distribution of the work, in any medium, provided the original work is not altered or transformed in any way, and that the work is properly cited. For commercial re-use, please 


\section{OXFORD \\ UNIVERSITY PRESS}

Great Clarendon Street, Oxford, OX2 6DP,

United Kingdom

Oxford University Press is a department of the University of Oxford.

It furthers the University's objective of excellence in research, scholarship, and education by publishing worldwide. Oxford is a registered trade mark of

Oxford University Press in the UK and in certain other countries

(C) M Klamert 2014

The moral rights of the author have been asserted

First Edition published in 2014

Impression: 1

All rights reserved. No part of this publication may be reproduced, stored in a retrieval system, or transmitted, in any form or by any means, without the prior permission in writing of Oxford University Press, or as expressly permitted

by law, by licence or under terms agreed with the appropriate reprographics rights organization. Enquiries concerning reproduction outside the scope of the above should be sent to the Rights Department, Oxford University Press, at the address above

You must not circulate this work in any other form and you must impose this same condition on any acquirer

Crown copyright material is reproduced under Class Licence

Number C01P0000148 with the permission of OPSI and the Queen's Printer for Scotland

Published in the United States of America by Oxford University Press 198 Madison Avenue, New York, NY 10016, United States of America

British Library Cataloguing in Publication Data

Data available

Library of Congress Control Number: 2013949379

ISBN 978-0-19-968312-3

Printed and bound in Great Britain by CPI Group (UK) Ltd, Croydon, CR0 4YY

Links to third party websites are provided by Oxford in good faith and for information only. Oxford disclaims any responsibility for the materials contained in any third party website referenced in this work.

This is an open access version of the publication distributed under the terms of the Creative Commons Attribution-NonCommercial-NoDerivs licence (http://creativecommons.org/licenses/by-nc-nd/3.0/), which permits non-commercial reproduction and distribution of the work, in any medium, provided the original work is not altered or transformed in any way, and that the work is properly cited. For commercial re-use, please contact academic.permissions@oup.com 


\section{Series Editors' Preface}

Marcus Klamert's book on 'The Principle of Loyalty in EU Law' is a welcome addition to this series. It is an important subject, and the book is divided into four parts.

In the first part, the author considers the way in which Article 4(3) TEU was drafted and its relevance for the themes in this book. We are introduced to what the author regards as specifications of loyalty, such as loyalty and conflict resolution, and loyalty and duties of abstention. We are introduced also to the addressees of the loyalty obligation, with discussion of horizontal loyalty, vertical loyalty and reverse vertical loyalty, the latter connoting obligations flowing from the EU to the Member States, rather than vice-versa. Klamert considers the relationship between loyalty and other doctrinal concepts such as good faith and pacta sunt servanda, as well as the federal dimension to fidelity, with comparative insights drawn from US, Canadian, and Australian law, and from a number of continental legal systems, such as Belgium, Austria and Germany. There is analysis of the extent to which the concept of loyalty can be said to have informed the CJEU's case law in seminal decisions such as Costa, ERTA and Francovich.

In the second part consideration is given to the way in which loyalty fosters the cohesion of EU law. Klamert argues that loyalty informs, underpins or shapes legal concepts developed by the EU courts in order to ensure that EU law can function in a cohesive manner. This leads to examination of supremacy, pre-emption, and the principle of effectiveness, although Klamert recognizes the diversity of meaning accorded to the concept of effectiveness in the CJEU's case law.

The focus in part three of the book shifts to the role played by loyalty in relation to cooperation in EU law. This provides the setting for examination of the rules concerning delimitation of competence between the EU and the Member States, and the role played by loyalty in the interpretation and application of the respective fields in which the EU and the Member States can exercise power. There is an overview of the distribution of competence in the post-Lisbon world, followed by analysis of the way in which loyalty impacts on the field of non-exclusive competence. The discussion includes consideration of the way in which loyalty plays a role in relation to certain kinds of secondary EU legislation.

The final part of the book deals with loyalty and the construction of the EU. The objective is to draw together certain more general conceptual issues that have occupied the courts and academic commentary, and to reveal the ways in which loyalty plays a role in relation to their development and content. This includes exploration of cooperation/conflict in the EU, and analysis of the extent to which loyalty can be seen as an independent source of obligation and as a general principle of law.

This is a thought-provoking book that will be of interest to all those who study EU law.

Paul Craig and Gráinne de Búrca

This is an open access version of the publication distributed under the terms of the Creative Commons Attribution-NonCommercial-NoDerivs licence (http://creativecommons.org/licenses/by-nc-nd/3.0/), which permits non-commercial reproduction and distribution of the work, in any medium, provided the original work is not altered or transformed in any way, and that the work is properly cited. For commercial re-use, please contact academic.permissions@oup.com 
This is an open access version of the publication distributed under the terms of the Creative Commons Attribution-NonCommercial-NoDerivs licence (http://creativecommons.org/licenses/by-nc-nd/3.0/), which permits non-commercial reproduction and distribution of the work, in any medium, provided the original work is not altered or transformed in any way, and that the work is properly cited. For commercial re-use, please contact academic.permissions@oup.com 


\section{Preface}

The purpose of this book is to offer a thorough discussion of the principle of loyalty in European Union law. In spite of its continued provision in primary law, in wording that has remained almost unchanged since the Rome Treaties, there is no comprehensive English language study on loyalty to date. While also addressing the pertinence of loyalty in the Common Foreign Security Policy, the focus of this book is on the other areas of Union law. 'Hard', confrontational rules on conflict resolution such as supremacy, pre-emption and duties of abstention are discussed alongside 'softer', more cooperative duties of conflict prevention such as duties of consideration and coordination.

This book introduces a novel way of classifying the very diverse roles loyalty plays in the European Union. It will distinguish between the effects loyalty prescribes for interlocking the legal orders of the Member States with Union law (Loyalty and the Cohesion of European Union law), its application for preventing and resolving conflicts (Loyalty and Cooperation in the European Union), and its constitutional aspects (Loyalty and the Construction of the European Union). Cohesion deals with loyalty as the rationale for the intervention of Union law in the legal orders of the Member States by principles such as supremacy, effectiveness, direct effect, and the Union interest. The Part on Cooperation is concerned, in particular, with the delimitation of the powers between the EU institutions and the Member States in terms of the distribution and the exercise of competence in matters such as supporting competences and mixed agreements. Finally, the Part on Construction, among other things, deals with the role of loyalty in shaping the EU constitution and with the question of whether loyalty has been neglected in the prevailing narratives on this process.

Each of these parts of the book, as well as the three introductory chapters, addresses important and yet unresolved questions pertaining to loyalty. Thus, its relation to other central concepts of Union law, such as solidarity, pre-emption, the Union interest, institutional balance, and the unity of international representation, is explored. The limits to the application of loyalty are discussed by introducing the concept of amplification, as well as its position among general principles of Union law and its controversial role in what is perceived as judicial lawmaking. This book also suggests several ways to systematize the manifold obligations grounded on loyalty in Union law, distinguishing duties of consideration from duties of coordination and duties of abstention, as well as the application of loyalty as a legal principle, a rule of interpretation, a supporting legal basis, or a separate source of obligations.

This is a book that I have thoroughly enjoyed writing. It allowed me to reflect on aspects of EU law I had so far not yet written about, and at the same time revisit and re-explore issues that have preoccupied me during the past years. When I started work on this study, loyalty in Union law had only been the subject of limited scholarly attention. While this has changed over recent years, especially in the literature on external relations, I believe that this book will contribute both to many general issues in EU law as well as to some legal issues particular to Union loyalty.

I am grateful to a number of people for different reasons. I sincerely have to thank Stefan Griller for his unfaltering support, inspiring ideas, comments, and the ability to lay a finger on every weakness of argument. Christoph Grabenwarter has been a supportive, resourceful and encouraging protagonist in bringing this book to completion. Erich Vranes has been a truly inspiring colleague in his ambitions and his work ethic. I want to express my gratitude to Marise Cremona for hosting me at the Law Department of

This is an open access version of the publication distributed under the terms of the Creative Commons Attribution-NonCommercial-NoDerivs licence (http://creativecommons.org/licenses/by-nc-nd/3.0/), which permits non-commercial reproduction and distribution of the work, in any medium, provided the original work is not altered or transformed in any way, and that the work is properly cited. For commercial re-use, please contact academic.permissions@oup.com 
the European University Institute at a crucial phase of the work on this book, for her inspiring courses that I have been allowed to attend, and the encouragement to pursue my chosen topic. I also want to thank the Institute of European and Comparative Law at the University of Oxford for hosting me during another crucial period towards the end of my work on this book. Nicholas Aroney, Peter Thalmann, and Andreas Orator have commented on different parts of the manuscript. I would also like to express my gratitude to my former colleagues at the WU for providing a stimulating and friendly environment for conducting my research throughout the last few years.

Last but certainly not least, I am grateful to Paul Craig and Gráinne de Búrca for having included this book in their series, and to Oxford University Press for being supportive all the way.

Vienna and Brussels

August 2013

This is an open access version of the publication distributed under the terms of the Creative Commons Attribution-NonCommercial-NoDerivs licence (http://creativecommons.org/licenses/by-nc-nd/3.0/), which permits non-commercial reproduction and distribution of the work, in any medium, provided the original work is not altered or transformed in any way, and that the work is properly cited. For commercial re-use, please contact academic.permissions@oup.com 


\section{Contents}

Table of Cases xiii

Table of Instruments $\quad$ xxi

Introduction $\quad 1$

1. The Background 1

2. Caveats as Regards Perspective and Methodology 2

3. The System Applied in this Study 4

\section{INTRODUCING LOYALTY}

1. Loyalty in the EU Treaties 9

1. Introduction 9

2. Loyalty before the Lisbon Treaty 10

3. The Lisbon Treaty Amendments 11

4. Specifications of Article 4 (3) TEU in the Treaties 13

5. Loyalty and National Identities 19

6. The Vectors of the Application of Loyalty 22

7. Conclusion 29

2. Loyalty in Context 31

1. Introduction 31

2. Some Remarks on Terminology 33

3. Distinguishing the Union Principle of Solidarity 35

4. The Relation with the Principles of Good Faith
and pacta sunt servanda

5. Federal Fidelity in the European Union 47

6. Conclusion 61

3. Loyalty and the Constitutionalization of EU Law 63

1. Introduction 63

2. Loyalty in the Literature 64

3. The Foundational Case Law Re-assessed 71

4. The Way Loyalty Has Been Used by the Court in the
Foundational Case Law

5. Conclusion 83

Conclusion of the Introductory Part 84

II. THE COHESION OF EUROPEAN UNION LAW

Introduction

4. A Primer on the Structure of Union Law 87

1. Introduction 87

2. The Unity of National Law and Union Law 88

This is an open access version of the publication distributed under the terms of the Creative Commons Attribution-NonCommercial-NoDerivs licence (http://creativecommons.org/licenses/by-nc-nd/3.0/), which permits non-commercial reproduction and distribution of the work, in any medium, provided the original work is not altered or transformed in any way, and that the work is properly cited. For commercial re-use, please contact academic.permissions@oup.com 
3. The (Inner) Unity of the Union Legal Order 92

4. Conclusion 99

5. Supremacy, Pre-emption, and the Union Interest 101

$\begin{array}{ll}\text { 1. Introduction } & 101\end{array}$

2. Some Thoughts on the Nature of Supremacy 101

3. Duties Unrelated to Supremacy Flowing from Secondary Law 105

4. Duties Unrelated to Supremacy Flowing from Preparatory Legal Acts

5. Do We Need a Concept of Pre-emption in Union Law? 115

6. The Union Interest 122

$\begin{array}{ll}\text { 7. Conclusion } & 123\end{array}$

6. Effectiveness, Judicial Protection, and Loyalty 125

$\begin{array}{ll}\text { 1. Introduction } & 125\end{array}$

2. The Principle of Effectiveness and the Enforcement $\begin{array}{ll}\text { of Individual Rights } & 126\end{array}$

3. Effectiveness and Compliance by the Member States 131

4. Effectiveness, Effective Judicial Protection, and Indirect Effect 133

5. Effectiveness, Effective Judicial Protection, and $\begin{array}{ll}\text { Duties of Abstention } & 136\end{array}$

6. Conclusion 137

Conclusion of the Part on Cohesion 139

\section{COOPERATION IN THE EUROPEAN UNION}

Introduction

7. A Primer on Union Competences 143

1. Codification in the Lisbon Treaty 143

2. Three Categories of Competences 144

3. The General System of External Powers of the Union
After Lisbon

4. Exclusive Competences 147

5. Non-exclusive Competences 157

6. Conclusion 159

8. Loyalty and Non-exclusive Competences 161

1. Introduction 161

2. Loyalty and 'Regular' Shared Competences 161

3. Loyalty and 'Irregular' Shared Competences 163

4. Loyalty and Supporting Competences 167

$\begin{array}{ll}\text { 5. Conclusion } & 171\end{array}$

9. Manifestations of Loyalty in Secondary Law 173

$\begin{array}{ll}\text { 1. Introduction } & 173\end{array}$

2. Non-supervisory Notification Obligations 174

3. Supervisory Notification Obligations on Technical Standards 175

This is an open access version of the publication distributed under the terms of the Creative Commons Attribution-NonCommercial-NoDerivs licence (http://creativecommons.org/licenses/by-nc-nd/3.0/), which permits non-commercial reproduction and distribution of the work, in any medium, provided the original work is not altered or transformed in any way, and that the work is properly cited. For commercial re-use, please contact academic.permissions@oup.com 
4. Hybrid: The Services Directive 177

5. Prohibitions of Frustration and Transitional Periods 178

6. 'Managed' Preclusion of Member States 179

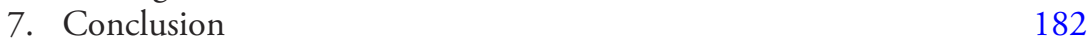

10. Loyalty and Mixed Agreements 183

1. Introduction 183

2. Competence and Mixed Agreements 185

3. The General Application of Loyalty to Mixed Agreements 188

4. Loyalty and the Requirement of Unity 190

5. Loyalty and the Conclusion of Mixed Agreements 192

6. Loyalty and Declarations of Competence 195

7. Loyalty and Common Positions 197

8. Loyalty and the Ratification of Mixed Agreements 202

9. Loyalty and the Interpretation and Implementation of
Mixed Agreements

10. Conclusion 206

Conclusion of the Part on Cooperation 207

\section{THE CONSTRUCTION OF THE EUROPEAN UNION}

Introduction

11. A Primer on Cooperation and Constitutional Conflict in the European Union

1. Introduction

2. Preliminary References and Other Interactions Between

Courts in the EU

3. Loyalty, Institutional Balance, and Conflicts of Legal Basis

4. The Relationship Between the ECJ and the Union Legislature

5. Constitutional Conflicts Between EU Law and Member State Legal Regimes

6. Conclusion

12. On the Nature of Loyalty 233

1. Introduction 233

2. Loyalty as an Independent Source of Obligations 234

3. Loyalty as a General Principle of Union Law 241

4. Conclusion 249

5. Interim Summary of the Roles of Loyalty in EU Law 250

13. Deconstructing Loyalty $\quad 252$

1. Introduction 252

2. Evaluation Criteria for the Reasoning of the Court 253

3. Loyalty, Effectiveness, and effet utile 261

4. Loyalty and Self-referential Reasoning 267

5. Conclusion 273

This is an open access version of the publication distributed under the terms of the Creative Commons Attribution-NonCommercial-NoDerivs licence (http://creativecommons.org/licenses/by-nc-nd/3.0/), which permits non-commercial reproduction and distribution of the work, in any medium, provided the original work is not altered or transformed in any way, and that the work is properly cited. For commercial re-use, please contact academic.permissions@oup.com 
14. Amplification and the Limits of Loyalty

1. Introduction

2. The Amplification of Provisions of Primary and Secondary Law

3. Loyalty, the Prohibition of Discrimination, and Inter se Treaties

4. The Amplification of Internal Union Rules

5. The Hurd Case

6. The Limits to Amplification

Conclusion of the Part on Construction 


\section{Table of Cases}

\section{WTO APPELLATE BODY}

United States-Import Prohibtion of Certain Shrimp and Shrimp Products

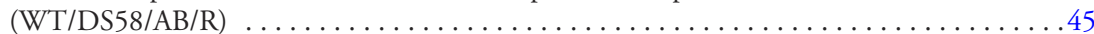

United States-Standards for Reformulated and Conventional Gasoline (WT/DS2/AB/R) . . . .45

\section{GERMAN CONSTITUTIONAL COURT}

1.Rundfunkentscheidung (Case 2 BvG 1/60 und 2 BvG 2/60) [1961] BVerfGE 12, 205 . . . . . 56 Alcan (Case 2 BvR 1210/98) [2000], Europäische Zeitschrift für Wirtschaftsrecht,

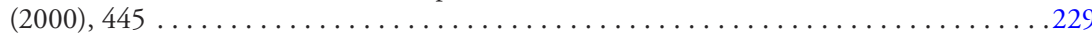

Antiterrordateigesetz (Case 1 BvR 1215/07), Judgment of 24 April 2013 . . . . . . . . . . . 230

Bananenmarktordnung (Case 2 BvL 1/97) [2000] BVerfGE 102, $147 \ldots \ldots \ldots \ldots \ldots \ldots .232$

Besoldungsgesetz von Nordrhein-Westfalen (Case 2 BvG 1/54) [1954] BVerfGE 4, 115 . . . . . . 56

Besoldungsvereinheitlichung (Case 2 BvF 1/71) [1972] BVerfGE 34, $9 \ldots \ldots \ldots \ldots \ldots \ldots . \ldots 7$

Europäischer Haftbefehl (Case 2 BvR 1826/09) [2009], <http:// www.bverfg.de/

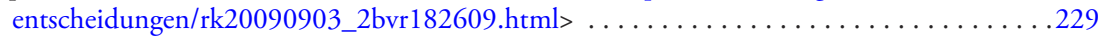

Finanzausgleichsgesetz (Case 1 BvF 2/51) [1952] BVerfGE 1, $117 \ldots \ldots \ldots \ldots \ldots \ldots \ldots$. . . . . 56

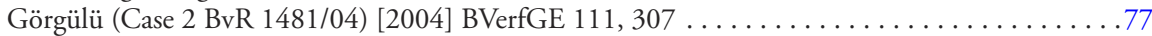

Honeywell (Case 2 BvR 2661/06) [2010] BVerfGE 126, 286 . . . . . 213-214, 227, 229-230, 257

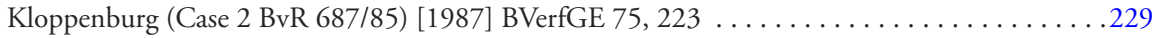

Lisbon Treaty (Case 2 BvE 2/08 et al. ) [2009] BVerfGE 123, 267 . . . 21, 211-212, 229, 231-232

Maastricht Treaty (Case 2 BvR 1877/97 and 2 BvR 50/98) [1998]

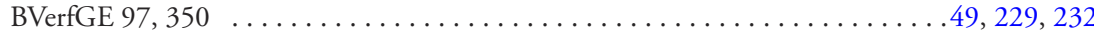

Neugliederung Hessen (Case 2 BvG 2/58, 2 BvE 1/59) [1961] BVerfGE 13, 54 . . . . . . . . . . 57

Niedersächsisches Landesbesoldungsgesetz (Case 2 BvN 1/69) [1974] BVerfGE 36, 342 . . . . . 55

Numerus Clausus II (Case 1 BvF 1/76 et al.) [1977] BVerfGE 43, $291 \ldots \ldots \ldots \ldots \ldots \ldots .51,57$

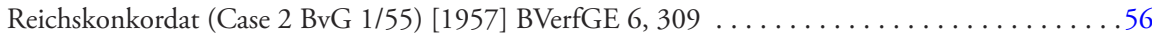

Solange I (Internationale Handelsgesellschaft) (Case 2 BvL 52/71) [1974]

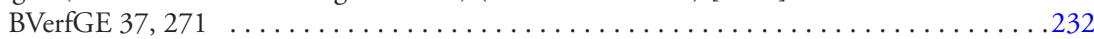

Solange II (Case 2 BvR 197/83) [1986] BVerfGE 73, $339 \ldots \ldots \ldots \ldots \ldots \ldots$. . . . . . . 89, 232

Teilzeitqualifizierung (Case 1 BvR 1036/99) [2001], Europäische Zeitschrift für

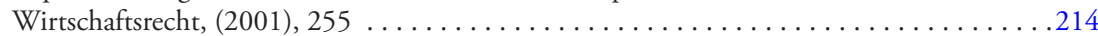

Wasser- und Schiffahrtsverwaltung (Case 2 BvG 1/62) [1967] BVerfGE 21, 312 . . . . . . . . . 57

Weihnachtsgeld (Case 2 BvQ 1/53, 2 BvQ 2/53) [1953] BVerfGE 3, $52 \ldots \ldots \ldots \ldots \ldots \ldots . \ldots 66$

Wohnungsbauförderung (Case 2 BvH 2/52) [1952] BVerfGE 1, $299 \ldots \ldots \ldots \ldots \ldots \ldots . .9,56$

\section{AUSTRIAN CONSTITUTIONAL COURT}

Jagdrecht/Forstrecht (Case G 81/84, 82/84) [1984] VfSlg. $10.292 \ldots \ldots \ldots \ldots \ldots \ldots \ldots . .57-58$

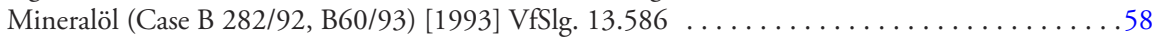

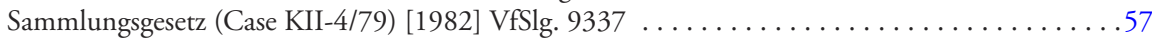

Semmering Basistunnel (Case G 256/98) [1999] VfSlg. $15.552 \ldots \ldots \ldots \ldots \ldots \ldots \ldots \ldots \ldots$

Tierschutz (Case V 17/06) [2007] VfSlg. 18.096 . . . . . . . . . . . . . . . . . . . . 57

Vorratsdatenspeicherung (Case G 47/12-11 et al.), Decision of 28 November $2012 \ldots \ldots \ldots .214$

Wr. Behindertengesetz (Case G 5/80) [1980] VfSlg. $8831 \ldots \ldots \ldots \ldots \ldots \ldots \ldots \ldots \ldots$. . . . . . . . . . . . .

\section{CZECH REPUBLIC CONSTITUTIONAL COURT}

Case Pl. ÚS 29/09 Lisbon II [2009], <http://www.usoud.cz/en/decisions > . . . . . . . . . . . 225

This is an open access version of the publication distributed under the terms of the Creative Commons Attribution-NonCommercial-NoDerivs licence (http://creativecommons.org/licenses/by-nc-nd/3.0/), which permits non-commercial reproduction and distribution of the work, in any medium, provided the original work is not altered or transformed in any way, and that the work is properly cited. For commercial re-use, please contact academic.permissions@oup.com 


\section{CONSTITUTIONAL COURT OF POLAND}

Case K 18/04 [2005], <http://www.trybunal.gov.pl/eng/summaries/documents/K_18_04_

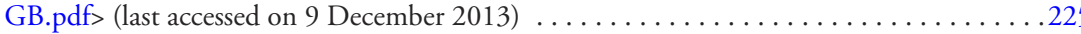

\section{CONSTITUTIONAL COURT OF HUNGARY}

Case 17/2004 (V 25) AB, <http://www.mkab.hu/letoltesek/en_0017_2004.pdf> (last

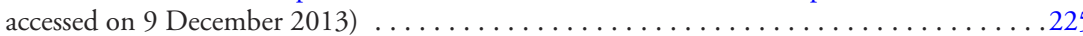

\section{EUROPEAN COURT OF JUSTICE}

A.G.M.-COS.MET Srl v Suomen Valtio and Tarmo Lehtinen (Case C-470/03) [2007] ECR I-2749 . . . . . . . . . . . . . . . . . . . . . . . . . . . . . . . . . . . 279

Accession to GATS (Opinion 1/08) [2009] ECR I-11129 . . . . . . . . . . . . . . . . 190 Adeneler and Others (Case C-212/04) [2006] ECR I-6057 . . . . . . . . . . 24, 92, 104, 108

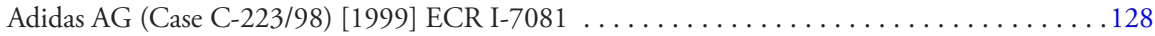
AIMA (Joined cases C-231/00, C-303/00 and C-451/00) [2004] ECR I-2869 . . . . . . . . . 127 Åkerberg Fransson, Judgment of 26 February 2013, (Case C-617/10) nyr . . . . . . . . . . . 230 Albany International (Case C-67/96) [1999] ECR I-5751 . . . . . . . . . . . . . . . 129, 277 Algera v Common Assembly (Joined cases 7/56 and 3-7/57) [1957-58] ECR 39 . . . . . . . . 268 Almelo (Case C-470/04) [2006] ECR I-7409 . . . . . . . . . . . . . . . . . . . . . . . . . 126

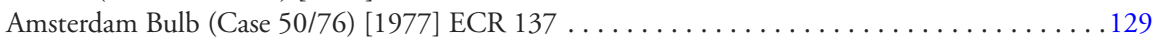
Ariete $($ Case 811/79) [1980] ECR 2545 . . . . . . . . . . . . . . . . . . . . . . . . . . . . . . 245 Athanasios Vatsouras and Josif Koupatantze (Joined cases C-22/08 and C-23/08) [2009] ECR I-4585 . . . . . . . . . . . . . . . . . . . . . . . . . . . . . . . . . 219 Atlanta Fruchthandelsgesellschaft (Case C-465/93) [1995] ECR I-3761 . . . . . . . . . . . . 213 Audiolux SA (Case C-101/08) [2009] ECR I-9823 . . . . . . . . . . . . . . . . . . 126 Azienda Agricola Giorgio, Giovanni e Luciano Visentin and Others (Case C-495/00)

[2004] ECR I-2993 . . . . . . . . . . . . . . . . . . . . . . . . . . . . . 125

Banks \& Co (Case C-390/98) [2001] ECR I-6117 . . . . . . . . . . . . . . . . . 127

Barber v Guardian Royal Exchange (Case C-262/88) [1990] ECR 1889 . . . . . . . . . . . . . 217

BayWa AG (Joined cases 146, 192 and 193/81) [1982] ECR I-1503 . . . . . . . . . . . 129 Belgium v Commission ('Maribel Scheme') (Case C-75/97) [1999] ECR I-3671 . . . . 42, 244-245

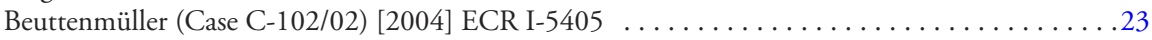
Bidar (Case C-209/03) [2005] ECR I-2119 . . . . . . . . . . . . . . . . . . . 35, 219, 222-224 Bjornekulla Fruktindustrier (Case C-371/02) [2004] ECR 5791 . . . . . . . . . . . . . . . . . 103

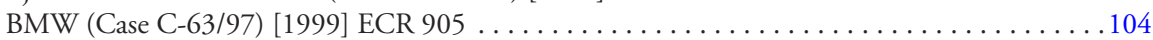
Brasserie du Pêcheur (Joined cases C-46/93 and C-48/93)

[1996] ECR I-1029 . . . . . . . . . . . . . 5, 79, 125, 131, 244-245, 260-261, 265, 271 British United Provident Association Ltd (BUPA) (Case T-289/03) [2008] ECR II-81. . . . . . . . 35

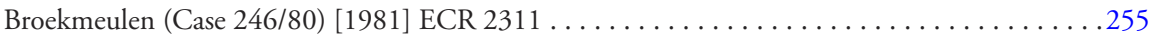

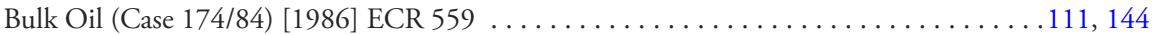
Cartagena Protocol on Biosafety (Opinion 2/00) [2001]

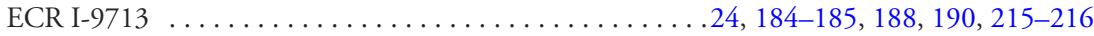

Centro-Com (Case C-124/95) [1997] ECR I-81 . . . . . . . . . . . . . . . . . 146

Christian Dior and Assco Gerüste (Joined cases C-300/98 and C-392/98) [2000]

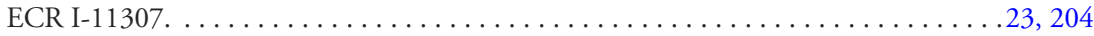

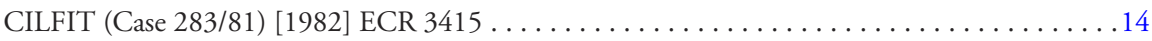

Cipolla (Joined cases C-94/04 and C-202/04) [2006] ECR I-11421 . . . . . . . . . . . . 276

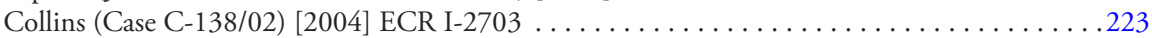

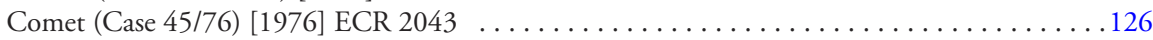

Commission v Austria (Brenner Motorway) (Case C-205/98) [2000] ECR I-7367 . . . . . . . . . 31

This is an open access version of the publication distributed under the terms of the Creative Commons Attribution-NonCommercial-NoDerivs licence (http://creativecommons.org/licenses/by-nc-nd/3.0/), which permits non-commercial reproduction and distribution of the work, in any medium, provided the original work is not altered or transformed in any way, and that the work is properly cited. For commercial re-use, please contact academic.permissions@oup.com 
Commission v Austria and Commission v Sweden (Joined cases C-205/06 and C-249/06) [2009] ECR I-1301 . . . . . . . . . . . . . . . . . . . . . . . .28, 161-163

Commission v Austria Case $(C-424 / 99)$ [2001] ECR I-9285 . . . . . . . . . . . . . . . . . 126

Commission v Belgium (Case 85/85) [1986] ECR 1149. . . . . . . . . . . . . . . . . 292

Commission v Belgium (Case C-6/89) [1990] ECR I-1595 . . . . . . . . . . . . . . . 244

Commission v Belgium (Directive 76/491/EEC) (Case C-374/89)

[1991] ECR I-367 . . . . . . . . . . . . . . . . . . . . . . 31, 237-238

Commission v Belgium (Directive 91/271/EEC) (Case C-236/99) [2000] ECR I-5657 . . . . . 240

Commission v Belgium (Family Allowances) (Case 186/85) [1987] ECR 2029 . . . . . . . . 286-287

Commission v Belgium (Holding) (Case 52/84) [1986] ECR 89 . . . . . . . . . . . . . 239, 245

Commission v Council (Accession of Vietnam to WTO), (Case C-13/07) removed

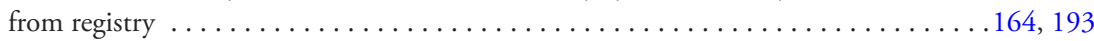

Commission v Council (Case 218/82) [1983] ECR 4063 . . . . . . . . . . . . . . . . . . . 222, 247

Commission v Council (ERTA) (Case 22/70) [1971] ECR 263 . . . . . . . . . 73-75, 81-82, 105,

$143,148,150,153-154,186,291$

Commission v Council (Lomé Convention) (Case 218/82) [1983] ECR 4063 . . . . . . . . 222, 247

Commission v Council (Nuclear Safety Convention) (Case C-29/99) [2002]

ECR I-11221 . . . . . . . . . . . . . . . . . . . . . . . . . . . . . . . . . . . . . . . . . . . 196-197

Commission v Council (Rotterdam Convention) (Case C-94/03) [2006] ECR I-1 . . . . . . . . 184

Commission v Council (Small Arms and Light Weapons) (Case C-91/05) [2008]

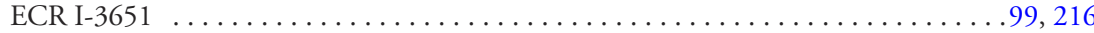

Commission v Denmark (Open Skies) (Case C-467/98) [2002]

ECR I-9519 . . . . . . . . . . . . 73, 106-107, 151, 154-156, 180, 234, 283-284

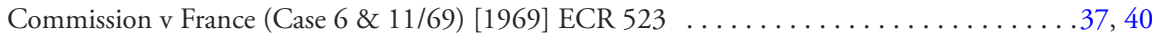

Commission v France (Case C-265/95) [1997] ECR I-6959 . . . . . . . . . . . . . . . . . . 278-280

Commission v France (Étang de Berre) (Case C-239/03) [2004] ECR I-9325 . . . . . . . . . . . 205

Commission v France (Fisheries) (Case C-304/02) [2005] ECR I-06263 . . . . . . . . . 15, 40, 173

Commission v France (National Agricultural Credit Fund) (Case 290/83) [1985]

ECR 439 . . . . . . . . . . . . . . . . . . . . . . . . . . . . . . . . . . . . . 292-294

Commission v Germany (Case C-61/94) [1996] ECR I-3989 . . . . . . . . . . . . . . . . . . 43

Commission v Germany (Heavy Goods Vehicles) (Case C-195/90) [1992]

ECR I-3141 . . . . . . . . . . . . . . . . . . . . . . . . . . . . . . . . . . .16-17

Commission v Germany (Inland Waterway) (Case C-433/03) [2005]

ECR I-6985 . . . . . . . . . . . . . . . . . . . . . 13, 111-113, 235

Commission v Germany (Market in Wine) (Case C-217/88) [1990] ECR I-2879 . . . . . . 42, 239

Commission v Germany (Primary Aluminium) (Case 94/87) [1989] ECR 175 . . . . . . . .239, 245

Commission v Germany (TIR Carnets) (Case C-105/02) [2006] ECR I-9659 . . . . . . . . . . 237

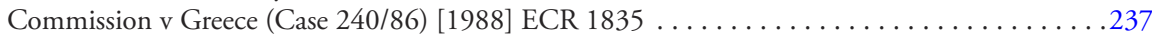

Commission v Greece (Community's Own Resources) (Case 68/88) [1989] ECR 2965 . . . . . . 129

Commission v Greece (Credit Terms) (Case 192/84) [1985] ECR 3967 . . . . . . . . . . . . . 28, 236

Commission v Greece (IMO) (Case C-45/07) [2009] ECR I-701 . . . . . . . . . . . 190, 198, 236

Commission v Greece (List D) (Case C-65/91) [1992] ECR I-5245 . . . . . . . . . . . . . . 238

Commission v Greece (Market in Feed Grain) (Case C-35/88) [1990] ECR I-3125. . . . . . . . . . 13

Commission v Greece (Olive Oil) (Case 272/86) [1988] ECR 4875 . . . . . . . . . . . . . . . . . 238

Commission v Ireland (Bern Convention) (Case C-13/00) [2002] ECR I-2943 . . . . . . . . . . 205

Commission v Ireland (Buy Irish) (Case C-249/81) [1982] ECR 4005 . . . . . . . . . . . . . . 277

Commission v Ireland (MOX Plant) (Case C-459/03) [2006] ECR I-4635 . . . . . . . . 15, 31,

186-187, 189, 191, 196, 204, 235, 240

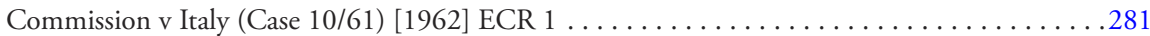

Commission v Italy (Case C-48/89) [1990] ECR I-2425 . . . . . . . . . . . . . . . . 237

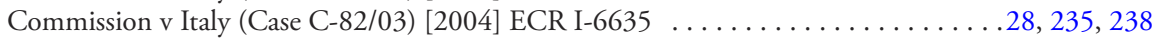

Commission v Italy (Premiums for Grubbing Fruit Trees) (Case 30/72) [1973] ECR $161 \ldots \ldots 128$

Commission v Italy (Premiums for Slaughtering Cows) (Case 39/72) [1973] ECR 101 . . . . . . 37

Commission v Italy (Public Works Contracts) (Case 274/83) [1985] ECR 1077 . . . . . . . . . 237

Commission v Italy (Recovery of Undue Payment) (Case 104/86) [1998] ECR 1799 . . . . . . . 132

Commission v Italy (Waste Management) (Case C-135/05) [2007] ECR I-3475 . . . . . . . . . 237

This is an open access version of the publication distributed under the terms of the Creative Commons Attribution-NonCommercial-NoDerivs licence (http://creativecommons.org/licenses/by-nc-nd/3.0/), which permits non-commercial reproduction and distribution of the work, in any medium, provided the original work is not altered or transformed in any way, and that the work is properly cited. For commercial re-use, please contact academic.permissions@oup.com 
Commission v Jégo-Quéré (Case C-263/02 P) [2004] ECR I-3425 . . . . . . . . . . . 127, 218

Commission v Luxembourg (Inland Waterway) (Case C-266/03) [2005] ECR I-4805 . . . . . . 13,

$111,188,191,235$

Commission v Luxemburg (Patent Agents) (Case C-478/01) [2003] ECR I-2351 . . . . . . . 236

Commission v Netherlands (Bathing Water) (Case 96/81) [1982] ECR 1791 . . . . . . . . . . 237

Commission v Netherlands (Drinking Water) (Case 97/81) [1982] ECR 1819 . . . . . . . . . 237

Commission v Parliament and Council (Basel Convention) (Case C-411/06) [2009] I-7585 . . 216

Commission v Portugal (Case C-404/97) [2000] ECR I-4897 . . . . . . . . . . . . 42, 239, 244

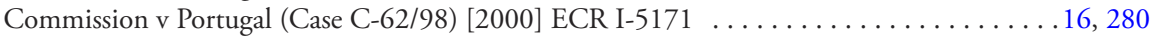

Commission v Spain (Case C-375/92) [1994] ECR I-923 . . . . . . . . . . . . . . . . . 236

Commission v Spain (Case C-421/98) [2000] ECR I-10375 . . . . . . . . . . . . . . . . 224

Commission v Spain (Magefesa Group) (Case C-499/99) [2002] ECR I-6031 . . 42, 237, 239, 244

Commission v Sweden (PFOS) (Case C-246/07) [2005] ECR I-6985 . . . . . . . . 65, 113-114,

$187-188,190,199-202$

Commission v Netherlands (Bilateral Air Transport Agreement) (Case C-523/04) [2007]

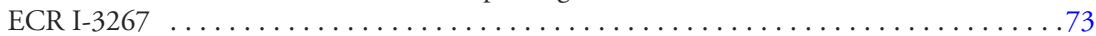

Commission v United Kingdom (Case C-40/92) [1994] ECR I-989. . . . . . . . . . . . . . 237

Commission v United Kingdom (Case C-466/98) [2002] ECR I-9427 . . . . . . . . . . . . 280

Commission v United Kingdom (Collective Redundancies) (Case C-383/92) [1994]

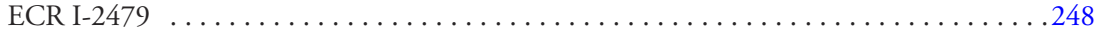

Commission v United Kingdom (Employees Rights) (Case C-382/92) [1994] ECR I-2435 . . . 248

Commission v United Kingdom (Sea Fisheries) (Case 804/79) [1981] ECR 1045 . . . . 61, 66, 110, 112

Compagnie Commerciale de l'Ouest and Others (Joined cases C-78/90 to C-83/90)

[1992] ECR I-1847 . . . . . . . . . . . . . . . . . . . . . . . . . . . . . . . 13

Connect Austria (Case C-462/99) [2003] ECR I-5197 . . . . . . . . . . . . . . . . . . . . 128-129

Consorzio Industrie Fiammiferi (CIF) (Case C-198/01) [2003] ECR I-8055 . . . . . . . . . . . 276

Coote (Case C-185/97) [1998] ECR I-5199 . . . . . . . . . . . . . . . . . . . . . . . . 135

Cornelis Kramer (Joined cases 3, 4 and 6/76) [1976] ECR 1279 . . . . . . . . . . . . . . 31

Corsica Ferries (Case C-18/93) [1994] ECR I-1783 . . . . . . . . . . . . . . . . . . . . . . . 13

Costa v ENEL (Case 6/64) [1964] ECR $585 \ldots \ldots \ldots \ldots \ldots \ldots \ldots \ldots .63,69,72,80-81,256$

Criminal Proceedings against André Allain et al (Case C-341/94) [1996] ECR I-4631 . . . . . 248

Criminal Proceedings against André Marchandise et al (Case C-332/89) [1991]

ECR I-1027 . . . . . . . . . . . . . . . . . . . . . . . . . . . . . . . . . . . . 276-277

Criminal Proceedings against Antoine Kortas (Case C-319/97) [1999]

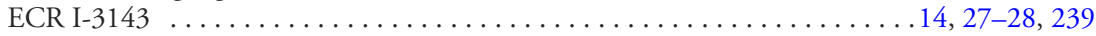

Criminal Proceedings against Hans van Lent (Case C-232/01) [2003] ECR I-11525 . . . . . 25, 27

Criminal Proceedings against Ioannis Doulamis (Case C-446/05) [2008] ECR I-1377 . . . . . . 276

Criminal Proceedings against José António Batista Morais (Case C-60/91) [1992]

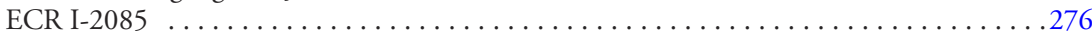

Criminal Proceedings against Manuele Arduino (Case C-35/99) [2002] ECR I-1529 . . . . . . 276

Criminal Proceedings against Maria Amélia Nunes and Evangelina de Matos

(Case C-186/98) [1999] ECR I-4883 . . . . . . . . . . . . . . . . . . . . . . 18, 129

Criminal Proceedings against Syuichi Yonemoto (Case C-40/04) [2005] ECR I-7755 . . . . . . 248

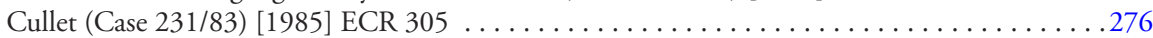

D $(\mathrm{C}-376 / 03)[2005]$ ECR I-5821 . . . . . . . . . . . . . . . . . . . . . . . 284-285

De Andrade (Case C-213/99) [2000] ECR I-11083 . . . . . . . . . . . . . . . . . . . . 129

Defrenne (Case 149/77) [1978] ECR 1365 . . . . . . . . . . . . . . . . . . . . . . 218

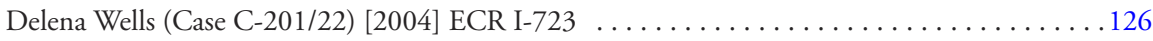

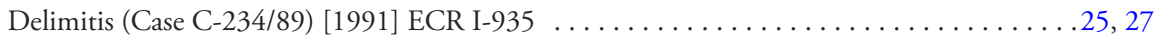

Delta Schiffahrts- und Speditionsgesellschaft (Case C-153/93) [1994] ECR I-2517 . . . . 129, 277

Demirel (Case 12/86) [1987] ECR 3719 . . . . . . . . . . . . . . . . . . . . . . . . . . . 195

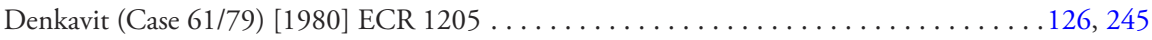

Deutsche Energiehandels- und Beratungsgesellschaft mbH (DEB) v Germany

(Case C-279/09) [2011] ECR I-13849 . . . . . . . . . . . . . . . . . . . 131

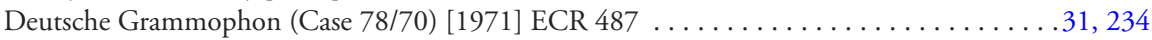

Diego Calí (Case C-343/95) [1997] ECR I-1547 . . . . . . . . . . . . . . . . . 276

Dillenkoffer et al v Germany (Joined cases C-178-9/94, 188-190/94) [1996] ECR I-4845 . . . . . . 131

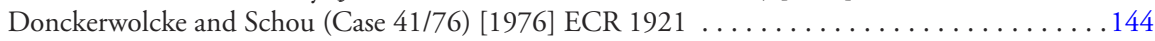

This is an open access version of the publication distributed under the terms of the Creative Commons Attribution-NonCommercial-NoDerivs licence (http://creativecommons.org/licenses/by-nc-nd/3.0/), which permits non-commercial reproduction and distribution of the work, in any medium, provided the original work is not altered or transformed in any way, and that the work is properly cited. For commercial re-use, please contact academic.permissions@oup.com 
Dorsch Consult Case (C-54/96) [1997] ECR I-4961 . . . . . . . . . . . . . . . 77, 133

Draft Agreement Relating to the Creation of the European Economic Area (Opinion

1/91) [1991] ECR I-6079 . . . . . . . . . . . . . . . . . . . . . . . . . . 246

Dreessen (Case C-31/00) [2002] ECR I-663 . . . . . . . . . . . . . . . . . . . . 13

Dubois and Cargo (Case C-16/94) [1995] ECR I-2421 . . . . . . . . . . . . . . 279, 292

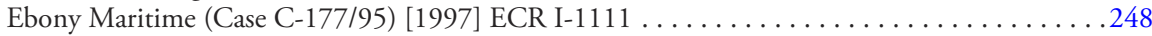

Edis (Case C-231/96) [1998] ECR I-4951 . . . . . . . . . . . . . . . . . . . . . 126

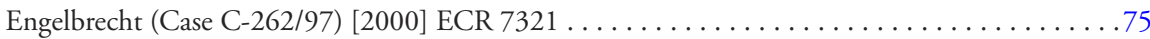

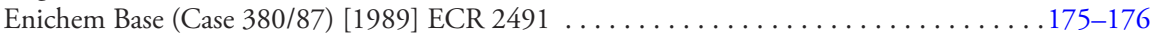

Eribrand (Case C-467/01) [2003] ECR I-6471 . . . . . . . . . . . . . . . . . . . . 126

European Laying-up Fund for Inland Waterway Vessels (Opinion 1/76) [1977]

ECR $741 \ldots \ldots \ldots \ldots \ldots \ldots \ldots 1,143,151,154-155,157,159,192-193,264-267$

Parliament v Council (Case C-65/93) [1995] ECR I-643 . . . . . . . . . . . . . . . . . . 28

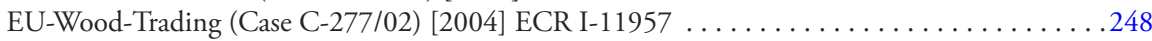

EvoBus Austria (Case C-111/97) [1998] ECR I-5411 . . . . . . . . . . . . . . . . . . . 77

Factortame (Case C-213/89) [1990] ECR I-2433 . . . . . . . . . . . . . . . . 129, 245

Fédération Charbonnière de Belgique (Case 8/55) [1956] ECR 292 . . . . . . . . . . . . 255, 264

Filipiak (Case C-314/08) [2009] ECR I-11049 . . . . . . . . . . . . . . . . . . . . . . 86

Fitzwilliam Executive Search (Case C-202/97) [2000] ECR I-883 . . . . . . . . . . . . . 31

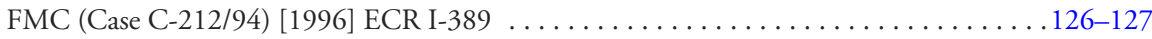

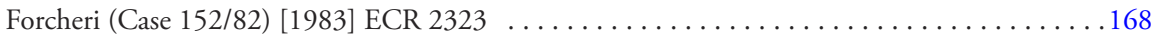

France v Commission (Competition Law Agreement) (Case 327/91) [1994] ECR I-3641 . . . 197

France v European Parliament (Joined cases 358/85 and 51/86) [1988] ECR $4821 \ldots \ldots .25-26$

France v United Kingdom (Sea Fisheries) (Case 141/78) [1979] ECR 2923 . . . . . . . . . . . 110

Francovich (Joined cases C-6/90 and C-9/90) [1991] ECR I-5357 . . . . .63, 79-80, 131-134, 253, 267

Franex NV (Case C-275/00) [2002] ECR I-10943 . . . . . . . . . . . . . . . . . 25, 27

Gebhard (Case C-55/94) [1995] ECR I-4165. . . . . . . . . . . . . . . . . . . . . . . . 219

Gebroeders Beentjes (Case 31/87) [1988] ECR 4635 . . . . . . . . . . . . . . . . . . . . . . . . . . 77

Gebrüder Reiff (Case C-185/91) [1993] ECR I-5801 . . . . . . . . . . . . . . . . . . . . . . . 129, 277

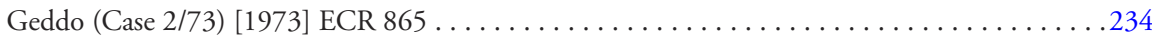

Gerhard Köbler v Austria (Case C-224/01) [2003] ECR I-10239 . . . . . . . . . . . . . . . 131

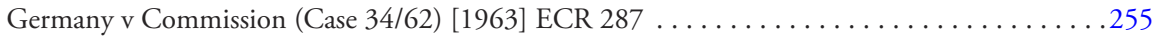

Germany v Commission (Case C-344/01) [2004] ECR I-2081 . . . . . . . . . . . . . . . . 25

Germany v Commission (Joined cases 281, 283, 284, 285 and 287/85) [1987] ECR $3203 \ldots 169$

Germany v Commission (Sea Fisheries) (Case 332/85) [1987] ECR $5143 \ldots \ldots \ldots \ldots \ldots \ldots . \ldots 110$

Germany v Parliament and Council (Case C-376/98) [2000] ECR I-8419 . . . . . . . . . . . . 222

Gestoras ProAmnistía and Others v Council (Case C-354/04 P) [2007] ECR I-1579 . . . . . . . . 95

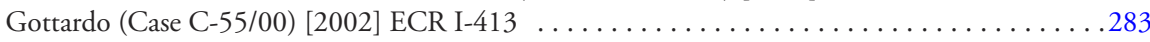

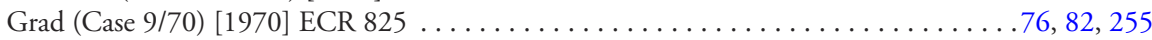

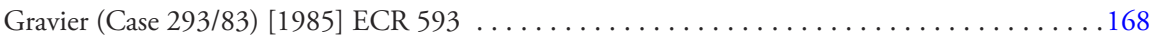

Greece v Commission (Clearance of EAGGF Accounts) (Case C-50/94) [1996]

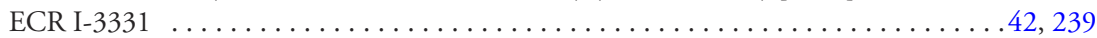

Greece v Commission (Project Abuja) (Case C-203/07 P) [2008] ECR I-8161 . . . . . . . . . 42-43

Greece v Commission (State Aid) (Case C-278/00) [2004] ECR I-3997 . . . . . . . . . 42, 239, 244

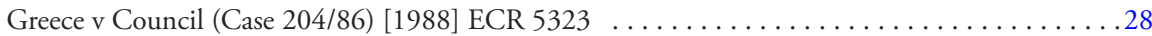

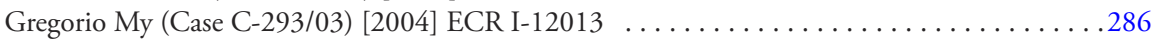

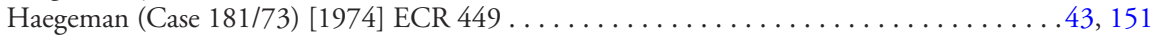

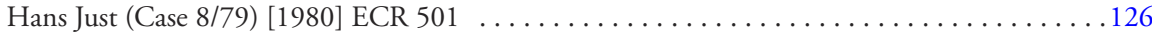

Hansa Fleisch Ernst Mundt (Case C-156/91) [1992] ECR I-5567 . . . . . . . . . . . . . . 108

Hansen \& Soen (Case C-326/88) [1990] ECR I-2911 . . . . . . . . . . . . . . 129, 247-248

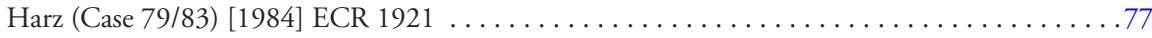

Hauptzollamt Mainz v C.A. Kupferberg \& Cie KG a.A. (Case 104/81) [1982]

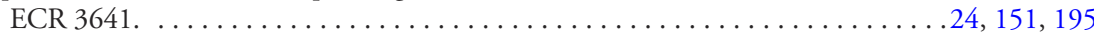

Hedley Lomas (Case C-5/94) [1996] ECR I-2553 . . . . . . . . . . . . . . . . . . 198, 224

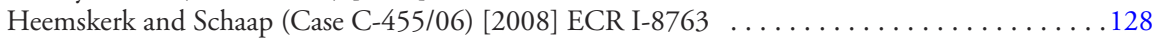

Hermés International (Case C-53/96) [1998] ECR I-3603 . . . . . 24, 184, 186, 190, 200-201, 204

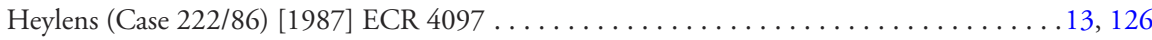

Hospital Ingenieure (Case C-258/97) [1999] ECR I-1405 . . . . . . . . . . . . . . . . 77

This is an open access version of the publication distributed under the terms of the Creative Commons Attribution-NonCommercial-NoDerivs licence (http://creativecommons.org/licenses/by-nc-nd/3.0/), which permits non-commercial reproduction and distribution of the work, in any medium, provided the original work is not altered or transformed in any way, and that the work is properly cited. For commercial re-use, please contact academic.permissions@oup.com 


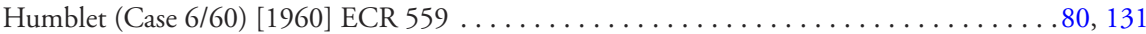

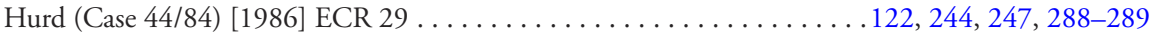

i-21Germany GmbH and Arcor AG \& Co. KG (Joined cases C-392/04 and C-422/04)

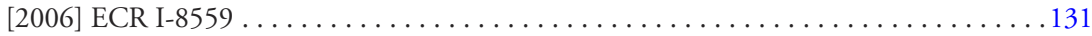

IAEA (Ruling 1/78) [1978] ECR $2151 \ldots \ldots \ldots \ldots \ldots \ldots \ldots . \ldots .24,184,188,190,192-193$

Idryma Koinonikon Asfaliseon (IKA) v Vasilios Ioannidis (Case C-326/00) [2003]

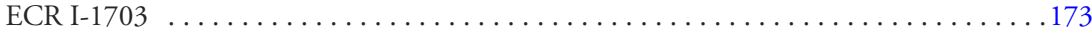

ILO Convention 170 (Opinion 2/91) [1993] ECR I-1061 . . . . . . . . . 24, 73-74, 106-107,

$155-156,186,188-189,191,197$

Ilonka Sayn-Wittgenstein v Landeshauptmann von Wien (Case C-208/09) [2010]

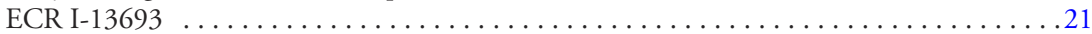

Imm. Zwartveld (Case C-2/88) [1990] ECR I-3365............... 11-12, 26-27, 174

Impact v Minister for Agriculture and Food (Case C-268/06) [2008]

ECR I-2483 ........................... 104, 130, 135-137

Imperial Chemical Industries (Case C-264/96) [1998] ECR I-4695 . . . . . . . . . . . . . . 133

Inspecteur van de Belastingdienst v X (Case C-429/07) [2009] ECR I-4833 . . . . . . . . . . 174

Inter-Environnement Wallonie (Case C-129/96) [1997] ECR $7411 \ldots \ldots \ldots$ 44, 82, 91-92, 108,

$136,161,202$

International Agreement on National Rubber (Opinion 1/78) [1979] ECR 2871 . . . . . . . . 193

International Fruit Company (Joined cases 51 to 54/71) [1971] ECR $1107 \ldots \ldots \ldots \ldots . .31,127$

Internationale Handelsgesellschaft (Case 11/70) [1970] ECR 1125 . . . . . . . . . 64, 72, 101

Intertanko (Case C-308/06) [2008] I-4057 . . . . . . . . . . . . . . . . . . . . 43

Ireland v Commission (Sea Fisheries) (Case 325/85) [1987] ECR $5041 \ldots \ldots \ldots \ldots \ldots \ldots \ldots$

Italy v Commission (Clearance of EAGGF Accounts) (Case 14/88) [1989] ECR 3677 . . . . . . 245

Jonkman (Joined cases C-231/06 to C-233/06) [2007] ECR I-5149 . . . . . . . . . . . 125, 132-133

Kapferer (Case C-234/04) [2006] ECR I-2585 . . . . . . . . . . . . . . . . . . . . . . 132

Kellinghusen (Joined cases C-36/97 and C-37/97) [1998] ECR I-6337 . . . . . . . . 31, 245

Kiriaki Angelidaki (Joined cases C-378/07 to C-380/07) [2009] ECR I-3071 . . . . . . . 92, 134

Kofisa Italia (Case C-1/99) [2001] ECR I-207 . . . . . . . . . . . . . . . . . . . . . . 129, 244-245

Kolpinghuis Nijmegen (Case 80/86) [1987] ECR 3969 . . . . . . . . . . . . . . . . 77, 104

Kraaijeveld (Case C-72/95) [1996] ECR I-5403 . . . . . . . . . . . . . . . . 77, 131

Krystyna Gmurzynska-Bscher v Oberfinanzdirektion Köln (Case C-231/89) [1990]

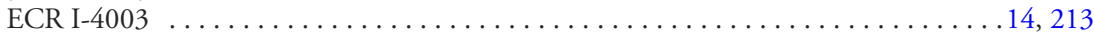

Kühne \& Heitz NV (Case C-453/00) [2004] ECR-837 . . . . . . . . . . . . 125, 132, 134, 245

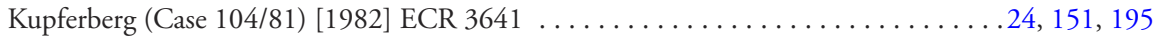

Lambert (Case 308/86) [1988] ECR 4369 . . . . . . . . . . . . . . . . . . . . . . . . 234

Laval (Case C-341/05) [2007] ECR I-11767 . . . . . . . . . . . . . . . . . . . . . 277

Leclerc (Case 229/83) [1985] ECR . . . . . . . . . . . . . . . . . . 31, 276, 292

Leifer and Others (Case C-83/94) [1995] ECR I-3231 . . . . . . . . . . . . . . . . 144

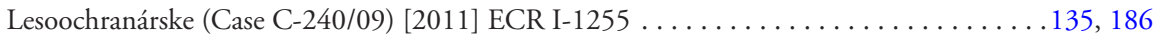

Lidl Italia (Case C-303/04) [2005] ECR I-7865 . . . . . . . . . . . . . . . . . . . . . 176

Lomé Convention (Case C-316/91) [1994] ECR I-625 . . . . . . . . . . . . . . . . 164-166

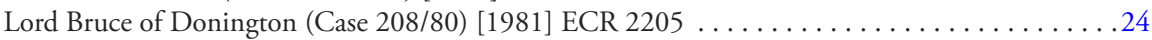

Lugano Convention (Opinion 1/03) [2006] ECR I-1145 . ........ .74, 107, 155, 158, 181, 186

Luxembourg v European Parliament (Seat and Working Place of the Parliament)

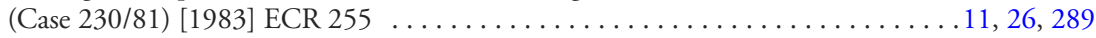

Luxemburg v European Parliament (Joined cases C-213/88 and C-39/89) [1991]

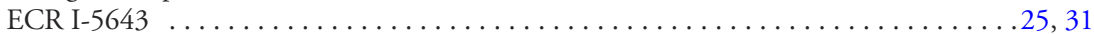

Maatschappij Drijvende Bokken (Case C-219/97) [1999] ECR I-6121 . . . . . . . . . . 129, 277

Mangold (Case C-155/04) [2005] ECR I-9981 . .......... .92, 136, 230, 253, 257, 269-270

Marguerite Johnston (Case 222/84) [1986] ECR $1651 \ldots \ldots \ldots \ldots \ldots \ldots \ldots \ldots$. . . . . 126, 135

Maribel Dominguez v Centre Informatique du Centre Ouest Atlantique and Préfet de la

Région Centre (Case C-282/10) [2012] nyr. . . . . . . . . . . . . . . . . . . . . . . 105

Marks \& Spencer (Case C-62/00) [2002] ECR I-6325 . . . . . . . . . . . . . . . . . 77

Marleasing v Comercial Internacional de Alimentación (Case C-106/89) [1990]

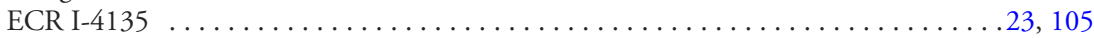

Marra (Joined cases C-200/07 and C-201/07) [2008] ECR $1 \ldots \ldots \ldots \ldots \ldots \ldots \ldots \ldots \ldots \ldots \ldots \ldots$

This is an open access version of the publication distributed under the terms of the Creative Commons Attribution-NonCommercial-NoDerivs licence (http://creativecommons.org/licenses/by-nc-nd/3.0/), which permits non-commercial reproduction and distribution of the work, in any medium, provided the original work is not altered or transformed in any way, and that the work is properly cited. For commercial re-use, please contact academic.permissions@oup.com 
Marshall II (Case C-271/91) [1993] ECR I-4367 . . . . . . . . . . . . . . . . . . . . 127

Masterfoods (Case C-344/98) [2000] ECR I-11369 . . . . . . . . . . . . . . . . . 2, 14, 214

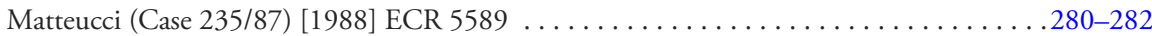

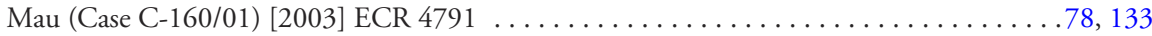

Merck Genéricos (Case C-431/05) [2007] ECR I-7001 . . . . . . . . . . . . . . 23, 204-205

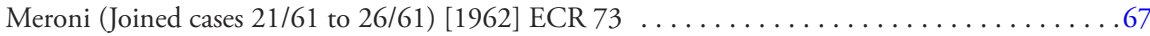

Michaniki AE v Ethniko Symvoulio Radiotileorasis and Ypourgos Epikrateias

(Case C-213/07) [2008] ECR I-9999 . . . . . . . . . . . . . . . . . . . . . . . 21

Ministero delle Finanze v IN.CO.GE.'90 (Joined cases C-10/97 to C-22/97) [1998]

ECR I-6307 . . . . . . . . . . . . . . . . . . . . . . . . . . . . . . . . 102

Mono Car Styling (Case C-12/08) [2009] ECR I-6653 . . . . . . . . . . . . . . . . . 104

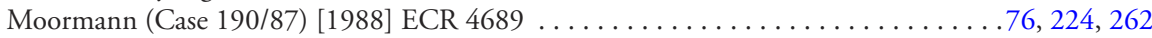

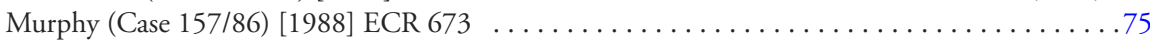

Netherlands v Commission (Sea Fisheries) (Case 326/85) [1987] ECR 5091 . . . . . . . . . . . 110

Ninni-Orasche (Case C-413/01) [2003] ECR I-13187 . . . . . . . . . . . . . . . . . . 35

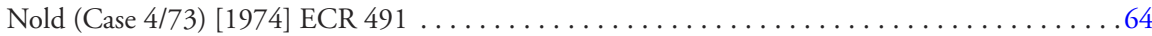

Opel Austria GmbH v Council (Case T-115/94) [1997] ECR II-39 . . . . . . . . . . . . . . 43

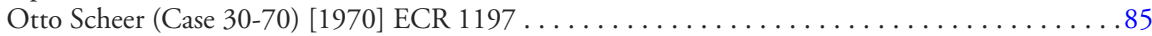

Palacios de la Villa (Case C-411/05) [2007] ECR I-8531 . . . . . . . . . . . . . . . . 268

Parliament v Council (Case C-65/93) [1995] ECR I-643 . . . . . . . . . . . . . . . 28

Parliament v Council (Chernobyl) (Case C-70/88) [1990] ECR I-2041 . . . .28-29, 216-217, 268

Parliament v Council (Delegation of Legislative Power) (Case C-133/06) [2008]

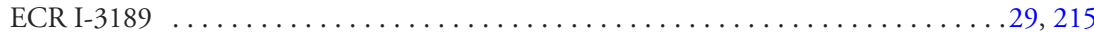

Parliament v Council (European Investment Bank) (Case C-155/07) [2008]

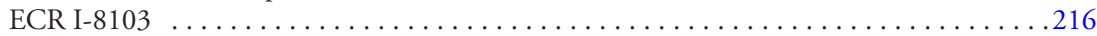

People's Mojahedin Organization of Iran v Council (Case T-284/08) [2008]

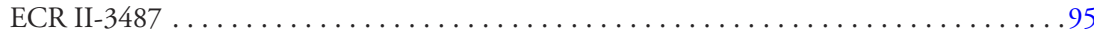

Peterbroeck (Case C-312/93) [1995] ECR I-4599 . . . . . . . . . . . . . . . . . . . . 126, 128

Pfeiffer (Joined cases C-397/01 and C-403/01) [2004] ECR I-8835 . . . . . . . . . 77, 103, 105,

$133-135,272$

Pierik II (Case 182/78) [1979] ECR 1977. . . . . . . . . . . . . . . . . . . . . 218

Pontin (Case C-63/08) [2009] ECR I-10467 . . . . . . . . . . . . . . . . . . . . . 135

Portugal and Spain v Council (Joined cases C-63/90 and C-67/90) [1992] ECR I-5073 . . . . 25-26

Portugal v Council (Case C-268/94) [1996] ECR I-6177 . . . . . . . . . . . . . . . . . . . . 164

Portugal v Council (Textiles) (Case C-149/96) [1999] ECR I-8395 . . . . . . . . . . . . 29, 42

PreussenElektra (Case C-379/98) [2001] ECR I-2099 . . . . . . . . . . . . . . . . . . 293-294

Procureur Général v Hans Buys et al (Case 5/79) [1979] ECR 3203 . . . . . . . . . . . . . 245

Pupino (Case C-105/03) [2005] ECR I-5285. . . . . . . . . . 11, 37-38, 76, 78, 81-82,

$94-95,245,254,272$

R. (On the Application of Mellor) v Secretary of State for Communities and Local

Government (Case C-75/08) [2009] ECR I-3799 . . . . . . . . . . . . . . . . . . . . . . . 125

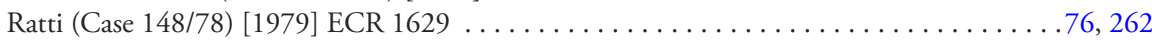

Regione Siciliana (Case C-15/06 P) [2007] ECR I-2591 . . . . . . . . . . . . . . . . . . . 127

Rewe (Case 33/76) [1976] ECR 1989 . . . . . . . . . . . . . . . . . . . . . . . . . . 126

Rewe-Handelsgesellschaft Nord mbH and Rewe-Markt Steffen v Hauptzollamt Kiel

(Case 158/80) [1981] ECR 1805 . . . . . . . . . . . . . . . . . . . . . . . . . . . 127

Rieser Internationale Transporte (Case C-157/02) [2004] ECR I-1477 . . . . . . . . . . . . . 108

Ruckdeschel (Joined cases 117/76 and 16/77) [1977] ECR 1753 . . . . . . . . . . . 218, 244

SA G.B.-INNO-B.M. v Association des Détaillants en Tabac (ATAB) (Case 13/77)

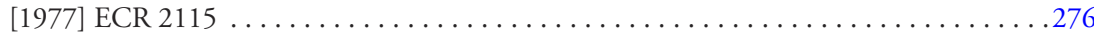

Säger (Case C-76/90) [1991] ECR I-4221 . . . . . . . . . . . . . . . . . . . . . 22, 219

Sahlstedt (Case C-362/06 P) [2009] ECR I-2903 . . . . . . . . . . . . . . . . . . . . . 42, 247

Saint-Gobain (Case C-307/97) [1999] ECR I-6161 . . . . . . . . . . . . . . . . . . 284

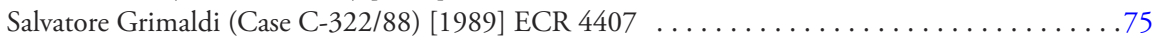

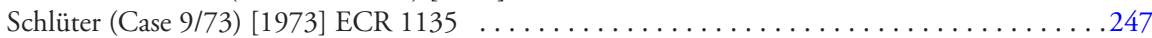

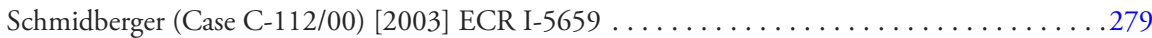

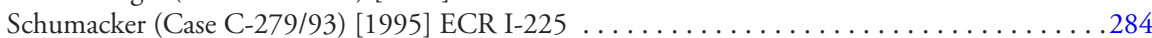

This is an open access version of the publication distributed under the terms of the Creative Commons Attribution-NonCommercial-NoDerivs licence (http://creativecommons.org/licenses/by-nc-nd/3.0/), which permits non-commercial reproduction and distribution of the work, in any medium, provided the original work is not altered or transformed in any way, and that the work is properly cited. For commercial re-use, please contact academic.permissions@oup.com 


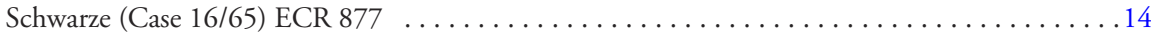
Security International SA v Signalson SA (Case C-194/94) [1996] ECR I-2201 . . . . . . 131, 176 Segi and Others v Council (Case C-355/04 P) [2007] ECR I-1657 . . . . . . . . . . . . . . 95 Simmenthal II (Case 106/77) [1978] ECR 629. . . . . . . . . . . . . . . . . . 101-102, 116 Siples (Case C-226/99) [2001] ECR I-277 . . . . . . . . . . . . . . . . . . . . 129, 244

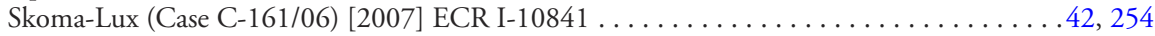
Stergios Delimitis v Henninger Bräu AG (Case C-234/89) [1991] ECR I-935 . . . . . . . . . . 25, 27 Stichting ROM-Projecten (Case C-158/06) [2007] ECR I-5103 . . . . . . . . . . . . . . . . 41 Stichting Zuid-Hollandse Milieufederatie (Case C-316/04) [2005] ECR I-9759 . . . . . . . . 179 Sweden v Commission (Public Access) (Case C-64/05 P) [2007] ECR I-11389 . . . . . . . . . 3, 31 Syndicat des Libraires de Normandie v L'Aigle Distribution (Case 254/87) [1988]

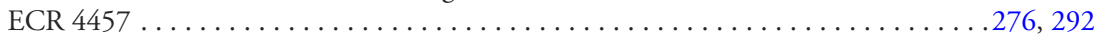

Ten Kate Holding (Case C-511/03) [2005] ECR I-8979 . . . . . . . . . . . . . . . . . 11, 31

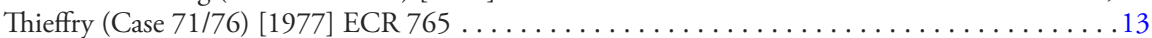

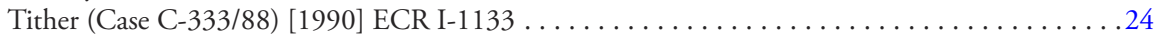

Unibet (Case C-432/05) [2007] ECR I-2271 . . . . . . . . . . . . . . 127, 130, 134-135

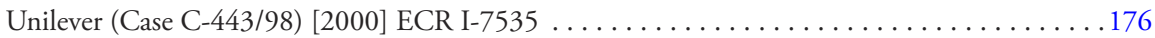

Unión de Pequeños Agricultores v Council (Case C-50/00 P) [2002]

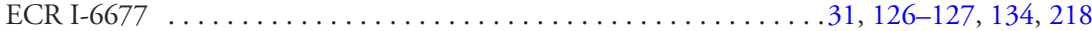

Union Francaise de Céréales (Case 6/78) [1978] ECR 1675 . . . . . . . . . . . . . . . . . . 259

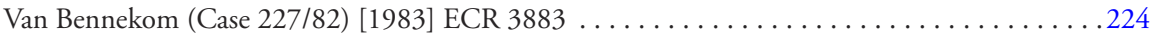

Van der Weerd (Joined cases C-222/05, C-223/05, C-224/05 and C-225/05) [2007]

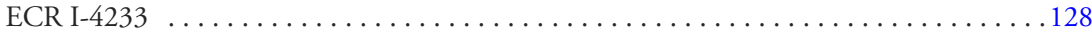

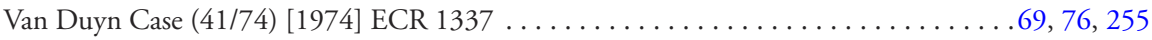

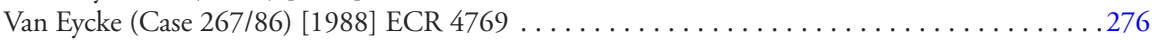

Van Munster (Case C-165/91) [1994] ECR I-4661 . . . . . . . . . . . . . . . . . . . . 75, 245

Van Schijndel (Joined cases C-430/93 and C-431/93) [1995] ECR I-4705 . . . . . . . . . . 128

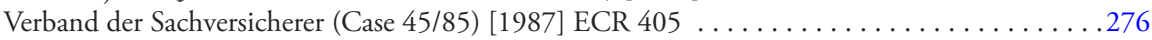

Verbond van Nederlandse Ondernemingen (Case 51/76) [1977] ECR $113 \ldots \ldots \ldots \ldots \ldots$. . . . . 262

Viking (Case C-438/05) [2007] ECR I-10779 . . . . . . . . . . . . . . . . . . . . . . . 277

Vlaamse Federatie van Verenigingen van Brood- en Banketbakkers, Ijsbereiders en

Chocoladebewerkers (VEBIC) (Case C-439/08) [2010] ECR I-12471 . . . . . . . . 104, 130

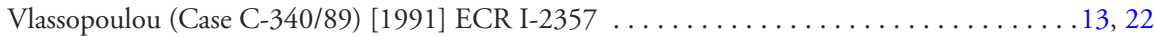

Von Colson (Case 14/83) [1984] ECR $1891 \ldots \ldots \ldots \ldots \ldots \ldots \ldots .77-78,81-82,134,272$

VTB-VAB and Galatea (Joined cases C-261/07 and C-299/07) [2009] ECR I-2949 . . . . . . . 23

Wagner Miret (Case C-334/92) [1993] ECR I-6911 . . . . . . . . . . . . . . . . . . . . 103

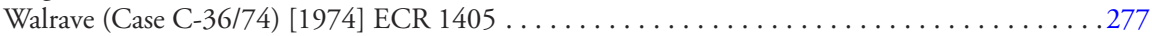

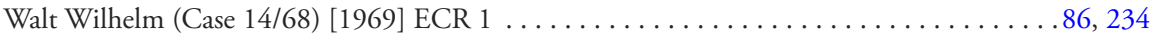

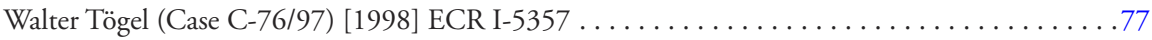

Werhof (Case C-499/04) [2006] ECR 2397 . . . . . . . . . . . . . . . . . . . . . . . . . . 222

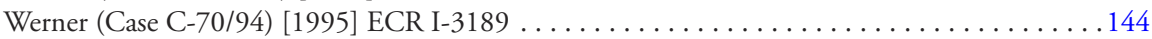

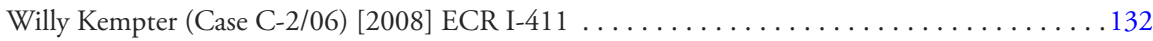

WTO (Opinion 1/94) [1994] ECR I-5267. . . . . . . . . . 24, 75, 151-152, 154-155, 186,

$188-190,193,203,288$

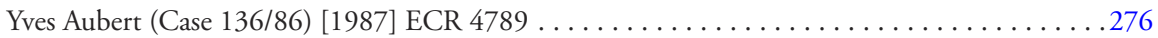

Zuckerfabrik Süderdithmarschen (Joined cases C-143/88 and C-92/89) [1991] ECR I-415

$.129,255$

This is an open access version of the publication distributed under the terms of the Creative Commons Attribution-NonCommercial-NoDerivs licence (http://creativecommons.org/licenses/by-nc-nd/3.0/), which permits non-commercial reproduction and distribution of the work, in any medium, provided the original work is not altered or transformed in any way, and that the work is properly cited. For commercial re-use, please contact academic.permissions@oup.com 


\section{Table of Instruments}

\section{EU TREATIES}

Treaty on Stability, Coordination and

Governance in the European

Monetary and Economic Union . . . . 296

Charter of Fundamental

Rights ..........4 47, 126, 137

Treaty establishing the European

Coal and Steel Community ...... 9-10,

$41,80,158$

Treaty establishing the European

Atomic Energy Community . . . . . . 192

\section{INTERNATIONAL AGREEMENTS}

General Agreement on Tariffs and

Trade ............. 45-46, 283

General Agreement on Trade in Services . ...283

Agreement on Trade Related Aspects

of Intellectual Property

Rights ......... 203-205, 241, 283

Vienna Convention on the Laws of

Treaties ........... 41, 44, 83

Charter of the United Nations . . . . . . 44, 85

Aarhus Convention ............ 135-136

Friendly Relations Declaration ........ 44

\section{EU SECONDARY LAW}

Commission Regulation (EC)

$865 / 2006$ laying down

detailed rules concerning the

implementation of Council

Regulation (EC) 338/97 on the

protection of species of wild

fauna and flora by regulating

trade therein [2006] OJ L166/1 _. . . 199

Council Decision (EC) 1999/468

laying down the procedures for

the exercise of implementing

powers conferred on the

Commission [1999] OJ L184/23 . . . 236

Council Directive (EC) 1999/70

concerning the framework

agreement on fixed term

work concluded by ETUC,

UNICE and CEEP [1999]

OJ L175/43 . . . . . . . . . . . 136-137

Council Directive (EC) 2001/40

on the mutual recognition of

decisions on the expulsion of

third country nationals [2001]
OJ L149/34 . . . . . . . . . . . . . . 94

Council Directive (EEC) 75/442 on

waste [1975] OJ L194/39 . . . . . . . . 91,

$175-176,178,248$

Council Directive (EEC) 76/207

on the implementation of the

principle of equal treatment

for men and women as

regards access to employment,

vocational training and

promotion, and working

conditions [1976]

OJ L39/40 ........ 78, 82, 134

Council Directive (EEC) 83/189

laying down a procedure for

the provision of information in

the field of technical standards

and regulations [1983]

OJ L109/8 . . . . . . . 175-176, 237

Council Directive (EEC) 90/387

on the establishment of

the internal market for

telecommunications services

through the implementation of

open network provision [1990]

OJ L192/1 . . . . . . . . . . . . 129

Council Directive (EEC) 91/414

concerning the placing of plant

protection products on the

market [1991] OJ L230/1 . . . . . . . 179

Council Regulation (EC) 1/2003 on

the implementation of the rules

on competition laid down in

Articles 81 and 82 of the Treaty

[2003] OJ L1/1 . . . . . . . 2, 130, 173

Council Regulation (EC) 116/2009

on the export of cultural goods

[2009] OJ L39/1 . . . . . . . . . 168

Council Regulation (EC) 343/2003

establishing the criteria and

mechanisms for determining

the Member State responsible

for examining an asylum

application lodged in one of

the Member States by a third-

country national (Dublin II)

[2003] OJ L50/1 ............. 41

Council Regulation (EC) 479/2008

on the common organisation of

the market in wine [2008]

OJ L148/1 ............... 200

Council Regulation (EEC) 1390/81

extending to self-employed

This is an open access version of the publication distributed under the terms of the Creative Commons Attribution-NonCommercial-NoDerivs licence (http://creativecommons.org/licenses/by-nc-nd/3.0/), which permits non-commercial reproduction and distribution of the work, in any medium, provided the original work is not altered or transformed in any way, and that the work is properly cited. For commercial re-use, please contact academic.permissions@oup.com 
persons and members of their families Regulation (EEC)

No $1408 / 71$ on the application

of social security schemes to employed persons and their families moving within the Community [1981] OJ L143/1 . . . . 218

Council Resolution on the first century of the cinema [1994] OJ C85/3 .............. 168

Directive (EC) 2001/95 on general product safety [2002] OJ L11/4 . . . 174

Directive (EC) 2004/38 on the right of citizens of the Union and their family members to move and reside freely within the territory of the Member States [2004] OJ L158/77 . .... 219, 223-224

Directive (EC) 2005/35 on shipsource pollution and on the introduction of penalties for infringements [2005] OJ L255/11 . . 43

Directive (EC) 2005/36 on the recognition of professional qualifications [2005] OJ L255/22 . . . 22

Directive (EC) $2006 / 123$ on services in the internal market [2006]

OJ L376/36 . . . . . . . 151, 156-157, 169, 174, 176-178,

$182,219,220-224$

Directive (EC) 98/48 laying down a procedure for the provision of information in the field of technical standards and regulations [1998] OJ L217/18 . . . . 175

Directive (EC) $98 / 8$ concerning the placing of biocidal products on the market [1998]

OJ L123/1 .......... 178, 179

Directive (EU) 2010/13 on the coordination of certain provisions laid down by law, regulation or administrative action in Member States concerning the provision of audiovisual media services (Audiovisual Media Services Directive) [2010] OJ L95/1 . . . . . 168

Directive (EU) 2011/24 on the application of patients' rights in cross-border healthcare [2011] OJ L88/45 .............. 169

Regulation (EC) 1337/2008 establishing a facility for rapid response to soaring food prices in developing countries [2008] OJ L 354/62
Regulation (EC) 1905/2006 establishing a financing instrument for development cooperation (DCI) [2006]

OJ L $378 / 41 \ldots \ldots \ldots \ldots \ldots \ldots . . \ldots 5$

Regulation (EC) 338/97 on the protection of species of wild fauna and flora by regulating trade therein [1997] OJ L61/1

Regulation (EC) 662/2009 establishing a procedure for the negotiation and conclusion of agreements between Member States and third countries on particular matters concerning the law applicable to contractual and non-contractual obligations [2009] OJ L200/25 . . . . . . . . 181-182

Regulation (EC) $725 / 2004$ on enhancing ship and port facility security [2004] OJ L129/6 . . . . . 236

Regulation (EC) 764/2008 laying down procedures relating to the application of certain national technical rules to products lawfully marketed in another Member State [2008]

OJ L218/21 . . . . . . . . . . . . . 174

Regulation (EC) 847/2004

on the negotiation and implementation of air service agreements between Member States and third countries [2004] OJ L157/7 . . . . . . . . . . . 180

Regulation (EU) 182/2011

laying down the rules and general principles concerning mechanisms for control by Member States of the Commission's exercise of implementing powers [2011]

OJ L55/13 ............. 236

\section{CONSTITUTIONAL LAW OF THE MEMBER STATES}

Federal Constitution of the Swiss Confederation .............. 51

Constitution of the United States of America . . . . . . . . . . . . . . . 52

Constitution of Belgium ............ 55

Basic Law for the Federal Republic of Germany ......... 55, 89, 229

Constitution of the French Republic . . . . . 89

Federal Constitutional Law of Austria . . . 129

This is an open access version of the publication distributed under the terms of the Creative Commons Attribution-NonCommercial-NoDerivs licence (http://creativecommons.org/licenses/by-nc-nd/3.0/), which permits non-commercial reproduction and distribution of the work, in any medium, provided the original work is not altered or transformed in any way, and that the work is properly cited. For commercial re-use, please contact academic.permissions@oup.com 


\section{Introduction}

\section{The Background}

Weatherill predicted in 1994 that (ex) Article 5 EEC 'is likely to be vigorously employed by the Court as a basis for an obligation to manage the varying patterns of integration so that the Community structure does not fragment'. ${ }^{1}$ In 2000, Temple Lang called the successor provision, Article $10 \mathrm{EC}$, 'the most important and most dynamic single Article in the E.C. Treaty'. ${ }^{2}$ Still, in a 2009 book on treaty conflict in the EU, Klabbers could claim that loyalty was 'surprisingly under-analysed and under-theorised'. ${ }^{3}$ Weatherill was spot on as we can see today and as I will show throughout this book. Temple Lang might have exaggerated to some degree, but at least the qualification of loyalty as the most dynamic single provision in the Treaties arguably does hold from today's perspective.

As I will discuss in detail later, loyalty today is enshrined in Article 4 (3) TEU, which provides for an obligation of Member States (1) to actively ensure compliance with the EU Treaty, (2) to facilitate the achievement of Union tasks, and (3) to abstain from any contravening measures. As I will also show, loyalty applies beyond the wording of this provision as a more general principle of Union law. This principle, despite the innocuous wording in what is now Article 4 (3) TEU (ex Article 10 EC, ex Article 5 EEC), has produced some of the strongest 'ties that bind' the Member States within the European Union. It is thus no exaggeration to claim that loyalty has been central to the development of Union law since the 1960s, and that it still shapes its structure today. How then could Klabbers have also been right in his statement?

Loyalty indeed has been an under-researched subject in European Union law. When I made the first preliminary assessment for this study in 2008, loyalty had been the subject of a rather limited amount of literature. Despite its overwhelming importance for defining and shaping the fabric of Community law, the loyalty principle has not received the special attention it arguably deserves. I have not found one English language monograph on it. The most authoritative non-German treatise is in French and dates from 1994. ${ }^{4}$ The German doctrine has been prolific but is largely outdated with only two pieces written in the twenty-first century. ${ }^{5}$ Whereas many of its implications such as the direct effect of directives and state liability are thoroughly researched, the loyalty principle itself has thus remained an elusive concept. Neither is the Court consistent

1 S. Weatherill, 'Beyond Preemption? Shared Competence and Constitutional Change in the European Community', in D. O'Keeffe and P.M. Twomey (eds), Legal Issues of the Maastricht Treaty (London: Chancery Law Publishing, 1994), 13-33, 32.

2 J. Temple Lang, 'General Report: The Duties of Cooperation of National Authorities and Courts and the Community Institutions under Article 10 EC Treaty', in Vol. 1, XIX F.I.D.E. Congress (2000, Helsinki), 373-426, quoted by J. Temple Lang, 'The Duties of Cooperation of National Authorities and Courts under Article 10 EC: Two More Reflections', European Law Review, 1 (2001), 84-89, 85.

3 J. Klabbers, Treaty Conflict and the European Union (Cambridge: Cambridge Univ. Press, 2009), 193, referring to 'Gemeinschaftstreue' and 'Community solidarity' instead of loyalty, which, as I will explain in Chapter 3, are not the same legal concept in EU law.

4 M. Blanquet, L'Article 5 du Traité C.E.E.: Recherche sur les Obligations de Fidélité des États Membres de la Communauté (Paris: LGDJ, 1994).

5 A. Hatje, Loyalität als Rechtsprinzip in der Europäischen Union (Baden-Baden: Nomos, 2001); A. Wille, Die Pflicht der Organe der Europäischen Gemeinschaft zur loyalen Zusammenarbeit mit den Mitgliedstaaten (Baden-Baden: Nomos, 2003).

This is an open access version of the publication distributed under the terms of the Creative Commons Attribution-NonCommercial-NoDerivs licence (http://creativecommons.org/licenses/by-nc-nd/3.0/), which permits non-commercial reproduction and distribution of the work, in any medium, provided the original work is not altered or transformed in any way, and that the work is properly cited. For commercial re-use, please contact academic.permissions@oup.com 
and methodical in its usage, nor has the doctrine proffered a convincing systematization adequately capturing its nature. Opinions in the doctrine have ranged from stressing its merely auxiliary role in case law to proclaiming that it is the most important principle of Union law. This has changed over the last three years, when loyalty became something of a darling of scholarship, particularly in the field of external relations. Indeed, it has been in this area that the Court of Justice (the 'Court', ECJ) has delivered some of the judgments most noteworthy for their prominent use of arguments based on loyalty.

\section{Caveats as Regards Perspective and Methodology}

This book is about many things, but it does not purport to examine all facets of loyalty. Thus, I am not discussing loyalty in terms of compliance in the meaning understood in especially political science theories. ${ }^{6}$ I am also not exploring the reasons why Member States are loyal to the Union in the sense that they comply with Union law obligations and decisions by the ECJ. ${ }^{7}$ Let me only note that this may be a worthwhile subject if approached from the perspective of international relations and public international law. Thus, Guzman has claimed that international law works because of reciprocity, retaliation, and repudiation (the 'three Rs of compliance'). ${ }^{8}$ In his view, the EU is 'perhaps the single greatest example of international cooperation' because matters of compliance and defection are markedly different compared to public international law. ${ }^{9}$ We will, however, take a comparative look at the principle of good faith, even though this could also be seen primarily in the context of reputation and compliance. ${ }^{10}$

Moreover, this book somewhat neglects the field of competition law, even though it is 'based on an obligation of sincere cooperation between the national courts, on the one hand, and the Commission and the Community Courts, on the other, in the context of which each acts on the basis of the role assigned to it by the Treaty'. ${ }^{11}$ While I will briefly address Regulation $1 / 2003^{12}$ in Chapter 9 on manifestations of loyalty in secondary law, a more

6 See, among others, G. Falkner et al., Complying with Europe? The Impact of EU Minimum Harmonisation and Soft Law in the Member States (Cambridge: Cambridge Univ. Press, 2005).

7 See L. Conant, Justice Contained: Law and Politics in the European Union (Ithaca: Cornell Univ. Press, 2002); M. Cremona (ed.), Compliance and the Enforcement of EU Law (The Collected Courses of the Academy of European Law; Oxford: Oxford Univ. Press, 2012).

8 See A.T. Guzman, How International Law Works: A Rational Choice Theory (Oxford and New York: Oxford Univ. Press, 2007), 40. With reciprocity, Guzman means that States honour their international law obligations because of the fear that other States would violate their own corresponding violations unless they do so. Retaliation refers to the threat of sanctions that disciplines States to comply with their obligations. Repudiation refers to the claim that States suffer 'reputational payoffs' in case they violate their obligations under international law.

9 Guzman, How International Law Works, 14. Indeed, it has been remarked that one key element distinguishing European Union law from public international law is the substitution in the EU of reciprocity and retaliation (countermeasures) by a complete system of remedies and a centralized jurisdiction to enforce them. See J.H.H. Weiler, 'The Transformation of Europe', The Yale Law Journal, (1991), 2403-2483, 2422, with references to the Court's case law in note 42 . One might even argue that the EU legal system internalizes and institutionalizes reputational values by virtue of loyalty. See M. Klamert, 'Review of Guzman, How International Law Works: A Rational Choice Theory', International Constitutional Law Journal, 4:2 (2010), 320-322.

10 See A. Alavi, 'Negotiating in the Shadow of Good Faith', in S.E. Gaines, B. Egelund Olsen, and K. Engsig Sørensen (eds), Liberalising Trade in the EU and the WTO: A Legal Comparison (Cambridge: Cambridge Univ. Press, 2012), 21-42, 25.

11 Case C-344/98 Masterfoods [2000] ECR I-11369, para 56.

12 Council Regulation (EC) 1/2003 on the implementation of the rules on competition laid down in Articles 81 and 82 of the Treaty [2003] OJ L 1/1.

This is an open access version of the publication distributed under the terms of the Creative Commons Attribution-NonCommercial-NoDerivs licence (http://creativecommons.org/licenses/by-nc-nd/3.0/), which permits non-commercial reproduction and distribution of the work, in any medium, provided the original work is not altered or transformed in any way, and that the work is properly cited. For commercial re-use, please contact academic.permissions@oup.com 
thorough examination of this field is beyond the confines of this study. ${ }^{13}$ Finally, I will not explore loyalty from the perspective of trust as a concept that without doubt plays a role in EU law in general and in some areas discussed in this book in particular, such as mutual recognition. ${ }^{14}$

Now for another caveat that is more intricate. This study requires us to discuss several legal concepts such as loyalty itself, solidarity, and pre-emption, all of which are poorly defined in the Treaty or not defined at all. This raises issues on how to deal with such unclear legal concepts in the present study. In many places, I will conduct what is called a Begriffswesensschau, which in our context refers to the exercise of describing, comparing, and distinguishing the usage of certain legal terms in EU law. Sometimes this comparative exercise will comprise terms from other legal disciplines such as public international law. For instance, we cannot analyse the concept of good faith in EU case law without looking at this concept from the public international law perspective. With some legal terms central to this study, I will in addition conduct an explication in order to clarify unclear legal concepts. ${ }^{15}$ An explication in the Carnapian sense is an interpretative process in which ordinary meaning plays a role, but only a subordinate one. ${ }^{16}$ Note here that it is a different matter to search for communalities between concepts employed in different legal orders, than to review the terminology used in European Union law against its inherent standards of suitability and consistency. In this book, I will do both things. On the one hand, the suitability of the terminology used in Union law in light of ordinary meaning and in view of its 'intra-unional' consistency will be explored. ${ }^{17}$ At the same time, I will add the view from the 'outside' by comparing concepts similar to loyalty existent in other legal systems.

Finally, note that stipulations with regard to terms and concepts made in this book are not true or false, just more or less suitable. ${ }^{18}$ The overarching classification I will propose later shall therefore not impose strict borders between the suggested categories. With

13 See, among others, R. Whish and D. Bailey, Competition Law, 7th edn. (Oxford: Oxford Univ. Press, 2012), 215-221; J. Temple Lang, 'The Development by the Court of Justice of the Duties of Cooperation of National Authorities and Community Institutions under Article 10 EC', Fordham International Law Journal, 31 (2008), 1483-1532; E. Schmidt-Aßmann, 'Verwaltungskooperation und Verwaltungskooperationsrecht in der Europäischen Gemeinschaft', Europarecht, 3 (1996), 270-301, 276-278.

14 See K. Nicolaidis, 'Trusting the Poles?: Towards a Regulatory Peace Theory in the World of Mutual Recognition', in I. Lianos and O. Odudu (eds), Regulating Trade in Services in the EU and the WTO: Trust, Distrust and Economic Integration (Cambridge: Cambridge Univ. Press, 2012), 263-297, 294, who distinguishes blind and binding trust, whereby the latter is 'grounded in the many ties that can bind regulators in their transnational cooperation'. See also Case C-64/05 P. Sweden v Commission (Public access to documents) [2007] ECR I-11389, paras 85-89, on the required dialogue between institutions and Member States where the implementation of rules of Community law is 'entrusted jointly' to them.

15 R. Carnap, Logical Foundations of Probability (Chicago: Univ. of Chicago Press, 1950).

16 R. Wank, Die juristische Begriffsbildung (Munich: Beck, 1985), 57; 'Im Kern ist Sinn der Explikation allerdings nicht die Beschäftigung mit einem Sprachgebrauch, sondern die Klärung von Sachfragen, indem ein Sachverhalt in Beziehung auf das Begriffssystem einer wissenschaftlichen Theorie erklärt wird.' (At the core of explication is not the study of language, but the clarification of issues, by explaining certain matters in relation to the system of concepts of a scientific theory.)

17 This (systemic) view from the inside as regards terminology is apposite not least because the Court has, all the while it was shaping and expanding the role of Article 4 (3) TEU over many years, never taken its cue either from national constitutional orders or from public international law. See the discussion of loyalty as a general legal principle of Union law in Chapter 12, where it is shown that general principles such as fundamental rights in contrast have been developed by taking recourse to national laws.

18 See Pawłowski, Begriffsbildung und Definition (Berlin, New York: De Gruyter, 1980), 183-184, for the difference between explication and definition. Scientific usefulness being one of the criteria for an explication in Carnap's meaning. For these criteria as developed by Pawłowski, 166 passim.

This is an open access version of the publication distributed under the terms of the Creative Commons Attribution-NonCommercial-NoDerivs licence (http://creativecommons.org/licenses/by-nc-nd/3.0/), which permits non-commercial reproduction and distribution of the work, in any medium, provided the original work is not altered or transformed in any way, and that the work is properly cited. For commercial re-use, please contact academic.permissions@oup.com 
regard to new definitions for established legal terms, I will propose relative concepts such as in the case of the concept of loyalty and the concept of cooperation. ${ }^{19}$ With the concept of pre-emption, I will conversely argue that a certain notion does not have any explicative value in legal terms. ${ }^{20}$ In some instances, it will prove difficult to disentangle the theoretical legal substance of legal concepts and principles of law from their use by the Union institutions. Thus, I will show that, while there are analogies between loyalty and the principle of pacta sunt servanda, especially the Court has applied loyalty largely in a suigeneris manner.

\section{The System Applied in this Study}

\subsection{The Case for a New Classification}

The literature, especially in Germany, has been very good at categorizing the various strands of case law on Articles 5 E(E)C, Article 10 EC and Article 4 (3) TEU in legal commentaries to the Treaties. ${ }^{21}$ Most of these books distinguish the rules prescribed by loyalty by their addresses and/or whether they provide for obligations to abstain or to take certain action.

Kahl has divided the implications of Article 4 (3) TEU into (1) obligations to act related to the implementation and enforcement of Union law, including regarding national remedies, and to the exercise of competences, (2) obligations to abstain mainly imposed on the Member States, (3) (reverse) obligations of the Union towards the Member States, and (4) mutual obligations of the institutions of Member States and Unions. ${ }^{22}$ Similarly, von Bogdandy and Schill have classified the effects of Article 4 (3) TFEU into obligations of the Member States and obligations of the Union. The former category is further divided into (1) prohibitions of thwarting Union law, (2) implementation obligations in a broader sense, (3) obligations concerning competences, (4) rules regarding the functioning of the institutions, and (4) obligations for the Union itself. ${ }^{23}$ Blanquet has also very much focused on the different vectors of the relationship between Member States and the Union, and on a distinction between positive and negative duties flowing from what is now Article 4 (3) TEU. ${ }^{24}$ Lenaerts and Van Nuffel have made the rather mystifying distinction between 'ancillary obligations with which the Member States and the institutions must comply in implementing a specific provision of Union law or even independently of such implementation' (i.e. what they call 'supplementary requirements'), and 'a prohibition on Member States or institutions to act where acting would constitute a misuse of powers' (i.e. what they refer to as 'derogatory requirements'). ${ }^{25}$

19 As to classifying termini, see Pawłowski, Begriffsbildung und Definition, 108. See Chapter 2.

20 See Chapter 5.

${ }^{21}$ Commentaries demand completeness paired with systematization.

22 W. Kahl, 'Art. 4 (3) EUV', in C. Calliess and M. Ruffert, EUVIAEUV: Das Verfassungsrecht der Europäischen Union mit Europäischer Grundrechtecharta, 4th edn. (Munich: Beck, 2011).

${ }^{23}$ A. von Bogdandy and S. Schill, 'Art. 4 EUV', in E. Grabitz, M. Hilf, and M. Nettesheim (eds), Das Recht der Europäische Union, Kommentar, Vol. II (Munich: Beck, 2010). See also M. Zuleeg, 'Art. 10 EGV', in H. von der Groeben and J. Schwarze (eds), Kommentar zum EU-/EG-Vertrag, 6th edn. (Baden-Baden: Nomos, 2003), who also distinguish mutual obligations of the Member States.

${ }_{24}$ Blanquet, L'Article 5 du Traité C.E.E..

${ }^{25}$ K. Lenaerts and P. Van Nuffel with R. Bray and N. Cambien (eds), European Union Law, 3rd edn. (London: Sweet \& Maxwell, 2011), 149.

This is an open access version of the publication distributed under the terms of the Creative Commons Attribution-NonCommercial-NoDerivs licence (http://creativecommons.org/licenses/by-nc-nd/3.0/), which permits non-commercial reproduction and distribution of the work, in any medium, provided the original work is not altered or transformed in any way, and that the work is properly cited. For commercial re-use, please contact academic.permissions@oup.com 
All these categorizations are without doubt useful in assorting the very diverse functions of loyalty and the constellations in which Article 4 (3) TEU has been employed. As I will show throughout this study, loyalty is a coat of many colours and it is not the least of tasks in this respect to put some order to the legion of cases decided by the Court on its basis. However, I submit that there are three deficiencies with such an approach, which I shall try to address. Firstly, it only insufficiently captures the 'transformative' nature of loyalty. The systematization proposed in this book shall thus draw attention to the constitutionalizing role of loyalty. Secondly, the tripartite system used herein collapses the very detailed and subject matter driven categories that are prevalent in the literature into only three large themes. Thirdly, this should contribute to finding common threads in the application of the loyalty principle by the Court, which have been missed by the more 'lexical' approaches to the subject. ${ }^{26}$

\subsection{The Four Parts of this Book}

The first part of this book titled Introducing Loyalty shall discuss some fundamental issues with regard to loyalty by way of three introductory chapters. The first chapter explores the drafting history of what is now Article 4 (3) TEU and discusses its specifications in the Treaties, which are shown to represent different aspects of loyalty and thus provide a sample of the wealth of effects loyalty has generated over the course of the years since its introduction in the Rome Treaties. The second chapter examines the addressees of loyalty in the European Union. This, among other things, deals with what I refer to as 'reverse' loyalty, imposing obligations on the Union institutions instead of on the Member States. Another chapter in this first part of the book will show that loyalty has widely been ignored in seminal writings on the constitutionalization of Union law. It will be argued that loyalty has played a very pronounced role in cases no less prominent than Costa v ENEL, ERTA, Brasserie du Pêcheur and von Colson. The final chapter of the first part looks at the broader context of loyalty by examining related concepts such as solidarity, pacta sunt servanda, and federal fidelity. By occasion of discussing the latter issue, I will deal with analogue concepts in selected federal states, and will briefly analyse the federal character of the European Union in a more general manner.

The second part of this book on the Cohesion of European Union Law sets off with a chapter on the 'unity' of Union law. This refers to both the question of whether Union law constitutes one single legal order governed by the same rules and principles, and to whether Union law and Member State laws are one single legal order or two different legal orders. The remainder of this part will deal with various principles of Union law that curtail the autonomy of the Member State by interlocking the legal orders of the Union with those of the Member States. One chapter will discuss the roles and relations between supremacy, loyalty, and the Union interest. On this basis, the 'fashionable' concept of pre-emption is also evaluated. Several effects established in case law on both the external capacities of Member States and their internal, regulatory autonomy are scrutinized, and it is explained why these effects cannot be fully explained in terms of supremacy. Another chapter explores the principle of effectiveness and its relation to loyalty. It will be shown that there is a red line connecting the case law on the implementation of directives, the enforcement of Union law more generally, and the cases on the

26 See Hatje, Loyalität als Rechtsprinzip, who defines creating uniformity in respect of national autonomy, ensuring cooperation, and settling of conflicts as the three functions the substance of loyalty should be measured against.

This is an open access version of the publication distributed under the terms of the Creative Commons Attribution-NonCommercial-NoDerivs licence (http://creativecommons.org/licenses/by-nc-nd/3.0/), which permits non-commercial reproduction and distribution of the work, in any medium, provided the original work is not altered or transformed in any way, and that the work is properly cited. For commercial re-use, please contact academic.permissions@oup.com 
force of national judicial and administrative decisions. Moreover, I will argue that there is an increasing tendency to sidestep the limitations of direct effect by relying on a strong notion of effectiveness paired with an indirect effect of directives.

In the part on Cooperation in the European Union, I will start with a brief discussion of the situation regarding competence following the Lisbon Treaty, thus continuing the exploration of the loyalty-based ERTA doctrine, among others. It will be shown that the codification of competences in the Treaty raises fundamental questions on the merits of this undertaking, and on its implications for the interpretation of the Treaty regime. The Cooperation part continues by examining the rules governing the exercise of shared and supporting competences, and especially the difficult to fathom 'irregular' shared competences such as for development policy. Another chapter will discuss manifestations of various aspects of loyalty in acts of Union secondary law such as duties of coordination and notification. Moreover, the pertinence of loyalty for mixed agreements is assessed, which relates, among other things, to the often-invoked unity of international representation, and the precepts flowing from loyalty with regard to the different stages in the process of negotiating and concluding such agreements.

The final part on the Construction of the European Union starts by exploring different constellations of conflict in Union law, which have so far been discussed in an entirely unrelated manner. While this on the one hand concerns the final arbiter question in the relationship between the ECJ and national (constitutional) courts, it on the other hand deals with cases where one might see a dispute between the Union legislator and the Court about who is the final lawmaker in the European Union. After that, I will probe the nature of loyalty by addressing whether loyalty is a legal principle in Union law, and more specifically, which kind of legal principle it is in light of the prevailing theories on the function of such principles in Union law. A chapter on deconstructing loyalty discusses the methods of interpretation of the European Court of Justice such as effet utile, its use of legal principles, and judicial activism in general. While there is abundant literature on these principles, their relationship to loyalty and the way loyalty, effectiveness, and effet utile have been used interchangeably by the Court, especially in its case law on state liability and the direct effect of directives, have so far not been discussed in depth. Finally, by introducing the concept of amplification, I will explore the way loyalty has extended the scope or the aims of Union law provisions. In this context, I will also discuss limits to the application of loyalty in EU law, asking whether it can reinforce any objective provided by the Treaty or whether it has a defined role in Union law that curtails its application.

This is an open access version of the publication distributed under the terms of the Creative Commons Attribution-NonCommercial-NoDerivs licence (http://creativecommons.org/licenses/by-nc-nd/3.0/), which permits non-commercial reproduction and distribution of the work, in any medium, provided the original work is not altered or transformed in any way, and that the work is properly cited. For commercial re-use, please contact academic.permissions@oup.com 


\section{PART I}

\section{INTRODUCING LOYALTY}

This is an open access version of the publication distributed under the terms of the Creative Commons Attribution-NonCommercial-NoDerivs licence (http://creativecommons.org/licenses/by-nc-nd/3.0/), which permits non-commercial reproduction and distribution of the work, in any medium, provided the original work is not altered or transformed in any way, and that the work is properly cited. For commercial re-use, please 
This is an open access version of the publication distributed under the terms of the Creative Commons Attribution-NonCommercial-NoDerivs licence (http://creativecommons.org/licenses/by-nc-nd/3.0/), which permits non-commercial reproduction and distribution of the work, in any medium, provided the original work is not altered or transformed in any way, and that the work is properly cited. For commercial re-use, please contact academic.permissions@oup.com 


\section{1 \\ Loyalty in the EU Treaties}

\section{Introduction}

The loyalty clause that I will discuss later is remarkable for several reasons: First, provisions on loyalty have been a constant element in the various EU Treaties, including the European Coal and Steel Community (ECSC) Treaty. ${ }^{1}$ Second, the wording of these provisions has barely changed since the 1950s and is thus very similar to what is currently stated in Article 4 (3) TEU. What has changed quite considerably, however, is the systematic context loyalty is placed in today. Third, the central loyalty clause has been complemented increasingly by various specifications of loyalty throughout the Treaties, some of which I will discuss later. Finally, the genealogy of Union loyalty apparently cannot be ascertained with certainty. The loyalty clause in Article 5 EEC that was adopted by the Rome Treaty and is discussed later had been inserted on the initiative of the German delegation and had been modelled after Article 86 ECSC. ${ }^{2}$ If the loyalty clause for the Community/Union was modelled after the one in the ECSC, this begs the question of the inspiration for the latter. I would suggest that what the drafters of the ECSC had in mind was a variation of the public international law principle of pacta sunt servanda. ${ }^{3}$ An indication of this perceived conventional nature of the loyalty clause is that in two books on the law of the ECSC, Article 86 is hardly mentioned or discussed in any depth. ${ }^{4}$ Moreover, according to the report of the French delegation, the provision should have a moral weight, but less a legal one. ${ }^{5}$

However, it is not too far-fetched a thought that the initiative of Germany with regard to the EEC also must be seen against the background of the German principle of federal fidelity (Bundestreue). I would suggest that it could hardly be a coincidence that, as I will show in Chapter 2, Bundestreue, while not expressly provided for in the German constitution, was first applied in the early 1950 s by the German Constitutional Court. ${ }^{6}$ Indeed, as I will also show in Chapter 2, Union loyalty bears resemblance to both pacta sunt servanda and federal fidelity.

1 M. Blanquet, L'Article 5 du Traité C.E.E.—Recherche sur les Obligations de Fidélité des États Membres de la Communauté (Paris: LGDJ, 1994), 5-6.

2 Blanquet, L'Article 5 du Traité C.E.E., 8.

3 See P. Mathijsen, Le Droit de la Communaute Europeenne du Charbon et de L'Acier: Une Etude des Sources (The Hague: Martinus Nijhoff, 1958), 28-29, on the absence of documents on the negotiations of the ECSC.

${ }^{4}$ See Mathijsen, Le Droit de la Communaute; W.J. Ganshof van der Meersch (ed.), Droit des Communautés européennes (Brussels: Larcier, 1969).

5 A 'portée morale, plus encore que juridique'. Quoted by K. Mortelmans, 'The Principle of Loyalty to the Community (Article 5 EC) and the Obligations of the Community Institutions', Maastricht Journal of European and Comparative Law, 5:1 (1998), 67-88, 67.

${ }^{6}$ Case 1 BvF 2/51 Finanzausgleichsgesetz [1952] BVerfGE 1, 117; Case 2 BvH 2/52 Wohnungsbauförderung [1952] BVerfGE 1, 299, 314.

This is an open access version of the publication distributed under the terms of the Creative Commons Attribution-NonCommercial-NoDerivs licence (http://creativecommons.org/licenses/by-nc-nd/3.0/), which permits non-commercial reproduction and distribution of the work, in any medium, provided the original work is not altered or transformed in any way, and that the work is properly cited. For commercial re-use, please contact academic.permissions@oup.com 


\section{Loyalty before the Lisbon Treaty}

The first important Treaty provision on loyalty was Article 86 of the now inexistent ECSC Treaty, which had the following wording: ${ }^{7}$

The Member States bind themselves to take all general and specific measures which will assure the execution of their obligations under the decisions and recommendations of the institutions of the Community, and facilitate the accomplishment of the Community's purposes.

The Member States bind themselves to refrain from any measures which are incompatible with the existence of the common market referred to in Articles 1 and $4 \ldots$

The case law by the Court of Justice on this specific variation of loyalty in the Coal and Steel Community is partly still relevant today. The German proposal for Article 5 EEC seemed to be the reason for the only substantive difference between Article 86 ECSC and Article 5 EEC, viz. the substitution of the reference to the common market in the former by the references to the objectives of the Treaty in the latter. ${ }^{8}$ Article 5 EEC read:

Member States shall take all appropriate measures, whether general or particular, to ensure fulfilment of the obligations arising out of this Treaty or resulting from action taken by the institutions of the Community. They shall facilitate the achievement of the Community's tasks.

They shall abstain from any measure which could jeopardise the attainment of the objectives of this Treaty.

In the EEC Treaty, loyalty had been situated in a slightly different context compared to today's Lisbon Treaty. Article 4 EEC provided the general mandate to the institutions, coupled with the principle of conferral. Whereas this proximity between conferral and loyalty has been retained until today, Article 6 (1) EEC at that time foresaw the duty of coordination of economic policies between the Member States. ${ }^{9}$ Thus, Articles 4 to 6 in the EEC Treaty regulated the whole range of relationships that are still important in the European Union, both between the institutions and the Member States (conferral), vice versa (loyalty), as well as the relationship between the Member States themselves (coordination of economic policies). ${ }^{10}$

Before the Intergovernmental Conferences leading to the Maastricht Treaty, apparently, the Commission had tried unsuccessfully to expand the reach of loyalty by specifying national rules on failure to comply with Community law. ${ }^{11}$ Thus, what had been Article 5 EC became Article 10 EC, but remained otherwise unchanged compared to Article 5 EEC quoted earlier. Loyalty in the Treaty, thus, consisted of two indents, of which one prescribed a positive obligation (to act), while the other foresaw a negative obligation (to abstain).

Addressees were, prima facie, the Member States under Article 10 EC, which did not expressly impose mutual duties of assistance and cooperation that were also binding on the Union. In other words, Article 10 EC (and Article 5 EEC before it) by their wording only concerned the bottom-up, 'vertical' relationship, as opposed to a top-down, 'reverse vertical' relationship. Nonetheless, the Court extended loyalty also to the reverse

7 See Chapter 6.

8 Blanquet, L'Article 5 du Traité C.E.E., 9.

9 Art. 6 (1) EEC: 'Member States, acting in close collaboration with the institutions of the Community, shall co-ordinate their respective economic policies to the extent that is necessary to attain the objectives of this Treaty.'

10 See also Blanquet, L'Article 5 du Traité C.E.E., 10.

11 D. Curtin, 'The Decentralised Enforcement of Community Law Rights: Judicial Snakes and Ladders', in D. Curtin and D. O'Keeffe (eds), Constitutional Adjudication in European Community and National Law (London: Butterworths, 1992), 33-49, 41.

This is an open access version of the publication distributed under the terms of the Creative Commons Attribution-NonCommercial-NoDerivs licence (http://creativecommons.org/licenses/by-nc-nd/3.0/), which permits non-commercial reproduction and distribution of the work, in any medium, provided the original work is not altered or transformed in any way, and that the work is properly cited. For commercial re-use, please contact academic.permissions@oup.com 
vertical sphere by imposing loyalty obligations on the Commission especially, as will be discussed later. In doing so, the Court has not been clear on the methodological approach chosen. In the leading case, the Court inferred duties of consideration incumbent on the Commission directly from ex Article 10 EC. ${ }^{12}$ In follow-up judgments, the Court in contrast spoke of 'mutual duties of sincere cooperation' imposed on the Member States by virtue of ' $\mathrm{t}$ ] he principle to which Article 10 EC gives expression', ${ }^{13}$ and of 'mutual duties of sincere cooperation, as embodied in particular in Article 5 of the EEC Treaty'. ${ }^{14}$ This case law that was widely considered proof of the existence of a more general principle of Union law transcending the wording and scope of the Treaty provisions, ${ }^{15}$ has been codified by the Lisbon Treaty, as we will see in the following. ${ }^{16}$

\section{The Lisbon Treaty Amendments}

\subsection{The Amended Loyalty Clause}

In the Lisbon Treaty, the rule corresponding to Article $10 \mathrm{EC}$ is now found in Article 4 (3) TEU and is worded as follows:

Pursuant to the principle of sincere cooperation, the Union and the Member States shall, in full mutual respect, assist each other in carrying out tasks which flow from the Treaties.

The Member States shall take any appropriate measure, general or particular, to ensure fulfilment of the obligations arising out of the Treaties or resulting from the acts of the institutions of the Union.

The Member States shall facilitate the achievement of the Union's tasks and refrain from any measure which could jeopardise the attainment of the Union's objectives.

An intricate question under the Nice Treaty had been whether loyalty in the Common Foreign and Security Policy (CFSP) was the same rule as in the other pillars. ${ }^{17}$ The removal of the pillar structure by the Lisbon Treaty and the shifting of the content of the former Article $10 \mathrm{EC}$ to Article 4 (3) TEU now applies a concept of loyalty to the whole of European Union law. This 'upgrading' of loyalty might be an acknowledgement of case law such as Pupino. ${ }^{18}$ However, as we will discuss in the Part on Cohesion, also after Lisbon the TEU retains a separate regime on the CFSP, including specific and differently worded provisions on loyalty, which displays a strong basis in the principle of solidarity. It will thus be argued in Chapter 4 that the 'unionization' of loyalty has been codified with regard to the former third pillar, but that CFSP loyalty continues to be different from non-CFSP loyalty, also under the Lisbon Treaty. ${ }^{19}$ Indents 2 and 3

12 Case C-2/88 Imm. Zwartveld [1990] ECR I-3365.

13 Case C-511/03 Ten Kate Holding [2005] ECR I-8979, para 28.

14 Case 230/81 Luxembourg v European Parliament (Seat and Working Place of the Parliament) [1983] ECR 255, para 37.

15 See Blanquet, L'Article 5 du Traité C.E.E., 291. See also J. Heliskoski, Mixed Agreements as a Technique for Organizing the International Relations of the European Community and its Member States (The Hague: Kluwer Law International, 2001), 64; M. Lück, Die Gemeinschaftstreue als allgemeines Rechtsprinzip im Recht der Europäischen Gemeinschaft: Ein Vergleich zur Bundestreue im Verfassungsrecht der Bundesrepublik Deutschland (Baden-Baden: Nomos, 1992), 23 with references to older German literature with the same tenor.

16 In Chapter 13, I will return to the reasoning by the Court with general principles in general, and with loyalty as a general principle in particular.

17 See on this A. Hatje, Loyalität als Rechtsprinzip in der Europäischen Union (Baden-Baden: Nomos, 2001).

18 Case C-105/03 Pupino [2005] ECR I-5285. 19 See Chapter 4 on the Structure of EU Law.

This is an open access version of the publication distributed under the terms of the Creative Commons Attribution-NonCommercial-NoDerivs licence (http://creativecommons.org/licenses/by-nc-nd/3.0/), which permits non-commercial reproduction and distribution of the work, in any medium, provided the original work is not altered or transformed in any way, and that the work is properly cited. For commercial re-use, please contact academic.permissions@oup.com 
are identical in wording to Articles $5 \mathrm{EEC}$ and Article $10 \mathrm{EC}$, which has left them unchanged since the Rome Treaty. The only substantive modification therefore is to be found in the first indent of Article 4 (3) TEU, ${ }^{20}$ which codifies the duty of mutual assistance between the Member States established by Zwartveld. ${ }^{21}$ One might surmise that it would have been utterly unfeasible to codify everything that has been decided based on loyalty by the Court of Justice over the years. However, in the drafts drawn up by the Convention on the Future of the European Union, more substantive changes had still been contemplated. ${ }^{22}$

What is a novelty in the first part of Article 4 (3) TEU is the notion of 'sincere cooperation'. It has been argued that this merely codifies one particular aspect of a broader principle of loyalty embodied by the entirety of Article 4 (3) TEU. ${ }^{23}$ However, this sentence marks the very beginning of a provision not divided into separate paragraphs. For this reason, the reference to the 'principle of sincere cooperation' could equally represent the title concept for the remainder of the duties contained in Article 4 (3) TEU. I would argue, firstly, that there is no difference between the notion of sincere cooperation and the notion of loyal cooperation under the Treaty. The 'principle of sincere cooperation' is rendered as 'Grundsatz der loyalen Zusammenarbeit' in the German version of the Treaty, and as 'principe de coopération loyale' in the French text. ${ }^{24}$ Secondly, I will argue later for considering duties of cooperation a subcategory of a more general principle of loyalty.

\subsection{The New Article 13 (2) TEU}

The newly worded Article 13 (2) TEU underlines the horizontal application of loyalty:

Each institution shall act within the limits of the powers conferred on it in the Treaties, and in conformity with the procedures, conditions and objectives set out in them. The institutions shall practice mutual sincere cooperation.

Article 13 (2) TEU, thus, expressly requires the institutions to display loyalty when exercising their powers, using the same language as provided in Article 4 (3) TEU on the mutual duties of Member States and Union institutions. Another similarity with Article 4 (3) TEU is the principle of conferred powers stated in both provisions.

Article 4 (3) TEU and its predecessors have never been construed by the Court as creating similar obligations for the relationship between the Union institutions themselves. The wording of ex Article 10 EC also did not easily lend itself to a construction that would not refer to the Member States. However, especially Cremona

20 W. Kahl, 'Art. 4 (3) EUV', in C. Calliess and M. Ruffert, EUVIAEUV: Das Verfassungsrecht der Europäischen Union mit Europäischer Grundrechtecharta, 4th edn. (Munich: Beck, 2011), para 86.

${ }_{21}$ Case C-2/88 Imm. Zwartveld [1990] ECR I-3365.

22 The loyalty principle had been limited to the context of the exercise of competence, and the second indent had been placed in the context of the later abolished supremacy clause. In addition, an explicit extension of the scope of loyalty to local and regional public authorities had been discussed, as well as a specific duty of loyalty vis-à-vis the Member States and the Union for regions with legislative powers. See Kahl, 'Art. 4 (3) EUV', para 85 with further references.

${ }^{23}$ See C. Vedder, 'Artikel I-5', in C. Vedder and W. Heintschell von Heinegg (eds), Europäischer Verfassungsvertrag (Baden-Baden: Nomos, 2007), para 1.

24 See A. Gamper, 'On Loyalty and the (Federal) Constitution', International Constitutional Law Journal, 4:2 (2010), 157, who notes that the German term is not common in German speaking countries, but seems to be a copy of the principle of 'leale collaborazione' provided in Art. 120 of the Italian Constitution. See also P. Unruh, 'Die Unionstreue: Anmerkungen zu einem Rechtsgrundsatz der Europäischen Union', Europarecht, (2002), 41-66.

This is an open access version of the publication distributed under the terms of the Creative Commons Attribution-NonCommercial-NoDerivs licence (http://creativecommons.org/licenses/by-nc-nd/3.0/), which permits non-commercial reproduction and distribution of the work, in any medium, provided the original work is not altered or transformed in any way, and that the work is properly cited. For commercial re-use, please contact academic.permissions@oup.com 
had already argued that the principles of cooperation were not limited to Member States but would apply also to inter-institutional cooperation. ${ }^{25}$ I will argue later that loyalty in this relationship is embodied by the principle of institutional balance.

\section{Specifications of Article 4 (3) TEU in the Treaties}

\subsection{Introduction}

Loyalty in Article 4 (3) TEU is subsidiary to more specific Treaty provisions. In 1993, the Court held that ex Article 5 EEC 'is worded so generally that there can be no question of applying it autonomously when the situation concerned is governed by a specific provision of the Treaty...' ${ }^{26}$ Similarly, while Article 4 (3) TEU can be relied upon with regard to a breach of Union competence, if the competence concerned is of an exclusive nature, any reference to ex Article $10 \mathrm{EC}$ is 'merely a corollary'. ${ }^{27}$ Thus, the Court has explicitly mentioned this lex specialis nature with regard to ex Article 43 EC (now Article 49 TFEU) and the duty of mutual recognition. ${ }^{28}$ It has been argued that Article 106 (1) TFEU on public undertakings and undertakings to which Member States grant special or exclusive rights expresses a special duty of loyalty addressed to the states, viz. not to enact or to maintain in force any measure contrary to the Treaties. ${ }^{29}$ Moreover, while Article 288 TFEU is lex specialis to Article 4 (3) TEU for the duty of the Member States to take all measures required to implement Union directives, Article 291 TFEU is now the special provision for this duty with respect to other binding Union acts. ${ }^{30}$ Article 197 TFEU has introduced the proclamation that the 'effective implementation of Union law by the Member States, which is essential for the proper functioning of the Union, shall be regarded as a matter of common interest', which could arguably already be derived from Article 4 (3) TEU. ${ }^{31}$ Even Article 114 (4) and (5) on deviations from harmonization measures has been qualified as expressions of Article 4 (3)

25 M. Cremona, 'Defending the Community Interest: The Duties of Cooperation and Compliance', in M. Cremona and B. de Witte (eds), EU Foreign Relations Law: Constitutional Fundamentals (Oxford and Portland, Oregon: Hart Publishing, 2008), 125-169, 157-158.

${ }^{26}$ Case C-18/93 Corsica Ferries [1994] ECR I-1783, para 18. See, in particular, Joined cases C-78/90 to C-83/90 Compagnie Commerciale de l'Ouest and Others [1992] ECR I-1847, para 19. See also Case C-35/88 Commission v Greece (Market in Feed Grain) [1990] ECR I-3125.

27 Opinion of AG Tizzano in Case C-433/03 Commissionv Germany (Inland Waterway) [2005] ECR I-6985, para 79; see also AG Léger in his Opinion in Case C-266/03 Commission v Luxembourg (Inland Waterway) [2005] ECR I-4805.

${ }^{28}$ Case C-31/00 Dreessen [2002] ECR I-663, para 30: 'In the light of the foregoing considerations it does not appear necessary to interpret Article $10 \mathrm{EC}$, the interpretation of Article $43 \mathrm{EC}$ alone being sufficient to provide the referring court with the reply that it needs.' Less clear is Case 71/76 Thieffry [1977] ECR 765, paras 15-17. See also Case C-340/89 Vlassopoulou [1991] ECR I-2357, para 14, and Case 222/86 Unectefv Heylens [1987] ECR 4097, para 12. For a different perspective, see J. Snell, 'Free Movement of Services and the Services Directive: The Legitimacy of the Case Law', in J. van de Gronden (ed.), EU and WTO Law on Services (The Hague: Kluwer Law International, 2008), 31-54, $40-41$, who goes to great lengths to rationalize mutual recognition in case law by resorting to the US Commerce Clause, among others.

${ }_{29}$ T. Bekkedal, 'Article 106 TFEU is Dead: Long Live Article 106 TFEU!', in E. Szyszczak et al. (eds), Developments in Services of General Interest (The Hague: TMC Asser, 2011), 61-102, 78, pointing to case law that prohibits Member States from enacting legislation that deprives the competition rules, which are directed at private undertakings, of their effectiveness.

${ }^{30}$ M. Ruffert, 'Art. 291 AEUV', in C. Calliess and M. Ruffert (eds), EUVIAEUV: Das Verfassungsrecht der Europäischen Union mit Europäischer Grundrechtecharta, 4th edn. (Munich: Beck, 2011).

31 M. Nettesheim, 'Art. 6 EUV', in E. Grabitz, M. Hilf, and M. Nettesheim (eds), Das Recht der Europäischen Union (Munich: Beck, 2011), para 27.

This is an open access version of the publication distributed under the terms of the Creative Commons Attribution-NonCommercial-NoDerivs licence (http://creativecommons.org/licenses/by-nc-nd/3.0/), which permits non-commercial reproduction and distribution of the work, in any medium, provided the original work is not altered or transformed in any way, and that the work is properly cited. For commercial re-use, please contact academic.permissions@oup.com 
TEU, establishing an obligation of the Member States to notify their measures to the Commission as soon as possible. ${ }^{32}$

Other pertinent examples are briefly discussed in the following. It will transpire that all of these provisions are examples of different facets of loyalty that are equally embodied by Article 4 (3) TEU proper; each of the provisions discussed illustrates and represents a distinct aspect of loyalty. While some of the provisions examined in the following cater to the 'cooperative' side of Union loyalty, others are rather expressions of its 'confrontational', conflict resolving side. These Treaty provisions therefore provide a sample of the wealth of effects loyalty has assumed over the course of the years since its introduction in the Rome Treaties.

\subsection{Loyalty and Institutional Cooperation}

The preliminary reference procedure pursuant to Article 267 TFEU is based on the cooperation between the Court of Justice and the national courts. Thus, we might say that the preliminary reference procedure, by its very nature as well as by its rules of procedure, embodies the loyalty principle in Union law.

Duties flowing from loyalty are also binding on national courts for matters within their jurisdiction. ${ }^{33}$ I would argue that national courts must exercise their powers in a way to avoid any significant risk of conflict in relation to decisions by the Union courts. Indeed, the Court has referred to the preliminary reference procedure as 'an instrument of cooperation between the Court of Justice and national courts'. ${ }^{34}$ In this vein, the Court has held that both the national courts and itself must 'make direct and complementary contributions to the working out of a decision'. ${ }^{35}$ In the CILFIT case, the Court emphasized that this obligation 'is based on cooperation, established with a view to ensuring the proper application and uniform interpretation of Community law in all the Member States, between national courts, in their capacity as courts responsible for the application of Community law, and the Court of Justice' ${ }^{36}$

It has been proposed that the need for this cooperation arises from two limitations of the Union system, viz. the lack of standing for individuals to bring appeals from national judicial decisions to the Court of Justice on the one hand, and the Court's lack of coercive powers to enforce its judgments on the other. ${ }^{37}$ The first deficiency is closely related to the preliminary rulings procedure, which is the only (indirect) way for individuals to challenge national law. ${ }^{38}$ Dehousse has submitted that, on paper, Article 267 TFEU could have given rise to either a hierarchical model, in which the ECJ would have

32 C. Tietje, 'Art. 114 AEUV', in E. Grabitz, M. Hilf, and M. Nettesheim (eds), Das Recht der Europäischen Union (Munich: Beck, 2011), paras 182-183, referring to Case C-319/97 Criminal Proceedings Against Antoine Kortas [1999] ECR I-3143. See note 133.

33 See Case C-344/98 Masterfoods [2000] ECR I-11369, para 49. See further later in this Chapter on the addressees of loyalty.

34 Case C-231/89 Krystyna Gmurzynska-Bscher v Oberfinanzdirektion Köln [1990] ECR I-4003, para 18.

35 Case 16/65 Schwarze ECR 877, 886.

36 Case 283/81 CILFIT [1982] ECR 3415, para 7.

37 M. Cappelletti, The Judicial Process in Comparative Perspective (Oxford: Clarendon Press, 1989). See also J.H.H. Weiler, 'A Quiet Revolution: The European Court of Justice and its Interlocutors', Comparative Political Studies, 26:4 (1994), 510-534, 523, as a requisite of the Court's power.

38 On the political science aspects of preliminary references and judicial dialogue in general, see T. de la Mare, 'Article 177 in Social and Political Context', in P.P. Craig and G. de Búrca (eds), The Evolution of EU Law (Oxford: Oxford Univ. Press, 1999); A.-M. Slaughter, 'A Typology of Transjudicial Communication', University of Richmond Law Review, 29 (1994), 99-132.

This is an open access version of the publication distributed under the terms of the Creative Commons Attribution-NonCommercial-NoDerivs licence (http://creativecommons.org/licenses/by-nc-nd/3.0/), which permits non-commercial reproduction and distribution of the work, in any medium, provided the original work is not altered or transformed in any way, and that the work is properly cited. For commercial re-use, please contact academic.permissions@oup.com 
tried to affirm its own superiority, or a cooperative model based on goodwill and mutual respect. ${ }^{39}$ At the same time, he also noted that the fact that 'Article 177 is entirely dependent on the goodwill of national courts' would militate for the cooperative model. ${ }^{40} \mathrm{I}$ will return to the nature of the preliminary reference procedure in Chapter 11.

Bourgeois has also rightly remarked that Article 260 TFEU on the enforcement of EU law was in fact stating the obvious as far as the EU institutions are concerned and it was an application of the Community loyalty clause as far as Member States are concerned. ${ }^{41}$ AG Geelhoed has made the same observation, specifying that one link with loyalty would be the fact that a situation of illegality must be remedied, and the second would be that the balance of rights and obligations of the Member States under the Treaty must not be disturbed by a Member State arrogating a privileged position to itself in respect of the fulfilment of its Treaty obligations. ${ }^{42}$

\subsection{Loyalty and the Resolution of Conflicts}

We will find the conflict function of loyalty a recurring theme in this study. In the Treaty, it is represented by two leges speciales to Article 4 (3) TEU.

The obligation incumbent on Member States pursuant to Article 344 TFEU 'not to submit a dispute concerning the interpretation or application of the Treaties to any method of settlement other than those provided for therein' is a specific emanation of the general duty of loyalty contained in Article 4 (3) TEU. ${ }^{43}$ In the MOX Plant case, in response to the Commission's claim that Ireland had failed in its duty of cooperation under ex Article 10 EC by bringing arbitral proceedings under the United Nations Convention on the Law of the Sea (UNCLOS) instead of bringing the case before the ECJ, the Court put this as follows:

The obligation devolving on Member States, set out in Article 292 EC, to have recourse to the Community judicial system and to respect the Court's exclusive jurisdiction, which is a fundamental feature of that system, must be understood as a specific expression of Member States' more general duty of loyalty resulting from Article 10 EC. ${ }^{44}$

The Court, consequently, did not find Ireland in breach of ex Article 10 EC, but only of ex Article 292 EC as regards the claim of starting arbitral proceedings. ${ }^{45}$ Although Article 344 TFEU does not deal with the classic form of norm conflict, it is a conflict clause nonetheless. The competence prerogative of the Court of Justice is safeguarded within the field of application of Union law against competing international fora for dispute resolution. ${ }^{46}$

39 R. Dehousse, The European Court of Justice (London: St. Martin's Press, 1998), 136-137.

40 Dehousse, The European Court of Justice, 136-137.

41 J.H.J. Bourgeois, 'The European Court of Justice and the WTO: Problems and Challenges', in J.H.H. Weiler (ed.), The EU, the WTO, and the NAFTA (Oxford: Oxford Univ. Press, 2001), 71-124, 94. 42 AG Geelhoed in Case C-304/02 Commission v France (Fisheries) [2005] ECR I-06263, paras 5 and 8 , referring to solidarity in this context, the relation of which with loyalty will be discussed in Chapter 2.

43 C.-O. Lenz, 'Art. 4', in C.-O. Lenz and K.-D. Borchardt (eds), EU-Verträge, Kommentar nach dem Vertrag von Lissabon, 5th edn. (Cologne and Vienna: Bundesanzeiger Verlag, 2010), para 11.

44 Case C-459/03 Commission v Ireland (MOX Plant) [2006] ECR I-4635, para 169.

45 Note that the Court in this case also found a distinct breach of ex Art. 10 EC concerning the duties of Ireland to inform the Commission, which I will discuss in Chapter 12.

46 See M. Cremona, 'Disconnection Clauses in EU Law and Practice', in C. Hillion and P. Koutrakos (eds), Mixed Agreements Revisited: The EU and its Member States in the World (Oxford and Portland, Oregon: Hart Publishing, 2010), 160-186, 179, who makes the valid point that, had a disconnection clause been included in UNCLOS preserving the autonomy of the Union legal order, the exclusive jurisdiction of the ECJ regarding a conflict between Ireland and the UK would have been much clearer.

This is an open access version of the publication distributed under the terms of the Creative Commons Attribution-NonCommercial-NoDerivs licence (http://creativecommons.org/licenses/by-nc-nd/3.0/), which permits non-commercial reproduction and distribution of the work, in any medium, provided the original work is not altered or transformed in any way, and that the work is properly cited. For commercial re-use, please contact academic.permissions@oup.com 
Article 351 TFEU (ex Article 307 EC) is concerned with the conflict of EU commitments with Member State agreements, and is perhaps the most complex of the specific expressions of loyalty in the Treaty. ${ }^{47}$ Article 351 TFEU is not about a transfer of competence from the Member States to the Union. It is concerned with conflicts between 'obligations' entered into by Member States vis-à-vis third states on the one hand with their obligations under Union law on the other, which are resolved in favour of the Union legal order. ${ }^{48}$ It provides that agreements concluded before 1 January 1958 by Member States with third states shall not be affected by the provisions of the Treaties. It continues:

To the extent that such agreements are not compatible with the Treaties, the Member State or States concerned shall take all appropriate steps to eliminate the incompatibilities established. Member States shall, where necessary, assist each other to this end and shall, where appropriate, adopt a common attitude...

Member States may be required by virtue of Article 351 (2) TFEU to renegotiate or even denunciate their treaties entering into force before 1 January 1958 or prior to a Member State's date of accession. ${ }^{49}$ This may include that Member States would have to amend the respective treaty to enable conclusion by the Union. ${ }^{50}$ This role of Article 351 TFEU has been deemed an application of the general duty of cooperation laid down in Article 4 (3) TEU. ${ }^{51}$

As such, Article 351 TFEU is the logical complement to the conflict rules based on Article 4 (3) TEU.52

\subsection{Loyalty and Duties of Abstention}

Article 92 TFEU (ex Article 72 EC, ex Article 76 EEC) provides for a national standstill obligation in the shared area of transport policy until the Union has passed the measures foreseen under Article 91 TFEU. It prohibits Member States from discriminating directly or indirectly against carriers of other Member States, unless the Council unanimously grants derogation. Germany had introduced a tax on the use of roads for all heavy goods vehicles, but at the same time had reduced the general motor vehicle tax only for national carriers. In the ensuing infringement procedure, the Court found that 'Article 76 of the Treaty seeks to prevent unilateral action by the Member States from making it more difficult for the Council to introduce the common transport policy, which constitutes one of the objectives of the Treaty listed in Article 3'. ${ }^{53}$ As such, the Court continued, 'it constitutes the concrete expression in the sphere of transport of the general obligation, imposed on Member States by Article 5 of the Treaty, to abstain from any measure which

\footnotetext{
47 See J. Klabbers, Treaty Conflict and the European Union (Cambridge: Cambridge Univ. Press, 2009), 116-149.

48 See M. Cremona, 'Defending the Community Interest', 132.

49 See C-62/98 Commission v Portugal [2000] ECR I-5171, para 49.

50 S. Lorenzmeier, 'Art. 351 AEUV', in E. Grabitz, M. Hilf and M. Nettesheim (eds), Das Recht der Europäischen Union (Munich: Beck, 2011), para 47.

51 Joined opinion of AG Tizzano in the 'open skies' cases, [2002] ECR I-9427, para 38. According to AG Tizzano, if the first para of Art. 351 TFEU applies, a Member State's failure to comply with the duty to cooperate in good faith amounts to an infringement of the second paragraph of Art. 351 TFEU.

52 See also Chapter 14.

53 Case C-195/90 Commission v Germany (Heavy Goods Vehicles) [1992] ECR I-3141, para 36. On this see C. Jung, 'Art 92 AEUV', in C. Calliess and M. Ruffert (eds), EUVIAEUV: Das Verfassungsrecht der Europäischen Union mit Europäischer Grundrechtecharta, 4th edn. (Munich: Beck, 2011), paras 2-6.
}

This is an open access version of the publication distributed under the terms of the Creative Commons Attribution-NonCommercial-NoDerivs licence (http://creativecommons.org/licenses/by-nc-nd/3.0/), which permits non-commercial reproduction and distribution of the work, in any medium, provided the original work is not altered or transformed in any way, and that the work is properly cited. For commercial re-use, please contact academic.permissions@oup.com 
could jeopardize the attainment of the objectives of the Treaty'. ${ }^{54}$ Germany was found in breach of ex Article 76 EC only, without a need to 'find a specific failure by that Member State to comply with Article 5 of the Treaty'. ${ }^{55}$

To bar national measures in the area of transport, which is a shared competence under Article 4 (1) (g) TFEU, without the existence of Union legislation, seems to de facto put Member States in the same position as in areas of exclusive competence, such as the Common Commercial Policy. Article 92 TFEU, however, does not bar any sort of transport-related measure by the Member States, but only such measures which are in some way discriminatory. It also includes a prohibition of merely abolishing existing privileges for foreign carriers, a practice that has unsuccessfully been argued in defence by the German Government in the earlier mentioned case. ${ }^{56}$ This makes it an expression of the general prohibition of discrimination now provided for in Article 18 TFEU, rather than of loyalty. Yet, what the objective Article 92 TFEU protects is the ability of the Union to regulate in the area of transport. This shall not be made more difficult by amendments to national laws which risk contradicting the fundamental Treaty principles. ${ }^{57}$ If the standard prohibition of discrimination was the only safeguard here, Member States could claim objective requirements to justify exceptions from this prohibition. This is not possible under Article $92 \mathrm{TFEU}$, from which the only possible derogation requires a (unanimous) Council decision. ${ }^{58}$ In further contrast to Article 92 TFEU, Article 18 TFEU does not bar Member States from putting an end to privileges of citizens of other Member States, as explained earlier.

Loyalty, thus, is not only a rule on conflicts between Union norms and Member State norms, but beyond that, a rule to protect the Treaty objectives even when they have not yet been transformed into legally binding acts, as I will discuss especially in Chapter 5 .

\subsection{Intervention: Combating Fraud}

Article 325 TFEU prescribes that the Union and the Member States shall counter fraud and any other illegal activities affecting the financial interests of the Union. It can be understood as a specification of loyalty in two distinct ways. Article 325 (3) TFEU requires the Member States to 'coordinate their action aimed at protecting the financial interests of the Union against fraud. To this end, they shall organize, together with the Commission, close and regular cooperation between the competent authorities'. Coordination here refers to the aim of abolishing legal and factual divergences between the Member States, which impede the effective combating of fraud. ${ }^{59}$ The cooperation between the national authorities required by Article 325 (3) TFEU implies the need to establish any necessary contact, exchange of information, and joint examination activities. ${ }^{60}$ Article 325 (3) TFEU, thus, represents the institutional, coordinative side of loyalty by requiring the actual cooperation of all parties concerned, similar to Articles 168 and 210 TFEU on health and development policy discussed later.

54 Case C-195/90 Commission v Germany [1992] ECR I-3141, para 36.

55 Case C-195/90 Commission v Germany [1992] ECR I-3141, para 38.

56 See Jung, 'Art 92 AEUV', para 4.

57 See D. Boeing, E. Kotthaus, and T. Maxian Rusche, 'Art. 92 AEUV', in E. Grabitz, M. Hilf, and M. Nettesheim (eds), Das Recht der Europäische Union (Munich: Beck, 2012), para 1.

58 Jung, 'Art 92 AEUV', para 8.

59 See S. Magiera, 'Art. 325 AEUV', in E. Grabitz, M. Hilf, and M. Nettesheim (eds), Das Recht der Europäische Union (Munich: Beck, 2012), para 33.

60 See Magiera, 'Art. 325 AEUV', para 34, and paras 52-56 for the details of this cooperation.

This is an open access version of the publication distributed under the terms of the Creative Commons Attribution-NonCommercial-NoDerivs licence (http://creativecommons.org/licenses/by-nc-nd/3.0/), which permits non-commercial reproduction and distribution of the work, in any medium, provided the original work is not altered or transformed in any way, and that the work is properly cited. For commercial re-use, please contact academic.permissions@oup.com 
Article 325 (2) TFEU requires Member States to 'take the same measures to counter fraud affecting the financial interests of the Union as they take to counter fraud affecting their own financial interests'. This is an expression of the interventionist side of loyalty, which shapes the nature of national law for the aim of safeguarding the interests of the Union. ${ }^{61}$ There is an apparent relation with case law based on loyalty providing for a principle of equivalence when applying sanctions in national law in connection with breaches of Union law, dealt with in detail in Chapter 6. This relation is evidenced by a case on the improper use of Community funds. ${ }^{62}$ The Court could not apply Article 325 (2) TFEU, since this provision was not in force at the material time. ${ }^{63}$ It invoked ex Article 5 EC instead to require the Member States 'to take all effective measures to penalise conduct harmful to the financial interests of the Community, whereby the penalty provided for must be analogous to those applicable to infringements of national law of similar nature and importance, and must be effective, proportionate and dissuasive'. ${ }^{64}$ At the same time, the Court held that the obligation under ex Article 5 EC is 'underlined' by what is now Article 325 (2) TFEU. ${ }^{65}$ It follows that, while Article 325 TFEU is the primary basis for such obligation in the present context, Article 4 (3) TEU can be referred to as a subsidiary legal basis. ${ }^{66}$

\subsection{Conclusion}

The specifications of loyalty in the Treaties discussed earlier tell us an important thing about loyalty, besides showing its diversity. What these provisions have in common is that loyalty is employed to protect a wide range of interests of the Union. It applies to avoid contradicting treaty commitments and prevents the undermining of the jurisdiction of the ECJ in Articles 349 and 351 TFEU. It safeguards the common market objective in the areas of the free movement of services by virtue of the principle of mutual recognition further explored later, and the objectives of Union transport policy under Article 92 TFEU. This 'common' Union interest, that is now explicitly mentioned in the lex specialis Article 197 TFEU, arguably is a general and pivotal point of reference for the application of loyalty especially in the field of external relations and will be analysed in detail in the Part on Cooperation, among others. Loyalty manifests itself as a duty of coordination in Articles 168 and 210 TFEU, as well as in Article 325 (3) TFEU. This will be discussed further in Chapter 8 with respect to non-exclusive competences. Its role in imposing certain standards on sanctions in national law pursuant to Article 325 (2) TFEU is a characteristic further explored in Chapter 6.

Notably, in all these aggregate states, loyalty has by far surpassed the wording of ex Article 10 EC. In the case of mutual recognition and policy area specific coordination, loyalty, for instance, is not primarily an obligation imposed on the Member States in their relation to the Union institutions, but creates obligations amongst the Member

61 See Magiera, 'Art. 325 TFEU', para 7.

62 Case C-186/98 Criminal Proceedings Against Maria Amélia Nunes and Evangelina de Matos [1999] ECR I-4883.

63 AG Jacobs in Case C-186/98 Nunes [1999] ECR I-4883, para 9.

${ }^{64}$ Case C-186/98 Nunes [1999] ECR I-4883, para 14.

65 Case C-186/98 Nunes [1999] ECR I-4883, para 13.

66 Magiera, 'Art. 325 TFEU', para 8, has pointed to the wording '(w)ithout prejudice to other provisions of the Treaties' in support of this claim.

This is an open access version of the publication distributed under the terms of the Creative Commons Attribution-NonCommercial-NoDerivs licence (http://creativecommons.org/licenses/by-nc-nd/3.0/), which permits non-commercial reproduction and distribution of the work, in any medium, provided the original work is not altered or transformed in any way, and that the work is properly cited. For commercial re-use, please contact academic.permissions@oup.com 
States themselves. The amended basis of loyalty in Article 4 (3) TEU now better reflects this broad range of the addressees of loyalty, by explicitly referring to mutual duties of cooperation.

\section{Loyalty and National Identities}

While under the preceding Treaties it was a stand-alone provision, loyalty in Article 4 (3) TEU is now grouped together with two quite distinct provisions in Article 4 (1) and (2) TEU. I would argue that this has fundamentally changed the normative context loyalty is placed in compared to the Nice Treaty. ${ }^{67}$ Article 4 (1) TEU is the logical opposite to the conferral rule contained in Article 5 TEU, emphasizing that powers not conferred remain with the Member States. ${ }^{68}$ Article 4 (2) TEU is a partly novel provision safeguarding the Member States' 'national identities', 'their essential State functions', and the area of 'national security' ${ }^{69}$ This is not the place to discuss exhaustively these new statements of reserved domains of the Member States. ${ }^{70}$ However, some comments are warranted in light of voices in the literature suggesting a certain relation between especially Article 4 (2) TEU and loyalty. Thus, Vedder has submitted that the respect of 'national identities' in Article 4 (2) TEU would be an emanation of the general principle of loyalty and that there would be a tension between this provision and the principle of solidarity. ${ }^{71}$ At the same time, he has claimed that the duty of cooperation between the Member States flowing from the general principle of loyalty is a specification of the solidarity between Member States. ${ }^{72}$ This, above all, demonstrates the need to explore whether there is a difference between solidarity and loyalty, which will be done in Chapter 2. Moreover, I would argue that if loyalty should thus be equivalent both to solidarity and to the protection of national identities, it defies logic to claim that there is a tension between solidarity and national identities. In any event, it is at odds with considering especially Article 4 (2) TEU on national identities well placed next to Article 4 (3) TEU on loyalty. ${ }^{73}$

Epiney has framed the concept now provided in Article 4 (2) TEU as an element of loyalty. ${ }^{74}$ She has argued that the respect for the federal structure of a Member State, notably of Germany, would ensure the attainment of Union objectives, since a Member

67 For a different perspective, see A. von Bogdandy and S. Schill, 'Art. 4 EUV', in E. Grabitz, M. Hilf and M. Nettesheim (eds), Das Recht der Europäische Union (Munich: Beck, 2010), para 1, who see the whole of Art. $4 \mathrm{TEU}$ as the key for the federal structure of the union.

68 Art. 4 (1) TEU.

69 'The Union shall respect the equality of Member States before the Treaties as well as their national identities, inherent in their fundamental structures, political and constitutional, inclusive of regional and local self-government. It shall respect their essential State functions, including ensuring the territorial integrity of the State, maintaining law and order and safeguarding national security. In particular, national security remains the sole responsibility of each Member State.'

70 See Lenz, 'Art. 4', paras 3-8; T. Konstadinides, 'Constitutional Identity as a Shield and as a Sword: The European Legal Order within the Framework of National Constitutional Settlement', Cambridge Yearbook of European Legal Studies, 13 (2010-2011), 195-218; L. Besselink, 'National and Constitutional Identity before and after Lisbon', Utrecht Law Review, 6:3 (2010), 36.

71 C. Vedder, 'Art. I-5', in C. Vedder and W. Heintschell von Heinegg (eds), Europäischer Verfassungsvertrag (Baden-Baden: Nomos, 2007), para 1 and para 3.

72 Vedder, 'Art I-5', para 18.

74 A. Epiney, 'Gemeinschaftsrecht und Föderalismus: "Landes-Blindheit” und Pflicht zur Berücksichtigung innerstaatlicher Verfassungsstrukturen', Europarecht, (1994), 301-324, 323. Agreeing with her, A. von Bogdandy, 'Europäische Prinzipienlehre', in A. von Bogdandy (ed.), Europäisches Verfassungsrecht: Theoretische und dogmatische Grundzüge (Heidelberg: Springer, 2003), 149-203, 202.

This is an open access version of the publication distributed under the terms of the Creative Commons Attribution-NonCommercial-NoDerivs licence (http://creativecommons.org/licenses/by-nc-nd/3.0/), which permits non-commercial reproduction and distribution of the work, in any medium, provided the original work is not altered or transformed in any way, and that the work is properly cited. For commercial re-use, please contact academic.permissions@oup.com 
State, whose national constitutional identity was not respected by the Union, would cease to contribute to fulfilling the Union interest. ${ }^{75}$ Instead, such Member State would act in self-interest and obstruct the work of the Union as a reaction. ${ }^{76} \mathrm{I}$ would proffer that it is somewhat circular to claim that by not respecting the particular interests of a Member State and because of that State's ensuing act of defiance, the fulfilment of the objectives of the Union were jeopardized, which in turn would give rise to an obligation to protect national interests to prevent this from happening in the first place. Although, as I will explain later in this Chapter, loyalty in the European Union is not a one-way obligation and it is incumbent on the Union institutions to take into account interests of the Member States, the Court has applied this 'reverse' duty of loyalty only in specific, rather technical cases. As far as I can see, case law does not suggest that loyalty should oblige the Union, in a general manner, to take account of interests of individual Member States for preserving their national identity. ${ }^{77}$ Hence, it is for good reason that the Lisbon Treaty provides for a specific clause safeguarding the respect of national identities, since this arguably cannot be read into Article 4 (3) TEU proper. That this is done, however, next to the provision on loyalty, is difficult to understand, for the following reasons. As will be shown throughout this book, loyalty in manifold ways has the effect of furthering the integration of the Member States as constituent elements of the European Union, of providing the basis for all sorts of duties of cooperation, and of interlocking the legal regimes of the Member States with the Union. In short, loyalty expresses the gravitational force of European Union law. ${ }^{78}$ The reservations made in Article 4 (2) TEU represent rather the opposite idea of periphery, since, when understood extensively, they are another limit to the exercise of Union competence besides subsidiarity and proportionality. ${ }^{79}$ While loyalty, as I will argue later, is one of the foundations of supremacy, Article 4 (2) TEU has been qualified as a principle to oppose the supremacy of Union law. ${ }^{80}$ Craig has shown that the notion of 'constitutional identity' first appeared in a decision by the French Conseil Constitutionnel, where it served as a conflict resolution mechanism in favour of national interests. ${ }^{81}$ The safeguarding of national identities is perhaps an even more absolute limit than the mentioned principles of subsidiarity and proportionality, which both comprise a strong element of balancing the interests and capabilities of the Union with those of the Member States. Hence, Article 4 (2) TEU

75 Epiney, 'Gemeinschaftsrecht und Föderalismus', 317. In a similar sense, E. Grabitz, 'Art. 5 EWGV', in E. Grabitz (ed.), Kommentar zum EWG-Vertrag (Munich: Beck, 1992), para 17.

76 Epiney, 'Gemeinschaftsrecht und Föderalismus', 317. Weiler's metaphor of exit and voice comes to mind here. See J.H.H. Weiler, 'The Transformation of Europe', The Yale Law Journal, (1991), 2403-2483.

77 See the discussion by M. Claes, 'Negotiating Constitutional Identity or Whose Identity is it Anyway?', in M. Claes et al. (eds), Constitutional Conversations in Europe: Actors, Topics and Procedures (Cambridge: Intersentia, 2012), 205-233, 226-227. Not even as a 'lighter' duty of consideration, as it has been put by A. Epiney, 'Zur Tragweite des Art. 10 EGV im Bereich der Außenbeziehungen', in J. Bröhmer and G. Ress (eds), Internationale Gemeinschaft und Menschenrechte: Festschrift für Georg Ress zum 70. Geburtstag am 21. Januar 2005 (Cologne: Heymanns, 2005), 441-459, 446.

78 Loyalty has been argued to encompass the positive duty of Member States to avoid conflict, which might be relevant the more competences are conferred to the Union, thus reducing a 'subsidiarian' Europe. See Konstadinides, 'Constitutional Identity', 207-208.

79 Vedder, 'Art I-5', para 3.

80 F.C. Mayer, 'Art. 19 EUV', in E. Grabitz, M. Hilf, and M. Nettesheim (eds), Das Recht der Europäischen Union (Munich: Beck, 2011), para 38.

${ }^{81}$ B. de Witte, 'Direct Effect, Primacy and the Nature of the Legal Order', in P.P. Craig and G. de Búrca, The Evolution of EU Law, 2nd edn. (Oxford: Oxford Univ. Press, 2011), 323-362, 355.

This is an open access version of the publication distributed under the terms of the Creative Commons Attribution-NonCommercial-NoDerivs licence (http://creativecommons.org/licenses/by-nc-nd/3.0/), which permits non-commercial reproduction and distribution of the work, in any medium, provided the original work is not altered or transformed in any way, and that the work is properly cited. For commercial re-use, please contact academic.permissions@oup.com 
might be a good match with the principle of conferral expressed in Article 4 (1) TEU, but less so with regard to loyalty. ${ }^{82}$

The connection between loyalty and Article 4 (2) TEU has also been made in the Lisbon judgment of the German Constitutional Court (BVerfG). In this judgment, which I will also discuss in Chapter 11, the BVerfG among other things reviewed 'whether the inviolable core content of the constitutional identity of the Basic Law ... is respected'. ${ }^{83}$ If Germany were to become a 'constituent State of a European federal State', this would amount to a change of the identity of Germany and a 'loss of statehood'. ${ }^{84}$ This was claimed to follow the 'principle of the Basic Law's openness towards European Law (Europarechtsfreundlichkeit)' and therefore not to contradict the principle of sincere cooperation provided in Article 4 (3) TEU. Without such review, according to the BVerfG, 'the fundamental political and constitutional structures of sovereign Member States' recognized by Article 4 (2) TEU could not be safeguarded. ${ }^{85}$ As argued, the principles enshrined in respectively Article 4 (2) and 4 (3) TEU are opposed to each other in a fundamental manner. If their application would have to be squared, this I would submit firstly cannot be the task of a national (constitutional) court, and secondly it cannot concern the review of provisions of an EU Treaty. Firstly, because if anybody would be entitled to review the claim of a violation of Article 4 (2) TEU, this would have to be the ECJ, not the respective national constitutional courts. ${ }^{86}$ This could entail from a request for a preliminary ruling regarding the interpretation of Article 4 (2) TEU by national constitutional courts, such as the BVerfG ${ }^{87}$ Secondly, if Article 4 (2) TEU were to be applied, e.g. with a claim for annulment, this would have to relate to Union secondary law but not as a standard of review for provisions in another EUTreaty, as it was done by the BVerfG.

It has been argued, with reference to the pre-Lisbon provision of Article 6 (3) TEU, that the obligation under Article 4 (2) TEU is subordinate to the obligations of the Member States to respect the EU's objectives in Article 3 TEU, ${ }^{88}$ and would thus also be subordinate to Article 4 (3) TEU. While it is not fully fathomable what the Court will make of Article 4 (2) TEU in the future, and whether it will not invoke it somehow offsetting the integrationist impetus that Article 4 (3) TEU possessed so far, it seems likely now that paragraph 2 will primarily be invoked in free movement and union citizenship cases in order to justify obstacles put up by Member States in defence of national interests. ${ }^{89}$ This would not directly place it in opposition to loyalty, but would

82 Konstadinides, 'Constitutional Identity', 218, arguing that Art. 4 (2) TEU carries the potential of complementing the principle of conferral under Art. 5 TEU, 'in that both provisions, in tandem, express the core of EU authority in the constitutional order of Member States'.

83 Konstadinides, 'Constitutional Identity', 218.

84 See, critical, D. Thym, 'In the Name of Sovereign Statehood: A Critical Introduction to the Lisbon Judgment of the German Constitutional Court', Common Market Law Review, (2009), 1795-1822, 1796. This implies a guarantee of Germany's membership in a European Union as an association of sovereign states instead of as a federal state. See also Thym, 'In the Name of Sovereign Statehood', 1799.

85 Case BvE 2/08 Lisbon.

86 Mayer, 'Art. 19 EUV', para 90, has argued that identity control is not national law-centred since the respect of Member States' 'national identities, inherent in their fundamental structures, political and constitutional, inclusive of regional and local self-government' is now explicitly provided by the Treaty. See also Claes, 'Negotiating Constitutional Identity', 207.

87 See, in this sense, Mayer, 'Art. 19 EUV', para 91.

88 Konstadinides, 'Constitutional Identity as a Shield and as a Sword', 199.

89 See AG Maduro in Case C-213/07 Michaniki AEv Ethniko Symvoulio Radiotileorasis and Ypourgos Epikrateias [2008] ECR I-9999, para 33; Case C-208/09 Ilonka Sayn-Wittgenstein v Landeshauptmann von Wien [2010] ECR I-13693; Konstadinides, 'Constitutional Identity as a Shield and as a Sword', 201-204.

This is an open access version of the publication distributed under the terms of the Creative Commons Attribution-NonCommercial-NoDerivs licence (http://creativecommons.org/licenses/by-nc-nd/3.0/), which permits non-commercial reproduction and distribution of the work, in any medium, provided the original work is not altered or transformed in any way, and that the work is properly cited. For commercial re-use, please contact academic.permissions@oup.com 
see its frame of application rather cabined by the principles governing the application of the fundamental freedoms. ${ }^{90}$ There is thus no indication now that the context the loyalty principle is placed in by the Lisbon Treaty should influence its scope or effect.

\section{The Vectors of the Application of Loyalty}

\subsection{Horizontal Loyalty}

With horizontal loyalty, I refer to obligations derived from Article 4 (3) TEU applying between the Member States. ${ }^{91}$ Thus, besides governing the (vertical) relationship between the Union institutions and the Member States, which is discussed later, the duties of cooperation such as those provided in Article 210 (1) TFEU on development cooperation and Article 168 TFEU on health policy concern the relationship between the Member States. ${ }^{92}$ Both provisions must be seen as an expression of a general obligation of loyalty. ${ }^{93}$ Another example is the provision in the earlier mentioned Article 351 TFEU on requiring Member States to assist each other 'where necessary' in eliminating incompatibilities between their 'old' treaties and Union law and to adopt a common attitude 'where appropriate'. ${ }^{94}$

Another more intricate example of duties of loyalty applying to the relationship between the Member States is mutual recognition. This principle requires Member States to consider other Member States' regulatory decisions in observance of the objective of the furtherance of the common market. ${ }^{95}$ The Professional Qualifications Directive 2005/36 enshrines this principle for established and non-established professionals. ${ }^{96}$ The fifth recital of the preamble of the precursor Directive confirmed the link between loyalty and the mutual recognition of diplomas. It stated that Member States would infringe ex Article $5 \mathrm{EC}$ if they required a national of a Member State to produce diplomas

90 Konstadinides, 'Constitutional Identity as a Shield and as a Sword', 207.

91 See E. Schmidt-Aßmann, 'Verwaltungskooperation und Verwaltungskooperationsrecht in der Europäischen Gemeinschaft', Europarecht, 3 (1996), 270-301, 294, who has considered ex Art. 5 EC a sufficiently broad basis for a comprehensive regime of administrative cooperation.

92 Art. 210 TFEU has the following wording: '(I)n order to promote the complementarity and efficiency of their action, the Union and the Member States shall coordinate their policies on development cooperation and shall consult each other on their aid programmes, including in international organisations and during international conferences.'

Art. 168 TFEU provides the following: 'The Union shall encourage cooperation between the Member States in the areas referred to in this Article and, if necessary, lend support to their action... Member States shall, in liaison with the Commission, coordinate among themselves their policies and programmes in the areas referred to in paragraph 1...' I will discuss both provisions in detail in Chapter 8 in the Part on Cooperation.

93 See, for Art. 168, B. Schmidt am Busch, 'Art. 168 AEUV', in E. Grabitz, M. Hilf, and M. Nettesheim (eds), Das Recht der Europäischen Union (Munich: Beck, 2011), para 26. See, for Art. 210, W. Benedek, 'Art. 210 AEUV', in E. Grabitz, M. Hilf, and M. Nettesheim (eds), Das Recht der Europäischen Union (Munich: Beck, 2011), para 3.

94 See S. Lorenzmeier, 'Art. 351 AEUV', in E. Grabitz, M. Hilf, and M. Nettesheim (eds), Das Recht der Europäischen Union (Munich: Beck, 2011), para 39.

95 See Case C-76/90 Säger [1991] ECR I-4221, para 15: ‘ . . in so far as that interest is not protected by the rules to which the person providing the services is subject in the Member State in which he is established.'

96 Directive (EC) 2005/36 on the recognition of professional qualifications [2005] OJ L255/22. In areas not covered by this regime, the Court continues to apply the principle of equivalence introduced in Case C-340/89 Vlassopoulou [1991] ECR I-2357, para 14, which, in turn, was inspired by the forerunners to Dir 2005/36. See further P.P. Craig and G. de Búrca, EU Law: Text, Cases and Materials, 5th edn. (Oxford: Oxford Univ. Press, 2011), 812.

This is an open access version of the publication distributed under the terms of the Creative Commons Attribution-NonCommercial-NoDerivs licence (http://creativecommons.org/licenses/by-nc-nd/3.0/), which permits non-commercial reproduction and distribution of the work, in any medium, provided the original work is not altered or transformed in any way, and that the work is properly cited. For commercial re-use, please contact academic.permissions@oup.com 
issued under the Member State's own education systems, where that person has already acquired all or part of those qualifications in another Member State. ${ }^{97}$

It has been argued that mutual recognition would require all actors to take due account of the others' legitimate interests in the exercise of their own competencies and functions, and that loyalty would embrace 'the message that the EU legal system can be autonomous only to the extent it is accepted or mutually recognised by the other legal systems' ${ }^{98}$ I would argue that one could adopt a broad or a narrow understanding of mutual recognition against this background.

The broad perspective is represented by the view of the Cassis de Dijon principle as a case of 'judicial' mutual recognition. ${ }^{99}$ As is well known, the Court was establishing the general prohibition of restrictions under the free movement of goods pursuant to Article $34 \mathrm{TFEU}$, allowing the free circulation of goods in the Union, provided they have lawfully been marketed in one Member State. A Member State, therefore, is required to accept the decision of other Member States on the quality and safety of goods as a matter of principle, except when it can invoke certain mandatory requirements as defined in Cassis. The German rule under review in Cassis de Dijon was assessed on its own, without looking for substantive functional equivalencies between home and host state rule. ${ }^{100}$

In contrast, a more narrow understanding would emphasize the mentioned close association between mutual recognition and loyalty, arguing for some degree of referral to the legal or factual situation in the home state, thus some degree of actual, factual cooperation on the side of the Member States. ${ }^{101}$ By this perspective, an automatism in co-opting regulatory decisions of other Member States, even if it only operates as a rule subject to exceptions such as in the Cassis de Dijon case law, would not qualify as mutual recognition.

\subsection{Vertical Loyalty}

On the part of the Member States, it is not difficult to identify the addressees of obligations based on loyalty. The main thrust of Article 4 (3) TEU and of loyalty clearly are obligations imposed on the Member States, as we will see throughout this book. Loyalty addresses all branches in the national state. The continued predominance of this vertical relationship is also reflected by the fact that the Lisbon Treaty has added only one paragraph not exclusively dealing with this vertical bond. A number of cases have clarified that not only the executive and legislative authorities of the Member States are bound by loyalty vis-à-vis the Union, but the national judiciary is bound as well. ${ }^{102}$ Since all

97 See Case C-102/02 Beuttenmüller [2004] ECR I-5405.

98 D. Curtin and I. Dekker, 'The Constitutional Structure of the European Union: Some Reflections on Vertical Unity-in-Diversity', in P. Beaumont, S. Lyons, and N. Walker (eds), Convergence and Divergence in European Public Law (Oxford and Portland, Oregon: Hart Publishing, 2002), 59-78, 70. See further Chapter 4 in the Part on Cohesion on this structural argument.

99 J. Pelkmans, 'Mutual Recognition in Goods: On Promises and Disillusions', Journal of European Public Policy, (2007), 699-716, 702.

100 See K. Armstrong, 'Mutual Recognition', in C. Barnard and J. Scott (eds), The Law of the Single European Market: Unpacking the Premises (Oxford and Portland, Oregon: Hart Publishing, 2002), 225-267, 233-235.

101 See M. Klamert, 'Of Empty Glasses and Double Burdens: Approaches to Regulating the Services Market à propos the Implementation of the Services Directive', Legal Issues of Economic Integration, (2010), 111-132. See also Armstrong, 'Mutual Recognition', 230, who uses the term 'other-regarding'.

102 See the Opinion of AG Colomer in Case C-431/05 Merck Genéricos [2007] ECR I-7001, para 56. See also Joined cases C-300/98 and C-392/98 Dior [2000] ECR I-11307, paras 36-38; Joined cases C-261/07 VTB-VAB and C-299/07 Galatea [2009] ECR I-2949, para 39; Case C-106/89 Marleasing v

This is an open access version of the publication distributed under the terms of the Creative Commons Attribution-NonCommercial-NoDerivs licence (http://creativecommons.org/licenses/by-nc-nd/3.0/), which permits non-commercial reproduction and distribution of the work, in any medium, provided the original work is not altered or transformed in any way, and that the work is properly cited. For commercial re-use, please contact academic.permissions@oup.com 
authorities of the Member States are required to ensure that the provisions of Union law take full effect, this also applies to national courts. ${ }^{103}$ Another case in point is the exclusive jurisdiction of the European Court of Justice over the interpretation of mixed agreements, discussed in detail in Chapter 10 in the Part on Cooperation. It has been written that 'the interpretation the Court is called upon to give represents its contribution to the fulfilment of the duty of cooperation between institutions and Member States... '104

Loyalty applies to the Member States even when they act within their own competences, or when they operate outside of the Treaty entirely. Grabitz argued in 1992 that loyalty binds the Member States also within their own sphere of sovereignty, obliging them to act in a manner to further the interests of the Union. ${ }^{105}$ This is supported by case law on the duties of the Member States as parties to mixed agreements. This will be explored fully in Chapter 10. Suffice it to note here that in this context the Court has repeatedly held that the duty of cooperation applies 'where it is apparent that the subject matter of an agreement or convention falls in part within the competence of the Community and in part within that of the Member States. ${ }^{106}$ The Court also held that by ensuring respect for Union commitments the Member States 'fulfil an obligation of Community law as well'. ${ }^{107}$ Thus, Member States are bound by Union law obligations and in particular by the duty of cooperation when they exercise their reserved competences within the context of a mixed agreement. ${ }^{108}$

Another example of loyalty's application in matters of national competence is case law that curtails the freedom of the Member States with regard to their national tax laws. While the Member States, as a matter of principle, are entitled to levy taxes on reimbursements for expenses by the European Parliament to its Members from Union funds, such charges are not permissible when the payments cover expenses, even when payment is received as a lump sum. The Court decided that loyalty applies to national tax laws applicable to Members of the European Parliament and held that there is a duty not to take measures which are likely to interfere with the internal functioning of the institutions of the Community'. ${ }^{109}$

Comercial Internacional de Alimentación [1990] ECR I-4135, para 8. See M. Cremona, 'Defending the Community Interest', 158, stressing that the duty of cooperation enshrined in Art. 4 (3) also applies to the cooperation between national courts and the Court of Justice.

103 Case C-212/04 Adelener [2006] ECR I-6057, para 122.

104 AG Tesauro in Case C-53/96 Hermès International [1998] ECR I-3603, para 21.

105 See E. Grabitz, 'Art. 5 EWGV', in E. Grabitz (ed.), Kommentar zum EWG-Vertrag (Munich: Beck, 1992), para 1.

106 See Ruling 1/78 IAEA [1978] ECR 2151, paras 34-36; Opinion 2/91 ILO [1993] ECR I-1061, para 36; Opinion 1/94 WTO [1994] ECR I-5267, para 108, and Opinion 2/00 Cartagena Protocol on Biosafety [2001] ECR I-9713, para 18.

107 Case 104/81 Kupferberg [1982] ECR 3641, para 13. See I. Cheyne, 'Haegeman, Demirel and their Progeny', in A. Dashwood and C. Hillion (eds), The General Law of EC External Relations (London: Sweet \& Maxwell, 2000), 20-41.

108 See also C. Hillion, 'Mixity and Coherence in EU External Relations: The Significance of the "Duty of Cooperation"', CLEER Working Papers, 2 (2009), 21-26, who has argued that Member States must 'fulfil all obligations they have undertaken so as not to compromise the Community's position and the achievement of its objectives under the agreement, and if need be to cooperate with it to address possible compliance deficiencies'. Hillion mentions the example of a Member State's breach of foreign and defence policy obligations flowing from a mixed agreement (a Member States competence), which could trigger the other party's cross-retaliation in the form of a reduction or suspension of trade in goods manufactured in the defaulting state (an EU competence).

109 Case 208/80 Lord Bruce of Donington [1981] ECR 2205, para 14; Case C-333/88 Tither [1990] ECR I-1133, para 16.

This is an open access version of the publication distributed under the terms of the Creative Commons Attribution-NonCommercial-NoDerivs licence (http://creativecommons.org/licenses/by-nc-nd/3.0/), which permits non-commercial reproduction and distribution of the work, in any medium, provided the original work is not altered or transformed in any way, and that the work is properly cited. For commercial re-use, please contact academic.permissions@oup.com 
The vertical application of loyalty finds its limits with purely political matters. The Court held that Member States are not required to cooperate in the Council, to make compromises, or to form majorities when possible. ${ }^{110}$ Moreover, Member States are not obliged to act in the common interest or to refrain from pursuing national interests within the Union institutions. ${ }^{111}$ Thus, loyalty plays no role in protecting minority interests in the Council, nor does it require Member States to accommodate the positions of other Member States when voting. ${ }^{112}$ Moreover, loyalty cannot be invoked as the legal basis for obstructing majority decisions. ${ }^{113}$

I would argue that this 'political exception' within the Union institutions applies a fortiori outside the realm of Union law. Thus, the sanctions that were adopted by the (then seventeen) Member States against Austria in response to its far-right government involving Jörg Haider's Freedom Party in 1999 should not be seen as an application of ex Article 10 EC. ${ }^{114}$ This would be different if one could argue that these sanctions jeopardized the interests of the Union. As the earlier discussion has shown, loyalty does not protect the interests of one Member State against the interests of other Member States, but it is primarily about the safeguarding of Union interests. ${ }^{115}$ Loyalty might therefore only have applied if the actions by the other Member States had affected the proper functioning of the Union or of its institutions. However, the sanctioning Member States apparently took great care to confine their actions to the bilateral level, such as sidelining Austrian representatives in diplomatic matters. ${ }^{116}$

\subsection{Reverse Vertical Loyalty}

While Member States are the foremost addressees of loyalty, Article 4 (3) TEU has always been employed by the Court to also prescribe mutual duties of cooperation between the Union institutions and the Member States and between the Union and Member State institutions. ${ }^{117}$ It has thus emphasized what is now explicitly stated in Article 4 (3) TEU, namely that loyalty rests on mutual duties, which bind not only the Member States but also the Union institutions. It has even been claimed that loyalty is equally strong when it applies to the Union institutions as when it binds the Member States. ${ }^{118}$ However, that this mutuality overall is asymmetrical is exemplified by the

110 Joined cases C-63/90 and C-67/90 PortugalandSpainv Council[1992] ECR I-5073, paras 52-53.

111 Joined cases C-63/90 and C-67/90 PortugalandSpainv Council[1992] ECR I-5073, paras 52-53.

112 See A. von Bogdandy, 'Rechtsfortbildung mit Art. 5 EG-Vertrag', in A. Randelzhofer, R. Scholz and D. Wilke (eds), Gedächtnisschrift für Eberhard Grabitz (Munich: Beck, 1995), 17-28, 27.

113 See J. Wieland, 'Germany in the European Union: The Maastricht Decision of the Bundesverfassungsgericht', European Journal of International Law, 5 (1994), 259-266, 262, who discusses a statement by the BVerfG.

114 But see P. Unruh, 'Die Unionstreue-Anmerkungen zu einem Rechtsgrundsatz der Europäischen Union', Europarecht, (2002), 41-66, 41-46. Instead, it has been argued that they constituted an unfriendly act under international law. See D. Richter, 'Unfriendly Act', Max Planck Encyclopedia of Public International Law (Heidelberg and Oxford: Oxford Univ. Press, 2013) (<http://www.mpepil. com>), para 25 .

115 When Member State interests have been considered by the Court, this was mostly done to counterbalance the pursuit of Union interests, such as in infringement proceedings. See Chapter 12.

116 See Unruh, 'Die Unionstreue', 41.

117 Joined cases 358/85 and 51/86 France v European Parliament [1988] ECR 4821, paras 34-35; Joined cases C-213/88 and C-39/89 Luxemburg v European Parliament [1991] ECR I-5643; Case C-275/00 Franex NV [2002] ECR I-10943, para 49; Case C-232/01 Criminal Proceedings Against Hans van Lent [2003] ECR I-11525, paras 72-77; Case C-234/89 Delimitis [1991] ECR I-935, para 53; Case C-344/01 Germany $v$ Commission [2004] ECR I-2081, para 79.

118 See Hillion, 'Mixity and Coherence', 29, who also relies on the IMO case, where the Commission was subjected to an obligation to consider the proposal by Greece in the Marsec. However, as I will

This is an open access version of the publication distributed under the terms of the Creative Commons Attribution-NonCommercial-NoDerivs licence (http://creativecommons.org/licenses/by-nc-nd/3.0/), which permits non-commercial reproduction and distribution of the work, in any medium, provided the original work is not altered or transformed in any way, and that the work is properly cited. For commercial re-use, please contact academic.permissions@oup.com 
fact that legislative action by the Council can never constitute a breach of ex Article 10 EC. ${ }^{119}$ This stands in stark contrast to lawmaking by the national legislators, which is one of the prime targets of the obligations under Article 4 (3) TEU.

The first statement ever by the Court on mutual duties of cooperation based on ex Article 5 EEC is made obiter in a case Luxembourg had brought against the European Parliament. ${ }^{120}$ This statement is confirmed by subsequent case law on the exercise of the powers of the Member States in relation to establishing the seat of the European Parliament. Because Strasbourg had been designated the provisional meeting place for the Parliament's plenary sittings, France contested measures establishing plenary facilities in Brussels. The Court finely balanced its prescription. While it imposed a duty on the Parliament 'to have regard' to Member State powers for establishing the seat of the institutions and to the decisions taken provisionally by them in the meantime, the Court also required the Member States to respect the powers and the functioning of the Parliament in taking these decisions. ${ }^{121}$ This is a duty to consider the powers and thus the interests of the Member States in establishing the seat of the institutions. It is against the background of such duty of consideration that the Court affirmed the right of the Parliament to hold part-sessions away from Strasbourg if 'such a decision remains exceptional in nature, thus respecting the position of that city as the normal meeting place, and is justified by objective reasons connected with the proper functioning of the Parliament' ${ }^{122}$ According to Article 341 TFEU, the seat of the institutions of the Union is determined by 'common accord' of the governments of the Member States, which is subject to the application of Article 4 (3) TEU. ${ }^{123}$

The leading case for the reverse relationship regarding duties of loyalty is the quite peculiar case of Zwartveld. ${ }^{124}$ At issue was the request by the Dutch rechter-commissaris for the production of information and documents by the Commission for prosecuting fraud in connection with the EC fish marketing regulations. This rechter-commissaris was not a court within the meaning of ex Article 177 EEC (now Article 267 TFEU), cutting it off from the normal means of judicial dialogue in the EU. ${ }^{125}$ What followed was a decision to escape 'the narrowness and inadequacies of positive law' in order to safeguard loyalty and the protection of individual rights. ${ }^{126}$ The Court conspicuously took a deep argumentative breath, quoting Costa and Les Verts to make a general case for the existence of the rule of law in the European Union. ${ }^{127}$ The Court continued by invoking ex Article 5

explain in Chapter 12, this duty imposed on the Commission was very weak, and the Court found a violation of much stronger obligations flowing from ex Art. $10 \mathrm{EC}$ against Greece.

119 See, however, Joined cases C-63/90 and C-67/90 Portugal and Spain v Council [1992] ECR I-5073, paras 52-53.

120 Case 230/81 Luxembourg v European Parliament (Seat and Working Place of the Parliament) [1983] ECR 255, para 37.

121 Joined cases 358/85 and 51/86 France v European Parliament [1988] ECR 4821, paras 34-35.

122 Joined cases 358/85 and 51/86 France v European Parliament [1988] ECR 4821, para 36.

123 F.C. Mayer, 'Art. 341 TFEU', in E. Grabitz, M. Hilf, and M. Nettesheim (eds), Das Recht der Europäischen Union (Munich: Beck, 2011), para 36.

124 Case C-2/88 Imm. Zwartveld [1990] ECR I-3365.

125 See B. de Witte, 'Interpreting the EC Treaty Like a Constitution: The Role of the European Court of Justice in Comparative Perspective', in R.C.L. Bakker, A.W. Heringa, and F.A.M. Stroink (eds), Judicial Control: Comparative Essays on Judicial Review (Antwerp: Apeldoorn, 1995), 133-152, 142.

126 See G. Tesauro, 'The Effectiveness of Judicial Protection and Co-operation between the Court of Justice and the National Courts', Yearbook of European Law, (1993), 1-17, 12.

127 Case C-2/88 Imm. Zwartveld [1990] ECR I-3365, paras 15-16. See the Court's reasoning, in para 23 , for affirming its jurisdiction 'to review, at the request of a national judicial authority and by means of a legal procedure appropriate to the objective pursued by that authority, whether the duty of sincere cooperation, incumbent on the Commission in this case, has been complied with'.

This is an open access version of the publication distributed under the terms of the Creative Commons Attribution-NonCommercial-NoDerivs licence (http://creativecommons.org/licenses/by-nc-nd/3.0/), which permits non-commercial reproduction and distribution of the work, in any medium, provided the original work is not altered or transformed in any way, and that the work is properly cited. For commercial re-use, please contact academic.permissions@oup.com 
EEC in order to proclaim duties of the Commission vis-à-vis the rechter-commissaris, in spite of the privileges and immunities of the EC, ${ }^{128}$ with the following words:

This duty of sincere cooperation imposed on Community institutions is of particular importance vis-à-vis the judicial authorities of the Member States, who are responsible for ensuring that Community law is applied and respected in the national legal system. ${ }^{129}$

Loyalty here can be seen as applying to the Commission on the one hand and to the Court on the other. The Commission was not only ordered to produce any documents required by the rechter-commissaris, but also to have their staff testify before it. The Commission could only refuse to provide the pertinent information by claiming imperative reasons relating to the need to avoid any interference with the functioning and independence of the Communities justifying its refusal to do so'. ${ }^{130}$ The Court of Justice considered itself bound to hear the request from the rechter-commissaris although technically it did not constitute a preliminary reference. We might therefore even say that Zwartveld applied loyalty in two ways, once in the form of the loyalty-based preliminary reference procedure, which was admitted in this case based on loyalty. ${ }^{131}$

While loyalty applies to all main organs of the Union apart from the Council, where the Court imposed duties of reverse loyalty, these were often a reflection and logical extension of distinct duties of cooperation on the part of the Member States. Thus, ex Article 100a (4) EC (now Article 114 (4) TFEU) was applied in combination with ex Article 10 EC to impose on Member States an obligation to notify provisions of national law that remain in force despite being incompatible with a harmonization measure. ${ }^{132}$ In exchange, the Court required the Commission to demonstrate 'the same degree of

128 Protocol on the Privileges and Immunities of the European Communities, attached to the Treaty Establishing a Single Council and Single Commission of the European Communities of 8 April 1965. See P. Lasok, The European Court of Justice: Practice and Procedure, 2nd edn. (London: Butterworths, 1994), 575.

129 Case C-2/88 Imm. Zwartveld [1990] ECR I-3365, para 18. See also Joined cases C-200/07 and C-201/07 Marra [2008] ECR 1, para 41. The Court in cases such as Case C-234/89 Stergios Delimitis $v$ Henninger Bräu AG [1991] ECR I-935 applied this finding in Zwartveld in a more general mould, beyond the narrow facts of the case. See Case C-234/89 Delimitis [1991] ECR I-935, para 53: 'Under Article 5 of the Treaty, the Commission is bound by a duty of sincere cooperation with the judicial authorities of the Member State, who are responsible for ensuring that Community law is applied and respected in the national legal system...'

130 Case C-2/88 Imm. Zwartveld [1990] ECR I-3365, para 25. The Commission did invoke imperative reasons, without, however, much success. See C. Durand, 'Le principe de coopération loyale entre les États membres et les institutions: les article 5 et 6 du traité CEE', in Commentaire Megret, Vol. I, 2nd edn. (Brussels: Éditions de l'Université de Bruxelles, 1992), 25-42, 41. See also Case C-275/00 Franex $N V$ [2002] ECR I-10943, para 49; Case C-232/01 van Lent [2003] ECR I-11525, paras 72-76. This is a parallel to the case law regarding the duties of the Parliament discussed earlier. Despite the different quality of cooperation concerned, in both constellations the Court applied 'objective reasons' and 'imperative reasons', respectively. With the Parliament, these set the limit for the freedom of its actions, and thus further defined its duty of consideration, whereas with the Commission, the imperative reasons equally limited the extent of its obligations, yet in a clearer rule-exception way than in the case of the Parliament.

131 See also Durand, 'Le Principe de Cooperation Loyale', 41: 'En outré, le Président a assurément considéré la Cour comme tenue elle-même par l'obligation de coopération loyale, en accueillant la "demande d'entraide judiciaire" soumise par le tribunal néerlandais, qui n'entrait dans aucune des catégories classiques de cas de saisine.' For a different perspective, see von Bogdandy and Schill, 'Art. 4 EUV', para 107. See also G. Bebr, 'Court of Justice: Judicial Protection and the Rule of Law', in D. Curtin and T. Heukels (eds), Institutional Dynamics of European Integration: Essays in Honour of Henry G. Schermers, Vol. II (Dordrecht/Boston/London: Martinus Nijhoff, 1994), 303-333, 323-327, who stresses that the request for assistance in this case should not be confused with a request for a preliminary ruling which was limited to questions of validity and interpretation.

132 Case C-319/97 Criminal Proceedings Against Antoine Kortas [1999] ECR I-3143.

This is an open access version of the publication distributed under the terms of the Creative Commons Attribution-NonCommercial-NoDerivs licence (http://creativecommons.org/licenses/by-nc-nd/3.0/), which permits non-commercial reproduction and distribution of the work, in any medium, provided the original work is not altered or transformed in any way, and that the work is properly cited. For commercial re-use, please contact academic.permissions@oup.com 
diligence and examine as quickly as possible the provisions of national law submitted to it' ${ }^{133}$ In infringement proceedings, the inherent procedural bias against Member States is somewhat offset by the requirement that the Commission's request for information on a specific charge must satisfy conditions of clarity and precision. While the Member States are, as I will discuss in Chapter 12, required to cooperate bona fide in any inquiry of the Commission and to supply it with all the necessary information, ${ }^{134}$ the Commission 'must specify the acts or omissions which, in its opinion, constitute the infringement'. ${ }^{135}$ Moreover, also the Commission in the context of Article 17 (1) TEU must 'take any steps which may facilitate mutual assistance between the Member States concerned and their adoption of a common attitude'. ${ }^{136}$

\subsection{Institutional Loyalty}

With institutional loyalty, I refer to obligations based on loyalty that apply between different Union institutions. This is now explicitly stated in the earlier mentioned Article 13 (2) TEU. ${ }^{137}$ I would suggest that loyalty in this constellation manifests itself in all variations of the principle of institutional balance. In contrast, it has been claimed that possible violations of institutional loyalty as provided under Article 13 (2) TEU should be resolved by applying the principle of proportionality. ${ }^{138}$ It seems, however, doubtful whether the balancing of interests of the institutions with the choice between several envisaged measures could be justiceable.

Institutional loyalty on the one hand concerns duties of inter-institutional dialogue especially in the co-decision procedure. ${ }^{139}$ Thus, the Court held that inter-institutional dialogue, on which the consultation procedure in particular is based, is subject to the same mutual duties of sincere cooperation as those which govern relations between Member States and the Community institutions' ${ }^{140}$ The Parliament was on this basis found to have 'failed to discharge its obligation to cooperate sincerely with the Council' when it did not appropriately react to a request for urgent debate by the Council. ${ }^{141}$

This, however, also concerns power struggles between the Council, the Commission, and the Parliament, mainly in the form of conflicts of legal bases. ${ }^{142}$ It can be argued

133 Case C-319/97 Kortas [1999] ECR I-3143. 134 See note 197.

135 See, to that effect, Case 192/84 Commission v Greece (Credit Terms) [1985] ECR 3967, para 20. See also the Opinion of AG Darmon in Case 192/84 Commission v Greece [1985] ECR 3967, at p 3972; Opinion of AG Poiares Maduro in Case C-82/03 Commission v Italy [2004] ECR I-6635, para 8.

136 Case C-205/06 Commission v Austria (BITs) [2009] ECR I-1301, para 44.

137 See Cremona, 'Defending the Community Interest', 157-158, arguing that 'the principle of cooperation is not limited to Member States, and also applies to inter-institutional cooperation'. See also C. Hillion, 'Tous pour un, un pour tous!: Coherence in the External Relations of the European Union', in M. Cremona (ed.), Developments in EU External Relations Law (Collected Courses of the Academy of European Law: Oxford Univ. Press, 2008), 10-36, 30-31, who, based on ex Art. 3 TEU, has argued that the Council and the Commission must ensure the consistency of the Union's external activities and that they must cooperate to this end. Most commentaries on ex Art. 10 EC or on Art. 4 (3) TEU do not mention this constellation as an application of duties of cooperation. But see now M. Nettesheim, 'Art. 13 AEUV', in E. Grabitz, M. Hilf, and M. Nettesheim (eds), Das Recht der Europäischen Union (Munich: Beck, 2011), para 79.

138 See Nettesheim, 'Art. 13 AEUV', para 79.

139 K. Lenaerts and P. Van Nuffel with R. Bray and N. Cambien (eds), European Union Law, 3rd edn. (London: Sweet \& Maxwell, 2011), 153-154.

140 Case C-65/93 European Parliament v Council [1995] ECR I-643, para 23. See also Case 204/86 Greece v Council [1988] ECR 5323, para 16.

141 Case C-65/93 European Parliament v Council [1995] ECR I-643, para 27.

142 Institutional balance has, however, more often been discussed in the context of cases of institutional self-empowerment. See Case C-70/88 Parliament v Council (Chernobyl) [1990] ECR I-2041;

This is an open access version of the publication distributed under the terms of the Creative Commons Attribution-NonCommercial-NoDerivs licence (http://creativecommons.org/licenses/by-nc-nd/3.0/), which permits non-commercial reproduction and distribution of the work, in any medium, provided the original work is not altered or transformed in any way, and that the work is properly cited. For commercial re-use, please contact academic.permissions@oup.com 
that inter-institutional conflicts are nothing but a conflict between the Union and the Member States, only that they are fought by substitutes. ${ }^{143}$ In most legal basis cases, the realization of the specific policy interests of the Member States will depend on whether the Council participates in lawmaking. This connection also reverberates in the leading case on institutional balance, stating that 'each of the institutions must exercise its powers with due regard for the powers of the other institutions' ${ }^{144}$

Portugalv Councilseems to militate against such understanding of loyalty. ${ }^{145}$ In 1994 , the Commission had signed with India and Pakistan respectively two 'Memoranda of Understanding' on arrangements in the area of market access for textile products containing a number of commitments by both the Union and the two countries mentioned. Portugal had openly opposed any such reciprocal concessions by the Member States other than those provided for in the World Trade Organization (WTO) Agreement on Textiles and Clothing. It claimed that the decision should not have been taken with majority voting but with unanimity. ${ }^{146}$ In its decision, the Court replied 'that the principle of cooperation in good faith between the Community institutions and the Member States has no effect on the choice of the legal basis of Community legal measures and, consequently, on the legislative procedure to be followed when adopting them'. ${ }^{147}$ However, as shown earlier, the Court has never obliged Member States to cooperate within the Council. I would therefore submit that it is in keeping with this case law that the Court rejected the claim by Portugal in the pertinent case. Portugal $v$ Council, thus, was not about a conflict of legal bases in the sense I will discuss in Chapter 11 as being partly resolved by considerations of loyalty.

\section{Conclusion}

It has been shown that loyalty is relevant in all constellations under Union law. It applies in the reverse vertical relationship between Union institutions and the Member States as well as between the institutions themselves. It binds Member States acting in not fully unionized fields of Union law as well as when they exercise their reserved competences in mixed agreements. More generally, I would argue that it has been shown that once Union interests are affected, loyalty applies irrespective of whether the matter belongs to the reserved powers of the Member States. This can concern the risk that obligations that the Member States have undertaken with their membership in the European Union are undermined or that the functioning of the institutions of the Union is jeopardized. In contrast, loyalty does not apply to agreements and cooperation of the Member States outside the framework of Union law or the Union institutions when this does not run counter to Union interests, such as with the case of the sanctions against Austria.

Case C-133/06 Parliament v Council (Delegation of Legislative Power) [2008] ECR I-3189. See Lenaerts and Van Nuffel with Bray and Cambien, European Union Law, 155, who under this title discuss also case law requiring the Member States to refrain from taking measures that might jeopardize the institutions' independence.

143 See also K. Lenaerts, 'EU Federalism in 3-D', in E. Cloots, G. de Baere, and S. Scottiaux (eds), Federalism in the European Union (Oxford and Portland, Oregon: Hart Publishing, 2012), 13-44, 24.

144 Case C-70/88 Parliament v Council (Chernobyl) [1990] ECR I-2041, para 22.

145 Case C-149/96 Portugal v Council (Textiles) [1999] ECR I-8395.

146 Portugal had also claimed that this disregard of its interests by the other Member States deciding with qualified majority under former Art. 133 EC (now Art. 207 TFEU) was in breach of the principle of cooperation in good faith.

147 Case C-149/96 Portugalv Council(Textiles) [1999] ECR I-8395.

This is an open access version of the publication distributed under the terms of the Creative Commons Attribution-NonCommercial-NoDerivs licence (http://creativecommons.org/licenses/by-nc-nd/3.0/), which permits non-commercial reproduction and distribution of the work, in any medium, provided the original work is not altered or transformed in any way, and that the work is properly cited. For commercial re-use, please contact academic.permissions@oup.com 


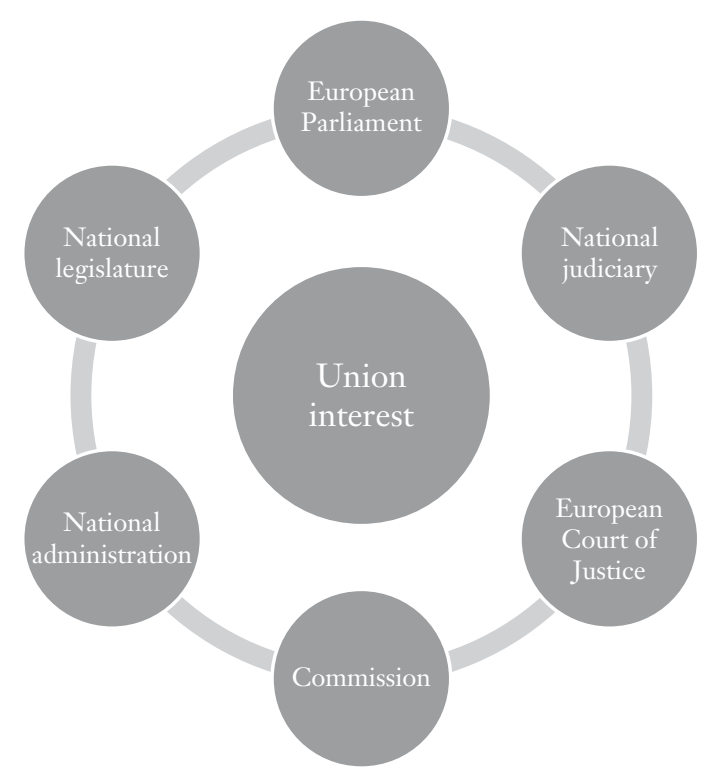

Figure 1.1 Union and National Actors Bound by the Union Interest

The above figure (Figure 1.1) summarizes the various actors that are bound to consider the interests of the Union in their relations with each other.

The specifications of Article 4 (3) TEU discussed earlier provide a 'taste' of the various and diverse functions of loyalty to be discussed in the next Chapters. Both the interventionist and the cooperative side of loyalty are reflected in the Treaties. What is reflected in neither the loyalty clause itself nor its specifications is the integrationist nature of loyalty. This has been exclusively relied upon by the European Court of Justice and will be discussed in Chapter 3 among others.

This is an open access version of the publication distributed under the terms of the Creative Commons Attribution-NonCommercial-NoDerivs licence (http://creativecommons.org/licenses/by-nc-nd/3.0/), which permits non-commercial reproduction and distribution of the work, in any medium, provided the original work is not altered or transformed in any way, and that the work is properly cited. For commercial re-use, please contact academic.permissions@oup.com 


\section{2 \\ Loyalty in Context}

\section{Introduction}

In its case law, the Court has often referred directly to Article 4 (3) TEU or its precursor provisions, without giving the obligation contained therein a specific name. ${ }^{1}$ In other judgments, it has spoken of an obligation or duty of 'loyal cooperation', ${ }^{2}$ or simply a 'duty of loyalty'. ${ }^{3}$ However, in the majority of cases it seems that the Court has used the notion of 'sincere cooperation', which had eventually been the one adopted in the newly worded Article 4 (3) TEU. ${ }^{4}$ In some cases in the present context, the Court has spoken of solidarity or good faith, concepts that we thus need to distinguish in the following. As far as I can see, what the Court of Justice has never used to date is the concept of (Union) fidelity, nor has it referred to the corresponding German term, which would be 'Gemeinschaftstreue' or 'Unionstreue'.'

The literature has an even worse record on consistency in terminology than the Court. This relates to three different concepts that have all been associated with loyalty. Firstly, the literature often makes a distinction between loyalty and duties of cooperation under Union law, mostly though without further explanation of what this distinction should entail in substantive terms. Before Lisbon, some qualified the principle of loyalty as the foundation of the duty of cooperation. ${ }^{6}$ Others have distinguished between supremacy and a duty of cooperation as different manifestations of Article 4 (3) TEU, with the former constraining Member State (external) action in a substantive manner, while the latter does so procedurally. ${ }^{7}$

The second related concept is solidarity. There have always been claims that there is no difference between the legal concepts of solidarity and loyalty in EU law, ${ }^{8}$ or that

1 Joined cases 51 to 54/71 International Fruit Company [1971] ECR 1107, para 3; Case 78/70 Deutsche Grammophon [1971] ECR 487, para 5; Joined cases 3, 4, and 6/76 Cornelis Kramer [1976] ECR 1279, paras 42/43; Case 229/83 Leclerc [1985] ECR 1, para 20.

2 Case C-374/89 Commission v Belgium (Directive 76/491/EEC) [1991] ECR I-367, para 15; Case C-64/05 P. Sweden v Commission (Public Access) [2007] ECR I-11389, para 85.

3 Case C-459/03 Commission v Ireland (MOX Plant) [2006] ECR I-4635, para 168.

${ }^{4}$ Joined cases C-213/88 and C-39/89 Luxemburg v European Parliament [1991] ECR I-5643, para 29; Joined cases C-36/97 and C-37/97 Kellinghusen [1998] ECR I-6337, para 30; Case C-202/97 Fitzwilliam Executive Search [2000] ECR I-883, para 51; Case C-205/98 Commission v Austria (Brenner Motorway) [2000] ECR I-7367, para 39; Case C-50/00 P. Unión de Pequeños Agricultores [2002] ECR I-6677, para 29; Case C-511/03 Ten Kate Holding [2005] ECR I-08979, para 28.

5 Note that fidelity is perhaps the best translation for the German notion of Treue such as in Bundestreue, which I will discuss later in this chapter.

${ }^{6}$ P. Eeckhout, External Relations of the European Union: Legal and Constitutional Foundations (Oxford: Oxford Univ. Press, 2004), 215. See also R. Frid, The Relations between the EC and International Organizations: Legal Theory and Practice (The Hague: Kluwer Law International, 1995), 149.

M. Cremona, 'Defending the Community Interest: The Duties of Cooperation and Compliance', in M. Cremona and B. de Witte (eds), EU Foreign Relations Law: Constitutional Fundamentals (Oxford and Portland, Oregon: Hart, 2008), 125-169, 126. See also E. Neframi, 'The Duty of Loyalty: Rethinking its Scope Through its Application in the Field of EU External Relations', Common Market Law Review, 47 (2010), 323-359, 325-331.

8 M. Zuleeg, 'Art. 5 EGV', in H. v d Groeben, J. Thiesing and C.-D. Ehlermann, EUVIEGV, 5th edn. (Baden-Baden: Nomos, 1997), para 1; W. Kaufmann-Bühler, 'Art 24 EUV', in E. Grabitz, M. Hilf

This is an open access version of the publication distributed under the terms of the Creative Commons Attribution-NonCommercial-NoDerivs licence (http://creativecommons.org/licenses/by-nc-nd/3.0/), which permits non-commercial reproduction and distribution of the work, in any medium, provided the original work is not altered or transformed in any way, and that the work is properly cited. For commercial re-use, please contact academic.permissions@oup.com 
the principle of sincere cooperation is an expression of Union solidarity. ${ }^{9}$ For Calliess, Article 4 (3) TEU is the procedural manifestation of the principle of solidarity. ${ }^{10}$ In an early study on ex Article 5 EEC, Söllner wrote of a duty of solidarity of the Member States to the Union. ${ }^{11}$ More recently, Hillion has distinguished these terms by claiming that the Member States' responsibility towards the Union flows from a requirement of solidarity, which is embodied in a principle of loyal cooperation, which again is the constitutional basis of a duty of cooperation. ${ }^{12}$

Thirdly, fidelity has often been relied on by those authors that have looked at Union law from the perspective of German constitutional law. ${ }^{13}$ Thus, Pescatore and Bleckmann have compared the duty of loyal cooperation to federal state law concepts, speaking of Community fidelity (Gemeinschaftstreue) in analogy to the German Bundestreue. ${ }^{14}$ Blanquet has claimed that Community fidelity ('fidélité communautaire') encompasses interstate solidarity, the principles of cooperation, collaboration, and loyalty. ${ }^{15}$ Loyalty itself he has reduced to denoting duties of abstention, while considering duties of solidarity a part of the scope of ex Article 5 EEC. ${ }^{16}$ With cooperation, he has referred to duties of implementation incumbent on the Member States, while collaboration is the term used for duties of the Member States to facilitate the functioning of the Union institutions by providing information and showing political goodwill especially within the Council, among others.

and M. Nettesheim (eds), Das Recht der Europäische Union, Kommentar, Vol. I (Munich: Beck, 2010), para 38; J. Bitterlich, 'Art. 24 EUV', in C.-O. Lenz and K.-D. Borchardt (eds), EU-Verträge, Kommentar nach dem Vertrag von Lissabon, 5th edn. (Cologne: Bundesanzeiger, Vienna: Linde, 2010), para 6.

9 K. Lenaerts and P. Van Nuffel, European Union Law, 3rd edn. (London: Sweet \& Maxwell, 2011), 147.

10 See C. Calliess, 'Perspektiven des Euro zwischen Solidarität und Recht: eine rechtliche Analyse der Griechenlandhilfe und des Rettungsschirms', Zeitschrift für europarechtliche Studien, 14:2 (2011), 213-282, 228; C. Calliess, 'Art. 222 AEUV', in C. Calliess and M. Ruffert (eds), EUVIAEUV: Das Verfassungsrecht der Europäischen Union mit Europäischer Grundrechtecharta, 4th edn. (Munich: Beck, 2011), para 9. See, in apparent contrast, M. Rossi, 'Art. 80 AEUV', in C. Calliess and M. Ruffert (eds), EUVIAEUV: Das Verfassungsrecht der Europäischen Union mit Europäischer Grundrechtecharta, 4th edn. (Munich: Beck, 2011), para 2, who speak of solidarity as a horizontal relationship supplementing the vertical principle of Union loyalty.

11 R. Söllner, Art. 5 EWG-Vertrag in der Rechtsprechung des Europäischen Gerichtshofes (Munich: VVF, 1985): 'Pflicht zur Solidarität'.

${ }_{12}$ C. Hillion, 'Mixity and Coherence in EU External Relations: The Significance of the "Duty of Cooperation"', CLEER Working Papers, 2 (2009), 8. See also G. de Baere, Constitutional Principles of EU External Relations (Oxford: Oxford Univ. Press, 2008), 253. A close relation between solidarity and cooperation (though not loyalty) has also been suggested by C. Tomuschat, 'Discussion Following the Presentation by Karel Wellens', in R. Wolfrum and C. Kojima (eds), Solidarity: A Structural Principle of International Law (Heidelberg et al.: Springer, 2010), 39-54, 44.

13 But see Grabitz, 'Art. 5 EWGV', para 15, who has rejected analogies to the German Bundestreue not only as being superfluous methodically but also fallacious, because the differences between the constitutional structures of a federal state and the Communty would not permit analogies from constitutional principles of one system to those of another system.

${ }_{14}$ P. Pescatore, 'Das Zusammenwirken der Gemeinschaftsrechtsordnung mit den nationalen Rechtsordnungen', Europarecht, (1970), 307-323; A. Bleckmann, 'Art. 5 EWG-Vertrag und die Gemeinschaftstreue: Zugleich ein Beitrag zur Entwicklung des allgemeinen europäischen Verwaltungsrechts', Deutsches Verwaltungsblatt, (1976), 483-487. With Gemeinschaftstreue, Bleckmann means the obligation of the Member States to consider their mutual interests in relation to the common interest of the then European Economic Community. See, for a similar approach, P. Unruh, 'Die Unionstreue: Anmerkungen zu einem Rechtsgrundsatz der Europäischen Union', Europarecht, (2002), 41-66.

${ }_{15}$ M. Blanquet, L'Article 5 du Traité C.E.E.: Recherche sur les Obligations de Fidélité des États Membres de la Communauté (Paris: LGDJ, 1994), 417.

16 M. Blanquet, L'Article 5 du Traité C.E.E., 22.

This is an open access version of the publication distributed under the terms of the Creative Commons Attribution-NonCommercial-NoDerivs licence (http://creativecommons.org/licenses/by-nc-nd/3.0/), which permits non-commercial reproduction and distribution of the work, in any medium, provided the original work is not altered or transformed in any way, and that the work is properly cited. For commercial re-use, please contact academic.permissions@oup.com 


\section{Some Remarks on Terminology}

\subsection{Loyalty and Duties of Cooperation}

I would argue that the duty of (sincere or loyal) cooperation should be understood as a subcategory of a more general principle of loyalty. ${ }^{17}$ This is a difference more of emphasis than of substance. Loyalty refers to an overarching concept in Union law, with duties of cooperation representing narrower facets thereof. It is a related question whether Article 4 (3) TEU embodies the entire legal substance of loyalty, or whether loyalty is a (general) principle of Union law transcending the scope of the Treaty provisions before and under the Lisbon Treaty. With the legal quality of loyalty, I will specifically deal in Chapter 12. The reasons for this distinction are owed mainly to ordinary meaning and to legal comparison. The term cooperation denotes a process just as much as it describes a relationship between different actors. In this vein, duties of mutual assistance between the Union and between the Member States are of a rather technical nature, as we shall see later. In particular, the Court remarkably often has referred to duties of cooperation (instead of to loyalty) in the context of mixed agreements, discussed in Chapter 10. In the Part on Cooperation, I explore this more technical side of loyalty. Cooperation in the sense of collaboration can be distinguished from a process of interaction between different actors or legal systems. ${ }^{18}$ This will be discussed in Chapter 11 with regard to the interplay between different courts in the EU and beyond. This border, however, is not razor-sharp if we think of cooperation between actors as any legal means of ensuring a certain interaction between (legal) systems, as it is arguably the case for the EU.

This leads to the further distinction within the (sub)category of duties of cooperation between duties of coordination, duties of consideration, and duties of abstention. ${ }^{19}$ Recall that this is merely a way of conceptualizing what can be found in case law and secondary law, but does not claim to be the only possible systematization, nor does it claim to be based on any conscious practice on the part of the institutions. Duties of coordination can be associated with mutual duties of information, notification, and consultation. ${ }^{20}$ Such duties based on loyalty can be found in secondary law and will be discussed in Chapter 9 in particular. Duties of abstention play a role especially with the implications of Union legal acts and other Union measures, and are discussed in Chapter 5 among others. Duties of consideration, finally, will be suggested as applying mainly in the context of the national application of Union directives. The following figure (Figure 2.1) summarizes this conceptual hierarchy, the categories of which will be fleshed out throughout this book.

17 In the same vein, E. Neframi, 'The Duty of Loyalty: Rethinking its Scope Through its Application in the Field of EU External Relations', Common Market Law Review, 47 (2010), 323-359, 325.

18 See C. Grabenwarter, 'Die Kooperation zwischen EuGH und EGMR', in C. Grabenwarter and E. Vranes (eds), Kooperation der Gerichte im europäischen Verfassungsverbund: Grundfragen und neueste Entwicklungen (Baden-Baden: Nomos, 2013), 35-44, 36-37.

19 In this sense, A. Gamper, 'Koordination im Bundesstaat: Ein "ungeschriebenes" Verfassungsprinzip?', in A. Rosner and P. Bußjäger (eds), Im Dienste der Länder-im Interesse des Gesamtstaates: Festschrift 60 Jahre Verbindungsstelle der Bundesländer (Vienna: Braumüller, 2011), 258-259, who also mentions the understanding adopted by the South-African Constitution.

20 R.L. Watts, Comparing Federal Systems, 3rd edn. (Montreal \& Kingston/London/Ithaca: McGill-Queen's Univ. Press, 2008), 117. For a contrasting view equating cooperation with coordination, see Gamper, 'Koordination im Bundesstaat', 257.

This is an open access version of the publication distributed under the terms of the Creative Commons Attribution-NonCommercial-NoDerivs licence (http://creativecommons.org/licenses/by-nc-nd/3.0/), which permits non-commercial reproduction and distribution of the work, in any medium, provided the original work is not altered or transformed in any way, and that the work is properly cited. For commercial re-use, please contact academic.permissions@oup.com 
Duties of cooperation

Duties of

consideration

Duties of coordination

Figure 2.1 Categories of Duties of Cooperation

\subsection{Federal and Constitutional Loyalty}

In order further to distinguish the overarching concept of loyalty, the distinction between the concepts of constitutional loyalty and federal loyalty is useful. In a federal system, constitutional loyalty means that the federation and the constituents' units have to obey the constitution in the performance of their duties and obligations without any reciprocity. ${ }^{21}$ In ordinary meaning, loyalty has been defined as the 'faithful adherence to the sovereign or lawful government', ${ }^{22}$ the 'devotion to a person or cause', ${ }^{23}$ or to an 'ideal, custom, institution, or product'. ${ }^{24}$ The definitions cited all allude to the concept of constitutional loyalty, which already existed in Ancient Rome, and still exists in Catholicism in the form of loyalty to God. In legal systems with a constitutional court in the mould advocated by Hans Kelsen, the judges of such courts are required to be loyal to the constitution. ${ }^{25}$

In contrast, federal loyalty requires all tiers to be mutually loyal to each other in order to achieve the goal of a federal or any decentralized system, which is to guarantee the smooth and harmonious functioning of the federal system, in spite of its inherent complexity. ${ }^{26}$ The distinction between federal and constitutional loyalty is also reflected by the Reference Framework for Regional Democracy of the Council of Europe, which however provides for federal loyalty on the one hand, and mutual loyalty on the other. ${ }^{27}$ Federal loyalty I would suggest is a synonym for (federal) fidelity. Thus, the ordinary meaning of fidelity has been defined as 'faithfulness, loyalty, unswerving allegiance to a person, party, bond, etc'. ${ }^{28}$ At another place, fidelity has been defined as 'faithfulness to one's

21 R. Smend, Verfassung und Verfassungsrecht (Berlin: Duncker \& Humblot, 1928), 254 passim. See also H. Bayer, Die Bundestreue (Tübingen: Mohr, 1961), 10.

22 Oxford English Dictionary, Online version, 2nd edn. 1989.

$23<$ http://en.wikipedia.org/wiki/loyalty>.

$24<$ http://en.wiktionary.org/wiki/loyalty>. See loyalist organizations, such as during the American Revolution or in Northern Ireland. Loyalty here is pledged 'to an established government, political party, or sovereign, especially during war or revolutionary change'. See <http://en.wikipedia.org/wiki/ Loyalist>.

25 See A. Gamper, 'On Loyalty and the (Federal) Constitution', International Constitutional Law Journal (<http://www.icl-journal.com>), 4:2 (2010), 157. See also Gamper’s references, at 168, to Sec. 41 (1) (d) of the South African Constitution, stipulating that all spheres of government and all organs of state within each sphere must be loyal to the Constitution.

${ }^{26}$ Gamper, 'On Loyalty and the (Federal) Constitution', 157.

27 Reference Framework for Regional Democracy (MCL-16[2009]11), 4. Here, mutual loyalty is the equivalent to federal loyalty, and federal loyalty carries the more unilateral/vertical meaning. See J. Kincaid, 'Comparative Observations', in J. Kincaid and G. Alan Tarr (eds), Constitutional Origins, Structure, and Change in Federal Countries (Montreal \& Kingston/London/Ithaca: McGill-Queen's Univ. Press, 2005), 409-448, 441; Watts, Comparing Federal Systems, 168.

${ }^{28}$ Oxford English Dictionary, Online version, 2nd edn. 1989.

This is an open access version of the publication distributed under the terms of the Creative Commons Attribution-NonCommercial-NoDerivs licence (http://creativecommons.org/licenses/by-nc-nd/3.0/), which permits non-commercial reproduction and distribution of the work, in any medium, provided the original work is not altered or transformed in any way, and that the work is properly cited. For commercial re-use, please contact academic.permissions@oup.com 
duties; accuracy, or exact correspondence to some given quality or fact; loyalty, especially to one's spouse; the degree to which a system accurately reproduces an input'. ${ }^{29}$ Both definitions suggest a certain area of overlap between fidelity and loyalty. Hatje has shown by reference to especially religious and ethical usage that loyalty is considered a more specific concept when compared to fidelity, implying a comparably stronger allegiance by subordinating the interests of others or even of oneself. ${ }^{30}$ In the following section, I will show that Union loyalty combines elements of both constitutional loyalty and federal loyalty (fidelity).

\section{Distinguishing the Union Principle of Solidarity}

\subsection{Introduction}

In a legal respect, the following analysis does not mean to deny the EU principle of solidarity its important role in many aspects of Union law, nor the constitutional status it has come to obtain. It is without doubt that 'solidarity is central to the relationship between social and market values'. ${ }^{31}$ Thus, the fundamental freedoms must be balanced against the objectives of social policy. ${ }^{32}$ Moreover, with regard to services of general economic interest the scope of application of the EU principle is heavily, yet not always transparently, dependent on considerations of solidarity. ${ }^{33}$ In this sense, solidarity has been seen to develop as a crucial agonist for claims to subsidiarity of the Member States. ${ }^{34}$ Moreover, solidarity has been invoked by the Court in its case law on Union citizenship for imposing duties of financial solidarity to citizens able to show some degree of integration into the society. 35

Hence, solidarity is without doubt a concept central to the European Union and to European Union law. ${ }^{36} \mathrm{I}$ will, however, show that solidarity in the EU mainly refers to the relations among the Member States, and not to the relation between the Member States and the Union. ${ }^{37}$ I will also show that it is rather political and non-binding than legally binding. This understanding of solidarity is in line with its ordinary meaning, where it is commonly defined as 'a form of obligation involving joint and several responsibilities

29 See <http://en.wiktionary.org/wiki/fidelity>.

30 A. Hatje, Loyalität als Rechtsprinzip in der Europäischen Union (Baden-Baden: Nomos, 2001), 16 with further references.

${ }^{31}$ M. Ross, 'Solidarity: A New Constitutional Paradigm for the EU?', in M. Ross and Y. Borgmann-Prebil (eds), Promoting Solidarity in the European Union (Oxford: Oxford Univ. Press, 2010), 23-45, 42.

32 Ross, 'Solidarity', fn 31.

33 Case T-289/03 British United Provident Association Ltd (BUPA), BUPA Insurance Ltd and BUPA Ireland Ltd v Commission [2008] ECR II-81.

${ }^{34}$ See Ross, 'Solidarity', 42.

35 See Case C-413/01 Ninni-Orasche [2003] ECR I-13187; Case C-209/03 Bidar [2005] ECR I-2119, para 60.

36 See also Chapter IV, Charter of Fundamental Rights. cf. the wealth of discussion on the issue of services of general interest, in which solidarity is frequently referred to in much the same sense as advocated here. See M. Ross, 'The Value of Solidarity in European Public Services Law', in M. Krajewski, U. Neergaard, and J. van de Gronden (eds), The Changing Legal Framework for Services of General Interest in Europe: Between Competition and Solidarity (The Hague: TMC Asser Press, Cambridge Univ. Press, 2009), 81-99, 94: 'Instead, solidarity becomes the central value and instrument with which to justify and organise a realignment of the interplay between markets and social justice.' Note, however, that Ross, 'The Value of Solidarity', 87, makes a passing connection with loyalty and ex Art. 10 EC, though without further expanding on this point in the remainder of his piece.

37 See J.-P. Terhechte, 'Art. 3 EUV', in E. Grabitz, M. Hilf and M. Nettesheim (eds), Das Recht der Europäische Union (Munich: Beck, 2010), para 57.

This is an open access version of the publication distributed under the terms of the Creative Commons Attribution-NonCommercial-NoDerivs licence (http://creativecommons.org/licenses/by-nc-nd/3.0/), which permits non-commercial reproduction and distribution of the work, in any medium, provided the original work is not altered or transformed in any way, and that the work is properly cited. For commercial re-use, please contact academic.permissions@oup.com 
or rights' ${ }^{38}$ It describes a 'bond of unity between individuals, united around a common goal or against a common enemy', and as expression of this unity, the 'willingness to give psychological and/or material support when another person is in a difficult position or needs affection'. ${ }^{39}$ Social solidarity refers to 'the integration, and degree and type of integration, shown by a society or group with people and their neighbors' ${ }^{40}$ Solidarity, by its ordinary meaning, thus is essentially a concept operating in the political dimension. ${ }^{41}$

In the following section, after briefly assessing the Treaty provisions on solidarity outside the Common Foreign and Security Policy (CFSP), I will have a look at some cases where solidarity was invoked in a rather specific way, different from the case law discussed earlier. This will be followed by an analysis of solidarity in the CFSP, where it is most prominently embedded.

\subsection{Solidarity in the Treaties Outside the CFSP}

The Lisbon Treaty abounds with references to solidarity, such as most conspicuously the 'solidarity clause' of Article 222 TFEU. ${ }^{42}$ Article 2 TEU refers to solidarity as a common value of the societies of the Member States of the Union. Article 3 (3) TEU lists the 'solidarity between generations' as one objective of Union policies, as well as the solidarity among Member States in the context of the promotion of economic, social, and territorial cohesion, and, in paragraph 5 , the 'solidarity and mutual respect among peoples'. Article 67 TFEU on the area of freedom, security, and justice exhorts the Union to 'frame a common policy on asylum, immigration and external border control, based on solidarity between Member States'. Article 80 TFEU adds that the policies of the Union shall be 'governed by the principle of solidarity and fair sharing of responsibility, including its financial implications, between the Member States'. This manifests itself in the European Refugee Fund, which provides for financial support for especially burdened Member States. ${ }^{43}$ Moreover, in Article 122 (1) TFEU, a mandate is given to the Council to decide, 'in a spirit of solidarity between Member States, upon the measures appropriate to the economic situation, in particular if severe difficulties arise in the supply of certain products, notably in the area of energy' ${ }^{44}$ These references to solidarity in the Treaty have led AG Kokott to argue against a broad teleological interpretation of Article 125 TFEU, which would prohibit the Member States in a case of emergency from voluntarily providing mutual assistance. ${ }^{45}$

I would argue that solidarity as such either exhorts certain values that should be aspired to by means of membership in the European Union, demands mutual assistance such as to reduce regional divergences in development through the instruments of

38 Oxford English Dictionary, Online version, 2nd edn. 1989.

39 <http://en.wiktionary.org/wiki/solidarity>. See also S. Stjernö, Solidarity in Europa: The History of an Idea (Cambridge, Cambridge Univ. Press, 2005), 88-89.

40 D. Jary and J. Jary (eds), Collins Dictionary of Sociology (Harper Collins, 1991), 621.

41 Ross, 'The Value of Solidarity', 85.

42 Title VII, Part V, TFEU on external action of the Union. Art. 222 (1) TFEU mandates that ' $t$ ] he Union and its Member States shall act jointly in a spirit of solidarity if a Member State is the object of a terrorist attack or the victim of a natural or man-made disaster'. In para 2, the Member States are called upon to coordinate between themselves in the Council should a Member State be the object of a terrorist attack or the victim of a natural or man-made disaster and should it request their assistance.

43 See Rossi, 'Art. 80 AEUV', paras 4-5.

44 The reference to solidarity in Art. 122 (1) TFEU is new compared to the corresponding Art. 100 (1) EC (Nice).

45 AG Kokott in Case C-370/12 Thomas Pringle v Government of Ireland, Ireland and The Attorney General [2012] ECR 00000, para 43.

This is an open access version of the publication distributed under the terms of the Creative Commons Attribution-NonCommercial-NoDerivs licence (http://creativecommons.org/licenses/by-nc-nd/3.0/), which permits non-commercial reproduction and distribution of the work, in any medium, provided the original work is not altered or transformed in any way, and that the work is properly cited. For commercial re-use, please contact academic.permissions@oup.com 
cohesion, or provides for a non-military duty of mutual assistance in Article 222 TFEU. This makes solidarity an expression of the fundamental principle of the equality of the Member States in the European Union, exhorting the unity between the Member States by prescribing mutual assistance either in kind or financially. ${ }^{46}$ Similar issues are discussed in public international law under the title of solidarity. ${ }^{47}$

\subsection{Solidarity in Case Law}

As mentioned earlier, in case law the Court has, in general, not used solidarity in connection with Article 4 (3) TEU and its precursors. There are, however, qualifications to this observation. In a judgment that is regularly referred to in support of claims as to the equivalence of solidarity and loyalty the Court spoke of ' $t \mathrm{t}]$ he solidarity which is at the basis of... the whole of the Community system in accordance with the undertaking provided for in [ex] Article 5 of the Treaty'. ${ }^{48}$ That solidarity may be 'in accordance' with loyalty, I will explain later. However, in this case on a unilateral action by France in the field of monetary policy, solidarity here was neither held equal to Article 4 (3) TEU nor considered its basis. Instead, France was found guilty of an unlawful exercise of its reserved powers and of a violation of the rules on state aid. In another case, without referring to loyalty, the Court spoke of a 'duty of solidarity accepted by Member States by the fact of their adherence to the Community'. ${ }^{49}$ This case showed that solidarity has a lot to do with implications of 'the equilibrium between advantages and obligations flowing from [a Member State's] adherence to the Community'. ${ }^{50}$ This balance prohibits the compromising of the interests of the Union by pursuing purely national (political) interests. ${ }^{51}$ Put in other words, it bars Member States from acting unilaterally when it would disturb this equilibrium. Again, the infringement was based neither on a breach of loyalty nor of solidarity, but appears to have been founded on a violation of ex Article 189 EEC (now Article 288 TFEU). ${ }^{52}$ Solidarity in these cases therefore was used as an ideal to be upheld, expressing a 'horizontal bond of unity' between the Member States. It was, however, not a ground for infringement or the source of concrete obligations for the Member States.

An altogether different story regarding the invocation of solidarity is Pupino, where the Court extended the scope of loyalty to the former third pillar to prescribe a duty of consistent interpretation for framework directives. ${ }^{53}$ The Court's main argument was derived from ex Article 1 TEU (Nice), proclaiming the objective of creating a new

46 See the references to solidarity in connection with the financial crisis, such as with U. Häde, 'Die europaische Wahrungsunion in der internationalen Finanzkrise: An den Grenzen europaischer Solidarität?', Europarecht, 6 (2010), 854-866. See however the rightly critical remarks as to the pertinence of solidarity in this context by M. Potacs, 'Die Europäische Wirtschafts- und Währungsunion und das Solidaritätsprinzip’, Europarecht, (2013), 133-146.

47 See K. Wellens, 'Revisiting Solidarity as a (Re-)Emerging Consitutional Principle: Some Further Reflections', in R. Wolfrum and C. Kojima (eds), Solidarity: A Structural Principle of International Law (Heidelberg et al.: Springer, 2010), 2-38, who refers to international disaster law, international humanitarian law, and state responsibility.

48 Case 6 \& 11/69 Commission v France [1969] ECR 523, para 16. See Blanquet, L'Article 5 du Traité C.E.E., 415.

49 Case 39/72 Commission v Italy (Premiums for Slaughtering Cows) [1973] ECR 101, para 24. At issue was again a unilateral action by a Member State, this time in implementing a regulation in the area of the Common Agricultural Policy.

50 Case 39/72 Commission v Italy [1973] ECR 101, para 25.

51 See Terhechte, 'Art. 3 EUV', para 57. 52 This is not explicitly stated in the judgment.

53 Case C-105/03 Pupino [2005] ECR I-5285. I will analyse the implications of this judgment for indirect effect and the unity of the EU legal order in Chapter 4.

This is an open access version of the publication distributed under the terms of the Creative Commons Attribution-NonCommercial-NoDerivs licence (http://creativecommons.org/licenses/by-nc-nd/3.0/), which permits non-commercial reproduction and distribution of the work, in any medium, provided the original work is not altered or transformed in any way, and that the work is properly cited. For commercial re-use, please contact academic.permissions@oup.com 
stage in the process of achieving an ever closer union among the peoples of Europe, on the basis of which relations between the Member States and between their peoples can be organised in a manner demonstrating consistency and solidarity ${ }^{54}$ The Advocate General in Pupino argued that this Treaty objective would not be achieved unless the Member States and Union institutions 'cooperate sincerely and in compliance with the law' ${ }^{55}$ While the Court itself was less direct in linking ex Article 1 TEU (Nice) with loyalty, ${ }^{56}$ the Court seemed to infer from consistency and solidarity a general principle of loyalty, which would make the latter an expression of the former. ${ }^{57}$ I would submit that this reference and the deduction on its basis indeed makes sense, but only when linking loyalty to the requirement of consistency and not to solidarity. One major category of obligations resulting from loyalty concerns the consistent interpretation of especially national law in light of Union law, as discussed later. This duty is partly owed to the need for a uniform (and consistent) application of Union law in the Member States. Thus, based on Pupino it can be shown that there is a connection between the requirement of consistency and loyalty, but not necessarily also between loyalty and solidarity.

\subsection{Solidarity in the CFSP}

Interestingly, the only reference to loyalty in the EU Treaties is in the parts on the CFSP. Article 24 (3) TEU obliges the Member States to 'support the Union's external and security policy actively and unreservedly in a spirit of loyalty and mutual solidarity'. Nonetheless, the literature has referred to this provision as the 'solidarity clause'. 58 Indeed, a brief overview of the provisions on the CFSP in the Treaties shows that solidarity is the predominant concept by the number of references. Thus, the general provisions in Title V of the TEU start, in Article 21 (1), by requiring Union action on the international scene to be guided by, among others, 'the principles of equality and solidarity'. In Article 24 (2) TEU the Union is called on to 'conduct, define and implement a common foreign and security policy, based on the development of mutual political solidarity among Member States...'

Article 32 TEU contains a broad obligation to consult in all CFSP matters and provides that 'Member States shall show mutual solidarity'. Different from ex Article 16 TEU (Nice), Article $32 \mathrm{TEU}$ now also obliges Member States to consult the others within the European Council or the Council before 'undertaking any action on the international scene or entering into any commitment which could affect the Union's interests'. While this has correctly been described a reinforcement of the information and consultation principle, it has also correctly been noted that the only effective 'sanction' for a violation of this obligation would be peer pressure. ${ }^{59}$

I would argue that all this implies an understanding of solidarity broadly in line with the references to solidarity in the non-CFSP parts of the Treaties mentioned earlier. Emphasis also in the CFSP is more on the (horizontal) relations between the Member States themselves, and less on the (vertical) relationship between the Member States and the Union that Article 4 (3) TEU mainly governs. There is also the reference to

${ }^{54}$ Case C-105/03 Pupino [2005] ECR I-5285, para 41 (emphasis added); AG Kokott in Case C-105/03 Pupino [2005] ECR I-5285, para 26.

55 AG Kokott in Case C-105/03 Pupino [2005] ECR I-5285, para 26 (emphasis added).

56 Case C-105/03 Pupino [2005] ECR I-5285, para 42.

57 See the argument by Calliess, 'Perspektiven des Euro zwischen Solidarität und Recht', 228.

58 Bitterlich, 'Art. 24 EUV', para 6.

59 See G. de Baere, Constitutional Principles, 263-264.

This is an open access version of the publication distributed under the terms of the Creative Commons Attribution-NonCommercial-NoDerivs licence (http://creativecommons.org/licenses/by-nc-nd/3.0/), which permits non-commercial reproduction and distribution of the work, in any medium, provided the original work is not altered or transformed in any way, and that the work is properly cited. For commercial re-use, please contact academic.permissions@oup.com 
equality next to solidarity in Article 21 (1) TEU and the mention of political solidarity in Article 24 (2) TEU, which confirms the strong political and idealistic side of this concept. In the same vein, the pledge to solidarity in Article 32 TEU when acting on the international political scene is, by its wording and context, not legally binding. I would submit that this predominance of solidarity is a reflection of the distinct nature of the CFSP under the Lisbon Treaty. This area has remained largely intergovernmental, continues to be governed by specific rules and procedures, provides for little participation of the Parliament, mostly foresees unanimity voting, ${ }^{60}$ and the Court of Justice does not have (direct) jurisdiction to hear cases on the CFSP. ${ }^{61}$ In such an inter-governmental setting, where the vertical relationship in the CFSP is much less developed in a legal sense, it is only consequential that the ties that bind the Member States are less strong compared to the other areas of Union law. ${ }^{62}$

Article 31 (1) TEU on the voting procedure in the CFSP seems to be a detractor in the present context. Following the rule that decisions in the CFSP are generally taken by unanimity, Article 31 (1) TEU provides for the following mechanism of 'constructive abstention': ${ }^{63}$

When abstaining in a vote, any member of the Council may qualify its abstention by making a formal declaration under the present subparagraph. In that case, it shall not be obliged to apply the decision, but shall accept that the decision commits the Union. In a spirit of mutual solidarity, the Member State concerned shall refrain from any action likely to conflict with or impede Union action based on that decision and the other Member States shall respect its position.

By invoking solidarity, Article 31 (1) TEU thus provides for a duty of abstention for the Member States. It applies a principle of solidarity to the vertical relationship between the Union as legislator in the CFSP on the one hand, and the Member States as subjects of a binding Union decision in this area on the other. At first glance, this obligation of abstention is very similar to the duty under Article 4 (3) TEU to 'refrain from any measure which could jeopardise the attainment of the Union's objectives', albeit the scope of application of Article 31 (1) TEU, clearly, is much narrower. This has led some commentators to see this provision as affirmation of the existence of a general duty of loyalty provided in Article 24 (3) TEU, ${ }^{64}$ or even an example of a German constitutional law inspired 'Unionstreue' (Union loyalty) in the CFSP. ${ }^{65}$ I would submit that one swallow does not make a summer. Even if Article 31 (1) TEU really were an application of CFSP loyalty or even of Union loyalty, this would hardly be consistent with the other references to solidarity in the CFSP, which, as discussed earlier, have a political connotation rather than a legal one. Moreover, when what is here called solidarity in fact amounts

60 See Art. 24 TEU, and, as to the Parliament, Art. 218 (6) TFEU. But see J. Wouters, D. Coppens and B. de Meester, 'The European Union's External Relations after the Lisbon Treaty', in S. Griller and J. Ziller (eds), The Lisbon Treaty: EU Constitutionalism without a Constitutional Treaty (Vienna, New York: Springer, 2008), 143-203, 163, on how the High Representative could extend qualified majority voting to areas of unanimity.

61 See Art. 275 TFEU. This is different to the former third pillar on cooperation in police and criminal matters, which has been 'depillarized' to a greater degree.

62 For a different perspective, see H.-J. Cremer, 'Art. 24 EUV', in C. Calliess and M. Ruffert (eds), EUVIAEUV: Das Verfassungsrecht der Europäischen Union mit Europäischer Grundrechtecharta, 4th edn. (Munich: Beck, 2011), para 12, who sees Art. 24 (3) TEU as borderline legal obligation and an expression of pacta sunt servanda, but does not explain what this entails concretely.

63 See in detail, W. Kaufmann-Bühler and N. Meyer-Landrut, 'Art. 31 EUV', in E. Grabitz, M. Hilf and M. Nettesheim (eds), Das Recht der Europäische Union (Munich: Beck, 2010), paras 13-18.

64 Kaufmann-Bühler and Meyer-Landrut, 'Art. 31 EUV', para 17.

65 See Bitterlich, 'Art. 24 EUV', para 7.

This is an open access version of the publication distributed under the terms of the Creative Commons Attribution-NonCommercial-NoDerivs licence (http://creativecommons.org/licenses/by-nc-nd/3.0/), which permits non-commercial reproduction and distribution of the work, in any medium, provided the original work is not altered or transformed in any way, and that the work is properly cited. For commercial re-use, please contact academic.permissions@oup.com 
to loyalty, this would collapse the meaning of the two terms into one concept of very fuzzy contours. In Chapter 4, I will therefore argue that CFSP loyalty is not the same as non-CFSP loyalty or, conversely, that Article 4 (3) TEU and all the effects based on it do not equally operate within the area of the CFSP.

\subsection{Conclusion}

In the provisions on the CFSP, as well as in other parts of the Treaty, solidarity primarily governs the horizontal relationship between the Member States. It represents the general political maxim that Member States shall support each other in financial or in other form. Solidarity unites the Member States financially and politically, because of shared goals and the willingness to integrate all Member States to an equal degree. This corresponds to the ordinary meaning of this term, signifying a 'bond of unity' in pursuance of a common goal. Solidarity, thus, is a principle guiding the conduct of Member States in their relation with each other. As such, it is rather a political than a legal concept, important exceptions aside.

As far as its application in the CFSP is concerned, it is also not enforceable before the Court of Justice. All this makes it a concept very much different from loyalty, which is the basis for distinct obligations for the Member States and which is enforceable before the Court of Justice by itself or in combination with other provisions, as I will expand on in other chapters. Moreover, as mentioned earlier and as will be further demonstrated Union loyalty is less about the (horizontal) bond between individuals or states and more about defining the vertical relationship between the Union and the Member States.

At the same time, the Court has been right in stating that solidarity is 'at the basis of...the whole of the Community system'. ${ }^{66}$ It is the expression of various duties of mutual financial and political assistance central to the functioning of an organization that has long left behind the limitations of having a purely economic raison d'être. The importance of cohesion and the novel provision on disaster relief assistance in Article 222 TFEU bear witness to this. The succession of bailouts for distressed Member States because of the global financial crisis in recent years must also be seen under the header of solidarity. ${ }^{67}$

As such, solidarity is also 'in accordance with' loyalty, as it was put by the Court. ${ }^{68}$ I would proffer that a union of states that is not built on the solidarity among those states cannot command loyalty to the rules that constitute it or that are created by it. Unilateral acts by Member States jeopardizing the balance of rights and obligations between the Member States would undermine the mutual trust the Union is built on. ${ }^{69}$ This makes solidarity the logical match to loyalty, which contributes the legally binding and enforceable rules integrating the so united Member States within the communality of the European Union. ${ }^{70}$ Such interconnection between loyalty and solidarity can

66 Case 6 \& 11/69 Commission v France [1969] ECR 523, para 16.

67 See, e.g., the various references to solidarity in the Strasbourg plenary session of 22-25 November 2010 of the European Parliament, rendered in 'State of Europe's economy dominates debates on EU summit', at <http://www.europarl.europa.eu/news/public/focus_page/008-94348-001-01-01-90120101112FCS94327-01-01-2006-2006/default_p001c011_en.htm>.

68 Case 6 \& 11/69 Commission v France [1969] ECR 523, para 16.

69 See AG Geelhoed in Case C-304/02 Commission v France (Fisheries) [2005] ECR I-6263, para 8.

70 Admittedly, there may be a grey area regarding mutual duties of the Member States, which are based on Art. 4 (3) TEU, but might also be seen as expressions of Union solidarity. See the cases mentioned by C. Calliess, 'Art. 1 EUV', in C. Calliess and M. Ruffert (eds), EUVIAEUV: Das Verfassungsrecht der Europäischen Union mit Europäischer Grundrechtecharta, 4th edn. (Munich: Beck, 2011), para 61.

This is an open access version of the publication distributed under the terms of the Creative Commons Attribution-NonCommercial-NoDerivs licence (http://creativecommons.org/licenses/by-nc-nd/3.0/), which permits non-commercial reproduction and distribution of the work, in any medium, provided the original work is not altered or transformed in any way, and that the work is properly cited. For commercial re-use, please contact academic.permissions@oup.com 
be illustrated by the case of the application of the Dublin II-Regulation. ${ }^{71}$ Dublin II foresees the primary responsibility of the Member State of entry for processing the asylum application to prevent forum shopping and to relieve the burden from the most sought-after Member States for applying for asylum. If a Member State now deliberately or without fault fails to shoulder this responsibility, it upsets this agreed balance between the Member States and thus violates the principle of solidarity. Legally enforceable consequences will, however, require a violation of the Dublin II-Regulation by that Member State, the implementation of which is an obligation for all Member States as a specification of Article 4 (3) TEU.

In this sense, Union solidarity strongly resembles the thrust of federal loyalty discussed earlier. This, however, does not mean to equate Union solidarity with Union loyalty, or to deem the latter a subcategory of the former. Union loyalty does not equal Union solidarity, irrespective of whether we refer to solidarity within the CFSP or in non-CFSP areas. ${ }^{72}$

\section{The Relation with the Principles of Good Faith and pacta sunt servanda}

\subsection{Introduction}

One reason for discussing good faith or bona fides in this book is that it has sometimes been invoked by the Court together with loyalty. ${ }^{73}$ Another, more ponderous reason is that one might see the principle of loyalty in the EU as the equivalent to or an expression of the customary principle of good faith in public international law. More generally still, Union loyalty might be considered but an expression of the rule pacta sunt servanda. Article 26 of the Vienna Convention on the Laws of Treaties (Vienna Convention, VCLT) provides that every treaty in force is binding upon the parties and 'must be performed by them in good faith'. This principle of interpretation in good faith flows directly from the rule pacta sunt servanda and forms an integral part of it. ${ }^{74}$ Kelsen at some point has considered pacta sunt servanda the basis of the universal legal order. ${ }^{75}$

As explained in Chapter 1, it seems likely that Article 5 EEC (based on Article 86 of the European Coal and Steel Community Treaty (ECSC)) was meant to adapt the principle of pacta sunt servanda for the EU. One might even argue that pacta sunt servanda would

For those it is, however, also better to refer to the concept of loyalty and not to solidarity, when the former is located primarily in the social and political dimension.

71 Council Regulation (EC) 343/2003 establishing the criteria and mechanisms for determining the Member State responsible for examining an asylum application lodged in one of the Member States by a third-country national (Dublin II) [2003] OJ L50/1. I am grateful to Christoph Grabenwarter for bringing this to my attention.

72 For a different perspective, see Ross, 'Solidarity', 42, who has claimed that ex Art. 10 EC 'is perhaps the clearest example of the levels of activity and commitment which classical solidarity demands', and that 'solidarity as a cooperative and social justice-led concept is perhaps more credible in maintaining that accommodation than the discourse of supremacy and compliance'.

73 I will not discuss the cases where good faith is employed in a different context, such as in Case C-158/06 Stichting ROM-projecten [2007] ECR I-5103, para 34 regarding the preclusion of repayment of amounts wrongly paid on grounds of the beneficiary's good faith.

74 M. Fitzmaurice, 'The Practical Working of the Law of Treaties', in M. Evans (ed.), International Law, 3rd edn. (Oxford: Oxford Univ. Press, 2010), 172-199, 181; G. White, 'The Principle of Good Faith', in V. Lowe and C. Warbrick (eds), The United Nations and the Principles of International Law: Essays in Memory of Micheal Akehurst (London and New York: Routledge, 1994), 230, 236.

75 H. Kelsen, Das Problem der Souveränität und die Theorie des Völkerrechts: Beitrag zu einer Reinen Rechtslehre (Tubingen: Mohr, 1920), 217, 262, and 284. But see H. Kelsen, The Pure Theory of Law (Berkeley: Univ. of California Press, 1967; orig. German publ. 1960), 216.

This is an open access version of the publication distributed under the terms of the Creative Commons Attribution-NonCommercial-NoDerivs licence (http://creativecommons.org/licenses/by-nc-nd/3.0/), which permits non-commercial reproduction and distribution of the work, in any medium, provided the original work is not altered or transformed in any way, and that the work is properly cited. For commercial re-use, please contact academic.permissions@oup.com 
apply by custom in the EU legal order, independent of what is written in the Treaties about loyalty and sincere cooperation. In this vein, AG Mazák has claimed that there is 'an enhanced obligation of good faith which is incumbent upon Member States of the European Union as regards their relations with one another and with the institutions of the European Union as a result of their membership of the EU' ${ }^{76}$ However, analogies between pacta sunt servanda and loyalty have been denied in passing by important voices in the literature. ${ }^{77}$ We must indeed note that not all principles of public international law necessarily apply also within the Union legal order. Thus, the EU Treaties are not construed to preserve state sovereignty when in doubt, nor does the rule of lex posterior apply. ${ }^{78}$

In the following section, I will show that while there are indeed some striking parallels between good faith and pacta sunt servanda and Union loyalty, there remain important differences. I will start by briefly laying out the pertinent case law of the Court.

\subsection{Good Faith and pacta sunt servanda in EU Law}

In many judgments, the Court refers to good faith merely as a semantic extension of the expression 'duty of cooperation', 'principle of cooperation', or 'obligation to cooperate' ${ }^{79}$ It appears that this reference to good faith has particularly often occurred in a line of case law imposing certain standards on the Member States for implementing Union secondary law, mainly in the context of directives and regulations in common market organization cases. ${ }^{80}$ Most famously among these, the Court alluded to good faith in the Tafelwein case on the failure of Germany immediately to implement the compulsory distillation notices required under Regulation 337/79/EEC. ${ }^{81}$ The Court held that 'the Commission and the Member State are obliged, by virtue of the reciprocal duties of genuine cooperation imposed on them in particular by Article 5 of the EEC Treaty, to work together in good faith in order to overcome those difficulties while complying in full with the provisions of the Treaty'. ${ }^{82}$ In a case such as this, good faith does not appear to hold any distinct meaning other than to emphasize the need for an honest and proactive way of interaction between the Member States and the Commission. Good faith, thus, has often been mentioned and invoked by the Court not as a synonym to loyalty. Instead, it has either served the Court to shore up the reference to Article 4 (3) TEU proper, or it has been employed to highlight the need for Member States and the Commission to cooperate to overcome difficulties in implementing Union law such as in the Tafelwein case.

76 AG Mazák in Case C-203/07 P. Greece v Commission (Project Abuja) [2008] ECR I-8161, para 83.

77 Lenz, 'Art. 4', para 11. See A. Epiney, 'Zur Tragweite des Art. 10 EGV im Bereich der Außenbeziehungen', in J. Bröhmer and G. Ress (eds), Internationale Gemeinschaft und Menschenrechte: Festschrift für Georg Ress zum 70. Geburtstag am 21. Januar 2005 (Cologne: Heymanns, 2005), 441-459, 444.

78 See F.C. Mayer, 'Art. 19 EUV', in E. Grabitz, M. Hilf, and M. Nettesheim (eds), Das Recht der Europäischen Union (Munich: Beck, 2011), para 68.

79 See the heading before paras 59-68 in Case C-149/96 Portugal v Council (Textiles) [1999] ECR I-8395: 'Breach of the principle of cooperation in good faith in relations between the Community institutions and the Member States'. See also Case C-161/06 Skoma-Lux [2007] ECR I-10841, para 41; Case C-362/06 P. Markku Sahlstedt [2009] ECR I-2903, para 43.

80 Case C-50/94 Greece $v$ Commission (Clearance of EAGGF Accounts) [1996] ECR I-3331, para 39; Case C-404/97 Commission v Portugal [2000] ECR I-4897, para 40; Case C-75/97 Belgium v Commission ('Maribel Scheme') [1999] ECR I-3671, para 88; Case C-499/99 Commission v Spain (Magefesa Group) [2002] ECR I-6031, para 24; Case C-278/00 Greece v Commission (State Aid) [2004] ECR I-3997, para 114.

81 Case C-217/88 Commission v Germany (Market in Wine) [1990] ECR I-2879.

82 Case C-217/88 Commission v Germany (Market in Wine) [1990] ECR I-2879, para 33.

This is an open access version of the publication distributed under the terms of the Creative Commons Attribution-NonCommercial-NoDerivs licence (http://creativecommons.org/licenses/by-nc-nd/3.0/), which permits non-commercial reproduction and distribution of the work, in any medium, provided the original work is not altered or transformed in any way, and that the work is properly cited. For commercial re-use, please contact academic.permissions@oup.com 
Other judgments, however, have employed good faith in a somewhat different, less 'unionist' way. Thus, in Opel Austria, the Court held that the principle of good faith is a rule of customary international law binding on the Union. ${ }^{83}$ In Intertanko, the Court held that the validity of Directive 2005/35 on ship-source pollution and on the introduction of penalties for infringements ${ }^{84}$ could not be assessed in the light of the International Convention for the Prevention of Pollution from Ships 1973 (as modified by the Protocol of 1978) (Marpol Convention). ${ }^{85}$ However, the Court continued that '[i]n view of the customary principle of good faith, which forms part of general international law, and of Article $10 \mathrm{EC}$, it is incumbent upon the Court to interpret those provisions taking account of Marpol 73/78'. ${ }^{86}$ Thus, in lieu of reviewing the pertinent Directive in the light of the Marpol Convention, the Directive had at least to be interpreted consistently with it. ${ }^{87}$ The decisive point in Intertanko was that the Marpol Convention bound the Member States, but did not bind the Union/Community itself because the Convention did not form an integral part of Union law, such as is the case with other international agreements concluded by the Union. ${ }^{88}$ Consequently, the case law of the Court on the duty to interpret secondary law in light of international agreements was not applicable in the Intertanko case. ${ }^{89}$ Against this background, it does make sense for the Court to resort to general principles of public international law instead. By this perspective, the additional reference to ex Article $10 \mathrm{EC}$ would not have been strictly required. Intertanko, therefore, firstly shows that good faith as a principle of public international law can apply within the Union, ${ }^{90}$ and secondly that it can share one of the effects of loyalty.

\subsection{Good Faith and pacta sunt servanda in Public International Law}

The principle of good faith is a general principle of public international law. ${ }^{91}$ It has been said that it 'combines moral ideas on correct action (honesty, seriousness, loyalty) and strictly legal contents (e.g. a ban on the abuse of legal rights)'.${ }^{92}$ Thus, good faith has

83 Case T-115/94 Opel Austria GmbH v Council [1997] ECR II-39, para 24. See J. Wouters, D. Coppens, and D. Geraets, 'The Influence of General Principles of Law', in S.E. Gaines, B. Egelund Olsen, and K. Engsig Sørensen (eds), Liberalising Trade in the EU and the WTO: A Legal Comparison (Cambridge: Cambridge Univ. Press, 2012), 43-74, 57.

84 Directive (EC) $2005 / 35$ on ship-source pollution and on the introduction of penalties for infringements [2005] OJ L255/11.

85 Case C-308/06 Intertanko [2008] I-04057, para 52. See Cremona, 'Member States as Trustees of the Union Interest: Participating in International Agreements on Behalf of the European Union', in A. Arnull et al. (eds), A Constitutional Order of States?: Essays in EU Law in Honour of Alan Dashwood (Oxford and Portland, Oregon: Hart Publishing, 2011), 435-457, 448-449; E. Denza, 'Note on Intertanko', European Law Review, (2008), 870-879.

86 See also Case C-203/07 P. Greece v Commission (Project Abuja) [2008] ECR I-8161.

87 See P.-J.Kuijper, 'International Responsibility for EU Mixed Agreements', in C. Hillion and P. Koutrakos, Mixed Agreements Revisited: The EU and its Member States in the World (Oxford and Portland, Oregon: Hart, 2010), 208-227, 221, arguing that this forumla is weaker than the conforming interpretation approach.

88 See Case 181/73 Haegeman [1974] ECR 449.

89 See C-61/94 Commission v Germany [1996] ECR I-3989, para 52.

90 See Epiney, 'Die Bindung der Europäischen Union an das allgemeine Völkerrecht', Europarecht, Beiheft (2012), 25-49, 33, who refers to this in support of her claim that the relationship between Union law and public international law is of a monist nature.

91 See J.F. O'Connor, Good Faith in International Law (Aldershot: Dortmann, 1991). See the various applications listed by M. Kotzur, 'Good Faith (Bona Fides)', Max Planck Encyclopedia of Public International Law (Heidelberg and Oxford: Oxford Univ. Press, 2013) (<http://www.mpepil.com>).

92 B. Simma, The Charter of the United Nations: A Commentary (Oxford: Oxford Univ. Press, 1994), 93. See Art. 300 of UNCLOS on 'Good faith and abuse of rights'. On good faith as the foundation of the theory of abuse of rights, see also White, 'The Principle of Good Faith', 244.

This is an open access version of the publication distributed under the terms of the Creative Commons Attribution-NonCommercial-NoDerivs licence (http://creativecommons.org/licenses/by-nc-nd/3.0/), which permits non-commercial reproduction and distribution of the work, in any medium, provided the original work is not altered or transformed in any way, and that the work is properly cited. For commercial re-use, please contact academic.permissions@oup.com 
been qualified as the basic postulate of the international legal order borrowed from the ethical realm and turned into a juridical principle of considerable value. ${ }^{93}$

Good faith plays different roles in the law of treaties as codified by the Vienna Convention. Firstly, there is the notion of good faith in the context of treaty interpretation. ${ }^{94}$ Secondly, good faith must guide the performance of treaties according to the principle of pacta sunt servanda. ${ }^{95}$ Moreover, there is the special rule of good faith to the effect that states shall not nullify the object and purpose of a treaty during the period between signature and entry into force. ${ }^{96}$ This does not entail that states would already have to comply with a treaty before ratification, yet there is a duty to refrain from acts that would defeat the object and purpose of a treaty even before it enters into force. ${ }^{97}$

Recommendations contained in General Assembly Resolutions must be considered in good faith based on the obligations of cooperation assumed by Members pursuant to Articles 1 (3), 2 (5) and 56 of the UN Charter. ${ }^{98}$ Finally, Principle 4 of the Friendly Relations Declaration, ${ }^{99}$ titled 'The duty of states to co-operate with one another in accordance with the Charter', provides that states 'shall fulfil in good faith the obligations assumed by them in accordance with the Charter'. ${ }^{100}$

Article 2 (2) of the UN Charter has been deemed the culmination of a development considering good faith as a test of reasonableness for the interpretation of international instruments. ${ }^{101}$ This has been confirmed by the International Law Commission, stating that if a treaty is open to two interpretations of which one does and the other does not enable the treaty to have appropriate effects, 'good faith and the objects and purpose of the treaty demand that the former interpretation should be adopted'. ${ }^{102}$ This maxim of magis valeat quam pereat mandates that, firstly, all provisions must be supposed to have been intended to have significance and to be necessary to express the intended meaning. ${ }^{103}$ Secondly, it means that instruments and provisions must be interpreted as if they had been intended 'to achieve some end', which prohibits an interpretation that would make a provision ineffective. ${ }^{104}$

It appears that good faith in public international law has also been used as a sort of gapfilling principle. The Algiers Declarations, which settled the Iran-US hostage crisis in $1981,{ }^{105}$ had only provided on the satisfaction or enforcement of awards of the Iran-US

${ }^{3}$ M. Virally, 'Review Essay: Good Faith in Public International Law', American Journal of International Law, 77 (1983), 130-134, 132-133.
${ }_{94}$ Art. 31 VCLT.
95 Art. 26 VCLT.
96 Art. 18 VCLT.

97 See A. Aust, 'Pacta Sunt Servanda', Max Planck Encyclopedia of Public International Law (Heidelberg and Oxford: Oxford Univ. Press, 2013) (<http://www.mpepil.com>), paras 5 and 8. Note the similarity with the duties of abstention imposed in Member States with regard to directives before the expiry of their transposition period. See Case C-129/96 Inter-Environnement Wallonie [1997] ECR 7411. See Chapter 4.

98 White, 'The Principle of Good Faith', 245; B. Sloan, 'General Assembly Resolutions Revisited (Forty Years Later)', British Yearbook of International Law, 58 (1987), 39-150, 121.

99 Declaration on Principles of International Law concerning Friendly Relations and Co-operation among States in Accordance with the Charter of the United Nations. See D. Richter, 'Unfriendly Act', Max Planck Encyclopedia of Public International Law (Heidelberg and Oxford: Oxford Univ. Press, 2013) (<http://www.mpepil.com >), para 9, who has called this a 'precursor to a universal principle of loyalty'.

100 UN GA Res 2625 (XXV), 24 October 1970.

101 White, 'The Principle of Good Faith', 236.

102 YB I.L.C. Yearbook 1966, Vol. II (Part 2), 219, para 6.

103 Fitzmaurice, 'The Practical Working of the Law of Treaties', 188.

104 Fitzmaurice, 'The Practical Working of the Law of Treaties', 188. See further on good faith and treaty interpretation, K. Schmalenbach, 'Capacity of States to Conclude Treaties', in O. Dörr and K. Schmalenbach (eds), Vienna Convention on the Law of Treaties: A Commentary (Berlin, Heidelberg: Springer), 108-109.

105 (1981) 20 I.L.M. 224. See White, 'The Principle of Good Faith', 241.

This is an open access version of the publication distributed under the terms of the Creative Commons Attribution-NonCommercial-NoDerivs licence (http://creativecommons.org/licenses/by-nc-nd/3.0/), which permits non-commercial reproduction and distribution of the work, in any medium, provided the original work is not altered or transformed in any way, and that the work is properly cited. For commercial re-use, please contact academic.permissions@oup.com 
claims tribunal in favour of US claimants, but not in favour of Iranian nationals. In Iran $v U S$, the Tribunal decided that the US was not obliged to compensate the Iranian party, which was referred to enforcement before US courts. ${ }^{106}$ The US, however, was obliged to implement the Algiers Declaration in good faith, meaning 'to provide some procedure or mechanism whereby enforcement may be obtained within its national jurisdiction, and to ensure that the successful Party has access thereto'. If no such procedure existed, the US was ordered to establish it by legislation or other means, and it 'must be available on a basis at least as favourable as that allowed to parties who seek recognition or enforcement of foreign arbitral awards'. ${ }^{107}$

It has been remarked that, while in the General Agreement on Tariffs and Trade (GATT) an obligation analogue to Article 4 (3) TEU for promoting the GATT's good was not required, it is a problem that this has not been changed with the World Trade Organization (WTO), where obligations such as to notify Preferential Trade Agreements consequently cannot be enforced. ${ }^{108}$ In WTO law, good faith and pacta sunt servanda have been invoked in connection with Article XX GATT. This provision has been said to incorporate a specific principle of good faith in WTO law. ${ }^{109}$ Article XX allows for justifications of violations of the GATT for certain reasons of public interest. However, under Article XX GATT such measures must not be applied in a manner 'that would constitute a means of arbitrary or unjustifiable discrimination between countries where the same conditions prevail', or as 'a disguised restriction on international trade...' 110 The Appellate Body found this to entail that WTO Members must 'explore adequately means, including in particular cooperation' with the governments of other Members in order to mitigate problems caused by such justified trade restriction. ${ }^{111}$ This also includes a prohibition of the abusive exercise of a state's rights and that such rights must be 'exercised bona fide, that is to say, reasonably'. ${ }^{112}$ This task of interpreting and applying the chapeau of Article XX thus involves balancing the rights of WTO Members to invoke an exception with the rights of the other Members under other GATT provisions. As a result, 'neither of the competing rights will cancel out the other and thereby distort and nullify or impair the balance of rights and obligations constructed by the Members themselves in that Agreement'. ${ }^{113}$ While good faith is therefore an expression of the doctrine of abus de droit, it has been argued that it does not have an independent application in WTO law. ${ }^{114}$

It has furthermore been claimed that the loyalty principle in Union law was comparable to the notion of non-violation in the GATT. ${ }^{15}$ The rationale for non-violation

106 (1987) 14 Iran-U.S. C.T.R. 324, Request for Interpretation by the Full Tribunal of the Algiers Declarations with respect to whether the US is Obligated to Satisfy Promptly Any Awards of the Tribunal Rendered in Favour of Iran against Nationals of the US.

107 (1987) 14 Iran-U.S. C.T.R. 324, 330-331.

108 A. Alavi, 'Negotiating in the Shadow of Good Faith', in S.E. Gaines, B. Egelund Olsen, and K. Engsig Sørensen (eds), Liberalising Trade in the EU and the WTO: A Legal Comparison (Cambridge: Cambridge Univ. Press, 2012), 21-42, 39.

109 C. Herrmann, W. Weiß and Ch. Ohler, Welthandelsrecht, 2nd edn. (Munich: Beck, 2007), 233.

110 This is called the Chapeau of Art. XX GATT.

111 WTO, Appellate Body, United States-Standards for Reformulated and Conventional Gasoline, WT/DS2/AB/R, 27.

112 WTO, Appelate Body, United States-Import Prohibtion of Certain Shrimp and Shrimp Products, WT/DS58/AB/R, para 158 .

113 United States-Shrimp, para 159.

114 J. Wouters, D. Coppens, and D. Geraets, 'The Influence of General Principles of Law', in S.E. Gaines, B. Egelund Olsen, and K. Engsig Sørensen (eds), Liberalising Trade in the EU and the WTO: A Legal Comparison (Cambridge: Cambridge Univ. Press, 2012), 43-74, 48-49.

115 P.-J. Kuijper, 'Re-reading External Relations Cases in the Field of Transport: The Function of Community Loyalty', in J. Bulterman et al. (eds), Views of European Law from the Mountain: Liber Amicorum for Piet-Jan Slot (The Hague: Kluwer Law International, 2009), 291-300, 293.

This is an open access version of the publication distributed under the terms of the Creative Commons Attribution-NonCommercial-NoDerivs licence (http://creativecommons.org/licenses/by-nc-nd/3.0/), which permits non-commercial reproduction and distribution of the work, in any medium, provided the original work is not altered or transformed in any way, and that the work is properly cited. For commercial re-use, please contact academic.permissions@oup.com 
complaints is that benefits from trade liberalization may be nullified because of either a GATT inconsistent or a GATT consistent behaviour by another WTO Member. ${ }^{116}$ Mavroides has specified that, in his opinion, non-violation complaints were 'an application of the good faith (bona fides) principle... '. ${ }^{117}$ There is a lot of similarity between the readings of the chapeau of Article XX GATT mentioned earlier and the understanding of non-violation. Both serve the purpose to strike a balance between different measures, one time in order not to nullify benefits under the agreement, another time to balance rights and obligations under the agreement.

\subsection{Conclusion}

Thus, good faith and pacta sunt servanda in public international law play a role both with regard to interpretation and with regard to conflict resolution in the broader sense. The role of good faith in gap-filling and treaty interpretation, as acknowledged by the International Law Commission, arguably echoes the effet utile principle in Union law. This makes them close relatives to loyalty, as I have started to discuss its functions earlier and will continue to do in the chapters to come. Constantinesco has highlighted the similarity of loyalty with good faith, if we conceive the former (also) as a principle of non-contradiction. He has argued that it is an exigency of pure logic that an actor should not act contrary to his own commitment to certain objectives and their realization, and that this would be anchored in ex Article 5 EEC. ${ }^{118}$ In his own words:

Larticle 5 du traité CEE ne serait alors que l'expression juridique du principe de noncontradiction. Il impliquerait que les Etats members ne puissent entraver le bon fonctionnement de l'organisation qu'ils ont voulue. Il signiferait aussi que les Etats doivent non seulement ne pas s'opposer à la mise en oeuvre de leur propre volonté, mais qu'ils doivent lui apporter leur concours actif, bref, qu'ils doivent tirer les conséquences de leur décision de crèer la Communauté et d'y appartenir. ${ }^{119}$

Thus, loyalty indeed could be seen as an enhanced principle of pacta sunt servanda, as it has been put by AG Mazák. Loyalty thus is stronger even where it is similar, such as in the obligation not to frustrate binding commitments entered into by states (a treaty before ratification in the case of international law, a directive before the expiry of the deadline for transposition in the case of EU law). Moreover, in the Union, loyalty not only ties the Member States to each other but also creates obligations towards the EU institutions, more than would be apposite in the intergovernmental setting that is the WTO. Finally, loyalty in Union law has the earlier discussed pronounced constitutionalizing role that also finds no match in the WTO for principled reasons.

In the following section, we will now turn to another close relative to Union loyalty.

116 Art. XXIII (1) (b) GATT.

117 P. Mavroides, The General Agreement on Tariffs and Trade: A Commentary (Oxford: Oxford Univ. Press, 2005), 412. Under the GATT, non-violation complaints may be raised 'against practically each and every government measure that might have an impact on the value of negotiated concessions'. Mavroides, The General Agreement on Tariffs and Trade, 414.

118 See Constantinesco, 'L'article CEE de la bonne foi', 108.

119 Constantinesco, 'L'article CEE de la bonne foi', 109.

This is an open access version of the publication distributed under the terms of the Creative Commons Attribution-NonCommercial-NoDerivs licence (http://creativecommons.org/licenses/by-nc-nd/3.0/), which permits non-commercial reproduction and distribution of the work, in any medium, provided the original work is not altered or transformed in any way, and that the work is properly cited. For commercial re-use, please contact academic.permissions@oup.com 


\section{Federal Fidelity in the European Union}

\subsection{Introduction}

As mentioned earlier, parts of the literature have always referred to the notion of fidelity when discussing duties flowing from now Article 4 (3) TEU. ${ }^{120}$ Others have drawn analogies to federal systems in a more general mould. Halberstam has argued that there is a 'fidelity approach' in the European Union (and in Germany), which he defines as the requirement for each level or unit of government to 'always act to ensure the proper functioning of the system of governance as a whole'. ${ }^{121}$ Halberstam, however, does not seem to equate fidelity with loyalty, and he refers to the duties under now Article 4 (3) TEU mostly not by the term 'fidelity', but as 'the duty of cooperation'. ${ }^{122}$ In a similar vein, Hay has argued that the 'federal orientation' of the Union structure would compel the acceptance of a constitutional principle designed to maintain that structure. ${ }^{123} \mathrm{It}$ is, however, striking that in a book devoted to federalism in the EU, loyalty is only mentioned prominently by AG Sharpston in the preface arguing that Article 4 (3) TEU provides 'the "glue" to keep the federal construction together'. ${ }^{124}$

In order to adequately deal with such analogies, we need to do two things. First, we will discuss whether the European Union in its present state is a federation. The argument here would be as follows: If federal loyalty is inherent with federal systems, and if the EU is a federal construct, federal loyalty would be inherent with EU law. Secondly, we will examine the substance of 'loyalty-like' rules in federal states. This should tell us whether concepts of loyalty in national states are similar to the concept of loyalty in Union law. There is a myriad of literature on federalism in general, on different federal systems in particular, and on the situation of the European Union in this respect. ${ }^{125}$ It is not my intention to engage with this subject more than absolutely necessary for answering these two issues.

\subsection{Federalism and the European Union}

The distinction between a federation and a confederation that is commonly made has its origins in the American experience, where the colonies went from forming a confederation

120 Only a few commentators have expressly denied the applicability of the Bundestreue to the EU. See U. Scheuner, 'Die Rechtssetzungsbefugnisse internationaler Gemeinschaften', in K. Zemanek et al. (eds), Völkerrecht und rechtliches Weltbild: FS für Verdross (Vienna: Springer, 1960), 229, 323.

121 See D. Halberstam, 'Of Power and Responsibility: The Political Morality of Federal Systems', Virginia Law Review, (2004), 731-834, 734, who however discusses the limits of the powers in approximating national laws and the Tobacco cases in the present context.

122 Halberstam, 'Of Power and Responsibility', 763-767. See also de Baere, Constitutional Principles, 253.

123 P. Hay, Federalism and Supranational Organizations: Patterns for New Legal Structures (Urbana and London: Univ. of Illinios Press, 1966), 196-197, and 200, who has referred to ex Arts. 6, 224, 225 , 219, and 8 (3)-(4) EEC, as well as Art. 10 (11) ECSC. See also E. Stein and P. Hay, 'Legal Remedies of Enterprises in the European Economic Community', The American Journal of Comparative Law, 9 (1960), 375-424, 400 .

124 E. Sharpston, 'Preface', in E. Cloots, G. de Baere, and S. Scottiaux (eds), Federalism in the European Union (Oxford and Portland, Oregon: Hart, 2012), v-viii, viii. The contributions in this book, in contrast, discuss numerous other features of Union law such as conferral, competence, and citizenship, but fail to further develop the role of loyalty.

125 See, among others, K. Nicolaïdis and R. Howse (eds), The Federal Vision: Legitimacy and Levels of Governance in the United States and the European Union (Oxford: Oxford Univ. Press, 2001); S. Fabbrini (ed.), Democracy and Federalism in the European Union and the United States: Exploring Post-National Governance (London: Routledge, 2005).

This is an open access version of the publication distributed under the terms of the Creative Commons Attribution-NonCommercial-NoDerivs licence (http://creativecommons.org/licenses/by-nc-nd/3.0/), which permits non-commercial reproduction and distribution of the work, in any medium, provided the original work is not altered or transformed in any way, and that the work is properly cited. For commercial re-use, please contact academic.permissions@oup.com 
to creating a federation in Philadelphia. ${ }^{126}$ A confederation has been defined by the direct relationship that lies between the shared institutions and the governments of the member states. ${ }^{127}$ Confederalism, therefore, has been closely associated with the integration theory of intergovernmentalism, acknowledging the institutionalized character of the Union. ${ }^{128}$ A distinction is also often made between dual federalism on the one hand that is associated with the US model of the separation between federal and state powers, and cooperative federalism in the Swiss and German mould on the other, which is based on 'interconnections, interdependence and co-operation between the various entities of the federation'. ${ }^{129}$

A federation has been defined by Watts as 'a compound polity combining constituent units and a general government, each possessing power delegated to it by the people through a constitution, each empowered to deal directly with the citizens in the exercise of a significant portion of its legislative, administrative, and taxing powers, and each directly elected by its citizens'. ${ }^{130}$ Wheare has found a federal government to exist if there is 'a single independent authority for the whole area in respect of some matters and that there are independent regional authorities for other matters, each set of authorities being co-ordinate with and not subordinate to the others within its own prescribed sphere'. ${ }^{131}$ Put in other words, a federation requires two levels of government which are 'within a sphere' coordinate and independent. ${ }^{132}$ A slightly different perspective has been advocated by Lenaerts, who has suggested affirming federalism 'whenever a divided sovereignty is guaranteed by the national or supranational constitution and umpired by the supreme court of the common legal order'. ${ }^{133}$ This division should apply both regarding the direct operation of the laws enacted by the sovereigns as well as concerning mutual political oversight. ${ }^{134}$ In a similar vein, it has been proposed that federal states must constitute a single scheme of government and jurisdiction based on a coherent set of constitutional principles. ${ }^{135}$

126 F. Laursen, 'Federalism: From Classical Theory to Modern Day Practice in the EU and Other Polities', in F. Laursen (ed.), EU and Federalism: Polities and Policies Compared (Farnham: Ashgate, 2010), 34. For an early discussion of this dichotomy with regard to the EU, see Hay, Federalism, 80-90.

127 R.L. Watts, 'Federalism, Federal Political Systems, and Federation', Annual Review of Political Science, 1 (1998), 117-137, 121.

128 M. Cini, 'Intergovernmentalism', in M. Cini and N. Pérez-Solórzano Borragán (eds), European Union Politics, 3rd edn. (Oxford: Oxford Univ. Press, 2010), 86-103, 93, 96.

129 A. von Bogdandy and J. Bast, 'The Federal Order of Competences', in A. von Bogdandy and J. Bast (eds), Principles of European Consitutional Law (Oxford et al.: Hart, Beck, Nomos, 2009), 285.

130 Watts, 'Federalism', 121.

131 K.C. Wheare, Federal Government, 4th edn. (London, New York, Toronto: Oxford Univ. Press, 1967), 35. Laursen, 'Federalism', 3-4, has remarked that Wheare's criterion of independence should be replaced by looking at the level of autonomy in a system instead. Intergovernmental cooperation in a federation for Wheare must be both between the general and the regional governments as well as inter-regional. See Wheare, Federal Government, 226-227. In the US, an intended institutionalization of such cooperation, the Governors' Conference, has never been established. See Wheare, Federal Government, 231-232.

132 P. Hogg, Constitutional Law of Canada, 5 th edn., Vol. I (Toronto: Thomson \& Carswell, 2011), 5-4-5-4.1. That he deemed to be true of Canada, Australia, and the United States, and to be untrue of the United Kingdom and New Zealand.

133 K. Lenaerts, 'Constitutionalism and the Many Faces of Federalism', American Journal of Comparative Law, 38 (1990), 205-263, 263. On the importance of a constitution and a supreme court, see also Wheare, Federal Government, 55.

134 Lenaerts, 'Constitutionalism', 263.

135 P. Eleftheriadis, 'The Structure of European Union Law', Cambridge Yearbook of European Legal Studies, 12 (2010), 121-150.

This is an open access version of the publication distributed under the terms of the Creative Commons Attribution-NonCommercial-NoDerivs licence (http://creativecommons.org/licenses/by-nc-nd/3.0/), which permits non-commercial reproduction and distribution of the work, in any medium, provided the original work is not altered or transformed in any way, and that the work is properly cited. For commercial re-use, please contact academic.permissions@oup.com 
Others have insisted that the traditional categories of federation and confederation should be discarded, ${ }^{136}$ and that instead the federal elements should be distinguished from the international elements in the following manner:

Federal is therefore used in an adjectival sense: it attaches to a particular function exercised by the organization and is used to denote, as to that function, a hierarchical relationship between the Communities and their members. It is another question what degree of functional federalism will permit a conclusion in institutional terms, that the organization is a 'federation'. ${ }^{137}$

In a similar vein, Watts has distinguished between federalism as a normative term, referring to the 'advocacy of multi-tiered government combining elements of shared-rule and regional self-rule' on the one hand, and federalism as a descriptive term, 'where, as in a spectrum, the categories are not sharply delineated'. ${ }^{138}$ In this vein, it has been argued convincingly that federal states may range in a spectrum 'running from a point that is close to disintegration into separate countries to a point that is close to the centralized power of a unitary state or an empire'. ${ }^{139}$ On this range, there may be a tipping point when central power completely overlaps regional power, which has for instance not yet been reached in Canada, Australia, or the United States. ${ }^{140}$

When we look at the literature on federalism and the European Union, the first thing to note is that, while federalism with some nation states such as Austria connotes a decentralizing streak, with the EU it mostly implies a stronger role for the Union in its relationship with the Member States. ${ }^{141}$ Secondly, we must note that there seems to be agreement only on the difficulty of fitting the European Union into either the confederation or the federation paradigm. ${ }^{142}$ While a number of notions to capture the nature of the EU as a specific type of federation have been proposed, none seems to have gained broader acceptance in the scientific debate. ${ }^{143}$ Thus, Weiler has proposed that the EU should be seen as a mixture of legal federalism and political confederalism, with the dominance of the Member States as Masters of the Treaty reflecting the latter. ${ }^{144}$ The German Constitutional Court (BVerfG) has proposed the concept of a Staatenverbund, which should be something more than a confederation, but also something less than a federation, and which will be discussed in Chapter $11 .{ }^{145}$ Trömmel has argued that the

136 See also T. Koopmans, Guest Editorial: 'Federalism: The Wrong Debate', Common Market Law Review, 29 (1992), 1047-1052.

137 Hay, 'Federalism', 90.

138 Watts, Comparing Federal Systems, 8.

140 Hogg, Constitutional Law of Canada, 5-3 and 5-4.

141 Aptly noted by P. Eleftheriadis, 'Federalism and Jurisdiction', in G. de Baere and E. Cloots (eds), Federalism and EU Law (Oxford: Hart Publishing, 2012), 45-64, 46. See Lenaerts, 'Constitutionalism', 208, who has argued that cases such as especially Van Gend \& Loos created 'a "constitution” of a central legal order, federally related to the legal orders of the Member States'.

${ }_{142}$ On the difficulty in comparing federal states with the Union because of its unique nature, see S.B. Wolinetz, 'Comparing the Incomparable: Treating the EU in Comparative Context', in F. Laursen (ed.), EU and Federalism: Polities and Policies Compared (Farnham: Ashgate, 2010), 27. See also at 34: 'Treating the EU as either a multi-level system or a system of governance is preferable to treating it as a federation.'

143 See I. Trömmel, ‘The European Union: A Federation Sui Generis?’, in F. Laursen (ed.), EU and Federalism: Polities and Policies Compared (Farnham: Ashgate, 2010), 44, with references.

144 J.H.H. Weiler, 'The Community System: The Dual Character of Supranationalism', Yearbook of European Law, (1981), 267-280; J.H.H. Weiler, The Constitution of Europe (Cambridge: Cambridge Univ. Press, 1999), 270-271. Similarly Watts, Comparing Federal Systems, 8, and the table at 10-11. See, as to these features, Watts, Comparing Federal Systems, 57-58: The pragmatical approach by the leaders in the EU has been said to have created a hybrid, which 'although originally a purely confederal arrangement, has in recent years incorporated some features of a federation'.

145 Case 2 BvR 1877/97 and 2 BvR 50/98 Maastricht Treaty [1998] BVerfGE 97, 350. See on the difficulties with conveying this concept in other languages, B. de Witte, 'The Pillar Structure and the

This is an open access version of the publication distributed under the terms of the Creative Commons Attribution-NonCommercial-NoDerivs licence (http://creativecommons.org/licenses/by-nc-nd/3.0/), which permits non-commercial reproduction and distribution of the work, in any medium, provided the original work is not altered or transformed in any way, and that the work is properly cited. For commercial re-use, please contact academic.permissions@oup.com 
Union is neither a federal state nor a fully-fledged federal system, but a system marked by some characteristic features of a federation (a federation sui generis). ${ }^{146}$ Nicolaïdis has contributed the distinction between a federal union and a federal state, and has argued that the EU qualifies as the former. ${ }^{147}$ Eleftheriadis has commented that this may support the claim of unionhood as opposed to statehood, but that it would not support a claim for federalism with regard to the EU, and that a federal union should rather be understood as analogous to a confederation. ${ }^{148}$ Within the federalism label, Schütze has argued that the EU has developed from a dual federalist system to a system with cooperative federalism. ${ }^{149}$

It is not my intention to contribute to this highly sophisticated debate, as this would be beyond the limits of this book. The present purposes do not require us to deal with the question which kind of federation the European Union constitutes. ${ }^{150}$ Note, however, that there is a certain overlap with the discussion on how to conceptualize the relationship between the constitutional order of the Union and its Member States, which will be addressed specifically in the Part on Construction. ${ }^{151}$ What I will show in the following section, in contrast, is that federal systems of any kind share certain fundamental rules, are indeed built on a certain 'federal principle', but that its contours are so unclear that parallels to Union loyalty barely bear fruit.

\subsection{Federal Loyalty}

If we assume that federalist is a relative or descriptive adjective, what would be the minimum threshold for federalism to exist in a certain constellation? In other words, what is the principle unifying all different representations of a federation? Famously, Wheare has defined the federal principle as 'the method of dividing powers so that the general and regional governments are each, within a sphere, co-ordinate and independent'. ${ }^{152}$ Similarly, a federal system would exist if overlapping power is incomplete or if the scope of central power is limited. ${ }^{153}$ I would submit that what is essential in federal systems is to ensure the harmonious interaction between the different legal entities. ${ }^{154}$

Nature of the European Union: Greek Temple or French Gothic Cathedral?', in T. Heukels, N. Blokker and M. Brus (eds), The European Union after Amsterdam: A Legal Analysis (The Hague: Kluwer Law International, 1998), 51-68, 65.

146 See Trömmel, 'The European Union', 53-54.

147 K. Nicolaiddis, 'We, the Peoples of Europe', Foreign Affairs, 83 (2004), 97-110, 102-105. Instead of a single demos, the mutual respect for national identities and institutions has been suggested as being paradigmatic for the Union. Also the right of Member States to withdraw from the Union has been referred to as setting a state apart from a union.

148 Eleftheriadis, 'The Structure of European Union Law', 121.

149 R. Schütze, From Dual to Cooperative Federalism: The Changing Structure of European Law (Oxford: Oxford Univ. Press, 2009). See also von Bogdandy and Bast, 'The Federal Order of Competences', 285: 'The co-operative character of the European federalism is still more pronounced since Member States and the Union are mostly required to closely co-operate in the exercise of their legislative powers, as well.'

150 On this, see Schütze, From Dual to Cooperative Federalism. See the notions of devolutionary federalism and dual federalism at Lenaerts, 'Constitutionalism and the Many Faces of Federalism', 206.

${ }^{151}$ See the notion of 'pluralist federalism', combining federalism and pluralism. On pluralism, see Chapter 11.

${ }_{152}$ Wheare, Federal Government, 10. See also at 14: 'Similarily in the case of a federation, the fundamental principle is that general and regional governments are co-ordinate'. See Wheare's definition earlier.

153 Hogg, Constitutional Law of Canada, 5-4.

154 See P. Kirchhof, 'Die Gewaltbalance zwischen staatlichen und europäischen Organen', Juristenzeitung, (1998), 965, 966, who has pointed to the need to secure a non-contradictory interplay

This is an open access version of the publication distributed under the terms of the Creative Commons Attribution-NonCommercial-NoDerivs licence (http://creativecommons.org/licenses/by-nc-nd/3.0/), which permits non-commercial reproduction and distribution of the work, in any medium, provided the original work is not altered or transformed in any way, and that the work is properly cited. For commercial re-use, please contact academic.permissions@oup.com 
Thus, early definitions of federations have already included a reference to loyalty when it was described as a contractual, voluntary relationship between states based on good faith. ${ }^{155}$ Federal loyalty, even where it is not expressly stipulated in a legal system, has been seen as 'an unwritten conditio sine qua non of a federal system'. ${ }^{156}$ The BVerfG held that such duty was inherent in the nature of a federal state as an unwritten principle of the constitutional order derived from the federal principle. ${ }^{157}$

Although all federal states require the subjection of the constituent states under the federal constitution, ${ }^{158}$ they cannot do without counterbalancing elements, such as the participation of the constituent states at the federal level (in particular with regard to the federal constitution) or the allocation of certain powers at constituent level. The very ambivalence of diversity in unity has been said to 'require mutuality and reciprocity instead of absolutism and unilateralism' as a legal pre-condition for any federal system'. ${ }^{159}$ Thus, Watts has stressed the importance of a kind of duty of mutual recognition for states by giving 'full faith and credit to the public acts, records, and judicial proceedings of every state'. ${ }^{160}$ These general elements of federal loyalty are reflected for instance in Article 44 of the Swiss Federal Constitution of 1999, stipulating that the federation and the cantons support each other in the performance of their duties and cooperate, that they owe each other respect and aid and that conflicts between them should be resolved through negotiation and mediation, if possible. ${ }^{161}$

However, the position of loyalty in a federal legal system very much depends on the way the spheres of the entities are delimited. It has been argued that all modern federal constitutions have adopted explicit or implicit rules to resolve a conflict between inconsistent or conflicting federal and provincial laws that are both valid. ${ }^{162}$ In this vein, Watts has noted that a 'federal constitution cannot be supposed to admit such overlap without accompanying rules that help both tiers to settle the question harmoniously'. ${ }^{163}$ We will thus see in the case studies later that loyalty takes a central role particularly in those regimes, where the statutory delimitation of competences provides no clear answers. ${ }^{164}$

of law flowing from different sources ('ein widerspruchsfreies Zusammenwirken des aus verschiedenen Quellen sprudelnden Rechts').

155 See the references in Laursen, 'Federalism', 5.

156 Watts, 'Comparative Conclusions', 335 passim.

157 Case 1 BvF 1/76 et al. Numerus Clausus II [1977] BVerfGE 43, 291, para 109: 'Dieser ungeschriebene Verfassungsgrundsatz, der dem bundesstaatlichen Prinzip entspringt...'.

158 Watts, Comparing Federal Systems, $157 . \quad 159$ Watts, Comparing Federal Systems, 157.

160 Watts, Comparing Federal Systems, 73. Not all decisions must be recognized, but when certain conditions are fulfilled, a divorce must be recognized.

161 Art. 120 of the Italian Constitution contains a clause on 'leale collaborazione', in the context of 'substitutive measures' that will be taken by the central government under certain conditions, all relating to the fact that the decentralized units do not exercise their powers properly or that there is specific need for a central treatment. See also Art. 2 of the Spanish Constitution on solidaridad. While the Spanish constitution does not define itself as federal, it provides for lists of powers that are exclusive to either the general or the regional government, while leaving the residual power to the central government. This is because 'Spain is a federation in all but name', being one of the most decentralized countries in Europe, where the 17 Autonomous Communities possess a considerable degree of self-rule. See Watts, Comparing Federal Systems, 42.

${ }_{162}$ Hogg, Constitutional Law of Canada, 16-3, mentions Art. 109 of the Australian Constitution and Art. 6 of the US Constitution. See also Wheare, Federal Government, 75-76.

163 Watts, 'Comparative Conclusions', 335 passim.

164 See in this vein, W. Schroeder, Das Gemeinschaftsrechtssystem (Tübingen: Mohr Siebeck, 2002), 401, who has noted that the importance for such rule on the relationship between the different federal levels might be mitigated by a federal order of competences.

This is an open access version of the publication distributed under the terms of the Creative Commons Attribution-NonCommercial-NoDerivs licence (http://creativecommons.org/licenses/by-nc-nd/3.0/), which permits non-commercial reproduction and distribution of the work, in any medium, provided the original work is not altered or transformed in any way, and that the work is properly cited. For commercial re-use, please contact academic.permissions@oup.com 


\subsection{Case Studies}

\subsubsection{Introduction}

In the following short case studies on the federal systems of the United States of America, Australia, Canada, Belgium, Austria, and Germany we will focus on the legal mechanisms available for resolving norm conflicts between the federal and the state level. Three related criteria can be distinstinguished here. Firstly, whether there is a clear delimitation between the competences of the two levels. Secondly, whether the legal system foresees concurrent powers, i.e. powers that can theoretically be exercised either on the state or the federal level. Thirdly, I suggest inquiring in this context whether federal law can invalidate state law. Normally, it has been written, under such rules, the validly enacted federal law prevails over the provincial (component-entity) law. ${ }^{165}$ In the case studies later we will see that while this is true with regard to especially the US and the Canadian systems, it is not true with regard for instance to the Austrian regime, and only in theory holds true with regard to Germany.

\subsubsection{Thin concepts of loyalty in the USA, Canada, and Australia}

The US constitution provides for a supremacy clause in Article VI, ${ }^{166}$ which is the basis for a very sophisticated doctrine on the demarcation of competences between the federal and the state levels. Norm conflicts are resolved by invalidating conflicting (state) laws, different thus from the merely 'disapplying' effect of supremacy in Union law. ${ }^{167}$ There are no concurrent powers foreseen under the US distribution of competences.

At the same time, there appears to be no parallel to principles of federal loyalty binding the states vis-à-vis the nation. ${ }^{168}$ The US law concept of federal comity seems poorly defined and not central to governing the relation between the states and the federal level. ${ }^{169} \mathrm{I}$ found only very few traces of a duty of consideration of Congress with regard to the interests of the states. In a footnote, Justice Marshall argued that Congress 'may not exercise power in a fashion that impairs the States' integrity or their ability to function effectively in a federal system'. ${ }^{170}$ This rather puts the burden on the federation than on the states. In another case, Justice Blackmun advocated a 'balancing approach'

165 This is in some systems referred to as the federal paramountcy rule. See Hogg, Constitutional Law of Canada, 16-2 and 16-3. In the Canadian Constitution, this is not explicitly provided but based on settled case law. See H. Brun and G. Tremblay, Droit Constitutionnel, 4th edn. (Montréal: Éditions Yvon Blais, 2002), 457. See Lenaerts, 'Constitutionalism', 263.

166 See Art. VI (2) of the US Constitution entitled 'Supremacy': 'This Constitution, and the Laws of the United States which shall be made in Pursuance thereof; and all Treaties made, or which shall be made, under the Authority of the United States, shall be the supreme Law of the Land; and the Judges in every State shall be bound thereby, any Thing in the Constitution or Laws of any State to the Contrary notwithstanding.'

167 See F. Jacobs and K. Karst, "The "Federal" Legal Order: The U.S.A. and Europe Compared: A Juridical Perspective', in M. Cappelletti and M. Seccombe (eds), Integration through Law: Europe and the American Federal Experience (Berlin: Walter de Gruyter, 1986), 169-243, 231-233.

168 M. Tushnet, 'What Then Is the American?', Arizona Law Review, (1996), 873, 880.

169 Tushnet, 'What Then Is the American?', 879-881. Instead of developing a concept of comity, an 'adversarial relationship' dominated early US federalism, giving a strong role to the Supreme Court. See R. Davis and D.J. Burnham, 'The Role of the Federal Judiciary in the Development of Federalism in West Germany and the United States', Boston College International \& Comparative Law Review, 12:1 (1989), 63-88, 81.

170 Quoted in J. Cohen and W. Varat, Constitutional Law: Cases and Materials, 10th edn. (New York: The Foundation Press, 1997), 375.

This is an open access version of the publication distributed under the terms of the Creative Commons Attribution-NonCommercial-NoDerivs licence (http://creativecommons.org/licenses/by-nc-nd/3.0/), which permits non-commercial reproduction and distribution of the work, in any medium, provided the original work is not altered or transformed in any way, and that the work is properly cited. For commercial re-use, please contact academic.permissions@oup.com 
that permitted federal legislation 'where the federal interest is demonstrably greater and where state. . compliance with imposed federal standards would be essential'. ${ }^{171}$

In Australian constitutional law, federalism is a central concept. ${ }^{172}$ While initially the US model has been a strong influence, the Engineers case ${ }^{173}$ about the relationship between the laws of the Commonwealth and the laws of the states marked the start of a distinct Australian constitutional law that is inspired by both UK and US experiences. ${ }^{174}$ Before the Engineers case, the prevailing view was that the Commonwealth Constitution accorded the states general immunity from being bound by Commonwealth laws. ${ }^{175}$ In the Engineers case, however, the High Court held that, as a general rule, the Commonwealth Parliament had power to enact laws binding the states. ${ }^{176}$ Section 109 of the Commonwealth Constitution states that when 'a law of a state is inconsistent with a law of the Commonwealth, the latter shall prevail, and the former shall, to the extent of the inconsistency, be invalid'. This means that only those aspects of a state law that are inconsistent become inoperative, and that the state law will revive if the Commonwealth law is repealed. ${ }^{177}$ Direct obvious inconsistency exists when simultaneous obedience is impossible, or when one law takes away a right or privilege conferred by the other law. ${ }^{178}$ Indirect inconsistency exists if Commonwealth law was intended 'as the law (and not merely a law) on that subject matter', regulating it completely and exhaustively. ${ }^{179}$ The identification of this intent to cover a field has been criticized as often being problematic before Australian courts. ${ }^{180}$

Canada is commonly called a confederation and is another system where there appears to be no notable concept of federal loyalty. ${ }^{181}$ Although Canada does not have the subordination of central government to the states that is characteristic of such a system, ${ }^{182}$ there has been a steady growth of the power of the provinces, making it less centralized than either the US or Australia. ${ }^{183}$ Canada has a 'cooperative federalism',

171 Cohen and Varat, Constitutional Law, 375-376.

172 See federalism as the first section in the first chapter (Australian Constitutionalism) in G. Winterton et al., Australian Federal Constitutional Law: Commentary and Materials, 2nd edn. (Sydney: The Law Book Company, 2007). The Commonwealth Constitution created a new legal entity, the Commonwealth of Australia. It was given formal status by the UK Commonwealth of Australia Constitution Act of 1900. The former colonies were preserved as legally autonomous provinces, each with its own formal constitutional document. It was only the Australia Act of 1986 that brought a complete break between Australia and the UK institutions. See P. Hanks, Constitutional Law in Australia, 2nd edn. (London: Butterworths, 1996), 10, 16, and 21. See, for a recent discussion of the federal nature of Australia, N. Aroney, The Constitution of a Federal Commonwealth: The Making and Meaning of the Australian Constitution (Cambridge: Cambridge Univ. Press, 2009).

173 Amalgamated Society of Engineers v Adelaide Steamship Co Ltd (1920) 28 CLR 129.

174 Hanks, Constitutional Law in Australia, 5.

175 So called intergovernmental immunity doctrine, or immunity of instrumentalities. This was deemed an implication of the federal structure of the Constitution. See further, K. Booker and A. Glass, 'The Engineers Case', in H.P. Lee and G. Winterton (eds), Australian Constitutional Landmarks (Cambridge: Cambridge Univ. Press, 2003), 34, 35.

176 Booker and Glass, 'The Engineers Case', 43.

177 Hanks, Constitutional Law in Australia, 261-262.

178 Hanks, Constitutional Law in Australia, 264; C. Howard, Australian Federal Constitutional Law, 3rd edn. (Sydney: The Law Book Company, 1985), 41-44.

179 Hanks, Constitutional Law in Australia, 267. This expanded concept of inconsistency 'allows for centralised (rather than shared) legislative control of a wide range of social and economic activities'. See Hanks, Constitutional Law in Australia, 283, referring to cases Clyde Engineering Co Ltd v Cowburn and Ex Parte McLean.

180 See the cases discussed by Hanks, Constitutional Law in Australia, 268-279.

181 See Hogg, Constitutional Law of Canada, 5-17-5-19.

182 Hogg, Constitutional Law of Canada, 5-5.

183 Hogg, Constitutional Law of Canada, 5-17. See Brun and Tremblay, Droit Constitutionnel, 437: 'On entend parfois dire que le Canada est une des federations les plus décentralisées au monde.'

This is an open access version of the publication distributed under the terms of the Creative Commons Attribution-NonCommercial-NoDerivs licence (http://creativecommons.org/licenses/by-nc-nd/3.0/), which permits non-commercial reproduction and distribution of the work, in any medium, provided the original work is not altered or transformed in any way, and that the work is properly cited. For commercial re-use, please contact academic.permissions@oup.com 
which however mainly relates to federal-provincial financial arrangements. ${ }^{184}$ Only three provisions in the Constitution of Canada explicitly confer concurrent powers, making exclusivity the rule and concurrency the exception. ${ }^{185}$ However, when a law has a double aspect such as careless driving, which pertains both to highway regulation and to criminal law, concurrency also occurs in practice. ${ }^{186}$ As I have mentioned, the federal paramountcy rule requires that federal law prevail over the laws of the provinces. Express contradiction is assumed when dual compliance is impossible. Moreover, Canadian courts have also accepted as inconsistent when 'a provincial law would frustrate the purpose of a federal law', provided both laws are valid and both could be complied with. ${ }^{187}$ Pre-emption such as in the US for provincial laws that supplement a federal law covering a certain field is not considered invoking the paramountcy doctrine by 'negative implication'. ${ }^{188}$ The effect of inconsistency here is that the provincial law becomes 'inoperative', as long as the inconsistent federal law is in force, being automatically revived if the federal law is repealed. ${ }^{189} \mathrm{Hogg}$ has argued that provincial laws in this case are neither automatically repealed, nor ultra vires, and do not even become inapplicable. ${ }^{190}$ As put by him:

The provincial power to enact the law is not lost; it continues to exist (so does the provincial law), although it remains in abeyance until such time as the federal Parliament repeals the inconsistent federal law. ${ }^{191}$

We shall see later that this is a striking parallel to the discussion on the consequences of the exercise of shared competences and on pre-emption in Union law.

\subsubsection{The middle ground: Belgium}

Belgium is the 'youngest full-fledged, if highly asymmetric federal state in Europe'. ${ }^{192}$ Three features are said to dinstinguish the Belgian distribution of powers, which has been called federalism of confrontation on a dualistic basis. ${ }^{193}$ This is firstly a progressive devolution that has produced a high degree of decentralization. Secondly, the powers allocated to each order of government have been mostly in the form of exclusive powers, ${ }^{194}$ with no

However, this is not entrenched in the Constitution, which would allow the federation to centralize more strongly. 'C'est à titre gracieux que les provinces jouissent toufours d'une certain autonomie au Canada.'

184 Hogg, Constitutional Law of Canada, 5-46.

185 Hogg, Constitutional Law of Canada, 15-44 and 15-45.

186 Under the 'pith and substance' rule a law is deemed valid if it incidentally regulates a matter falling within the other entity's powers. See Hogg, Constitutional Law of Canada, 15-45 and 15-46.

187 Hogg, Constitutional Law of Canada, 16-7 referring to Law Society of B.C. v Mangat [2001] 3 S.C.R. 113, para 72. More cautious in their reading of the case law are Brun and Tremblay, Droit Constitutionnel, 459-460.

188 Hogg, Constitutional Law of Canada, 16-10 to 16-14.

189 Hogg, Constitutional Law of Canada, 16-6.

190 Hogg, Constitutional Law of Canada, 16-19 to 16-20. The latter is due to possible confusion with the doctrine of 'interjurisdictional immunity', which limits the power of the provincial legislatures to enact laws extending into core areas of exclusive federal jurisdiction. In this case, the provincial law is yielding not merely to an inconsistent federal law, but to an implied constitutional prohibition rendering the application of the law ultra vires.

191 Hogg, Constitutional Law of Canada, 16-20.

192 A. Alen, P. Peeters and W. Pas, 'Bundestreue im belgischen Verfassungsrecht', Jahrbuch des öffentlichen Rechts, 42 (1994), 439-505.

193 Alen, Peeters, and Pas, 'Bundestreue im belgischen Verfassungsrecht', 439.

194 See also P. Peeters, 'Federalism: A Comparative Perspective: Belgium Transforms from a Unitary to a Federal State', in B. de Villiers (ed.), Evaluating Federal Systems (Dordrecht, Boston, London: Martinus Nijhoff, 1994), 200.

This is an open access version of the publication distributed under the terms of the Creative Commons Attribution-NonCommercial-NoDerivs licence (http://creativecommons.org/licenses/by-nc-nd/3.0/), which permits non-commercial reproduction and distribution of the work, in any medium, provided the original work is not altered or transformed in any way, and that the work is properly cited. For commercial re-use, please contact academic.permissions@oup.com 
shared or concurrent jurisdiction, other than in specific and exceptional situations. ${ }^{195}$ The residual powers thus belong to the federal state, with only marginal intrusion in federal fields. Thirdly, there is a considerable measure of asymmetry between the units. ${ }^{196}$ It has been argued that the authority of the Belgium constitution is so universally accepted in Belgium that there is no need for a "

Despite these very clearly delimited spheres of competence between the state and the provinces, Article 143 of the Belgian Federal Constitution stipulates that 'the federation, the communities, the regions and the Common Community Commission heed federal loyalty, when it comes to the exercise of their respective powers, in order to prevent conflicts of interests'. It has, however, been noted that this concept of loyalty is one of the most blurry in the institutional system of Belgium. ${ }^{198}$ Its application requires that a legislative entity considers itself seriously impaired by a project or a proposal for a law, or that an adminstrative entity considers itself impaired by a decision or the lack of it. ${ }^{199}$ Moreover, federal loyalty in Belgium is distinct from a conflict of compentences in that it calls for a political solution and not a legal one, and consequently it is not resolved by the Conseil d'Etat or the Cour d'arbitrage but comes before the comite de concentration. ${ }^{200}$

\subsubsection{Thick concepts of loyalty in Germany and Austria}

In Germany, there are exclusive but also konkurrierende (competing) competences delimiting the regulatory powers of the German federal state from those of the German Länder (provinces). The concept of a competing competence is very similar to shared competences in Union law, which I will discuss in Chapter 8. Under German law, it has been argued that there is 'a strong "dualist" notion that at a given point in time there is only one level of government competent to legislate in a particular area' ${ }^{201} \mathrm{~A}$ conflict of norms according to Article 31 German Basic Law (Grundgesetz, GG) requires the existence of two norms of different entitities, which are both competent and which regulate the same matter. ${ }^{202}$ In such a case, German constitutional law provides for the invalidation of the norm at the state level (lex superior derogat legi inferiori). ${ }^{203}$

At the same time, federal loyalty has a long tradition in German law. Already in 1916 with regard to the relations between the German Empire and the individual states, it had been claimed that the federal principle required that the Empire's politics were conducted not as an expression of the superiority of the Empire, but in the spirit of the federal-minded fidelity of an ally. ${ }^{204}$ In one of its first decisions on the opposition

195 F. Delpérée, 'Constitutional Law', in H. Bocken and W. de Bondt (eds), Introduction to Belgian Law (The Hague, London, Boston: Kluwer Law International and Brussels: Bruylant, 2001), 60.

196 Watts, Comparing Federal Systems, 44.

197 B. de Witte, 'The European Union as an International Legal Experiment', in G. de Búrca and J.H.H. Weiler (eds), The Worlds of European Constitutionalism (Cambridge: Cambridge Univ. Press, 2012), 19-56, 46.

198 M. Uyttendaele, Précis de Droit Constitutionnel Belge: Regards sur un systeme institutionnel paradoxal, 3rd edn. (Brussels: Bruylant, 2005), 998: 'Il s'agit là de l'un des concepts les plus flous de notre systeme institutionnel.'

199 Uyttendaele, Précis de Droit Constitutionnel Belge, 998.

200 Uyttendaele, Précis de Droit Constitutionnel Belge, 990 and 1000.

201 Von Bogdandy and Bast, 'The Federal Order of Competences', 285.

202 Case 2 BvN 1/69 Niedersächsisches Landesbesoldungsgesetz [1974] BVerfGE 36, 342 passim. See Schroeder, Gemeinschaftsrechtssystem, 401.

203 Inferior law can therefore only be invalidated by valid superior law, which presupposes the delimitation of competences between the two levels. See Schroeder, Gemeinschaftsrechtssystem, 401-402.

204 R. Smend, Verfassung und Verfassungsrecht (Berlin: Duncker \& Humblot, 1928), 51; M. Lück,

Die Gemeinschaftstreue als allgemeines Rechtsprinzip im Recht der Europäischen Gemeinschaft: Ein Vergleich

This is an open access version of the publication distributed under the terms of the Creative Commons Attribution-NonCommercial-NoDerivs licence (http://creativecommons.org/licenses/by-nc-nd/3.0/), which permits non-commercial reproduction and distribution of the work, in any medium, provided the original work is not altered or transformed in any way, and that the work is properly cited. For commercial re-use, please contact academic.permissions@oup.com 
of one province to a federal plan of distribution for construction support, the BVerfG referred to Smend and held that it would be in accordance with the federal principle that all entities in the federation are bound by a mutual constitutional duty to be loyal and to cooperate (Bundestreue). ${ }^{205}$ According to the BVerfG, both the federation and the Länder are obliged to cooperate pursuant to the nature of the constitutional 'pact' between them and have to contribute to its consolidation as well as to the maintenance of the well-understood interests of the federation and the constituent states. ${ }^{206}$ Thus, pertinent cases concerned the safeguarding of the budgetary balance between the provinces and the German federal state, ${ }^{207}$ or established duties of support among the states, such as concerning financial aid. ${ }^{208}$ The principle has also been invoked to grant all states equal rights in negotiations with the federation, preventing discrimination because of party preferences, or the circumvention of the necessary participation of the states in the first place. ${ }^{209}$ Moreover, in cases where cooperation between the federation and the constitutent states is required by law, the principle imposes readiness to reach agreement and will even overcome a requirement for uninamity if a party relies on unfounded objections. ${ }^{210}$ In contrast, Bundestreue does not require a state to implement a treaty concluded by the federation when the latter lacks legislative jurisdiction to adopt its own implementing legislation. ${ }^{211}$ State legislation in the field of public education based on exclusive competence had been challenged by the federal government for being inconsistent with its obligations under the Concordat with the Holy See. ${ }^{212}$

Bundestreue is contingent on the existence of competence, but it cannot change the order of competences. ${ }^{213}$ This is the accessory nature of the German Bundestreue as a

zur Bundestreue im Verfassungsrecht der Bundesrepublik Deutschland (Baden-Baden: Nomos, 1992), 93: 'Das bündische Prinzip verlange, daß die Reichspolitik nicht im Geiste der formellen staatsrechtlichen Überordnung, sondern in dem der bundesfreundlichen "Vertragstreue" eines gleichgeordneten "Verbündeten" geführt werden.'

205 Case 2 BvH 2/52 Wohnungsbauförderung [1952] BVerfGE 1, 299, 314. In other words, it established a legal obligation to a federal-friendly conduct ('Rechtspflicht zu bundesfreundlichem Verhalten'). In this respect, it has been argued that the notion of Bundestreue is misleading insofar as it implies only a one-way obligation that is owed by the provinces to the federal state. See A. Gamper, 'Koordination im Bundesstaat: Ein “ungeschriebenes” Verfassungsprinzip?', in A. Rosner and P. Bußjäger, Im Dienste der Länder: Im Interesse des Gesamtstaates: Festschrift 60 Jahre Verbindungsstelle der Bundesländer (Vienna: Braumüller, 2011), 257, 258.

206 Case 2 BvG 1/55 Reichskonkordat [1957] BVerfGE 6, 309, 361.

207 Case 2 BvG 1/54 Besoldungsgesetz von Nordrhein-Westfalen [1954] BVerfGE 4, 115; Case 2 BvQ 1/53, 2 BvQ 2/53 Weihnachtsgeld [1953] BVerfGE 3, 52.

208 Case 1 BvF 2/51 Finanzausgleichsgesetz [1952] BVerfGE 1, 117, 130-131, which however refers to the federal principle (bundesstaatliches Prinzip) and not to the Bundestreue.

209 See Lück, Die Gemeinschaftstreue, 102. See Case 2 BvG 1/60 and 2 BvG 2/60 1. Rundfunkentscheidung [1961] BVerfGE 12, 205. It had negotiated only with politically 'friendly' state governments, but not with those controlled by the opposition, it had attempted to present the states with a fait accompli by scheduling the signing and the notarization of the incorporation papers from one day to the next, and it had attempted to shortcut them by designating a federal minister to act as trustee. See Davis and Burnham, 'Development of Federalism', 29, on the controversy surrounding this judgment, which they claim was the high point of the importance of the principle in Germany.

210 Hay, Federalism, 194-195. See also Case 2 BvH 2/52 Wohnungsbauförderung [1952] BVerfGE $1,299,315$.

211 Hay, Federalism, 309, 328, 361.

212 This has been critized in Hay, Federalism, 195, fn 107: 'This reasoning is not convincing: it is difficult to see why federal fidelity might not require states to exercise restraint even in the exercise of their exclusive jurisdiction for the sake of the common interest...' '... resort to the principle of federal fidelity had been invoked as the only possible solution for the conflict between international obligation and exclusive jurisdiction of states.'

213 Lück, Die Gemeinschaftstreue, 95.

This is an open access version of the publication distributed under the terms of the Creative Commons Attribution-NonCommercial-NoDerivs licence (http://creativecommons.org/licenses/by-nc-nd/3.0/), which permits non-commercial reproduction and distribution of the work, in any medium, provided the original work is not altered or transformed in any way, and that the work is properly cited. For commercial re-use, please contact academic.permissions@oup.com 
duty on how to exercise competence, thus presupposing its existence. ${ }^{214}$ Under this rule, in Germany, competences must be exercised in a manner that not only respects the interests of other entities, but also contributes to them being realized. ${ }^{215}$ States must cooperate with the federation if this is necessary to realize the objectives of federal law. ${ }^{216}$ More generally, it shall prevent the substantial undermining of interests by one entity through lawmaking by the other. ${ }^{217}$ It follows that the Bundestreue primarily creates duties of abstention for either the federation or the provinces in applying the law ('Rechtsausübungsschranke'). However, the Bundestreue has also been invoked by the BVerfG to establish the pre-emption of the state legislative powers when the federation has initiated a legislative procedure. ${ }^{218}$

Under Austrian constitutional law, the states are competent where the federal state is not competent. The competence of the provinces is therefore residual. ${ }^{219}$ In contrast to German law, Austrian constitutional law does not foresee competing competences of the federal state and the provinces. ${ }^{220}$ This means that in theory one and the same matter can only be assigned to one single competence norm, and that identical powers of the state lawmaker and the federal lawmaker cannot exist. ${ }^{221}$ In other words, the areas of competence of the federal state and the provinces coexist separately and on an equal level. ${ }^{222}$ On the other hand, the Austrian Constitutional Court (Verfassungsgerichtshof, $\mathrm{VfGH}$ ) stated in one case that under the system of the distribution of competences in the Austrian constitution contradictory (gegensätzliche) yet validly enacted provisions by the federal state and the provinces may occur. ${ }^{223}$ For this case, however, the Austrian constitution does not explicitly foresee a conflict resolution mechanism. ${ }^{224}$ It is this gap that is filled by the principle of consideration (Berücksichtigungspflicht) that has been introduced by the VfGH. ${ }^{225}$

The dogmatic foundation of the principle of consideration is unclear and disputed. ${ }^{226}$ While some have derived it from the principle of equality, ${ }^{227}$ or have denied its necessity

214 Case 1 BvF $1 / 76$ et al. Numerus Clausus II [1977] BVerfGE 43, 291, 348-349, which speaks of reigning in the 'egoisms' of the federation and the provinces; Case 2 BvG 1/62 Wasser-und Schiffahrtsverwaltung [1967] BVerfGE 21, 312.

215 Case 2 BvG 2/58, 2 BvE 1/59 Neugliederung Hessen [1961] BVerfGE 13, 54, 75: 'Da der Bundesstaat ein gegliederter Staat ist, müssen Bund und Länder bei der Ausübung des ihnen zufallenden Anteils an der Staatsgewalt auf die Interessen des anderen Teils Rücksicht nehmen.' Lück, Die Gemeinschaftstreue, 96.

216 Lück, Die Gemeinschaftstreue, 101.

217 Lück, Die Gemeinschaftstreue, 98; Hay, Federalism, 194.

218 Case 2 BvF 1/71 Besoldungsvereinheitlichung [1972] BVerfGE 34, 9, 29: ‘... Jedenfalls verbietet in Fällen wie dem vorliegenden die Pflicht zu bundesfreundlichem Verhalten, daß die Länder noch von ihrem Gesetzgebungsrecht Gebrauch machen, sobald der Bund dieselbe Materie zum Gegenstand eines Gesetzgebungsverfahrens zu machen beginnt.'

219 Art. 15 (1) Austrian Constitution (Bundesverfassungsgesetz, BV-G).

220 Case KII-4/79 Sammlungsgesetz [1982] VfSlg. 9337; H. Mayer, 'Neue Wege der Kompetenzinterpretation?', Österreichische Juristenzeitung, (1986), 513-520, 515 with further references. 221 Mayer, 'Neue Wege der Kompetenzinterpretation?', 515.

222 P. Bußjäger, 'Bundesstaat und Gleichheitsgrundsatz', Juristische Blätter, (2007), 289-298, 290.

223 Case G 81/84, 82/84 Jagdrecht/Forstrecht [1984] VfSlg. 10.292. Critical Mayer, 'Neue Wege der Kompetenzinterpretation?', 516.

224 See U. Davy, 'Zur Bedeutung des bundesstaatlichen Rücksichtnahmegebotes für Normenkonflikte', Österreichische Juristenzeitung, (1986), 225-234, 229.

225 Case G 5/80 Wr. Behindertengesetz [1980] VfSlg. 8831. Whereas the VfGH has always referred to a principle of mutual consideration, the duties flowing from it have largely been imposed on the provinces and not on the federal state. But see Case V 17/06 Tierschutz [2007] VfSlg. 18.096.

226 See R. Walter, H. Mayer and G. Kucsko-Stadlmayer, Grundriss des österreichischen Bundesverfassungsrechts (Vienna: Manz, 2007), 177.

227 H. Schäffer, 'Kompetenzverteilung und Rücksichtnahmepflicht im Bundesstaat: Das Erkenntnis "Jagdrecht/Forstrecht" und die Neuorientierung der Kompetenzinterpretation', Zeitschrift für

This is an open access version of the publication distributed under the terms of the Creative Commons Attribution-NonCommercial-NoDerivs licence (http://creativecommons.org/licenses/by-nc-nd/3.0/), which permits non-commercial reproduction and distribution of the work, in any medium, provided the original work is not altered or transformed in any way, and that the work is properly cited. For commercial re-use, please contact academic.permissions@oup.com 
altogether, ${ }^{228}$ the case law of the VfGH rather suggests that it is founded in the federal principle and the principle of the unity of the legal order. ${ }^{229}$ Moreover, there is case law where the VfGH argued in the present context that both the federal lawmaker and the state lawmaker are prohibited from passing rules that would entail an unjustified impairment of the effectiveness of the rules of the respective other lawmaker. ${ }^{230}$ This would occur when the interests of the respective other entity are negated. ${ }^{231}$ This means that the Austrian principle of consideration is addressed to the authorities when they apply the law. ${ }^{232}$ Federal and state laws on competence must be interpreted in light of the constitutional principle of consideration, asking whether the envisaged rules do not lead to a substantial perturbance of the legislative activities of the other lawmaker. ${ }^{233}$ If a law is not susceptible to such interpretation, it will be declared invalid by the VfGH. ${ }^{234}$ In the best-known judgment on the principle of consideration, the VfGH invalidated parts of a provincial act on limiting the right of individuals to enter forests because it would not adequately consider the right to keep forests open to the public provided in the federal forest act. 235

Federal loyalty does therefore not determine the conferral of competence as such in the Austrian legal order. ${ }^{236}$ However, it ensures that the respective entity duly considers the interests of the other entity involved. This shows that norm conflicts are not inherent in the legal norms themselves, but may arise at the stage of the application of the law. ${ }^{237}$

\subsubsection{Conclusion}

This brief description of the federal systems of the US, Australia, and Canada has shown that all three regimes have strong rules of competence delimitation that reduce the potential overlap between federal and state powers. There is no concurrency in the US and it is the exception in Canada. At least under the US constitution, the rule of invalidation applies to conflicts between federal and state legislation. This relative clarity of delimiting the two spheres of the federate space seems to go hand in hand with very weak or non-existent rules of loyalty/fidelity/comity. The situation in Belgium also pairs a rather mutually exclusive separation of federal and state level with a very unclear concept of loyalty. In contrast, in the more centralized and more intertwined constitutional

Verwaltung, (1985), 357, 366; R. Novak, 'Bundesstaatliche Rücksichtnahme', in H. Schäffer et al. (eds), Staat-Verfassung-Verwaltung: FS für Friedrich Koja (Vienna, New York: Springer, 1998), 357.

228 Mayer, 'Neue Wege der Kompetenzinterpretation?', 518.

229 See Case G 5/80 Wr. Behindertengesetz [1980] VfSlg. 8831 for references to the first rationale, and Case G 81/84, 82/84 Jagdrecht/Forstrecht [1984] VfSlg. 10.292 and Case B 282/92, B 60/93 Mineralöl [1993] VfSlg. 13.586 for references to the argument of the assumption that the Austrian legal order is 'harmonized'. See also B.-C. Funk, Das System der bundesstaatlichen Kompetenzverteilung im Lichte der Verfassungsrechtsprechung (Vienna: Wilhelm Braumüller, 1980), 90, who has argued that the principle is immanent in the constitution as an unwritten legal principle.

${ }^{230}$ Case B 282/92, B 60/93 Mineralöl [1993] VfSlg. 13.586. See Mayer, 'Neue Wege der Kompetenzinterpretation?', 519.

${ }^{231}$ Case B 282/92, B 60/93 Mineralöl [1993] VfSlg. 13.586.

232 See Case B 1678/03 et al. Tourismusgesetz [2005] VfSgl. 17.478.

${ }^{233}$ Mayer, 'Neue Wege der Kompetenzinterpretation?', 514. As a first step, this requires an assessment as to whether the federal legislator is competent to enact a certain norm.

234 See Case G 256/98 Semmering Basistunnel [1999] VfSlg. 15.552.

235 Case G 81/84, 82/84 Jagdrecht/Forstrecht [1984] VfSlg. 10.292.

236 Mayer, 'Neue Wege der Kompetenzinterpretation?', 515.

237 Mayer, 'Neue Wege der Kompetenzinterpretation?', 516.

This is an open access version of the publication distributed under the terms of the Creative Commons Attribution-NonCommercial-NoDerivs licence (http://creativecommons.org/licenses/by-nc-nd/3.0/), which permits non-commercial reproduction and distribution of the work, in any medium, provided the original work is not altered or transformed in any way, and that the work is properly cited. For commercial re-use, please contact academic.permissions@oup.com 
systems of Germany and Austria, loyalty plays a much greater role. In Austria, the principle of consideration, arguably in comparison has the strongest role with regard to competences. In contrast to the Bundestreue in Germany, it may even cause the invalidation of validly enacted laws of the provinces and, in theory, even of the federal state. I would suggest that this is a direct consequence of the absence of competing competences in Austrian law and of the equal hierarchical rank of state and provincial laws.

This brief overview arguably calls for a strong instrument for policing grey areas, which consequently exist between the spheres of the legal entities. It confirms the claim made from another perspective and partly for different countries that 'a relationship exists between the ambiguity of constitutional provisions pertaining to the federal division of powers on the one hand, and trust between the partners of this federal compact on the other'. ${ }^{238}$

\subsection{Comparing Union Loyalty with State Concepts of Loyalty}

Based on the above, we cannot really claim that a principle of federal loyalty applies in every federal system, nor that it is of a uniform or even comparable nature. Instead, the earlier discussion has shown that there is a wide divergence between the different legal systems in this respect. This means, however, that even if we would qualify the European Union as a federal system, and if we would argue that this would entail the existence of a principle of federal loyalty, this would not tell us very much about its substance. Conversely, this finding also undermines the rather simplistic argument that because the Union is not a (fully-fledged) federal state, there cannot exist a principle of loyalty. ${ }^{239}$ Even if the European Union were a federation sui generis or 'merely' federal in a descriptive, 'adjectivist' manner, this would not rule out that there applies a specific principle of loyalty within the Union system.

However, our findings go some way in explaining the prominence of loyalty in the EU. As I will explain in the course of this book and in Chapter 12 on Coordination especially, the legal territory for which the Union is competent, also after the Treaty of Lisbon, remains a moving target with various types of implied external competences constantly displacing the border between Union and Member State powers. As I will show, it is this border that is policed predominantly by Article 4 (3) TEU. Mixed agreements are a showcase for this lack of clarity in the delimitation of competences and it is small wonder that this area of law continues to be the focus of even the most recent publications on Article 4 (3) TEU. ${ }^{240}$ In this very context, Temple Lang has given a noteworthy explanation for the ubiquity of loyalty in the jurisprudence of the Court:

In the Community, Member States have wide powers. Article 5 is particularly important because the Community, unlike most federations, has no clear or fixed boundary between Community and State powers, and because the Community depends much more than most federations on having its policies carried out by Member States. ${ }^{241}$

This is echoed by the apposite observation by de Witte that in the EU, in contrast to all federal states, supremacy must primarily be applied by the Member State courts and

238 C. Erk and A.-G. Gagnon, 'Constitutional Ambiguity and Federal Trust: Codification of Federalism in Canada, Spain and Belgium’, Regional \& Federal Studies, 10:1 (2000), 92-111, 109.

239 This has been claimed in the German literature. See the references at Lück, Die Gemeinschaftstreue, 138 , fn 6.

240 See E. Neframi, 'The Duty of Loyalty: Rethinking its Scope Through its Application in the Field of EU External Relations', Common Market Law Review, 47 (2010), 323-359, 331-338.

241 Neframi, 'The Duty of Loyalty', 331-338.

This is an open access version of the publication distributed under the terms of the Creative Commons Attribution-NonCommercial-NoDerivs licence (http://creativecommons.org/licenses/by-nc-nd/3.0/), which permits non-commercial reproduction and distribution of the work, in any medium, provided the original work is not altered or transformed in any way, and that the work is properly cited. For commercial re-use, please contact academic.permissions@oup.com 
cannot be enforced by the 'constitutional' court unless the ECJ is given the occasion by way of a preliminary reference. ${ }^{242}$ I would argue that this not only explains why promoting the acceptance of the supremacy doctrine was essential in the EU, as argued by de Witte, but it also explains the relatively greater role of loyalty in EU law.

There are thus some indisputable and striking parallels between especially the German and the Austrian concept of loyalty and the Union law principle. Firstly, this concerns case law of both the BVerfG and the ECJ on duties of abstention from unilateral measures that would undermine the finances of the other entity. ${ }^{243}$ Secondly, both principles have been invoked to uphold the effectiveness of the respective legal order. ${ }^{244}$ Thirdly, there is a conspicuous parallel between the case law by the BVerfG on abstention duties for the provinces resulting from a legislative initiative of the federal state on the one hand, and ECJ case law on the pre-empting effect of Council initiatives in the Union, discussed in Chapter 5.

While it is thus not unfounded to compare loyalty in these systems with Union loyalty, some factors very clearly distinguish Union loyalty from the national concepts discussed earlier. Firstly, Temple Lang is correct in pointing out the reliance of the Union legislator on national courts and authorities to implement its decisions. Indeed, as I will discuss in the Part on Cohesion specifically, loyalty has played a crucial role in this area. It has 'Europeanized' the Member State administrations. Here, the European Union is indeed different from other political systems, also of those of a federal nature. Witness of this is the uniqueness of the preliminary reference proceeding, which makes national courts of every level accomplices in European integration, as well as of the directive as legislative instrument, which embodies the shared task that is regulating in the European Union. Moreover, indirect implementation of law is the rule in the EU, with Member States in general applying their national procedural law, which is complemented and sometimes even replaced by Union law standards based to a large extent on loyalty, as I will explain in the Part on Cohesion. One might assume that, had the Union a general procedural law such as the German Verwaltungsverfahrensgesetz or the Austrian Allgemeines Verwaltungsverfahrensgesetz, loyalty in the EU would be less interventionist. ${ }^{245}$

Another aspect of Union loyalty that makes it very distinct from the national law concepts discussed earlier is its important role in the foundational case law of the European Court of Justice, which will be discussed in Chapter 3. Failure to aknowledge this role undermines any general claim on the analogue nature of Bundestreue and Union loyalty. ${ }^{246}$ Specifically, the role of loyalty in establishing implied external competences casts doubt on the claim that Union loyalty, like the Bundestreue, cannot confer new competences

242 De Witte, 'International Legal Experiment', 46.

243 See also Lück, Die Gemeinschaftstreue, 128.

244 See also Lück, Die Gemeinschaftstreue, 129.

245 See also Lück, Die Gemeinschaftstreue, 131-132.

246 See for instance the approach by Lück, Die Gemeinschaftstreue, 135, who on such flimsy basis concludes that there are no sizeable differences between Union loyalty and Bundestreue: 'Aus diesem Grund bestehen zwischen der Gemeinschaftstreue und der Bundestreue auch insoweit keine ins Gewicht fallenden Unterschiede. Sieht man von dem Sonderfall der "Sachwalterregelung” ab, so stellen beide Prinzipien vielmehr vergleichbare, in Geltungsumfang, Wirkungsweise und Funktionen sogar identische Rechtsgrundsätze dar.'

See also A. Bleckmann, 'Art. 5 EWG-Vertrag und die Gemeinschaftstreue: Zugleich ein Beitrag zur Entwicklung des allgemeinen europäischen Verwaltungsrechts', Deutsches Verwaltungsblatt, (1976), 483-487, who does not discuss one single decision of the Court of Justice and considers case law based on then Art. 5 EEC unsubstantial to that date, despite a number of important judgments that had already been handed down by then. Nonetheless, Bleckmann is prescient in discussing a number of implications of loyalty, which have only been decided much later by the Court, such as on the withdrawal of national administrative decisions, and on the 'unionisation' of national administrative

This is an open access version of the publication distributed under the terms of the Creative Commons Attribution-NonCommercial-NoDerivs licence (http://creativecommons.org/licenses/by-nc-nd/3.0/), which permits non-commercial reproduction and distribution of the work, in any medium, provided the original work is not altered or transformed in any way, and that the work is properly cited. For commercial re-use, please contact academic.permissions@oup.com 
and that they merely determine the manner in which competences are exercised. ${ }^{247}$ Moreover, the accessory nature of the German Bundestreue is likely to have influenced the flawed understanding in especially early German literature that Union loyalty may not be the independent basis of legal obligations. ${ }^{248}$ As I will show in Chapter 12, this has been proven wrong by the case law of the Court, which has based a number of distinct legal obligations exclusively on Articles 5 EC, 10 EC, or 4 (3) TEU. ${ }^{249}$

Hence, I would submit that the Court has employed loyalty to far greater effect than it has been done in any of the constitutional systems mentioned earlier, including the German. Finally, I would also argue that the Bundestreue combines two principles, which are distinct in European Union law. ${ }^{250}$ As I have already argued, solidarity and loyalty must be distinguished in Union law. While the former governs the relations between the Member States and has a strong political component, the latter primarily governs the vertical relationship and is enforceable before the courts. The Bundestreue in contrast comprises both aspects because it also establishes obligations which relate to the process of decision-making and to financial support among the German provinces.

\section{Conclusion}

I would therefore argue that there is not much sense in comparing either of the national principles of federal loyalty with Union loyalty. It might be more apposite to see Union loyalty in a broader context, encompassing elements of national concepts of federal loyalty, of constitutional loyalty, together with a more general notion more similar to the paradigm of pacta sunt servanda. Hay has argued that Member States should be bound by all obligations that flow from the fact of association itself, and that the federal nature of the Union would require a general 'federal-mindedness'. ${ }^{251}$ As such, federal loyalty would serve to 'advance the [federal] process in areas not yet provided for under the Treaties to the extent that the Community interest requires such an extension'. ${ }^{252}$ As I will argue throughout this book, Union loyalty indeed should be seen as the lever to enforcing the Union interest in a variety of constellations. This makes it a much more flexible and much less limited principle in Union law compared to its application in the national law that I have discussed earlier. In this vein, Constantinesco has suggested that loyalty (as enshrined in ex Article 5 EEC), in a novel manner, would tie together the

law in general. See at 484-486. For a more case law based approach, see however A. Bleckmann, 'Die Rechtsprechung des Europäischen Gerichtshofes zur Gemeinschaftstreue', Recht der internatinalen Wirtschaft, (1981), 653 .

${ }^{247}$ Lück, Die Gemeinschaftstreue, 103-107. See also A. Epiney, 'Zur Tragweite des Art. 10 EGV im Bereich der Außenbeziehungen', in J. Bröhmer and G. Ress (eds), Internationale Gemeinschaft und Menschenrechte: Festschrift für Georg Ress zum 70. Geburtstag am 21. Januar 2005 (Cologne: Heymanns, 2005), 441-459, 453 ('Kompetenzausübungsschranke').

248 Lück, Die Gemeinschaftstreue, 108, 113, 125.

${ }^{249}$ In general, it is remarkable how the development of Union loyalty has proven commentators wrong again and again. Söllner, Art. 5 EWG-Vertrag, 28, has been proven wrong in her claim that Union loyalty could not apply among the Member States by cases such as Zwartveld. Lück, Die Gemeinschaftstreue, 22-23, while pointing this misjudgment out to Söllner, has himself been proven wrong when claiming that the Sea Fisheries case (Case 804/79 Commission v United Kingdom (Sea Fisheries) [1981] ECR 1045) could not be applied beyond the specific area of the Common Fisheries Policy.

250 For a different perspective, see Lück, Die Gemeinschaftstreue, 130.

251 Hay, Federalism, 201.

This is an open access version of the publication distributed under the terms of the Creative Commons Attribution-NonCommercial-NoDerivs licence (http://creativecommons.org/licenses/by-nc-nd/3.0/), which permits non-commercial reproduction and distribution of the work, in any medium, provided the original work is not altered or transformed in any way, and that the work is properly cited. For commercial re-use, please contact academic.permissions@oup.com 
principles of bona fides, of fidelity, and of non-contradiction, surpassing the first, being inspired by the second, and enriching the latter. ${ }^{253}$

It is apposite to inquire at this stage whether the constitutionalizing role of loyalty that is apparent from the case law of the Court and is discussed in Chapter 3 can be explained by such synthetic nature of Union loyalty encompassing elements of both national and public international law principles. Was the Court aware that it was applying a principle of unclear genealogy to yet unchartered effects? In Chapter 3, I will argue that there seems to have been no 'strategy' on the part of either of the actors with regard to the use of loyalty in EU law. It rather appears that Article 5 EEC and its precursors were the only available Treaty provisions on the basis of which the Court could rationalize developments of Union law it deemed apposite as integration deepened over the years.

253 V. Constantinesco, 'L'article CEE de la bonne foi à la loyauté communautaire', in F. Capotorti et al. (eds), Du Droit International and droit de l'intégration: Liber Amicorum Pierre Pescatore (Baden-Baden: Nomos, 1987), 97-114, 114.

This is an open access version of the publication distributed under the terms of the Creative Commons Attribution-NonCommercial-NoDerivs licence (http://creativecommons.org/licenses/by-nc-nd/3.0/), which permits non-commercial reproduction and distribution of the work, in any medium, provided the original work is not altered or transformed in any way, and that the work is properly cited. For commercial re-use, please contact academic.permissions@oup.com 


\section{3 \\ Loyalty and the Constitutionalization of EU Law}

\section{Introduction}

Usually, cases discussed in the context of constitutionalization are those which, first, vested individuals with rights against the Member States, ${ }^{1}$ and, second, fundamentally redefined the relationship between the Union and the Member States. ${ }^{2}$ In the words of Weiler, the process of constitutionalization makes the rapport between the Union and the Member States indistinguishable from analogous legal relationships in constitutional federal states'. ${ }^{3}$ Stone Sweet and Caporaso have defined the constitutionalization of the Treaty system as 'the process by which the EC Treaties have evolved from a set of legal arrangements binding upon sovereign states, into a vertically integrated legal regime conferring judicially enforceable rights and obligations on all legal persons and entities, public and private, within the EC territory'. ${ }^{4}$

According to a widely held view, this is most clearly represented by the judgments of the Court on direct effect, supremacy, implied external competences and human rights. ${ }^{5}$ Following the criteria for the choice of cases to qualify, I suggest considering also the case law on establishing state liability as well as the jurisprudence on the indirect effect of directives in the present context. ${ }^{6}$ State liability clearly has greatly empowered the Union citizens against their Member States, while at the same time curtailing the sovereignty of the latter. The obligation to interpret national law in light of Union directives and framework decisions under the former third pillar does not directly give rights to individuals. Nevertheless, it is arguably another important part of the system of the protection of

1 See Joined cases C-6/90 and C-9/90 Francovich [1991] ECR I-5357, para 31: ‘... The subjects of that legal system are not only the Member States but also their nationals. Just as it imposes burdens on individuals, Community law is also intended to give rise to rights which become part of their legal patrimony...'

2 See the opinion by AG Lagrange in Case 6/64 Costa $v$ ENEL [1964] ECR 585, 601, who already refers to the case as concerning the 'constitutional relations between the European Economic Community and its Member States'.

3 J.H.H. Weiler, 'The Transformation of Europe', The Yale Law Journal, (1991), 2403-2483.

4 A. Stone Sweet and J. Caporaso, 'From Free Trade to Supranational Polity: The European Court and Integration', in W. Sandholtz and A. Stone Sweet (eds), European Integration and Supranational Governance (Oxford: Oxford Univ. Press, 1998), 102.

5 See the literature reffered to by M. Poiares Maduro, We the Court: The European Court of Justice and the European Economic Constitution (Oxford and Portland, Oregon: Hart Publishing, 1998), 7-8.

6 See in this vein, Stone Sweet and Caporaso, 'From Free Trade to Supranational Polity', 103, who ascribe this case law to a second wave of constitutionalization. See C. Timmermans, 'The Constitutionalisation of the European Union', Yearbook of European Law, (2002), 1, who, in addition, has identified Case 26/62 Van Gend en Loos v Nederlandse Administratie der Belastingen [1963] ECR 1 (autonomous legal order) and the elaboration of principles and rules governing remedies for the protection of Community rights in the national legal systems. The Van Gend case law he has discussed under the title direct effect.

This is an open access version of the publication distributed under the terms of the Creative Commons Attribution-NonCommercial-NoDerivs licence (http://creativecommons.org/licenses/by-nc-nd/3.0/), which permits non-commercial reproduction and distribution of the work, in any medium, provided the original work is not altered or transformed in any way, and that the work is properly cited. For commercial re-use, please contact academic.permissions@oup.com 
individuals against deficiencies in the implementation of Union law by the Member States, creating far-reaching duties for national courts. ${ }^{7}$

In the following section, I will show that with the great majority of this constitutionalizing case law, loyalty has played a role, and partly a very prominent one. ${ }^{8}$ One might assume that the verve of the academic discussion on loyalty would have reflected the development of the case law by the Court. However, this has not been the case. In general, the role of loyalty and of ex Articles 5 and 10 EC has been strangely under-represented as an explanatory tool for the way the Court has shaped Union law in all the classic narratives on the constitutionalization of European Union law. This discussion will be followed by an alternative take on some of the foundational case law, aiming to show that loyalty has been widely neglected as a legal basis in this context. This is subject to a caveat: Since my focus in this book is on loyalty, I will present a narrative based on the role of loyalty. This does not mean that there are not other possible threads in the foundational case law of the Court, such as especially the 'new legal order' argument that is also discussed later. ' Without doubt, it is also highly apposite to acknowledge the role of loyalty 'to ensure the proper functioning' of the Union in a sense of guaranteeing its effectiveness, as I will discuss in the Part on Cohesion. ${ }^{10}$ However, there is more to it than that. Loyalty not 'merely' holds the building together, but also props up its foundations. I submit that this integrationist role of Article 4 (3) TEU is vital in fully understanding the nature of loyalty.

\section{Loyalty in the Literature}

\subsection{A Generally Slow Reception}

Loyalty has received a delayed reception by a large part of the literature, and when it was discussed, the perspectives taken have differed considerably as I will show later. A notable exception has always been the German literature, which has produced systematic and comprehensive studies on loyalty. ${ }^{11}$ There is an obvious connection here to the prominence of the 'sister' concept of the Bundestreue in German constitutional law discussed

7 See also F. Mayer, 'Art. 19 EUV', in E. Grabitz, M. Hilf, and M. Nettesheim (eds), Das Recht der Europäischen Union (Munich: Beck, 2011), para 40: '... eine der zentralen Grundlagen des Verhältnisses der nationalen Rechtsordnungen zur Unionsrechtsordnung' (one of the central foundations of the relation between the national legal orders and the Union law order).

8 The notable exception is the case law introducing the human rights dimension to Union law such as Case 11/70 Internationale Handelsgesellschaft [1970] ECR 1125, and Case 4/73 Nold [1974] ECR 491, as well as the judgments establishing the direct effect of Treaty provisions such as Van Gend en Loos. On the former see A. Tizzano, 'The Role of the ECJ in the Protection of Fundamental Rights', in A. Arnull, P. Eeckhout, and T. Tridimas (eds), Continuity and Change in EU Law (Oxford: Oxford Univ. Press, 2009), 125; B. de Witte, 'The Past and Future Role of the European Court of Justice in the Protection of Human Rights', in P. Alston (ed.), The EU and Human Rights (Oxford: Oxford Univ. Press, 1999), 859-897; A. von Bogdandy, 'The European Union as a Human Rights Organization?: Human Rights and the Core of the European Union', Common Market Law Review, (2000), 1307-1338.

9 See the account by S. Weatherill, 'Activism and Restraint in the European Court of Justice', in P. Capps, M. Evans, and S. Konstadinidis (eds), Asserting Jurisdiction: International and European Legal Perspectives (Oxford and Portland, Oregon: Hart Publishing, 2003), 255-281.

10 See D. Halberstam, 'Of Power and Responsibility: The Political Morality of Federal Systems', Virginia Law Review, (2004), 731-834.

11 I would suggest that this, on the one hand, is owed to the German tradition of writing legal commentaries, which favoured a greater focus on individual Treaty provisions. See now, most comprehensively, A. von Bogdandy and S. Schill, 'Art. 4 EUV', in E. Grabitz, M. Hilf and M. Nettesheim (eds), Das Recht der Europäische Union (Munich: Beck, 2010).

This is an open access version of the publication distributed under the terms of the Creative Commons Attribution-NonCommercial-NoDerivs licence (http://creativecommons.org/licenses/by-nc-nd/3.0/), which permits non-commercial reproduction and distribution of the work, in any medium, provided the original work is not altered or transformed in any way, and that the work is properly cited. For commercial re-use, please contact academic.permissions@oup.com 
earlier, which has in general prompted some relatively early discussions of Union loyalty in German literature, albeit from a very distinct angle as shown earlier. ${ }^{12}$ An exception is also the work by Temple Lang, who has pioneered the English language research on this subject. ${ }^{13}$ It is telling that the first monographic treatment of loyalty, which is still widely quoted, is by Blanquet and dates from $1994 .{ }^{14}$

This initial neglect has been compensated in recent times, when it seems that the literature has 'discovered' loyalty and has accorded it a much more systematic examination as a result. Loyalty has received, and continues to attract, most attention in the literature on the law of external relations. ${ }^{15}$ This is not surprising since it is this field of Union law where the Court has most extensively employed the principle of loyalty in recent years, as will be discussed in Chapter 10 on mixed agreements in particular. ${ }^{16}$ Even in this field, however, where the importance of ex Article $10 \mathrm{EC}$ has been stressed almost habitually, for a long time this has not led to a more thorough analysis, ${ }^{17}$ or the discussion has been confined to the significant yet narrow context of mixed agreements. ${ }^{18}$ Only Cremona and Hillion have taken to exploring the workings of loyalty in EU external relations law in a more comprehensive manner. ${ }^{19}$ In 2010 , Neframi published the first more general article on loyalty in a major journal since the year 2001, still with a considerable focus on its use in external relations law. ${ }^{20}$

In the following section, I will briefly present some of the different perspectives that have been adopted with regard to loyalty in the literature. I will then discuss a small number of contributions the whole focus of which has not been on loyalty, but which have drawn a bigger picture of the process of constitutionalization in the European Union.

12 See the references in Chapter 2, note 14. See J. Temple Lang, 'The Development by the Court of Justice of the Duties of Cooperation of National Authorities and Community Institutions under Article 10 EC', Fordham International Law Journal, 31 (2008), 1483-1532, 1484, who has noted that even lawyers that had noted the similarity with the German law principle did not see that ex Art. 10 EC would become siginificant in the EU.

13 J. Temple Lang, 'Community Constitutional Law: Article 5 EEC Treaty', Common Market Law Review, (1990), 645-681. In a series of articles, he took stock of the wealth of case law on loyalty handed down by that time in order to assess the relevance and power of this principle, which he claims has been underestimated. See at 647. One reason for this, he has proffered, is 'that the Court never thought it necessary or useful to attempt to write any general statement or formula covering or describing the whole range of Article 10 case law'. See J. Temple Lang, 'The Development by the Court of Justice of the Duties of Cooperation', 1497.

${ }_{14}$ M. Blanquet, L'Article 5 du Traité C.E.E.: Recherche sur les Obligations de Fidélité des États Membres de la Communauté (Paris: LGDJ, 1994).

15 See e.g. A. Epiney, 'Zur Tragweite des Art. 10 EGV im Bereich der Außenbeziehungen', in J. Bröhmer and G. Ress (eds), Internationale Gemeinschaft und Menschenrechte: Festschrift für Georg Ress zum 70. Geburtstag am 21. Januar 2005 (Cologne: Heymanns, 2005), 441-459. See also G. de Baere, Constitutional Principles of EU External Relations (Oxford: Oxford Univ. Press, 2008), 252-264.

16 Especially Case C-246/07 Commission v Sweden (PFOS) [2005] ECR I-6985 has sparked interest in Art. 4 (3) TEU as the basis of duties of abstention of the Member States and has prompted rather alarmist comments. See P. Delgado Casteleiro and J. Larik, 'The Duty to Remain Silent: Limitless Loyalty in EU External Relations?', European Law Review, (2011), 524.

17 See the standard work by P. Koutrakos, EU International Relations Law (Oxford and Portland, Oregon: Hart Publishing, 2006), where loyalty is treated at pp 105-106 and 116.

${ }^{18}$ I. Hendry, I.D. Hyett, and S. MacLeod, The External Relations of the European Communities: A Manual of Law and Practice (Oxford: Oxford Univ. Press, 1996), 145-150.

19 M. Cremona, 'Defending the Community Interest: The Duties of Cooperation and Compliance', in M. Cremona and B. de Witte (eds), EU Foreign Relations Law: Constitutional Fundamentals (Oxford and Portland, Oregon: Hart Publishing, 2008), 125-169, 132; C. Hillion, 'Mixity and Coherence in EU External Relations: The Significance of the "Duty of Cooperation" , CLEER Working Papers, 2 (2009).

20 E. Neframi, 'The Duty of Loyalty: Rethinking its Scope Through its Application in the Field of EU External Relations', Common Market Law Review, 47 (2010), 323-359.

This is an open access version of the publication distributed under the terms of the Creative Commons Attribution-NonCommercial-NoDerivs licence (http://creativecommons.org/licenses/by-nc-nd/3.0/), which permits non-commercial reproduction and distribution of the work, in any medium, provided the original work is not altered or transformed in any way, and that the work is properly cited. For commercial re-use, please contact academic.permissions@oup.com 


\subsection{Different Perspectives}

Pescatore discussed the nature and effect of ex Article 5 EEC as early as $1970 .{ }^{21} \mathrm{He}$ considered loyalty as so important that, were it not stated in Article 5 EEC, it would have applied as an unwritten legal principle. ${ }^{22}$ Furthermore, he distinguished cooperation between the Community and the Member States in the process of political deliberations at the beginning of the lawmaking process on the one hand, and cooperation once a legal act has been passed on the other. While cooperation in the first instance had been considered as rather intergovernmental, at the second stage Pescatore had no longer seen a partnership between sovereign states, but a hierarchical relationship between the entity and its parts. ${ }^{23}$ Notably, Pescatore deemed ex Article 5 EEC applicable to both cases of cooperation, thus also to the political stage before binding legal acts are passed. How precisely loyalty should work in such constellation, he failed to explain. However, Pescatore mentioned that, in the legislative process, the Member States participate as advocates of their respective national interests, yet with a view to reaching an equilibrium serving the overall interests of the Union. ${ }^{24}$

Indeed, especially in the Chapter on Cohesion, we will see that loyalty not only informs the obligations of Member States because of the passing of a legal act by the Union, although this certainly is an important field of its operation; loyalty moreover already applies when there is no such binding concretization of Union objectives yet, when there is instead a concerted Union action, a negotiating mandate by the Council, or even merely a concerted common strategy in the Council. ${ }^{25}$ While these partly very recent developments in case law could not have been foreseen by Pescatore, he has pointed at a key rationale for such extensive application of loyalty in the European Union. As I will argue in this book, Member States are bound to respect the distinct interests of the Union within the whole field of application of Union law, irrespective of the passing of a specific legal act by the Union legislator. ${ }^{26}$

Outside of Germany, the earliest article on loyalty that has been widely quoted dates from 1987. ${ }^{27}$ As mentioned, Constantinesco has alluded to principles familiar from public international law such as bona fides to qualify ex Article $5 \mathrm{EEC}$ 'un véritable principe fondamental du droit communautaire: le principe de coopération'. ${ }^{28}$ In his article, Constantinesco has also mentioned the concept of coherence in connection with loyalty. We will see that loyalty in the European Union, indeed, has a lot to do with safeguarding the interest of the Union in being coherent in its actions. ${ }^{29}$ However, while

21 P. Pescatore, 'Das Zusammenwirken der Gemeinschaftsrechtsordnung mit den nationalen Rechtsordnungen', Europarecht, (1970), 307-323.

22 Pescatore, 'Zusammenwirken', 322.

${ }^{23}$ Pescatore, 'Zusammenwirken', 322: 'Diese Art der Zusammenarbeit ist nicht mehr eine der Partnerschaft zwischen souveränen Nationalstaaten, sondern ein Verhältnis der Hierarchie zwischen dem Ganzen und seinen Teilkörperschaften.'

${ }^{24}$ Pescatore, 'Zusammenwirken', $322 . \quad{ }^{25}$ See Chapter 5.

26 Already in the early literature, it was remarked that Union loyalty has a broader application in that it produces obligations in an area of exclusive competence when the Union fails to take necessary measures. See M. Lück, Die Gemeinschaftstreue als allgemeines Rechtsprinzip im Recht der Europäischen Gemeinschaft: Ein Vergleich zur Bundestreue im Verfassungsrecht der Bundesrepublik Deutschland (Baden-Baden: Nomos, 1992), 106, referring to Case 804/79 Commission v United Kingdom (Sea Fisheries) [1981] ECR 1045.

27 V. Constantinesco, 'Larticle CEE de la bonne foi à la loyauté communautaire', in F. Capotorti et al. (eds), Du Droit International aud droit de l'intégration: Liber Amicorum Pierre Pescatore (Baden-Baden: Nomos, 1987), 97-114.

${ }^{28}$ Constantinesco, 'L'article CEE de la bonne foi', 114 (emphasis in the original).

29 Witness to this, for instance, is the interest in the unity of international representation, which I will discuss in Chapter 10 in relation to mixed agreements.

This is an open access version of the publication distributed under the terms of the Creative Commons Attribution-NonCommercial-NoDerivs licence (http://creativecommons.org/licenses/by-nc-nd/3.0/), which permits non-commercial reproduction and distribution of the work, in any medium, provided the original work is not altered or transformed in any way, and that the work is properly cited. For commercial re-use, please contact academic.permissions@oup.com 
loyalty protects the Union interests, loyalty is not one-dimensional. As I have shown earlier, loyalty manages the relation between the Member States and the Union and vice versa; it even partly governs the relations between the Member States themselves. In this multi-vector relationship, the Member States and the policy interests they pursue are not necessarily subordinated to those of the Union. Put in other words, the Union interest does not trump the national interest in any case. This will become particularly visible in the field of external relations. ${ }^{30}$

In a contribution written in 1990, Schermers and Pearson approach Article 5 EEC in a novel way. They highlight the 'double role of Member States as, on the one hand, being part of the "internal machinery" of the Union, while, on the other hand, being the "opposing party in many of the Community's activities" '. ${ }^{31}$ In their 'insider' role, Member States are responsible for the functioning of the Council and the other organs of the EU. In their 'outsider' role, they are required to implement directives perhaps enacted against their votes and to terminate subsidies they have granted, but which were declared illegal by the Commission. ${ }^{32}$ Schermers and Pearson have submitted that this is different in cases where a Member State pursues interests opposed to those of the Union. ${ }^{33}$ However, even in this constellation, 'Member States should take the Community's interests into account. They are not allowed to only regard their own interests' ${ }^{34}$

The authors continue to explore this dichotomy, among other things, with respect to Member States' duties in the Council. They approvingly quote Ipsen on the point that the actual Union interest is only represented by the ultimate decision made by the Council. ${ }^{35}$ As we will discuss especially in the Part on Coordination, matters have been somewhat refined in the meantime and the Union interest Schermers and Pearson evoke as the pivotal element delimiting the 'insider' from the 'outsider' role of the Member States can no longer be attached to decisions made by the Council alone. Member States may become 'insiders' already at an earlier and still less formalized stage of Union activity. However, the focus on the Union interest being the determining factor for the relationship between Union and Member States still resonates today. The double role of Member States, evoked by Schermers and Pearson, adds an interesting view on the difficult space between the political and the legal realm loyalty operates in.

Hatje, finally, has defined the substance of loyalty by a set of specific functions it should serve, which he considers inherent in the Treaties. ${ }^{36}$ For this, Hatje has proposed uniformity of the Union legal order in combination with respect for the autonomy of the Member States, the safeguarding of cooperation, and the settlement of conflicts. ${ }^{37}$ These three functions of uniformity, cooperation, and the resolution of conflicts will also

30 De Baere, Constitutional Principles, 252, has called loyal cooperation the key in the balance between subsidiarity and consistency'.

31 H. Schermers and P.J. Pearson, 'Some Comments on Article 5 of the EEC Treaty', in J.F. Baur, K.J. Hopt, K.P. Mailänder (eds), Festschrift für Ernst Steindorff zum 70. Geburtstag am 13. März 1990 (Berlin: de Gruyter, 1990), 1359-1378, 1360-1361.

32 Schermers and Pearson, 'Some Comments' 1360-1361. The authors, at 1362, make an interesting comparison to the Meroni case law of the Court in order to argue that Member States cannot waive or delegate their responsibilities as 'insiders'. See Joined cases 21/61 to 26/61 Meroni [1962] ECR 73. See S. Griller and A. Orator, 'Everything under control?: The "Way Forward” for European Agencies in the Footsteps of the Meroni Doctrine', European Law Review, (2010), 3-35.

33 Schermers and Pearson, 'Some Comments', 1362.

34 Schermers and Pearson, 'Some Comments', 1363 (emphasis in the original).

35 Schermers and Pearson, 'Some Comments', 1365, referring to H.P. Ipsen, Europäisches Gemeinschaftsrecht (Tübingen: Mohr Siebeck, 1972), 261.

36 A. Hatje, Loyalität als Rechtsprinzip in der Europäischen Union (Baden-Baden: Nomos, 2001), 50.

37 Hatje, Loyalität als Rechtsprinzip, 50-51: 'Einheitsbildung bei gleichzeitiger Sicherung von Autonomie, Gewährleistung von Kooperation und Moderation von Konflikten'.

This is an open access version of the publication distributed under the terms of the Creative Commons Attribution-NonCommercial-NoDerivs licence (http://creativecommons.org/licenses/by-nc-nd/3.0/), which permits non-commercial reproduction and distribution of the work, in any medium, provided the original work is not altered or transformed in any way, and that the work is properly cited. For commercial re-use, please contact academic.permissions@oup.com 
be recurring themes in this book. As we will see, uniformity plays an important role with exclusive external competence as well as with the principle of the interest in the unity of international representation of the Union, discussed in Chapter 10. Cooperation is the title of one of the Parts of this book, referring to rules of consideration, coordination, and abstention that are based on loyalty. The conflict solving function of loyalty finally is central to many of the arguments proffered in this book, where I propose a broad understanding of conflicts going beyond norm conflict in a narrow sense.

\subsection{A History of Neglect: The Literature on Constitutionalization}

There are several classic narratives on the role of the European Court of Justice in creating an unwritten European constitution. ${ }^{38}$ Cappelletti, Seccombe, and Weiler have focused on a comparison between federal legal systems. ${ }^{39}$ Maduro has explored this role by example of the Court's jurisprudence in the area of the free movement of goods. ${ }^{40}$ Burley and Matti have adopted a political science and international relations perspective. ${ }^{41}$ The most famous narrative yet has been submitted by Stein, blending a legal with an institutional approach, ${ }^{42}$ and by Weiler, combining a legal with a political discourse. ${ }^{43}$

One recurring and fundamental rationale for constitutionalization in the European Union has been the autonomy of the Union order, proclaimed by the Court for the first time in Van Gend en Loos. ${ }^{44}$ The Court relied on an interpretation in light of 'the spirit, the general scheme and the wording' of ex Article 28 EC. ${ }^{45}$ It was this argument of the sui generis nature of (then) Community law which led the Court to modify the rules on establishing the self-executing character of rules in Community law. ${ }^{46}$ However, note that the direct effect of Treaty provisions that was decided in Van Gend was essentially a rule of interpretation. It was not necessarily about the relation of such rule to domestic law. In other words, it was not yet about conflict. This conflict was decided in favour of Community law eight years later in Costa $v E N E L$. The establishment of the supremacy of Community law in Costa, further discussed later, on the one hand has been seen as the logical complement to the principle of direct effect introduced in Van Gend. ${ }^{47}$ As such,

38 For this term see E. Stein, 'Lawyers, Judges, and the Making of a Transnational Constitution', The American Journal of International Law, (1981), 1-27; J.H.H. Weiler, 'The Transformation of Europe', The Yale Law Journal, (1991), 2403-2483.

39 M. Cappelletti, M. Seccombe, and J.H.H. Weiler, 'Integration Through Law: Europe and the American Federal Experience: A General Introduction', in M. Cappelletti, M. Seccombe, and J.H.H. Weiler (eds), Integration Through Law: Europe and the American Federal Experience, Vol. I (Berlin: de Gruyter, 1986), 3-68.

${ }^{40}$ M. Poiares Maduro, We the Court: The European Court of Justice and the European Economic Constitution (Oxford and Portland, Oregon: Hart Publishing, 1998).

${ }^{41}$ A.-M. Burley and W. Matti, 'Europe Before the Court: A Political Theory of Legal Integration', International Organization, 47 (1993), 41-76.

42 Stein, 'Lawyers'. $\quad 43$ Weiler, 'Transformation', 2403-2483.

44 See on this 'new legal order' argument, P.P. Craig, 'Constitutions, Constitutionalism, and the European Union', European Law Journal, 7:2 (2001), 125-150, 132-134.

${ }^{45}$ Apart from Art. 28 EC (now Art. 32 TFEU) itself, the Court did not mention any other Treaty norm in support of its reasoning.

46 B. de Witte, 'Direct Effect, Supremacy, and the Nature of the Legal Order', in P.P. Craig and G. de Búrca (eds), The Evolution of EU Law (Oxford: Oxford Univ. Press, 1999), 177-213, 181, instructively, explains that the crucial contribution of Van Gend was not the introduction of direct effect since this was familiar to public international law and, in the Treaty was provided for regulations, but that it then became the Court which decided about a provision's direct effect instead of the Member States.

${ }^{47}$ See further Stein, 'Lawyers', 10-13.

This is an open access version of the publication distributed under the terms of the Creative Commons Attribution-NonCommercial-NoDerivs licence (http://creativecommons.org/licenses/by-nc-nd/3.0/), which permits non-commercial reproduction and distribution of the work, in any medium, provided the original work is not altered or transformed in any way, and that the work is properly cited. For commercial re-use, please contact academic.permissions@oup.com 
it makes sense to see the rationale behind Costa likewise as essentially an extension of the suigeneris argument in Van Gend, as has been done by Stein. ${ }^{48}$ However, this ignores the fact that the Court invoked a different reasoning in Costa, one which was heavily based on loyalty as I will show later, but which is not mentioned once by Stein. ${ }^{49}$ Stein also fails to mention ex Article $5 \mathrm{EC}$ in connection with ERTA, which, as I will explain, is another case where this reference is hard to ignore. ${ }^{50}$

Another common theme in explaining the constitutionalizing case law of the Court relies on the argument of effectiveness or efficiency. ${ }^{51}$ In the words of Weiler from his highly influential 'Transformation' article:

One possible rationale underlying the Court's jurisprudence in both direct effect and supremacy has been its attempt to maximize the efficiency by which the Community performs the tasks entrusted to it by the Treaty. As part of this rationale, one must consider the question of specific powers granted the Community to perform these tasks. Direct effect and supremacy will not serve their functions if the Community does not have the necessary instruments at its disposal. The issue in which this consideration came to the fore, in 1970, was the treaty-making power of the Community. The full realization of many E.C. internal policies clearly depended on the ability of the Community to negotiate and conclude international treaties with third parties. $^{52}$

This rationale of the effectiveness of (then) Community law is partly an extension of the autonomy theme mentioned earlier. If the Member States pledged allegiance to the Community, they must certainly wish for the functioning of the legal edifice thus established. However, effectiveness is itself rooted in loyalty, as I will explain later. Despite this fact and the numerous references to loyalty in the foundational case law he discusses, Weiler equally does not mention loyalty once.

In another prominent narrative by Cappelletti, Seccombe, and Weiler, the uniformity theme is added to the equation:

The process of constitutionalization in the jurisprudence of the Court of Justice can be explained entirely in terms of the apparently quite orthodox legal philosophy adopted by the Court. The principle of effectiveness - enshrined in the basic maxim of pacta sunt servanda-which is at the root of the doctrine of direct effect, coupled with the principle of uniformity derived from procedural elements (e.g. article 177) and substantive elements (e.g. article 5) in the Treaty, lead by an inevitable logic to supremacy and pre-emption. ${ }^{53}$

This does mention ex Article 5 EC in connection with supremacy and pre-emption, discussed more specifically in Chapter 5. However, it is submitted that the passing reference to loyalty equally fails to do justice to its prominent role in the foundational case law of the Court. I will show that, despite the absence of an explicit supremacy or conflict clause in the Treaties, loyalty is the rule that was invoked by the Court to settle issues of the relationship between the Community (Union) legal order and these regimes of the

48 See Case 6/64 Costa v ENEL [1964] ECR 585, 593. See Stein, 'Lawyers', 11-12.

49 Stein also discussed all those cases under the constitutional tenet that expanded direct effect to the other freedoms, such as C-43/75 Defrenne v Sabena (No 2) [1976] ECR 455, [1976] ICR 547, [1981] 1 All ER 122, Case 41/74 van Duyn [1974] ECR 1337, and Case 33/74 Van Binsbergen [1974] ECR 1229. This of course relatively diminishes, by a count of the numbers, the importance of Costa and ERTA (Case 22-70 Commission of the European Communities $v$ Council of the European CommunitiesEuropean Agreement on Road Transport [1971] ECR 263).

50 Stein, 'Laywers', 22-23. $\quad 51$ Or to effet utile. See de Witte, 'Direct Effect', 183.

52 Weiler, 'Transformation', 2415-2416.

53 Cappelletti, Seccombe, and Weiler, 'Integration', 30.

This is an open access version of the publication distributed under the terms of the Creative Commons Attribution-NonCommercial-NoDerivs licence (http://creativecommons.org/licenses/by-nc-nd/3.0/), which permits non-commercial reproduction and distribution of the work, in any medium, provided the original work is not altered or transformed in any way, and that the work is properly cited. For commercial re-use, please contact academic.permissions@oup.com 
Member States. Mancini, in another seminal article, has also mentioned ex Article 5 EC in connection with supremacy:

... the Rome Treaty, while including some hortatory provisions to the same effect (Article 5), fails to state squarely whether Community law is pre-eminent vis-à-vis prior and subsequent Member State law. ${ }^{54}$

It comes as no surprise that ex Article $5 \mathrm{EC}$ is entirely ignored by those authors whose central argument is the essentially political instead of legal attitude of the Court in this early phase. Thus, Burley and Matti, in an otherwise magisterial account of the Court from a neofunctionalist perspective, have asserted that all constitutional cases 'are reasoned not on the basis of specific provisions of the Treaty or Community secondary legislation but on the accomplishment of the most elementary Community goals set forth in the Preamble of the Treaty'. ${ }^{55}$ In this vein, teleological interpretation has been claimed to be the rationale for 'everything from direct effect to the pre-emption of Member State negotiating power'. ${ }^{56}$ Besides the fact that this ignores completely that ex Article $5 \mathrm{EC}$ was invoked by the Court in both Costa and ERTA, ${ }^{57}$ it will be shown later that effet utile, while central to the case law on direct effect, was not the central argument in ERTA. It will also be discussed that the Court used arguments based on effet utile and arguments based on Article 4 (3) TEU in a different manner. ${ }^{58}$

We have thus seen that, in the 'grand' narratives on the constitutionalization of the Union, loyalty plays no or only a minor role as an explanatory force from a legal perspective. However, the role of loyalty for the constitutionalization of Union law has not been neglected in all quarters in the present context. Von Bogdandy has observed that ex Article $10 \mathrm{EC}$ was the basis for determining the relationship between the EU and the Member States, and that all concrete obligations and prohibitions to ensure the functioning of the Union and its legal order were based on ex Article 10 EC, even though this has not always been disclosed by the Court. ${ }^{59}$ De Witte has recognized that ex Article 10 $\mathrm{EC}$ was one argument among others in the major cases on direct effect and supremacy. ${ }^{60}$ Curtin, finally, has noted the following:

A vital part of the Court's constitutionalization of the EC Treaty has depended upon the elaboration, based on Article $5 \mathrm{EEC}$ and the principle of cooperation of Member States, of increasingly far-reaching obligations on national judges in the context of their Community law mandate. ${ }^{61}$

By analysing the foundational case law of the Court, I will show in the following section that this has indeed been the case.

54 G.F. Mancini, 'The Making of a Constitution for Europe', Common Market Law Review, 26 (1989), 596-599, 599.

55 Burley and Matti, 'Europe before the Court', 68.

56 Burley and Matti, 'Europe before the Court', 68.

57 According to R. Schütze, 'Supremacy Without Pre-emption?: The Very Slowly Emergent Doctrine of Pre-emption', Common Market Law Review, 43:4 (2006), 1023-1048, 1048 (fn 95), ex Art. 19 EC 'as the constitutional rationale underlying the twin doctrines of supremacy and pre-emption'.

58 But see Burley and Matti, 'Europe before the Court', 70, who claim that the Court camouflages controversial political decisions in "technical" legal garb'.

59 A. von Bogdandy, 'Rechtsfortbildung mit Art. 5 EG-Vertrag', in A. Randelzhofer, R. Scholz and D. Wilke (eds), Gedächtnisschrift für Eberhard Grabitz (Munich: Beck, 1995), 17-28, 19 with further references.

${ }^{60}$ De Witte, 'Direct Effect', 194 (fn 78).

${ }^{61}$ D. Curtin, 'The Decentralised Enforcement of Community Law Rights: Judicial Snakes and Ladders', in D. Curtin and D. O'Keeffe (eds), Constitutional Adjudication in European Community and National Law (London: Butterworths, 1992), 33-49, 41.

This is an open access version of the publication distributed under the terms of the Creative Commons Attribution-NonCommercial-NoDerivs licence (http://creativecommons.org/licenses/by-nc-nd/3.0/), which permits non-commercial reproduction and distribution of the work, in any medium, provided the original work is not altered or transformed in any way, and that the work is properly cited. For commercial re-use, please contact academic.permissions@oup.com 


\section{The Foundational Case Law Re-assessed}

\subsection{Introduction}

In the judgments of the Court that will be analysed later, loyalty played a conspicuous and multifaceted role. In two instances, viz. Costa and ERTA, it was the sole basis for the integrationist leap handed down by the Court. In three other important developments of Union law, viz. the direct effect of directives, the interpretation obligation, and state liability, it was the second legal basis besides effet utile, effectiveness, and Article 288 TFEU, respectively.

I will show that loyalty in the cases discussed served the resolution of various conflicts between Union and Member State rules. The second situation that will be shown to have prompted the invocation of loyalty was the justification of different duties of interpretation of national law in light of Union law. These two strands of application are related on two grounds. Firstly, the interpretation of national laws may prevent norm conflicts arising in the first place. Thus, it will be argued that the indirect effect of directives is preferable to direct effect for resolving inconsistencies and deficiencies of national laws in the 'shadow' of Union directives. Secondly, the duty of consistent interpretation of national law also involves the resolution of a conflict not between substantive legal norms, but between conflicting methods of interpretation, thus between norms of procedure.

We will also see in the following section that the application of loyalty has often not been very consistent. Thus, in at least two instances, the Court omitted any reference to Article 5 EEC and to Article 10 EC after having initially based its reasoning on these provisions. Conversely, ex Article $10 \mathrm{EC}$ was added belatedly as rationale for direct effect, whereas initially the Court had solely argued based on effet utile. Moreover, while in early case law both state liability and the indirect effect of directives have been presented as being derived from loyalty among other things, in later cases these principles were proclaimed as being inherent in the European legal order.

\subsection{Loyalty's Role in Costa $v$ ENEL}

As mentioned earlier, in Van Gend, the only explicit reference to a Treaty provision made by the Court was to ex Article $28 \mathrm{EC}$, and the principal argument of the Court to establish direct effect was the sui generis nature of (then) Community law. In contrast, in Costa the Court produced a cascade of interrelated arguments to justify supremacy over pre-existing national law. Firstly, it repeated the sui generis argument, ${ }^{62}$ stressed the subjective side of obligations under Community law, ${ }^{63}$ and referred to 'the terms and the spirit of the Treaty'. ${ }^{64}$ Secondly, it made the systematic argument that 'wherever the Treaty grants the States the right to act unilaterally, it does this by clear and precise provisions', and it listed a number of examples for this point. Thirdly, the Court referred to regulations under Article 288 TFEU, which would otherwise be 'meaningless'. 65

62 'By contrast with ordinary international treaties, the EEC Treaty has created its own legal system...'

63 '.... have thus created a body of law which binds both their nationals and themselves.'

64 'The integration into the laws of each Member State of provisions which derive from the Community, and more generally the terms and the spirit of the Treaty...'

65 'This provision, which is subject to no reservation, would be quite meaningless if a State could unilaterally nullify its effects by means of a legislative measure which could prevail over Community law.'

This is an open access version of the publication distributed under the terms of the Creative Commons Attribution-NonCommercial-NoDerivs licence (http://creativecommons.org/licenses/by-nc-nd/3.0/), which permits non-commercial reproduction and distribution of the work, in any medium, provided the original work is not altered or transformed in any way, and that the work is properly cited. For commercial re-use, please contact academic.permissions@oup.com 
This last argument is an example of the use of effet utile by the Court. However, because this argument merely 'confirms' its finding of supremacy as the Court put it, this should not be considered the principal argument in this case. ${ }^{66}$ It is submitted that the methodological anchor in the Treaty for the dictum in Costa and, thus, at the core of the Court's reasoning, lies the following sentence:

The executive force of Community law cannot vary from one State to another in deference to subsequent domestic laws, without jeopardizing the attainment of the objectives of the Treaty set out in Article 5(2) and giving rise to the discrimination prohibited by Article 7. ${ }^{67}$

This part of the judgment is the only part that cannot be accused of being somewhat circular, in contrast to especially the sui generis argument. The reference by the Court to the prohibition of discrimination obviously rephrases the uniformity theme, made more explicit in other judgments. The reference to ex Article 5 (2) EC, which obliges the Member States to 'abstain from any measure which could jeopardise the attainment of the objectives of this Treaty', must here be understood as being connected to the objective of preventing all discrimination within the scope of Community law. Ex Article 5 (2) EC itself states no objectives and the judgment also does not mention any other Treaty objectives. This means that Member States must abstain from applying national law that conflicts with prior Union law, since this would risk subjecting nationals of Member States to divergent and therefore discriminatory regimes under domestic law.

I would submit that the prohibition against disturbing the objectives of the Union that is provided in ex Article 5 (2) EC constituted the only Treaty-based justification why national law must yield to Union law. Put differently, the abstention obligation qua loyalty displaced the public international law principle of lex posterior derogatpriori. This is the conflict avoidance function of loyalty, a function that could have been derived from neither ex Article $7 \mathrm{EC}$ nor from any of the other provisions mentioned in Costa. The fact that the reasoning of the Court in the relevant part of the judgment was not (yet) about specific national measures, makes it quite clear that Costa was not necessarily concerned with a conflict of norms. Instead, it was a general statement on the nature and effect of Union law, and the Treaty objective it safeguarded was an equally very general prohibition of discrimination.

In subsequent cases, the principle of supremacy has been further developed by the Court. ${ }^{68}$ It is striking that loyalty has never again been mentioned in any subsequent judgment on supremacy. From Costa onwards, the Court invoked Costa as authority without repeating the judicial foundation of this judgment itself. It is as if once loyalty had served its purpose of rationalizing a quite audacious interpretation of the Treaties, it was quickly put back into the 'closet' again. As noted by Temple Lang, 'it is a feature of the case law on Article 10 that, because the principles are regarded as clear and so do not need discussion in later judgments, the principle is repeated later, without the Court mentioning that the principle is based on Article 10' ${ }^{69}$

One reason for this might be that, as shown earlier, the way in which the Court reasoned the introduction of supremacy is multilayered and, as such, not very suitable to be repeated in later judgments. To continue arguing based on ex Article $5 \mathrm{EC}$ and

\footnotetext{
66 But see S. Seyr, Der effet utile in der Rechtsprechung des Europäischen Gerichtshofs (Berlin: Duncker \& Humblot, 2008), 176.

67 Case 6/64 Costa v ENEL [1964] ECR 585, 594.

68 Case 11/70 Internationale Handelsgesellschaft [1970] ECR 1125; Case 106/77 Simmenthal II [1978] ECR 629.

69 Temple Lang, 'The Development by the Court of Justice of the Duties of Cooperation', 1487.
}

This is an open access version of the publication distributed under the terms of the Creative Commons Attribution-NonCommercial-NoDerivs licence (http://creativecommons.org/licenses/by-nc-nd/3.0/), which permits non-commercial reproduction and distribution of the work, in any medium, provided the original work is not altered or transformed in any way, and that the work is properly cited. For commercial re-use, please contact academic.permissions@oup.com 
on the range of other arguments presented in Costa may have exposed the delicate structure the principle of supremacy has been built on methodologically. Another reason might be that, had the alleged logic conceived in Costa remained on the table, the subsequent expansion of the supremacy doctrine to all national law in Simmenthal might have become even more unpalatable for the Member States. After all, while the primacy of posterior national law might fall under the obligation to abstain from perturbing Union law, this is a much less convincing rationale for the primacy of Union law over pre-existing national law; moreover, it does not at all explain why national law would be rendered 'automatically inapplicable', as the Court put it in Simmenthal. ${ }^{70}$ While I do not mean there are no valid grounds to decide in this manner in the case law following Costa, this would arguably have required resort to other principles of Union law. ${ }^{71}$ However, the irony that lies in this shift of reasoning is that it can be argued that the principle of effectiveness is itself a manifestation of loyalty. ${ }^{72}$

\subsection{The ERTA case and Opinion 2/91}

Loyalty played an even more prominent role in the ERTA case on the competence to conclude the European Agreement on Road Transport, (in)famous for introducing the implied powers doctrine to EU external relations law. ${ }^{73}$ According to ERTA, the Union acquires exclusive external competence for the conclusion of international agreements with third states such as the one mentioned as a consequence of the passing of secondary law. The Court in this judgment referred to ex Article 3 (e) EC on the adoption of a common policy in the sphere of transport, and to both parts of ex Article 5 EC. ${ }^{74}$ It continued as follows:

If these two provisions [Articles 3 and 5] are read in conjunction, it follows that to the extent to which Community rules are promulgated for the attainment of the objectives of the Treaty, the Member States cannot, outside the framework of the Community institutions, assume obligations which might affect those rules or alter their scope. ${ }^{75}$

Again, a Treaty objective, this time the common policy in the field of transport, was combined with a reference to loyalty. Perhaps even more clearly than in Costa, ERTA established an obligation of abstention incumbent on the Member States. It served the avoidance of conflict between Union objectives and international obligations entered into by the Member States. It is therefore submitted that loyalty here had a very similar function as in Costa discussed earlier. By this view, ex Article 5 EC was the pivotal argument on which the Court based its finding in ERTA. ${ }^{76}$ This is supported by the fact that in subsequent important cases such as the Open Skies judgments, the Court repeated the reference to ex Article $10 \mathrm{EC}$ as the principal legal basis for the ERTA principle. ${ }^{77}$

70 Case 106/77 Simmenthal II [1978] ECR 629.

71 In Simmenthal, the Court referred to Union law's 'effectiveness'. See Case 106/77 Simmenthal II [1978] ECR 629, paras 18, 20, 22, and 23.

72 See Chapter 13.

73 Case 22/70 Commission v Council (ERTA) [1971] ECR 263.

74 Case 22/70 ERTA [1971] ECR 263, paras 20-21.

75 Case 22/70 ERTA [1971] ECR 263, para 22.

76 See P. Eeckhout, EU External Relations Law, 2nd edn. (Oxford: Oxford Univ. Press, 2011), 84. See also the remarkable analysis of the case by J. Temple Lang, 'The ERTA Judgment and the Court's Case-law on Competence and Conflict', Yearbook of European Law, 6 (1986), 183-218.

77 The Court referred to para 22 of Case 22/70 ERTA [1971] ECR 263 quoted earlier and to the preceding para 21, where the Court had rendered the wording of ex Art. 5 EC. See Case C-467/98 Commission v Denmark [2002] ECR I-9519, paras 110-112. See also Case C-523/04 Commission v The

This is an open access version of the publication distributed under the terms of the Creative Commons Attribution-NonCommercial-NoDerivs licence (http://creativecommons.org/licenses/by-nc-nd/3.0/), which permits non-commercial reproduction and distribution of the work, in any medium, provided the original work is not altered or transformed in any way, and that the work is properly cited. For commercial re-use, please contact academic.permissions@oup.com 
Moreover, the compliance with ex Article 5 EC was the only ground mentioned by the Court for not finding an infringement by the Member States in the specific setting of the ERTA case. ${ }^{78}$

We should also note that loyalty played a prominent role in Opinion 2/91 on the powers to conclude the ILO Convention. ${ }^{79}$ This Opinion restated the wording of ex Article 5 EEC, before finding that exclusivity could also arise because a field was largely covered by Union rules, even if the agreement in question did not contradict common rules. ${ }^{80}$ Thus, the Court introduced another inroad for establishing exclusive external powers. This explicit connection between loyalty and implied exclusive powers was also made in Opinion 1/03 on the competence for concluding the Lugano Convention. ${ }^{81}$

Such view is opposed by Kuijper, who has regarded loyalty as 'not indispensable' for establishing treaty-making power of the Union in ERTA. He has contended that the Court built its finding in ERTA on (1) an implied powers argument based on the personality of the Community and the 'scheme of the treaty', (2) 'the logical argument' that 'if this is so, there is a close link between internal and external measures based on the Treaty and that Member States may not affect or alter the internal measures by national external measures', (3) a repetition of the latter argument based on ex Articles 3 and 5 EC, (4) an argument for implied external powers based on ex Article $75 \mathrm{EC}$, and (5) the express treaty-making mandate provided in Regulation 543/69. ${ }^{82}$ Let us briefly examine his arguments, which I do not find compelling.

(1) When the Court refers to the legal personality of the Union in connection with treaty-making powers, ${ }^{83}$ this does not mean that we need not 'determine in a particular case the community's authority to enter into international agreements' ${ }^{84}$ In other words, legal personality does entail treaty-making capacity, but does not tell us when it exists and if it is exclusive or shared.

(2) Neither the affirmation of legal personality nor the reference to the scheme of the Treaty as such would compel to require 'measures adopted, within the framework of those provisions, by the community institutions ${ }^{\prime}{ }^{5}$ for the establishment of such external competence. ${ }^{86}$ There is also exclusive competence when this is necessary for achieving Treaty objectives without the need for a prior internal measure. ${ }^{87}$ This might explain the statement in paragraph 16 that competence 'may equally flow from other provisions of the treaty'.

Netherlands (Bilateral Air Transport Agreement) [2007] ECR I-3267, paras 74-76. But see P.-J. Kuijper, 'Re-reading External Relations Cases in the Field of Transport: The Function of Community Loyalty', in J. Bulterman et al. (eds), Views of European Law from the Mountain: Liber Amicorum for Piet-Jan Slot (The Hague: Kluwer Law International, 2009), 291-300, 298, who sees the role of loyalty in these cases in light of their peculiar circumstances.

78 See Case 22/70 ERTA [1971] ECR 263: 'It may therefore be accepted that, in carrying on the negotiations and concluding the agreement simultaneously in the manner decided on by the council, the member states acted, and continue to act, in the interest and on behalf of the community in accordance with their obligations under article 5 of the treaty.' See on the specifics of the case, Eeckhout, $E U$ External Relations Law, 62.

79 Opinion 2/91 ILO Convention 170 [1993] ECR I-1061.

80 Opinion 2/91 ILO Convention 170 [1993] ECR I-1061, para 10. See further on this Opinion in Chapter 7.

${ }^{81}$ See Opinion 1/03 Lugano Convention [2006] ECR I-1145, para 119.

${ }^{82}$ Kuijper, 'Re-reading', 294. $\quad{ }_{83}$ Case 22/70 ERTA [1971] ECR 263, paras 13-14.

${ }^{84}$ Case 22/70 ERTA [1971] ECR 263, para 15.

85 Case 22/70 ERTA [1971] ECR 263, para $16 . \quad{ }^{86}$ But see Kuijper, 'Re-reading', 294.

87 See the 'ILO principle' introduced by Opinion 2/91 ILO Convention 170 [1993] ECR I-1061, discussed in Chapter 7. See M. Klamert and N. Maydell, 'Lost in Exclusivity: Implied Non-exclusive External Competences in Community Law', European Foreign Affairs Review, 13 (2008), 493-513.

This is an open access version of the publication distributed under the terms of the Creative Commons Attribution-NonCommercial-NoDerivs licence (http://creativecommons.org/licenses/by-nc-nd/3.0/), which permits non-commercial reproduction and distribution of the work, in any medium, provided the original work is not altered or transformed in any way, and that the work is properly cited. For commercial re-use, please contact academic.permissions@oup.com 
(3) Paragraphs 17 to 22 of ERTA can and should be read as one argument, whereby ex Article 5 provides the basis for the duty of abstention for Member States as a result of the passing of common rules. ${ }^{88}$ There is no indication in the wording of the judgment that paragraphs 20 to 22 are merely a repetition or a reinforcement of the reasoning made in the preceding paragraphs.

(4) To claim, furthermore, that ex Article 75 (1) EC, directing the Council to lay down common rules and 'any other appropriate provisions', provided implied external competence ${ }^{89}$ does not necessarily explain why such competence should have been exclusive, which, however, was essential in ERTA. ${ }^{90}$

(5) The last point is especially tricky and the Part on Cooperation is a more appropriate place to deal with it. Suffice it to note here that I do not see any substantial difference between the ERTA principle on the one hand, and what will be referred to as the WTO principle on the other. While the former creates exclusivity qua the passing of a common rule, the latter creates exclusivity as the result of a mandate to 'enter into any negotiations with third countries which may prove necessary' that is provided in such measure. ${ }^{91}$ The negotiating mandate granted in Regulation 543/69 did not dispense with the need to rationalize the ERTA doctrine. If such mandate granted in an act of secondary law were sufficient for establishing exclusive external competence, there would have been no further need to justify a transfer of competence because of a legal Union act where such mandate is not provided.

I would therefore conclude that ex Article 5 EC in ERTA should be seen as the central legal basis for pre-empting the Member States because of the passing of common rules. Loyalty arguably was the only appropriate Treaty provision in force at that time to achieve, in combination with the Treaty objectives, such far-reaching implication for the treaty-making authority of the Member States. I will return to the importance of the concretization of the Union objectives to provide some qualification for the effect of Article 4 (3) TEU and to the relevance of Regulation 543/69 in this context in Chapter 14.

\subsection{Loyalty and the Effect of Union Law in National Law}

\subsubsection{Direct effect}

Ex Article 10 EC is the exclusive legal basis for the obligation of Member States to construe national law in light of the EU Treaty. This has been made clear in the van Munster case with regard to ex Article $48 \mathrm{EC}$ (now Article 45 TFEU). ${ }^{92}$ A difference in legislation between retirement schemes for migrant workers and that for non-migrant workers had caused migrant workers to lose a social security advantage. The Court held that this would discourage migrant workers from actually exercising their right to freedom of movement. ${ }^{93}$ It therefore ordered the referring national court to strive to interpret its national law in a way as to avoid such outcome.

88 But see Kuijper, 'Re-reading', who sees ex Arts. 3 and 5 EC as merely underpinning the 'logical argument' derived from implied powers.

89 That it did not confer express competence is also stated by the Court in Case 22/70 ERTA [1971]

ECR 263, para 28.

90 See also Eeckhout, EU External Relations Law, 63.

91 Opinion 1/94 WTO [1994] ECR I-5267.

92 Case C-165/91 van Munster [1994] ECR I-4661, para 34. See the judgment in Case 157/86 Murphy [1988] ECR 673, para 11; Case C-322/88 Salvatore Grimaldi [1989] ECR 4407, and Case C-262/97 Engelbrecht [2000] ECR 7321, para 39.

93 Case C-165/91 van Munster [1994] ECR I-4661, para 32.

This is an open access version of the publication distributed under the terms of the Creative Commons Attribution-NonCommercial-NoDerivs licence (http://creativecommons.org/licenses/by-nc-nd/3.0/), which permits non-commercial reproduction and distribution of the work, in any medium, provided the original work is not altered or transformed in any way, and that the work is properly cited. For commercial re-use, please contact academic.permissions@oup.com 
In contrast, in the leading cases establishing the direct effect of directives, the Court only referred to Article 288 TFEU and the 'useful effect' of the directive concerned, which would otherwise have been weakened. ${ }^{94}$ In Moormann, however, direct effect was suddenly based 'on the combined provisions of the third paragraph of Article 189 and Article 5 of the EEC Treaty'. ${ }^{95}$ This shows the close rapport between arguments based on effet utile and arguments based on ex Article 10 EC. ${ }^{96}$ While Moormann implies that these two rationales may even be exchangeable, I will explain in the Part on Construction that it is apposite to distinguish them for methodological reasons.

The indirect effect of Union directives is a central example of two distinct duties based on Article 4 (3) TEU. ${ }^{97}$ For this, dealt with in the following section, the period before the expiry of the transposition deadline ('pre-term') must be distinguished from the period after this point in time ('post-term').

\subsubsection{Indirect effect pre-term: Consideration}

I have argued elsewhere that Article 4 (3) TEU applies as the sole legal basis for a duty of consideration incumbent on national authorities of the binding objective of a directive prior to the expiry of a directive's deadline for implementation. ${ }^{98}$ The argument, in a nutshell, is as follows: During this implementation term, the national legislator is free to postpone (full) transposition until the term's expiry. However, since the objective expressed in the directive is already binding on the Member States, national courts must interpret national law in light of a directive in order to satisfy Article 4 (3) TEU. Whether a directive is a part of national law from its coming into existence, or only from the end of the implementation period, is irrelevant for present purposes. ${ }^{99}$ For reasons of legal certainty, this anticipatory indirect effect does not affect national methods of interpretation. It does not possess the force to set aside national law, neither substantive nor procedural. ${ }^{100}$ The latter is the main difference compared to indirect effect post-term.

I would submit that it does, however, require national authorities to provide a reasoning if they decide to deviate from the directive's objective. The exact contours of this duty of consideration are difficult to gauge. Thus, while the German Constitutional Court has introduced a duty of national authorities to consider the European Convention of Human Rights as construed by the European Court of Human Rights, this has been met

94 Case 41/74 van Duyn [1974] ECR 1337, para 12; Case 51/76 Verbond van Nederlandse Ondernemingen [1977] ECR 113, para 23; Case 148/78 Ratti [1979] ECR 1629, paras 20-23. See also Case 9/70 Grad [1970] ECR 825, para 5.

95 Case 190/87 Moormann [1988] ECR 4689, para 24. See also Curtin, 'The Decentralised Enforcement', 37.

96 Temple Lang, 'The Development by the Court of Justice of the Duties of Cooperation', has argued that Moorman is the most striking result of a general failure to refer to ex Art. $10 \mathrm{EC}$, causing the importance of loyalty to be underestimated.

97 With regard to directives, I will alternatively refer to the terms 'indirect effect', 'consistent interpretation', and 'interpretation obligation'. See M. Klamert, 'Judicial Implementation of Directives and Anticipatory Indirect Effect: Connecting the Dots', Common Market Law Review, (2006), $1251-1275,1251$.

98 Klamert, 'Judicial Implementation', 1271. But see the opponents of such view referenced in Klamert, 'Judicial Implementation', 1271, fn 113.

99 But see Chapter 4.

100 This explains why the obligation to interpret national law in conformity with Community law, which is based solely on Art. 10 EC, has less force than indirect effect. See C-105/03 Criminal Proceedings Against Maria Pupino [2005] ECR I-5285, para 47.

This is an open access version of the publication distributed under the terms of the Creative Commons Attribution-NonCommercial-NoDerivs licence (http://creativecommons.org/licenses/by-nc-nd/3.0/), which permits non-commercial reproduction and distribution of the work, in any medium, provided the original work is not altered or transformed in any way, and that the work is properly cited. For commercial re-use, please contact academic.permissions@oup.com 
with apprehension in the literature. ${ }^{101}$ Nettesheim has argued that Article 4 (3) TEU would vest recommendations by the Commission with a limited legal force, obliging Member States as their addressees not to simply ignore them, but to duly take them into account and to justify if they reject them. ${ }^{102}$ This would not be enforceable, however, nor would a violation of such duty of consideration be sanctioned. ${ }^{103}$ I would argue that such obligation would also apply with indirect effect pre-term, with the decisive difference that this could be enforceable and subject to sanctions under the infringement procedure.

\subsubsection{Indirect effect post-term: Disapplication}

The duty of interpretation of national law in the light of a directive after the expiry of its deadline for implementation is not primarily based on Article 4 (3) TEU. ${ }^{104}$ In the judgments introducing the indirect effect of Union directives, for the longest time, the Court simultaneously referred to what are now Article 288 TFEU and Article 4 (3) TEU as reasons for requiring national courts to interpret national law in the light of a directive. ${ }^{105}$ This has been held in wording such as the following, repeated identically in several judgments:

That being the case, it must be reiterated first of all that the Member States' obligation arising from a directive to achieve the result envisaged by the directive and their duty under Article 5 of the EC Treaty to take all appropriate measures, whether general or particular, to ensure fulfilment of that obligation is binding on all the authorities of Member States, including, for matters within their jurisdiction, the courts. It follows that, when applying national law, whether adopted before or after the directive, the national court having to interpret that law must do so, as far as possible, in the light of the wording and the purpose of the directive so as to achieve the result it has in view and thereby comply with the third paragraph of Article 189 of the EC Treaty ... ${ }^{106}$

In the more recent Pfeiffer case, in contrast, the Court omitted any reference to Article 4 (3) TEU. Instead it found that '[T] he requirement for national law to be interpreted in conformity with Community law is inherent in the system of the Treaty, since it permits the national court, for the matters within its jurisdiction, to ensure the full effectiveness of Community law when it determines the dispute before it... '. ${ }^{107}$ However, in the

101 See Case 2 BvR 1481/04 Görgülü [2004] BVerfGE 111, 307, 315 passim. See the analysis of this obligation by L. Viellechner, 'Berücksichtigungspflicht als Kollisionsregel', Europäische Grundrechte Zeitschrift, (2011), 203-207. Critical of the normative value of this concept is also C. Grabenwarter, 'Grundrechtsvielfalt und Grundrechtskonflikte im europäischen Mehrebenensystem: Wirkungen von EGMR-Urteilen und der Beurteilungsspielraum der Mitgliedstaaten', Europäische Grundrechte Zeitschrift, 38:8 (2011), 229-232, 230.

102 M. Nettesheim, 'Art. 288 AEUV', in E. Grabitz, M. Hilf, and M. Nettesheim (eds), Das Recht der Europäischen Union (Munich: Beck, 2011), para 206.

103 Nettesheim, 'Art. 288 AEUV', para 206.

104 See also Klamert, 'Judicial Implementation', 1251-1275.

105 Case 14/83 von Colson [1984] ECR 1891, para 26; Case 79/83 Harz [1984] ECR 1921, para 26. See also Case 222/84 Marguerite Johnston [1986] ECR 1651, para 53; Case 80/86 Kolpinghuis Nijmegen [1987] ECR 3969, para 12; Case 31/87 Gebroeders Beentjes [1988] ECR 4635, para 12. But see, among others, Case C-72/95 Kraaijeveld, [1996] ECR 5403, para 55, where ex Art. 249 EC and 'the directive itself' were invoked.

106 Case C-54/96 Dorsch Consult [1997] ECR I-4961, para 43. Same wording in Case C-76/97 Walter Tögel ECR [1998] I-5357, para 25; Case C-111/97 EvoBus Austria [1998] ECR I-5411, para 18; Case C-258/97 Hospital Ingenieure [1999] ECR I-1405. See also Case C-62/00 Marks \& Spencer [2002] ECR I-6325, para 42.

107 Joined cases C-397/01 and C-403/01 Pfeiffer [2004] ECR I-8835, para 114. Also noted by M. Ross, 'Effectiveness in the European Union Legal Order(s): Beyond Supremacy to Constitutional

This is an open access version of the publication distributed under the terms of the Creative Commons Attribution-NonCommercial-NoDerivs licence (http://creativecommons.org/licenses/by-nc-nd/3.0/), which permits non-commercial reproduction and distribution of the work, in any medium, provided the original work is not altered or transformed in any way, and that the work is properly cited. For commercial re-use, please contact academic.permissions@oup.com 
judgment in the Mau case, which the Court calls on as authority in the quoted paragraph, there is still the reference to the original reasoning based on ex Articles 10 and 249 EC. ${ }^{108}$ The importance of loyalty for establishing indirect effect as a matter of principle is also confirmed by the judgment in Pupino with regard to framework decisions, discussed in the Part on Cohesion. ${ }^{109}$

There is a fundamental difference between the way loyalty works with regard to respectively direct effect and indirect effect. With the direct effect of directives, the Court collapsed the findings in Van Gend, Costa, and Simmenthal to decree that certain provisions in directives are directly effective, that they take priority over national law and that conflicting national law must not be applied as a result. As I have argued earlier, Costa relied on the specific conflict avoidance function contained in ex Article 5 EC, which could not have been derived from any other provision of the Treaty. Thus, the reference to loyalty in connection with the direct effect of directives recalls the conflict discourse in which this obligation is situated. Loyalty here is as much an adequate choice as it was in Costa. When in Costa it protected the objective of prohibiting discrimination, in the landmark case von Colson it safeguarded the objectives of Directive 76/207. ${ }^{110}$ This is slightly different once supremacy is considered a principle of Union law and its basis no longer requires affirmation, because it follows that directly applicable provisions in a binding instrument of Union law also take priority over national law. By such reading, the reference to what is now Article 288 TFEU makes the point that directives are legally binding. A reference to what is now Article 4 (3) TEU then becomes redundant, unless it serves to restate the legal basis for supremacy itself.

The same supremacy discourse can be conducted with regard to the obligation to interpret national law in light of directives. However, in this context its use is less apparent. Indirect effect is detached from direct effect because it applies independent of the self-executing nature of a directive. ${ }^{111}$ However, while there is no conflict of norms in the narrow sense in the case of the interpretation obligation, the binding nature of a directive's objective must be honoured by the Member States by means of the less intrusive construction duty. While the primary foundation of indirect effect must be seen in the respective Treaty provision itself, Article $288 \mathrm{TFEU}$ is not lex specialis in relation to Article 4 (3) TEU. At the same time, while Article 4 (3) TEU could not alone create such far-reaching obligations emanating from a directive, it contributes the 'conflictive' side of the obligation to interpret national law by requiring national authorities to disapply rules of construction under domestic law in order to attain the directive's objective. I would argue that, because this interventionist aspect of indirect effect, which will be explored in detail in Chapter 6, cannot be based on Article 288 TFEU proper, the Court is correct in applying Article 4 (3) TEU in conjunction with it.

Proportionality?', European Law Review, (2006), 476-498, 482. I have argued elsewhere that reliance on 'inherency', which we will also encounter with state liability later, arguably is less compelling from a theoretical perspective than the invocation of specific Treaty provisions, making it more and not less difficult to determine the effects and scope of the interpretation obligation. See Klamert, 'Judicial Implementation', 1253-1254.

108 Case C-160/01 Mau [2003] ECR I-4791, para 34.

109 See Case C-105/03 Criminal Proceedings Against Maria Pupino [2005] ECR I-5285, para 43.

110 See Case 14/83 von Colson [1984] ECR 1891.

111 See M. Klamert, 'Richtlinienkonforme Auslegung und unmittelbare Wirkung von EG-Richtlinien in der Rechtsprechung der österreichischen Höchstgerichte', Juristische Blätter, 130:3 (2008), 158-170. For a different perspective based on a too generalizing reading of Case C-212/04 Adelener [2006] ECR I-6057, see R. Lööf, 'Temporal Aspects of the Duty of Consistent Interpretation in the First and Third Pillars', European Law Review, 32 (2007), 888-895, 892.

This is an open access version of the publication distributed under the terms of the Creative Commons Attribution-NonCommercial-NoDerivs licence (http://creativecommons.org/licenses/by-nc-nd/3.0/), which permits non-commercial reproduction and distribution of the work, in any medium, provided the original work is not altered or transformed in any way, and that the work is properly cited. For commercial re-use, please contact academic.permissions@oup.com 


\subsection{Loyalty and State Liability}

The obligation of Member States to compensate their citizens under certain conditions for damages because of breaches of Union law does not fit with the conflict rationale prevalent in the constitutional case law discussed previously. It, however, has something to do with the 'fulfilment of the obligations arising out of the Treaties', and with 'the achievement of the Union's tasks', as set out in Article 4 (3) TEU. Deficiencies in the transposition of secondary law were the reason for the lawsuit that prompted the Court decision in Francovich. State liability can thus be seen as another way to safeguard the objectives of primary or secondary law. We may conceive the reasoning based on loyalty with regard to state liability as being located in the same context as the invocation of loyalty in Costa to safeguard the prohibition of discrimination, in ERTA to protect the common transport policy, and in von Colson to preserve the fulfilment of the objective of the directive at issue.

The main reason stated by the Court in Francovich is the need to safeguard the full effectiveness of rights derived from Union law. ${ }^{112}$ Moreover, the Court finds state liability to be 'inherent in the system of the Treaty'. ${ }^{113}$ I will return to this principle of effectiveness and the way it is employed by the Court in Francovich in Chapter 13. Ex Article $10 \mathrm{EC}$ is only referred to as a 'further basis' for its introduction:

A further basis for the obligation of Member States to make good such loss and damage is to be found in Article 5 of the Treaty, under which the Member States are required to take all appropriate measures, whether general or particular, to ensure fulfilment of their obligations under Community law... ${ }^{114}$

However, in Brasserie du Pêcheur, an important follow-up case, the Court restated the line of reasoning displayed in Francovich in the following manner:

In order to determine those conditions, account should first be taken of the principles inherent in the Community legal order which form the basis for State liability, namely, first, the full effectiveness of Community rules and the effective protection of the rights which they confer and, second, the obligation to cooperate imposed on Member States by Article 5 of the Treaty. ${ }^{115}$

This wording seems to upgrade the role of loyalty as a basis for establishing state liability. While in Francovich loyalty clearly is only presented as an additional argument to reinforce a finding already made based on effectiveness, it seems a rationale of equal value in Brasserie du Pêcheur. ${ }^{116}$ An explanation for this not entirely faithful rendition of the original argument in Francovich might be the sharp criticism the brevity of the reasoning in the latter case has met in the literature. ${ }^{117}$ Refashioning this reasoning as not only being

112 Joined cases C-6/90 and C-9/90 Francovich [1991] ECR I-5357, paras 33-34. But see T. Tridimas, The General Principles of EU Law, 2nd edn. (Oxford: Oxford Univ. Press, 2006), 499, who has already with regard to Francovich stated that the Court based its decision on the two grounds of effectiveness and ex Art. 10 EC.

113 Joined cases C-6/90 and C-9/90 Francovich [1991] ECR I-5357, para 35.

114 Joined cases C-6/90 and C-9/90 Francovich [1991] ECR I-5357, para 36.

115 Joined cases C-46/93 and C-48/93 Brasserie du Pêcheur [1996] ECR I-1029, para 39. R. Nazzini, 'Potency and Act of the Principle of Effectiveness: The Development of Competition Law Remedies and Procedures in Community Law', in C. Barnard and O. Odudu (eds), The Outer Limits of European Union Law (Oxford and Portland, Oregon: Hart Publishing, 2009), 401-435, 415-417, who distinguishes full effectiveness as the legal basis from the effective protection of individual rights also mentioned by the Court.

116 But see G. Conway, The Limits of Legal Reasoning and the European Court of Justice (Cambridge: Cambridge Univ. Press, 2012), 30, who does not see an explicit Treaty basis for state liability in these cases.

117 See, among others, C. Tomuschat, 'Das Francovich-Urteil des EuGH: Ein Lehrstück zum Europarecht', in O. Due, M. Lutter, and J. Schwarze (eds), Festschrift für Ulrich Everling, Vol. II (Baden-Baden: Nomos, 1995), 1585-1609.

This is an open access version of the publication distributed under the terms of the Creative Commons Attribution-NonCommercial-NoDerivs licence (http://creativecommons.org/licenses/by-nc-nd/3.0/), which permits non-commercial reproduction and distribution of the work, in any medium, provided the original work is not altered or transformed in any way, and that the work is properly cited. For commercial re-use, please contact academic.permissions@oup.com 
based on the argument of effectiveness, but also to the same degree on loyalty, might have been a move to dispel these doubts as to the legitimacy of the finding in Francovich. ${ }^{118}$

However, there is another possible perspective on Francovich and state liability, which makes the connection to loyalty much more evident. In the paragraph from Francovich quoted earlier, the Court also stated that among the Member State obligations the fulfilment of which must be ensured by virtue of ex Article $10 \mathrm{EC}$ 'is the obligation to nullify the unlawful consequences of a breach of Community law'. ${ }^{119}$ As an authority for this, the Court referred to the Humblet case. In the judgment that dates from 1960, Article 86 of the (now expired) European Coal and Steel Community (ECSC) Treaty was central for the Court holding the following:

In fact if the Court rules in a judgment that a legislative or administrative measure adopted by the authorities of a Member State is contrary to Community law, that Member State is obliged, by virtue of Article 86 of the ECSC Treaty, to rescind the measure in question and to make reparation for any unlawful consequences which may have ensued. ${ }^{120}$

Thus, the loyalty clause in the ECSC Treaty formed the basis for a specific obligation of state liability for breaches of the ECSC Treaty, long before the Court transferred this principle to the EU. We can therefore already see in Humblet that loyalty may carry the principle of state liability, though in a different contractual context. ${ }^{121}$ With this link the Court made clear that it considers the part of (now) Article 4 (3) TEU on the obligations of the Member States in connection with the 'fulfilment of the obligations arising out of the Treaties' a valid rationale on which to base state liability.

\section{The Way Loyalty Has Been Used by the Court in the Foundational Case Law}

In the political science and international relations literature, several approaches have been proffered to analyse the forces driving European integration. ${ }^{122}$ In the following, I will adopt the approach advanced by the institutionalism school in international relations. ${ }^{123}$ I will thus focus on the Union institutions, important actors, and the different interests they pursue in the EU arena. This examination, however, will be limited to the issue of interest for this study, which is whether we can detect any patterns concerning the invocation of loyalty in the foundational case law of the Court.

118 We have seen that with supremacy the Court has rather done the opposite and has proceeded from an elaborate reasoning in Case 6/64 Costa v ENEL [1964] ECR 585 to presenting supremacy as requiring no justification in later judgments.

119 Joined cases C-6/90 and C-9/90 Francovich [1991] ECR I-5357, para 36.

120 Case 6/60 Humblet [1960] ECR 559, 569.

121 See however the view by A. Barav, 'Omnipotent Courts', in D. Curtin and T. Heukels (eds), Essays in Honour of Henry G. Schermers (Dordrecht: Martinus Nijhoff, 1994), 265-302, 287, that the reference to Humblet in Francovich in this context was not wholly warranted.

122 See the overview at M. Poiares Maduro, 'Interpreting European Law: Judicial Adjudication in a Context of Constitutional Pluralism', European Journal of Legal Studies, (2007), 1-21, 12.

123 For an institutionalist analysis of the preferences of the Commission in several policy fields, see M. Pollack, 'The Engines of Integration? Supranational Autonomy and Influence in the European Union', in W. Sandholtz and A. Stone Sweet, European Integration and Supranational Governance (Oxford: Oxford Univ. Press, 1998), 217-249, 249, arguing, among other things, that the Commission and the Court of Justice share a preference for deeper integration, but that the Court defends the institutional balance against a too strong pull of the Commission, such as to gain negotiation powers in the external trade policy.

This is an open access version of the publication distributed under the terms of the Creative Commons Attribution-NonCommercial-NoDerivs licence (http://creativecommons.org/licenses/by-nc-nd/3.0/), which permits non-commercial reproduction and distribution of the work, in any medium, provided the original work is not altered or transformed in any way, and that the work is properly cited. For commercial re-use, please contact academic.permissions@oup.com 
That there is a strategy behind the interaction between the Commission and the Court is demonstrated by the fact that the Commission prefers to bring cases before the Court, which have a greater chance of being complied with by the Member States even when they are of lesser importance. ${ }^{124}$ Moreover, the Court itself can influence the role of loyalty and thus shape its own judicial agenda by reformulating questions submitted by national courts in preliminary ruling proceedings. ${ }^{125}$ However, there seems to have been no agenda pursued by the Court in preliminary rulings as regards the role of loyalty. Neither have the questions submitted by the national courts in the relevant cases contained a reference to ex Articles 5 or $10 \mathrm{EC}$, nor has the Court redrafted the requests to this end. In Costa, the referring national court raised a number of Treaty articles that had allegedly been infringed by the Italian law at issue. ${ }^{126}$ Similarly, many years later in von Colson, the referring German labour court presented the Court with a considerable number of questions, yet none of those mentioned ex Article $5 \mathrm{EC}$, or, for that matter, a duty of consistent interpretation of national law. ${ }^{127}$ Also in Pupino, again many years later, the referring court did not raise any argument as to the application of loyalty in the third pillar, which was to become the central justification for the Court to apply indirect effect to framework decisions. ${ }^{128}$ Not only did loyalty not appear in any of the questions presented by the referring courts in the cases under scrutiny, in addition, loyalty was not even mentioned once in any of these cases as an argument in support of or against the respective finding of the Court. This means that neither the parties involved, nor the Member States making submissions during the proceedings, nor the Advocate Generals in their opinions had relied on ex Articles 5 and 10 EC, respectively.

In most of the pertinent cases, this can be explained by the fact that the entire debate preceding the findings of the Court had had an entirely different direction. Thus, in Costa, the debate during the proceedings had centred on the interpretation of various articles of the Treaty and whether they were 'self-executing', in the language of public international law that had still been commonplace at that time. While AG Lagrange had discussed the issue of the relationship between Union law and a newly enacted national law in terms of a conflict between 'opposing legal rules... which both apply to the domestic system', ${ }^{129}$ he had failed to suggest a Treaty based solution to this conflict. Instead, he had rather seemed to plead to the Italian Constitutional Court simply to accept the supremacy of Union law without any specific legal basis. Neither AG Lagrange nor the Member States, therefore, had argued based on loyalty. Hence, the groundbreaking solution the Court came up with had not been expected by any of the actors involved.

In ERTA, the Commission and the Council had both focused on ex Articles 75 EEC and 308 EEC, arguing whether the first provision alone or only in combination with the latter rule could have conferred exclusive competence to the Union in this case. ${ }^{130}$ It was also by relying on ex Article 308 EEC that the Commission had argued in terms of the avoidance of a conflict between the pertinent Regulation 543/69 and the ERTA agreement entered into by some Member States. ${ }^{131}$ AG Dutheillet de Lamothe equally had

124 Poiares Maduro, 'Interpreting European Law', 10. See also Stein, 'Lawyers', 24, on the close alliance between the Commission and the Court in the early constitutional phase.

125 cf. Poiares Maduro, 'Interpreting European Law', 19.

126 Case 6/64 Costa v ENEL [1964] ECR 585.

127 See Case 14/83 von Colson [1984] ECR 1891, para 6.

128 See Case C-105/03 Criminal Proceedings Against Maria Pupino [2005] ECR I-5285, para 8.

129 AG Lagrange in Case 6/64 Costa v ENEL [1964] ECR 585, 602.

130 Case 22/70 Commission v Council (ERTA) [1971] ECR 263, 267-271.

131 Case 22/70 ERTA [1971] ECR 263, 271-272.

This is an open access version of the publication distributed under the terms of the Creative Commons Attribution-NonCommercial-NoDerivs licence (http://creativecommons.org/licenses/by-nc-nd/3.0/), which permits non-commercial reproduction and distribution of the work, in any medium, provided the original work is not altered or transformed in any way, and that the work is properly cited. For commercial re-use, please contact academic.permissions@oup.com 
not brought up ex Article 5 EEC and instead discussed the concept of implied powers, which she recommended the Court not to adopt. ${ }^{132}$ As we have seen, in contrast, the Court relied on loyalty and Treaty objectives to rationalize the transfer of the exclusive right to exercise competence to the Union because of the passing of common rules.

In von Colson, the main discussion was on the interpretation of the Equal Treatment Directive 76/207/EEC, ${ }^{133}$ and the Member States' autonomy to impose sanctions for its violation. The Commission had relied heavily on the principle of effectiveness to argue that the legal consequences of a breach of the principle of equal treatment in relation to the access to employment must not be 'derisory'. ${ }^{134}$ AG Rozes, in her opinion in von Colson, had quoted ex Article $10 \mathrm{EC}$, but only in the context of the requirements for the effective implementation of the Directive. ${ }^{135}$ She had called on the national court to use its judicial discretion to impose a punishment appropriate to the character and the objective of the provisions of Community law the observance of which the penalty is intended to safeguard'. ${ }^{136}$ Nobody, hence, had fully anticipated that the obligation for national authorities to interpret national law in light of directives would be the solution offered by the Court to the lack of horizontal direct effect. ${ }^{137}$

Hence, it appears that the Court invoked loyalty in a manner not foreseeable to the parties concerned in the cases discussed earlier. The absence of loyalty in the deliberations and submissions in these cases stands in stark contrast to its role in the reasoning of the Court. It is especially noteworthy in this context that the Commission apparently was initially reluctant to promote the use of loyalty. ${ }^{138}$ Only in more recent, foundational cases involving loyalty, the situation was already different from the outset. While also with state liability and the decision in Francovich, neither the Commission nor the Member States seemed to have argued with ex Article 10 EC specifically, the parties to the case clearly knew what was on the table. By the time of the judgment in Inter-Environnement Wallonie, discussed in Chapter 4, loyalty was not unknown anymore. ${ }^{139}$ Thus, the Commission endorsed the position of the claimant party in the proceedings before the referring national court, which had based its claim on the primacy of Community law and on ex Article 5 EC. ${ }^{140}$

132 AG Dutheillet de Lamothe in Case 22/70 ERTA [1971] ECR 284-296, especially at 291-293.

133 Council Directive (EEC) 76/207 on the implementation of the principle of equal treatment for men and women as regards access to employment, vocational training and promotion, and working conditions [1976] OJ L39/40.

134 Case 14/83 von Colson [1984] ECR 1891, 1900.

135 Opinion of AG Rozes in Case 14/83 von Colson [1984] ECR 1891, 1911.

136 AG Rozes in Case 14/83 von Colson [1984] ECR 1891, 1919, herself quoting Case 8/77 Sagulo [1977] ECR 1495.

137 Contrast this with Case C-105/03 Criminal Proceedings Against Maria Pupino [2005] ECR I-5285, where the decision of the Court to prescribe the obligation of consistent interpretation also with regard to framework decisions in the former third pillar came as no surprise to the parties. The Commission had argued in favour, whereas Italy and the UK were among the Member States opposing this result. See the opinion of AG Kokott in Case C-105/03 Criminal Proceedings Against Maria Pupino [2005] ECR I-5285, paras 19-22.

138 See also Case 9/70 Grad [1970] ECR 825, where both the Commission and the German Government submitted that ex Art. 5 EEC was too general and too imprecise. See also Temple Lang, 'The Development by the Court of Justice of the Duties of Cooperation', 1484, noting that the Commission did not at first see the full potential of ex Art. 10 EC.

139 Case C-129/96 Inter-Environnement Wallonie [1997] ECR 7411.

140 Case C-129/96 Inter-Environnement Wallonie [1997] ECR 7411, paras 36-37. Conversely, Belgium and France considered that until the period prescribed for transposition of a directive has expired, the Member States would remain free to adopt national rules contradicting a directive. The UK and the Netherlands had a more accommodating view, but were still opposed to introducing a new duty based on loyalty. See paras 38-39.

This is an open access version of the publication distributed under the terms of the Creative Commons Attribution-NonCommercial-NoDerivs licence (http://creativecommons.org/licenses/by-nc-nd/3.0/), which permits non-commercial reproduction and distribution of the work, in any medium, provided the original work is not altered or transformed in any way, and that the work is properly cited. For commercial re-use, please contact academic.permissions@oup.com 


\section{Conclusion}

Weiler has noted that the official records show that all parties were fully aware of the “ "new legal order" teleology as part of [the Court's] legal reasoning process', and that this argument may have rendered the Court's decisions predictable and consistent. ${ }^{141}$ I would instead argue that, at least with the cases examined earlier, the Court's reasoning was only predictable insofar as the Member States could no longer expect that the Court would apply the logic of public international law to issues of Union law. However, it seems difficult to uphold the claim that the Court's reasoning was foreseeable in view of the fact that, as mentioned, the discussion before judgments such as ERTA and von Colson had reflected neither the direction nor the actual magnitude of the finding of the Court in these cases. Whether the case law appeared consistent at the time when the pertinent judgments were handed down might be difficult to assess from today's perspective. With hindsight, it is certainly possible to find consistency in the repeated decision of the Court to adopt a rationale that resolves issues of conflict to the advantage of the Union legal order and that seeks to ensure the effectiveness of Union law.

Furthermore, in light of the case law discussed earlier, it is hard to understand that the Court's judgments have been attacked for lack of textual support in the Treaty. ${ }^{142}$ It is also noteworthy that those who have countered this criticism referred not to the precursor provisions of Article 4 (3) TEU but to Article 31 (1) of the Vienna Convention on Treaties. ${ }^{143}$ As similar to Union loyalty this provision may be in many respects, as I have explained earlier, it has not been mentioned once by the Court in the cases I have discussed. Loyalty, in contrast, has been a recurring and central basis for these foundational cases.

I would argue that this neglect of loyalty's role has prevented-and continues to prevent - the required discussion on principles and methods that are underpinning Union law to this day. In other words, the incomplete narrative on the constitutionalization has contributed to a persistent ambiguity surrounding central instruments in the argumentative arsenal of the Court. In a kind of self-fulfilling prophecy, it might even have encouraged the maintenance of a rather opaque style of reasoning by the Court. In the Part on Construction, I will return to the methodological issues raised by the juggling by the Court of concepts and principles such as loyalty, effectiveness, and effet utile.

141 J.H.H. Weiler, 'Review of Law and Policy in the European Court of Justice, by. H. Rasmussen', Common Market Law Review, 24 (1987), 555-589, 573.

142 See H. Rasmussen, On Law and Policy in the European Court of Justice: A Comparative Study in Judicial Policymaking (Dordrecht: Martinus Nijhoff, 1986). See also T. Hartley, Constitutional Problems of the EU (Oxford and Portland, Oregon: Hart Publishing, 1999), 41, who, of those cases I have discussed, however only referred to ERTA. On ex Art. 5 EC's role in Francovich, Hartley, Constitutional Problems, 61, had the following to say: 'At most, this vague provision might require Member States to enact legislation to provide for liability; by no stretch of the imagination can it be regarded as directly creating it.'

143 See Weatherill, 'Activism and Restraint', 255, 258.

This is an open access version of the publication distributed under the terms of the Creative Commons Attribution-NonCommercial-NoDerivs licence (http://creativecommons.org/licenses/by-nc-nd/3.0/), which permits non-commercial reproduction and distribution of the work, in any medium, provided the original work is not altered or transformed in any way, and that the work is properly cited. For commercial re-use, please contact academic.permissions@oup.com 


\section{Conclusion of the Introductory Part}

We have seen that we know very little about the origins of loyalty in Union law. It is, however, likely that there was no intention for it to become the constitutionalizing basis for so many important developments of Union law. We have also seen that there are parallels to many other legal principles, such as especially pacta sunt servanda and good faith in international law, and principles of federal fidelity/loyalty existent in some more centralized Member States such as Germany and Austria. The powerful application of loyalty in EU law I have suggested can be explained by a comparably 'soft' delimitation of the respective spheres of the EU and the Member States. Overlapping areas of competence, reliance on Member State enforcement of EU law, and the absence of any provision on conflict in the Treaties made Article 4 (3) TEU the logical choice for the Court to rationalize its constitutionalizing case law. There is, however, no indication that this trajectory of loyalty could have been foreseen, or that it followed any agenda by the actors involved.

In its role as principle of federal fidelity, besides its function as core provision of constitutional loyalty, Union loyalty has a close relation to the principle of solidarity. While sharing a horizontal dimension with solidarity, however, loyalty primarily addresses the vertical axis between the Member States and the Union. The specifications of Article 4 (3) TEU throughout the Treaty illustrate its various manifestations as duties of coordination, for intervention in national law, and for conflict resolution, which all will be expounded in the following parts of this book.

While loyalty is legally enforceable in contrast to solidarity, and may even apply to areas of reserved competence of the Member States, it does not apply to the political decision-making in the Council. It does, however, bind the Union institutions in both procedural and legal basis matters. I have also argued that loyalty is not counterbalanced by Article 4 (2) TEU on the protection of national identities. Even though this is now placed in close context to loyalty, there is no indication that this could influence its future scope or effect. 


\section{PART II \\ THE COHESION OF EUROPEAN UNION LAW}

\section{Introduction}

In an article published in the Harvard International Law Review in 2006, Slaughter and Burke-White proclaim that the future of international law would and should lie in an international system capable of responding to cross-border challenges by interfering with the sovereignty of nation states by forcing them to pursue global objectives. ${ }^{1}$ They quote Article 2 (7) of the UN Charter, stating that international law and the institutions generating and monitoring it shall not 'intervene in matters which are essentially within the domestic jurisdiction of any state'. ${ }^{2}$ Compared to this view, they endorse 'the European way of law', having the right and sometimes the obligation 'to intervene in and to influence what were previously the exclusive jurisdiction and political processes of national governments'. ${ }^{3}$

This chapter is about precisely this interference with Member State sovereignty, the intervention in matters of domestic jurisdiction and jurisprudence, about requiring Member States to act in pursuance of the Union interest; ${ }^{4}$ and it is about the role loyalty plays in all of this. ${ }^{5}$ Whereas Slaughter and Burke-White cast a wider net by referring to European soft power in enlargement on the one hand and to the implementation of Union directives on the other, we are more concerned with the latter. ${ }^{6}$ I will thus look at the rules governing the relationship between national law and EU law for ensuring the cohesion of the national and the Union legal systems. ${ }^{7}$ There are a number of different concepts or principles in Union law related to loyalty, not all of which exist in the Treaty and, partly, they do not even feature in the case law of the Court. The most obvious example of this is the principle of supremacy, which I have shown is partly founded on

1 A.-M. Slaughter and W. Burke-White, 'The Future of International Law is Domestic (or, The European Way of Law)', Harvard International Law Review, 47:2 (2006), 327-352, 328.

2 Slaughter and Burke-White, 'The Future of International Law', 328.

3 Slaughter and Burke-White, 'The Future of International Law', 352.

4 See the reference to 'supranational judicial intervention in national procedural systems' used by P. van Cleynenbreugel, 'Judge-Made Standards of National Procedure in the Post-Lisbon Constitutional Framework', European Law Review, 37:1 (2012), 90-100, 91.

5 See Case 30-70 Otto Scheer [1970] ECR 1197, para 8, for an example of an intervention by the Member States in fulfilment of 'the general obligation expressed in Article 5 of the Treaty'.

6 While it is not my intention to assess the uniqueness of this process, or whether it should be a model for international law, we should take note of the outside perception of the force of Union law.

7 See, for the use of the concept of cohesion in a similar vein, M. Zuleeg, 'A Community of Law: Legal Cohesion in the European Union', Fordham International Law Journal, 20:3 (1996), 623-637.

This is an open access version of the publication distributed under the terms of the Creative Commons Attribution-NonCommercial-NoDerivs licence (http://creativecommons.org/licenses/by-nc-nd/3.0/), which permits non-commercial reproduction and distribution of the work, in any medium, provided the original work is not altered or transformed in any way, and that the work is properly cited. For commercial re-use, please contact academic.permissions@oup.com 
loyalty, and has only found its way into the Treaty through a declaration annexed to the Lisbon Treaty. ${ }^{8}$

I will show that exploring the nature and the limits of supremacy for explaining certain effects of Union secondary law and preparatory acts by the Council is important for fully understanding the operation of the ERTA principle, the ILO principle, and the effects of Union directives in national law. The Union interest is another distinct legal concept derived from loyalty, and I will discuss its merits in providing a rationale for several effects that cannot be explained with supremacy. Pre-emption is yet another concept which is equally not provided in the Treaty and which does not exist in the case law of the Court in the form it is presented in the literature. ${ }^{9}$ I will analyse the merits of pre-emption as a legal principle that is often also deemed to have its basis ultimately in Article 4 (3) TEU. ${ }^{10}$ Moreover, Temple Lang has argued that loyalty provides the basis for the principles of equivalence and effectiveness in restraining national procedural autonomy. ${ }^{11}$ Indeed, as I will also discuss in this Part, the Court has blurred the borders between effectiveness and other concepts established to effectuate Union law within the national legal orders, such as direct effect, consistent interpretation, and judicial protection, for which loyalty plays a crucial role as noted earlier.

This Part therefore analyses and demarcates several elemental legal concepts that are closely connected to loyalty, and all of which rationalize some degree of prerogative of the Union vis-à-vis the Member States. ${ }^{12}$ If we want to discuss the legal effect of Union law within the legal orders of the Member States, however, we have to start by doing two things. Firstly, we must discuss the nature of the Union legal system. In other words, if we want to understand the effect of different instruments of Union law within national law, it is necessary initially to understand whether Union law itself constitutes a unitary legal structure, built upon the same legal principles and having the same legal force in all its areas of application. ${ }^{13}$ Only by performing this exercise, can we assess the relationship between different parts of Union law and national law. Secondly and separately, we must briefly revisit the discussion on the relationship between EU law and national law, in other words, we have to deal with the monism and dualism debate.

8 In case law, which is therefore still the basis for applying supremacy, the Court has for a long time not referred to supremacy or primacy, but has used the term preclusion instead. See E.D. Cross, 'Pre-emption of Member State Law in the European Economic Community: A Framework for Analysis', Common Market Law Review, (1992), 447-472, 454. But see Case 14/68 Walt Wilhelm [1969] ECR 1, para 4, and more recent cases such as Case C-314/08 Filipiak [2009] ECR I-11049, para 82.

9 Entering the term in EUR-Lex only produces references to pre-emption in the context of shareholder or contractual rights.

10 M. Cremona, 'External Relations and External Competence of the European Union', in P.P. Craig and G. de Búrca, The Evolution of EU Law, 2nd edn. (Oxford: Oxford Univ. Press, 2011), 217-268, 253.

11 J. Temple Lang, 'Developments, Issues and New Remedies: The Duties of National Authorities and Courts under Article 10 of the EC Treaty', Fordham International Law Journal, 27 (2004), 1904-1939, 1908.

12 The present Chapter will deal with what has been termed the application relation between these two systems, while in the Part on Construction, I will discuss the relationship between Union law and national law in terms of hierarchy and heterarchy, i.e. in terms of what has been called the validity relation. See, for this distinction, D. Curtin and I. Dekker, 'The Constitutional Structure of the European Union: Some Reflections on Vertical Unity-in-Diversity', in P. Beaumont, S. Lyons, and N. Walker (eds), Convergence and Divergence in European Public Law (Oxford and Portland, Oregon: Hart Publishing, 2002), 59-78, 61-62.

13 Unity will thus be confined to this meaning of a system governed by the same fundamental rules derived from loyalty. See, for a discussion and a critique of the concept of unity, C. Herrmann, 'Much Ado about Pluto?', in M. Cremona and B. de Witte (eds), EU Foreign Relations Law: Constitutional Fundamentals (Oxford and Portland, Oregon: Hart Publishing, 2008), 19, 33-36.

This is an open access version of the publication distributed under the terms of the Creative Commons Attribution-NonCommercial-NoDerivs licence (http://creativecommons.org/licenses/by-nc-nd/3.0/), which permits non-commercial reproduction and distribution of the work, in any medium, provided the original work is not altered or transformed in any way, and that the work is properly cited. For commercial re-use, please contact academic.permissions@oup.com 


\section{4 \\ A Primer on the Structure of Union Law}

\section{Introduction}

Two issues regarding the legal structure of the European Union concern us for the present purpose. Firstly, there is the question of the relation between Union law and national law, or more specifically the effects of the former within the latter. It will be shown that monism and dualism remain the ubiquitous legal theories for conceptualizing this relation. These theories also underpin more recent and seemingly distinct concepts, such as the unitary nature of the legal order encompassing Union law and national law. ${ }^{14}$ This is not the place to engage in a monism/dualism debate with regard to the European Union legal order in general terms. ${ }^{15}$ However, we will see that a debate in terms of monism and dualism has only limited merit without precisely qualifying what kind of monism one is talking about. Moreover, I will argue in the following that it does not matter whether we perceive the relationship between national law and Union law as monistic or dualistic when we look at the example of the effects of Union directives in national law. Directives have been taken up in the literature to illustrate that these instruments partake in a legal order separate from the Union legal order. A critical discussion of this position provides an apposite backdrop for the discussion of the various effects of directives and other Union law measures in national law.

Secondly, the following will deal with an altogether different issue, which has nonetheless also been discussed in the literature under the heading unity of the legal order. ${ }^{16}$ In this other context, unity refers to, if we want, the inner unity of Union law, viz. the question whether the whole of Union law is governed by the same legal principles and whether these legal principles have the same effect in especially the Common Foreign and Security Policy (CFSP) and the areas of Union law that are not part of the CFSP. In the present context, the prevalence of such discussion is readily visible. As mentioned, loyalty has been 'moved' from what is now the TFEU to the TEU. What does this mean for all the legal effects that have been based on loyalty and that we have already discussed in Chapter 3? Does loyalty also apply in the CFSP, or more precisely as I will show this question must be framed, does the same principle of loyalty that has been invoked by the Court in its foundational case law, among other things, apply with equal force in the CFSP? Recall that solidarity has been identified as the dominant legal principle governing the relations between the Member States in the area of the CFSP. In the following, I will propose to distinguish between CFSP loyalty and non-CFSP loyalty.

14 J. Dickson, 'Directives in EU Legal Systems: Whose Norms Are They Anyway?', European Law Journal, 17:2 (2011), 190-212, 195-196.

15 For this, see among others, S. Griller, 'Völkerrecht und Landesrecht: unter Berücksichtigung des Europarechts', in R. Walter, C. Jabloner, and K. Zeleny (eds), Hans Kelsen und das Völkerrecht (Vienna: Manz, 2004), 83-120.

16 A. von Bogdandy, 'The Legal Case for Unity: The European Union as a Single Organization with a Single Legal System’, Common Market Law Review, (1999), 887, 889.

This is an open access version of the publication distributed under the terms of the Creative Commons Attribution-NonCommercial-NoDerivs licence (http://creativecommons.org/licenses/by-nc-nd/3.0/), which permits non-commercial reproduction and distribution of the work, in any medium, provided the original work is not altered or transformed in any way, and that the work is properly cited. For commercial re-use, please contact academic.permissions@oup.com 


\section{The Unity of National Law and Union Law}

\subsection{Monism and Dualism}

The terms monism and dualism are often used, but rarely is it explained what exactly is meant by them. In general, dualism refers to the idea that domestic law and international law are independent legal orders, and invariably portrays the international (European) legal order as the supreme one. ${ }^{17}$ In contrast, monism refers to the belief that domestic and international law are both components of the same legal system, and that conflicts between norms that originate from different systems cannot be resolved on dualist grounds. ${ }^{18}$ Consequently, monism can accord primacy either to domestic law or to international law within a distinct legal system. ${ }^{19}$ A purely monist theory would thus claim that all international norms take precedence over all domestic legal norms. ${ }^{20}$

Somek has argued that dualism is alive in the European Union because national constitutions contain provisions on the relevance of international law, and because the conflicting claims to supremacy in the EU context have taught us that there is no unifying perspective. ${ }^{21}$ Indeed, most national courts take a detour to national law in order to legitimize EU law supremacy. ${ }^{22}$ Put in other words, national supreme courts tend to interpret Union law from the perspective of their national constitutional law, thus creating a parallel version of Union law. ${ }^{23}$ This is expressed in the Lisbon judgment of the German Constitutional Court (BVerfG), where it upholds the Solange I tenet that supremacy is based on empowerment by the German constitution. ${ }^{24}$ The BVerfG thus sees the German law of accession as a bridge between the Union legal order and national

17 See J.G. Starke, 'Monism and Dualism in the Theory of International Law', British Yearbook of International Law, 17 (1936), 74-76.

18 A. Somek, 'Kelsen Lives', European Journal of International Law, 18:3 (2007), 409-451, 421 and 432-424: 'It can be the case, according to dualist premises, that while public international law demands $\mathrm{x}$, the domestic legal order commands non-x. Joint obedience is impossible. Two different systems with different basic norms give rise to an external conflict of norms.'

19 Starke, 'Monism and Dualism', 74-76; S. Griller, Die Übertragung von Hoheitsrechten auf zwischenstaatliche Einrichtungen (Vienna, New York: Springer, 1989), 345.

20 While Kelsen assumed the existence of one Grundnorm, Hart distinguished validation proper from validating purport. See H.L.A. Hart, 'Kelsen's Doctrine of the Unity of Law', in S.L. Paulson and B. Litschewski Paulson (eds), Normativity and Norms: Critical Perspectives on Kelsenian Themes (Oxford: Oxford Univ. Press, 1998), 560-563. The former exists when a norm becomes adopted with the intent of creating it based on another one, such as when a national parliament adopts a law pursuant to constitutional procedures. The latter exists when a norm is declared to be the relevant legal standard for certain transactions by the conflict of law statutes of another state, rendering rules that fit a certain description valid regardless of whether they were generated in order to become parts of the legal system containing the description. See the discussion at Somek, 'Kelsen Lives', 426-427.

${ }^{21}$ Somek, 'Kelsen Lives', 421.

22 F.C. Mayer, 'Art. 19 EUV', in E. Grabitz, M. Hilf, and M. Nettesheim (eds), Das Recht der Europäischen Union (Munich: Beck, 2011), para 96; cf. C. Grabenwarter, 'National Constitutional Law Relating to the European Union', in A. von Bogdandy and J. Bast (eds), Principles of European Constitutional Law (Munich: Beck, 2010), 83-129, 90-91. For a general overview and more detailed presentation of this argument see M. Poiares Maduro, 'Contrapunctual Law: Europe's Constitutional Pluralism in Action', in N. Walker (ed.), Sovereignty in Transition (Oxford and Portland, Oregon: Hart Publishing, 2003), 501. See also D. Chalmers, 'Judicial Preferences and the Community Legal Order', The Modern Law Review, 60 (1997), 164-199; M. Kumm, 'The Jurisprudence of Constitutional Conflict: Constitutional Supremacy in Europe before and after the Constitutional Treaty', European Law Journal, 11/3 (2005), 262-307, and the contributions in A.-M. Slaughter, A. Stone Sweet and J.H.H. Weiler (eds), The European Courts and National Courts: Doctrine and Jurisprudence (Oxford and Portland, Oregon: Hart Publishing, 1998).

23 See Mayer, 'Art. 19 EUV', para 98.

24 BVerfGE 123, 267, 397.

This is an open access version of the publication distributed under the terms of the Creative Commons Attribution-NonCommercial-NoDerivs licence (http://creativecommons.org/licenses/by-nc-nd/3.0/), which permits non-commercial reproduction and distribution of the work, in any medium, provided the original work is not altered or transformed in any way, and that the work is properly cited. For commercial re-use, please contact academic.permissions@oup.com 
law, mandating the former's application in Germany. Thus, when the BVerfG assesses the Lisbon Treaty, it does so, among others, on grounds of a claim that it transfers sovereign powers to the Union and thus undermines the right of German citizens to vote in national parliamentary elections guaranteed by Article 38 Grundgesetz (Basic Law). ${ }^{25}$ In the same vein, in France the supremacy of Union law is based on Article 88 of the French Constitution. ${ }^{26}$

An argument made by von Bogdandy might be seen as an implicit rebuttal of Somek's position. Von Bogdandy has discussed equal liberty, human rights, democracy, and the rule of law in terms of whether they constitute foundational principles, applying to the Union and to the Member States alike. ${ }^{27}$ This has been directly countered by the claim that all these 'founding principles' merely apply within the scope of application of EU law, do therefore not structure the legal order as a whole, and are consequently no proof of monism with regard to EU law. ${ }^{28}$ I would submit that loyalty, in this sense, would have been a much more interesting case to discuss in connection with the argument on a single set of constitutional principles for the Union and the Member States. We have seen that loyalty applies both to the Member States and to the Union institutions and that it even applies to the Member States when they act within their own spheres of competence. It would thus appear that loyalty is a constitutional principle applying to the Union and to the Member States alike, which would support the claim that Union law and national law cannot be strictly separated legal orders.

I would argue that another weakness of the mentioned models, besides their frequently imprecise use, lies in describing the nature of the relationship between the national judiciary and the ECJ, or the Union constitution and the national constitutions in general. Monism and dualism fail to provide a framework for an important implication of the nature of European Union law, viz. the simultaneous application of two legal regimes of different provenance in the Member States of the EU. This intertwining of the constitutions on the national level is better captured by the concept of a 'dual constitution' existing in the Member States. ${ }^{29}$ The German Constitutional Court, in a similar vein, has spoken of the 'functional intertwinement of the European and Member State judiciaries' as well as a 'partial functional incorporation of the ECJ into the domestic court system'. ${ }^{30}$ The focus of this concept is the necessity of the Member States to cope with the multifarious ways European law permeates the national legal order.

25 See D. Thym, 'In the Name of Sovereign Statehood: A Critical Introduction to the Lisbon Judgment of the German Constitutional Court', Common Market Law Review, (2009), 1795-1822, 1796.

26 See Grabenwarter, 'National Constitutional Law', 91.

27 A. von Bogdandy, 'Founding Principles', in A. von Bogdandy and J. Bast (eds), Principles of European Constitutional Law (Oxford and Portland, Oregon: Hart Publishing, Munich: Beck, 2010), 11; and A. von Bogdandy, 'Founding Principles of EU Law: A Theoretical and Doctrinal Sketch', European Law Journal, 16:2 (2010), 95.

28 See P. Eleftheriadis, 'The Structure of European Union Law', Cambridge Yearbook of European Legal Studies, 12 (2010), 121, 148, based on a definition of monism as being dependent on whether 'the general organisational principles that define and organise the way in which EU law is applied and enforced in concrete circumstances' are 'the principles of its own legal order...' (at 10), and basing his argument on the not fully convincing claim that von Bogdandy had meant to argue for the EU as a social and a new legal order with a constitutional order replacing the existing constitutional orders of the Member States (at 33).

29 T. Öhlinger, 'Die Verfassung im Schmelztiegel der europäischen Integration: Österreichs neue Doppelverfassung', in T. Öhlinger (ed.), Verfassungsfragen einer Mitgliedschaft zur Europäischen Union (Vienna, New York: Springer, 1999), 165 passim.

30 BVerfG, Solange II, BVerfG 73, 339, 376 passim.

This is an open access version of the publication distributed under the terms of the Creative Commons Attribution-NonCommercial-NoDerivs licence (http://creativecommons.org/licenses/by-nc-nd/3.0/), which permits non-commercial reproduction and distribution of the work, in any medium, provided the original work is not altered or transformed in any way, and that the work is properly cited. For commercial re-use, please contact academic.permissions@oup.com 
While I will discuss other theories to conceptualize the relation between the Union and the national constitutions in Chapter 11, this functional view is the vanguard of the following analysis of the effects of directives. It will be shown firstly that while the monism/dualism dichotomy may be ill-suited to describing the actual relation between the legal orders of the most important Member States and EU law, using these terms is still preferable to concepts that only seem distinct, in particular when normative conclusions are derived from such models. ${ }^{31}$

\subsection{The Test Case: The Effects of Directives in National Law}

Article 288 TFEU prescribes that a directive 'shall be binding, as to the result to be achieved, upon each Member State to which it is addressed, but shall leave to the national authorities the choice of form and methods'. In order to enable the Member States to make this choice, directives normally provide for an implementation period of two years starting from their date of publication in the Official Journal.

Dickson has argued for a '27 plus 1 or distinct but interacting legal systems model' based on the ability of a national legal system to determine the validity of its norms and their relation to norms from other normative systems. ${ }^{32}$ Dickson seems to see a normative value in the mentioned model, which should form a first and necessary step towards evaluating and assessing 'intra-, trans-, supra-, and inter-national governance arrangements'. ${ }^{33}$ However, she fails to explain what precisely this should entail for our understanding of directives and their effect on national law. She has instead argued that because the BVerfG and other national constitutional courts have reserved to themselves control over the validity of Union law in their territory, this would show that directives emanate from a distinct legal order and thus cannot become part of the national legal system from the date of entry into force. ${ }^{34}$ Direct effect of directives as evidence of their direct applicability is countered with the argument that 'certain conditions must be met and justificatory hurdles surmounted in order for them to penetrate into national legal systems, making them binding at certain times and under certain conditions in national legal systems, when certain triggers operate'. ${ }^{35}$

There are several problems with this reasoning. Firstly, it is disingenuous to use the concept mentioned earlier while at the same time professing in a footnote not to adopt a monist/dualist approach.

Secondly, the fact that the BVerfG or other constitutional courts qualify the 'opening' of the German legal order to EU law norms by controls of ultra vires and constitutional identity does not impinge on the effects of directives. ${ }^{36}$ Put in other words, whether

31 T. Hartley, 'National Law, International Law and EU Law: How Do They Relate?', in P. Capps, M. Evans and S. Konstadinidis (eds), Asserting Jurisdiction: International and European Legal Perspectives (Oxford and Portland, Oregon: Hart Publishing, 2003), 65.

32 See, Dickson, 'Directives in EU Legal Systems', 208 and 211. Dickson uses the expression 'calling the shots'.

33 Dickson, 'Directives in EU Legal Systems', 211.

34 Dickson, 'Directives in EU Legal Systems', 208-210. The last conclusion is not made explicitly by Dickson, but must follow from her initial rejection of the corresponding claim by S. Prechal, Directives in EC Law, (Oxford: Oxford Univ. Press, 2005) 92-93, referenced at Dickson, 'Directives in EU Legal Systems', 196. Moreover, 'when directives operate as they are intended to, they appear plausibly to be interpreted as norms of a distinct EU legal system, designed to guide the future development of, but not themselves qua directives become part of, those Member States' legal systems with which they interact'. See Dickson, 'Directives in EU Legal Systems', 195-196.

35 Dickson, 'Directives in EU Legal Systems', 200 and 203.

36 See Chapter 11.

This is an open access version of the publication distributed under the terms of the Creative Commons Attribution-NonCommercial-NoDerivs licence (http://creativecommons.org/licenses/by-nc-nd/3.0/), which permits non-commercial reproduction and distribution of the work, in any medium, provided the original work is not altered or transformed in any way, and that the work is properly cited. For commercial re-use, please contact academic.permissions@oup.com 
a Member State adopts a dualist approach is not relevant unless this reflects on direct effect, indirect effect, or any other effect of Union directives. Thus, in the German legal order, directives are applied not based on a (hypothetical) permission, but because the German legal order has opened itself to EU law, including to the case law of the ECJ. Put in yet more 'dualist' language, this means that there is no specific transformation of each and every Union law act in order for it to acquire validity in German law. Instead, there is an anticipated general transformation of Union law, subject to a reserved and limited control for constitutionality. ${ }^{37}$ I would thus argue that the effects that directives take in the legal order of the Member States are determined by Union law, including the case law of the Court of Justice. This in turn means that directives, once they have entered into force, are a legal fact to be duly considered within the national legal orders. To consider whether directives have direct effect after the expiry of the term for implementation because EU law says so or because national law says so, is therefore a non-starter. ${ }^{38}$

Thirdly, Dickson's argument that directives only become a part of the national legal order under further conditions of applicability set up by Union law or by the Member States is seriously weakened by failing to mention the case law on effects of directives in national law before the expiry of the transposition term. ${ }^{39}$ The Inter-Environnement Wallonie case concerned a Belgian NGO that had requested annulment of a law requiring authorization for setting up and running installations intended specifically for the collection, pre-treatment, disposal, or recovery of toxic or dangerous waste. This exception was alleged to infringe the 'Waste Directive' 75/442, among others. While the Directive allowed for exemptions from the general permit requirement, the national rule was claimed not to be in conformity with the conditions for such exemptions set up under the Directive. The Belgian rule had been adopted at a time when the period allowed by the directive for its transposition had not yet expired. On an order for reference by the Belgian Conseil d'État, the Court recalled the binding force of the result prescribed by the Directive and that the duty under ex Article 5 EC to take all appropriate measures, whether general or particular, was binding also on the Member States' courts. ${ }^{40}$ Then the Court stressed that Member States cannot be faulted for not having transposed the directive pre-term, but that they must take the measures necessary to ensure that the result prescribed by the directive is achieved at the end of that period, during the transposition period. ${ }^{41}$ The Court held as follows:

Although the Member States are not obliged to adopt those measures before the end of the period prescribed for transposition, it follows from the second paragraph of Article 5 in conjunction with the third paragraph of Article 189 of the Treaty and from the directive itself that during that period they must refrain from taking any measures liable seriously to compromise the result prescribed. ${ }^{42}$

37 On the distinction between specific and general transformation, see Griller, Übertragung von Hoheitsrechten, 352-359. That a non-qualified debate in a monism/dualism discourse is at best confusing can also be demonstrated by the example of the UK. While the European Communities Act of 1972 may be subject to amendment and the UK's membership in the EU may therefore be easily reversible, there can be no question that in the UK the binding nature of Union law is generally accepted and does not require a 'trigger', whenever a directive or regulation enters into force.

38 If Dickson wanted to cast this into doubt, she would have needed to argue that the Court's case law is ultra vires or otherwise flawed.

39 While herself being rather selective in taking note of the specific effects directives can have in a national legal order, Dickson has critisized Prechal for arguing away the argument of estoppel made by the Court in order to justify direct effect, which in Prechal's opinion is not necessary because directives are directly applicable at any rate.

40 Case C-129/96 Inter-Environnement Wallonie [1997] ECR 7411, para 40.

41 Case C-129/96 Inter-Environnement Wallonie [1997] ECR 7411, paras 43-44.

42 Case C-129/96 Inter-Environnement Wallonie [1997] ECR 7411, para 45.

This is an open access version of the publication distributed under the terms of the Creative Commons Attribution-NonCommercial-NoDerivs licence (http://creativecommons.org/licenses/by-nc-nd/3.0/), which permits non-commercial reproduction and distribution of the work, in any medium, provided the original work is not altered or transformed in any way, and that the work is properly cited. For commercial re-use, please contact academic.permissions@oup.com 
For this duty of abstention, it is immaterial whether the national measure adopted means to transpose the directive concerned. ${ }^{43}$ This means, however, that Directives take effect not from the time their implementation term expires but from the moment of their notification, as has also been explicitly stated in Inter-Environnement Wallonie. ${ }^{44}$ While directives may not be directly applicable as legal norms conferring rights or imposing obligations pre-term, they are part of Union law and therefore part of national law from the time they enter into force.

\subsection{Conclusion}

I would therefore argue that it is irrelevant whether directives take effect pre-term and post-term because they are an integral part of the domestic legal system (monism), or because they are a part of a foreign (EU) legal system and are referred to by the domestic system's constitutional legal order. Whereas monism and dualism may be useful to conceptualize the jurisdictional hurdles mounted by the national constitutional courts of some Member States, the general and anticipated transformation of Union law even in Member States commonly considered as being dualist makes this a moot point with regard to directives. Monism and dualism will re-enter the discussion in this book in Chapter 11, where they will be shown to inform concepts to describe the interaction between the constitutional courts of the Member States with the ECJ in questions of ultra vires and constitutional identities.

\section{The (Inner) Unity of the Union Legal Order}

\subsection{Introduction}

This discussion about whether the EU has a unitary or a separate structure of course predates the Lisbon Treaty. Detractors from the unity thesis could above all be found in Germany, both in commentaries as well as in judgments of the BVerfG. ${ }^{45}$ The most radical pro-unity thesis at these times has been the one advocated by von Bogdandy and Nettesheim, arguing that the EU after the Amsterdam Treaty was one single organization with its own legal order, within which the former EC and the other pillars have been integrated. ${ }^{46} \mathrm{~A}$ more moderate position has been advanced by De Witte's image of the French gothic cathedral, wherein the EC as the central nave alongside the 'somewhat lower and somewhat darker side aisles' of the CFSP and cooperation in justice and home affairs (CJHA) has been allowed to retain a separate legal existence as an organization. ${ }^{47}$

43 Case C-155/04 Mangold [2005] ECR I-9981, para 68; Joined cases C-378/07 to C-380/07 Kiriaki Angelidaki [2009] ECR I-3071, para 206.

44 See Case C-129/96 Inter-Environnement Wallonie [1997] ECR 7411, para 41: 'It follows from that provision that a directive has legal effect with respect to the Member State to which it is addressed from the moment of its notification.' Similarly, Case C-212/04 Adelener [2006] ECR I-6057, para 119: 'It follows that a directive produces legal effects for a Member State to which it is addressed-and, therefore, for all the national authorities - following its publication or from the date of its notification, as the case may be.' See U. Schliesky, 'Die Vorwirkung von gemeinschaftsrechtlichen Richtlinien', Deutsches Verwaltungsblatt, (2003), 631-641, 637. See, for a different perspective, C. Haguenau, L'application effective du droit communautaire en droit interne (Brussels: Bruylant, 1995), 271 passim.

45 cf. Herrmann, 'Much Ado about Pluto?', 22-23.

46 A. von Bogdandy and M. Nettesheim, 'Ex Pluribus Unum: Fusion of the European Communities into the European Union', European Law Journal, 2 (1996), 267.

${ }^{47}$ B. de Witte, 'The Pillar Structure and the Nature of the European Union: Greek Temple or French Gothic Cathedral?', in T. Heukels, N. Blokker, and M. Brus (eds), The European Union after

This is an open access version of the publication distributed under the terms of the Creative Commons Attribution-NonCommercial-NoDerivs licence (http://creativecommons.org/licenses/by-nc-nd/3.0/), which permits non-commercial reproduction and distribution of the work, in any medium, provided the original work is not altered or transformed in any way, and that the work is properly cited. For commercial re-use, please contact academic.permissions@oup.com 
In support of the unity thesis at this time reference was made to the existence of common institutions and global rules of change introduced by the Maastricht Treaty, and the eradication of references to the Member States in provisions on the former second and third pillars, among other indications, introduced by the Amsterdam Treaty. ${ }^{48}$ At that time it was already adumbrated that, had the Court been given the opportunity to decide on the effect of acts under the former second and third pillars, it might well have awarded them supremacy and direct effect. ${ }^{49}$

Pro-unity arguments have also involved legal principles of Union law. Thus, it has been argued that although the EC pillar must be considered relatively independent from national law qua legal validity, it must be considered firmly intertwined 'through the operation of several general legal principles such as those relating to the applicability of EC law in the national legal orders and the principle of loyalty'. ${ }^{50}$ Similarly, von Bogdandy has reasoned that the legal consequence of the single legal order theory was that the legal principles developed under the former first pillar, such as supremacy, loyalty, non-discrimination, and direct effect, could in general be applied also to the other pillars, and to secondary instruments adopted thereunder. ${ }^{51}$ Ross, in 2006, posited that if the duty of loyalty owed by Member States was freely exportable between the EC and EU pillars under the current Treaty arrangements, 'then presumably the cargo of developments that floats on the raft of Art. 10 must come with it'. ${ }^{52}$ In a similar vein, it has been argued that loyalty in the CFSP is the same legal concept as loyalty in the former first pillar, and that even if CFSP loyalty were distinct from non-CFSP loyalty, it would still not prevent or limit the application of Article 4 (3) TEU. ${ }^{53}$

I would argue that such a view all too readily assumes the equal force of some of the duties based on loyalty in the three pillars before Lisbon. It is one thing to argue that loyalty is of 'general application' in EU law; it is another thing to say that 'supranational' loyalty is 'freely exportable' between the pillars and has the same force and the same effect in all former pillars. Put in other words, it is one thing to claim that 'national measures implementing Union acts under former Title V or Title VI of the TEU (Nice version) are subject to scrutiny in the light of ex Article 10 EC, ${ }^{54}$ but another to explain what precisely this entails for the implementation powers of the Member States. That loyalty must play a role also in the CFSP is apparent from the fact alone that there is more explicit mention of loyalty in the CFSP than in any other part of the Treaties, as I will show in the following section. I will start by briefly discussing the situation before the Lisbon Treaty, before coming to the role of loyalty in both the CFSP and in the former third pillar under the Lisbon Treaty.

Amsterdam: A Legal Analysis (The Hague: Kluwer Law International, 1998), 51-68, 58 passim, and 64. Only this, de Witte was right to argue, would explain why the EC continued to conclude international agreements with third states.

48 De Witte, 'The Pillar Structure', 59-64. $\quad 49$ De Witte, 'The Pillar Structure', 65.

50 Curtin and Dekker, 'The Constitutional Structure of the European Union: Some Reflections on Vertical Unity-in-Diversity', in P. Beaumont, S. Lyons, and N. Walker (eds), Convergence and Divergence in European Public Law (Oxford and Portland, Oregon: Hart Publishing, 2002), 59-78, 60.

51 Von Bogdandy, 'The Legal Case for Unity', 887, 889.

52 M. Ross, 'Effectiveness in the European Legal Order(s): Beyond Supremacy to Constitutional Proportionality?', European Law Review, (2006), 474-496, 483.

53 W. Kaufmann-Bühler, 'Art 24 EUV', in E. Grabitz, M. Hilf and M. Nettesheim (eds), Das Recht der Europäische Union, Kommentar, Vol. I (Munich: Beck, 2010), para 38.

54 Von Bogdandy and Nettesheim, 'Ex Pluribus Unum', 283.

This is an open access version of the publication distributed under the terms of the Creative Commons Attribution-NonCommercial-NoDerivs licence (http://creativecommons.org/licenses/by-nc-nd/3.0/), which permits non-commercial reproduction and distribution of the work, in any medium, provided the original work is not altered or transformed in any way, and that the work is properly cited. For commercial re-use, please contact academic.permissions@oup.com 


\section{2 'Intergovernmental' Loyalty Pre-Lisbon}

There have been indications early on that loyalty to some degree would also apply within the former third pillar. It has been argued that a directive on the mutual recognition of decisions on the expulsion of third country nationals represented the application of loyalty in the third pillar. ${ }^{55}$ Indeed, as I have shown earlier, the Court has expressly based mutual recognition within the former first pillar on what is now Article 4 (3) TEU. It thus seems apposite to assume that a similar measure under the former third pillar was founded on the same principle of law.

Another argument $e$ contrario could be based on the express limitations of framework decisions compared to directives. Thus, Curtin and Dekker have noted that the explicit lack of direct effect of framework decisions meant conversely that the decision on their having direct effect or not was taken away from the Member States, unlike in a relationship governed by public international law. ${ }^{56}$ Moreover, it meant that these decisions were in principle directly applicable within the national order, not requiring the transformation characteristic of public international law. ${ }^{57}$ This in turn was held to imply them having indirect effect in national law. ${ }^{58}$

These indirect effects and thus a certain unity of the former first and third pillars were, in principle, confirmed by the Court's decision of 2005 in Pирino. ${ }^{59}$ The Court pointed to the alleged similarity of the effects of the legal instruments under former Title VI of the Treaty. ${ }^{60}$ The Court continued in the following manner:

It would be difficult for the Union to carry out its task effectively if the principle of loyal cooperation, requiring in particular that Member States take all appropriate measures, whether general or particular, to ensure fulfilment of their obligations under European Union law, were not also binding in the area of police and judicial cooperation in criminal matters, which is moreover entirely based on cooperation between the Member States and the institutions, as the Advocate General has rightly pointed out in paragraph 26 of her Opinion. ${ }^{61}$

Thus, even though framework decisions did not have direct effect, they had indirect effect in national law. However, this arguably did not automatically entail this effect being applied by the same standards and limits as under the former first pillar. ${ }^{62}$ It has been argued that the cooperation in former Title IV refers predominantly to cooperation between the (authorities of the) Member States, instead of to the vertical relationship at the core of Article 4 (3) TEU. ${ }^{63}$ Moreover, in Pupino, the Court conspicuously was

55 Council Directive (EC) 2001/40 on the mutual recognition of decisions on the expulsion of third country nationals [2001] OJ L149/34. See Curtin and Dekker, 'The Constitutional Structure of the European Union', 73, who, at 73-75, also point to developments in Union criminal law in support of their argument.

56 Curtin and Dekker, 'The Constitutional Structure of the European Union', 68.

57 Curtin and Dekker, 'The Constitutional Structure of the European Union', 68. See also Herrmann, 'Much Ado about Pluto?', 19, 46.

58 Herrmann, 'Much Ado about Pluto?', 68-69.

59 Case C-105/03 Criminal Proceedings Against Maria Pupino [2005] ECR I-5285.

60 Case C-105/03 Criminal Proceedings Against Maria Pupino [2005] ECR I-5285, para 36.

61 Case C-105/03 Criminal Proceedings Against Maria Pupino [2005] ECR I-5285, para 42. In her opinion referred to by the Court, AG Kokott additionally argued that loyal cooperation between the Member States and the institutions is 'the central purpose of Title VI of the Treaty on European Union, appearing both in the title-Provisions on Police and Judicial Cooperation in Criminal Matters - and again in almost all the articles'. AG Kokott in Pupino, para 26.

62 See, for an apparently different perspective, G. de Baere, Constitutional Principles of EU External Relations (Oxford: Oxford Univ. Press, 2008), 259-260.

${ }^{63}$ See M. Fletcher, 'Extending "Indirect Effect" to the Third Pillar: The Significance of Pupino', European Law Review, 30 (2005), 862-877, 871.

This is an open access version of the publication distributed under the terms of the Creative Commons Attribution-NonCommercial-NoDerivs licence (http://creativecommons.org/licenses/by-nc-nd/3.0/), which permits non-commercial reproduction and distribution of the work, in any medium, provided the original work is not altered or transformed in any way, and that the work is properly cited. For commercial re-use, please contact academic.permissions@oup.com 
more cautious in its wording on the force of indirect effect with regard to the framework decision at issue compared with cases in the former first pillar. ${ }^{64}$ On the other hand, the Court had also adopted the limitations pertaining to the indirect effect of directives, such as legal certainty and non-retroactivity to framework decisions. ${ }^{65}$ However, as I will argue later, in the area of CJHA, Pupino can be said to have anticipated the changes brought about by the Lisbon Treaty.

Pupino was not relevant with regard to the CFSP since it did not concern measures in the former second pillar. In contrast, the Court in Segi concerned a common position implementing a UN Security Council Resolution, which was, however, also based on the former third pillar provision of Article $34 \mathrm{TEU}$ (Nice). ${ }^{66}$ The Court in this case clarified the binding nature of common positions based on loyalty, with the following words:

A common position requires the compliance of the Member States by virtue of the principle of the duty to cooperate in good faith, which means in particular that Member States are to take all appropriate measures, whether general or particular, to ensure fulfilment of their obligations under European Union law (see Pupino, paragraph 42). ${ }^{67}$

Thus, the concept of loyalty the Court had referred to in Pupino was held to be equally relevant with respect to a common position under the second pillar. Since the earlier quote was phrased in general terms, this finding seemed not to be restricted to the specific 'cross-pillar' measure that was in issue in Segi.

The general application of a certain concept of loyalty was confirmed by a judgment of the Court of First Instance in the case of People's Mojahedin Organization of Iran (PMOI) ${ }^{68}$ It held that the principle of cooperation in good faith is 'of general application and is especially binding in the area of police and judicial cooperation in criminal matters'. In spite of this general statement, the facts of the case itself were rather specific. Two instruments, an EC regulation and a CFSP common position had introduced 'a specific form of cooperation between the Council and the Member States in the context of combating terrorism'. ${ }^{69}$ Notably, the Court of First Instance did not mention the specific CFSP provisions on loyalty discussed in detail later. Instead, it emphasized that the mentioned form of cooperation between the Council and the Member States had been introduced by secondary law, and that it was not based directly on ex Article 10 EC. Moreover, the actual duty of cooperation imposed in the PMOI case was a sort of obligation of recognition for the Council with regard to assessments of national authorities.

64 See Case C-105/03 Criminal Proceedings Against Maria Pupino [2005] ECR I-5285, para 47: 'The obligation on the national court to refer to the content of a framework decision when interpreting the relevant rules of its national law ceases when the latter cannot receive an application which would lead to a result compatible with that envisaged by that framework decision. In other words, the principle of conforming interpretation cannot serve as the basis for an interpretation of national law contra legem...'. See M. Klamert, 'Judicial Implementation of Directives and Anticipatory Indirect Effect: Connecting the Dots', Common Market Law Review, (2006), 1251-1275.

65 See Case C-105/03 Criminal Proceedings Against Maria Pupino [2005] ECR I-5285, paras 44-45.

66 Case C-355/04 P. Segi and Others v Council [2007] ECR I-1657.

67 See Case C-355/04 Segi [2007] ECR I-1657, para 52; Case C-354/04 P. Gestoras ProAmnistía and Others $v$ Council [2007] ECR I-1579, para 52. See the claim of a contra legem interpretation of ex Art. $35 \mathrm{TEU}$ in order to ensure effective judicial protection of the claimants' rights by A. Arnull, 'The Principle of Effective Judicial Protection in EU Law: An Unruly Horse?', European Law Review, (2011), 51-70, 69-70.

68 Case T-284/08 People's Mojahedin Organization of Iran v Council [2008] ECR II-3487, para 52.

69 This cooperation mechanism provided therein 'entails, for the Council, the obligation to defer as far as possible to the assessment conducted by the competent national authority, at least where it is a judicial authority, in particular in respect of the existence of "serious and credible evidence or clues" on which its decision is based'.

This is an open access version of the publication distributed under the terms of the Creative Commons Attribution-NonCommercial-NoDerivs licence (http://creativecommons.org/licenses/by-nc-nd/3.0/), which permits non-commercial reproduction and distribution of the work, in any medium, provided the original work is not altered or transformed in any way, and that the work is properly cited. For commercial re-use, please contact academic.permissions@oup.com 
This is quite a different matter than meddling with the nature and effect of legal instruments as such, such as was done by the Court of Justice in the Pupino case with regard to the former third pillar.

Hence, both Segi and the PMOI case make it not entirely clear that the concept of loyalty that was invoked in these cases corresponded to the same kind of loyalty that was applied at that time in the EC Treaty, or even to the one that was applied by the Court of Justice in the Pupino case discussed earlier. The dictum in the PMOI case on the 'general application' of loyalty should rather be understood as a reference to the general idea of loyalty, not to a specific concept of loyalty such as the one developed by the Court under the former first pillar.

In the following section, I will argue that this impression of a distinct concept of loyalty applying in the CFSP continues to find support in the provisions in the part on the CFSP of the Lisbon Treaty. ${ }^{70}$

\subsection{Loyalty in the PJC and the CFSP after Lisbon}

With regard to the area of police and justice cooperation (PJC) under the Lisbon Treaty, there is certainly more support for an analogous treatment of secondary law. Firstly, framework decisions have been abandoned as legal instruments, with directives being foreseen also in this area. Secondly, as mentioned, there is no need for the Court any more to 'transfer' former first pillar loyalty to the former second pillar because loyalty now pertains to the whole Union. Temple Lang has predicted an important role for loyalty in the former third pillar, such as regards the duty of national courts to raise questions of EU law on their own initiative and to give effective judicial protection to individuals. ${ }^{71}$

Matters remain more complex with the CFSP, where I have shown that solidarity is the dominant principle. In general, the weak restraining effect of decisions in the CFSP should be pointed out. ${ }^{72}$ It would be difficult to argue for the analogue application of Article 4 (3) TEU-based loyalty, when this would mean that the highly interventionist 'cargo' applying to directives would equally apply to decisions in the CFSP. ${ }^{73}$ Indeed, it is hard to imagine that an instrument under the CFSP could have a direct effect on individuals. ${ }^{74}$ For this, we could also not rely on the arguments beside loyalty made by the Court in support of the direct effect of former first pillar directives. ${ }^{75}$ There is no preliminary reference procedure, nor is there a duty of implementation the breach of which can be sanctioned.

70 But see Kaufmann-Bühler, 'Art 24 EUV', para 38.

${ }^{71}$ J. Temple Lang, 'The Development by the Court of Justice of the Duties of Cooperation of National Authorities and Community Institutions under Article 10 EC', Fordham International Law Journal, 31 (2008), 1483-1532, 1524.

72 See the discussion in C. Hillion and R. Wessel, 'Restraining External Competences of EU Member States', in M. Cremona and B. de Witte (eds), EU Foreign Relations Law: Constitutional Fundamentals (Oxford and Portland, Oregon: Hart Publishing, 2008), 79-121, 83-86.

73 This should also not have changed by the addition of the obligation for the Member States to comply with the Union's action in Art. 24 (3) TEU. But see Kaufmann-Bühler, 'Art. 24 EUV', para 39, who talks in general of (Union) loyalty in the context of the CFSP, but at the same time fails to derive any concrete duties of Member States based on this, with the exception of a duty of cooperation when implementing decisions of the Council on sanctions. This, however, is claimed by reference to the $P M O I$ case, which I have explained earlier, does not permit generalization.

${ }_{74}$ Kaufmann-Bühler, 'Art. 24 EUV', para 46, with regard to PJC measures.

75 See Chapter 3.

This is an open access version of the publication distributed under the terms of the Creative Commons Attribution-NonCommercial-NoDerivs licence (http://creativecommons.org/licenses/by-nc-nd/3.0/), which permits non-commercial reproduction and distribution of the work, in any medium, provided the original work is not altered or transformed in any way, and that the work is properly cited. For commercial re-use, please contact academic.permissions@oup.com 
However, some provisions in the Treaty on the CFSP discussed here do indeed bear resemblance to Article 4 (3) TEU and have prompted some analogies in the literature. Article 24 (3) TEU prescribes a concept of loyalty similar to the duty provided in Article 4 (3) TEU, involving both negative ('refrain from') and positive ('shall support') obligations: ${ }^{76}$

The Member States shall support the Union's external and security policy actively and unreservedly in a spirit of loyalty and mutual solidarity and shall comply with the Union's action in this area.

The Member States shall work together to enhance and develop their mutual political solidarity. They shall refrain from any action which is contrary to the interests of the Union or likely to impair its effectiveness as a cohesive force in international relations.

The Council and the High Representative shall ensure compliance with these principles.

Compared to the Nice Treaty, Article 24 (3) TEU has been modified on two accounts, but not with regard to the mention of loyalty. ${ }^{77}$ It is noteworthy that Article 24 (3) TEU does not refer to an obligation of loyalty or sincere cooperation such as Article 4 (3) TEU, but refers to support by the Member States 'in the spirit of loyalty' instead. This difference in wording alone seems to imply that loyalty in the CFSP is not of the same quality as in the non-CFSP areas. ${ }^{78}$ Cremona has argued that Article 24 (3) can be seen to counterbalance the fact that the Commission does not have enforcement powers in relation to the CFSP, rather than as replacing the general loyalty clause in Article 4 (3) TEU. ${ }^{79}$ Thus, Article 24 (3) TEU has been interpreted as requiring Member States to consult with the other Member States in all matters pertaining to the CFSP. ${ }^{80}$ Moreover, it has been deemed to prohibit Member States from abusing the EU for settling bilateral problems with other Member States, or to use tie-in bilateral deals to propel their political goals in the EU. ${ }^{81}$ This makes CFSP loyalty the basis for duties of information and consideration on the part of the Member States. These duties may be of a binding legal nature and, as such, more than a political best effort obligation. ${ }^{82}$ However, this is grey theory in view of the fact that they are not legally enforceable before the ECJ, ${ }^{83}$ and that some Member States may not even fully accept them in the CFSP. ${ }^{84}$ This view of their political,

76 See Hillion, 'Mixity and Coherence in EU External Relations: The Significance of the "Duty of Cooperation"', CLEER Working Papers, 2 (2009), 33.

77 In the first indent, the Member States are now also obliged to comply with the Union's action in the CFSP, which recalls the above-discussed Segi case. In the third indent, the High Representative has been added as custodian of the duties under Art. 24 (3) CFSP, following the creation of this position by the Lisbon Treaty. The wording of ex Art. 11 (2) TEU (Nice) had already been reinforced compared to the precursor norm, Art. J.1 (4) TEU (Maastricht). See H.-J. Cremer, 'Art 14 EUV', in C. Calliess and M. Ruffert (eds), EUVIEGV, 3rd edn. (Munich: Beck, 2007), para 4.

78 See also Kaufmann-Bühler, 'Art. 24 EUV', para 94.

79 M. Cremona, 'The Two (or Three) Treaty Solution: The New Treaty Structure of the EU', in A. Biondi, P. Eeckhout, and S. Ripley (eds), European Union Law after the Treaty of Lisbon (Oxford: Oxford Univ. Press, 2011), 40-61, 53.

80 Bitterlich, 'Art. 24 EUV', in C.-O. Lenz and K.-D. Borchardt (eds), EU-Verträge, Kommentar nach dem Vertrag von Lissabon, 5 th edn. (Cologne and Vienna: Bundesanzeiger, 2010), para 6. See Art. 275 TFEU.

81 Kaufmann-Bühler, 'Art. 24 EUV', para 42.

82 Bitterlich, 'Art. 24 EUV', para 6. See also Kaufmann-Bühler, 'Art. 24 EUV', para 11.

83 Bitterlich, 'Art. 24 EUV', para 6. See Art. 275 TFEU. Also, in the future, the Court remains prevented in the CFSP from taking the same central role for developing loyalty as it has done in the former first pillar and in the former third pillar.

84 Recall that, in the PMOI case, concrete duties of cooperation in the CFSP have been founded on secondary law, instead of on either ex Art. 10 EC or CFSP provisions. See also Kaufmann-Bühler, 'Art. 24 EUV', para 40, who mentions the British resistance to adopting the former Art. 11 (2) TEU (Nice) in the Constitutional Treaty.

This is an open access version of the publication distributed under the terms of the Creative Commons Attribution-NonCommercial-NoDerivs licence (http://creativecommons.org/licenses/by-nc-nd/3.0/), which permits non-commercial reproduction and distribution of the work, in any medium, provided the original work is not altered or transformed in any way, and that the work is properly cited. For commercial re-use, please contact academic.permissions@oup.com 
non-binding nature is supported by the political nature of the mandate of the Council and the High Representative, having no power to take binding decisions regarding the duties provided in Article 24 (3) TEU. 85

Another provision that bears resemblance to (the second indent of) Article 4 (3) TEU is (the second sentence of) Article 28 (5) TEU:86

Should there be any major difficulties in implementing a decision as referred to in this Article, a Member State shall refer them to the Council which shall discuss them and seek appropriate solutions. Such solutions shall not run counter to the objectives of the decision referred to in paragraph 1 or impair its effectiveness.

Article 28 (5) TEU concerns all situations in which a Member State does not consider itself in the position fully to comply with the obligations flowing from a joint action. ${ }^{87}$ The provision bars Member States from unilaterally claiming objective or subjective reasons for such failure; instead, they must resort to the Council, which has to find an 'appropriate' solution under the condition that it does 'not run counter to the objectives of the decision or impair its effectiveness'. Appropriateness, thus, is a coda for a specific form of mutual consideration without a right for the Member State concerned to demand the termination of a decision. ${ }^{88}$ I would thus argue that this provision is of a very distinct nature and only faintly recalls the Inter-Environnement Wallonie case law discussed earlier.

The 'transfer' of ex Article 10 EC to the CFSP has also been argued based on ex Article $47 \mathrm{TEU}$, which provided for the priority of taking measures under the first pillar over adopting measures under the second and third pillars. ${ }^{89}$ Thus, non-CFSP loyalty would bind the Member States when acting in the Council on CFSP matters, and CFSP loyalty would be lex specialis to Article 4 (3) TEU loyalty, meaning that the former must be interpreted in light of the latter. ${ }^{90}$ Before Lisbon, ex Article 47 TEU had been thought to have two further and related consequences. Firstly, Member States should not invoke obligations imposed on the $\mathrm{EU}$ in order to free themselves from obligations incumbent on the EC under an EC-EU agreement. ${ }^{91}$ Secondly, an action or inaction of the EU in matters of CFSP or PJC should not affect the rights and obligations of the EC in such a constellation. ${ }^{92}$ Thus, it has been contended that compliance with the EU part of

85 Kaufmann-Bühler, 'Art. 24 EUV', para 5 with further references.

${ }^{86}$ Further examples of a broadly defined duty of cooperation in the field of CFSP are Art. 28 (3) to (5) TEU, Art. 31 (1) TEU, Art. 32 TEU on the (horizontal) duty of consultation of Member States in the European Council and the Council, Art. 34 TEU, and Art. 35 TEU. See Hillion and Wessel, 'Restraining External Competences', 81-82, who discuss Art. 32 TEU perhaps a bit too prominently.

87 H.-J. Cremer, 'Art. 14 EUV', in C. Calliess and M. Ruffert (eds), EUVIEGV, 3rd edn. (Munich: Beck, 2007), para 24.

${ }^{88}$ Cremer, 'Art. 14 EUV', para 24.

89 Art. 47 TEU stipulated that 'nothing in [the TEU] shall affect the Treaties establishing the European Communities or the subsequent Treaties and Acts modifying and supplementing them'. See in this regard, S. Griller and M. Klamert, 'Das Aussenwirtschaftsrecht der EU', in M. Holoubek and M. Potacs (eds), Öffentliches Wirtschaftsrecht (Vienna, New York: Springer, 2007), 1112-1116. This provision in the Nice Treaty allegedly subordinated the loyalty provision in ex Art. 11 (2) TEU (Nice) to ex Art. 10 EC, preventing Member States from relying on ex Art. 11 (2) TEU 'to justify an infringement of their obligations under Article 10 EC'. See Hillion and Wessel, 'Restraining External Competences', 95.

${ }_{90}$ Hillion and Wessel, 'Restraining External Competences', 95, with respect to the Nice Treaty.

${ }_{91}$ Hillion and Wessel, 'Restraining External Competences', 95.

92 Hillion and Wessel, 'Restraining External Competences', 31, mentions retaliation against the EC-EU as one party for default by the EU, particularly when a mixed agreement does not include a declaration of competence.

This is an open access version of the publication distributed under the terms of the Creative Commons Attribution-NonCommercial-NoDerivs licence (http://creativecommons.org/licenses/by-nc-nd/3.0/), which permits non-commercial reproduction and distribution of the work, in any medium, provided the original work is not altered or transformed in any way, and that the work is properly cited. For commercial re-use, please contact academic.permissions@oup.com 
an agreement should not be jeopardized by the Community, unless such compliance amounts to a violation of ex Article 47 TEU. ${ }^{93}$

The 'pillar priority' mandated by ex Article 47 TEU has been abolished by the Lisbon Treaty, and Article 40 TEU no longer subordinates the intergovernmental part of EU law to its supranational part. ${ }^{94}$ Even if it had been true under the Nice Treaty, which I doubt, ${ }^{95}$ this particular argument has therefore become untenable with Lisbon as the foundation for protecting action in non-CFSP areas from action in the CFSP. Thus, there is no reason to find actions of Member States unlawful because they violate prescriptions the Court has established on the basis of Article 4 (3) TEU. I would suggest that non-CFSP loyalty might only affect CFSP matters in one area, viz. the special case of mixed agreements involving both CFSP and non-CFSP matters. ${ }^{96}$ As I will discuss in Chapter 10, in the context of mixed agreements, Member States and the Union are subject to a duty of cooperation also when acting within their respective exclusive powers. ${ }^{97}$ In the absence of sub-ordination of one policy area to the other, I would argue that the need for cooperation between Member States acting within the CFSP and Member States acting in a non-CFSP policy field in a mixed setting is now to be found in the principle of coherence and the unity of international representation in external relations. ${ }^{98} \mathrm{At}$ the least, loyalty here requires the Union institutions in non-CFSP areas to consider the interests of the institutions acting in the CFSP. This special case of mixed agreements therefore is an example of the application of Article 4 (3) TEU loyalty to the Member States also when they are acting within the CFSP.

\section{Conclusion}

We can conclude this Chapter by observing that there is unity between national legal orders and Union law even in legal systems that are perceived as dualist such as the UK. On the other hand, this unity may be fragile in Member States that are considered monist, such as Germany. I have shown that without this unity, certain effects of Union directives in national law in particular would be difficult to rationalize. In contrast to this relation between Member States and the Union legal order, there is less unity within the Union legal system, which also entails an uneven force of loyalty-based effects. While

93 Hillion and Wessel, 'Restraining External Competences', 30.

94 M. Klamert, 'Conflicts of Legal Basis: No Legality and No Basis but a Bright Future under the Lisbon Treaty?', European Law Review, (2010), 497-515.

95 The case law on ex Art. 47 TEU (Nice) protected the EC from being sidelined by measures taken in the ambit of the EU. It had never been invoked by the Court in the context of breaches by a Member State of Community law. See Griller and Klamert, 'Außenwirtschaftsrecht der EU', 1099-1175.

96 See the discussion by Hillion, 'Mixity and Coherence', 29-30, on the Schengen agreement concluded with Switzerland jointly by the (former) EC and the (former) EU. He has claimed that the institutions as well as the Member States acting in the context of the EU 'are equally bound to cooperate with the Community, e.g. when negotiating, concluding and implementing the provisions of the agreement that relate to titles V and/or VI TEU'.

97 See Chapter 10.

98 See ex Art. 3 TEU and now Art. 21 (3) TEU: 'The Union shall ensure consistency between the different areas of its external action and between these and its other policies. The Council and the Commission, assisted by the High Representative of the Union for Foreign Affairs and Security Policy, shall ensure that consistency and shall cooperate to that effect.' The Treaty in these provisions not only deals with the CFSP but with external action in a broad sense including areas with a traditionally close rapport to the CFSP such as (the non-CFSP) development policy. See Case C-91/05 Commission v Council (Small Arms and Light Weapons) [2008] ECR I-3651. See M. Klamert, 'Art. 205 AEUV', in H. Mayer and K. Stöger (eds), EUVIAEUV Kommentar (Vienna: Manz, 2010), paras 1-7.

This is an open access version of the publication distributed under the terms of the Creative Commons Attribution-NonCommercial-NoDerivs licence (http://creativecommons.org/licenses/by-nc-nd/3.0/), which permits non-commercial reproduction and distribution of the work, in any medium, provided the original work is not altered or transformed in any way, and that the work is properly cited. For commercial re-use, please contact academic.permissions@oup.com 
this discrepancy has been abolished by the Lisbon Treaty amendments with regard to the former third pillar, as had already been signalled by Pupino, I have argued that the CFSP remains governed by a different principle of loyalty. The fact that Article 4 (3) TEU in theory also applies to the CFSP does not easily outweigh the still distinct legal nature of the CFSP, nor can it gloss over the fact that there is a distinct loyalty provision for this area. Arguably, transferring the 'cargo' of Article 4 (3) TEU to this area would not only strain the Court's jurisdiction, but would also be difficult to defend on systematic grounds. This would only be conceivable by (further) feats of judicial lawmaking by the Court, which would need to overcome limitations of jurisdiction as well as the textual and contextual arguments laid down earlier. The real test case would be a claim to supremacy for an act adopted under the CFSP. In such a case, however, it seems unlikely that the Court would not assign the Union act supremacy, had it the cognition to do so; ${ }^{99}$ and if this happened, the other legal principles that are based on loyalty would not be too far off any more.

99 Herrmann, 'Much Ado about Pluto?', 46; K. Lenaerts and P. Van Nuffel, European Union Law, 3rd edn. (London: Sweet \& Maxwell, 2011), 754.

This is an open access version of the publication distributed under the terms of the Creative Commons Attribution-NonCommercial-NoDerivs licence (http://creativecommons.org/licenses/by-nc-nd/3.0/), which permits non-commercial reproduction and distribution of the work, in any medium, provided the original work is not altered or transformed in any way, and that the work is properly cited. For commercial re-use, please contact academic.permissions@oup.com 


\section{5 \\ Supremacy, Pre-emption, and the Union Interest}

\section{Introduction}

In this Chapter, I will discuss various duties of Member States that result from the adoption of a legislative act by the Union, or that flow from Union acts that have not yet reached the stage of becoming a formal act of secondary law or have not yet been concluded as an international agreement. I will argue that supremacy fails to provide the rationale for these restraints on Member State rights because with these constellations certain elements that are characteristic of a situation calling for the application of supremacy are absent. This will pick up our discussion of other loyalty-based principles such as ERTA and Opinion 1/76. Besides not fitting the supremacy paradigm, the effects of secondary law that I will discuss later have in common that they are all duties of abstention for the Member States, barring Member States from entering into commitments vis-à-vis third states and from taking national measures when this runs counter to the implementation obligation. I will discuss the concept of pre-emption, which plays an important role in the literature for explaining these effects of Union secondary law. I will show that there are no convincing reasons for considering pre-emption a distinct legal concept of EU law. Finally, I will examine the role of the Union interest in the present context.

\section{Some Thoughts on the Nature of Supremacy}

\subsection{The Basic Operation of Supremacy}

It is not my intention to give a full account of genesis and the nature of the principle of supremacy here. ${ }^{1}$ Suffice it to recall that Costa $v$ ENEL was the origin of the supremacy doctrine in Union law. ${ }^{2}$ In subsequent cases, especially Internationale Handelsgesellschaft, this principle has been defined and further refined. ${ }^{3}$ Simmenthal II has clarified that the result of a conflict between national law and Union law is that the former is 'automatically inapplicable'. ${ }^{4}$

Supremacy, it is proffered, is a very general prescription of what happens when national law clashes with Union law, which may be characterized by two basic features. The first is its rationale, which is to ensure the effective and uniform application of Union law in the internal legal orders of the Member States. The second is its effect, which is the

1 See, for this, among others, B. de Witte, 'Direct Effect, Primacy and the Nature of the Legal Order', in P.P. Craig and G. de Búrca (eds), The Evolution of EU Law, 2nd edn. (Oxford: Oxford Univ. Press, 2011), 323-362.

2 See Chapter 3. $\quad 3$ Case 11/70 Internationale Handelsgesellschaft [1970] ECR 1125.

4 Case 106/77 Simmenthal II [1978] ECR 629, para 14.

This is an open access version of the publication distributed under the terms of the Creative Commons Attribution-NonCommercial-NoDerivs licence (http://creativecommons.org/licenses/by-nc-nd/3.0/), which permits non-commercial reproduction and distribution of the work, in any medium, provided the original work is not altered or transformed in any way, and that the work is properly cited. For commercial re-use, please contact academic.permissions@oup.com 
resolution of conflicts with national law by its disapplication instead of its invalidation. To resolve a conflict in such a manner logically presupposes the actual existence both of a national law that must not be applied, and of Union law mandating its disapplication. Thus, supremacy requires an actual conflict between two norms that are capable of being applied to the facts of a case. ${ }^{5}$ This, conversely, does not imply that there is a difference in the primacy of Union law depending on whether it concerns pre-existing or 'supervening' national law. ${ }^{6}$ Irrespective of whether a norm of national law has already been adopted before the entry into force of a Union law measure, or whether a Member State passes new laws in conflict with Union law in both cases, there is an actual conflict leading to the automatic suspension of the application of the national laws concerned. ${ }^{7}$

The different forms of exclusivity will be discussed in Chapter 7. Suffice it to note here that Article 2 (1) TFEU defines exclusive Union competence as a policy area where 'only the Union may legislate and adopt legally binding acts...'. This form of exclusivity will be referred to as a priori exclusivity. ${ }^{8}$ The Lisbon Treaty now provides an exhaustive list of policy areas falling under such a priori exclusivity in Article 3 (1) TFEU. By what I will refer to as exclusivity superveniens, the Union acquires exclusive competence through the passage of common rules by the Union legislator. The standard example for this is the exercise of shared competence as now defined in Article 2 (2) TFEU, leaving Member States the right to exercise their competence to the extent that the Union has not exercised its competence'.

For largely theoretical reasons, I would argue that it is possible to distinguish between supremacy and exclusivity superveniens as the result of the adoption of an act of Union law under shared competence for the following reasons. In Simmenthal II, the Court held that supremacy would 'also preclude the valid adoption of new legislative measures to the extent to which they would be incompatible with Community provisions'. ${ }^{10}$ As discussed earlier, however, there is no difference in the effect of supremacy between existing national law and newly enacted national law. ${ }^{11}$ To be more precise, there is no difference as soon as such new national law is enacted, because from this point in time, an actual conflict exists and the provision of national law is set aside to the extent that it is required to resolve the conflict with Union law. However, already prior to the passing of such new national law, starting from the entry into force of the Union law measure, Member States are arguably required to abstain from enacting conflicting measures. We can therefore identify a separate duty of abstention triggered by the passage of an act of Union law such as a directive or a regulation that applies before supremacy sets in. From a practical perspective, this distinct duty of abstention will hardly ever be enforced. ${ }^{12}$ However,

5 De Witte, 'Direct Effect', 341-342; M. Nettesheim, 'Art. 288 AEUV', in E. Grabitz, M. Hilf and M. Nettesheim (eds), Das Recht der Europäischen Union (Munich: Beck, 2011), para 52. For a different view, see K. Lenaerts and T. Corthaut, 'Of Birds and Hedges: The Role of Primacy in Invoking Norms of EU Law', European Law Review, 31 (2006), 289-315, 297 in particular, who seem to advocate a broader criterion of 'inconsistency'.

${ }^{6}$ Joined cases C-10/97 to C-22/97 Ministero delle Finanze v IN.CO.GE.'90 [1998] ECR I-6307, paras $18-21$.

7 See R. Schütze, 'Supremacy Without Pre-emption?: The Very Slowly Emergent Doctrine of Pre-emption', Common Market Law Review, 43:4 (2006), 1023-1048, 1030.

8 It is also sometimes referred to as constitutional exclusivity as opposed to legislative exclusivity, however, this is a less appropriate term. See Chapter 7.

9 Directives or regulations, such as to approximate national laws for the functioning of the common market pursuant to Art. 114 TFEU, preclude Member States from passing laws when they purport to regulate the same matters already regulated by the Union.

10 Case 106/77 Simmenthal II [1978] ECR 629, para $14 . \quad 11$ See supra note 6.

12 Because as soon as it is breached, there is also a rule of national law to which supremacy can be applied.

This is an open access version of the publication distributed under the terms of the Creative Commons Attribution-NonCommercial-NoDerivs licence (http://creativecommons.org/licenses/by-nc-nd/3.0/), which permits non-commercial reproduction and distribution of the work, in any medium, provided the original work is not altered or transformed in any way, and that the work is properly cited. For commercial re-use, please contact academic.permissions@oup.com 
this should not distract from the important fact that supremacy, when understood in the manner suggested earlier as requiring an actual conflict, has its limitations even in what can be considered its most exemplary constellation, viz. the direct conflict between provisions of Union law and those of national law.

\subsection{Two Qualifications on the Characteristics of Supremacy}

We cannot really speak of a conflict of norms in connection with supremacy without qualifying this statement both in terms of what is considered a 'norm' for the present purpose, and in terms of the disapplication paradigm.

As to the definition of conflicts in Union law, I would argue that this must be understood in a broad sense. ${ }^{13}$ It is not only about the clash between provisions of primary or secondary law with a norm of national law; supremacy also applies to the collision of regulatory objectives of Union provenance, which do not as such constitute proper legal norms, if by this we refer to norms that can be applied to facts. This can be illustrated by the example of Union directives. ${ }^{14}$ The classic model for a conflict of norms requires a directive to be directly applicable in order to produce a disapplication effect on national law. However, Article 288 TFEU arguably already vests directives with the power of supremacy over national law with regard to their objectives. Supremacy here determines the intensity of the obligation of consistent interpretation of national law after the expiry of the term for the directive's transposition. The objective of a directive takes priority over an interpretation of national law that would be required by the rules of the respective national legal order. In other words, supremacy entails precedence of consistent interpretation over all other national methods of construction. Supremacy, in this case of indirect effect, thus operates in the absence of a legal norm fully applicable in national law, but still sets aside Member State laws in the form of national methods of construction. ${ }^{15}$

This means that supremacy can be the solution to both a conflict between directly applicable Union law and substantive national law, as well as to a conflict between (the concretization of Treaty objectives in the form of) objectives of directives and procedural national law. Procedural law, in the broad sense, includes national methods of construction, which, in case of a conflict with the directive's objective and 'directive-enabling' rules of construction, must be set aside. ${ }^{16}$ Thus, the Court constrained national courts in their discretion in applying national methods of construction, such as in Wagner Miret with regard to historical interpretation relying on travaux préparatoires. ${ }^{17}$ We should however be careful to note that this does not say anything as to whether national courts

13 See E. Vranes, 'The Definition of "Norm Conflict" in International Law and Legal Theory', The European Journal of International Law, 17:2 (2006), 395-418, for a discussion of the inadequacies of traditional definitions of conflicts of norm and of competence.

14 See for the following argument, M. Klamert, 'Judicial Implementation of Directives and Anticipatory Indirect Effect: Connecting the Dots', Common Market Law Review, (2006), 1251-1275.

15 Klamert, 'Judicial Implementation', 1274.

16 Similar C.-W. Canaris, 'Die richtlinienkonforme Auslegung und Rechtsfortbildung im System der juristischen Methodenlehre', in H. Koziol and P. Rummel (eds), Im Dienste der Gerechtigkeit: Festschrift für Franz Bydlinski (Vienna, New York: Springer, 2002), 59 and 66 passim.

17 See Case C-334/92 Wagner Miret [1993] ECR 1-191, para 21. Repeated in Joined cases C-397/01 and C-403/01 Pfeiffer [2004] ECR I-8835, para 112. See also Case C-371/02 Bjornekulla Fruktindustrier [2004] ECR 5791. One might therefore argue that there are traces of a European methodological standard with respect to the obligation of consistent interpretation. See M. Klamert, 'Richtlinienkonforme Auslegung und unmittelbare Wirkung von EG-Richtlinien in der Rechtsprechung der österreichischen Höchstgerichte', Juristische Blätter, 130:3 (2008), 158-170.

This is an open access version of the publication distributed under the terms of the Creative Commons Attribution-NonCommercial-NoDerivs licence (http://creativecommons.org/licenses/by-nc-nd/3.0/), which permits non-commercial reproduction and distribution of the work, in any medium, provided the original work is not altered or transformed in any way, and that the work is properly cited. For commercial re-use, please contact academic.permissions@oup.com 
must interpret contra legem or praeter legem, in view of the repeated statements that indirect effect must not lead to such a result. ${ }^{18}$ Hence, while the first effect can be called substantive supremacy, the second effect can be termed procedural supremacy. ${ }^{19}$

The second qualification to the definition of supremacy relates to its effect of setting aside national law and we will again illustrate it by the example of Union directives. Directly effective provisions in directives not only entail the disapplication of conflicting national law, but may also replace provisions of national law as the source of enforceable rights of individuals. While the former is the exclusionary effect of directly effective provisions in directives, the latter implication is called the substitution effect and is thus more than disapplication. ${ }^{20}$ An analogous effect applies also with regard to the indirect effect of directives. When a Member State legal order does not avail itself of methods of interpretation enabling the national authorities to comply with the obligation to interpret their laws in light of a directive, they may nonetheless be required to apply all methods necessary to realize the supremacy of the directive's objective, such as in the UK, as I have shown elsewhere. ${ }^{21}$ In this case, we can therefore speak of a substitution effect with regard to national procedural law, in addition to the exclusion effect that entails the setting aside of national methods of construction.

Note that we should be careful to insist on this distinction between substantive and procedural supremacy. In most of its case law, the Court has used the so-called Marleasing formula and ordered the national court to interpret their laws 'as far as possible'. ${ }^{22}$ Predominantly, the prescriptions of the Court have remained abstract and formulistic, and the Court has not forced the outcome of a consistent interpretation on national courts. ${ }^{23}$ An exception has been Marleasing itself, which has been criticized for producing a de facto horizontal direct effect since the Court seemed to deprive the national court

18 See, to this effect, Case 80/86 Kolpinghuis Nijmegen [1987] ECR 3969, para 13; Case C-212/04 Adelener and Others [2006] ECR I-6057, para 110; Case C-12/08 Mono Car Styling [2009] ECR I-6653, para 61. See AG Mengozzi in Case C-439/08 Vlaamse federatie van verenigingen van Brood-en Banketbakkers, Ijsbereiders en Chocoladebewerkers (VEBIC) VZ [2010] ECRI-12471, paras 98-99. See also Case C-268/06 Impact v Minister for Agriculture and Food [2008] ECR I-2483, where Irish law ruled out retrospective application of legislation unless there was a clear and unambiguous indication to the contrary. The Court held that it was for the national court to establish whether the relevant provision of national law contained any such indication, otherwise this would amount to interpreting the section contra legem.

19 See for these two notions, E. Neframi, 'The Duty of Loyalty: Rethinking its Scope Through its Application in the Field of EU External Relations', Common Market Law Review, 47 (2010), 323-359, 327 , referring to the principle of effectiveness.

${ }^{20}$ For this distinction, see among others, Anonymous, 'Horizontal Direct Effect: A Law of Diminishing Coherence?', Common Market Law Review, (2006), 1; H. Jarass and S. Beljin, 'Die Bedeutung von Vorrang und Durchführung des EG-Rechts', Neue Zeitschrift für Verwaltungsrecht, (2004), 1; K. Lenaerts and T. Corthaut, 'Of Birds and Hedges: The Role of Primacy in Invoking Norms of EU Law', 289-315, 291-292; Klamert, 'Richtlinienkonforme Auslegung', 158-170.

21 See Klamert, 'Judicial Implementation', 1273, with references.

22 See also amongst many Case C-63/97 BMW [1999] ECR 905. In Joined cases C-397/01 and C-403/01 Pfeiffer [2004] ECR I-8835, the Court stated that a national court must do whatever lies within its jurisdiction' to achieve the result prescribed in a directive. Joined cases C-397/01 and C-403/01 Pfeiffer [2004] ECR I-8835, paras 118 and 119. I have argued elsewhere that this does not put indirect effect on a new norm-hierarchical footing, but only specifies the 'as far as possible' dictum without adding new flesh to the obligation. See Klamert, 'Judicial Implementation', 1253. Similar S. Prechal in her annotation to 'Pfeiffer et al.', Common Market Law Review, 42 (2005), 1445-1463, 1458.

${ }^{23}$ On Centrosteel, similarily criticized, see Klamert, 'Judicial Implementation', 1254. See also J.C.M. de Almeida, 'L'effet direct des directives, l'interprétation conforme du droit national et la jurisprudence de la Cour Supreme de Justice portugaise', in N. Colneric et al. (eds), Une communauté de droit: Festschrift für Gil Carlos Rodríguez Iglesias (Berlin: Berliner Wissenschafts-Verlag, 2003), 235-244, 241.

This is an open access version of the publication distributed under the terms of the Creative Commons Attribution-NonCommercial-NoDerivs licence (http://creativecommons.org/licenses/by-nc-nd/3.0/), which permits non-commercial reproduction and distribution of the work, in any medium, provided the original work is not altered or transformed in any way, and that the work is properly cited. For commercial re-use, please contact academic.permissions@oup.com 
of any discretion whatsoever. ${ }^{24}$ In Pfeiffer on Directive 93/104 on working time, AG Colomer argued in favour of an exclusionary horizontal effect of directives between private parties in spite of the lack of direct effect of the directive. ${ }^{25}$ In the AG's opinion, this should have precluded a provision of German law on working time, which allowed for the extension of working hours beyond ten hours in the German Red Cross Collective Agreement. This has not been followed by the Court, albeit it alluded to conflicts of norms and their resolution by means of the German technique of teleologische Reduktion (the 'reduction' of the scope of application of a norm of national law for teleological purposes under strict conditions). ${ }^{26}$

The case law on directives thus shows that supremacy requires the existence of a fully applicable Union law norm, which can set aside conflicting national law and in some cases also applies itself within the national legal order. In the following, I will discuss the ensuing limitations of supremacy in three constellations. Firstly, when there is no correlation between the 'legal space' occupied by Union measures and the scope of national law concerned. Secondly, when there is no measure of national law that could be set aside, and finally, when rights of the Member States to act are impaired albeit no provision of Union law exists that could be applied directly in national law.

\section{Duties Unrelated to Supremacy Flowing from Secondary Law}

\subsection{The ERTA Effect}

According to Article 3 (2) TFEU, the Union has exclusive competence for the conclusion of an international agreement when this would 'affect common rules or alter their scope'. This codifies the principle introduced by the ERTA case discussed earlier. ${ }^{27}$ The rationale behind empowering the Union because of the passing of common rules internally is that Member States should not undermine and contradict these rules by entering into conflicting obligations with third states. This rule thus protects the integrity and uniformity of Union action. ${ }^{28}$

As explained earlier, in the case of a direct conflict between Union law and national law, supremacy requires national authorities to set aside such national laws and regulations. This, in contrast, does not apply in the same manner when a Member State concludes an international agreement which affects or undermines common rules of the Union, thus violating the ERTA rule. The reason for this difference is that there is no direct conflict between an international external agreement of a Member State ${ }^{29}$ and 'common rules' of the Union, at least as far as the public international side is concerned. The reason is that a directive or regulation is not capable of directly disapplying a Member State treaty concluded with a third state under public international law.

24 Case C-106/89 Marleasing SA v Comercial Internacional de Alimentacion SA [1990] ECR 4135. See Klamert, 'Judicial Implementation', 1258, with further references.

25 See the second opinion by AG Colomer in Joined cases C-397/01 and C-403/01 Pfeiffer [2004] ECR I-8835, paras 25 passim. But see the rejection of this view by AG Trstenjak in Case C-282/10 Maribel Dominguez v Centre Informatique du Centre Ouest Atlantique and Préfet de la Région Centre [2012] ECR 00000.

26 See M. Klamert, 'Richtlinienkonforme teleologische Reduktion bis zur Gegenstandslosigkeit: Methodologische Anmerkungen zur Zugabenverbot-Entscheidung des OGH 4 Ob 208/10g', Juristische Blätter, 11 (2011), 738-742, on the way these references should be understood.

27 Case 22/70 Commission v Council (ERTA) [1971] ECR 263. See R. Schütze, 'Lisbon and the Federal Order of Competences: A Prospective Analysis', European Law Review, (2008), 709-722, 714. 28 See Chapter 3. $\quad 29$ See also Chapter 14.

This is an open access version of the publication distributed under the terms of the Creative Commons Attribution-NonCommercial-NoDerivs licence (http://creativecommons.org/licenses/by-nc-nd/3.0/), which permits non-commercial reproduction and distribution of the work, in any medium, provided the original work is not altered or transformed in any way, and that the work is properly cited. For commercial re-use, please contact academic.permissions@oup.com 
In other words, common rules are not able directly to prevent a third state from claiming its rights under the agreement against the Member State that is party to the treaty in question. The safeguarding of Union interests in such a case depends entirely on the obligation incumbent on the Member State concerned to renegotiate or denounce their international obligations, as will be explained in Chapter 14. The ERTA effect, therefore, is comparable to exclusivity as regards the duty of abstention both rules contain. Unlike the implications of the passing of Union measures on the internal capacities of Member States, however, with ERTA this is not coupled with the same threat of the application of supremacy. ${ }^{30}$

The ERTA principle thus shows that supremacy has its limits with explicating important processes in Union law. The constraints on Member States brought about by the ERTA doctrine cannot be explained by recourse to supremacy, since at the core of the $E R T A$ effect is a duty of abstention cutting across from the internal to the external level. In contrast, supremacy only applies to the matters internal to the Union. Thus, whereas the laws a Member State enacts in honouring an international agreement with a third state may not be applied against other Member States, the agreement itself cannot be set aside. I will explain later how this crucial qualification contributes to the confusion in the literature on situating ERTA in its relation to supremacy and on an alleged principle of pre-emption.

\subsection{The ILO Principle}

In Opinion 2/91, the Court had to assess the authority of the Community to enter into Convention No 170 of the International Labour Organization (ILO) concerning safety in the use of chemicals at work. ${ }^{31}$ The Court found that the matters covered by Convention No 170 did not affect the minimum regulations contained in Community directives on social policy. ${ }^{32}$ Thus, there was no ERTA effect. Other directives, in contrast, conferred more extensive protection on workers than the Convention, as well as contained provisions that were narrower in scope. The Court then introduced what will be referred to here as the ILO principle or effect:

While there is no contradiction between these provisions of the Convention and those of the directives mentioned, it must nevertheless be accepted that Part III of Convention No 170 is concerned with an area which is already covered to a large extent by Community rules progressively adopted since 1967 with a view to achieving an ever greater degree of harmonization... ${ }^{33}$

In Opinion 2/91, the Court still held that the commitments arising from the Convention could 'affect the Community rules laid down in those directives'. ${ }^{34}$ In that sense, this tenet might be seen merely as a subcategory of the ERTA principle. ${ }^{35}$ In the Open Skies cases on the legality of bilateral 'open skies' agreements of certain Member States with

30 See also J. Temple Lang, 'The ERTA Judgment and the Court's Case-law on Competence and Conflict', Yearbook of European Law, 6 (1986), 183-218, 197, 200, who notes that the duty of Member States to avoid conflicts is stronger in the external dimension since these conflicts are harder to resolve.

31 Opinion 2/91 ILO Convention 170 [1993] ECR I-1061. In Chapter 7, we will explore what has happened to this rule under the Lisbon Treaty.

32 Opinion 2/91 ILO Convention 170 [1993] ECR I-1061, paras 18-21.

33 Opinion 2/91 ILO Convention 170 [1993] ECR I-1061, para 25.

34 Opinion 2/91 ILO Convention 170 [1993] ECR I-1061, para 26.

35 See, among others, A.G. Tizzano in his Opinion in Case C-467/98 Commission v Denmark(Open Skies) [2002] ECR I-9519, para 75, framing this as a rule preventing common rules from being affected by way of 'contagion'.

This is an open access version of the publication distributed under the terms of the Creative Commons Attribution-NonCommercial-NoDerivs licence (http://creativecommons.org/licenses/by-nc-nd/3.0/), which permits non-commercial reproduction and distribution of the work, in any medium, provided the original work is not altered or transformed in any way, and that the work is properly cited. For commercial re-use, please contact academic.permissions@oup.com 
the United States of America, however, the Court more clearly distinguished the ERTA effect from the $I L O$ effect. ${ }^{36}$ In Opinion $1 / 03$, the Court spoke of the application of the latter rule as a distinct 'test', for which it was necessary 'to take into account not only the current state of Community law in the area in question but also its future development, insofar as that is foreseeable at the time of that analysis' ${ }^{37}$

In Opinion 1/03, the Court mentioned that the rationale of the ILO principle was 'to ensure a uniform and consistent application of the Community rules and the proper functioning of the system they establish...' ${ }^{38}$ Indeed, while the rationale of ERTA is to safeguard the effectiveness of common rules, the ILO principle, by ensuring the effective and uniform application of (a 'system' of) common rules rather than the integrity of a specific rule, must be seen as predicated by notions of uniformity as much as of effectiveness. Thus, once Union legislative activity has passed a certain threshold of scope, national action in the respective field might undermine the underlying regulatory scheme.

The ILO effect cross-cuts from the internal to the external sphere in the same manner as the ERTA effect discussed earlier. It thus has consequences for treaty making (by the Member States) by virtue of lawmaking (by the Union). As with $E R T A$, for this reason alone it must be distinguished from supremacy. At the same time, as I have explained elsewhere, its prospective element and the lack of a strict requirement of correlation between the scope of EU and national measures clearly distinguish the $I L O$ principle from the ERTA effect. ${ }^{39} \mathrm{With}$ the ILO principle there is furthermore no correlation between the scope of the Union measure concerned and the reach of its constraining effect. In other words, it generates a duty of abstention to some extent irrespective of whether there is an actual or potential conflict between the internal Union measure and Member State commitments. This effect has no parallel in internal Union lawmaking. As explained, a directive only precludes Member State laws and regulations to the extent it regulates a certain matter. This is another reason, therefore, why supremacy does not operate here. To the extent that there is preclusion of the Member States not corresponding to the scope of common rules passed, there is also no conflict susceptible to being resolved by supremacy as defined earlier.

\subsection{The Anticipatory Effects of Directives}

As stated in Article 288 TFEU, a directive is binding as to the result to be achieved, but leaves the choice of form and methods of implementing this objective to the national authorities. Member States are therefore commonly given a grace period of two years to make the necessary amendments in their national legal order. However, a directive is already part of Union law and hence part of national law from the time it enters into force, as already mentioned. ${ }^{40}$ From this time onwards, the obligation to attain conformity with the directive is binding on national authorities including Member

36 Case C-467/98 Commission v Denmark (Open Skies) [2002] ECR I-9519, para 82: 'According to the Court's case-law, that is the case where the international commitments fall within the scope of the common rules (AETR judgment, paragraph 30), or in any event within an area which is already largely covered by such rules (Opinion 2/91, paragraph 25).'

37 Opinion 1/03 Lugano Convention [2006] ECR I-1145, para 126.

38 Opinion 1/03 Lugano Convention [2006] ECR I-1145, para 128.

39 See M. Klamert, 'Dark Matter: Competence, Jurisdiction and "the Area Largely Covered by EU Law”: Comment on Lesoochranárske’, European Law Review, (2012), 340-350.

40 See Chapter 4.

This is an open access version of the publication distributed under the terms of the Creative Commons Attribution-NonCommercial-NoDerivs licence (http://creativecommons.org/licenses/by-nc-nd/3.0/), which permits non-commercial reproduction and distribution of the work, in any medium, provided the original work is not altered or transformed in any way, and that the work is properly cited. For commercial re-use, please contact academic.permissions@oup.com 
State courts. ${ }^{41}$ This produces some effects in the national legal order which are independent of a potential direct effect of a directive after the expiry of the deadline for implementation.

One important effect of this nature was introduced by the Court in the InterEnvironnement Wallonie ruling. ${ }^{42}$ Recall that according to this ruling, Member States must refrain from taking any measures that would seriously compromise a directive's result even before the expiry of the deadline of transposition. In this case, the Court gave detailed instructions for the national courts on the factors they should consider in this process. Thus, 'the national court must consider, in particular, whether the provisions in issue purport to constitute full transposition of the directive, as well as the effects in practice of applying those incompatible provisions and of their duration in time'. ${ }^{43}$ If the provisions in issue 'are intended to constitute full and definitive transposition of the directive, their incompatibility with the directive might give rise to the presumption that the result prescribed by the directive will not be achieved within the period prescribed if it is impossible to amend them in time'. ${ }^{44}$ Conversely, if a Member State adopts transitional measures or implements a directive in stages, this for the Court would not necessarily compromise the result prescribed in a directive. ${ }^{45}$

In the Adelener case, this 'passive obligation' ${ }^{46}$ imposed on the Member States was extended by the Court to apply also to interpretations of national law by Member State courts during that period:

It follows that, from the date upon which a directive has entered into force, the courts of the Member States must refrain as far as possible from interpreting domestic law in a manner which might seriously compromise, after the period for transposition has expired, attainment of the objective pursued by that directive. ${ }^{47}$

Neither in Inter-Environnement Wallonie nor in Adelener the Court alluded to direct effect in view of the fact that the period for implementing the pertinent directives had not yet expired. Consequently, because there was no directly effective Union law norm in Inter-Environnement Wallonie, there was thus no norm conflict in the traditional sense. If we consider supremacy as referring to the capacity of Union law to resolve conflicts with national law by ordering its disapplication or substitution, a directive cannot partake in this before the implementation period has expired for the Member States. Before that time, a directive cannot require (substantive or procedural) provisions of national law to be set aside or to be substituted by those of the directive. The same distinction is also expressed in other case law, where the Court held that national courts must give direct effect and 'refrain from applying pre-existing national rules contrary to the directive' only post-term. ${ }^{48}$

41 Klamert, 'Judicial Implementation', 1271. AG Jacobs in his opinion (para 30) stresses that the obligation to fulfil the objective of a directive is created with the entering into force of the directive pursuant to Art. 297 TFEU.

42 Case C-129/96 Inter-Environnement Wallonie [1997] ECR 7411.

43 Case C-129/96 Inter-Environnement Wallonie [1997] ECR 7411, para 47.

44 Case C-129/96 Inter-Environnement Wallonie [1997] ECR 7411, para 48.

45 Case C-129/96 Inter-Environnement Wallonie [1997] ECR 7411, para 49.

46 Compare Case C-157/02 Rieser Internationale Transporte [2004] ECR I-1477, para 67.

47 Case C-212/04 Adelener [2006] ECR I-6057, para 123.

48 Case C-156/91 Hansa Fleisch Ernst Mundt [1992] ECR I-5567, para 20; Case C-157/02 Rieser [2004] ECR I-1477, paras 67-69.

This is an open access version of the publication distributed under the terms of the Creative Commons Attribution-NonCommercial-NoDerivs licence (http://creativecommons.org/licenses/by-nc-nd/3.0/), which permits non-commercial reproduction and distribution of the work, in any medium, provided the original work is not altered or transformed in any way, and that the work is properly cited. For commercial re-use, please contact academic.permissions@oup.com 


\subsection{Conclusion}

With directives, we must therefore distinguish two different stages with corresponding different effects on national law.

With its entry into force, until the expiry of the transposition deadline, a directive precludes the Member States following the Inter-Environnement Wallonie and Adelener jurisprudence. As I have explained in Chapter 4, at this stage moreover applies the obligation of the Member States to consider the binding objective of a Union directive when applying national law. Both duties are owed to Article 288 TFEU in conjunction with Article 4 (3) TEU. The 'anticipatory' duty of consideration incumbent on national courts is a precursor to the fully-fledged obligation of consistent interpretation.

The expiry of the transposition deadline of a directive enacted in an area of shared competence transfers the right to exercise competence from the Member States to the Union. Member States, therefore, are precluded from acting within the scope of the directive by exclusivity superveniens. Because of the ERTA effect, they are also precluded from entering into international agreements when these could affect the scope or effect of a directive. Both duties are essentially abstention duties; in the case of ERTA it was originally based on Article 4 (3) TEU and is now provided in Article 3 (2) TFEU. I would submit, for the sake of clarity, that these two effects are conditional on the ending of the deadline for transposition, because if they applied already before that time, there would be no need for the prohibition of frustration. Finally, with the expiry of the deadline for transposition, supremacy applies as substantive supremacy in the shape of direct effect, provided the directive satisfies the requirements of being sufficiently precise and unconditional. In addition, the obligation to interpret national law consistently with the objective of a directive imposes procedural supremacy, setting aside national rules of construction in order to enable the indirect effect of a directive.

The following figure (Figure 5.1) shows the diverse effects and duties depending on the stage of the 'life cycle' of a Union directive.
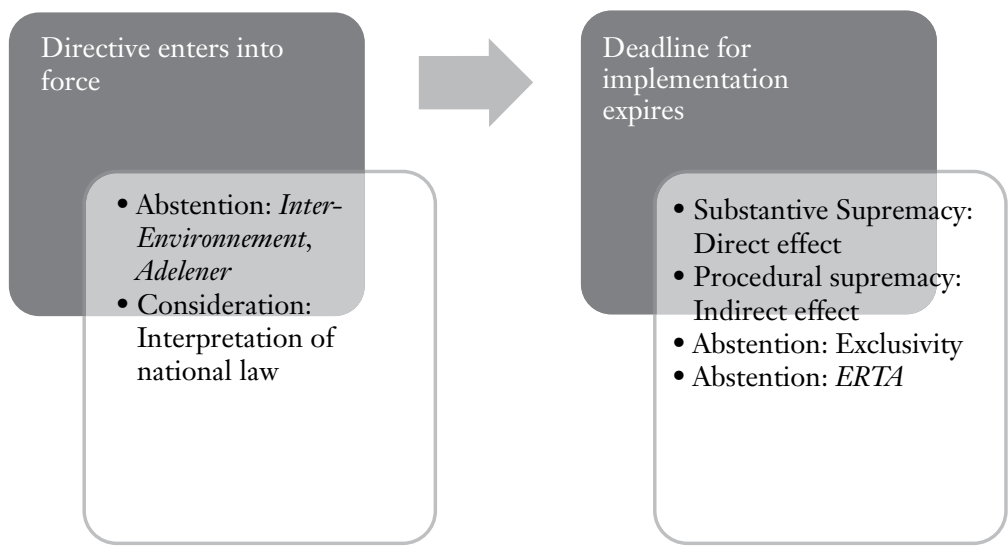

Figure 5.1 Different Effects for Different Stages of the 'Life' of a Directive 


\section{Duties Unrelated to Supremacy Flowing from Preparatory Legal Acts}

\subsection{The Effect of Commission Proposals}

In an early case on the Common Fisheries Policy, the Court prescribed duties of abstention for the Member States after quoting ex Article 10 EC (now Article 4 (3) TEU) in the following terms:

This provision [ex Article $10 \mathrm{EC}$ ] imposes on Member States special duties of action and abstention in a situation in which the Commission, in order to meet urgent needs of conservation, has submitted to the Council proposals which, although they have not been adopted by the Council, represent the point of departure for concerted Community action. ${ }^{49}$

The background of the case was the failure of the Council to pass measures relating to the conservation of the resources of the sea, which it was exclusively competent to do. The Court did not rule out the possibility for a Member State to adopt (limited) measures in this field on its own, but required the Member States 'to seek the approval of the Commission, which must be consulted at all stages of the procedure' ${ }^{50}$ It made clear, however, that, although the Council had not fully regulated in the pertinent field, it had done enough to express its 'intention to reinforce the authority of the Commission's proposals and, on the other hand, its intention to prevent the conservation measures in force from being amended by the Member States without any acknowledged need'. ${ }^{51}$

In this case, thus, a Commission proposal is deemed sufficient for precluding the Member States. ${ }^{52}$ Note, however, that this concerns a policy area where the Union has a priori exclusive competence. In such a policy field, Member States, as a rule, must obtain permission from the Union to act. ${ }^{53}$ The peculiarity of this case is that the Union had failed to act in urgent matters. Only in this constellation was there a legal need to prohibit the Member States from acting in place of the Union. It was decisive that the Council had at least expressed its interest in regulating and had expressed the objectives of its policy on the matter.

The assessment of the Member State rights in the face of a Commission proposal, consequently, is different in other constellations, and even more so when such a proposal is only being prepared. The Sea Fisheries case was thus distinguished by the Court in the Bulk Oil case, where it defined the circumstances justifying unilateral measures by a Member State in an area of exclusive competence in a very narrow manner:

An obligation on the part of the Council to adopt a policy on a fixed date; the Council's inability to comply with that obligation; the existence of a Commission communication approved by the Council under which, in the absence of common rules, national measures can be taken only in so

49 Case 804/79 Commission v United Kingdom (Sea Fisheries) [1981] ECR 1045, para 28. See also Case 325/85 Ireland v Commission (Sea Fisheries) [1987] ECR 5041, para 15; Case 326/85 Netherlands $v$ Commission (Sea Fisheries) [1987] ECR 5091, para 21; Case 332/85 Germany v Commission (Sea Fisheries) [1987] ECR 5143, para 20.

50 Case 804/79 Commission v United Kingdom (Sea Fisheries) [1981] ECR 1045, para 27.

51 Case 804/79 Commission v United Kingdom (Sea Fisheries) [1981] ECR 1045, para 25.

52 See Case 141/78 France v United Kingdom (Sea Fisheries) [1979] ECR 2923, para 8, where the Court held that duties of cooperation are 'particularly necessary in a situation in which it has appeared impossible, by reason of divergences of interest which it has not yet been possible to resolve, to establish a common policy and in a field such as that of the conservation of the biological resources of the sea in which worthwhile results can only be attained thanks to the co-operation of all the member states'.

53 See Chapter 7.

This is an open access version of the publication distributed under the terms of the Creative Commons Attribution-NonCommercial-NoDerivs licence (http://creativecommons.org/licenses/by-nc-nd/3.0/), which permits non-commercial reproduction and distribution of the work, in any medium, provided the original work is not altered or transformed in any way, and that the work is properly cited. For commercial re-use, please contact academic.permissions@oup.com 
far as they are strictly necessary in order to achieve the desired objective, they are not discriminatory, they comply with the Treaty and the Commission's approval has been sought. ${ }^{54}$

Note that the duty of abstention prescribed by the Court in the Sea Fisheries case was based on ex Article 10 EC, and did not merely flow from a priori exclusivity. Exclusivity here was apparently not deemed a sufficiently strong rationale for reining in the Member States. Note that a pronounced interest of the Union did not play a decisive role here.

The case discussed in the following section concerns the exercise of shared competence and a clearer concretization of the Union interest.

\subsection{The Effect of Council Mandates to Negotiate}

The Commission had brought two infringement cases against Luxembourg and Germany in the field of transport policy. ${ }^{55}$ The two Member States had negotiated and concluded bilateral agreements with some central European states, which at that time were not yet European Union members. These agreements concerned the transport of passengers and goods between the parties by inland waterways, and the reciprocal use of their inland waterways in general. After the start of negotiations on these bilateral agreements, but prior to their ratification, the Commission was mandated by a Council decision to negotiate a corresponding Community agreement with the same states. Consequently, the Commission called on the Member States 'to abstain from any initiative likely to compromise the proper conduct of the negotiations initiated at Community level and, in particular, to abandon ratification of agreements already initialled or signed, and to forgo the opening of further negotiations with the countries of Central and Eastern Europe relating to inland waterway transport'. ${ }^{56}$

The Court, in its judgment, after repeating the finding in the Sea Fisheries case, agreed with the Commission and imposed a duty of abstention or 'at the very least a duty of close cooperation' on the Member States concerned. ${ }^{57}$ In the full wording of the Court:

The adoption of a decision authorising the Commission to negotiate a multilateral agreement on behalf of the Community marks the start of a concerted Community action at international level and requires, for that purpose, if not a duty of abstention on the part of the Member States, at the very least a duty of close cooperation between the latter and the Community institutions in order to facilitate the achievement of the Community tasks and to ensure the coherence and consistency of the action and its international representation. ${ }^{58}$

The Court thus drew an analogy between the Commission proposal in the Sea Fisheries case and the negotiating mandate in the present Waterway cases. Both are, thus, a 'point of departure for concerted Community action'. Recall, however, that the Sea Fisheries

54 Case 174/84 Bulk Oil [1986] ECR 559, para 56. See also L. Gormley, 'Some Further Reflections on the Development of General Principles of Law within Article 10 EC', in U. Bernitz, J. Nergelius, and C. Cardner (eds), General Principles of EC Law in a Process of Development (The Hague: Kluwer Law International, 2008), 303-313, 309.

55 Case C-266/03 Commission v Luxembourg (Inland Waterway) [2005] ECR I-4805, and Case C-433/03, Commission v Germany (Inland Waterway) [2005] ECR I-6985.

56 Case C-266/03 Inland Waterway [2005] ECR I-4805, para 18.

57 Case C-266/03 Inland Waterway [2005] ECR I-4805, para 60; Case C-433/03 Inland Waterway [2005] ECR I-6985, paras 60-74. See P.-J. Kuijper, 'Re-reading External Relations Cases in the Field of Transport: The Function of Community Loyalty', in J. Bulterman et al. (eds), Views of European Law from the Mountain. Liber Amicorum for Piet-Jan Slot (The Hague: Kluwer Law International, 2009), 291-300, 300, who sees a violation of ex Art. 300 EC instead of a breach of ex Art. 10 EC.

58 Case C-266/03 Inland Waterway [2005] ECR I-4805, para 60.

This is an open access version of the publication distributed under the terms of the Creative Commons Attribution-NonCommercial-NoDerivs licence (http://creativecommons.org/licenses/by-nc-nd/3.0/), which permits non-commercial reproduction and distribution of the work, in any medium, provided the original work is not altered or transformed in any way, and that the work is properly cited. For commercial re-use, please contact academic.permissions@oup.com 
case concerned a measure under a priori exclusivity, while in the Waterway cases the competence allocation was not exclusive but shared. ${ }^{59}$ Union legislation existing at the time of the Waterway cases, in the opinion of the Court, only regulated market access for Union carriers but not the matters dealt with under the agreements at issue. ${ }^{60}$

While the manifest intention of the Union to exercise its shared competence by means of a negotiating mandate for the conclusion of a Union agreement, in the pertinent cases, restrained the Member States, the Court stopped short of ordering a full duty of abstention. It is argued that this would have been difficult to reconcile with the finding by the Court that there was no exclusive competence in the present case. ${ }^{61}$ It could also not have been justified by referring to the Sea Fisheries case alone, for reasons of its specific background mentioned earlier. ${ }^{62}$ Instead, the emphasis here is on a duty of cooperation and consultation. This is also reflected in the part of the Sea Fisheries case on the requirement 'to seek the approval of the Commission, which must be consulted at all stages of the procedure'. ${ }^{63}$ Reinforcing the requirement for consultation in the case against Germany was the existence of a gentlemen's agreement annexed to the negotiating mandate providing for close coordination between the Commission and the Member States. ${ }^{64}$ The Court held that the Member States' failure to cooperate or consult with the Commission after the Council Decision and, thus, before implementing and ratifying their own agreements 'compromised the achievement of the Community's task'. ${ }^{65}$ Respectively, it 'jeopardised the implementation of the Council Decision and, consequently, the accomplishment of the Community's task and the attainment of the objectives of the Treaty'. ${ }^{66}$ Thus, the Court found a violation of ex Article 10 EC (now Article 4 (3) TEU) on the part of both Germany and Luxembourg. ${ }^{67}$

It has been argued that to impose a duty of abstention in this situation would amount 'to an AETR effect by anticipation'. ${ }^{68}$ At the same time, however, it has been claimed that 'all "duties of action and abstention" do not seem to be ruled out', and that the Court has implicitly imposed 'duties other than those of information and consultation'. ${ }^{69}$ In support of this claim, it has been mentioned that it did not sway the Court that Luxembourg and Germany had offered to terminate their own bilateral agreements eventually once the Union agreement had entered into force. ${ }^{70}$ Indeed, it is difficult to see what the two Member States should have done other than abstaining from ratification of their bilateral agreements. At the least, they would have had to let the Commission dictate the conditions for concluding the agreements. This would have meant re-negotiation, which, as explained in Chapter 14, is the 'normal' consequence of a conflict between new external treaties of Member States and Union law. However, there was no 'Union law' adopted in these cases yet, there was 'only' a mandate to negotiate for the Commission. Thus, it is indeed fair to say that what the Court prescribed in the Waterway cases was a de facto duty of abstention for Germany and Luxembourg.

59 This difference is also emphasized by C. Hillion, 'Mixity and Coherence in EU External Relations: The Significance of the "Duty of Cooperation"', CLEER Working Papers, 2 (2009), 15.

60 Case C-433/03 Inland Waterway [2005] ECR I-6985, paras 48-53.

61 See also M. Cremona, 'Defending the Community Interest: the Duties of Cooperation and Compliance', in M. Cremona and B. de Witte (eds), EU Foreign Relations Law: Constitutional Fundamentals (Oxford and Portland, Oregon: Hart Publishing, 2008), 125-169, 164.

62 But see Kuijper, 'Re-reading', 299.

63 Case 804/79 Commission v United Kingdom (Sea Fisheries) [1981] ECR 1045, para 27.

64 See Case C-433/03 Inland Waterway [2005] ECR I-6985, para 62.

65 See Case C-433/03 Inland Waterway [2005] ECR I-6985, para 62.

66 See Case C-433/03 Inland Waterway [2005] ECR I-6985, paras 69-70.

67 See Case C-433/03 Inland Waterway [2005] ECR I-6985, para 72.

68 Hillion, 'Mixity', 15. 69 Hillion, 'Mixity', 15. ${ }^{70}$ Hillion, 'Mixity', 15.

This is an open access version of the publication distributed under the terms of the Creative Commons Attribution-NonCommercial-NoDerivs licence (http://creativecommons.org/licenses/by-nc-nd/3.0/), which permits non-commercial reproduction and distribution of the work, in any medium, provided the original work is not altered or transformed in any way, and that the work is properly cited. For commercial re-use, please contact academic.permissions@oup.com 
The Waterway cases are another example of how loyalty steps in as the rationale for constraints on Member States' action, when supremacy or exclusivity do not apply. ERTA would only have applied here if the Union had already concluded its own international agreement or had passed internal common rules. Supremacy does not work with regard to external agreements of the Member States, as explained earlier. In addition, the conflict was only imminent here, since Germany and Luxembourg had themselves also not yet concluded their bilateral external agreements. The Court, thus, again resorted to loyalty to resolve the pertinent issue. While this is not expressly stated in the judgment, it can be inferred from its reference to the Sea Fisheries case as authority. The prescribed 'duty of loyal abstention' in the Court's quotation cited earlier is linked to the 'Community tasks', on the one hand, and the 'coherence and consistency of the action and its international representation' on the other. ${ }^{71}$ The former can be seen as a reference to the Union objectives mentioned in Article 4 (3) TEU last sentence. The latter element of coherence and consistency can be seen as a more general restatement of the Union interest in the unity of international representation, which plays an important role with mixed agreements, and is discussed in Chapter 10.

\subsection{The Effect of a Union Strategy in International Conventions}

The Stockholm Convention case ${ }^{72}$ shows that Member States are not only bound by a formal Council decision, but also by other acts on the Union level providing the starting point for concerted action, such as a certain strategy for Union action.

In the case at issue, both the European Union and, among other Member States, Sweden were parties to the Stockholm Convention on Persistent Organic Pollutants (POPs), a multilateral agreement regulating substances harmful to the environment. The Convention required parties to reduce or eliminate the release of POPs listed in its Annexes. As a matter of principle, any party to the Convention may propose a substance to be added to these Annexes, on which a decision is then taken by a conference of the parties. The issue at hand was whether Sweden could unilaterally propose to add a new group of substances, perfluoroctane sulfonates (PFOS), to the agreement. Sweden had threatened to do so if an agreement on a common proposal was not reached in the Council, which was indeed not the case. At the time of Sweden's proposal under the Stockholm Convention, a Union regulatory framework was in place, which however did then not yet include PFOS. ${ }^{73}$ Thus, it was assumed that the proposal concerned a matter for which the Union was not exclusively competent. ${ }^{74}$

In this case, AG Poiares Maduro had proposed to prohibit Member States from taking individual action as long as there was a process ongoing at the EU level, and irrespective of whether Sweden 'felt that its efforts to achieve a common proposal on the addition of PFOs to the Convention were as doomed as lemmings heading towards the edge of a cliff', ${ }^{75}$

71 See Case C-433/03 Inland Waterway [2005] ECR I-6985, para 60.

72 Case C-246/07 Commission v Sweden (PFOS) [2005] ECR I-6985.

73 The question of exclusive competence was not raised in the case. AG Poiares Maduro in his opinion in Case C-246/07 PFOS [2005] ECR I-6985, paras 28-30, qualifies the Community rules as minimum regulation, which prevented the application of the pre-emptive effect.

74 Opinion of AG Poiares Maduro in Case C-246/07 PFOS [2005] ECR I-6985, paras 29-31. But see the discussion on common positions in mixed agreements in Chapter 10.

75 Opinion of AG Poiares Maduro in Case C-246/07 PFOS [2005] ECR I-6985, para 58.

This is an open access version of the publication distributed under the terms of the Creative Commons Attribution-NonCommercial-NoDerivs licence (http://creativecommons.org/licenses/by-nc-nd/3.0/), which permits non-commercial reproduction and distribution of the work, in any medium, provided the original work is not altered or transformed in any way, and that the work is properly cited. For commercial re-use, please contact academic.permissions@oup.com 
In a similar vein, the Court recalled the Sea Fisheries and the Inland Waterway case law. On this basis, it proceeded to 'examine whether, as the Commission maintains, there was at the time a Community strategy in that regard which was not to propose the listing of PFOS immediately in the context of that convention, inter alia for economic reasons' ${ }^{76}$ Indeed, the Court found that PFOS would have been nominated under another agreement, the Aarhus Protocol, 'as soon as the Commission had submitted a proposal for Community legislation on control measures in respect of that substance', and that a number of events showed that that was in fact under way. ${ }^{77}$ The Court did not adopt the view adumbrated by the Advocate General by ruling out that there might have been 'a "decision-making vacuum" or even a waiting period equivalent to the absence of a decision' ${ }^{78}$ Instead, it held that 'in 2005, there was a common strategy not to propose, at that time, to list PFOS in Annex A to the Stockholm Convention', but to propose it instead to the Aarhus Protocol. ${ }^{79}$

It has been correctly posited that the line drawn here by the Court is a fine one, the argument being based on working party minutes and Council conclusions. ${ }^{80}$ Moreover, the general implications of this finding are difficult to assess, since the Stockholm Convention provides for specific rules on proposals by Member States of regional economic integration organizations such as the Union. The voting rights in the Persistent Organic Pollutants Review Committee, which makes obligatory recommendations for listing substances in Annex A to the Convention, are mutually exclusive. ${ }^{81}$ Thus, the Union and its Member States are not entitled to exercise rights under the Convention concurrently. A vote by Sweden would therefore have undermined the position of the Union, ${ }^{82}$ or at least caused 'legal uncertainty for the Member States, the Secretariat of the Stockholm Convention and non-member countries which are parties to that convention'. ${ }^{83}$

Thus, the Court extended the precluding effect of preparatory legislative acts to include also a 'concerted common strategy within the Council', adding however that such proposal 'was submitted within an institutional and procedural framework such as that of the Stockholm Convention'. ${ }^{84}$ The claim for infringement in this case was based on ex Article $10 \mathrm{EC}$ in combination with 'the principle of unity in the international representation of the Union and its Member States'. ${ }^{85}$ This therefore is another example of obligations of Member States which cannot be rationalized either by competence or by supremacy. Accordingly, the Court responded to concerns of some intervening Member States over a 'competence creep' based on ex Article $10 \mathrm{EC},{ }^{86}$ by recalling that loyalty was of a 'general application'. ${ }^{87}$ What is not entirely clear from this case is whether the obligation that Sweden had violated by making the unilateral proposal constituted a duty of abstention or only of standstill. In other words, could Sweden have acted within the framework of the Stockholm Convention if the common strategy within the Council had eventually failed? The general answer to this is given in the part on loyalty and mixed agreements in Chapter 10. The pertinent judgment, it is

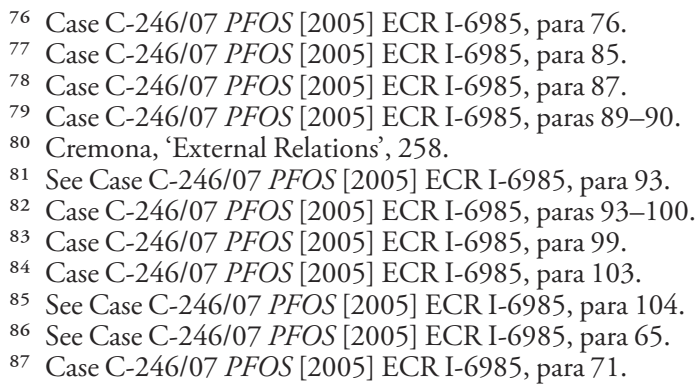

This is an open access version of the publication distributed under the terms of the Creative Commons Attribution-NonCommercial-NoDerivs licence (http://creativecommons.org/licenses/by-nc-nd/3.0/), which permits non-commercial reproduction and distribution of the work, in any medium, provided the original work is not altered or transformed in any way, and that the work is properly cited. For commercial re-use, please contact academic.permissions@oup.com 


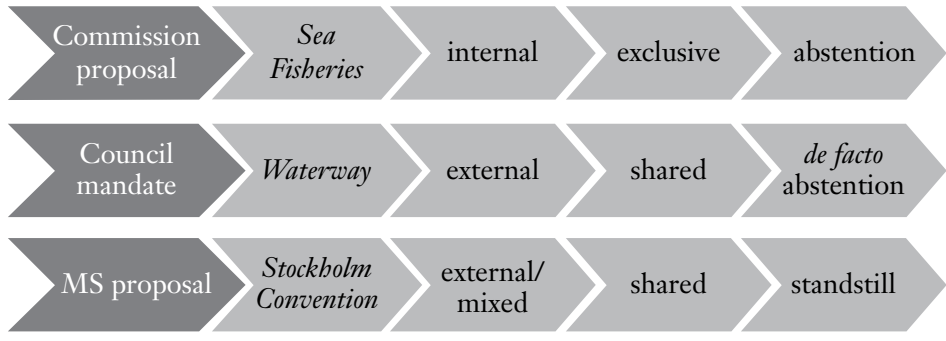

Figure 5.2 Different Triggers for Different Duties of the Member States

suggested, only permits the conclusion that the prescription for Sweden hinged on the existence of the common strategy, which would rather argue for a standstill obligation in this case.

\subsection{Conclusion}

The above figure (Figure 5.2) depicts the decisive elements of the Sea Fisheries case, the Waterway decisions and the Stockholm Convention judgment. It shows that they differ on all accounts including the precise nature of the obligations prescribed. The only commonality is that the precepts are all based on loyalty, coupled with a pronounced Union interest in the latter two instances.

The decisive element mandating a constraint for the Member States is that, in all cases, there was the outline of a 'concerted action' or a 'common strategy' of the Union and that this provided the rationale for the duties imposed on the Member States. Such action or strategy appears to require some involvement of the Council, by expressing its interest in regulating and the objectives of its policy in the Sea Fisheries case, by issuing a negotiating mandate in the Waterway cases, or by adopting a certain strategy for action within the Council. A Commission proposal alone, in either constellation, would arguably not have been sufficient.

While, as explained, these cases are not based on exclusivity or on supremacy, we need to explore in more depth which legal principle or rationale has been applied here. In the following, I will start by discussing the concept of pre-emption, which has not been invoked in relation to the case law discussed earlier as far as I can see. It does however play an important role in the literature for explaining the case law discussed earlier on the effects of Union secondary law. After that, I will look more closely at the merits of loyalty in the present context.

\section{Do We Need a Concept of Pre-emption in Union Law?}

\subsection{Introduction}

Pre-emption has a reputation for being 'one of the most obscure areas of Community law', ${ }^{88}$ and has received a considerable amount of attention over the years by scholars

${ }^{88}$ M. Cappelletti, M. Seccombe, and J.H.H. Weiler, 'Integration Through Law: Europe and the American Federal Experience: A General Introduction', in M. Cappelletti, M. Seccombe, and J.H.H. Weiler (eds), Integration Through Law: Europe and the American Federal Experience, Vol. I (Berlin: de Gruyter, 1986), 3-71, 32; Cross, 'Pre-emption', 448.

This is an open access version of the publication distributed under the terms of the Creative Commons Attribution-NonCommercial-NoDerivs licence (http://creativecommons.org/licenses/by-nc-nd/3.0/), which permits non-commercial reproduction and distribution of the work, in any medium, provided the original work is not altered or transformed in any way, and that the work is properly cited. For commercial re-use, please contact academic.permissions@oup.com 
trying to define its role in Union law. ${ }^{89}$ Moreover, in many texts on European Union law, especially on competences, it is used as if it were on a level with supremacy or direct effect in terms of importance and the certainty of its existence as a distinct principle of Union law. Indeed, some have not distinguished between supremacy and pre-emption at all, considering them to be 'two sides of the same coin'. ${ }^{90}$ Others have likened pre-emption to exclusivity superveniens. ${ }^{91}$ Supremacy and exclusivity are clearly very different on various accounts. While the former can be qualified as an instrument of conflict resolution, exclusivity delimits the spheres of responsibility of the Member States from those of the Union and is thus rather about the prevention of conflicts. Despite the seemingly clear-cut distinction between supremacy and exclusivity and the consensus that these are different kinds of rules in Union law, the literature on pre-emption displays both a discourse in terms of supremacy and a discourse in terms of exclusivity. It thereby probably provides the only example of a discussion of these two principles of Union law in the same context. The mystery of pre-emption is thus not surprising. ${ }^{92}$

In this section, I will argue that it is not apposite to conjure up a legal principle of pre-emption with regard to matters for which Union law has supremacy and exclusivity as established and sufficiently precise concepts. The statement of the Court in the Simmenthal II case, which gave rise to some discussion in respect of the scope of supremacy, ${ }^{93}$ has been invoked as proof of the existence of a principle of pre-emption different from supremacy. The former has been claimed to apply to new legislative measures, while supremacy is supposed to apply to pre-existing national laws. ${ }^{94}$ As a distinct legal principle this view already shows the futility of pre-emption, when the case to which it should apply (i.e., supervening national law) in fact also comes under the scope of supremacy, as explained earlier. It is important to distinguish in theory the constraints imposed on the Member States prior to the entry into force of such new national law as being separate from supremacy, as explained earlier. ${ }^{95}$ However, similar to other theories on pre-emption discussed in the following section that display a delimitation that is more refined, it is submitted, this hardly justifies pre-emption as a legal concept in Union law.

\subsection{No Clear Delimitation of Pre-emption from Competence}

There is also a strong link between the discussion in the literature on pre-emption and on exclusivity superveniens, with pre-emption being used to refer to exclusivity superveniens

89 See, most recently, Schütze, 'Supremacy Without Pre-emption?'.

90 S. Krislov, C.-D. Ehlermann, and J.H.H. Weiler, 'The Political Organs and the Decision-making Process in the United States and the European Community', in M. Cappelletti, M. Seccombe, and J.H.H. Weiler (eds), Integration Through Law: Europe and the American Federal Experience, Vol. I (Berlin: de Gruyter, 1986), 3-112, 90.

91 A. Rosas, 'The European Union and Mixed Agreements', in A. Dashwood and C. Hillion (eds), The General Law of EC External Relations (London: Sweet \& Maxwell, 2000), 203, 205; Cross, 'Pre-emption'; K. Lenaerts and P. Van Nuffel, European Union Law, 3rd edn. (London: Sweet \& Maxwell, 2011), 128-129.

92 See S. Weatherill, 'Beyond Preemption? Shared Competence and Constitutional Change in the European Community', in D. O'Keeffe and P.M. Twomey (eds), Legal Issues of the Maastricht Treaty (London: Chancery Law Publishing, 1994), 13, 18.

93 Case 106/77 Simmenthal II [1978] ECR 629, para 14, where it is stated that the precedence of Community law would 'also preclude the valid adoption of new legislative measures to the extent to which they would be incompatible with Community provisions'. See supra note 10.

94 Cross, 'Pre-emption', 449; C. Calliess, 'Art. 5 EGV', in C. Calliess and M. Ruffert (eds), EUVI $E G V$, 3rd edn. (Munich: Beck, 2007), para 32.

95 See note 10 .

This is an open access version of the publication distributed under the terms of the Creative Commons Attribution-NonCommercial-NoDerivs licence (http://creativecommons.org/licenses/by-nc-nd/3.0/), which permits non-commercial reproduction and distribution of the work, in any medium, provided the original work is not altered or transformed in any way, and that the work is properly cited. For commercial re-use, please contact academic.permissions@oup.com 
as defined earlier. ${ }^{96}$ In other words, the exercise of a shared competence is often considered the cause for the 'pre-emption' of the Member States. We gain nothing, it is submitted, if we call this pre-emption, unless we reduce the import of pre-emption to its ordinary meaning expressing that one actor (here: the Member State) is forestalled by another actor (here: the EU). ${ }^{97}$ Then, however, this would not constitute a legal principle of Union law, but merely be a description of exclusivity superveniens in other terms.

More complex is the theory by Krislov, Ehlermann, and Weiler, who have distinguished pre-emption from supremacy, which is defined as a principle that renders inapplicable a national legal norm conflicting with a 'positive Community measure'. ${ }^{98}$ Weiler, writing individually, in a similar fashion has argued that with supremacy, 'Member States would be precluded from making only those international agreements which were in direct conflict with the Community obligation'. ${ }^{99}$ He has argued that pre-emption, in contrast, 'precedes this situation in the temporal and (legal) spatial sense'. ${ }^{100}$ In a spatial sense this would concern a situation 'where there may not exist a specific Community measure, but where the entire policy area-the legal space-has become "occupied", or even potentially occupied, by the Community in the sense that it is the duty of the Community to fill and regulate that area'. ${ }^{101}$ Pre-emption in a temporal sense is deemed to occur 'even in the absence of, or before the adoption of, a specific Community rule' ${ }^{102}$ Weiler, again individually, writes that under pre-emption, 'Member States would be precluded from any international agreement in the area in question'.

This spatial dimension of pre-emption submitted by Krislov, Ehlermann, and Weiler brings to mind the a priori exclusive competence discussed earlier. ${ }^{103} \mathrm{With}$ such exclusive competence, it is apposite to speak of a 'duty' on the side of the Union to regulate a specific policy area. The same can be said with regard to Weiler's view. The Common Commercial Policy precludes Member States from entering into international agreements on all matters covered by Article 207 TFEU. The temporal perspective on pre-emption referred to earlier, on the other hand, seems to deny any relevance for exclusivity superveniens. Instead, it suggests that pre-emption applies without a Union measure but does not explain in which case exactly.

In my opinion, it does not make much sense to create another term for a priori exclusivity, ${ }^{104}$ just as it is not advisable to use pre-emption as a synonym for exclusivity

96 See the references in note 91.

97 According to the Oxford Online Dictionary, 'to pre-empt' is defined as '[T] ineffective; to preclude; to prevent (an anticipated occurrence), esp. by taking particular action; to take such action in advance of (another person), to forestall'. 'Pre-emption' is defined in the context of US law as ' $[\mathrm{T}]$ he overriding of one piece of legislation by another, typically of a state law by a federal one'.

98 Krislov, Ehlermann, and Weiler, 'The Political Organs', 90.

99 Krislov, Ehlermann, and Weiler, 'The Political Organs', 90.

100 Krislov, Ehlermann, and Weiler, 'The Political Organs', 90.

101 Krislov, Ehlermann, and Weiler, 'The Political Organs', 90.

102 Krislov, Ehlermann, and Weiler, 'The Political Organs', 90.

103 See also Schütze, 'Supremacy Without Pre-emption', 1035. Cross, 'Pre-emption', 453, refutes this distinction between supremacy and pre-emption since it limits the definition of pre-emption to what Cross calls 'occupation of the field pre-emption', ignoring the fact that 'many conflicts between Community legislation and Member State law involve areas of regulation that will continue to be subject to dual regulation by both the Member States and the Community'. I am not entirely clear what Cross means by areas subject to dual legislation unless it refers to areas of shared competences as opposed to areas of a priori exclusivity.

104 But see also F. Jacobs and K. Karst, "The "Federal" Legal Order: The U.S.A. and Europe Compared: A Juridical Perspective', in M. Cappelletti and M. Seccombe (eds), Integration Through Law: Europe and the American Federal Experience (Berlin: de Gruyter, 1986), 169-243, 237: '. . . cases

This is an open access version of the publication distributed under the terms of the Creative Commons Attribution-NonCommercial-NoDerivs licence (http://creativecommons.org/licenses/by-nc-nd/3.0/), which permits non-commercial reproduction and distribution of the work, in any medium, provided the original work is not altered or transformed in any way, and that the work is properly cited. For commercial re-use, please contact academic.permissions@oup.com 
superveniens. If one wanted to define pre-emption, however, it seems flawed to include the case of a priori exclusivity, but not of exclusivity superveniens.

\subsection{No Clear Delimitation of Pre-emption from Supremacy}

Cross was the first to submit a typology of different forms of pre-emption in Union law. ${ }^{105}$ The definition of pre-emption proposed by Cross is broad and purports to 'include all instances of actual or potential conflict between Member State law and Community legislation'. ${ }^{106}$ Cross has divided this further into the categories of 'express saving', 'express pre-emption', 'occupation of the field pre-emption' and 'conflict pre-emption' 107

The first two types of pre-emption refer to provisions in Union legislation that either explicitly allow Member States some room to enact national laws within the scope of the Union measure (express saving), or explicitly bar them from doing so (express pre-emption). ${ }^{108}$ Occupation of the field pre-emption is described as the result of $d e$ facto exhaustive rules of secondary law. ${ }^{109}$ The last category of conflict pre-emption has been defined by Cross as either constituting a conflict between national implementing law and secondary law (direct conflict pre-emption), or when 'national law, although not in direct conflict with Union legislation, "interferes with the proper functioning of the common organization of the market" ' (obstacle conflict pre-emption). ${ }^{110}$

Cross has repeatedly referred to measures enacted under the Common Agricultural Policy to explicate his theory, while the remainder of the cases he discusses concern product harmonization. Cross, thus, has essentially presented a theory on how to classify the different effects secondary law has on the regulatory autonomy of Member States. This is useful as far as it goes, but completely ignores the effects of internal Union measures on the external powers of the Member States. It is submitted that any theory on pre-emption would have to take account also of the external relations side of the relationship between Union and national powers. The same can be said of the most elaborate, German-language study on the subject of pre-emption, which has explicitly acknowledged Cross's influence. ${ }^{111}$ In spite of its comprehensive title, it is also confined to the implications of secondary law on Member State regulatory powers. ${ }^{112}$

The most recent study on pre-emption has been offered by Schütze. ${ }^{113}$ While implying that he reframes the discussion on pre-emption from scratch, Schütze has largely adopted the categories of Cross by distinguishing 'field pre-emption' (which Cross calls occupation of the field pre-emption), 'rule pre-emption' (direct conflict pre-emption in Cross's parlance), and 'obstacle pre-emption' (termed obstacle conflict pre-emption by Cross). Field pre-emption arises, according to Schütze, when the Union

where the Member States are precluded from legislating, not because legislation would conflict with Community law, but because the competence in question is an exclusively Community competence'.

105 Cross, 'Pre-emption'.

107 Cross, 'Pre-emption', 456.

109 Cross, 'Pre-emption', 456.

106 Cross, 'Pre-emption', 471.

108 Cross, 'Pre-emption', 456.

110 Cross, 'Pre-emption', 456.

111 A. Furrer, Die Sperrwirkung des sekundären Gemeinschaftsrechts aufdie nationalen Rechtsordnungen (Baden-Baden: Nomos, 1994) (the pre-emptive effect of secondary Community law on national legal orders).

112 See also the otherwise magisterial analysis by Weatherill, 'Beyond Preemption?', who does not claim to define preemption as a legal concept, however, but rather argues in favour of shared competence and minimum harmonization, at 21 passim.

113 Schütze, 'Supremacy Without Pre-emption', 1033.

This is an open access version of the publication distributed under the terms of the Creative Commons Attribution-NonCommercial-NoDerivs licence (http://creativecommons.org/licenses/by-nc-nd/3.0/), which permits non-commercial reproduction and distribution of the work, in any medium, provided the original work is not altered or transformed in any way, and that the work is properly cited. For commercial re-use, please contact academic.permissions@oup.com 
lawmaker has exhaustively legislated in a specific field of law. ${ }^{114}$ As a result, 'any national legislation within the occupied field is prohibited'. ${ }^{115}$ This has been claimed to 'reproduce the effects of a "real" exclusive competence within the occupied field'. ${ }^{116}$ Obstacle pre-emption, in contrast, presupposes 'the finding that national law somehow interferes with the proper functioning or impedes the objectives of the Community legislation' ${ }^{117}$ Rule pre-emption, finally, has been suggested to denote the 'most concrete form of conflict' between national legislation and 'a specific Community rule' ${ }^{118}$

Schütze has expanded Cross's theory by presenting an explanation for the relationship between pre-emption and supremacy, which has been conspicuously absent in the work of Cross. For him, supremacy 'denotes the superior hierarchical status of the Community legal order over the national legal orders and thus gives Community law the capacity to pre-empt national law' ${ }^{119}$ Pre-emption shall define 'the actual degree to which national law will be set aside by Community legislation'. ${ }^{120}$ Thus, according to Schütze, 'the pre-emption doctrine determines what constitutes a conflict, whereas the supremacy clause decides how that conflict is to be resolved'. ${ }^{121}$ This approach expressly draws on the pre-emption doctrine in US constitutional law. ${ }^{122}$ While the US Constitution also refers to the notion of supremacy, it does not distinguish it from pre-emption. ${ }^{123}$ Pre-emption in US constitutional law is a general title for any sort of conflict of norms, ${ }^{124}$ which is resolved by invalidating conflicting (state) laws, in contrast to Union law. ${ }^{125}$ This arguably explains the fact that the principle of Union law primacy loses any specific role with both mentioned authors.

Consequently, both authors have also qualified the direct conflict between provisions of national law and provisions of Union law as a case of pre-emption. According to Schütze, such conflict, like any other, is resolved by invoking the principle of supremacy and results in the disapplication of national law. This shows how artificial it is in Union law to divide this process by invoking two presumably distinct legal principles, pre-emption as defining the nature of conflict and supremacy for resolving it. While it is certainly useful to emphasize when a conflict between Union law and national law arises, pre-emption is an ambiguous term in this respect when it is meant to adopt a US law concept. Both by its ordinary meaning mentioned earlier, as well as its meaning in US law, pre-emption already comprises the solution to a conflict.

Moreover, Schütze's theory reduces the relationship between supremacy and pre-emption to mere cause-and-effect. As I have already explained, things are more

114 Schütze, 'Supremacy Without Pre-emption', 1040.

115 Schütze, 'Supremacy Without Pre-emption', 1040.

116 Schütze, 'Supremacy Without Pre-emption', 1040.

117 Schütze, 'Supremacy Without Pre-emption', 1041.

118 Schütze, 'Supremacy Without Pre-emption', 1042 (emphasis in the original).

119 Schütze, 'Supremacy Without Pre-emption', 1033 (emphasis in the original).

120 Schütze, 'Supremacy Without Pre-emption', 1033 (emphasis in the original).

121 Schütze, 'Supremacy Without Pre-emption', 1044. This position has already been advanced by M. Waelbroeck, 'The Emergent Doctrine of Community Pre-emption: Consent and Redelegation', in W. Sandelow and E. Stein (eds), Courts and Free Markets: Perspectives from the United States and Europe, Vol. II (Oxford: Oxford Univ. Press, 1982), 548-580, 551.

122 See works as early as G. Glenn, 'Pre-emption in Connection with Unfair Trade', Columbia Law Review, (1919), 29-46; C.E. Glander and A.E. Dewey, 'Municipal Taxation: A Study of the Pre-emption Doctrine’, Ohio State Law Journal, (1948), 72-97. See further G. Sullivan and K. Gunther, Constitutional Law, 14th edn. (New York: Foundation Press, 2001), 314-323.

123 On Art. VI (2) of the US Constitution, see Chapter 2. For a different perspective, see Schütze,

'Supremacy Without Pre-emption', 1039; Cross, 'Pre-emption', 453-455.

124 See Sullivan and Gunther, Constitutional Law, 314-323.

125 See Jacobs and Karst, 'The "Federal” Legal Order', 231-233.

This is an open access version of the publication distributed under the terms of the Creative Commons Attribution-NonCommercial-NoDerivs licence (http://creativecommons.org/licenses/by-nc-nd/3.0/), which permits non-commercial reproduction and distribution of the work, in any medium, provided the original work is not altered or transformed in any way, and that the work is properly cited. For commercial re-use, please contact academic.permissions@oup.com 
complex, especially when taking the external dimension and the effects of Union directives into account. A concept of pre-emption, which is contingent on supremacy or even analogous to it as suggested by Schütze and Cross, fails as an analytical frame for the effects of Union law not coming under supremacy. In other words, I would submit that a concept of pre-emption that cannot capture the full variety of constellations where duties of abstention for the Member States arise has very limited value. If however we were to assign these effects to the mentioned pre-emption categories, this would arguably create more confusion than it actually purports to resolve, as I will demonstrate in the following section.

\subsection{No Clear Categorization}

Neither Cross nor Schütze deal with the Inter-Environnement case law on the abstention duties of Member States during the transposition period for Union directives discussed earlier. Would this come under obstacle pre-emption or under rule pre-emption? Member States are certainly barred from impeding the objectives of Union legislation, viz. of a directive in this case. Does this make it an example of obstacle pre-emption? On the other hand, the directive already constitutes a specific Union rule, which would call for the category of rule pre-emption. In any case, what would we gain if we came to any conclusion on this? We would still need to resort to the specifics of these effects of not implemented directives.

The ERTA effect presents us with similar problems in this context. According to Weiler, the non-affection standard prescribed by the Court in ERTA stands midway between supremacy as a principle of conflict resolution and pre-emption as a concept describing the occupation of a certain policy field by the Union, being 'more than supremacy but less than pre-emption'. ${ }^{126}$ With the ERTA case law, Weiler has remarked, the Court has moved the concept of exclusivity in a 'gray area between supremacy and pre-emption'. ${ }^{127} \mathrm{He}$ has suggested however that more recent case law on ERTA has shown that the Court indeed requires something coming very close to conflict to exist between an internal Union measure and an international agreement by a Member State to trigger this effect. ${ }^{128}$

Weiler's problem with locating ERTA in this respect is understandable when we recall that the conflict underlying ERTA is not a conflict that can be resolved by means of supremacy alone. Thus, if Schütze were serious about the relation between supremacy and pre-emption he has suggested, ERTA could not be qualified as a case of pre-emption, since it does not fully apply supremacy. Irrespective of this problem, would ERTA fall under the mentioned categories of obstacle pre-emption or under field pre-emption? Schütze has qualified the ERTA effect as a case of field pre-emption. ${ }^{129}$ Recall that field pre-emption arises when the Union lawmaker has exhaustively legislated for a specific field of law. ${ }^{130}$ This, however, is not the case with the ERTA doctrine, at least not with the kind now codified in Article 3 (2) TFEU. Schütze himself has rightly emphasized how

126 See Jacobs and Karst, 'The "Federal” Legal Order', 231-233.

127 Weiler, 'Mixity and the Federal Principle', 173.

128 Weiler, 'Mixity and the Federal Principle', 173.

129 R. Schütze, 'Federalism and Foreign Affairs: Mixity as an (Inter)national Phenomenon', in C. Hillion and P. Koutrakos (eds), Mixed Agreements Revisited: The EU and its Member States in the World (Oxford and Portland, Oregon: Hart Publishing, 2010), 57-86, 30. Cross would probably concur on this.

130 Schütze, 'Supremacy Without Pre-emption', 1040.

This is an open access version of the publication distributed under the terms of the Creative Commons Attribution-NonCommercial-NoDerivs licence (http://creativecommons.org/licenses/by-nc-nd/3.0/), which permits non-commercial reproduction and distribution of the work, in any medium, provided the original work is not altered or transformed in any way, and that the work is properly cited. For commercial re-use, please contact academic.permissions@oup.com 
the Court has proceeded in its case law painstakingly comparing the scope of the international agreement envisaged for conclusion by Member States, on the one hand, with the scope of the internal Union measure (the 'common rule') on the other. ${ }^{131}$ Member States are not barred from external action in a 'field' of law in the sense of a certain policy area. The existence of a conflict, in contrast, must be carefully assessed against the scope of the common rule and the envisaged agreement at issue. To subsume the ERTA effect under field pre-emption as defined by Schütze, at any rate, insinuates implications for Member State regulatory powers greater than actually mandated by this principle. ERTA, therefore, rather seems to correspond if at all to the category of rule pre-emption. Again, the question remains what we would gain from such a finding, when it would not free us from considering the specifics of ERTA to fully comprehend its nature.

The $I L O$ principle might be called a case of field pre-emption, since it grants exclusive external power when the Union has regulated 'in a field largely covered by Union measures'. In this case, as explained, there is indeed a preclusion of the Member States' right to enter into international agreements for more than the scope of a specific rule. As will be discussed, however, the exact relation of the ILO principle to the core ERTA doctrine after Lisbon is all but opaque. Again, to assign this principle to a pre-emption category would not really convey any additional information on its application.

Thus, a legal concept of pre-emption, should it have any distinct meaning in Union law, would need to accommodate these effects, as well as the effects of preparatory legal acts of Union rules discussed earlier. The Sea Fisheries case and the Inland Waterway cases equally preclude Member State rights and would therefore have to be accounted for as well. This wide range of effects of Union law on national regulatory and treaty-making authority, it is submitted, makes any meaningful categorization impossible.

\subsection{Conclusion}

I therefore suggest that there is no reason to conceive of pre-emption as a distinct legal principle in Union law. As mentioned already at the beginning of this section, pre-emption is not a concept referred to in case law either. Effects of Union law as diverse as ERTA or those prescribed by the Inter-Environnement Wallonie case law do not gain in transparency when they are forced into categories adopted from US law.

This, on the other hand, should not discourage the use of pre-emption by its ordinary meaning as preventing one party from acting because of a measure taken by another actor. This implies a use for this term especially in the context of the various duties of abstentions unrelated to supremacy and exclusivity explained earlier. In a widely quoted comparative study on US and EU constitutional law, pre-emption in the EU has therefore also been seen as 'going beyond the principle of supremacy', even though this apparently does consider pre-emption to be a distinct legal principle. ${ }^{132}$ It is arguably not necessary to strenuously define a distinct legal concept which is neither used in case law nor mentioned in the Treaty, which cannot provide a useful categorization of the effects of Union law, and which, finally, has in the past caused more confusion about its nature than it has helped us in understanding the mechanism of Union law.

This rejection of pre-emption is underpinned when we realize that there is a principle of Union law which is provided in the Treaty, is invoked by the Court especially when it cannot refer to supremacy or competence, as explained earlier, and of which pre-emption itself has been considered a derivation. This of course is loyalty, to which, for the present purpose, we turn now.

131 Schütze, 'Mixity', 78.

132 Jacobs and Karst, 'The “Federal” Legal Order', 237.

This is an open access version of the publication distributed under the terms of the Creative Commons Attribution-NonCommercial-NoDerivs licence (http://creativecommons.org/licenses/by-nc-nd/3.0/), which permits non-commercial reproduction and distribution of the work, in any medium, provided the original work is not altered or transformed in any way, and that the work is properly cited. For commercial re-use, please contact academic.permissions@oup.com 


\section{The Union Interest}

When neither exclusivity, nor supremacy, nor a concept of pre-emption built on supremacy, can explain important legal consequences of the passing of Union measures and the acts preceding their adoption, there must be another rationale at work here. In all the constellations examined in this section, the Union lawmaker has concretized the objectives of the Treaty, either by passing legally binding measures including international agreements or by engaging in the decision-making process by at least a strategy on action in the Council.

In the present context, the Union interest has been offered as a model of explanation by Cremona. ${ }^{133}$ It has been suggested that it operates prior to the passing of Union legislation or the conclusion of international agreements by the Union as a rule to 'prevent conflict rather than preclude Member State action' ${ }^{134}$ Different from pre-emption, the Union interest, as an expression of the duty of cooperation, has been conceived 'as a restraint on but not a denial of Member State competence'. ${ }^{135}$

If we look at the effects connected with secondary law or preparatory measures of the Union discussed throughout this chapter, it is noteworthy that they all prescribe duties of abstention. Supremacy, in contrast, mandates disapplication and/or substitution and, as explained, is about conflict resolution by precluding Member States, to paraphrase Cremona. This would make the Union interest an instrument of conflict prevention by the definition referred to earlier. If we consider case law such as the Inland Waterway cases or the Stockholm Convention, I am not sure whether this does not underestimate the effects prescribed there. As to the second definition quoted earlier, I would only qualify a priori exclusivity as an outright denial of competence, which the Union interest is claimed not to produce. Exclusivity superveniens, in contrast, denies the Member States the right to exercise their shared competence, but it does not deny this competence per se, as will be explained in the Part on Cooperation. Thus, when Cremona argues that the Union interest is about a restraint of competence, this definition would also seem to fit exclusivity superveniens.

I suggest that especially the case law on the constraining effect of concerted actions and strategies within the Council shows that it is not a principle of Union interest alone which is the legal basis of the prescriptions in these cases. The concept of Union interest can be understood as the broadest possible point of reference for the duty of compliance with or the duty of consideration for certain objectives of Union law. ${ }^{136}$ The Union interest itself however does not impose duties of abstention on the Member States. It does not serve yet as another self-sufficient principle for policing the border between the exercise of Union and national powers. I will come back to these limits of loyalty in Chapter 14 on Amplification.

I would argue instead that the legal basis for the obligations we have discussed is loyalty. The third sentence of Article 4 (3) TEU contains the general duty of abstention linked to Union law objectives. Recall its wording:

The Member States shall facilitate the achievement of the Union's tasks and refrain from any measure which could jeopardise the attainment of the Union's objectives.

133 Cremona, 'Defending the Community Interest', 130.

134 Cremona, 'Defending the Community Interest', 130.

135 Cremona, 'Defending the Community Interest', 168.

136 See also Case 44/84 Hurd [1986] ECR 29, discussed in Chapter 14.

This is an open access version of the publication distributed under the terms of the Creative Commons Attribution-NonCommercial-NoDerivs licence (http://creativecommons.org/licenses/by-nc-nd/3.0/), which permits non-commercial reproduction and distribution of the work, in any medium, provided the original work is not altered or transformed in any way, and that the work is properly cited. For commercial re-use, please contact academic.permissions@oup.com 
I submit that this provision is the basis for binding obligations of abstention of the Member States to protect the Union interest. The Union interest thus provides a point of reference for locating the objectives protected by Article 4 (3) TEU. ${ }^{137}$ As such, the Union interest is safeguarded only if it is expressed in a sufficiently concrete form, which will have to involve at the least the mentioned concerted regulatory action or common strategy within the Council. However, we do not need to stop here.

The Union interest in the Inland Waterway and Stockholm Convention cases was the unity of international representation, or, more generally, the consistency and coherence of Union action. This is a very specific interest relevant in the context of the external relations of the Union. However, since every action of the Union must serve a certain Union interest, it is also involved when the Union passes a directive or other measure. The more concrete and mature in a legal sense the expression of Union interest is, the stricter the obligations flowing from Union law will become. This explains why we must also see the case law on anticipatory effects of directives in this perspective. A directive can be conceived as a concretization of the Union interest by realizing a certain objective of the Treaty. Because of the implementation period of directives, there is a sequence of steps in effecting this interest.

This 'process of interest graduation' starts with a Commission proposal for a legal act. The proposal alone will normally not have any precluding effect on the Member States. ${ }^{138}$ However, a Commission proposal might impose restraints when it provides for the point of departure for concerted Union action following the case law discussed. This would be based on Article 4 (3) TEU as a means of protecting the Union interest, since there is no reason why we should not assume that also in a constellation not related to external relations there could be a Union interest precluding the Member States from acting unilaterally. This could be the case when adoption has to be postponed, but this is only because of a certain strategy within the Council.

\section{Conclusion}

Supremacy, it has been suggested, has its limits. An increasing number of cases decided by the ECJ invoke loyalty or a duty of cooperation and refer to Union interests as arguments for imposing mainly duties of abstention on the Member States. Pre-emption is, for several reasons, not a suitable concept for denoting these operations of Union law. Firstly, no theory on pre-emption has so far accounted for both the internal and the external effects of Union law measures, or has justified its raison-d'etre in Union law, apart from categorization and showing analogies to US law. Secondly, it seems pointless to propose a further principle for referring to supremacy or exclusivity superveniens, when there are other effects of Union measures curtailing the autonomy of the Member States that are not accounted for.

I have proposed instead to see loyalty as the basis for effects extending the import of directives on national regulatory autonomy, or constraining Member States in areas of shared competence. Thus, loyalty would apply across the board in all instances that neither apply supremacy nor are a matter of competence, making it a principle of conflict

137 In 1994, Weatherill remarked that loyalty 'bridges the State/Community gap by stressing the Community context in which national action occurs'. See Weatherill, 'Beyond Preemption?', 31.

138 But see Chapter 8 on the exercise of regular shared competences.

This is an open access version of the publication distributed under the terms of the Creative Commons Attribution-NonCommercial-NoDerivs licence (http://creativecommons.org/licenses/by-nc-nd/3.0/), which permits non-commercial reproduction and distribution of the work, in any medium, provided the original work is not altered or transformed in any way, and that the work is properly cited. For commercial re-use, please contact academic.permissions@oup.com 
resolution on a par with supremacy and exclusivity, and adding substantially to its many other roles discussed in previous chapters of this book. This development may also be owed to the increasing complexity of external relations law, especially where supremacy, as explained, has a particularly weak role and where the competence issue is often shrouded in ambiguity. It thus comes as no surprise that loyalty plays a pivotal role for mixed agreements as the culmination of the competence calamity, as discussed in further detail later.

The Union interest I have suggested to provide the direction for the application of the duty of abstention is provided in a general manner in Article 4 (3) TEU. The reference to a general interest in coherence and consistency of Union action in the Inland Waterway cases suggests that loyalty might also create obligations to safeguard the Union interest outside the realm of external relations. If we want to remain alert to these developments, it is advisable to recognize the potentials of supremacy and exclusivity as well as their inadequacies.

This is an open access version of the publication distributed under the terms of the Creative Commons Attribution-NonCommercial-NoDerivs licence (http://creativecommons.org/licenses/by-nc-nd/3.0/), which permits non-commercial reproduction and distribution of the work, in any medium, provided the original work is not altered or transformed in any way, and that the work is properly cited. For commercial re-use, please contact academic.permissions@oup.com 


\section{6}

\section{Effectiveness, Judicial Protection, and Loyalty}

\section{Introduction}

The effectiveness of Union law means, 'the authorities of the Member State must take the general or particular measures necessary to ensure that Community law is complied with within that state', as the Court put it in Jonkman. ${ }^{1}$ Recall that Article 4 (3) TEU states that the Member States 'shall take any appropriate measure, general or particular, to ensure fulfilment of the obligations arising out of the Treaties or resulting from the acts of the institutions of the Union'. This clearly shows the close relation between effectiveness and loyalty, which will be explored from a methodological perspective in Chapter 13.

It has been noted that the principle of effectiveness is employed by the Court in a number of different constellations, from secondary law and the fundamental freedoms to being applied independently of specific Union legislation. ${ }^{2}$ This Chapter will not discuss effectiveness exhaustively, but will focus on its roles in effective judicial protection and in effective compliance with Union law. As I will argue, these are two interrelated sides to the principle of effectiveness in Union law, and loyalty has repeatedly been mentioned as the legal basis in both strands of case law. Exemplarily, Advocate General Léger has noted the role of loyalty in Factortame as being to ensure the legal protection which persons derive from the direct effect of provisions of Community law', as well as in Francovich as being 'to ensure fulfilment of their obligations under Community law'. ${ }^{3}$

Thus, in the following, I will discuss the role of effectiveness as a means to ensure the effective judicial protection of Union citizens in exercising rights provided in instruments of Union law such as directives. ${ }^{4}$ In this vein, it will be shown that, such as supremacy, the principle of effectiveness can lead either to the disapplication of national (procedural) law or to the introduction of new rules to the realm of national law. ${ }^{5}$ The first approach has been called positive convergence and has been associated with the Francovich/Brasserie case law, whereas the second approach was

1 Joined cases C-231/06 to C-233/06 Jonkman [2007] ECR I-5149, para 38; Case C-495/00 Azienda Agricola Giorgio, Giovanni e Luciano Visentin and Others [2004] ECR I-2993, para 39.

2 M. Ross, 'Effectiveness in the European Union Legal Order(s): Beyond Supremacy to Constitutional Proportionality?', European Law Review, (2006), 476-498, 479.

3 Opinion of AG Léger in Case C-453/00 Kühne \& Heitz NV [2004] ECR-837.

4 See T. Tridimas, The General Principles of EU Law, 2nd edn. (Oxford: Oxford Univ. Press, 2006), 419; A. Arnull, 'The Principle of Effective Judicial Protection in EU Law: An Unruly Horse?', European Law Review, (2011), 51-70; P. Nebbia, 'The Double Life of Effectiveness', Cambridge Yearbook of European Legal Studies, 10 (2007/2008), 287-302; W. Schroeder, Das Gemeinschaftsrechtssystem (Tübingen: Mohr Siebeck, 2002), 435. But see AG Kokott in C-75/08 R. (On the Application of Mellor) $v$ Secretary of State for Communities and Local Government [2009] ECR I-3799, para 28, arguing that the principle of effective legal protection is a specific expression of the principle of effectiveness.

5 See in a similar vein, P. van Cleynenbreugel, 'Judge-Made Standards of National Procedure in the Post-Lisbon Constitutional Framework', European Law Review, 37:1 (2012), 90-100, 91-92. See also T. Heukels and J. Tib, 'Towards Homogeneity in the Field of Legal Remedies: Convergence and Divergence', in P. Beaumont, S. Lyons, and N. Walker (eds), Convergence and Divergence in European Public Law (Oxford and Portland, Oregon: Hart Publishing, 2002), 111, 127, who have argued that the

This is an open access version of the publication distributed under the terms of the Creative Commons Attribution-NonCommercial-NoDerivs licence (http://creativecommons.org/licenses/by-nc-nd/3.0/), which permits non-commercial reproduction and distribution of the work, in any medium, provided the original work is not altered or transformed in any way, and that the work is properly cited. For commercial re-use, please contact academic.permissions@oup.com 
seen to reflect a tendency of negative convergence and was associated with the Rewe case law. ${ }^{6}$

Moreover, I will show the shared ancestry of the principle of state liability with the jurisprudence on the binding force of national decisions. Against this background, more recent case law will be analysed, which is increasingly blurring the border between supremacy, direct effect, and indirect effect both with regard to secondary law as well as international agreements concluded by the Union. This development is connected with judicial control becoming first a general principle of law, ${ }^{7}$ then being awarded constitutional status by the Court ${ }^{8}$ and finally being lifted to the constitutional level by Article 19 (1) TEU9 and Article 47 of the Charter of Fundamental Rights. ${ }^{10}$

\section{The Principle of Effectiveness and the Enforcement of Individual Rights}

\subsection{The Initial Autonomy of the Member States}

In the landmark case Rewe, the Court referred to 'the principle of cooperation laid down in Article 5 of the Treaty' for reminding the national courts of their duty to ensure the legal protection 'which citizens derive from the direct effect of the provisions of Community law'. ${ }^{11}$ It continued that, in the absence of Union rules, it was for the domestic legal system of each Member State 'to designate the courts having jurisdiction and to determine the procedural conditions' with respect to such protection, 'it being understood that such conditions cannot be less favourable than those relating to similar actions of a domestic nature'. ${ }^{12}$ In Denkavit, the Court added that these conditions must not 'make it impossible in practice to exercise the rights which the national courts are bound to protect'. ${ }^{13}$ This thus introduced what was later to be called the 'principle of effectiveness' and the 'principle of equivalence'. ${ }^{14}$

'communautarisation' of national procedural law is characterized by the gradual replacement of national procedural rules by (then) Community law standards on the one hand, and by the creation of (then) Community minimum standards on the other.

6 Heukels and Tib, 'Towards Homogeneity', 127.

7 Case 222/84 Marguerite Johnston [1986] ECR 1651, para 18; Case 222/86 Heylens and Others [1987] ECR 4097, para 14; Case C-424/99 Commission v Austria [2001] ECR I-9285, para 45; Case C-50/00 P. Unión de Pequeños Agricultores v Council [2002] ECR I-6677, para 39; and Case C-467/01 Eribrand [2003] ECR I-6471, para 61.

8 Case C-101/08 Audiolux SA e.a. contre Groupe Bruxelles Lambert SA (GBL) e.a. et Bertelsmann AG e.a. [2009] ECR 2009 I-9823, para 63.

9 Art. 19 TEU requires 'remedies sufficient to ensure effective legal protection in the fields covered by Union law'.

10 See D. Leczykiewicz, “Effective Judicial Protection” of Human Rights After Lisbon: Should National Courts be Empowered to Review EU Secondary Law?’, European Law Review, 35 (2010), 326.

11 Case 33/76 Rewe [1976] ECR 1989, para 5.

12 Case 33/76 Rewe [1976] ECR 1989, para 5. See also Case 45/76 Comet [1976] ECR 2043, paras 11-13; Case 8/79 Hans Just [1980] ECR 501.

13 Case 61/79 Denkavit [1980] ECR 1205, para 12; Case C-312/93 Peterbroeck [1995] ECR I-4599, para 12. See also Case C-212/94 FMC [1996] ECR I-389, para 52.

14 Case C-231/96 Edis [1998] ECR I-4951, para 34; Case C-470/04 Almelo [2006] ECR I-7409, para 59; Case C-201/22 Delena Wells [2004] ECR I-723, para 67. Equivalence will not concern us here further. For a critique of the seemingly two-pronged test, see M. Bobek, 'Why There is no Principle of "Procedural Autonomy" of the Member States', in B. de Witte and H. Micklitz (eds), The European Court of Justice and the Autonomy of the Member States (Cambridge: Intersentia, 2011), 305-322.

This is an open access version of the publication distributed under the terms of the Creative Commons Attribution-NonCommercial-NoDerivs licence (http://creativecommons.org/licenses/by-nc-nd/3.0/), which permits non-commercial reproduction and distribution of the work, in any medium, provided the original work is not altered or transformed in any way, and that the work is properly cited. For commercial re-use, please contact academic.permissions@oup.com 
While these first cases were about the direct effect of a Treaty provision and a regulation, in later judgments the principle of effectiveness was applied in the same manner with the enforcement of the direct effect of directives. ${ }^{15}$ More generally, the ECJ has emphasized repeatedly, 'national authorities may not undermine either the effect or the effectiveness of Community law'. ${ }^{16}$ This makes effectiveness the focal point of mergence of both supremacy and direct effect, ${ }^{17}$ the 'consequential development' of the case law on the direct effect of directives, ${ }^{18}$ and a principle applied in the context of the primacy of Union law, ${ }^{19}$ respectively derived from both supremacy and direct effect. ${ }^{20}$

At the same time, the Court for a long time deferred responsibility to the Member States for establishing a system of legal remedies and procedures in order to ensure effective judicial protection. ${ }^{21}$ This procedural and institutional autonomy in implementing the prescriptions of Union law was expressed in the following dictum of the Court in International Fruit:

Although under Article 5 of the Treaty the Member States are obliged to take all appropriate measures, whether general or particular, to ensure fulfilment of the obligations arising out of the Treaty, it is for them to determine which institutions within the national system shall be empowered to adopt the said measures. ${ }^{22}$

This means that it was up to the Member States to choose which 'specific national bodies' should be competent in the Member States, as well as how these bodies should be entrusted with the powers to implement Union law requirements. ${ }^{23}$ The question of the availability of remedies was also determined under national law. ${ }^{24}$

However, we will show in the following that this balance between the demand of Member States to be active and take measures to protect Union law rights on the one hand, and the non-intervention approach adopted with regard to the ways and means of the required national framework on the other has recently been tipped in favour of intervention. It has thus been claimed, 'the general principle of effective judicial protection seems to have established itself as hierarchically superior to that of national procedural autonomy'. ${ }^{25}$ It has even been proffered that because of its recently gained primary law

15 Case C-271/91 Marshall II [1993] ECR I-4367.

16 Case C-212/94 FMC [1996] ECR I-389; Case C-390/98 Banks \& Co [2001] ECR I-6117.

17 See the references by B. de Witte, 'Direct Effect, Primacy and the Nature of the Legal Order', in P.P. Craig and G. de Búrca (eds), The Evolution of EU Law, 2nd edn. (Oxford: Oxford Univ. Press, 2011), 177-213, 190.

18 K.-D. Borchardt, 'Richterrecht durch den Gerichtshof der Europäischen Gemeinschaften', in A. Randelzhofer, R. Scholz, and D. Wilke (eds), Gedächtnisschrift für Eberhard Grabitz (Munich: Beck, 1995), 29, 36, who notes that direct effect itself has already been an example of judicial lawmaking, yet that this has already been condoned by the German Federal Consitutional Court.

19 Tridimas, General Principles, 5.

20 Tridimas, General Principles, 418.

21 Case C-50/00 P. Unión de Pequeños Agricultores [2002] ECR I-6677, paras 41 and 62; Case C-263/02 P. Jégo-Quéré [2004] ECR I-3425, para 34; Case C-432/05 Unibet [2007] ECR I-2271, paras 38-44; Case C-15/06 P. Regione Siciliana [2007] ECR I-2591, para 39.

22 Joined cases 51 to 54/71 International Fruit Company [1971] ECR 1107, para 3.

23 Joined cases 51 to 54/71 International Fruit Company [1971] ECR 1107, para 3. In several judgments, the Court explicitly used the term discretion in connection with the modalities of the implementation of Union legislation. National authorities must 'exercise their discretion in compliance with the general rules of Community law, which include the principles of proportionality, legal certainty and the protection of legitimate expectations'. See Joined cases C-231/00, C-303/00 and C-451/00 AIMA [2004] ECR I-2869, para 57.

24 Case 158/80 Rewe-Handelsgesellschaft Nord mbH and Rewe-Markt Steffen v Hauptzollamt Kiel [1981] ECR 1805.

25 Arnull, 'The Principle of Effective Judicial Protection in EU Law', 68.

This is an open access version of the publication distributed under the terms of the Creative Commons Attribution-NonCommercial-NoDerivs licence (http://creativecommons.org/licenses/by-nc-nd/3.0/), which permits non-commercial reproduction and distribution of the work, in any medium, provided the original work is not altered or transformed in any way, and that the work is properly cited. For commercial re-use, please contact academic.permissions@oup.com 
position it may produce direct effect in the same vein as the general principle of the prohibition of discrimination on grounds of age in Mangold. ${ }^{26}$

\subsection{The Exclusionary Side of Effectiveness}

It has been argued that under the application of effectiveness, national rules regulating judicial proceedings have only played an 'ancillary' or subservient role in European Union law, and that they were to be set aside to the extent that they significantly impeded effective EU law enforcement. ${ }^{27}$ Thus, based on what is now Article 4 (3) TEU, Member States were prevented from pleading national provisions or domestic practices in order to justify failure to observe obligations and time limits arising from Union regulations. ${ }^{28}$ Similarly, the Court ruled that for the enforcement of a regulation, 'recourse to rules of national law is possible only in so far as it is necessary for the correct application of that regulation and in so far as it does not jeopardise either the scope or the effectiveness thereof...'. ${ }^{29}$

In this context, the Rewe doctrine has been criticized for lack of clarity and predictability in its application in subsequent case law. ${ }^{30}$ Thus, the Peterbroek judgment, where the Court ordered the setting aside of a procedural rule restricting national courts from raising issues of their own motion because it would exclude the application of Union law, has been claimed to represent the nadir of the power of subsistence of national procedural rules in the face of the exigencies of Union law. ${ }^{31}$ On the same day, in Van Schijndel, the Court upheld a similar national rule, distinguishing Peterbroek on the facts. ${ }^{32}$ It seems that this more measured approach has prevailed in cases such as Heemskerk, where the Court held that national courts were not required to consider questions of Union law of their own motion if the result would be to infringe a national principle such as the prohibition of a reformatio in pejus. ${ }^{33}$

However, in the Connect Austria case the exclusionary potential of effectiveness came to full blossom. ${ }^{34}$ Under Austrian law, individuals did not have a right to appeal against decisions of the national regulatory authority on the allocation, removal, and revocation of licences and on the approval of transfers of and amendments to licences in telecommunications matters. While the review by the Constitutional Court was limited

26 Arnull, 'The Principle of Effective Judicial Protection in EU Law', 68.

27 See C. Kakouris, 'Do the Member States Possess Judicial Procedural Autonomy?', Common Market Law Review, 34 (1997), 1390; W. Van Gerven, 'Of Rights, Remedies and Procedures', Common Market Law Review, 37 (2000), 502. See further M. Claes, The National Courts' Mandate in the European Constitution (Oxford and Portland, Oregon: Hart Publishing, 2006), 120-148; R. Schütze, 'Supremacy Without Pre-emption?: The Very Slowly Emergent Doctrine of Pre-emption', Common Market Law Review, 43:4 (2006), 1023-1048, 1031.

28 Case 30/72 Commission v Italy (Premiums for Grubbing Fruit Trees) [1973] ECR 161, para 11.

29 Case C-223/98 Adidas AG [1999] ECR I-7081, para 25.

30 Case C-223/98 Adidas $A G$ [1999] ECR I-7081, para 118

31 C-312/93 Peterbroeck Van Campenhout \& Cie SCS v Belgium [1995] ECR I-4599.

32 Joined cases C-430/93 and C-431/93 Van Schijndel and Van Veen v Stichting Pensioenfonds voor Fysiotherapeuten [1995] ECR I-4705. See S. Prechal, 'Community Law in National Courts: The Lessons From van Schijndel', Common Market Law Review, 35 (1998), 681. Joined cases C-222/05, C-223/05, C-224/05 and C-225/05 Van der Weerd v Minister van Landbouw, Natuur en Voedselkwaliteit [2007] ECR I-4233, para 40.

33 Case C-455/06 Heemskerk and Schaap v Productschap Vee en Vlees [2008] ECR I-8763.

34 Case C-462/99 Connect Austria [2003] ECR I-5197. See for the background and a critique on the complex national implications of this judgment, V. Madner, 'Effektiver gerichtlicher Rechtsschutz, Anwendungsvorrang und zuständige gerichtliche Kontrollinstanz', Zeitschrift für Verwaltung, 1 (2011), 1. See also M. Holoubek, 'Die Zuständigkeit bei unmittelbarer Anwendung von Gemeinschaftsrecht', in M. Holoubek and M. Lang, Abgabenverfahren und Gemeinschaftsrecht (Vienna: Linde, 2006), 65.

This is an open access version of the publication distributed under the terms of the Creative Commons Attribution-NonCommercial-NoDerivs licence (http://creativecommons.org/licenses/by-nc-nd/3.0/), which permits non-commercial reproduction and distribution of the work, in any medium, provided the original work is not altered or transformed in any way, and that the work is properly cited. For commercial re-use, please contact academic.permissions@oup.com 
under the Austrian Constitution, Article 133 (4) B-VG ruled out appeals to the Austrian Administrative Court alleging the unlawfulness of decisions by the national regulatory authority. However, Article 5a (3) of Directive 90/387 required Member States to ensure that suitable mechanisms exist at national level under which a party affected by a decision of the national regulatory authority has a right of appeal to an independent body. ${ }^{35}$ Article 5a (3) of Directive 90/387 was not directly effective-at least the Court did not say so. The Court found that 'the national court must fully apply Community law and protect the rights conferred thereunder on individuals, if necessary disapplying any provision in the measure the application of which would... lead to a result contrary to that directive, whereas national law would comply with the directive if that provision was not applied...' 36

\subsection{The Creationist Side of Effectiveness}

Member States are required to introduce sanctions for breaches of Union law, in case Union legislation does not provide penalties for infringement or refers to national law. ${ }^{37}$ These sanctions must be imposed 'under conditions, both procedural and substantive, which are analogous to those applicable to infringements of national law of a similar nature and importance and which, in any event, make the penalty effective, proportionate and dissuasive'. ${ }^{38}$ Consequently, Article 4 (3) TEU requires that such measures may even include criminal penalties where Union legislation only provides for civil ones. ${ }^{39}$

Similarly, the Court in early case law held that when Union law contains no specific provisions relating to supervision by competent national authorities, the 'only requirement' is that these authorities 'act in this field with the same degree of care as they exercise in implementing their national legislation, so as to prevent any erosion of the effectiveness of Community law' ${ }^{40}$ This thus was an expression of the principle of equivalence. Later, however, Factortame established the principle that a national court seized of a dispute governed by Union law must be in a position to grant interim relief in order to ensure the full effectiveness of the judgment to be given on the existence of the rights claimed under Community law. ${ }^{41}$ Factortame has been called a 'high-water mark of this loyal acceptance of the integrationist logic of Community law'. ${ }^{42}$ It can

35 Council Directive (EEC) 90/387 on the establishment of the internal market for telecommunications services through the implementation of open network provision [1990] OJ L192/1.

36 Case C-462/99 Connect Austria [2003] ECR I-5197, para 40.

37 See Case 50/76 Amsterdam Bulb [1977] ECR 137, para 32.

38 Case 68/88 Commissionv Greece (Community's Own Resources) [1989] ECR 2965; Case C-326/88 Hansen \& Soen [1990] ECR I-2911, para 17; Case C-213/99 de Andrade [2000] ECR I-11083; Case C-185/91 Gebrüder Reiff [1993] ECR I-5801, para 55; Case C-153/93 Delta Schiffahrts- und Speditionsgesellschaft [1994] ECR I-2517, para 14; Case C-67/96 Albany International [1999] ECR I-5751, para 65; Case C-219/97 Maatschappij Drijuende Bokken [1999] ECR I-6121, para 55.

39 Case C-186/98 Criminal Proceedings Against Nunes and de Matos [1999] ECR I-4883, paras 12-14.

40 Joined cases 146, 192, and 193/81 BayWa AG [1982] ECR I-1503, para 22.

41 See also Case C-213/89 Factortame [1990] ECR I-2433, paras 19-21. See also Joined cases C-143/88 and C-92/89 Zuckerfabrik Süderdithmarschen [1991] ECR I-415; Case C-1/99 Kofisa Italia [2001] ECR I-207, para 48; Case C-226/99 Siples [2001] ECR I-277, paras 17-19. cf. M. Nettesheim, 'Grundsatz der Wirksamkeit des Gemeinschaftsrechts', in A. Randelzhofer, R. Scholz, and D. Wilke (eds), Gedächtnisschrift für Eberhard Grabitz (Munich: Beck, 1995), 447-468, 461. See the criticism of the 'inadequate' reply by the Court by A. Barav, 'Omnipotent Courts', in D. Curtin and T. Heukels (eds), Essays in Honour of Henry G. Schermers (Dordrecht: Martinus Nijhoff, 1994), 265-302, 274.

42 See the memorable words of N. MacCormick, Questioning Sovereignty (Oxford: Oxford Univ. Press, 1999), 98: 'Norms that had hitherto been considered central to the basic doctrine of UK constitutional law, the doctrine of parliamentary sovereignty, turned out to be defeasible in favour of a weak

This is an open access version of the publication distributed under the terms of the Creative Commons Attribution-NonCommercial-NoDerivs licence (http://creativecommons.org/licenses/by-nc-nd/3.0/), which permits non-commercial reproduction and distribution of the work, in any medium, provided the original work is not altered or transformed in any way, and that the work is properly cited. For commercial re-use, please contact academic.permissions@oup.com 
therefore be said that procedural autonomy with regard to remedies under national law is confined to the procedural framework, whereas the choice of remedies is mandated by Union law. 43

This creationist side of the principle of effectiveness has also been displayed in recent case law of the Court. Unibet concerned British and Maltese internet betting companies that had advertised in Sweden, but had been stopped by claims by the Swedish authorities of a violation of national gaming laws. Under Swedish law, there was no self-standing action for declaratory judgment in order to dispute the compatibility of the Swedish gaming law with Union law. ${ }^{44}$ The Court argued that Union law should not create new remedies, unless it was 'apparent... that no legal remedy existed which made it possible to ensure, even indirectly, respect for an individual's rights under [Union] law ...'. ${ }^{45}$ In Impact, a specialized Irish court was ordered directly to apply the provisions of a directive, in spite of the fact that national law did not explicitly grant it permission to do so. ${ }^{46}$ The Court referred to the argument of whether a separate claim based directly on the directive before an ordinary court would involve procedural disadvantages' that were liable to render excessively difficult the exercise of the rights conferred by EU law. ${ }^{47}$

Finally, another recent case demonstrates that effectiveness can also mean that competences may be created or that procedural rights that have not existed under national law may be introduced by virtue of Union law. The VEBIC case concerned the Belgian procedural organization of judicial review against decisions by competition authorities within the scope of EU competition law. Council Regulation 1/2003 $3^{48}$ had provided in Article 35, entitled 'Designation of competition authorities of Member States', that the Member States shall designate the competition authority or authorities, including courts, responsible for the application of ex Articles 81 and 82 EC 'in such a way that the provisions of this regulation are effectively complied with'. Moreover, it stated that the Member States may allocate different powers and functions to those different national authorities, whether administrative or judicial. The Court held that Article 35 must be interpreted as precluding national rules which do not allow a national competition authority to participate, as a defendant or respondent, in judicial proceedings brought against a decision that the authority itself has taken. ${ }^{49}$ However, because the 'mere' setting aside of the national rule did not provide an adequate solution in this case, the Court granted the national competition authorities the right to participate in appellate proceedings against their own decisions as a matter of EU law. ${ }^{50}$

reading of Parliament's incapacity to be bound by its own prior decisions. Injunctions ran against a Secretary of State to prevent his acting on a contested Act of Parliament, and the Act itself was in due course disapplied. After twenty years of UK membership in the Communities, the chicken wrapped up in the European Communities Act 1972 came home finally to roost.'

43 Van Cleynenbreugel, 'Judge-Made Standards of National Procedure', 91.

44 Arnull, 'The Principle of Effective Judicial Protection in EU Law', 55-56: 'The judgment in Unibet makes it clear that the overriding consideration is the effective protection of Union law rights.'

45 Case C-432/05 Unibet [2007] ECR I-2271, para 41.

46 Case C-268/06 Impact v Minister for Agriculture and Food [2008] ECR I-2483. See, in a similar vein, Van Cleynenbreugel, 'Judge-Made Standards of National Procedure', 93, who has deemed this case the advent of a new yet unclear standard for effectiveness, requiring not merely the disapplication of national rules, but the development of new national procedural rules.

47 Case C-439/08 Vlaamse Federatie van Verenigingen van Brood-en Banketbakkers, Ijsbereiders en Chocoladebewerkers (VEBIC) VZ [2010] ECR I-12471.

48 Council Regulation (EC) 1/2003 on the implementation of the rules on competition laid down in Articles 81 and 82 of the Treaty [2003] OJ L 1/1.

49 Case C-439/08 VEBIC [2010] ECR I-12471, para 64.

50 Case C-439/08 VEBIC [2010] ECR I-12471, para 59.

This is an open access version of the publication distributed under the terms of the Creative Commons Attribution-NonCommercial-NoDerivs licence (http://creativecommons.org/licenses/by-nc-nd/3.0/), which permits non-commercial reproduction and distribution of the work, in any medium, provided the original work is not altered or transformed in any way, and that the work is properly cited. For commercial re-use, please contact academic.permissions@oup.com 
Thus, all the cases mentioned earlier show that if national procedural law jeopardizes the effective enforcement of EU law, this can lead to the adaptation of national rules, both of a procedural nature as well as of national rules on competence. ${ }^{51}$

\section{Effectiveness and Compliance by the Member States}

Effectiveness has also served the interest of the effective compliance of Member States with Union law, such as expressed in cases like Kradijeveld ${ }^{2}$ and CIA Security. ${ }^{53}$ In the following, however, I will briefly analyse how the Court has 'closed the circle' by establishing a 'loyalty red line' connecting case law on state liability, the binding force of national decisions, and the duty of rectification of national law. All these at first sight very diverse strands of case law are based on loyalty and the idea of the nullification of unlawful consequences of infringements of Union law. ${ }^{54}$

Recall that the Court, in Francovich, rationalized the introduction of the principle of state liability with ensuring 'the full effectiveness of Community rules'. ${ }^{55}$ Effectiveness and state liability here, of course, also serve the interest of the individual in judicial protection, such as in the case law described earlier. However, what distinguishes this example of the application of effectiveness here is that it is not necessarily connected to directly effective rights or supremacy in general, such as with the enforcement case law discussed earlier. In Dillenkoffer, already the failure to transpose a directive into national law within the prescribed time limit was deemed a sufficiently serious breach to give rise to state liability. ${ }^{56}$ Subsequent case law has shown that state liability applies to any form of breach of Union law, including by acts of the national judiciary. ${ }^{57}$ State liability has thus been created by the Court to come to terms with situations when Member States do not comply with their EU law obligations, and when direct effect is unavailable. In such situations, state liability is the ultimate ratio, not for enforcing the substance of the Union instrument concerned, but for making good the damage caused by the omission of a Member State. ${ }^{58}$ This function of effectiveness has even been considered the most important by Tridimas. ${ }^{59}$ Recall further that in Brasserie du Pêcheur the effectiveness rationale for state liability was supported by an explicit reference to what is now Article 4 (3) TEU. ${ }^{60}$

The fact that the payment of damages may not be the only way to nullify the unlawful consequences of an infringement of Union law had already been expressed in Humblet, where the Court spoke of the obligation 'to rescind the measure in question and to make reparation for any unlawful consequences which may have ensued'. ${ }^{61}$ In Wells,

51 See, for an account of the related Case C-279/09 Deutsche Energiehandels-und Beratungsgesellschaft $m b H(D E B) v$ Germany [2011], Van Cleynenbreugel, 'Judge-Made Standards of National Procedure', 94.

52 Case C-72/95 Kraaijeveld [1996] ECR I-5403.

53 Case C-194/94 Security International SA v Signalson SA [1996] ECR I-2201. See Nebbia, 'The Double Life of Effectiveness'.

54 See for the 'circle' methaphor, the Opinion of AG R. J. Colomer in Joined cases C-392/04 i-21Germany GmbH and C-422/04 Arcor AG \& Co. KG [2006] ECR I-8559, para 92.

55 Joined cases C-6/90 and C-9/90 Francovich [1991] ECR I-5357, para 34.

56 Joined cases C-178-9/94, 188-190/94 Dillenkoffer et al. v Germany [1996] ECR I-4845.

57 See Case C-224/01 Gerhard Köblerv Austria [2003] ECR I-10239.

58 Constrast the view by Schroeder, Gemeinschaftsrechtssystem, 435, who relates effectiveness to the uniform application of Union law in the Member States.

59 Tridimas, General Principles, 498.

60 Joined cases C-46/93 and C-48/93 Brasserie du Pêcheur [1996] ECR I-1029.

61 Case 6/60 Humblet [1960] ECR 559, 569.

This is an open access version of the publication distributed under the terms of the Creative Commons Attribution-NonCommercial-NoDerivs licence (http://creativecommons.org/licenses/by-nc-nd/3.0/), which permits non-commercial reproduction and distribution of the work, in any medium, provided the original work is not altered or transformed in any way, and that the work is properly cited. For commercial re-use, please contact academic.permissions@oup.com 
the intimate relation between state liability and the revocation of national decision is clearly shown. ${ }^{62}$ When the United Kingdom contended that there was no obligation on the competent authority to revoke or modify the permission issued for the working of the quarry in issue in this case or to order discontinuance of the working therein, the Court responded with a succession of arguments on Member State duties of nullification. Firstly, referring to Francovich, the Court found that it is clear from settled case-law that under the principle of cooperation in good faith laid down in Article 10 EC the Member States are required to nullify the unlawful consequences of a breach of Community law', and that this obligation was owed by every organ of the Member State concerned. ${ }^{63}$ Secondly, and flowing from this obligation, the Court held that 'all the general or particular measures necessary' would include 'the revocation or suspension of a consent already granted'. ${ }^{64}$ In the pertinent case, this led the Court to find that the national court must determine whether it is possible under domestic law to revoke or suspend a consent that had already been granted, or alternatively, whether it is possible to claim compensation for the harm suffered. ${ }^{65}$

The judgment in Kühne \& Heitz specified the conditions under which the exclusionary side of nullification must be applied. ${ }^{66}$ The facts of the case are well known and need not be repeated. ${ }^{67}$ In essence, a German administrative body had taken a decision that did not conform to a judgment of the European Court of Justice. The Court found that 'the administrative body concerned is, in accordance with the principle of cooperation arising from Article $10 \mathrm{EC}$, under an obligation to review that decision...' ${ }^{68}$ This was confirmed as a matter of principle in Kapferer, where the Court concluded, however, that 'Article $10 \mathrm{EC}$ does not require a national court to disapply its internal rules of procedure in order to review and set aside a final judicial decision if that decision should be contrary to Community law' ${ }^{69}$

Finally, in the third strand of the nullification case law and again based on loyalty, the Court held that direct effect and supremacy 'do not release Member States from their obligation to remove any provisions incompatible with Community law from their domestic legal order' ${ }^{70}$ This obligation is also without prejudice to the principle of state liability. ${ }^{71}$ The rationale is that the maintenance of such provisions would

62 Case C-201/02 Wells [2004] ECR I-723, para 64; Joined cases C-231/06 to C-233/06 Jonkman [2007] ECR I-5149, para 37.

63 Case C-201/02 Wells [2004] ECR I-723, para 64.

${ }^{64}$ Case C-201/02 Wells [2004] ECR I-723, para 65.

${ }^{65}$ Case C-201/02 Wells [2004] ECR I-723, para 70.

66 Case C-453/00 Kühne \& Heitz [2004] ECR I-837.

67 See M. Potacs, 'Bestandskraft staatlicher Verwaltungsakte oder Effektivität des Gemeinschaftsrechts?: Anmerkung zum Urteil vom 13. Januar, Kühne \& Heitz NV/Productschap voor Pluimvee en Eieren, Rs C-453/00', Europarecht, (2004), 595-603; A. Hatje, 'Die Rechtskraft und ihre Durchbrechungsmöglichkeiten im Lichte des Gemeinschaftsrechts', in M. Holoubek and M. Lang (eds), Das EuGH-Verfahren in Steuersachen (Vienna: Linde, 2000) 133-149, W. Frenz, 'Rücknahme eines gemeinschaftsrechtswidrigen belastenden VA', Deutsches Verwaltungsblatt, (2004), 373-376.

${ }_{68}$ Case C-453/00 Kühne \& Heitz [2004] ECR I-837, para 27. This obligation however was subject to several conditions, viz. whether the administrative body has the power to reopen the final decision under national law, the administrative decision in question has become final as a result of a judgment of a national court ruling at final instance, that judgment is based on a misinterpretation of Union law, no preliminary ruling has been sought, and the person concerned complained to the administrative body immediately after becoming aware of the misinterpretation. Case C-453/00 Kühne \& Heitz [2004] ECR I-837, para 28. See also Case C-2/06 Willy Kempter [2008] ECR I-411, paras 38-39.

${ }^{69}$ Case C-234/04 Kapferer [2006] ECR I-2585.

70 Case 104/86 Commission v Italy (Recovery of Undue Payment) [1998] ECR 1799, para 12.

71 Joined cases C-231/06 to C-233/06 Jonkman [2007] ECR I-5149, paras 39-40.

This is an open access version of the publication distributed under the terms of the Creative Commons Attribution-NonCommercial-NoDerivs licence (http://creativecommons.org/licenses/by-nc-nd/3.0/), which permits non-commercial reproduction and distribution of the work, in any medium, provided the original work is not altered or transformed in any way, and that the work is properly cited. For commercial re-use, please contact academic.permissions@oup.com 
cause ambiguity and the resulting legal uncertainty would 'affect rights deriving from Community rules' ${ }^{72}$ To this end, national authorities must ensure that national law is rectified as soon as possible, and that the rights that individuals derive from Union law are given full effect. ${ }^{73}$

Hence, the principle underlying the liability, the revocation, and the rectification strands of case law is that unlawful consequences of breaches of Union law, whatever form they may take, must be nullified, by whatever means required. All this serves the overarching purpose of the effective enforcement of Union law within a Member State, and is ultimately founded on Article 4 (3) TEU.

\section{Effectiveness, Effective Judicial Protection, and Indirect Effect}

So far, I have discussed the indirect effect of Union directives in national law relating to the legal basis of this duty of interpretation. ${ }^{74}$ Moreover, I have dealt with the duty of consideration incumbent on Member States' authorities with regard to the binding objective of directives prior to their entry into force. ${ }^{75}$ Finally, I have explained that supremacy also operates in the context of this interpretation obligation in the form of a disapplication of national methods of interpretation if these prevent the fulfilment of the objective of a directive. ${ }^{76}$ Like state liability, indirect effect does not require the existence of direct effect and the latter principle's effects, viz. the exclusion and/or substitution of substantive national law must be distinguished from the effects of the former, viz. the exclusion and/or substitution of national methods of interpretation. However, recall also that in Marleasing the border between direct and indirect effect has been blurred and that there were several calls for an exclusion effect qua consistent interpretation. ${ }^{77}$ I will show in the following that the employment of these various instruments combined with the increasing reliance on the overarching purpose of effectiveness has begun to blur the borders between direct effect, indirect effect, and the non-frustration obligation.

Indirect effect has the ultimate aim of ensuring the full, correct, and timely implementation of directives. ${ }^{78}$ The connection with effectiveness is revealed in Pfeiffer, where the Court held that the interpretation obligation is inherent in the system of the Treaty, since it permits the national court, for the matters within its jurisdiction, to ensure the full effectiveness of Community law...' ${ }^{79}$ By tying indirect effect to the principle of effective judicial protection, the Court may have bolstered the legal basis for indirect effect. ${ }^{80}$ However, the close relation to the effectiveness case law is already apparent in

72 Case C-264/96 Imperial Chemical Industries [1998] ECR I-4695, para 34.

73 Joined cases C-231/06 to C-233/06 Jonkman [2007] ECR I-5149, para 38.

74 See Chapter $3 . \quad 75$ See Chapter $5 . \quad 76$ See Chapter 6. 77 See Chapter 5.

78 See Case C-54/96 Dorsch Consult [1997] ECR I-4961, para 43, stating that ex Art. 10 EC prescribes the obligation of consistent interpretation 'in the light of the wording and the purpose of the directive so as to achieve the result it has in view'. This does not mean that in general implementation will require a clear and transparent legislative action in a Member State.

79 Joined cases C-397/01 and C-403/01 Pfeiffer [2004] ECR I-8835, para 114, citing C-160/01, Mau, [2003] ECR 4791, para 34, where the nexus between the principle of effectiveness and indirect effect was only made implicitly. More precisely, for the obligation to interpret national law in conformity with Community law, which is apparently meant to encompass indirect effect as an umbrella term, cf. W.-H. Roth, 'Die richtlinienkonforme Auslegung', Europäisches Wirtschafts- und Steuerrecht, 9 (2005), 385-396, 386.

80 S. Drake, "Twenty Years After Von Colson: The Impact of "Indirect Effect" on the Protection of the Individual's Community Rights', European Law Review, 30 (2005), 329-348, 334 passim. See however Klamert, 'Judicial Implementation of Directives and Anticipatory Indirect Effect: Connecting

This is an open access version of the publication distributed under the terms of the Creative Commons Attribution-NonCommercial-NoDerivs licence (http://creativecommons.org/licenses/by-nc-nd/3.0/), which permits non-commercial reproduction and distribution of the work, in any medium, provided the original work is not altered or transformed in any way, and that the work is properly cited. For commercial re-use, please contact academic.permissions@oup.com 
the early von Colson case, which represents both the effective judicial protection paradigm, as well as the duty of consistent interpretation. In von Colson, the Court required Member States 'to adopt measures which are sufficiently effective to achieve the objective of the directive and to ensure that those measures may in fact be relied on before the national courts by the persons concerned'. ${ }^{81}$ It has thus correctly been observed that there is an ancestral line from von Colson on indirect effect via Johnston on effective judicial protection to UPA on the standing of individuals to challenge Union law. ${ }^{82}$ In UPA, the Court held as follows:

... in accordance with the principle of sincere cooperation laid down in Article 5 of the Treaty, national courts are required, so far as possible, to interpret and apply national procedural rules governing the exercise of rights of action in a way that enables natural and legal persons to challenge before the courts the legality of any decision or other national measure relative to the application to them of a Community act of general application, by pleading the invalidity of such an act. ${ }^{83}$

In the Connect Austria case discussed earlier, where national constitutional law had to be set aside, the national courts were also required to use consistent interpretation 'to determine whether domestic law establishes suitable mechanisms to recognise the right of individuals to appeal against decisions of the national regulatory authority'. ${ }^{84}$

At the same time, the recent Angelidaki case shows the connection between the nullification case law and the non-direct effects of directives. ${ }^{85} \mathrm{After}$ requiring the national court to interpret its national law consistent with the pertinent directive, the Court held that national courts must 'so far as possible' 'interpret and apply the relevant provisions of national law in such a way that it is possible duly to punish the abuse and to nullify the consequences of the breach of Community law'. ${ }^{86}$ The Court then required Greece not to frustrate the attainment of the directive's result, followed by the concluding statement that 'all the authorities of the Member States are subject to the obligation to ensure that provisions of Community law take full effect'. ${ }^{87}$

Interestingly, the Marleasing judgment questioned earlier, of all precedents, has come to play an increasing role in recent case law on effective judicial protection. Already in his Opinion in Pfeiffer, AG Colomer required that where it is impossible to provide an interpretation which conforms to the directive concerned, the national court must ensure the full effectiveness of Community law by setting aside on its own authority,

the Dots', Common Market Law Review, (2006), 1254, pointing to the starkly diverging understanding of the judgment by, on the one hand, Drake, 'Twenty Years after Von Colson', 342, who does not consider Pfeiffer to impose an obligation for interpretation contra legem, and K. Riesenhuber and R. Domröse, 'Richtlinienkonforme Rechtsfindung und nationale Methodenlehre', Recht der internationalen Wirtschaft, (2005), 47-54, 52 passim, on the other.

81 Case 14/83 von Colson [1981] ECR 1891. See the very similar wording in Article 6 of Directive $76 / 207$ on equal treatment for men and women as regards access to employment, vocational training and promotion, and working conditions, OJ (1976) L39/40: 'Member States shall introduce into their national legal systems such measures as are necessary to enable all persons who consider themselves wronged by failure to apply to them the principle of equal treatment ... to pursue their claims by judicial process after possible recourse to other competent authorities.'

82 Arnull, 'The Principle of Effective Judicial Protection in EU Law', 53.

83 See Case C-50/00 P. Unión de Pequeños Agricultores [2002] ECR I-6677, para 42; See A. Arnull, 'Annotation to Case C-432/05, Unibet (London) Ltd v Justitiekanslern', Common Market Law Review, 44 (2007), 1763.

84 C-50/00 P. UPA [2002] ECR I-6677, para 39.

85 Joined cases C-378/07 to C-380/07 Kiriaki Angelidaki [2009] ECR I-3071.

86 Joined cases C-378/07 to C-380/07 Kiriaki Angelidaki [2009] ECR I-3071, para 203

87 Joined cases C-378/07 to C-380/07 Kiriaki Angelidaki [2009] ECR I-3071, para 207, referring to Joined cases C-6/90 and C-9/90 Francovich [1991] ECR I-5357, Case C-453/00 Kühne \& Heitz [2004] ECR I-837, and Joined cases C-397/01 and C-403/01 Pfeiffer [2004] ECR I-8835.

This is an open access version of the publication distributed under the terms of the Creative Commons Attribution-NonCommercial-NoDerivs licence (http://creativecommons.org/licenses/by-nc-nd/3.0/), which permits non-commercial reproduction and distribution of the work, in any medium, provided the original work is not altered or transformed in any way, and that the work is properly cited. For commercial re-use, please contact academic.permissions@oup.com 
where appropriate, any conflicting provisions of national law. ${ }^{88}$ The Unibet judgment has finally been claimed to show that a broader principle of effective judicial protection 'imposes on national courts a duty of consistent interpretation reminiscent of that laid down in Marleasing' ${ }^{89}$ Indeed, the way the Court phrased the part on indirect effect and effective judicial protection in this case makes it difficult to ascertain where indirect effect should have its limits for fulfilling this objective. The Court held that 'it is for the national courts to interpret the procedural rules governing actions brought before them ... in such a way as to enable those rules, wherever possible, to be implemented in such a manner as to contribute to the attainment of the objective... of ensuring effective judicial protection of an individual's rights under Community law' ${ }^{90}$ This tension has not gone unnoticed. In her Opinion in Unibet, AG Sharpston doubted that by virtue of the interpretation obligation the national court must extend the right under national law to seek a declaratory judgment to applicants. ${ }^{91}$ She had pointed to the contra legem limit of indirect effect and to the prevailing view in Sweden, that Swedish law could not possibly be construed in such a manner. ${ }^{92}$

Lesoochranárske is another case where the Court seemed impervious to the strong indication that national law could not be interpreted in a manner to accommodate (an international agreement forming a part of) Union law. ${ }^{93}$ A Slovak environmental protection association (the 'zoskupenie') had been informed of the initiation of a number of administrative proceedings brought by hunting associations on the grant of derogations to the system of protection for species such as the brown bear, access to protected countryside areas, and requests for the use of chemical substances in such areas. The zoskupenie applied to the Slovak Ministry of the Environment to be given the status of a party to the administrative proceedings concerning the grant of those derogations. However, since environmental associations can only be 'participants' in administrative proceedings according to Slovak law, this request was rejected at the administrative level. In the subsequent court proceedings, the zoskupenie argued that Article 9 (3) of the Aarhus Convention had direct effect. ${ }^{94}$ The direct effect of Article 9 (3) was denied by the Court. ${ }^{95}$ It then made broad references to the Impact case, concluding that if the effective protection of EU environmental law is not to be undermined, it is inconceivable that Article 9(3) of the Aarhus Convention be interpreted in such a way as to make it in practice impossible or excessively difficult to exercise rights conferred by EU law' ${ }^{96}$ The Court continued that it would be for the national court, in order to ensure effective judicial protection in the fields covered by EU environmental law, to interpret its national law in a way that, to the fullest extent possible, is consistent with the objectives laid down in Article 9 (3) of the Aarhus Convention. ${ }^{97}$

88 AG Colomer in Joined cases C-397/01 and C-403/01 Pfeiffer [2004] ECR I-8835, para 58.

89 Arnull, 'The Principle of Effective Judicial Protection in EU Law', 55.

90 Case C-432/05 Unibet [2007] ECR I-2271, para 44. See similar Case C-63/08 Pontin [2009] ECR I-10467, para 75, referring by analogy to Case 222/84 Marguerite Johnston [1986] ECR 1651, para 17, Case C-185/97 Coote [1998] ECR I-5199, para 18, and Case C-268/06 Impact v Minister for Agriculture and Food [2008] ECR I-2483, para 54.

91 AG Sharpston in Case C-432/05 Unibet [2007] ECR I-2271, para 54.

92 See AG Sharpston in Case C-432/05 Unibet [2007] ECR I-2271, para 55.

93 Case C-240/09 Lesoochranárske Zoskupenie VLKv Ministerstvo Životného Prostredia Slovenskej Republiky [2011] ECR I-1255.

94 This provision obliges the parties to the Convention to ensure that members of the public 'have access to administrative or judicial procedures to challenge acts and omissions by private persons and public authorities which contravene provisions of its national law relating to the environment'.

95 Case C-240/09 Lesoochranárske [2011] ECR I-1255, para 46.

96 Case C-240/09 Lesoochranárske [2011] ECR I-1255, paras 47-49 (emphasis added).

97 Case C-240/09 Lesoochranárske [2011] ECR I-1255, para 50. See also para 51 for the references to Unibet and Impact and the conclusion that it is the duty for the referring court 'to interpret, to the fullest

This is an open access version of the publication distributed under the terms of the Creative Commons Attribution-NonCommercial-NoDerivs licence (http://creativecommons.org/licenses/by-nc-nd/3.0/), which permits non-commercial reproduction and distribution of the work, in any medium, provided the original work is not altered or transformed in any way, and that the work is properly cited. For commercial re-use, please contact academic.permissions@oup.com 
I have argued elsewhere that this finding can only be understood based on the Court's earlier claim that Article 9 (3) of the Aarhus Convention fell within the scope of EU law because of the Habitats Directive. By this argument, the Court managed to make the access to justice in Article 9 (3) a procedural right conferred by EU law and, consequently, the standard of interpretation for national law. ${ }^{98}$ Moreover, this has been the first time as far as I can see that the Court has imposed a duty of consistent interpretation of national law in the light of international agreements. ${ }^{99}$ Again, the wording recalls the Marleasing formula, and again, national law was not very receptive to such interpretative solution.

\section{Effectiveness, Effective Judicial Protection, and Duties of Abstention}

In the preceding chapters, I have explained that loyalty is the basis of duties of abstention for the Member States, and that these duties can be unrelated to supremacy. I have also expounded that Union directives cannot partake in the effects of supremacy, viz. substitution and/or exclusion, before the implementation period has expired for the Member States. ${ }^{100}$ Recall that the abstention duty established in the Inter-Environnement Wallonie line of case law, which I have discussed earlier, took effect before the expiry of the transposition deadline of a directive, and did thus not presuppose its direct effect. The Impact case discussed in the following suggests that one of these two qualifications to the non-frustration obligation may no longer be valid in the context of effective judicial protection. ${ }^{101}$

Impact concerned a reference by an Irish court on the interpretation of the framework agreement on fixed-term work annexed to Directive 1999/70. ${ }^{102}$ The directive was only implemented by Ireland in 2003, two years after the expiry of the deadline. Note therefore that, in contrast to Inter-Environnement Wallonie, the case is situated in the 'post-term' period, yet pre-transposition. The referring court had asked whether provisions of the framework agreement were directly effective. While affirming that framework agreements implemented by Council directives might have direct effect, the Court found that the framework's provision on preventing abuse arising from the use of successive fixed-term contracts did not possess direct effect, because it let Member States choose from a range of alternative methods for preventing such abuse. Thus, direct effect was wanting here not because of the nature of the relationship involved, which

extent possible, the procedural rules relating to the conditions to be met in order to bring administrative or judicial proceedings in accordance with the objectives of Article 9(3) of the Aarhus Convention and the objective of effective judicial protection of the rights conferred by EU law, so as to enable an environmental protection organisation, such as the zoskupenie, to challenge before a court a decision taken following administrative proceedings liable to be contrary to EU environmental law'.

98 An international agreement can only be the yardstick for the interpretation of national law if it forms a part of Union law. Since this depends on the Union's competence, such analysis cannot evade an assessment in these terms, and applying reasoning based on the 'sphere of EU law' such as in Merck or the 'application' or 'scope' of EU law such as in Lesoochranárske is no substitute for this.

${ }_{99}$ Such duty has previously only concerned Union secondary law. See P. Eeckhout, EU External Relations Law, 2nd edn. (Oxford: Oxford University Press, 2011), 355-357.

100 Case C-129/96 Inter-Environnement Wallonie [1997] ECR 7411, paras 40, 43-44.

101 Case C-268/06 Impact [2008] ECR I-2483.

102 Council Directive (EC) $1999 / 70$ concerning the framework agreement on fixed-term work concluded by ETUC, UNICE, and CEEP [1999] OJ L175/43. This directive was also relevant in Case C-155/04 Mangold [2005] ECR I-9981.

This is an open access version of the publication distributed under the terms of the Creative Commons Attribution-NonCommercial-NoDerivs licence (http://creativecommons.org/licenses/by-nc-nd/3.0/), which permits non-commercial reproduction and distribution of the work, in any medium, provided the original work is not altered or transformed in any way, and that the work is properly cited. For commercial re-use, please contact academic.permissions@oup.com 
was vertical, but because of the insufficient level of determination of the framework agreement's provision.

The referring court then wanted to know whether a Member State, acting as an employer, was precluded from renewing a fixed-term employment contract for up to eight years shortly before the national implementing legislation entered into force. According to the Opinion of AG Kokott in Impact, this should not have been the case in view of the absence of direct effect. ${ }^{103}$ The Court in contrast found that the Directive's obligation would be rendered ineffective if a Member State, acting as an employer, were permitted to renew contracts for an unusually long term in the period between the expiry of the deadline for implementation and the entry into force of the national implementing legislation. ${ }^{104}$ For this finding, it relied on ex Article 10 EC, the third paragraph of ex Article 249 EC, and on Directive 1999/70 itself. ${ }^{105}$

The judgment in Impact has been criticized for blurring the boundaries between direct effect and the duty of abstention as operated in the Inter-Environnement Wallonie case law. ${ }^{106}$ While it has been argued that the ruling in Inter-Environnement Wallonie might extend a fortiori beyond the expiry of the implementation deadline where measures giving effect to the directive have not been adopted in good time, it has been observed that the consequences of the Impact decision seem to be markedly different from those of the Inter-Environnement Wallonie case. ${ }^{107}$ In Impact, the effect prescribed by the Court precluded Ireland from renewing employment contracts for a certain term. This cannot be compared to direct effect on formal grounds because there was no Union law norm applied to exclude provisions of national law, such as has occurred in CIA Security or Wells. ${ }^{108}$ Clearly, the rationale of the decision in Impact was to safeguard the effect of the directive's objective, which would have been seriously compromised had Ireland as an employer created a contractual fait accompli before the entry into force of the implementing laws.

Hence, the finding in Impact did not involve supremacy, nor did it rely on direct effect (that is based on supremacy). I would argue that the rationale must be sought in loyalty, which here establishes a rather pragmatic solution for a breach of Union law, which needs a more effective sanction than available under the infringement procedure. This means, however, that the difference between the Inter-Environnement Wallonie case law and what has been called exclusionary (direct) effect has been eroded, which the Court should have acknowledged in its judgment by setting its finding in relation to Inter-Environnement Wallonie. Moreover, this finding in Impact implies that it is the objective of a directive which is vested with powers to establish duties of abstention for the Member States, independent from the direct effect of individual provisions in directives.

\section{Conclusion}

The fundamental right to an effective remedy in Article 47 of the Charter and the principle of sincere cooperation have been suggested as the two main constitutional principles enabling the creation of procedural standards by the European Court of Justice. ${ }^{109}$

\footnotetext{
103 AG Kokott in Case C-268/06 Impact [2008] ECR I-2483.

104 Case C-268/06 Impact [2008] ECR I-2483, para 91.

105 Case C-268/06 Impact [2008] ECR I-2483, para 90.

106 Arnull, 'The Principle of Effective Judicial Protection in EU Law', 59.

107 Arnull, 'The Principle of Effective Judicial Protection in EU Law', 59.

108 Arnull, 'The Principle of Effective Judicial Protection in EU Law', 69.

109 Van Cleynenbreugel, 'Judge-Made Standards of National Procedure', 95.
}

This is an open access version of the publication distributed under the terms of the Creative Commons Attribution-NonCommercial-NoDerivs licence (http://creativecommons.org/licenses/by-nc-nd/3.0/), which permits non-commercial reproduction and distribution of the work, in any medium, provided the original work is not altered or transformed in any way, and that the work is properly cited. For commercial re-use, please contact academic.permissions@oup.com 
It has been argued that what is at work here is 'guided deference', where the ECJ provides a blueprint for national courts for a coherent and unified procedural framework, with the right to a fair trial and the principle of loyal cooperation demanding a judicial dialectic between the national and the EU level. ${ }^{110}$ Thus, curiously, here for once loyalty has been relied on to counter claims of judicial activism. ${ }^{11}$

This could, however, also been seen differently. Loyalty and the fundamental right to an effective remedy could be seen to provide the two additional constitutional bases in combination with Article 19 (1) TEU to legitimize a mandate for the Court to intervene in matters of national procedural law. The Impact case in particular could be qualified as requiring that the fundamental principle of effective judicial protection were directly applied within national law. It has thus been observed that the principle of effective judicial protection, as a general principle of law with constitutional status in certain circumstances may produce direct effect and this may lead to renewed activism on the part of the Court. ${ }^{112}$ Indeed, what else was prescribed in the Inter-Environnement Wallonie case law than a form of exclusionary effect of directives, yet pre-term, while in Impact, this effect was post-term?

The close relationship between loyalty and effective judicial protection, which I have demonstrated, has prompted Arnull to submit that the clause 'Member States shall provide remedies sufficient to ensure effective legal protection in the fields covered by Union law' in Article 19 (1) TEU should better be included at the end of Article 4 (3) TEU. ${ }^{113}$ This is an apposite observation in view of the fact that Union loyalty places the bulk of its obligations on the Member States, and in view of the fact that loyalty plays a ubiquitous role in all duties imposed on the Member States to further the effectiveness of Union law in a broad sense. I would suggest that there is no need to conceive effective judicial protection as a general principle in its own right. It could instead be argued that it embodies a qualified constitutional interest of the Union. As such, it could be made effective based on Article 4 (3) TEU by imposing duties of abstention irrespective of direct effect and supremacy. This would, however, run counter to the requirement I have defended that a Union interest must be sufficiently concrete.

110 Van Cleynenbreugel, 'Judge-Made Standards of National Procedure', 97: 'Sincere co-operation thus requires the Court to take harmonised legislation into account; but if such legislation does not exist, the principle invites the Court to develop particular standards that could guide national procedural systems in implementing the right to a fair trial under art. 47 of the Charter.

111 See Van Cleynenbreugel, 'Judge-Made Standards of National Procedure', 95.

112 Arnull, 'The Principle of Effective Judicial Protection in EU Law', 68.

113 Arnull, 'The Principle of Effective Judicial Protection in EU Law', 53. In Art. 19 the provision is located in a title headed 'Provisions on the Institutions' with the rest of it concerning the Court of Justice.

This is an open access version of the publication distributed under the terms of the Creative Commons Attribution-NonCommercial-NoDerivs licence (http://creativecommons.org/licenses/by-nc-nd/3.0/), which permits non-commercial reproduction and distribution of the work, in any medium, provided the original work is not altered or transformed in any way, and that the work is properly cited. For commercial re-use, please contact academic.permissions@oup.com 


\section{Conclusion of the Part on Cohesion}

Loyalty is the basis of various effects of Union measures and other expressions of the Union interest on national regulatory and contractual autonomy. We have seen that it fills gaps in constellations where supremacy or competence cannot take full effect. This can concern the need for effects cross-cutting from the internal to the external domain, cases where there is no conflict between national and EU measures, or where the Union measures have not yet 'matured' to take full effect, such as with directives before the expiry of the transposition or a concerted action in the Council. The underlying rationale and the required point of reference for the resulting duties of abstention is a qualified Union interest as a specific concretization of a Union objective. I have shown that there are no convincing reasons to refer to a distinct legal principle of pre-emption to explain these matters.

I have also discussed the common genealogy of two seemingly very different strands of case law, viz. on the effective judicial protection of Union citizens in exercising rights provided in instruments of Union law, and on the compliance by the Member States with Union law. In both strands of the case law, which are commonly seen as based on the principle of effectiveness, loyalty has taken very diverse and arguably central roles. This shared conceptual and systematic basis of the 'nullification' and the 'revocation' case law makes effective judicial protection a close relation of a traditionally very interventionist side of Union law.

Thus, while there is still an inherent limit with directives because of the Member State prerogative in Article $288 \mathrm{TFEU}$, state liability shows that the nullification paradigm can also spawn rules that transplant national standards. This, I have shown, reflects on recent case law on judicial protection, where the Court has approached the watershed where indirect pre-emptive effect strongly resembles exclusionary direct effect. This would make sense if we understood effective judicial protection as a qualified constitutional interest of the Union. However, as I will discuss in Part III regarding the interest in the unity of international representation, without concretization such interest cannot create obligations for the Member States.

This is an open access version of the publication distributed under the terms of the Creative Commons Attribution-NonCommercial-NoDerivs licence (http://creativecommons.org/licenses/by-nc-nd/3.0/), which permits non-commercial reproduction and distribution of the work, in any medium, provided the original work is not altered or transformed in any way, and that the work is properly cited. For commercial re-use, please contact academic.permissions@oup.com 
This is an open access version of the publication distributed under the terms of the Creative Commons Attribution-NonCommercial-NoDerivs licence (http://creativecommons.org/licenses/by-nc-nd/3.0/), which permits non-commercial reproduction and distribution of the work, in any medium, provided the original work is not altered or transformed in any way, and that the work is properly cited. For commercial re-use, please contact academic.permissions@oup.com 


\section{PART III}

\section{COOPERATION IN THE EUROPEAN UNION}

\section{Introduction}

In Part II, I focused on the importance of loyalty for the legal cohesion of European Union law by virtue of principles such as supremacy and effectiveness. I will now turn to a discussion of the role of loyalty in shaping the rules on how the Member States and the Union cooperate with each other. This part thus continues to show the wide range of the various roles of loyalty and the diverse yet related duties that have been applied based on them. 'Hard', confrontational rules, such as supremacy and duties of abstention, are discussed alongside 'softer', cooperative duties, such as duties of consideration and coordination.

I will start by discussing the situation regarding competence following the Lisbon Treaty. Here especially issues pertaining to what have hitherto been called 'implied external competences' are addressed. Principles such as those introduced by the ERTA case law, which, as already mentioned, have their basis in ex Article 5 EEC, are now 'codified' in the Lisbon Treaty. This raises some fundamental questions on the success of this drafting effort, and the implications for our general understanding of the interpretation of competences in the European Union.

Other matters examined in this Part concern the importance of loyalty for governing the exercise of shared and supporting competences. The difficult to fathom 'irregular' shared competences, such as development cooperation, are exemplary for raising questions as to the Union's relationship with the Member States in an area not primarily regulated by the principles of supremacy or exclusivity. I will also discuss manifestations of loyalty in Union secondary law, which reflect some of its diverse roles, ranging from 'hard' duties of standstill and abstention to 'softer' obligations of notification and consideration.

In a final chapter of this part of the book, the pertinence of loyalty for mixed international agreements is assessed. Mixity very often is the legal formula for the exercise of non-exclusive competences in the external sphere. In crucial contrast to their exercise for internal lawmaking, externally, the issue of managing the so-called vertical axis between the Union and the Member States is complicated by the import of international law and the need to consider the perspective of third states. I will discuss, among other things, loyalty's relation to the pervasive principle of the unity of international representation, and will suggest some general guidelines for applying loyalty in this context. On this basis, precepts with regard to the different stages in the process of negotiating, concluding, and acting under such agreements are explored, such as the complex issues surrounding common positions by the Council.

This is an open access version of the publication distributed under the terms of the Creative Commons Attribution-NonCommercial-NoDerivs licence (http://creativecommons.org/licenses/by-nc-nd/3.0/), which permits non-commercial reproduction and distribution of the work, in any medium, provided the original work is not altered or transformed in any way, and that the work is properly cited. For commercial re-use, please contact academic.permissions@oup.com 
This is an open access version of the publication distributed under the terms of the Creative Commons Attribution-NonCommercial-NoDerivs licence (http://creativecommons.org/licenses/by-nc-nd/3.0/), which permits non-commercial reproduction and distribution of the work, in any medium, provided the original work is not altered or transformed in any way, and that the work is properly cited. For commercial re-use, please contact academic.permissions@oup.com 


\section{7 \\ A Primer on Union Competences}

\section{Codification in the Lisbon Treaty}

With the Lisbon Treaty we are facing a novelty in European Union law since, for the first time, case law by the European Court of Justice in a matter of utmost complexity, with key cases dating back to the 1960s, has been 'codified' in the Treaty. ${ }^{1}$ This effort is the result of a long debate about the order of competences in the European Union occasioned by the Draft Constitutional Treaty. ${ }^{2}$ This codification begs the initial and fundamental question on how to deal with this novel situation when assessing the new provisions on competences in the Lisbon Treaty. Do we consider them the new 'law of the land' and accept that they are perhaps not meant to reflect faithfully in every detail the case law regime applying before the entry into force of the Lisbon Treaty, but that they are, crucially, meant to be complete? ${ }^{3}$ Alternatively, is it apposite to examine and interpret the new Treaty provisions on competences in light of (pre-Lisbon) case law and review them by the same standards that have been applied to this case law previously?

The intention behind the codification in the Lisbon Treaty clearly was to provide a conclusive, complete rendition of the order of competences. It was meant to make 'explicit the jurisprudence of the Court to facilitate the action of the Union in a globalised world, in particular when dealing with the external dimension of internal policies and action'. ${ }^{4}$ As I will also argue in Chapter 11, travaux préparatoires as expressions of the historical, subjective intentions behind the drafting of the Treaties should play a greater role now. With regard to the formerly implied external competences, this militates for considering Articles 3 (2) and 216 (1) TFEU as providing the full and complete picture after Lisbon. Thus we would have to understand the statement in Article 216 (1) TFEU

\footnotetext{
1 On the external dimension of the Lisbon Treaty see, among many others, M. Cremona, 'Defining Competence in EU External Relations: Lessons from the Treaty Reform Process', in A. Dashwood and M. Maresceau (eds), Law and Practice of EU External Relations: Salient Features of a Changing Landscape (Cambridge: Cambridge Univ. Press, 2008), 34-69; J. Wouters, D. Coppens and B. de Meester, 'The European Union's External Relations after the Lisbon Treaty', in S. Griller and J. Ziller (eds), The Lisbon Treaty: EU Constitutionalism without a Constitutional Treaty (Vienna, New York: Springer, 2008), 143203. I have discussed two of the central cases in this respect-Case 22/70 Commission v Council (ERTA) [1971] ECR 263 and Opinion 1/76 European Laying-up Fund [1977] ECR 741—in Chapter 3.

2 See, among many others, P.P. Craig, 'Competence: Clarity, Conferral, Containment and Consideration', European Law Review, (2004),323-344;A. Hable, 'TheEuropean Constitution: Changes in the Reform of Competences with a Particular Focus on the External Dimension', Working Paper of the Research Institute for European Affairs, (2005); B. de Witte, 'Clarifying the Delimitation of Powers', and I. Pernice, 'Rethinking the Methods of Dividing and Controlling the Competencies of the Union', both in Europe 2000-Le Grand Debat, available at <http://ec.europa.eu/governance/whats_new/ europe2004_en.pdf> (last accessed 7 January 2013).

3 See P.P. Craig, The Lisbon Treaty: Law, Politics and Treaty Reform (Oxford: Oxford Univ. Press, 2010), 167: 'The translation of highly complex case law into the form of a Treaty article is always difficult. The almost inevitable tendency is to shed certain of the nuances from that jurisprudence in order to be able to put something down on paper in manageable form.'

${ }^{4}$ Final report of Working Group VII on External Action, 16 December 2002, Conv 459/02.
}

This is an open access version of the publication distributed under the terms of the Creative Commons Attribution-NonCommercial-NoDerivs licence (http://creativecommons.org/licenses/by-nc-nd/3.0/), which permits non-commercial reproduction and distribution of the work, in any medium, provided the original work is not altered or transformed in any way, and that the work is properly cited. For commercial re-use, please contact academic.permissions@oup.com 
that the Union, among other things, possesses treaty-making power 'where the Treaties so provide'. This can be read as a specific declaration of the principle of conferral with regard to the external capacity of the Union. This principle of conferral, though already expressly provided under the Nice Treaty, has arguably been further emphasized by adopting not only Article 5 TEU from the Nice Treaty, but by also adding a 'flip side' provision in Article 4 (1) TEU, already mentioned in Chapter 1.

To assume competence only 'where the Treaties so provide' rules out any (implied) external competences not expressly provided by the Treaties. There is, however, a problem with such a strict view of conferral and the meaning of codification. It will be argued in the following that the new competence provisions must still be read in light of (pre-Lisbon) case law, for three reasons. First, the codification is quite patently flawed on key principles such as ERTA, unless we assume that the Lisbon Treaty should radically modify the case law regime by way of codification. ${ }^{5}$ Second, resort to case law is necessary because of the striking mismatch between the complexities of the Court's case law and the terseness of the 'new' Treaty provisions, such as concerning the ILO principle on exclusive competence for areas largely covered by common rules. The third reason why the 'old' case law regime will remain valid is that the important ECJ Opinion on the Lugano Convention, in particular, could not possibly have been considered when planning to make all the implied competences explicit. All this renders the claim that the Lisbon Treaty has made the regime on implied competences fully explicit difficult to uphold.

I will thus argue later that there are good reasons to assume that what the Lisbon Treaty expressly provides is not all there is with regard to Union competences. Before that, however, I will offer a brief summary of the order of (express) Union competences following the Lisbon Treaty, as well as a discussion of what this entails in terms of terminology.

\section{Three Categories of Competences}

Under the Lisbon Treaty, there are now only the categories of exclusive, shared, and supporting competences. ${ }^{6}$ For all of them the Treaty foresees a general definition on the one hand and a list of pertinent policy areas on the other. This is meant as a categorization, but not as a substitute for referring to the detailed provisions in the respective title of the TFEU for assessing their scope and nature. ${ }^{7}$

Article 2 (1) TFEU defines exclusive Union competence as an area where 'only the Union may legislate and adopt legally binding acts, the Member States being able to do so themselves only if so empowered by the Union or for the implementation of Union acts'. In other words, Member States cannot regulate in areas that fall under the exclusive competence of the Union unless they are specifically authorized to do so. ${ }^{8}$

Codification does not necessarily mean the one-to-one provision of elements of case law without being allowed to alter some aspects in the process. I doubt, however, whether we can still speak of codification when a key tenet of case law is simply turned on its head, as discussed later.

${ }^{6}$ In the German version of the Lisbon Treaty these are called ausschließliche Zuständigkeiten, geteilte Zuständigkeiten and competences for the Unterstützung, Koordinierung or Ergänzung of national measures.

7 See Craig, 'Competence', 335, occasioned by the Draft Constitutional Treaty. cf. Craig, The Lisbon Treaty, 169, on account of the provisions for social policy.

${ }^{8}$ Case 41/76 Donckerwolcke and Schou [1976] ECR 1921; Case 174/84 Bulk Oil [1986] ECR 559; Case C-70/94 Werner [1995] ECR I-3189, and Case C-83/94 Leifer and Others [1995] ECR I-3231.

This is an open access version of the publication distributed under the terms of the Creative Commons Attribution-NonCommercial-NoDerivs licence (http://creativecommons.org/licenses/by-nc-nd/3.0/), which permits non-commercial reproduction and distribution of the work, in any medium, provided the original work is not altered or transformed in any way, and that the work is properly cited. For commercial re-use, please contact academic.permissions@oup.com 
Article 3 (1) TFEU lists the areas of this a priori exclusive competence of the Union. ${ }^{9}$ In some of these areas, the Lisbon Treaty has brought about some significant clarifications and extensions, such as concerning the scope of the Common Commercial Policy in particular. $^{10}$

Article 3 (2) contains a codification of what has previously been known as implied exclusive external competences. It distinguishes exclusivity for treaty making when the conclusion of an international agreement 'is provided for in a legislative act of the Union', when it 'is necessary to enable the Union to exercise its internal competence', or to the extent a Member State measure 'may affect common rules or alter their scope'. I will return to this definition in the discussion on external competences later.

Article 2 (2) TFEU is about shared competence, which is defined as follows:

The Member States shall exercise their competence to the extent that the Union has not exercised its competence. The Member States shall again exercise their competence to the extent that the Union has decided to cease exercising its competence.

As I will explain later, this is the primary cause of preclusion of Member State rights to act. In this provision, notably, no mention is made of a loss of competence per se suffered by Member States following the activation of a shared competence. Also for this category of competences the Treaty now provides a list of pertinent matters in Article 4 TFEU, which includes, among others, environmental policy. ${ }^{11}$

Article 4 TFEU, moreover, distinguishes two matters from these 'regular' shared competences in the following terms:

In the areas of research, technological development and space, the Union shall have competence to carry out activities, in particular to define and implement programmes; however, the exercise of that competence shall not result in Member States being prevented from exercising theirs.

In the areas of development cooperation and humanitarian aid, the Union shall have competence to carry out activities and conduct a common policy; however, the exercise of that competence shall not result in Member States being prevented from exercising theirs. ${ }^{12}$

I will specifically discuss development cooperation as the most important of these 'irregular' shared competences later in this chapter.

Article 2 (5) TFEU introduces a third category of competences. It states 'the Union shall have competence to carry out actions to support, coordinate or supplement the actions of the Member States, without thereby superseding their competence in these

9 Customs union; the establishing of the competition rules necessary for the functioning of the internal market; monetary policy for the Member States whose currency is the euro; the conservation of marine biological resources under the Common Fisheries Policy; Common Commercial Policy.

See, on this list of exclusive competences, R. Schütze, 'Lisbon and the Federal Order of Competences: A Prospective Analysis', European Law Review, (2008), 709-722, 712, who also discusses the inclusion of competition policy in this list, thus an area which before Lisbon had rather been called a parallel competence. On competition policy, see also Craig, The Lisbon Treaty, 160-161.

10 See Cremona, 'Defining Competence', 46 passim; P.-C. Müller-Graff, 'The Common Commercial Policy Enhanced by the Reform Treaty of Lisbon?', in A. Dashwood and M. Maresceau (eds), Law and Practice of EU External Relations: Salient Features of a Changing Landscape (Cambridge: Cambridge Univ. Press, 2008), 188-201.

${ }_{11}$ Internal market; social policy, for the aspects defined in this Treaty; economic, social, and territorial cohesion; agriculture and fisheries, excluding the conservation of marine biological resources; environment; consumer protection; transport; trans-European networks; energy; area of freedom, security, and justice; common safety concerns in public health matters, for the aspects defined in this Treaty. The Common Foreign and Security Policy (CFSP) would also have to fall under this category, despite it being not meant to preclude the Member States. See, on this discrepancy, Cremona, 'Defining Competence', 63 passim.

12 Art. 4 (4) and (5) TFEU.

This is an open access version of the publication distributed under the terms of the Creative Commons Attribution-NonCommercial-NoDerivs licence (http://creativecommons.org/licenses/by-nc-nd/3.0/), which permits non-commercial reproduction and distribution of the work, in any medium, provided the original work is not altered or transformed in any way, and that the work is properly cited. For commercial re-use, please contact academic.permissions@oup.com 
areas'. In matters falling under this category, the Union is allowed to pass legally binding acts. These, however, 'shall not entail harmonization of Member States' laws or regulations'. Article 6 TFEU lists the following policy areas as supporting competences: the protection and improvement of human health; industry; culture; tourism; education, vocational training, youth and sport; civil protection and administrative cooperation.

All matters not mentioned in the Treaty are sometimes called reserved competences or retained powers of the Member States. ${ }^{13}$ In these the Member States are in principle free to act, but must respect and must not be in breach of Union law. ${ }^{14}$

\section{The General System of External Powers of the Union After Lisbon}

Article 216 (1) TFEU, as mentioned, provides that the Union possesses treaty-making power 'where the Treaties so provide'. It continues that the Union is also competent:

(1) 'where the conclusion of an agreement is necessary in order to achieve, within the framework of the Union's policies, one of the objectives referred to in the Treaties'

(2) 'or is provided for in a legally binding Union act'

(3) 'or is likely to affect common rules or alter their scope'.

Note that this is a general statement and does not tell us about the exclusive or shared nature of external powers so conferred.

There is, as also mentioned, a specific provision on exclusive external competence in Article 3 (2) TFEU:

The Union shall also have exclusive competence for the conclusion of an international agreement when its conclusion is provided for in a legislative act of the Union or is necessary to enable the Union to exercise its internal competence, or in so far as its conclusion may affect common rules or alter their scope.

Article 216 (1) TFEU thus is essentially a copy of the major part of Article 216 (1) TFEU quoted earlier, with one exception: There is a curious mismatch between the wording of Article 216 (1) TFEU conferring competence when it is necessary for the Union to conclude an international agreement to achieve Union 'objectives', and the wording of Article 3 (2) TFEU linking such necessity with the exercise of the Union's 'internal competence'. Is this difference significant in view of the fact that Article 216 TFEU does not specify the kind of competence it is concerned with, whereas Article 3 (1) TFEU is only about exclusive competence?

In the following, I will explore this issue and the problems identified in the introduction to this section first with regard to external exclusive competence and, second, concerning external non-exclusive competence. I will focus on exclusive competence conferred in Article 3 (2) TFEU and in Article 216 (1) TFEU, thus on powers that have been referred to as implied external powers before the Lisbon Treaty. ${ }^{15}$ The reasons

13 See C. Hillion, 'Mixity and Coherence in EU External Relations: The Significance of the "Duty of Cooperation"', CLEER Working Papers, 2 (2009), 21; I. MacLeod, I.D. Hendry, and S. Hyett, The External Relations of the European Communities: A Manual of Law and Practice (Oxford: Oxford Univ. Press, 1996), 149.

14 Case C-124/95 Centro-Com [1997] ECR I-81, paras 25 and 27.

15 I will thus also not discuss Art. 352 TFEU (ex Art. 308 EC). See on this, among others, Cremona, 'Defining Competence', 53 passim.

This is an open access version of the publication distributed under the terms of the Creative Commons Attribution-NonCommercial-NoDerivs licence (http://creativecommons.org/licenses/by-nc-nd/3.0/), which permits non-commercial reproduction and distribution of the work, in any medium, provided the original work is not altered or transformed in any way, and that the work is properly cited. For commercial re-use, please contact academic.permissions@oup.com 
for this are, first, that there is still a lot of ambiguity in this context, and, second, as emphasized in previous chapters, there is a close relation between loyalty, ERTA, and exclusivity in general. ${ }^{16}$

\section{Exclusive Competences}

\subsection{A Priori Exclusivity}

As mentioned earlier, Article 2 (1) TFEU defines exclusive Union competence as a policy area where 'only the Union may legislate and adopt legally binding acts...'. This form of exclusivity, as mentioned, is referred to as a priori exclusivity. ${ }^{17}$ The relationship between Union and Member State powers under such competence is not dynamic in its dependence on the existence of secondary law or on any other Union activity. It bars Member State measures in the respective policy field irrespective of the enactment of Union measures. Even inertia by the Union does not re-empower the Member States. As I have explained, the Lisbon Treaty now provides an exhaustive list of policy areas falling under such a priori exclusivity in Article 3 (1) TFEU.

\subsection{Exclusivity Superveniens}

\subsubsection{Dynamic and transitory nature}

What I call exclusivity superveniens is dynamic in the sense that the Union only acquires exclusive competence through the passage of common rules by the Union legislator. The standard example for this is the exercise of shared competence as now defined in Article 2 (2) TFEU, giving Member States the right to exercise their competence 'to the extent that the Union has not exercised its competence'. ${ }^{18}$

In contrast to a priori exclusivity, the transfer of competence can be only temporary here, with Member State powers being reactivated in case the Union measure is repealed. This right of the Member States to 'again exercise their competence to the extent that the Union has decided to cease exercising its competence' is now explicitly stated in the new Article 2 (2) TFEU. ${ }^{19}$ The transitory nature of exclusivity superveniens entails that Member States, as a matter of principle, retain their power to legislate in the area covered by a certain Union measure. ${ }^{20}$ In this vein, Article 2 (2) TFEU also speaks only

16 See M. Cremona, 'Defending the Community Interest: The Duties of Cooperation and Compliance', in M. Cremona and B. de Witte (eds), EU Foreign Relations Law: Constitutional Fundamentals (Oxford and Portland, Oregon: Hart Publishing, 2008), 125-169, 168.

17 It is also sometimes referred to as constitutional exclusivity as opposed to legislative exclusivity, though this is a less appropriate term. See note 33 .

18 Directives or regulations, such as to approximate national laws for the functioning of the common market pursuant to Art. 114 TFEU, preclude Member States from passing laws when they purport to regulate the same matters already regulated by the Union.

19 Declaration No. 18 on the delimitation of competences attached to the Lisbon Treaty clarifies that this case may arise 'when the relevant EU institutions decide to repeal a legislative act, in particular better to ensure constant respect for the principles of subsidiarity and proportionality'.

20 This is even the case when the Union regulates exhaustively. See A. von Bogdandy and J. Bast, 'The Federal Order of Competences', in A. von Bogdandy and J. Bast, Principles of European Constitutional Law (Oxford and Portland, Oregon: Hart Publishing; Munich: Beck; Baden-Baden: Nomos, 2009), 291. For a different perspective, see K. Lenaerts and P. van Nuffel, Constitutional Law of the European Union, 2nd edn. (London: Sweet \& Maxwell, 2005), 96, who have written of Member State power which 'ceases to exist once the Community actually exercises its own competence' (emphasis added).

This is an open access version of the publication distributed under the terms of the Creative Commons Attribution-NonCommercial-NoDerivs licence (http://creativecommons.org/licenses/by-nc-nd/3.0/), which permits non-commercial reproduction and distribution of the work, in any medium, provided the original work is not altered or transformed in any way, and that the work is properly cited. For commercial re-use, please contact academic.permissions@oup.com 
of the Member States' loss of the right to exercise their competence, not of the loss of their competence as such. ${ }^{21}$ Thus, exclusivity superveniens as the result of the exercise of shared competence entails a dynamic, ${ }^{22}$ but potentially only transitory, shift in the right to exercise regulatory powers. ${ }^{23}$

\subsubsection{Correlation required}

With directives, conflict only arises to the extent that they prescribe harmonization and, therefore, they do not fully curtail Member States when they only provide for minimum rules or regulate matters only partially. Union powers are furthermore qualified by Treaty-based exceptions such as those provided in Article 114 (4) and (5) TFEU, or by other exemptions included in the instrument itself. This is now expressed by the general definition of shared competence in Article 2 (2) TFEU, which allows Member States to 'exercise their competence to the extent that the Union has not exercised its competence'. ${ }^{24}$ This definition has been criticized in the literature as representing 'a bewildering conception of shared competence', failing to provide for the case of minimum harmonization. ${ }^{25}$ However, this ignores the situation with regard to the 'internal' effect of Union legislation being fully comparable with its external implications.

The wording used by the Court in the ERTA case law, further discussed later, is the following:

To the extent to which Community rules are promulgated for the attainment of the objectives of the Treaty, the Member States cannot, outside the framework of the Community institutions, assume obligations which might affect those rules or alter their scope. ${ }^{26}$

We could easily modify this tenet on external competences to describe the consequences of the exercise of competences by the Union for the capacities of Member States to legislate on the internal plane:

To the extent to which Union rules are promulgated for the exhaustive regulation of a subject matter falling under the objectives of the Treaty, the Member States cannot, outside the framework of this Union measure, assume obligations which might affect those rules or alter their scope.

This shows the synchronicity of descriptions of the consequences of the passing of measures on both levels. I might even just as well have left out the qualification 'exhaustive' in the wording on internal implications, since the requirement of correlation between the scope of the rule and the scope of its effect, arguably, is already expressed by the words 'to

This is no longer stated in this manner in K. Lenaerts and P. van Nuffel, European Union Law, 3rd edn. (London: Sweet \& Maxwell, 2011), 129-130.

${ }^{21}$ Noted also by Schütze, 'Lisbon and the Federal Order of Competences', 716. See also R. Schütze, 'Supremacy Without Pre-emption?: The Very Slowly Emergent Doctrine of Pre-emption', Common Market Law Review, 43:4 (2006), 1023-1048, 1031.

${ }^{22}$ See the critique of this term in connection with competences by von Bogdandy and Bast, 'The Federal Order of Competences', 292, who however seem only to refute the claim that Union institutions are able to change the content of a legal basis by their legislative activity.

${ }^{23}$ However, see the concerns at von Bogdandy and Bast, 'The Federal Order of Competences', 304, as to the requirement of an actus contrarius to repeal legal acts in the Union, making this more difficult than in Member State systems.

${ }^{24}$ Emphasis added.

25 See Schütze, 'Lisbon and the Federal Order of Competences', 715-716.

${ }^{26}$ Case 22/70 Commission v Council (ERTA) [1971] ECR 263. This is made explicit in, among others, Opinion 2/92 OECD [1995] ECR I-521: ' $\ldots$ the Member States, whether acting individually or collectively, only lose their right to enter into obligations with non-member countries as and when there are common rules which could be affected by such obligations.'

This is an open access version of the publication distributed under the terms of the Creative Commons Attribution-NonCommercial-NoDerivs licence (http://creativecommons.org/licenses/by-nc-nd/3.0/), which permits non-commercial reproduction and distribution of the work, in any medium, provided the original work is not altered or transformed in any way, and that the work is properly cited. For commercial re-use, please contact academic.permissions@oup.com 
the extent'. Also, under the ERTA principle, external commitments by Member States are only prohibited as far as the lawmaking powers of the Union go internally. Thus, when the internal legal basis on environmental policy explicitly allows Member States to adopt stricter standards, Union directives adopted on this basis are not able to restrain the Member States internally any less than regarding their treaty-making powers, irrespective of whether the possibility of minimum harmonization is explicitly provided for in Article 2 (2) TFEU. ${ }^{27}$ In other words, why should there be a mention of such possible restraints of lawmaking powers with shared competence internally, when this is also missing in the provisions on the ERTA effect in Article 3 (2) TFEU and has not raised any concerns there?

Hence, just as the definition of the ERTA principle in the Treaty or in the case law quoted earlier requires little qualification as regards minimum common rules, this is also unnecessary with exclusivity superveniens, I would argue. There is always and in both constellations the prerequisite of a correlation between the scope of the Union measure and the scope of application of the national measure for supremacy to apply. National law, consequently, only has to yield as far as the 'legal space' is occupied by Union law. This has also been reinforced by Protocol No. 25 on Shared Competence annexed to the Lisbon Treaty. ${ }^{28}$

\subsubsection{The analogy to German law}

As explained in Chapter 2, in Germany there are konkurrierende (competing) competences delimiting the regulatory powers of the German federal state from those of the German Länder (provinces). It is this German law background some (German) authors had in mind when they insisted, before Lisbon, that the Community's non-exclusive competences are shared instead of concurrent. ${ }^{29}$ This is the reason, moreover, why some have cried wolf about the codification of shared competences in Article 2 (2) TFEU, suspecting this to be a conscious move towards concurrent competence in the style of German federalism. ${ }^{30}$

First, such discussion largely ignores that there is no readily apparent difference between the concepts of shared and concurrent competences for those not steeped in German constitutional law. Second, to thereby intimate that the exercise of a concurrent competence by the federal state in Germany has fundamentally different implications compared with the exercise of a shared competence by the Union is misleading. Under German law, the exercise of a concurrent competence by the federal state no more transforms this competence into one exclusively attributed to the federal state than is the case in Union law. ${ }^{31}$ Thus, it is not apposite to speculate whether, with the Lisbon Treaty, 'to

27 See, for a recent discussion of this, Craig, The Lisbon Treaty, 172.

28 'With reference to Art 2 of the Treaty on the Functioning of the European Union on shared competence, when the Union has taken action in a certain area, the scope of this exercise of competence only covers those elements governed by the Union act in question and therefore does not cover the whole area.'

29 Schütze, 'Supremacy Without Pre-emption', 1031.

30 See Nettesheim, 'Die Kompetenzordnung im Vertrag über eine Verfassung für Europa', Europarecht, (2004), 511-546, 529.

31 Compare Art. 2 (2) TFEU ('The Member States shall exercise their competence to the extent that the Union has not exercised its competence') with Art. 72 (1) German Basic Law (Grundgesetz): 'Im Bereich der konkurrierenden Gesetzgebung haben die Länder die Befugnis zur Gesetzgebung, solange und soweit der Bund von seiner Gesetzgebungszuständigkeit nicht durch Gesetz Gebrauch gemacht hat.' (On matters within the concurrent legislative power, the Länder shall have power to legislate as long

This is an open access version of the publication distributed under the terms of the Creative Commons Attribution-NonCommercial-NoDerivs licence (http://creativecommons.org/licenses/by-nc-nd/3.0/), which permits non-commercial reproduction and distribution of the work, in any medium, provided the original work is not altered or transformed in any way, and that the work is properly cited. For commercial re-use, please contact academic.permissions@oup.com 
the extent that the European Union exercises its "shared" powers, the Member States would lose their very competence to legislate'. ${ }^{32}$ The fact that the preclusion of Member States because of the exercise of a shared competence is now expressly provided by the Lisbon Treaty does not change anything in this regard, it is submitted. ${ }^{33}$ Thirdly, even in the German doctrine, the notion of concurrent competence is not considered fully appropriate. ${ }^{34}$

This goes to show that there are other good reasons beyond those already advanced to abandon the notion of concurrent competences and to speak of shared competences as provided by the Lisbon Treaty.

\subsection{The ERTA Principle}

\subsubsection{The codification}

As mentioned, exclusive Union competence applies to the extent a Member State measure 'may affect common rules or alter their scope'. ${ }^{35}$ This is the codification of the classic ERTA doctrine, establishing exclusivity whenever common rules are likely to be affected or their scope altered. Note that the wording in the Treaty is different and states that it is the conclusion of a Union agreement (sic!) which must not affect common rules. ${ }^{36}$ This makes little sense, does not reflect the ERTA jurisprudence, and demonstrates that the codification is partly but patently flawed. ${ }^{37}$ This undermines any claim that it must not be referred to the Court's pre-Lisbon jurisprudence for interpreting Article 3 (2) TFEU.

as and to the extent that the Federation has not exercised its legislative power by enacting a law.) See also T. Maunz, 'GG Art. 71', in T. Maunz and G. Dürig (eds), Grundgesetz Kommentar (Munich: Beck, 2011), para 20, on the non-recognition of the creation of an exclusive competence of the federal state because of its exercise of a concurrent competence.

32 See Schütze, 'Lisbon and the Federal Order of Competences', 716. This flawed analogy might be explained by German literature, which misleadingly writes of the extinction (Erlöschen) and abolition (Vernichtung) of the competence of the provinces in Germany as a result of the activation of a concurrent competence by the federal state. See C. Seiler, 'GG Art. 72', in V. Epping and C. Hillgruber (eds), Beck'scher Online-Kommentar GG (Munich: Beck, 2011), paras 3-5. See, in contrast, Maunz, 'GG Art. 72', para 9, who refers to 'Sperrwirkung' (pre-emption) in this respect.

33 Of course, since the preclusion of the Member States is now based on the Treaty, it is thus 'constitutionalized'. I cannot see what dogmatic or practical difference this should make, yet it provides a good argument against the usage of the terms 'constitutional exclusivity' and 'legislative exclusivity' under the Lisbon Treaty. Why this new provision in the Treaty, considering that in Germany state laws are automatically void following the exercise of a concurrent competence, might furthermore change the nature of supremacy in Union law is hard to comprehend. For a different perspective, see Schütze, 'Lisbon and the Federal Order of Competences', 716.

34 Maunz, 'GG Art. 72', paras 5-6, on the preference for the term 'Vorranggesetzgebung' (primacy competence) instead.

35 Case 22/70 ERTA [1971] ECR 263. See Schütze, 'Lisbon and the Federal Order of Competences', 714 .

36 Art. 3 (2) TFEU: 'The Union shall also have exclusive competence for the conclusion of an international agreement. .. in so far as its conclusion may affect common rules or alter their scope.'

37 See Schütze, 'Lisbon and the Federal Order of Competences', 715; Cremona, 'Defining Competence', 58 .

This is an open access version of the publication distributed under the terms of the Creative Commons Attribution-NonCommercial-NoDerivs licence (http://creativecommons.org/licenses/by-nc-nd/3.0/), which permits non-commercial reproduction and distribution of the work, in any medium, provided the original work is not altered or transformed in any way, and that the work is properly cited. For commercial re-use, please contact academic.permissions@oup.com 


\subsubsection{The nature of common rules}

In the Open Skies cases, the Court refers to 'common rules, whatever form these may take'. ${ }^{38}$ While this broad definition comprises secondary law that cannot safely be qualified as harmonization measures, ${ }^{39}$ it is more difficult to argue that international agreements concluded by the Union themselves equally constitute common rules in the sense of the ERTA judgment for the lack of clear pronunciations by the Court. This, however, has important practical implications for the Member States, among others, by playing a decisive role in the discussion of common positions in the context of mixed agreements later in this Chapter. In the literature, reference in support of considering international agreements as common rules is made to statements by the ECJ in Opinion 1/76 discussed later, ${ }^{40}$ and to the application of Opinion 1/76 to the General Agreement on Trade in Services (GATS) in the WTO Opinion. ${ }^{41}$ The principle established by Opinion $1 / 76$, however, grants exclusivity due to necessity, and not because of an international agreement by the Union, as explained later. It might therefore be more apposite to conceive the conclusion of international agreements in an area of shared competence ${ }^{42}$ as a case sui generis. Since any Union agreement forms an integral part of Union law, ${ }^{43}$ it can reverberate on the internal side by affecting national laws and regulations. At the same time, any international agreement concluded by the Union forestalls treaty making by the Member States to the extent the Union is competent to enter into obligations and chooses to exercise such competence as well.

An important question not arising in the context of internal common rules is owed to the possibility of concluding treaties bilaterally or multilaterally. If the Union enters into a multilateral treaty by exercising its shared external competence, it is clear that Member States are precluded from undertaking commitments within the same forum, which would undermine or affect the Union commitments. If we apply this ERTA non-affection standard however to 'bilateral' agreements of the Union, it will be difficult to argue that the effect of such agreement is impaired by international agreements of the Member States with other states, even when they concern the same subject matter.

\subsubsection{Which type of exclusivity?}

Some commentators have strongly argued for considering ERTA a case of a priori exclusivity before the Lisbon Treaty. ${ }^{44}$ The Lisbon Treaty has done nothing to clarify this,

38 Case C-467/98 Commission v Denmark (Open Skies) [2002] ECR I-9519, para 77: ‘. . . with a view to implementing a common policy envisaged by the Treaty, adopts provisions laying down common rules, whatever form these may take'.

39 See, on the Services Directive, M. Klamert, 'Of Empty Glasses and Double Burdens: Approaches to Regulating the Services Market à propos the Implementation of the Services Directive', Legal Issues of Economic Integration, (2010), 111-132.

40 P. Gilsdorf, 'Die Außenkompetenzen der EG im Wandel', Europarecht, (1996), 145, 149.

41 See J. Heliskoski, Mixed Agreements as a Technique for Organizing the International Relations of the European Community and its Member States (The Hague: Kluwer Law International, 2001), 43, referring to Opinion 1/94 WTO [1994] ECR I-5267, para 85: 'It is understandable, therefore, that external powers may be exercised, and thus become exclusive, without any internal legislation having first been adopted.' cf. N. Neuwahl, 'The WTO Opinion and Implied External Powers of the Community: A Hidden Agenda?', in A. Dashwood and C. Hillion (eds), The General Law of EC External Relations (London: Sweet \& Maxwell, 2000), 139-151, 144 on the general ambiguity of this statement.

42 Only here a pre-emptive effect would be relevant since under exclusive competence Member States would be precluded from entering into international agreements a priori.

43 Case 181/73 Haegeman [1974] ECR 449; Case 104/81 Hauptzollamt Mainz v C.A. Kupferberg \& Cie $K G$ a.A. [1982] ECR 3641.

${ }^{4}$ Nettesheim, 'Kompetenzordnung', 449. See also A. von Bogdandy and J. Bast, 'Art. 5 EGV', in E. Grabitz and M. Hilf (eds), Das Recht der Europäischen Union (Munich: Beck, 2005), para 33.

This is an open access version of the publication distributed under the terms of the Creative Commons Attribution-NonCommercial-NoDerivs licence (http://creativecommons.org/licenses/by-nc-nd/3.0/), which permits non-commercial reproduction and distribution of the work, in any medium, provided the original work is not altered or transformed in any way, and that the work is properly cited. For commercial re-use, please contact academic.permissions@oup.com 
since Article 3 TFEU does not explicitly distinguish between different types of exclusive competence, as mentioned. Such a view would mean, according to the differentiation laid out earlier, that the transfer of powers between the Union and the Member States would not be transient, and that the passing of common rules by the Union would thus entail a sort of 'legislative a priori exclusivity'. Member States would be prohibited from entering into international agreements with third states, unless they are explicitly mandated by the Union to do so. For the external capacities of the Member States, in such a case, it would therefore also be irrelevant whether the Union repeals the common rule concerned. They would not regain competence once lost. I submit that there is no indication that common rules giving cause to the ERTA effect cannot be repealed and the powers of Member States be restored in much the same manner as is the case with the exercise of competences internally and now expressly stated in Article 2 (2) TFEU.

The only possible rationale for such a fundamental difference between the consequences of the passing of Union measures internally and externally could be the greater need for coherence in Union external relations law. ${ }^{45}$ One could argue that it is to the detriment of the standing of the European Union on the international scene that the division of competences between the Union and the Member States changes in accordance with the status quo of Union legislation. However, despite the relevance of the coherence argument in related contexts as I will show later in this chapter, it is not convincing here as a basis for such a far-reaching claim as to the nature of the ERTA effect. Union law practice shows, in contrast, that third parties to mixed agreements regularly try to protect themselves precisely against the dynamic relationship between Union and national powers by requiring (updated) declarations of competence from the Union. ${ }^{46}$

Thus, if we want to discuss ERTA in relation to competence, it should be seen as a case of exclusivity superveniens and not of a priori exclusivity. However, applying the notion of exclusivity superveniens to the internal as well as the external effect of the exercise of shared competence obfuscates an important difference of the ERTA effect, discussed in Chapter 10 in the context of mixed agreements.

\subsection{The WTO Principle}

According to Article 3 (2) TFEU, the Union alone is competent when the conclusion of an international agreement 'is provided for in a legislative act of the Union' ${ }^{47}$ This is the so-called WTO principle, since in this Opinion the Court decided that the Union acquires exclusive external competence whenever 'the Community has concluded in its internal legislative acts provisions relating to the treatment of nationals of non-member countries or expressly conferred on the institutions powers to negotiate with non-member countries. ${ }^{48}$ This part in particular has given rise, among other things, to the claim that 'the

See, however, C. Calliess, 'Art. 5 EGV', in C. Calliess and M. Ruffert (eds), EUVIEGV, 3rd edn. (Munich: Beck, 2007), para 34.

45 See M. Cremona, 'Coherence through Law: What Difference will the Treaty of Lisbon Make?', Hamburg Review of Social Sciences, (2008), 11-36; C. Hillion, 'Tous pour un, un pour tous!: Coherence in the External Relations of the European Union', in M. Cremona (ed.), Developments in EU External Relations Law, Collected Courses of the Academy of European Law (Oxford: Oxford Univ. Press, 2008), 10-36.

46 See Chapter 10 on mixed agreements.

47 For example where Union legislation provides for international negotiations. cf. Eeckhout, External Relations of the European Union: Legal and Constitutional Foundations (Oxford: Oxford Univ. Press, 2004), 99.

48 Opinion 1/94 WTO [1994] ECR I-5267, para 95. See Eeckhout, External Relations, 99.

This is an open access version of the publication distributed under the terms of the Creative Commons Attribution-NonCommercial-NoDerivs licence (http://creativecommons.org/licenses/by-nc-nd/3.0/), which permits non-commercial reproduction and distribution of the work, in any medium, provided the original work is not altered or transformed in any way, and that the work is properly cited. For commercial re-use, please contact academic.permissions@oup.com 
Lisbon Treaty would opt against the theory of legislative pre-emption and in favour of subsequent constitutional exclusivity in the external sphere'. ${ }^{49}$ This is based on the idea that there is an important difference between powers the Union acquires as the result of the passing of legislative acts (the common rules mentioned earlier) and powers conferred in the Treaty itself. It is claimed that the WTO principle undermines the constitutional division of powers since the Union can empower itself with exclusive competences. ${ }^{50}$ Indeed, the $W T O$ principle is a peculiar way for the Union to acquire exclusive external competence. The implications of this principle, however, largely depend on how we choose to interpret it. For this, two approaches are conceivable.

If we read this provision narrowly, it can be seen as a variation of the ERTA principle. If the Union, qua the ERTA principle, may acquire exclusive competence by virtue of any form of internal legislation, this should apply a fortiori when Union instruments are more specific on the external mandate of the Union institutions, or when they already contain an 'international' element regarding the treatment of third-country nationals. The proviso here is that these specific rules on external capacities are connected to the subject matter of the legislative act. A good example is the ERTA case itself, where a Regulation had provided for a treaty-making negotiating mandate, but only for the scope of the international agreements in question. ${ }^{51}$ According to such a view, therefore, I see no fundamental difference between the ERTA principle and the WTO principle, provided there is a substantive relation between the 'internal' content and the 'external' content of common rules. This then is no threat to the constitutional division of powers and should not be compared to external competences expressly conferred by the Treaty itself. ${ }^{52}$

If, on the other hand, we consider that Article 3 (2) TFEU now speaks, very tersely, of exclusive competence when this 'is provided for in a legislative act of the Union', this may be taken to mean, in theory, that in a Union regulation on matter X the Union could empower itself to negotiate with third states on matter Y. As far as I can see, there is no case law on the precise meaning of the WTO principle before the Lisbon Treaty. Yet, if in doubt, I submit that Article 3 (2) TFEU should be construed narrowly on this. Anything else would, in a fundamental manner, run counter to the principle of conferral, the importance of which, as mentioned, is further emphasized in the Lisbon Treaty. ${ }^{53}$ The wording as chosen in the Lisbon Treaty, however, cannot really give rise to the concerns referred to earlier. While terser, it is not different in substance from what the Court has already held to apply before the Lisbon Treaty. ${ }^{54}$ I do not see how the codification of this, besides prolonging the legal uncertainty on the precise criteria for the application of the principle, should fundamentally change the manner in which the division of competences between the Union and the Member States is devised.

49 Schütze, 'Lisbon and the Federal Order of Competences', 713.

50 Schütze, 'Lisbon and the Federal Order of Competences', 713.

51 Case 22/70 ERTA [1971] ECR 263, paras 28-29: 'Although it is true that Articles 74 and 75 do not expressly confer on the Community authority to enter into international agreements, nevertheless the bringing into force, on 25 March 1969, of Regulation No. 543/69 of the Council on the harmonization of certain social legislation relating to road transport... necessarily vested in the Community power to enter into any agreements with third countries relating to the subject-matter governed by that Regulation. This grant of power is moreover expressly recognized by Article 3 of the said Regulation which prescribes that: "The Community shall enter into any negotiations with third countries which may prove necessary for the purpose of implementing this Regulation”.'

52 For a different perspective, see Schütze, 'Lisbon and the Federal Order of Competences', 713.

53 See also Cremona, 'Defining Competence', 57; Hable, 'The European Constitution', 21-22.

54 See note 48 .

This is an open access version of the publication distributed under the terms of the Creative Commons Attribution-NonCommercial-NoDerivs licence (http://creativecommons.org/licenses/by-nc-nd/3.0/), which permits non-commercial reproduction and distribution of the work, in any medium, provided the original work is not altered or transformed in any way, and that the work is properly cited. For commercial re-use, please contact academic.permissions@oup.com 


\subsection{The Opinion 1/76 Principle}

According to Article 3 (2) TFEU, exclusivity is established when an international agreement 'is necessary to enable the Union to exercise its internal competence'. This codifies the controversial Opinion 1/76 principle that the Union possesses exclusive competence to conclude international agreements if its powers for passing internal measures cannot be exercised without such international action..$^{55}$ Opinion 1/76 was about the distribution of competences between the (former) EC and the Member States regarding the conclusion of an agreement on a scheme for the elimination of disturbances for navigation on the Rhine. The Court, after a rendition of its judgment in ERTA and the Kramer decision held as follows:

... The court has concluded inter alia that whenever Community law has created for the institutions of the Community powers within its internal system for the purpose of attaining a specific objective, the Community has authority to enter into the international commitments necessary for the attainment of that objective even in the absence of an express provision in that connection.

... the power to bind the Community vis-à-vis third countries nevertheless flows by implication from the provisions of the treaty creating the internal power and in so far as the participation of the community in the international agreement is, as here, necessary for the attainment of one of the objectives of the community. ${ }^{56}$

The Court found it necessary for the ex Community to enter into the pertinent agreement on its own because the planned scheme could not be established by autonomous Union rules due to the need for the participation of Switzerland..$^{57}$ The Community thus was granted an implied exclusive external competence for the very narrow aspects of the common transport policy concerned and in the absence of any secondary legislation. ${ }^{58}$ Instead, the Court for the first time introduces a test of necessity for establishing exclusive competence. ${ }^{59}$

Such exclusive competence has only been assumed once by the Court, but has been raised as argument repeatedly by the Commission in particular. ${ }^{60}$ Article 216 (1) TFEU, as mentioned, puts this somewhat differently by referring to the necessity of achieving one of the Treaty objectives instead. ${ }^{61}$ Leaving this discrepancy aside for the moment,

55 Opinion 1/76 European Laying-up Fund [1977] ECR 741, para 2: 'In this case, however, it is impossible fully to attain the objective pursued by means of the establishment of common rules pursuant to Article 75 of the Treaty, because of the traditional participation of vessels from a third state, Switzerland, in navigation by the principal waterways in question, which are subject to the system of freedom of navigation established by international agreements of long standing.'

56 Opinion 1/76 European Laying-up Fund [1977] ECR 741, paras 3-4.

57 The participation of several Member States was only due to the special circumstances of the case.

58 This would have been required under Case 22/70 ERTA [1971] ECR 263 in order to establish exclusivity.

59 On this test, see M. Klamert and N. Maydell, 'Lost in Exclusivity: Implied Non-exclusive External Competences in Community Law', European Foreign Affairs Review, 13 (2008), 493.

60 Opinion 1/94 WTO [1994] ECR I-5267, para 86 on GATS and the Agreement on Trade Related Aspects of Intellectual Property Rights (TRIPS): 'That is not the situation in the sphere of services: attainment of freedom of establishment and freedom to provide services for nationals of the Member States is not inextricably linked to the treatment to be afforded in the Community to nationals of non-member countries or in non-member countries to nationals of Member States of the Community.' See also Case C-467/98 Commission v Denmark (Open Skies) [2002] ECR I-9519 (pars pro toto), on air transport.

61 See Cremona, 'Defining Competence', 56-57, who makes the valid argument that to refer to Treaty objectives in general instead of to internal (market) competence could possibly greatly extend the scope of this kind of external competence. See M. Cremona, 'External Relations and External Competence of the European Union', in P.P. Craig and G. de Búrca, The Evolution of EU Law, 2nd edn. (Oxford: Oxford Univ. Press, 2011), 225.

This is an open access version of the publication distributed under the terms of the Creative Commons Attribution-NonCommercial-NoDerivs licence (http://creativecommons.org/licenses/by-nc-nd/3.0/), which permits non-commercial reproduction and distribution of the work, in any medium, provided the original work is not altered or transformed in any way, and that the work is properly cited. For commercial re-use, please contact academic.permissions@oup.com 
this part of Article 3 (2) TFEU demonstrates that the codification does not dispose of the need to resort to the jurisprudence of the Court from before Lisbon. In recent case law, the Court has reinforced the conditions for this kind of exclusivity, requiring an inextricable link between internal policy objectives and an international agreement. ${ }^{62}$ It is submitted that there is no reason why this specification of the necessity standard of the Opinion 1/76 principle should not continue to apply also under the Lisbon Treaty.

When it is argued that the mentioned codification is flawed because it borrows wording from the European Union's general 'residual competence' under Article 352 TFEU (ex Article $308 \mathrm{EC}),{ }^{63}$ this is an argument which is difficult to follow. ${ }^{64}$ What is found in Article 3 (2) TFEU is language the Court has often used in the past, most importantly in Opinion 1/76 itself. Such argument only makes sense en rapport with, indeed, similar and broader wording found in Article 216 (1) TFEU. Article 216 (1) TFEU, however, does not necessarily concern exclusive external competence; a difference which is important, as argued later.

Note that the Opinion 1/76 kind of exclusive external Union competence may be situated somewhere between a priori exclusivity and exclusivity superveniens. Exclusivity here is already to some degree 'built into' a certain Treaty norm, the objectives of which cannot be realized in the external sphere unless an international agreement is concluded by the Union alone. The static element of the Union objective provided in the Treaty, in this case, is linked with the dynamic element of a specific measure envisaged to address this objective. Thus, Article 3 (2) TFEU mandates exclusivity when this combination requires the exclusive responsibility of the Union for the measure concerned. Exclusivity superveniens, in contrast, is entirely contingent on an action by the Union.

\subsection{The ILO Principle}

Article 3 (2) TFEU raises the question of what happened to the so-called ILO principle. According to Opinion 2/91, the Union possesses exclusive competence where an international agreement falls 'within an area which is already largely covered by such rules'. ${ }^{65}$ This test has also been applied in judgments by the Court that are more recent, such as the Open Skies cases. ${ }^{66}$ If we assume that the omission of the ILO principle in Article 3 (2) TFEU is deliberate, this would mean either that this rule no longer applies under the Lisbon Treaty, or that it must be read into the ERTA principle mentioned earlier. The latter approach, however, would further discredit the claim that the Lisbon Treaty has made fully explicit the regime on implied competences in Union law. The former approach, in contrast, would arguably restrain the Union in its external powers,

62 Opinion 1/94 WTO [1994] ECR I-5267, para 87; Case C-467/98 Commission v Denmark (Open Skies) [2002] ECR I-9519, para 56 passim. cf. P. Koutrakos, EU International Relations Law (Oxford and Portland, Oregon: Hart Publishing, 2006), 113 and 125. Critical, J.H.J. Bourgeois, 'The EC in the WTO and Advisory Opinion 1/94: An Echternach Procession', Common Market Law Review, (1995), 763-787, 780 .

63 Art. 352 (1) TFEU: 'If action by the Union should prove necessary, within the framework of the policies defined in the Treaties, to attain one of the objectives set out in the Treaties, and the Treaties have not provided the necessary powers...'.

64 But see Schütze, 'Lisbon and the Federal Order of Competences', 713.

65 Opinion 2/91 ILO Convention 170 [1993] ECR I-1061, para 25. This ILO standard, to my knowledge, has never actually been deemed fulfilled for establishing exclusive competence. Instead, the Court has repeatedly relied on this tenet to establish its jurisdiction for interpreting mixed agreements. See Chapter 10 .

66 Case C-467/98 Commission v Denmark (Open Skies) [2002] ECR I-9519, para 82; Opinion 1/03 Lugano Convention [2006] ECR I-1145, para 126.

This is an open access version of the publication distributed under the terms of the Creative Commons Attribution-NonCommercial-NoDerivs licence (http://creativecommons.org/licenses/by-nc-nd/3.0/), which permits non-commercial reproduction and distribution of the work, in any medium, provided the original work is not altered or transformed in any way, and that the work is properly cited. For commercial re-use, please contact academic.permissions@oup.com 
since the Union could acquire exclusive external competence only to the extent of the scope of the internal measure actually passed, instead of for a whole policy area based on measures largely covering such area. ${ }^{67}$

I have already explained that, both with ERTA and exclusivity superveniens in the internal sphere, the scope of the Union measure concerned (directive, regulation, 'common rule') is decisive. It determines the extent of the duty of abstention as the result of common rules, on the one hand, and the extent of the duty of abstention and the disapplication of conflicting national law as the result of the exercise of shared competence on the other. ERTA locks the assignment of exclusive external competence to the test whether common rules are affected or whether their scope is altered by an international agreement of the Member States. Thus, the ERTA effect requires a conflict between Union rules and a Member State measure. I have explained that this is not a conflict which can be resolved by supremacy, but it is a conflict nonetheless.

This is different with the $I L O$ principle. That the Court distinguishes the ERTA effect from the $I L O$ principle is illustrated by the Open Skies cases, even if this could arguably be done in a clearer manner. Following the finding that ex Article 84 (2) EC confers power on the Council to decide on matters of air transport, the Court proceeded to determine the circumstances under which the Community acquires external competence because of the exercise of its internal competence. The judgment continues as follows:

According to the Court's case-law, that is the case where the international commitments fall within the scope of the common rules (AETR judgment, paragraph 30), or in any event within an area which is already largely covered by such rules (Opinion 2/91, paragraph 25). In the latter case, the Court has held that Member States may not enter into international commitments outside the framework of the Community institutions, even if there is no contradiction between those commitments and the common rules (Opinion 2/91, paragraphs 25 and 26). ${ }^{68}$

Thus the ERTA effect is distinguished from the ILO effect by the fact that 'in the latter case', exclusivity is established on the grounds of Union measures even if there is no contradiction (i.e. conflict) between these rules and Member State commitments. ${ }^{69}$ This is consistent with the way, for ERTA, the Court very carefully, over more than twenty paragraphs, assesses the existence of such conflict with regard to certain regulations adopted by the Council. ${ }^{70}$ Unfortunately, this difference is often neglected in the literature when the $I L O$ principle is merely seen as a subcategory of the ERTA principle..$^{71} \mathrm{I}$ have argued elsewhere that, if the Court is taken at its word here, the Services Directive ${ }^{72}$ would have precluded Member States externally in the whole services field and not merely in those matters regulated by the Directive itself. ${ }^{73}$ This, therefore, would already have shifted the right to exercise external competence from the domain of the Member States to the Union for the full scope of the GATS before this was achieved by the amendments to Article 207 TFEU on the Common Commercial Policy by the Lisbon Treaty.

67 But see Schütze, 'Lisbon and the Federal Order of Competences', 714, who considers the (so understood) codification on this point an 'expansion of the European Union's sphere of exclusive competences'.

${ }_{68}$ Case C-467/98 Commission v Denmark (Open Skies) [2002] ECR I-9519, para 82.

69 See also M. Klamert and N. Maydell, 'Rechtsfragen der impliziten Außenkompetenz der EG illustriert am Beispiel der Dienstleistungsrichtlinie und der Minimum Platform on Investment', Europarecht, (2008), 589-602. The Court, however, did not examine whether the ILO standard for establishing exclusive external competence was satisfied in this case.

70 See Case C-467/98 Commission v Denmark (Open Skies) [2002] ECR I-9519, paras 90-122.

71 See Craig, The Lisbon Treaty, 164.

72 Directive (EC) 2006/123 on services in the internal market [2006] OJ L376/36.

${ }^{73}$ Klamert and Maydell, 'Rechtsfragen der impliziten Außenkompetenz', 593 passim.

This is an open access version of the publication distributed under the terms of the Creative Commons Attribution-NonCommercial-NoDerivs licence (http://creativecommons.org/licenses/by-nc-nd/3.0/), which permits non-commercial reproduction and distribution of the work, in any medium, provided the original work is not altered or transformed in any way, and that the work is properly cited. For commercial re-use, please contact academic.permissions@oup.com 
It is revealing as to the ambiguity of this principle that this consequence has apparently gone largely unnoticed in the otherwise highly controversial debates on the Services Directive. $^{74}$

\subsection{Conclusion}

Since the Lisbon Treaty, as argued earlier, has failed to codify formerly implied exclusive competences in a manner that faithfully reflects the case law before Lisbon, in the following section, I will continue to refer to the principles stated in Article 3 (2) TFEU as the ERTA doctrine, the WTO principle and Opinion 1/76 exclusivity. I will also continue to refer to the ILO principle, despite its absence from Article 3 (2) TFEU.

\section{Non-exclusive Competences}

\subsection{Introduction}

As mentioned, Article 216 (1) TFEU does not elaborate on the non-exclusive side of external competences; in contrast to Article 3 (2) TFEU it expressly pertains to exclusive competence. In its first part, Article 216 (1) TFEU merely apodictically states that they exist 'where the Treaties so provide'. Moreover, the general provisions in the TFEU on shared and supporting competences discussed earlier do not specifically mention any external dimension. If specific Treaty provisions were explicitly to confer a shared external power for the Union, Member States would be prevented from acting to the extent this power is exercised. The Union, in this case, could enter into international agreements without further conditions apart from requirements stated in the legal basis itself. As already explained, such international Union agreement does have an effect on Member State autonomy that is not much different from the import of the passing of common rules internally. ${ }^{75}$

While this concerns the case where external shared competence is explicitly conferred by the Treaty, it does not answer the question whether there may also be shared external powers of the Union when this is not expressly provided for in the Treaty. In the following section, I will distinguish between the status quo before the entry into force of the Lisbon Treaty and the present situation.

\subsection{The Situation Before Lisbon}

Before the Lisbon Treaty, there was a debate on whether the Union possesses unconditional (shared) treaty-making power in all areas and the extent the Treaty confers on the Union powers for internal lawmaking. The position arguing in favour of such unfettered treaty-making competence of the Union is referred to as parallelism of internal and

74 But see Dir 2006/123, Rec. 16, which states: 'This Directive concerns only providers established in a Member State and does not cover external aspects. It does not concern negotiations within international organisations on trade in services, in particular in the framework of the General Agreement on Trade in Services (GATS).' This, apparently, however, should not be taken to refer to matters of competence.

75 This, of course, only holds true if such pre-emptive effect is not ruled out by the Treaty itself, which is the case in policy areas such as, among others, environment and development cooperation discussed further later.

This is an open access version of the publication distributed under the terms of the Creative Commons Attribution-NonCommercial-NoDerivs licence (http://creativecommons.org/licenses/by-nc-nd/3.0/), which permits non-commercial reproduction and distribution of the work, in any medium, provided the original work is not altered or transformed in any way, and that the work is properly cited. For commercial re-use, please contact academic.permissions@oup.com 
external powers of the Union, or as in foro externo foro interno. ${ }^{76}$ The opposing theory posited that there is an implied non-exclusive external competence of the Union only when the attainment of an objective of the Treaty in respect of the exercise of an internal competence would be furthered by external action of the Community. ${ }^{77}$ In support of this latter, more sovereignty-friendly view, I would point to the Opinion of the Court on the conclusion of the Lugano Convention, where the Court has arguably confirmed the need to apply such a test of facilitation for the exercise of implied shared competence. ${ }^{78}$ It has also been submitted that the test of facilitation is most likely fulfilled with internal competences comprising a strong 'international element', such as Article 79 (4) TFEU on the free movement of persons, and with provisions which extend to relationships with third countries, such as Article 64 (2) TFEU on the movement of capital. ${ }^{79}$

\subsection{The Situation After Lisbon}

Three different positions are conceivable as to what the Lisbon Treaty has changed concerning the pertinent issue.

First, it could be argued that shared external competences no longer exist, since the Lisbon Treaty means to codify the competences of the Union and has not adopted shared external competences unless specifically provided for individual matters. This, however, would imply that they do not exist either under a test of facilitation or by any other rule. ${ }^{80}$ This, notably, would also undermine the position of those who claimed, before Lisbon, that the principle in foro interno in foro externo applies beyond doubt in Union law. ${ }^{81}$

Second, it could be argued based on the provisions of the Lisbon Treaty that a general shared external competence exists. This is where the mentioned difference in wording between Article 3 (2) TFEU and Article 216 (1) TFEU becomes relevant. Recall that the latter provision does not specify the exclusive or non-exclusive nature of the competences it confers. While the close similarity in wording with Article 3 (2) TFEU on exclusivity suggests, at first reading, that the corresponding parts of Article 216 (1) TFEU are equally about exclusive competence, this understanding of Article 216 (1) TFEU is not the only one possible. When external competence is conferred where the conclusion of an agreement is 'necessary' to fulfil objectives of the Treaties, this could relate both to exclusive and to shared external competence. ${ }^{82}$ In this case, we could read this as codifying

76 See, as representatives, R. Schütze, 'Parallel External Powers in the European Community: From "Cubist" Perspectives Towards "Naturalist” Constitutional Principles?', Yearbook of European Law, 23 (2004), 225-274, 235, and T. Tridimas, 'The WTO and OECD Opinions', in A. Dashwood and C. Hillion (eds), The General Law of EC External Relations (London: Sweet \& Maxwell, 2000), 48-60, 57 .

77 A. Dashwood, 'The Attribution of External Relations Competence', in A. Dashwood and C. Hillion (eds), The General Law of EC External Relations (London: Sweet \& Maxwell, 2000), 115-138, 134; S. Griller and K. Gamharter, 'External Trade: Is there a Path through the Maze of Competences?', in S. Griller and B. Weidel (eds), External Economic Relations and Foreign Policy in the European Union (Vienna, New York: Springer, 2002), 65-112, 79-80; Klamert and Maydell, 'Lost in Exclusivity', 502-508.

78 Opinion 1/03 Lugano Convention [2006] ECR I-1145.

79 Klamert and Maydell, 'Lost in Exclusivity', 508. Recall that the assumption of exclusive competence, in contrast, requires the test of necessity codified in Art. 216 (1) and 3 (2) TFEU discussed later.

80 See Schütze, 'Lisbon and the Federal Order of Competences', 714; Cremona, 'An Assessment of the Provisions on EU External Action in the Constitutional Treaty', EUI Working Paper, 30 (2006), 10-11.

81 See the references by Klamert and Maydell, 'Lost in Exclusivity', 495.

82 But see Craig, The Lisbon Treaty, 400, who seems to confine Art. 216 (1) TFEU to exclusive competence.

This is an open access version of the publication distributed under the terms of the Creative Commons Attribution-NonCommercial-NoDerivs licence (http://creativecommons.org/licenses/by-nc-nd/3.0/), which permits non-commercial reproduction and distribution of the work, in any medium, provided the original work is not altered or transformed in any way, and that the work is properly cited. For commercial re-use, please contact academic.permissions@oup.com 
the double necessity standard applying to either exclusive competence or non-exclusive competence. ${ }^{83}$ After all, case law invoked in support of implied shared competence before the Lisbon Treaty, such as the Lugano Opinion, has also only referred to 'necessity' and not to facilitation. Nonetheless, as explained, there are good reasons to argue also for a facilitation standard on its basis. If we affirm this category of conditional shared competence based on case law prior to the Lisbon Treaty, however, where it is only stated in a very circumscribed manner, it is submitted that we should have no trouble also reading it into the analogous wording of Article 216 (1) TFEU. This is also supported by the fact that, as argued, other parts on external competence in the Lisbon Treaty equally have to rely on interpretation in light of the case law before Lisbon in order not to be nonsensical (the ERTA principle) or overly broad (the Opinion $1 / 76$ principle).

There is a third possible way of approaching this issue, which is to argue that in this specific case the intention of the drafters to make all implied competences explicit should not guide us in our interpretation of Article 216 (1) TFEU. At the time of the Convention on the Future of Europe, the Lugano Opinion had not yet been handed down by the Court. The case law on this issue before the Lugano Opinion was not conclusive, and even after this Opinion it would have been difficult for the drafters to codify this kind of implied competence, because little could (and can) be said on it with certainty. ${ }^{84}$ This, therefore, might be a case where it is still apposite to fully resort to the (pre-Lisbon) case law to establish competence.

\section{Conclusion}

I submit that the earlier assessment weighs in favour of the continued existence of a conditional shared external competence based either on Article 216 (1) TFEU or pre-Lisbon case law. In any case, apart from all the other ambiguities in the present context left unresolved by the Lisbon Treaty and the new ambiguities created by it, it is deplorable that an opportunity has been passed for enhancing clarity on the important issue of shared external competences.

The Lisbon Treaty classifies Union competences both in substance and in terminology. This deserves to be successful at least on the latter account in view of the confusion previously reigning in this matter. In terms of substantive achievements, the Lisbon Treaty must be considered a failure in the present context, when we consider clarity, conferral, containment, and consideration as the four major forces driving the reform process resulting in the Treaty provisions discussed in this section. ${ }^{85}$ Clarity must be deemed a failure since the new provisions of Article 3 (2) and Article 216 (1) TFEU will not remove the need to resort to pre-Lisbon case law for guidance on key principles. One might probably even say that the task of the drafters of the Constitutional Treaty and, based on their work, the drafters of the Lisbon treaty was doomed to fail because of the complexities of the case law. ${ }^{86}$ As regards conferral, the Lisbon Treaty has not answered

83 See the doctrine of implied powers in public international law, where such powers are implied whenever they are essential for the fulfilment of an organization's objects and purposes, but where the power to be implied must not be indispensably required. cf. D. Akande, 'International Organizations', in M. Evans (ed.), International Law, 3rd edn. (Oxford: Oxford Univ. Press, 2010), 252-283, 265, citing H. Lauterpacht.

84 cf. Klamert and Maydell, 'Lost in Exclusivity'. $\quad 85$ See Craig, The Lisbon Treaty, 157.

86 In a similar vein, B. de Witte, 'Too Much Constitutional Law in the European Union's Foreign Relations?', in M. Cremona and B. de Witte (eds), EU Foreign Relations Law: Constitutional Fundamentals (Oxford and Portland, Oregon: Hart Publishing, 2008), 3, 11: 'The Court's case law on that matter is

This is an open access version of the publication distributed under the terms of the Creative Commons Attribution-NonCommercial-NoDerivs licence (http://creativecommons.org/licenses/by-nc-nd/3.0/), which permits non-commercial reproduction and distribution of the work, in any medium, provided the original work is not altered or transformed in any way, and that the work is properly cited. For commercial re-use, please contact academic.permissions@oup.com 
the question of the scope and conditions of shared external powers of the Union. This creates the risk that the old confusion will keep the Court at the forefront of delimiting external powers in the Union, with results that might well nullify the newly affirmed principle of conferral. ${ }^{87}$ Containment has therefore also probably failed bearing in mind that the amendments were meant to get a firm hold on the implied competences regime. Consideration in the sense of a systematic re-assessment of the competence matter as a whole is the only aspect which cannot be regarded as a failure, but only because it did not happen in the first place. ${ }^{88}$

In the following, I will take a closer look at non-exclusive competences, where I will argue that loyalty is especially important not as their basis as with some (formerly) implied competences discussed earlier, but as the central rule for guiding their exercise.

so complex that, when the members of the Convention on the Future of the Union set out to codify the Court's case law on this point, they failed to get it right and the combined reading of Article I-13(2) and Article III-323(1) is neither a correct codification of the case law nor otherwise satisfactory.'

87 See for a similar verdict on other premises Cremona, 'Defining Competence', 57.

88 See Cremona, 'Defining Competence', 57.

This is an open access version of the publication distributed under the terms of the Creative Commons Attribution-NonCommercial-NoDerivs licence (http://creativecommons.org/licenses/by-nc-nd/3.0/), which permits non-commercial reproduction and distribution of the work, in any medium, provided the original work is not altered or transformed in any way, and that the work is properly cited. For commercial re-use, please contact academic.permissions@oup.com 


\section{8 \\ Loyalty and Non-exclusive Competences}

\section{Introduction}

In the following, I will deal with non-exclusive competences in more detail than done so far. In the present context, this is apposite for the following reasons. What I call regular shared competences have been discussed earlier both in terms of their now explicit foundation in the Lisbon Treaty, as well as with regard to exclusivity superveniens as the consequence of their exercise by the Union.

In thissection, Iwillassessatheory thathas proposed tocombinetheInter-Environnement Wallonie case law with the rules governing regular shared competences. Moreover, it has often been argued in the literature that loyalty is also the key principle guiding the exercise of supporting competences such as for health and culture. However, no specific account has been produced to date of how precisely these Union powers are governed by Article 4 (3) TEU.

Finally, there are competences mentioned in Article 2 (2) TFEU which I call irregular shared competences, in particular development policy. These are a hybrid between shared and supporting competence, which suggests that loyalty has a role to play there too.

\section{Loyalty and 'Regular' Shared Competences}

As explained in Chapter 7, Article 4 TFEU provides for two different kinds of shared competences. The first are those I have called regular shared competences and their exercise generates exclusivity superveniens, as discussed earlier. When regular shared competences are exercised with the instrument of regulations, this effect is rather straightforward. The standard instruments in this respect, however, are directives. These, as also discussed previously, produce a number of distinct legal constraints on the Member States, depending on the maturity of the Union interest expressed by them. One of them has been introduced by the Inter-Environnement Wallonie case law discussed earlier and prohibits Member States from 'taking any measures liable seriously to compromise the result prescribed' in the directive. ${ }^{1}$

This case law on the effect of Union directives based on loyalty and Article 288 TFEU has been proposed to apply also prior to the exercise of a shared competence by the Union. ${ }^{2}$ It has been submitted, ' $[\mathrm{t}]$ hat the Court has to date found Article $10 \mathrm{EC}$ to be applicable to the period for implementing directives, but not to the exercise of

\footnotetext{
1 Case C-129/96 Inter-Environnement Wallonie [1997] ECR 7411, paras 45 passim. See Chapters 4 and 6.

2 Opinion of AG Poiares Maduro in Joined cases C-205/06 Commission v Austria and C-249/06 Commission v Sweden [2009] ECR I-1301, paras 33-38.
}

This is an open access version of the publication distributed under the terms of the Creative Commons Attribution-NonCommercial-NoDerivs licence (http://creativecommons.org/licenses/by-nc-nd/3.0/), which permits non-commercial reproduction and distribution of the work, in any medium, provided the original work is not altered or transformed in any way, and that the work is properly cited. For commercial re-use, please contact academic.permissions@oup.com 
Community competence granted by the Treaty, is purely a matter of chance'. ${ }^{3}$ In support of this claim, it has been pointed out that in both cases 'a conflict with national legislation can occur only after a certain point in time, respectively the end of the period for transposition and the exercise of Community competence'. ${ }^{4}$ I have explained earlier in detail why this is precisely the reason why supremacy does not apply before the deadline for transposition has expired. Before this deadline expires, there is no conflict between Union law and national law, since the directive has not yet matured to a form where it can require to be applied in national law. The same applies to shared competences; before these competences are exercised, no legal act by the Union exists that could be held against national law.

However, to find that supremacy does not operate in either situation does not allow for an analogy regarding the effects preceding such situation with directives and shared competences, respectively. First, it does make a difference that with directives the expiry of the transposition period and, thus, the graduation of the legal norm is certain, whereas the exercise of a shared competence remains a mere possibility. ${ }^{5}$ In the same vein, it is relevant that competence norms are provided in the Treaty yet require an actual activation by the Union legislator, whereas directives already constitute such activation. ${ }^{6}$ As explained in Chapter 5, loyalty applies only when there is a certain expression of Union interest, beyond the mere objectives provided by the Treaty. The fact that Article 4 (3) TEU third sentence speaks generally of the 'objectives of this Treaty' as the reference for duties of abstention of the Member States should not be read as the 'naked' Treaty objectives. ${ }^{7}$ In light of the Sea Fisheries and Waterways jurisprudence discussed earlier, it does make a difference that with shared competences the Union legislator has not yet expressed the intent to activate its powers, i.e. has not taken 'Union action' and has not concretized the Union interest. Thus, there is, in my opinion, a decisive difference between the 'result prescribed' in a directive, which is the cause of the abstention duty in Inter-Environnement Wallonie quoted earlier, on the one hand, and the regulatory objective expressed in the legal basis for a shared competence on the other. ${ }^{8}$

Apart from the fact that the analogy refuted earlier would impose a sequential double abstention duty on Member States by Article 4 (3) TEU applying before the exercise of competence, and exclusivity superveniens applying after the exercise, there would be other problems with the proposed restraint on Member States. Assuming a duty of abstention under certain conditions with regard to shared competences lacks the precise target date for assessing the need to preclude the Member States. With a directive, this is

\footnotetext{
3 AG Poiares Maduro in Joined cases C-205/06 Commission v Austria and C-249/06 Commission $v$ Sweden [2009] ECR I-1301, para 38. The Court in its judgments against Austria and Sweden only applied ex Art. 307 EC.

4 AG Poiares Maduro in Joined cases C-205/06 Commission v Austria and C-249/06 Commission v Sweden [2009] ECR I-1301, para 37.

5 AG Poiares Maduro in Joined cases C-205/06 Commission v Austria and C-249/06 Commissionv Sweden [2009] ECR I-1301, para 39.

${ }^{6}$ AG Poiares Maduro in Joined cases C-205/06 Commission v Austria and C-249/06 Commission v Sweden [2009] ECR I-1301, para 39. As mentioned, a directive's objective is binding from the moment the instrument has been passed by the Union legislator. The fact that Member States are given a 'grace period' to adapt their national laws should not distract from this.

7 See AG Poiares Maduro in Joined cases C-205/06 Commission v Austria and C-249/06 Commission $v$ Sweden [2009] ECR I-1301, para 38. See also Chapter 14 on amplification.

8 See also P. Koutrakos, 'Annotation to Case C-205/06, Commission v. Austria and Case C-249/06, Commission v. Sweden', Common Market Law Review, (2009), 2059-2076, 2066-2067; C. Tietje, 'Art. 114 AEUV', in E. Grabitz, M. Hilf, and M. Nettesheim, Das Recht der Europäischen Union, Kommentar (Munich: Beck, 2011), para 65.
}

This is an open access version of the publication distributed under the terms of the Creative Commons Attribution-NonCommercial-NoDerivs licence (http://creativecommons.org/licenses/by-nc-nd/3.0/), which permits non-commercial reproduction and distribution of the work, in any medium, provided the original work is not altered or transformed in any way, and that the work is properly cited. For commercial re-use, please contact academic.permissions@oup.com 
when the deadline for transposition expires, while Member States are free to act after a directive enters into force, as long as their actions do not jeopardize the attainment of the obligation of full transposition by the point of time mentioned. However, what point of time would be decisive with objectives provided by competence norms?

The theory discussed has been presented against the background of the BIT cases against Austria and Sweden. ${ }^{9}$ In these cases, the Commission had claimed that the bilateral investment agreements of these Member States did not provide for the restrictions on the free movement of capital to and from third countries, which the Union could introduce based on ex Articles 57 (2), 59, and 60 (1) EC, but had not done at that time. It was, therefore, the urgency of possible Union measures, such as sanctions, which should justify the restraints on the freedom of Member States to commit themselves in their relations with third states. Should the analogy with directives hold, Member States would have to be prohibited from entering into international agreements that they could not terminate or modify fast enough to enable the Union to act effectively under the Treaty provisions mentioned. This, however, would not provide a clear indication for the Member States as to when they would have to abstain from acting themselves in order not to jeopardize the exercise of such Union powers.

This, however, does not mean that loyalty could not take effect in combination with a clear expression of Union interest connected to shared competence. Externally, as discussed in Chapter 5, a Council mandate to negotiate furnishes an early manifestation of such interests, as illustrated by the Waterways decision of the Court. As explained, the Court required the Member State concerned to inform the Commission and allow it a certain amount of time to decide whether to exercise its competence. With internal lawmaking, in contrast, there exists no comparable event; the passing of an act of secondary law based on a regular shared competence is 'only' preceded by a Commission proposal. In situations where the Treaty clearly requires expeditious action, such Commission proposal could already exceptionally generate duties based on Article 4 (3) TEU as an expression of Union interest. However, in view of the fact that even an expression of Union interest by the Council does not create full abstention duties, I would submit that the constraints produced by a Commission proposal would also not go beyond obligations of information and consultation for the Member States.

\section{Loyalty and 'Irregular' Shared Competences}

\subsection{Introduction}

As already mentioned, the policy areas listed under Article 4 (3) and (4) TFEU are irregular shared competences. The exercise of competence by the Union in the areas of research, technological development, and space and, more importantly, development cooperation and humanitarian aid 'shall not result in Member States being prevented from exercising theirs'. ${ }^{10}$ Union development policy shall rather contribute to Member State policy in that field. Thus, Article 208 (1) TFEU states that Union measures and Member States measures in this field 'complement and reinforce each other'. As it has been put, development policy is a field where the more activity there is by the Member

9 Joined cases C-205/06 Commission v Austria and C-249/06 Commission v Sweden [2009] ECR I-1301.

${ }_{10}$ Economic, financial, and technical cooperation with third countries regulated in Art. 212 (3) TFEU is an irregular shared competence not provided in the non-exhaustive list in Art. 4 TFEU.

This is an open access version of the publication distributed under the terms of the Creative Commons Attribution-NonCommercial-NoDerivs licence (http://creativecommons.org/licenses/by-nc-nd/3.0/), which permits non-commercial reproduction and distribution of the work, in any medium, provided the original work is not altered or transformed in any way, and that the work is properly cited. For commercial re-use, please contact academic.permissions@oup.com 
States and the Union the better it is for the attainment of the objectives of the Treaty. ${ }^{11}$ At the same time, the Treaty makes clear that the fields of action of the Union and the Member States are not identical. Article 211 TFEU, in this vein, speaks of the 'respective spheres of competence'. ${ }^{12}$

For development cooperation and humanitarian aid, Article 209 (1) TFEU allows the Union 'to carry out activities and conduct a common policy' under the ordinary legislative procedure. ${ }^{13}$ The ability of the Union to conduct a 'common policy' for development cooperation and humanitarian aid must not be read as conferring the power to harmonize national laws in this field. ${ }^{14}$ The large numbers of regulations that have been based on ex Article 179 EC (now Article 209 TFEU) in the past are mostly about providing financial assistance to developing countries. ${ }^{15}$ While they establish a common policy, inherently they are not of a harmonizing character. ${ }^{16}$

\subsection{The External Side of Irregular Competences}

Externally, development policy under ex Article 181 EC (now Article 211 TFEU) has been defined in a number of judgments by the ECJ as entitling Member States to enter into commitments themselves vis-à-vis third states concerning development cooperation, which may be done collectively, individually, or even jointly with the Union. ${ }^{17}$ The generally non-pre-emptive nature of development cooperation and humanitarian aid competences is also reflected in their provisions on external relations. The same as the Nice Treaty had already provided in ex Article 181 EC (development cooperation) and Article 181a EC (humanitarian aid), the corresponding provisions of the Lisbon Treaty emphasize that the power of the Union to conclude international agreements does not prejudice the Member State's treaty-making powers. In the words of Article 209 (2) TFEU on development cooperation:

The Union may conclude with third countries and competent international organisations any agreement helping to achieve the objectives referred to in Article 21 of the Treaty on European Union and in Article 208 of this Treaty.

The first subparagraph shall be without prejudice to Member States' competence to negotiate in international bodies and to conclude agreements. ${ }^{18}$

Thus, once the Union enters into an international agreement the Member States are not necessarily precluded from also entering into obligations with third states. ${ }^{19}$

11 AG Kokott in Case C-13/07 Commission v Council (Accession of Vietnam to WTO), removed from registry, para 70 .

12 'Within their respective spheres of competence, the Union and the Member States shall cooperate with third countries and with the competent international organisations.'

13 The area of research, technological development, and space also seems to be qualified regarding the nature of measures that may be passed under their umbrella, since a common policy is not foreseen.

14 Case C-268/94 Portugalv Council [1996] ECR I-6177, paras 39 and 47. When harmonizing powers are conferred in the Lisbon Treaty, this is expressly stated. See Art. 114 (1) and (4) TFEU.

15 See, among many others, Regulation (EC) 1337/2008 establishing a facility for rapid response to soaring food prices in developing countries [2008] OJ L 354/62.

16 See M. Klamert, 'Art. 209 AEUV', in H. Mayer and K. Stöger (eds), EUVIAEUV Kommentar (Vienna: Manz, 2010), paras 3-8.

17 See Case C-268/94 Portugalv Council [1996] ECR I-6177, para 36.

18 See also Art. 214 (4) TFEU.

19 AG Jacobs in Case C-316/91 Lomé Convention [1994] ECR I-625, para 50: 'It cannot be accepted, however, that, as the Parliament contended especially at the oral hearing, once the Community undertakes an obligation by entering into an international agreement, the Member States are necessarily excluded from undertaking that obligation jointly with the Community.'

This is an open access version of the publication distributed under the terms of the Creative Commons Attribution-NonCommercial-NoDerivs licence (http://creativecommons.org/licenses/by-nc-nd/3.0/), which permits non-commercial reproduction and distribution of the work, in any medium, provided the original work is not altered or transformed in any way, and that the work is properly cited. For commercial re-use, please contact academic.permissions@oup.com 
However, this right must be placed under the condition that these obligations do not affect or alter the scope of the Union (part of the joint) agreement. It is a fallacy to rule out the possibility of conflict between Union and national measures in an area such as development policy. ${ }^{20}$ This danger may be less prevalent here since, in the words of AG Jacobs, 'the risk that action undertaken by the Member States may have adverse consequences on action undertaken by the Community is much less than it is in other areas such as that of social policy'. ${ }^{21}$ However, suppose that both the Union and one or several Member States grant financial assistance to the same developing countries. As a matter of principle, the existence of Union measures does not prevent the Member States from also providing assistance. Yet, it is submitted that Union law requires the Union and the Member States to coordinate to avoid such Member State action undermining the effectiveness of the Union measures. In the following section, I will discuss two different conceivable constellations with different degrees of disturbance of this union effectiveness, both of which call for the application of loyalty.

\subsection{The Role of Loyalty}

Union action may be affected when double structures are established or identical projects are funded on Member State level and on EU level. Double structures may lead to inefficiency and unnecessary administrative costs, while additional Member State funding may make EU funding superfluous. For this constellation, which does not amount to a full conflict, Article 210 (1) TFEU provides the following specification of the general principle of loyalty: ${ }^{22}$

(I)n order to promote the complementarity and efficiency of their action, the Union and the Member States shall coordinate their policies on development cooperation and shall consult each other on their aid programmes, including in international organisations and during international conferences.

This provision comprises active duties of coordination such as the regular exchange of information, joint studies and evaluations, and the streamlining of separate programmes. ${ }^{23}$ A specification of Article 210 (1) TFEU can be found in Regulation 1905/2006 establishing a financing instrument for development cooperation (DCI). ${ }^{24}$ The DCI's Article 3 (6) calls for 'regular and frequent exchanges of information' between the Commission and the Member States, and 'joint multiannual programming, based

20 This, however, is encouraged when referring to development cooperation as 'parallel' competence. See R. Schütze, 'Lisbon and the Federal Order of Competences: A Prospective Analysis', European Law Review, (2008), 709-722, 717, who has asked: 'Why can two parallels "complement" each other and why emphasise a duty of co-operation for two levels that supposedly could never come into conflict?'. This is a good example why the drafters of the Lisbon Treaty chose well in avoiding the term 'parallel' in the context of competences. It is somewhat circular to pick a certain term to denote a category of competence and then to infer from the chosen term the characteristics that such a kind of competence should have. Clearly, in geometry, parallels cannot meet. To follow, however, that 'parallel' competences cannot enter into conflict and that for this reason there is no need for cooperation is not convincing.

21 AG Jacobs in Case C-316/91 Lomé Convention [1994] ECR I-625, para 49.

22 There is no such rule for the cooperation with non-developing countries in Art. 212 TFEU. However, loyalty arguably extends the same principles also to this related area. See F. Hoffmeister, 'Art. 212 AEUV', in E. Grabitz, M. Hilf, and M. Nettesheim (eds), Das Recht der Europäischen Union (Munich: Beck, 2011), para 12.

23 K. Schmalenbach, 'Art. 210 AEUV', in C. Calliess and M. Ruffert (eds), EUVIAEUV, 4th edn. (Munich: Beck, 2011), para 4.

24 Regulation (EC) 1905/2006 establishing a financing instrument for development cooperation (DCI) [2006] OJ L 378/41.

This is an open access version of the publication distributed under the terms of the Creative Commons Attribution-NonCommercial-NoDerivs licence (http://creativecommons.org/licenses/by-nc-nd/3.0/), which permits non-commercial reproduction and distribution of the work, in any medium, provided the original work is not altered or transformed in any way, and that the work is properly cited. For commercial re-use, please contact academic.permissions@oup.com 
on partner countries' poverty reduction or equivalent strategies and partner countries' own budget processes, by common implementation mechanisms including shared analysis, by joint donor-wide missions and by the use of co-financing arrangements'

The second possible situation, in contrast, might not be prevented by the specific duty of cooperation foreseen in the Treaty. This would be the case when a Member State provides support to the same project under contradicting conditions (condition $\mathrm{x}$ instead of condition $\mathrm{y}$ ), or under an additional condition (condition $\mathrm{x}+1$ ). There are three possible approaches to resolving this issue: (1) Union actions are given priority and Member States must abstain from undermining them or remove incompatibilities in existing measures ('pro-Union'). (2) The Member State can go ahead with its measure irrespective of a contradicting (preceding or following) Union measure ('pro-Member State'). (3) Both actors, the Union as well as the Member State, must cease their activities when they cannot arrive at common terms.

In support of the first, the pro-Union view argues Declaration Nr. 10 'on Articles $109,130 \mathrm{r}$ and $130 \mathrm{y}$ of the Treaty establishing the European Community' attached to the Maastricht Treaty. ${ }^{25}$ It refers to the competences for, among others, environment (now Article 191 (4) TFEU) and development cooperation (now Article 209 TFEU), and has the following wording:

The Conference considers that the provisions of Article 109 (5), Article 130r (4), second subparagraph, and Article $130 \mathrm{y}$ do not affect the principles resulting from the judgement handed down by the Court of Justice in the AETR case.

Since the wording of the relevant Treaty provisions has not changed, this Declaration must still be considered as a guideline for their interpretation. It has also not been qualified by Declaration 36 to the Lisbon Treaty. ${ }^{26}$ It can only mean that in (the unlikely) case of conflict, Member States must abstain from entering into international agreements, which could affect or undermine a Union measure in this policy field. ${ }^{27}$ These measures include international agreements concluded by the Union, since they, as explained, also constitute common rules within the meaning of Article 3 (2) TEU. This means, conversely, that Member States are precluded neither in their internal options, since ERTA is a cross-cutting duty of abstention, nor, more importantly, in their external capacity, as a matter of principle. The latter freedom, however, is upon the condition that the Member States do not enter into conflicting obligations with third states. ${ }^{28}$

This resolves the contradiction between the no-preclusion standard prescribed by Article 4 (3) and (4) TFEU for irregular shared competences on the one hand, and Declaration 10 on the relevance of ERTA in this area on the other. It also finds support in the Treaty, where Article 208 TFEU requires the Union and the Member States to complement and to reinforce each other's actions. While this might be read as a prohibition on adopting conflicting measures addressed to both the Member States and the Union

25 See <http://www.eurotreaties.com/maastrichtfinalact.pdf>.

26 'The Conference confirms that Member States may negotiate and conclude agreements with third countries or international organisations in the areas covered by Chapters 3, 4 and 5 of Title V of Part Three in so far as such agreements comply with Union law.'

27 Recall that 'common rules' is a broad term and is not limited to harmonization measures, which are prohibited under development policy.

${ }^{28}$ See AG Jacobs in Case C-316/91 Lomé Convention [1994] ECR I-625, 641: 'Once the Community enters into an international agreement, the Member States are precluded from doing anything capable of affecting that agreement or altering its scope. The exact limits of the duty imposed on the Member States in that context cannot be laid down in advance but depend on the agreement in question.' See also J. McMahon, The Development Co-operation Policy of the EC (The Hague: Kluwer Law International, 1998), 241.

This is an open access version of the publication distributed under the terms of the Creative Commons Attribution-NonCommercial-NoDerivs licence (http://creativecommons.org/licenses/by-nc-nd/3.0/), which permits non-commercial reproduction and distribution of the work, in any medium, provided the original work is not altered or transformed in any way, and that the work is properly cited. For commercial re-use, please contact academic.permissions@oup.com 
with resulting mutual duties of abstention, a systematic interpretation, not least in view of the fact that irregular shared competences are classified as shared, arguably militates for a pro-Union approach. ${ }^{29}$

\subsection{Conclusion}

The difference to regular shared competences, then, lies in the fact that coordinated or joint action by the Union and the Member States is explicitly exhorted in the Treaty. The Union shall normally complement existing Member State development policy measures and vice versa. The 'normal' consequence of the passing of secondary law in areas of regular shared competences, in contrast, is that Member States are barred from taking action, unless it implements the Union law measures. With irregular shared competences we, therefore, cannot really speak of exclusivity superveniens as the result of the exercise of competence by the Union. The adoption of development policy measures by the Union, as a rule, does not preclude the Member States. Witness of this is the prohibition on harmonizing national laws based on irregular shared competences. In other words, we might conclude that regular shared competences differ from irregular ones with regard to the normal 'cooperative' situation foreseen by the Treaty. This means that a Union measure shall not preclude the Member States but provide the basis for complementary action. Where irregular and regular shared competences do not differ, however, is in a case where Member States adopt (internal or external) measures which undermine or contradict Union measures ('the confrontational' case). As with regular shared competences, this is not allowed by Union law. There is, thus, some reason in placing irregular shared competences in the shared competences basket. ${ }^{30}$

In the following section, I will discuss supporting competences, which, according to the classification introduced by the Lisbon Treaty, should also differ from irregular shared competences.

\section{Loyalty and Supporting Competences}

\subsection{Introduction}

It has already been mentioned in the first part of this Chapter that the Lisbon Treaty has introduced a competence category entitling the Union 'to carry out actions to support, coordinate or supplement the actions of the Member States, without thereby superseding their competence in these areas'. ${ }^{31}$ Harmonization of Member State laws or regulations is explicitly prohibited in the policy areas falling under this competence. ${ }^{32}$ The most important Union measures in these areas, therefore, are based on other legal bases such as Article 114 TFEU on approximation with measures related to health

29 For a different perspective, see K. Schmalenbach, 'Art. 209 AEUV', in C. Calliess and M. Ruffert (eds), EUVIAEUV: Das Verfassungsrecht der Europäischen Union mit Europäischer Grundrechtecharta, 4th edn. (Munich: Beck, 2011), paras 11-12.

30 Critical Schütze, 'Lisbon and the Federal Order of Competences', 717; P.P. Craig, The Lisbon Treaty: Law, Politics and Treaty Reform (Oxford: Oxford Univ. Press, 2010), 171.

31 Art. 2 (5) TFEU. See the list in Art. 6 TFEU, comprising the protection and improvement of human health; industry; culture; tourism; education, vocational training, youth, and sport; civil protection and administrative cooperation.

32 See Craig, The Lisbon Treaty, 176-178, who notes that this will make the meaning of harmonization vital after Lisbon.

This is an open access version of the publication distributed under the terms of the Creative Commons Attribution-NonCommercial-NoDerivs licence (http://creativecommons.org/licenses/by-nc-nd/3.0/), which permits non-commercial reproduction and distribution of the work, in any medium, provided the original work is not altered or transformed in any way, and that the work is properly cited. For commercial re-use, please contact academic.permissions@oup.com 
policy, and Article 207 TFEU on commercial policy with measures related to culture. ${ }^{33}$ Typical measures taken under the competence for culture are Council resolutions, decisions, and conclusions. ${ }^{34}$

Thus, supporting competences have in common with irregular shared competences that their exercise does not preclude Member State action, even when this is expressed with a different wording in Article 2 (5) TFEU. With regard to the external sphere, there is one line common to the Treaty provisions on culture, health, and education:

The Union and the Member States shall foster cooperation with third countries and the competent international organisations [in the sphere of public health]. ${ }^{35}$

Recall that with irregular shared competences, there is, on the one hand, a mandate to conclude international agreements with third countries, which, on the other hand, shall not preclude Member State external competence. ${ }^{36}$ The wording for supporting competences clearly is much weaker as it only provides for measures to 'foster cooperation' with third countries. Nonetheless, this must be understood as conferring the power to enter into international agreements for the Union. Same as with development cooperation, the prohibition of harmonization cannot be circumvented by such an international agreement. ${ }^{37}$

\subsection{The Role of Loyalty}

\subsubsection{Introduction}

Such as with irregular shared competences, we may distinguish between the cooperative side of the relationship between Member States and the Union and the confrontational side. Both are governed by loyalty in different manifestations. Regarding 'cooperation' it is, again, apposite to ask for the legal instruments to maximize the effectiveness and the efficiency of Union action. Regarding 'confrontation', in contrast, it must again be enquired which side shall prevail when there is, despite cooperation, an actual or imminent conflict between Union and national action in the field concerned.

Arguments that loyalty does not fully apply in areas of supporting competence must be rejected in view of the fact that Member States are bound by loyalty even when they exercise their national, 'retained' competences, thus act in areas where there is no Union competence at all. ${ }^{38}$ I would submit that the minimum requirement is that the Member

33 See Directive (EU) 2010/13 on the coordination of certain provisions laid down by law, regulation, or administrative action in Member States concerning the provision of audiovisual media services (Audiovisual Media Services Directive) [2010] OJ L95/1. See on this B. de Witte, 'A Competence to Protect: Pursuing Non-Market Aims Through Internal Market Laws', in P. Syrpis (ed.), The Judiciary, the Legislature and the EU Internal Market (Cambridge: Cambridge Univ. Press, 2012), 25-46, 34-35. See also Council Regulation (EC) 116/2009 on the export of cultural goods [2009] OJ L39/1, based on ex Art. 133 EC. The Court has condoned this practice in Union lawmaking of regulating cultural matters with instruments based on other legal bases in Case 152/82 Forcheri [1983] ECR 2323, para 17; and in Case 293/83 Gravier [1985] ECR 593, para 19.

34 See, among others, Council Resolution on the first century of the cinema [1994] OJ C85/3.

35 Art. 168 (3) TFEU. See Arts. 165 (3) and 166 (3) TFEU for education and Art. 167 (3) TFEU for culture.

36 See also Art. 214 (4) TFEU.

37 P. Eeckhout, External Relations of the European Union: Legal and Constitutional Foundations (Oxford, Oxford Univ. Press, 2011), 96; M. Cremona, 'Defining Competence in EU External Relations: Lessons from the Treaty Reform Process', in A. Dashwood and M. Maresceau (eds), Law and Practice of EU External Relations: Salient Features of a Changing Landscape (Cambridge: Cambridge Univ. Press, 2008), 34-69, 52.

38 See Chapters 1 and 10.

This is an open access version of the publication distributed under the terms of the Creative Commons Attribution-NonCommercial-NoDerivs licence (http://creativecommons.org/licenses/by-nc-nd/3.0/), which permits non-commercial reproduction and distribution of the work, in any medium, provided the original work is not altered or transformed in any way, and that the work is properly cited. For commercial re-use, please contact academic.permissions@oup.com 
States take due consideration of the interests of the Union. If loyalty is operating across the whole board also in matters entirely out of the realm of Union powers, it must apply even more in the field of supporting competences, where there is a competence of the Union. While this does not go so far as to oblige Member States to participate in Union cultural programmes, the Union, conversely, is not required to contribute to actions initiated by the Member States. Thus, the Union is entitled to conduct an independent external policy. ${ }^{39}$ This, however, does not abolish the risk of both inefficiencies as well as conflicts, even though the latter are less likely with supporting competences, as I will explain in the following section.

\subsubsection{The cooperative perspective}

Article $168 \mathrm{TFEU}$ on health policy explicitly provides for the application of a detailed duty of cooperation addressed to both the Union as well as to the Member States. According to this provision, the Union shall encourage cooperation between the Member States, in particular to improve the complementarity of their health services in cross-border areas. Moreover, Member States shall also coordinate among themselves, 'in liaison with the Commission'. 'The Commission may, in close contact with the Member States, take any useful initiative to promote such coordination, in particular initiatives aiming at the establishment of guidelines and indicators, the organisation of exchange of best practice, and the preparation of the necessary elements for periodic monitoring and evaluation.'

Thus, the recent Healthcare Directive 2011/24/EU has been based also on Article 168 TFEU and contains various mechanisms of cooperation in its Chapter IV as an integral part of the framework. ${ }^{40}$ This has been claimed to 'give expression, in specific terms, to the complementary competence for which the Union has received recognition in the area of health'. ${ }^{41}$

An obligation of the Member States to listen to the Commission and not to reject its input without reason can be inferred from the wording 'in liaison with the Commission'. ${ }^{42}$ Further duties even of the Member States in this context can be argued based on a judgment of the Court on the interpretation of ex Article 118 EEC (now Article 156 TFEU) on social policy. Ex Article 118 EEC conferred on the Commission 'the task of promoting close cooperation between Member States in the social field', and the mandate to act in close contact with the Member States by making studies, delivering opinions, and arranging consultations. In regard to this provision, the Court held that the Commission must be able to require the Member States to notify essential information and to take part in consultations. ${ }^{43}$

39 See, for culture, H.-J. Blanke, 'Art. 167 AEUV', in C. Calliess and M. Ruffert (eds), EUVI AEUV: Das Verfassungsrecht der Europäischen Union mit Europäischer Grundrechtecharta, 4th edn. (Munich: Beck, 2011), para 6.

40 Directive (EU) 2011/24 on the application of patients' rights in cross-border healthcare [2011] OJ L88/45.

${ }_{41}$ S. de la Rosa, 'The Directive on Cross-border Healthcare or the Art of Codifying Complex Case Law', Common Market Law Review, 49 (2012), 15-46, 42. Qualifying the cooperation mechanisms in the Dir 2006/123 as merely ancillary in comparison might, however, underestimate their potential.

42 See T. Kingreen, 'Art. 168 TFEU', in C. Calliess and M. Ruffert (eds), EUVIAEUV: Das Verfassungsrecht der Europäischen Union mit Europäischer Grundrechtecharta, 4th edn. (Munich: Beck, 2011), para 24.

43 Joined cases 281, 283, 284, 285, and 287/85 Germany v Commission [1987] ECR 3203, para 28.

This is an open access version of the publication distributed under the terms of the Creative Commons Attribution-NonCommercial-NoDerivs licence (http://creativecommons.org/licenses/by-nc-nd/3.0/), which permits non-commercial reproduction and distribution of the work, in any medium, provided the original work is not altered or transformed in any way, and that the work is properly cited. For commercial re-use, please contact academic.permissions@oup.com 
Article 156 TFEU on social policy now has a very similar wording compared to Article $168 \mathrm{TFEU}$ on health policy. ${ }^{44}$ I would submit that the mentioned duties of information and consultation on the part of the Member States vis-à-vis the Commission should also apply with regard to coordination between the Member States in the field of health policy, because the duties are linked to the tasks of the Commission, which, as shown, do not differ in these areas.

In contrast to health and social policy, the Treaty provisions on cultural policy are conspicuously devoid of any mention of duties of coordination, consultation, or information. I submit that this is a lacuna in the Treaty and the rules laid out earlier applying to the field of health policy must be extended to action related to cultural policy in the Union. Health policy is the same kind of competence as cultural policy and both can generate Union measures not only to support the Member States, but also to 'coordinate or supplement the actions of the Member States. ${ }^{45}$ As stated by the Court in the judgment quoted earlier on social policy, the Commission cannot fulfil these tasks properly when Member States are not under an obligation to inform them about their activities in this field. The second reason why stronger obligations of cooperation seem apposite here is the fact that cultural policy is prone to ineffectiveness and inefficiency as much as or perhaps even more so than health policy, because cultural policy largely is about granting financial aid and creating support programmes. Put in other words, if policy areas such as development policy and even health policy are explicitly made subject to a duty of cooperation to avoid inconsistencies and inefficiency, this appears equally apposite for a policy area such as culture.

\subsubsection{The confrontational perspective}

As much as it is wrong to rule out conflict with regard to development cooperation, as I have shown, it is a fallacy to argue that Union cultural measures cannot be affected by or undermine Member State measures. ${ }^{46}$ While under the Nice Treaty cultural policy measures in the Union have been subject to unanimity, Article 167 (5) TFEU now prescribes the ordinary legislative procedure. Thus, when conflicts have been unlikely for political reasons under the Nice Treaty, the majority rule introduced by the Lisbon Treaty in theory enables measures conflicting with interests of one Member State or of a minority of Member States. This is irrespective of the fact that the Union is only vested with the power to adopt 'incentive measures' under Article 167 (5) TFEU. As mentioned with regard to development policy, conflicts may also arise with national and Union measures that provide financial support.

The prescription of the objectives for Union activity in this field in Article 167 (2) $\mathrm{TFEU}^{47}$ must not necessarily limit the Union. The only decisive restraint on the Union

44 'To this end, the Commission shall act in close contact with Member States by making studies, delivering opinions and arranging consultations both on problems arising at national level and on those of concern to international organisations, in particular initiatives aiming at the establishment of guidelines and indicators, the organisation of exchange of best practice, and the preparation of the necessary elements for periodic monitoring and evaluation. The European Parliament shall be kept fully informed.'

45 See further R. Schütze, 'Co-operative Federalism Constitutionalised: The Emergence of Complementary Competences in the EC Legal Order', European Law Review, (2006), 167-184, on the different sides of Art. 168 TFEU after the changes brought in by the Lisbon Treaty.

46 But see J. Heliskoski, Mixed Agreements as Technique for Organizing the International Relations of the European Community and its Member States (The Hague: Kluwer Law International, 2001), 39.

47 The provision mentions improvement of the knowledge and dissemination of the culture and history of the European peoples, conservation and safeguarding of cultural heritage of European

This is an open access version of the publication distributed under the terms of the Creative Commons Attribution-NonCommercial-NoDerivs licence (http://creativecommons.org/licenses/by-nc-nd/3.0/), which permits non-commercial reproduction and distribution of the work, in any medium, provided the original work is not altered or transformed in any way, and that the work is properly cited. For commercial re-use, please contact academic.permissions@oup.com 
is the provision in Article 167 (1) TFEU that the Union 'shall contribute to the flowering of the cultures of the Member States, while respecting their national and regional diversity and at the same time bringing the common cultural heritage to the fore'. Thus, the Treaty obliges the Union to act in the interests of national culture and regional diversity, such as with measures to protect national minorities. ${ }^{48}$ As long as the Union complies with this general mandate, compatibility with a direction parallel to national cultural policies would not be required. However, the nature of measures taken within the cultural policy of the Union is clearly different from those taken in an area such as development policy. As discussed, development policy, though not allowed to harmonize national laws, does produce regulations and directives. Supporting competences, in contrast, are exercised based on decisions and resolutions by the Union, and shall provide the basis for support not granted by the Member States individually.

While unlikely, a conflict could thus arise when the Union is establishing a programme to protect national minorities, which a Member State is not willing to protect. A systematic interpretation, taking into account the delimitation of supporting competences from (irregular) shared competences, and the absence of a statement such as Declaration Nr. 10 on ERTA, argues for a pro-Member State approach here. This means that, in the very unlikely case that Union measures and national measures apply to the same project or programme, and there is a contradiction between the requirements for funding of either party, Member States will not be precluded. Put in other words, as long as there is more money, it does not matter if this is given under contradicting conditions.

\section{Conclusion}

In this Chapter, I have discussed the role of loyalty with the exercise of different kinds of non-exclusive competence. It appears that the lesser the degree of preclusion of Member State rights is as a consequence of the exercise of non-exclusive competences by the Union, the more important and the more detailed are the duties flowing from the principle of loyalty. Thus, duties of cooperation play no role either before or in the aftermath of the exercise of a regular shared competence. Instead, exclusivity superveniens and a duty of abstention regarding external action for the Member States following the ERTA principle govern this area.

With regular shared competences, irregular shared competences such as development cooperation have in common that common rules in the sense of ERTA can be passed by the Union on their basis. However, since harmonization is ruled out in areas such as development cooperation, exclusivity superveniens does not play a great role. As if to compensate for this relative lack of preclusion, the Treaty provides for a specific duty of cooperation with a strong role for the Commission to foster complementarity and effectiveness in these policy fields.

Supporting competences such as on health policy equally provide for specific provisions on cooperation. However, different from the explicit call on the Member States to coordinate with the Union, supporting competences rather emphasize the need for coordination among the Member States, with the Commission taking more of an auxiliary role. In spite of this difference in wording and substance, I have argued to

significance, non-commercial cultural exchanges, and artistic and literary creation, including in the audiovisual sector.

48 For a different perspective, see Blanke, 'Art. 167 AEUV', paras 5-6.

This is an open access version of the publication distributed under the terms of the Creative Commons Attribution-NonCommercial-NoDerivs licence (http://creativecommons.org/licenses/by-nc-nd/3.0/), which permits non-commercial reproduction and distribution of the work, in any medium, provided the original work is not altered or transformed in any way, and that the work is properly cited. For commercial re-use, please contact academic.permissions@oup.com 


\begin{tabular}{|c|c|c|c|c|c|}
\hline $\begin{array}{l}\text { Features } \\
\text { Competence }\end{array}$ & $\begin{array}{l}\text { Harmonization } \\
\text { allowed }\end{array}$ & $\begin{array}{c}\text { Common } \\
\text { rules }=E R T A \\
\text { applies }\end{array}$ & $\begin{array}{l}\text { Directives, } \\
\text { Regulations } \\
\text { may be } \\
\text { passed }\end{array}$ & $\begin{array}{c}\text { Specific } \\
\text { duties of } \\
\text { cooperation } \\
\text { apply }\end{array}$ & $\begin{array}{l}\text { Pro-Union } \\
\text { conflict } \\
\text { resolution } \\
\text { approach }\end{array}$ \\
\hline $\begin{array}{l}\text { Regular } \\
\text { shared }\end{array}$ & Yes & Yes & Yes & No & Yes \\
\hline $\begin{array}{l}\text { Irregular } \\
\text { shared }\end{array}$ & No & Yes & Yes & Yes & Yes \\
\hline Supporting & No & No & No & Yes & No \\
\hline
\end{tabular}

Figure 8.1 Different Categories of Competence and Their Characteristics, in Particular with Regard to Loyalty

extend the principles expressly provided for development cooperation and health to an area such as culture, which lacks corresponding wording. In particular, this would extend the obligation of notification and consultation with the Commission across the whole field of irregular and supporting competences. Furthermore, the Commission should be entitled to impose a structure on the obligatory coordination of national policies in all of these areas.

With all competences discussed earlier, I have distinguished a cooperative perspective from a confrontational perspective and have argued that the latter is apposite also in areas where the Treaty seems to rule out any preclusion of Member State measures. Thus, irregular shared competences harbour enough potential for conflict that it is necessary to decide on whether to take a pro-Union or a pro-Member State approach to resolving them. On this point, I have suggested that a systematic interpretation of the relevant Treaty provisions argues for a pro-Union approach with irregular shared competences, and a Member State friendly approach with supporting competences.

The above figure (Figure 8.1) summarizes these different characteristics of the various categories of competences discussed in this Chapter.

This is an open access version of the publication distributed under the terms of the Creative Commons Attribution-NonCommercial-NoDerivs licence (http://creativecommons.org/licenses/by-nc-nd/3.0/), which permits non-commercial reproduction and distribution of the work, in any medium, provided the original work is not altered or transformed in any way, and that the work is properly cited. For commercial re-use, please contact academic.permissions@oup.com 


\section{9}

\section{Manifestations of Loyalty in Secondary Law}

\section{Introduction}

Union secondary law provides for a number of applications and substantiations of the principle of loyalty in various contexts. Firstly, this can take the form of a restatement of the active duty under Article 4 (3) first indent in acts of secondary law. Thus, Article 1 of Regulation 2847/93 establishing a control system for the Common Fisheries Policy calls on the Member States to adopt appropriate measures to ensure the effectiveness of the Union system for conservation and management of fishery resources, and has been qualified by the Court as a specification of ex Article 10 EC. ${ }^{1}$

Secondly, loyalty in secondary law can represent duties of coordination requiring Member States and the Union actively to manage their relations with each other. Information, notification, and consultation obligations provide examples for these kinds of duties based on loyalty. Thus, certain acts of secondary law foresee duties of exchanging information between the Member States themselves or between the Member States and Union institutions. An example of cooperation in the former constellation is the duty of national institutions to cooperate in matters of social security rights under Regulation No. 1408/72, for which the Court explicitly referred to ex Article 10 EC. ${ }^{2}$

An example of the cooperation between the Member States and the Union can be found in Regulation 1/2003 on the implementation of the rules on competition laid down by Articles 101 and 102 TFEU. ${ }^{3}$ Article 11 of this Regulation requires the Commission and the national competent authorities (NCA) to apply the Union competition rules 'in close cooperation'. Article 13 states that where NCAs of two or more Member States have initiated proceedings under Articles 101 and 102 TFEU in the same case, this may preclude other Member States as well as the Commission. If there is, however, a Commission decision on the application of Articles 101 and 102 TFEU, Article 16 of Regulation 1/2003 safeguards the uniform application of EU competition law by precluding decisions by national courts or NCAs that would run counter to the decision adopted by the Commission. ${ }^{4}$ Against this background, Article 15 requires the mutual exchange of information and assessments between the Commission and NCAs

1 Case C-304/02 Commission v France (Fisheries) [2005] ECR I-06263.

2 See Case C-326/00 Idryma Koinonikon Asfaliseon (IKA) v Vasilios Ioannidis [2003] ECR I-1703.

3 Council Regulation (EC) $1 / 2003$ on the implementation of the rules on competition laid down in Articles 81 and 82 of the Treaty [2003] OJ L 1/1.

4 SeeW.Durner, 'Die Unabhängigkeit nationaler Richter im Binnenmarkt:Zu den Loyalitätspflichten nationaler Gerichte gegenüber der EG-Kommission, insbesondere auf dem Gebiet des Kartellrechts', Europarecht, (2004), 547-574, has called this provision an expression of a general trend towards a 'cooperative separation of powers' between Member States and Union, moving the control of the national judiciary from the 'repressive instrument' of infringement to a preventive instrument of cooperation (556). The insinuation of such a general rule that would apply to all Commission decisions and non-binding communications seems however rather alarmist and in ignorance of the special nature of Union competition law.

This is an open access version of the publication distributed under the terms of the Creative Commons Attribution-NonCommercial-NoDerivs licence (http://creativecommons.org/licenses/by-nc-nd/3.0/), which permits non-commercial reproduction and distribution of the work, in any medium, provided the original work is not altered or transformed in any way, and that the work is properly cited. For commercial re-use, please contact academic.permissions@oup.com 
on the one side, and Member State courts on the other. This cooperation mechanism shall ensure the 'coherent application of the competition rules in the Member States', ${ }^{5}$ and is as such 'part of the general principle of sincere cooperation, referred to in Article $10 \mathrm{EC}$, which governs the relationships between the Member States and the Community institutions ${ }^{6}{ }^{6}$ Thus, where a national court considers that the Commission has not provided enough information to justify assistance with a 'dawn raid', it cannot simply dismiss the request but must seek further information from the Commission. ${ }^{7}$

Thirdly, albeit rarely discussed in the present context, manifestations of loyalty in secondary law can also constitute very precise mechanisms of control of Member State activities in certain fields. In the following section, I will focus on secondary law providing examples of notification obligations and will discuss the extent to which they impose supervision over the Member States, and the instruments for enforcing this supervision. I will also examine where to situate the screening mandate provided in the recent Services Directive in this respect. Standstill obligations that are prescribed especially with regard to the notification of technical standards are the link to a discussion in the final part of this Chapter of fully-fledged abstention duties provided in acts of secondary law.

\section{Non-supervisory Notification Obligations}

Some notification obligations in secondary law are not meant to give the Commission powers to supervise Member State activities. This concerns those notifications addressed to the Commission or transmitted by Union mechanisms that have the primary purpose of informing the other Member States. Thus, Regulation 764/2008 requires Member States to inform each other via notification to the Commission about restrictive national measures amounting to a direct or indirect general prohibition or refusal of marketing authorization, among others. ${ }^{8}$ One can think here also of Directive 2001/95/EC imposing subsidiary safety requirements for products, which set up the Rapid Information System (RAPEX) hosted by the Commission for informing the Member States of a safety problem calling for quick action. ${ }^{9}$

Services Directive 2006/123, discussed later in detail, foresees the establishment of 'liaison points' that shall handle all communications and requests for information and consultation between the Member States. These liaison points shall also inform the Commission when Member States fail to comply with their respective obligations. Under the title 'alert mechanism', Article 32 of the Directive requires Member States to inform the Commission and all other States about service activities that could cause serious damage to the health or safety of persons or to the environment'. ${ }^{10}$ Article 33 Services Directive foresees mutual information exchange on disciplinary or administrative actions, criminal sanctions, or decisions concerning fraudulent insolvency.

5 Case C-429/07 Inspecteur van de Belastingdienst v X [2009] ECR I-4833, para 20.

${ }^{6}$ Case C-429/07 Inspecteur van de Belastingdienst v X [2009] ECR I-4833, para 21. The Court makes reference to Case C-2/88 Imm. Zwartveld [1990] ECR I-3365, para 18.

7 See J. Temple Lang, 'The Development by the Court of Justice of the Duties of Cooperation of National Authorities and Community Institutions under Article 10 EC', Fordham International Law Journal, 31 (2008), 1483-1532, 1525-1526.

8 Regulation (EC) 764/2008 laying down procedures relating to the application of certain national technical rules to products lawfully marketed in another Member State [2008] OJ L218/21.

9 Directive (EC) 2001/95 on general product safety [2002] OJ L11/4. This Directive is currently being revised within the Commission. There are other examples for such rapid information or rapid alert system, such as in the field of cosmetics.

10 Dir 2006/123, Art 32.

This is an open access version of the publication distributed under the terms of the Creative Commons Attribution-NonCommercial-NoDerivs licence (http://creativecommons.org/licenses/by-nc-nd/3.0/), which permits non-commercial reproduction and distribution of the work, in any medium, provided the original work is not altered or transformed in any way, and that the work is properly cited. For commercial re-use, please contact academic.permissions@oup.com 
Article 3 (2) of Directive 75/442 on waste (now repealed) ${ }^{11}$ required the Member States to notify two different kinds of national measures. On the one hand, Member States had to inform the Commission of draft rules concerning the use of products which might have been a source of technical difficulties as regards waste disposal or lead to excessive disposal costs. On the other hand, they were required to inform the Commission of all draft rules designed to encourage the prevention, recycling, and processing of waste. In Enichem Base, when asked by the national court for a preliminary ruling on the direct effect of Article 3 (2) of the Directive, the ECJ held as follows:

Article 3 (2) merely requires the Member States to inform the Commission in good time of any draft rules within the scope of that provision, without laying down any procedure for Community monitoring thereof or making implementation of the planned rules conditional upon agreement by the Commission or its failure to object. ${ }^{12}$

The obligation imposed on the Member States by Article 3(2) is intended to ensure that the Commission is informed of any plans for national measures regarding waste disposal so that it can consider whether Community harmonizing legislation is called for and whether the draft rules submitted to it are compatible with Community law, and take appropriate measures if necessary. ${ }^{13}$

Despite the strong element of supervision that is found to exist here by the Court, it found neither grammatical nor teleological grounds for affirming direct effect. ${ }^{14}$

The following discussion of Directive 98/34 and the case law handed down in this regard will show that there is a fine line to granting direct effect for similarly conceived instruments of Union law.

\section{Supervisory Notification Obligations on Technical Standards}

Directive 98/34 provides for information procedures for two kinds of national measures. First, it concerns so-called standards, which is any technical specification that a recognized standardization body has approved for repeated or continuous application, compliance with which, however, is not compulsory. ${ }^{15}$ Second, the Directive applies to technical regulations, which is any technical specification or other requirement relating to industrial, agricultural, and fishing products, the observance of which is compulsory for its marketing or use. ${ }^{16}$ The first step provided in the Directive is that national standardization bodies must inform the Commission and all the other European and national standardization bodies of its draft standards and regulations, or of amendments thereof. This triggers a period of three months during which the Member State concerned must refrain from adopting draft technical regulations, four months for drafts in the form of a voluntary agreement, and six months for all other drafts where the Commission delivers a detailed opinion indicating that the draft may impede the free movement of goods. Moreover, there is a standstill obligation for twelve months if the Commission wants

11 Council Directive (EEC) 75/442 on waste [1975] OJ L194/39.

12 Case 380/87 Enichem Base [1989] ECR 2491, para 20.

13 Case 380/87 Enichem Base [1989] ECR 2491, paras 20, 21.

14 Case 380/87 Enichem Base [1989] ECR 2491, paras 20, 22.

15 Directive (EC) 98/48 laying down a procedure for the provision of information in the field of technical standards and regulations [1998] OJ L217/18, Art 1.

16 Council Directive (EEC) 83/189 laying down a procedure for the provision of information in the field of technical standards and regulations [1983] OJ L109/8. Dir 98/48 extends the application of the information procedures mentioned earlier to information society services. These are services rendered against payment, electronically and at the individual request of a services recipient, excluding radio and television broadcasting services.

This is an open access version of the publication distributed under the terms of the Creative Commons Attribution-NonCommercial-NoDerivs licence (http://creativecommons.org/licenses/by-nc-nd/3.0/), which permits non-commercial reproduction and distribution of the work, in any medium, provided the original work is not altered or transformed in any way, and that the work is properly cited. For commercial re-use, please contact academic.permissions@oup.com 
to propose or adopt a legislative act in the same area, or if the national draft concerns a subject already covered by a Commission proposal. ${ }^{17}$ Should the Council adopt a common position during this period, the standstill period even extends to eighteen months in total. ${ }^{18}$

The connection between the notifications prescribed by Directive $98 / 34$ and loyalty are clearly shown by its fifth recital, which refers to ex Article $10 \mathrm{EC}$ and states that it is essential for the Commission to have the necessary information at its disposal before the adoption of technical provisions by the Member States. ${ }^{19}$ Another manifestation of loyalty, if we recall its role in justifying direct effect, has been introduced by the Court in the CIA Security case law on the identically worded notification and suspension periods provided in the precursor Directive 83/189. ${ }^{20}$ The Court distinguished the supervision mechanism in Directive 83/189 from the one in Directive 75/442, discussed earlier, by the following words:

In the present case, however, the aim of the directive is not simply to inform the Commission. As already found in paragraph 41 of this judgment, the directive has, precisely, a more general aim of eliminating or restricting obstacles to trade, to inform other States of technical regulations envisaged by a State, to give the Commission and the other Member States time to react and to propose amendments for lessening restrictions to the free movement of goods arising from the envisaged measure and to afford the Commission time to propose a harmonizing directive. Moreover, the wording of Articles 8 and 9 of Directive 83/189 is clear in that those articles provide for a procedure for Community control of draft national regulations and the date of their entry into force is made subject to the Commission's agreement or lack of opposition. ${ }^{21}$

Thus, the ECJ established the direct effect of the notification obligation and declared that all national rules that have not been notified must be set aside before national courts. While this was discussed controversially at the time of the publication of the judgment against the well-known background of horizontal direct effect, it has in the meantime be confirmed by the Court in a number of decisions with regard to Directive 98/34. ${ }^{22}$ One might argue that loyalty in such cases takes effect in a double sense, once as the background for the duty of notification, and secondly as one of the legal bases for direct effect, as discussed in Chapter 3.

In the following section, I will discuss Services Directive 2006/123, which was controversial even before the Council adopted it, though for other reasons. It contains a strikingly similar notification mechanism compared to both Directive 75/442 and Directive 98/34.

17 Art. 9 (4): 'Member States shall postpone the adoption of a draft technical regulation for 12 months from the date of receipt by the Commission of the communication referred to in Article 8 (1) if, within the three months following that date, the Commission announces its intention to propose or adopt a directive, regulation or decision on the matter in accordance with Article 189 of the Treaty.'

18 Art. 9 (5): 'If the Council adopts a common position during the standstill period referred to in paragraphs 3 and 4, that period shall, subject to paragraph 6, be extended to 18 months.'

19 Case C-303/04 Lidl Italia [2005] ECR I-7865, para 17.

20 Case 380/87 Enichem Base [1989] ECR 2491, para 41.

21 Case C-194/94 CIA Security [1996] ECR I-2201, para 50; Case C-443/98 Unilever [2000] ECR $\mathrm{I}-7535$.

22 See the references at <http://ec.europa.eu/enterprise/tris/case_law/index_de.htm>. cf. P.P. Craig and G. de Búrca, EU Law: Text, Cases and Materials, 5 th edn. (Oxford: Oxford Univ. Press, 2011), 595.

This is an open access version of the publication distributed under the terms of the Creative Commons Attribution-NonCommercial-NoDerivs licence (http://creativecommons.org/licenses/by-nc-nd/3.0/), which permits non-commercial reproduction and distribution of the work, in any medium, provided the original work is not altered or transformed in any way, and that the work is properly cited. For commercial re-use, please contact academic.permissions@oup.com 


\section{Hybrid: The Services Directive}

Services Directive 2006/123 23 submits the freedom of establishment and the freedom to provide services to a novel statutory regime. ${ }^{24}$ As concerns the former freedom, it regulates authorization schemes of Member States ${ }^{25}$ and 'prohibited requirements', respectively 'requirements to be evaluated', ${ }^{26}$ including a blacklist of barred measures in Article 14. As concerns the freedom to provide services, the Directive deals exclusively with requirements and contains a blacklist of national measures in Article 16 (2). Authorization schemes as well as requirements under both chapters are subjected to a test of non-discrimination, 'necessity', and proportionality. ${ }^{27}$

The Services Directive introduces various mechanisms for ensuring compliance with its provisions and monitoring progress made in opening the services market. The most 'intrusive' instrument in this respect concerns non-discriminatory requirements restricting the freedom of establishment. Article 15 (6) Services Directive provides that from 28 December 2006 Member States may only introduce new requirements listed in Article 15 (2) if the conditions of necessity and proportionality are met. Such national measures must be notified to the Commission and their introduction must be justified. The Commission communicates the provisions concerned to the other Member States, and at the same time examines their lawfulness itself. The Directive provides for a period of three months from receipt of notification for the Commission to issue a decision requesting the Member State to refrain from adopting the notified requirement, or, if already adopted, to repeal it. Article 15 (7) Services Directive, however, explicitly stipulates that such notification does not bar Member States from adopting the requirements in question.

A similar procedure is required with regard to safety measures pursuant to Article 18 in conjunction with Article 35 Services Directive. The Member State where the service provider is established is required, on request of the host Member State, to respond appropriately to a service considered unsafe. Only when measures by the home Member State are deemed inadequate by the host Member State may the latter unilaterally adopt safety measures under the conditions provided under Article 18 Services Directive. This, however, is subject to a standstill obligation for the Member State of fifteen working days according to Article 35 (4) Services Directive. The Commission, to which the intended adoption must be notified and justified, has to decide 'as a matter of urgency' on the lawfulness of the measures. If it considers them non-compliant, the Commission must ask the Member State either to waive the adoption or to terminate the safety measures.

Thus, both screening duties mentioned confer rights of control to the Commission when a Member State introduces new, potentially restrictive, or unsafe measures. They do not, however, empower the Commission to directly influence the behaviour of Member States, since the Services Directive does not provide for specific sanctions in cases where Member States do not comply with the decisions of the Commission on the legality of

23 Dir 2006/123.

24 See, comprehensively, C. Barnard, 'Unravelling the Services Directive', Common Market Law Review, (2008), 323-394, and V. Hatzopoulos, 'Assessing the Services Directive (2006/123/EC)', Cambridge Yearbook of European Legal Studies, (2007-2008), 215-261.

25 Dir 2006/123, Art. 9-13. Dir 2006/123, Art. 4 (6) defines authorization schemes as 'any procedure under which a provider or recipient is in effect required to take steps in order to obtain from a competent authority a formal decision, or an implied decision, concerning access to a service activity or the exercise thereof'.

26 Dir 2006/123, Arts. 14-15. See the definition of requirements in Dir 2006/123, Art. 4 (7).

27 Dir 2006/123, Arts. 9, 10, 15, and 16.

This is an open access version of the publication distributed under the terms of the Creative Commons Attribution-NonCommercial-NoDerivs licence (http://creativecommons.org/licenses/by-nc-nd/3.0/), which permits non-commercial reproduction and distribution of the work, in any medium, provided the original work is not altered or transformed in any way, and that the work is properly cited. For commercial re-use, please contact academic.permissions@oup.com 
the measures notified. The decision requesting the Member State to abide is no more than that, a request without sanction in case of disobedience. Moreover, Member States are not barred under the Directive from introducing national measures even when they are, eventually, judged unlawful by the European Commission. The three-month deadline for the Commission to issue its decision pursuant to Article 15 Services Directive is not a standstill obligation. The standstill obligation of fifteen working days under Article 35 Services Directive, in contrast, applies to the time between the notification of the intended safety measures and their adoption, but equally has no bearing on the decision on legality by the Commission. ${ }^{28}$ Thus, even if Member States have to let some time lapse after notification before adopting safety measures under Article 18, they have no such obligation at all with requirements under Article 15 Services Directive, and even less do they have to wait for the response of the Commission in either matter.

There is an explicit link between the notification duties under the Services Directive and the notification obligation under Directive 98/34 discussed earlier since, pursuant to Article 15 (7) Services Directive, the notification of a draft national law in accordance with Directive 98/34/EC is qualified as notification under Article 15 Services Directive. I would submit that the screening mechanism both for requirements and for safety measures under the Services Directive must be located somewhere in-between the non-supervisory tools in instruments such as Directive 75/442 on the one hand, and the supervisory regime provided by Directive 98/34 on the other. Both the Court's arguments in CIA Security quoted earlier on the general aim of the mechanism and the centrality of the provision of Union control on draft national measures applies to the Services Directive's screening mechanism. The standstill obligation in Directive 98/43, though not explicitly invoked in the judgment mentioned earlier, is, however, enabling effective control, while its absence makes Union supervision tepid in the case of the Services Directive. Nonetheless, the screening in the Services Directive is still more of a supervision regime than a pure notification-only obligation. The question is, thus, whether the fact that the ultimate 'bite' is wanting with the screening mechanism in the Services Directive is sufficient to distinguish it from the findings in the case law on Directive 98/34, and to deny direct effect. ${ }^{29}$ Should the Court grant direct effect here, the consequences, clearly, would be far-reaching.

\section{Prohibitions of Frustration and Transitional Periods}

As I have explained in Chapter 5 in the Part on Cohesion, one consequence of the passage of a directive is that Member States are barred from taking judicial or legislative measures which would jeopardize the attainment of the directive's objective at the time of the expiry of the deadline for implementation. ${ }^{30}$ Two directives in the field of product harmonization have raised questions as to the application of this abstention duty.

Directive 98/8 required an authorization for the marketing of biocidal products, which Member States could only grant if the active substances included were listed in Annexes to the Directive and if a number of other conditions were satisfied. ${ }^{31}$ In a derogation from this obligation, Article 16 (1) of the Directive stipulated that a Member

28 See Dir 2006/123, Art. 35 (5).

29 See for a more detailed analysis M. Klamert, 'Die Notifizierungspflichten der Dienstleistungsrichtlinie: ein Fall für den EuGH?', Deutsches Verwaltungsblatt, (2008), 829-832.

30 See Chapters 4 and 6.

31 Directive (EC) 98/8 concerning the placing of biocidal products on the market [1998] OJ L123/1.

This is an open access version of the publication distributed under the terms of the Creative Commons Attribution-NonCommercial-NoDerivs licence (http://creativecommons.org/licenses/by-nc-nd/3.0/), which permits non-commercial reproduction and distribution of the work, in any medium, provided the original work is not altered or transformed in any way, and that the work is properly cited. For commercial re-use, please contact academic.permissions@oup.com 
State could continue to apply its existent practice of placing biocidal products on the market for a period of ten years. This provision was interpreted by the Court as not constituting a 'standstill' obligation. ${ }^{32}$ However, referring to Inter-Environnement Wallonie, the Court held that the Member States' right to amend their systems for the authorization of biocidal products cannot be regarded as unlimited, and that this applies also to a transitional period such as that provided in Article 16 (1). ${ }^{33}$ Thus, the Court concluded, 'the second paragraph of Article 10 EC and the third paragraph of Article 249 EC, and Directive 98/8, require that during the transitional period prescribed in Article 16(1) of that directive the Member States refrain from adopting any measures liable seriously to compromise the result prescribed by that directive' ${ }^{34}$

Similar provisions were contained in Article 8 (2) of Directive 91/414 on plant protection products. ${ }^{35}$ Article 8 (1) on 'transitional measures and derogations' of this Directive gave the Member States the right, until two years after the notification of the Directive, to provisionally authorize the marketing of certain plant protection products. This was placed under the condition that, among other things, the Member State submit a dossier on the respective substance, which had to satisfy certain criteria set up in Annexes to the Directive. Moreover, Article 8 (2) provided that Member States, for a period of twelve years following the notification of Directive 91/414, could authorize the marketing of the mentioned products should they have already been on the market two years before the date of notification of the Directive. After the Directive's adoption, the Directive required the Member State to withdraw or modify the relevant authorizations if the Commission did not approve these active substances within the mentioned twelve-year period. Again, the Court did not qualify this as a standstill obligation. ${ }^{36}$ However, the Court held that the Member States' right to act during the transitional period of twelve years was not without limits. Consequently, national legislation that did not require submission of a dossier, and that did not require the competent authority to check whether the plant protection product in question would harm human and animal health and the environment, was deemed precluded by the Directive.

Thus, while under the Inter-Environnement Wallonie case law the date of the expiry of the deadline for transposition was decisive for the application of the prohibition of frustration for the Member States, in these cases the transitional periods in the directives mentioned were found to extend this prohibition. ${ }^{37}$ In the following section, we now come to secondary law that established a more pronounced duty of abstention.

\section{6. 'Managed' Preclusion of Member States}

The varied approach in case law between prescribing full abstention and de facto pre-emption is reflected by the 'fall-out' from the Open Skies judgments in the area of air transport policy, already discussed in Chapter 5. Recall that the Court had decided

32 Case C-316/04 Stichting Zuid-Hollandse Milieufederatie [2005] ECR I-9759, para 40.

33 Case C-316/04 Stichting Zuid-Hollandse Milieufederatie [2005] ECR I-9759, paras 41-42.

34 Case C-316/04 Stichting Zuid-Hollandse Milieufederatie [2005] ECR I-9759, paras 41-42.

35 Council Directive (EEC) $91 / 414$ concerning the placing of plant protection products on the market [1991] OJ L230/1.

36 Case C-316/04 Stichting Zuid-Hollandse Milieufederatie [2005] ECR I-9759, para 40.

37 Dir 91/414, Art. 34 of that directive provides that the Member States are to bring into force the measures necessary to comply with the directive not later than twenty-four months after its entry into force. According to Dir 91/414, Art. 35, the Directive is to 'enter into force on the 20th day following its publication', that is to say, on 14 May 1998.

This is an open access version of the publication distributed under the terms of the Creative Commons Attribution-NonCommercial-NoDerivs licence (http://creativecommons.org/licenses/by-nc-nd/3.0/), which permits non-commercial reproduction and distribution of the work, in any medium, provided the original work is not altered or transformed in any way, and that the work is properly cited. For commercial re-use, please contact academic.permissions@oup.com 
that Member State bilateral agreements with the USA would affect several regulations concluded by the Union in this field and that the Union, thus, has exclusive competence with respect to various aspects of such agreements. ${ }^{38}$

In view of the envisaged replacement of these bilateral agreements with Union agreements, the Council adopted Regulation 874/2004 on the negotiation and implementation of air service agreements between Member States and third countries. ${ }^{39}$ The aim of this Regulation was 'to ensure close cooperation between the Member States and the Community institutions, both in the process of negotiation and conclusion and in the fulfilment of the commitments entered into', in cases where an agreement falls partly within the competence of the Community and partly within that of its Member States. ${ }^{40}$

Article 1 of the Regulation allowed Member States to enter into negotiations with third countries for the conclusion or modification of air service agreements concerning a new air service if certain standard clauses were included in such negotiations and a notification procedure was followed. ${ }^{41}$ The Commission was given the right to participate as an observer in such negotiations, and other Member States could make comments following the notification of the agreement. Within fifteen working days of receipt of the notification, the Commission could inform the Member State concerned that the negotiations were likely to 'undermine the objectives of Community negotiations underway with the third country concerned, and/or lead to an agreement which is incompatible with Community law'. When the negotiations had resulted in an agreement, which incorporated the clauses mentioned, the Member States were authorized to conclude the respective agreement. ${ }^{42}$

In a case where the negotiations result in an agreement which does not incorporate these clauses, Article 4 (3) of Regulation 847/2004 provides that the Member State shall only be authorized to conclude the agreement 'provided that this does not harm the object and purpose of the Community common transport policy'. Thus, the Regulation imposes certain conditions on the conclusion of non-standardized 'external' bilateral agreements on air service for attaining the authorization of the Commission. This constitutes a qualified abstention obligation not contingent on the exercise of a Union competence, imposed directly by means of secondary law. ${ }^{43}$ This mechanism gives the Union full control over negotiations in an area of shared competence and enables it to prevent any obstruction, ambiguity, or contradiction by the actions of Member States. In addition, Article 4 (4) of the Regulation foresaw that if there already existed a Council mandate for negotiations with third countries on the replacement of certain provisions in existing bilateral agreements, Member States could also be authorized to provisionally apply and/or conclude their bilateral agreement. ${ }^{44}$ The wording of this provision ('may'

38 See Case C-467/98 Commission v Denmark (Open Skies) [2002] ECR I-9519, paras 99-106.

39 Regulation (EC) 847/2004 on the negotiation and implementation of air service agreements between Member States and third countries [2004] OJ L157/7. See also the discussion of the Conclusions of the JHA Council on readmission agreements and the consequences of the entry into force of the Amsterdam Treaty, 27-28 May 1999. See M. Cremona, 'Defending the Community Interest: The Duties of Cooperation and Compliance', in M. Cremona and B. de Witte (eds), EU Foreign Relations Law: Constitutional Fundamentals (Oxford and Portland, Oregon: Hart Publishing, 2008), 125-169, 162.

40 Reg EC 847/2004, Rec. 4. The Recital also refers to the requirement of unity in international representation, which will be discussed in Chapter 10 on mixed agreements.

41 And that it does not lead to a more restrictive arrangement. See Art. 3.

42 Art. 4 (2). $\quad{ }^{43}$ See further Cremona, 'Defending the Community Interest', 140-141.

44 Art. 4 (4).

This is an open access version of the publication distributed under the terms of the Creative Commons Attribution-NonCommercial-NoDerivs licence (http://creativecommons.org/licenses/by-nc-nd/3.0/), which permits non-commercial reproduction and distribution of the work, in any medium, provided the original work is not altered or transformed in any way, and that the work is properly cited. For commercial re-use, please contact academic.permissions@oup.com 
instead of 'shall') indicates that the granting of authorization is entirely at the discretion of the Commission. ${ }^{45}$

This form of 'managed' preclusion generated by an act of secondary law seems not much different from external exclusivity because the conclusion of an international agreement 'is provided for in a legislative act of the Union'. ${ }^{46}$ However, note that this WTO principle is at another level with regard to the relations between the Union and the Member States. In such a case, the Member States would be under even stricter constraints than in the situation regulated by Article 4 (3) of the Regulation.

Regulation 662/2009 based on ex Articles 61 (c), 65, and 67 (5) EC is another example of managed preclusion in a different context. ${ }^{47} \mathrm{It}$ is the reaction to the existence of bilateral agreements of Member States in the area of the law applicable to contractual and non-contractual obligations. The need to eliminate incompatibilities between these agreements and Union law results from ex Article 307 EC (now Article 351 TFEU) as well as from the finding by the Court in Opinion 1/03 on the Lugano Convention. ${ }^{48}$ Recall that the Court in this Opinion found that the Union has exclusive competence to conclude an international agreement on this matter. In Recital 7, the Regulation quotes ex Article 10 EC and claims its 'general application' irrespective of exclusivity with regard to international agreements on specific civil justice issues. The Court then found the Regulation to require 'a coherent and transparent procedure' for authorizing 'a Member State to amend an existing agreement or to negotiate and conclude a new agreement, in particular where the Community itself has not indicated its intention to exercise its [exclusive] external competence to conclude an agreement by way of an already existing mandate of negotiation or an envisaged mandate of negotiation'. ${ }^{49}$

For this purpose, Article 3 of the Regulation obliges the Member States to notify the Commission of their intentions of opening or continuing negotiations on an agreement or on its conclusion. Following this notification, under Article 4 the Commission must assess whether 'the envisaged agreement appears not to render Community law ineffective and not to undermine the proper functioning of the system established by that law; and the envisaged agreement would not undermine the object and purpose of the Community's external relations policy as decided by the Community'. According to Article 5 of Regulation 662/2009, the Commission, within ninety days, may authorize such negotiations under the condition that the envisaged agreement must contain a clause providing for full or partial denunciation, or for direct replacement, of the relevant provisions of such agreement by a Union agreement. Even in the case of such formal authorization by the Commission, the Regulation requires the Member State concerned to accept observer status of the Commission in the negotiations, at least to inform it of the progress of the negotiations, and to notify their outcome by transmitting the text of the agreement concluded by the Member State. Still at this stage, the Commission

45 We can assume that it is this arrangement the Commission would have preferred in the Inland Waterway cases, and might want to adopt in the BITS cases. As to the latter, see M. Cremona, 'External Relations and External Competence of the European Union', in P.P. Craig and G. de Búrca, The Evolution of EU Law, 2nd edn. (Oxford: Oxford Univ. Press, 2011), 225, 259.

46 Art. 3 (4) TFEU.

47 Regulation (EC) 662/2009 establishing a procedure for the negotiation and conclusion of agreements between Member States and third countries on particular matters concerning the law applicable to contractual and non-contractual obligations [2009] OJ L200/25.

48 Opinion 1/03 Lugano Convention [2006] ECR I-1145. See Chapter 7.

49 See Reg 662/2009, Rec. 8. This procedure should be without prejudice to the exclusive competence of the Community and the provisions of Articles 300 and 307 of the Treaty. It should be regarded as an exceptional measure and should be limited in scope and in time.

This is an open access version of the publication distributed under the terms of the Creative Commons Attribution-NonCommercial-NoDerivs licence (http://creativecommons.org/licenses/by-nc-nd/3.0/), which permits non-commercial reproduction and distribution of the work, in any medium, provided the original work is not altered or transformed in any way, and that the work is properly cited. For commercial re-use, please contact academic.permissions@oup.com 
must give a reasoned decision on the compliance of the agreement with the conditions set up by the Regulation, or may refuse to authorize the conclusion of the agreement. ${ }^{50}$ The latter decision triggers a succession of deadlines for a Commission opinion to be issued to the Member State concerned, as well as to the European Parliament and to the Council. ${ }^{51}$

\section{Conclusion}

Loyalty must be seen as the basis for duties provided in secondary law for the Member States to inform the Commission of measures they intend to adopt which might constitute an obstacle to the common market. I have differentiated between regimes only prescribing a duty of notification and such regimes set up by secondary law that establish an effective control over the activities at national level. As we have seen, secondary law provides for a variety of forms in this respect, ranging from simple notification, to notification coupled with rights of supervision for the Commission, and to regimes where supervision of notified measures triggers a standstill obligation for the Member States.

The various screening duties provided in the Services Directive do not entail any (extra-judicial) assessment of legality other than from the Member State itself. The exceptions are the 'screening' duties pursuant to Articles 15 and 35 Services Directive, where the Commission is entitled to decide on the legality of new requirements for established service providers and for safety measures for services stricto sensu. Devoid of any additional instrument of coercion, these 'screening' duties in the Services Directive stay well behind comparable mechanisms of a similar kind, such as under Directive 98/34. I have submitted that there seem to be missing clear criteria for affirming or denying direct effect in these constellations.

50 See Reg 662/2009, Art. 9.

51 There are deadlines for a request by the Member State to enter into discussions with a view to finding a solution, for another Commission decision after such discussions, and for notification of the Commission's final decision to the European Parliament and to the Council.

This is an open access version of the publication distributed under the terms of the Creative Commons Attribution-NonCommercial-NoDerivs licence (http://creativecommons.org/licenses/by-nc-nd/3.0/), which permits non-commercial reproduction and distribution of the work, in any medium, provided the original work is not altered or transformed in any way, and that the work is properly cited. For commercial re-use, please contact academic.permissions@oup.com 


\section{Loyalty and Mixed Agreements}

\section{Introduction}

International agreements either can be concluded by the Union, by all or some Member States, or by the Union jointly with all or some Member States. The latter case is known as mixed agreements.

Mixity is mandatory when an agreement can be divided into two parts of which one falls under the exclusive competence of the EU and the other comes under the competence of the Member States. ${ }^{1}$ Agreements that would not allow the participation of Member States without the consent of the Union, such as in a field where the Union possesses exclusive competence, but which nonetheless are concluded jointly, are referred to as cases of false mixity. ${ }^{2}$ Incomplete or partially mixed agreements are those where one or several Member States have not become parties to an agreement. ${ }^{3}$ We may also distinguish mixed agreements by the number of third parties as either bilateral or multilateral mixed agreements. ${ }^{4}$

Mixity is only facultative as regards the participation of the Member States if an international agreement affects exclusive as well as non-exclusive EU competences. In such case it can be concluded alone by the Union or, alternatively, jointly by the Union and the Member States. ${ }^{5}$ This kind of facultative mixity applies irrespective of whether the non-exclusive competence of the Union is of a shared or supporting nature. In matters of supporting competence, both the Union and the Member States retain their power to act irrespective of agreements concluded by the other side. If the objective of an international agreement thus falls within the scope of a supporting competence of the Union, such as the area of health policy, the Union is entitled to conclude the agreement jointly with the Member States. The Union, however, could also choose to forgo its supporting competence or may even be obliged to do so due to the subsidiarity principle. ${ }^{6}$ If matters

1 See A. Rosas, 'The European Union and Mixed Agreements', in A. Dashwood and C. Hillion (eds), The General Law of EC External Relations (London: Sweet \& Maxwell, 2000), 203-204.

2 An example is the International Coffee Agreement of 2001. See Koutrakos, EU International Relations Law (Oxford and Portland, Oregon: Hart Publishing, 2006), 152. See also Rosas, 'Mixed Agreements', 205 (with further references).

3 J. Heliskoski, Mixed Agreements as a Technique for Organizing the International Relations of the European Community and its Member States (The Hague: Kluwer Law International, 2001), 128 (with examples); Rosas, 'Mixed Agreements', 206.

4 See A. Kumin and P. Bittner, 'Die "gemischten" Abkommen zwischen der Europäischen Union und ihren Mitgliedstaaten einerseits und dritten Völkerrechtssubjekten andererseits', Europarecht, Beiheft, (2012), 75-91, 78-79.

5 Thus, already prior to the amendments of the provisions on the Common Commercial Policy by the Lisbon Treaty, the WTO agreements did not require the participation of the Member States. See M. Klamert and N. Maydell, 'Lost in Exclusivity: Implied Non-exclusive External Competences in Community law', European Foreign Affairs Review, 13 (2008), 493-513. See also S. Griller and K. Gamharter, 'External Trade: Is There a Path Through the Maze of Competences?', in S. Griller and B. Weidel (eds), External Economic Relations and Foreign Policy in the European Union (Vienna, New York: Springer, 2002), 65-112, 81-84.

6 See Rosas, 'Mixed Agreements', 203-206, who comes to the same result. I have argued elsewhere that the UNESCO Convention on the Protection and Promotion of the Diversity of Cultural

This is an open access version of the publication distributed under the terms of the Creative Commons Attribution-NonCommercial-NoDerivs licence (http://creativecommons.org/licenses/by-nc-nd/3.0/), which permits non-commercial reproduction and distribution of the work, in any medium, provided the original work is not altered or transformed in any way, and that the work is properly cited. For commercial re-use, please contact academic.permissions@oup.com 
regulated in an international agreement fall under shared competence and under exclusive Member State competence, mixity is also facultative. However, in such a case the Member States would be allowed to conclude the agreement without the Union, should the latter choose not to activate its powers.

Mixed agreements thus can be defined as international agreements between the European Union, the Member States, and third states, for which the participation of the Member States is either legally required or politically desired. ${ }^{7}$ Put in other words, mixity requires at least two distinct regulatory objectives in an international agreement affecting two different types of competences, mandating or merely enabling mixity. ${ }^{8}$

One reason for mixity is that Member States often refuse to be sidelined by the Union in their external relations. The Union thus continues to conclude international agreements together with the Member States that it could shoulder alone. ${ }^{9}$ This concerns trade and cooperation agreements, such as the Economic Partnership Agreement with the CARIFORUM States of 2008. ${ }^{10}$ The so called Political Dialogue and Cooperation Agreements with Costa Rica, El Salvador, Guatemala, Honduras, Nicaragua, and Panama and with the Andean Community, each of 2003, also presumably owe their name to the Member States' wish to make crystal clear that they are not exclusively about development cooperation, in which case mixity would not have been required. ${ }^{11}$ At the same time, mixity has also served as a convenient political escape from the 'jungle' of (external) competences. ${ }^{12}$ This has been reinforced by the fact that the Court has never required full clarification of the distribution of competence under mixed agreements. ${ }^{13}$ Finally, Member States often consider mixity as strategically and politically advantageous, both from the perspective of the development of Union law and the protection of their interests. ${ }^{14}$

Expressions, signed in 2005, could also have been concluded by the Union without the Member States. See M. Klamert, 'Rechtsprobleme gemischter Abkommen der EG illustriert am Beispiel der UNESCO Konvention über den Schutz und die Förderung der Vielfalt kultureller Ausdrucksformen', Zeitschrift für öffentliches Recht/Journal of Public Law, (2009), 217-235 (with an abstract in English).

7 S. Griller and M. Klamert, 'Das Aussenwirtschaftsrecht der EU', in M. Holoubek and M. Potacs (eds), Öffentliches Wirtschaftsrecht (Vienna, New York: Springer, 2007), 1120-1121. For a different definition, see Koutrakos, EU International Relations Law, 150. cf. Eeckhout, EU External Relations Law, 2nd edn. (Oxford: Oxford Univ. Press, 2011), 212-214; Heliskoski, Mixed Agreements, 44.

8 This does not apply in cases of false mixity.

9 Mixity has been the rule with international commodity agreements and association agreements pursuant to Art. 217 TFEU, based on the PROBA 20-arrangement. cf. Eeckhout, EU External Relations Law, 219.

10 But see Rosas, 'Mixed Agreements', 218; Eeckhout, EU External Relations Law, 198, who saw this trend in decline.

11 cf. M. Maresceau, 'A Typology of Mixed Bilateral Agreements', in C. Hillion and P. Koutrakos (eds), Mixed Agreements Revisited: The EU and its Member States in the World (Oxford and Portland, Oregon: Hart Publishing, 2010), 11, 16.

${ }_{12}$ See Eeckhout, EU External Relations Law, 220-221; Heliskoski, Mixed Agreements, 11 and 69; H. Schermers, 'The Internal Effect of Community Treaty-making', in D. O'Keeffe and H. Schermers (eds), Essays in European Law and Integration (Deventer: Kluwer, 1982), 167, 170; AG Tesauro in Case C-53/96 Hermès International [1998] ECR I-3603, para 14 (fn 13).

13 See Ruling 1/78 IAEA [1978] ECR 2151, paras 112-113. See also, more recently, Opinion 2/00 Cartagena Protocol [2001] ECR I-9713, para 17. But see Case C-94/03 Commission v Council (Rotterdam Convention) [2006] ECR I-1, para 55, where the Court is partial to the interest of third parties in understanding the division of competences within the EU. This is also noted by P. Koutrakos, 'Annotation to Case C-94/03 Commission v Council (Rotterdam Convention)', Common Market Law Review, (2007), 171-194, 186.

${ }^{14}$ See the instructive account by A. Rosas, 'The Future of Mixity', in C. Hillion and P. Koutrakos (eds), Mixed Agreements Revisited: The EU and its Member States in the World (Oxford and Portland, Oregon: Hart Publishing, 2010), 367, 368-371.

This is an open access version of the publication distributed under the terms of the Creative Commons Attribution-NonCommercial-NoDerivs licence (http://creativecommons.org/licenses/by-nc-nd/3.0/), which permits non-commercial reproduction and distribution of the work, in any medium, provided the original work is not altered or transformed in any way, and that the work is properly cited. For commercial re-use, please contact academic.permissions@oup.com 
Mixity has intrigued scholarship because it can safely be called the apotheosis of complexity in external relations law. ${ }^{15}$ This is aptly illustrated later where I discuss that the distribution of competence may be even more intricate under a mixed agreement than it already is in 'normal' situations. While commentators are divided in their opinion on the usefulness and soundness of mixed agreements, ${ }^{16}$ the frequency of their usage as a form of contractual interaction with third states has mooted these discussions. ${ }^{17}$ Mixity is common practice especially in the areas of transport, environmental protection, and fisheries, as well as with association agreements. ${ }^{18}$ Still, many intricate legal issues persist regarding this matter, and this section will discuss those related to loyalty.

In the following section, I will show that loyalty carries some very general prescriptions relating to mixed agreements, but that it has until fairly recently not been the basis of concrete duties for the Member States. I have already discussed the PFOS case in Chapter 5, which is also relevant here since the Stockholm Convention is a mixed agreement. Recall that I have argued that the legal force of loyalty as a rule of abstention is not 'endless', but that there are limits to its application. This, as I will show, also holds true with regard to the specific issues pertaining to the negotiation, conclusion, ratification, implementation, and interpretation of mixed agreements. First, however, we need to discuss some specifics on competence in the present context.

\section{Competence and Mixed Agreements}

In stark contrast to the practical relevance of mixed agreements for the conduct of external relations of the Union, the Treaties have always been reticent on this subject. The Nice Treaty only provided for mixity in ex Article 133 (6) EC, at least acknowledging its existence. ${ }^{19}$ The Lisbon Treaty, having discarded most of the special rules under the Common Commercial Policy, makes no mention any more of mixed agreements. There are also no Treaty rules on the proper negotiation of such agreements, in contrast to Article 218 TFEU for (pure) EU agreements. ${ }^{20}$ Because of this dearth of Treaty basis

15 In this sense M. Dolmans, Problems of Mixed Agreements: Division of Powers within the EEC and the Rights of Third States (The Hague: Kluwer Law International, 1985), and P. Allott, 'Adherence to and Withdrawal from Mixed Agreements', in D. O'Keeffe and H. Schermers (eds), Mixed Agreements (Deventer: Kluwer, 1983), 97-121, 118-119. See also P. Olson, 'Mixity from the Outside: the Perspective of a Treaty Partner', in C. Hillion and P. Koutrakos (eds), Mixed Agreements Revisited: The EU and its Member States in the World (Oxford and Portland, Oregon: Hart Publishing, 2010), 331: 'a seemingly endless series of practical problems'.

16 See, on the one hand, A. Dashwood, 'Annotation to Opinion 2/00 Cartagena Protocol', Common Market Law Review, (2002), 353-368, and on the other hand, Eeckhout, EU External Relations Law, 264-265: 'In many cases, mixity is an unnecessary burden ... ', '... Mixity is therefore best avoided ...'. cf. R. Schütze, 'Federalism and Foreign Affairs: Mixity as an (Inter)national Phenomenon', in C. Hillion and P. Koutrakos (eds), Mixed Agreements Revisited: The EU and its Member States in the World (Oxford and Portland, Oregon: Hart Publishing, 2010), 57-68, 82-83.

17 The Treaties Office Database of the European Commission lists around 130 entries for mixed agreements since 1995 .

18 See Eeckhout, EU External Relations Law, 219; Maresceau, 'Typology', 17-20. Environmental protection, however, is an area where Member States are not prevented from adopting stricter standards according to Art. 193 TFEU, which does make mixity more likely. cf. M. Klamert, 'New Conferral or Old Confusion?: The Perils of Making Implied Competences Explicit and the Example of the Competence for Environmental Policy', CLEER Working Paper, 6 (2011).

19 '... concluded jointly by the Community and the Member States'.

20 Noted by M. Cremona, 'Defining Competence in EU External Relations: Lessons from the Treaty Reform Process', in A. Dashwood and M. Maresceau (eds), Law and Practice of EU External Relations: Salient Features of a Changing Landscape (Cambridge: Cambridge Univ. Press, 2008), 34-69, 63.

This is an open access version of the publication distributed under the terms of the Creative Commons Attribution-NonCommercial-NoDerivs licence (http://creativecommons.org/licenses/by-nc-nd/3.0/), which permits non-commercial reproduction and distribution of the work, in any medium, provided the original work is not altered or transformed in any way, and that the work is properly cited. For commercial re-use, please contact academic.permissions@oup.com 
for mixity, the Court has time after time been called upon to rule on disputes involving mixed agreements.

Many of these cases have centred on the competence of the Union for concluding international agreements. When the Union concludes a mixed agreement, it thereby exercises its competence. This competence may be an a priori exclusive one, such as for the Common Commercial Policy, or may be exclusive because of the existence of common rules within the meaning of ERTA. Alternatively, the competence exercised by the Union when concluding an international agreement may be a non-exclusive one. I have explained that the passing of directives and regulations is not the only way the Union may become exclusively competent for a certain matter falling under an international agreement. This also occurs when the international agreement by the Union is concluded as part of a mixed agreement together with the Member States. Thus, in MOX Plant, the Court, after explaining that the Union possesses shared competence in the field of environmental law, ${ }^{21}$ continues that 'it is necessary to establish whether and to what extent the Community, by becoming a party to the Convention, elected to exercise its external competence in matters of environmental protection'. ${ }^{22}$ This exercise by the Union of a competence such as for environmental policy triggers the ERTA effect. Thus, if some matter fell under shared competence before the conclusion of an international agreement and such competence is activated by the Union by means of concluding the agreement, the part of the agreement itself constitutes a 'common rule' within the meaning of ERTA. ${ }^{23}$

The problem is, however, that the Court never decides on this aspect of ERTA in its case law, and thus fails to make complete findings on the distribution of competences under a mixed agreement. ${ }^{24}$ Whenever the Court has been asked to pronounce on the existence of exclusive Union competence under an international agreement, it has limited its findings to exclusivity by virtue of 'internal' common rules. ${ }^{25}$ Whether shared competences had been activated by the Union in the process of concluding an agreement has never been an issue.

The Court therefore did not acknowledge the fact that both the WTO agreements and the ILO Convention could have been concluded alone by the Union, if it had fully made use of its shared powers. ${ }^{26} \mathrm{On}$ occasion of the Opinion on the conclusion of the Lugano Convention, ${ }^{27}$ the Court had for once explicitly been asked to speak out also on shared competences. ${ }^{28}$ While the Court in this opinion confirmed the existence of implied non-exclusive competences of the Union, the Convention was deemed to fall

21 See Case C-459/03 Commission v Ireland (MOX Plant) [2006] ECR I-4635, para 95.

22 Case C-459/03 MOX Plant [2006] ECR I-4635, para 76.

23 See the Opinion of AG Poiares Maduro in Case C-459/03 MOX Plant [2006] ECR I-4635, paras 23 and 33. See further, Klamert, 'New Conferral or Old Confusion?', 10-11. But see AG Sharpston's Opinion in Case C-240/09 Lesoochranárske [2011] ECR I-1255, para 43, who infers only this from Case 22/70 Commission v Council (ERTA) [1971] ECR 263: 'The Community can acquire such exclusive competence through internal regulation.' This is different from the exercise of supporting external competence, where Member States are not precluded by international commitments by the Union, as explained earlier.

${ }^{24}$ See also M. Cremona, 'Defending the Community Interest: The Duties of Cooperation and Compliance', in Marise Cremona and Bruno de Witte (eds), EU Foreign Relations Law: Constitutional Fundamentals (Oxford and Portland, Oregon: Hart Publishing, 2008), 125-169, 147.

25 See Opinion 1/94 WTO [1994] ECR I-5267, paras 1 and 98; Opinion 2/91 ILO Convention 170 [1993] ECR I-1061, para 39. See also Case C-53/96 Hermès International [1998] ECR I-3603, para 25.

26 cf. Klamert and Maydell, 'Lost in Exclusivity', 493-513.

27 Convention on the Jurisdiction and the Recognition and Enforcement of Judgments in Civil and Commercial Matters.

28 See Opinion 1/03 Lugano Convention [2006] ECR I-1145, para 134.

This is an open access version of the publication distributed under the terms of the Creative Commons Attribution-NonCommercial-NoDerivs licence (http://creativecommons.org/licenses/by-nc-nd/3.0/), which permits non-commercial reproduction and distribution of the work, in any medium, provided the original work is not altered or transformed in any way, and that the work is properly cited. For commercial re-use, please contact academic.permissions@oup.com 
under exclusive competence qua internal common rules, and again Union competence was not clearly demarcated. Also in MOX Plant, where it was highly relevant 'whether and to what extent the Community, by becoming a party to the Convention, elected to exercise its external [shared] competence in matters of environmental protection', ${ }^{29}$ for reasons specific to the case the Court could avoid pronouncing on this issue. ${ }^{30}$

However, this makes the competence situation after the conclusion of a mixed agreement potentially even more complex than it was before such treaty was entered into by the Union and the Member States. Apart from the question whether the Union or the Member States have exercised their respective powers for concluding parts of a mixed agreement, which can only be clarified by a full declaration of competence, sometimes the Union expressly chooses not to exercise its shared competence. It has been argued that in this case the matters concerned automatically fall within exclusive Member State competence. ${ }^{31}$ To me it seems more plausible that they instead remain within shared competence. ${ }^{32}$ Take the PFOS case: Sweden's claim that competence for the proposal was shared in this case was not examined by the Court, which seemed content with the acquiescence by the Commission. ${ }^{33}$ If we accept this assumption, it means that even though the Union had a shared competence to regulate in this precise matter, and despite the conclusion of an agreement that covered persistent organic pollutants (POPs), i.e. the parent category of substances, the conclusion of the Stockholm Convention did not transfer the right to act on perfluorooctane sulfonates (PFOS) to the Union. However, we can equally not assume that the Member States were exclusively competent after that point in time. Had this been the case, there would have been no discussion on whether Sweden or the Union had the right to make a proposal on PFOS under the agreement. The duties of abstention imposed by the Court on Sweden only make sense assuming that the competence situation was still in limbo.

After the conclusion of a mixed agreement, we must therefore distinguish four different constellations:

(1) Matters covered by a mixed agreement which come under Member State competence. In an agreement on the protection of forests this, for example, would be the competence for the cultivation of forests.

(2) Matters, which fall within the exclusive competence of the Union. In the mentioned context, this would be matters pertaining to the Common Agricultural Policy.

(3) Matters regulated by the mixed agreement that have been falling under shared competence, and remain in shared competence after the agreement's conclusion.

(4) Matters that have been shared before the conclusion, but are drawn to the Union side because of its decision to exercise its competence.

29 Case C-459/03 MOX Plant [2006] ECR I-4635, paras 94-96.

30 Case C-459/03 MOX Plant [2006] ECR I-4635, para 108: 'It follows that, within the specific context of the Convention, a finding that there has been a transfer to the Community of areas of shared competence is contingent on the existence of Community rules within the areas covered by the Convention provisions in issue ...' For a different perspective on this finding, see J. Heliskoski, 'Adoptions of Positions under Mixed Agreements (Implementation)', in C. Hillion and P. Koutrakos (eds), Mixed Agreements Revisited: The EU and its Member States in the World (Oxford and Portland, Oregon: Hart Publishing, 2010), 153-154.

31 See Heliskoski, Mixed Agreements, 46-47.

32 Sceptical also Cremona, 'Defending the Community Interest', 125.

33 Case C-246/07 Commission v Sweden (PFOS) [2005] ECR I-6985, para 72: 'In the present case, the Commission has pointed out that it was not claiming that the Community had exclusive competence to submit a proposal for the listing of PFOS in Annex A to the Stockholm Convention. It must therefore be assumed that competence is shared.'

This is an open access version of the publication distributed under the terms of the Creative Commons Attribution-NonCommercial-NoDerivs licence (http://creativecommons.org/licenses/by-nc-nd/3.0/), which permits non-commercial reproduction and distribution of the work, in any medium, provided the original work is not altered or transformed in any way, and that the work is properly cited. For commercial re-use, please contact academic.permissions@oup.com 
As we will see, this distinction will play a role with common positions in particular. Before I come to specific duties based on loyalty, I will first discuss some general prescriptions derived from case law in the present context.

\section{The General Application of Loyalty to Mixed Agreements}

In a host of cases, the Court has stressed the importance of loyalty and of the duty of cooperation in various contexts pertaining to mixed agreements. In most instances, however, such statements have been of a very general nature, prescribing duties of coordination between the Union and the Member States, or duties to consider the interests of the Union within the framework of a mixed agreement.

In the MOX Plant case on the mixed UNCLOS agreement, the Court prescribed a duty of the Member States to inform and consult with the competent Community institutions before initiating dispute settlement against another Member State. ${ }^{34}$ This obligation was about the prevention of conflict in situations where the exclusive powers of the Union or, specifically, the Court of Justice, are jeopardized. While in MOX Plant there was exclusive Union competence, the duty of information and consultation must be seen in a more general context. The reason is that the provisions of a mixed agreement apply not only between the Member States, but also between the Member States and the Union. Therefore, the Member States' commitments vis-à-vis third states under such an agreement are also owed to the Union. ${ }^{35}$ From this, we can deduce a general obligation, irrespective of the competence situation, for Member States and the Union to coordinate and consult with each other within mixed agreements if the interests of either party are affected. ${ }^{36}$

Thus, in the Inland Waterway cases already discussed, the Court held that the duty of cooperation 'is of general application and does not depend either on whether the Community competence concerned is exclusive or on any right of the Member States to enter into obligations towards non-member countries. ${ }^{37}$ It further held that the duty applies 'where it is apparent that the subject matter of an agreement or convention falls in part within the competence of the Community and in part within that of the Member States'. ${ }^{38}$ Duties of cooperation apply in the process of the negotiation of a

${ }^{34}$ Instituting the proceedings under UNCLOS was held to contradict the exclusive jurisdiction of the Court under ex Art. 292 EC.

${ }^{35}$ M. Cremona, 'Disconnection Clauses in EU Law and Practice', in C. Hillion and P. Koutrakos (eds), Mixed Agreements Revisited: The EU and its Member States in the World (Oxford and Portland, Oregon: Hart Publishing, 2010), 160, 180.

36 See I. Govaere, 'Beware of the Trojan Horse: Dispute Settlement in (Mixed) Agreements and the Autonomy of the EU Legal Order', in C. Hillion and P. Koutrakos (eds), Mixed Agreements Revisited: The EU and its Member States in the World (Oxford and Portland, Oregon: Hart Publishing, 2010), 187, 206, who mentions the hypothetical case that EU efforts to come to a negotiated solution to a dispute with a third country might be thwarted by dispute settlement procedures initiated by a Member State.

37 Case C-266/03 Commission v Luxemburg [2005] ECR I-4805, para 58; Case C-246/07 PFOS [2005] ECR I-6985, para 64.

38 See Ruling 1/78, IAEA [1978] ECR 2151, paras 34-36; Opinion 2/91 ILO Convention 170 [1993] ECR I-1061, para 36; Opinion 1/94 WTO [1994] ECR I-5267, para 108; and Opinion 2/00 Cartagena Protocol on Biosafety [2001] ECR I-9713, para 18. This, taken literally, would reduce its scope to cases of mandatory mixity. There is, however, no reason to not also apply Art. 4 (3) TEU to any sort of mixed agreement, independent of the nature of competences this involves. cf. Heliskoski, Mixed Agreements, 211, C. Hillion, 'Mixity and Coherence in EU External Relations', in C. Hillion and P. Koutrakos (eds), Mixed Agreements Revisited: The EU and its Member States in the World (Oxford and Portland, Oregon: Hart Publishing, 2010), 87, 106.

This is an open access version of the publication distributed under the terms of the Creative Commons Attribution-NonCommercial-NoDerivs licence (http://creativecommons.org/licenses/by-nc-nd/3.0/), which permits non-commercial reproduction and distribution of the work, in any medium, provided the original work is not altered or transformed in any way, and that the work is properly cited. For commercial re-use, please contact academic.permissions@oup.com 
mixed agreement, its conclusion, and the fulfilment of the commitments entered into, ${ }^{39}$ as well as to its ratification. ${ }^{40}$

In some cases, the Court has qualified the strength of loyalty in the context of mixity. The Court thus held that loyalty applies especially in areas where the respective competences are 'closely interrelated'. ${ }^{41}$ In the same vein, cooperation between the Union and the Member States has been found to be more imperative when the mixed agreement is constituted by sub-agreements, which are 'inextricably interlinked', such as is the case with the WTO agreements. ${ }^{42}$ The Court has also found that the duty is all the more necessary when the Community must conclude an international agreement 'through the medium' of the Member States, as was the case with agreements under the umbrella of the ILO and the International Maritime Organisation (IMO). ${ }^{43}$

Thus, duties of cooperation apply under a flexible system; they are more robust:

(1) the more intertwined and complex the competence situation is regarding an international agreement, or

(2) the more complex the international agreement itself is.

While this does not tell us much about the substance of duties based on loyalty, it goes to demonstrate the generally strong role of loyalty in mixed agreements, ${ }^{44}$ for which we would proffer two reasons. One is connected to the earlier discussion on the relationship between supremacy and loyalty, and to the limitations of loyalty in the external sphere. The second reason relates to the (public) international (law) aspects arising in the context of mixed agreements.

As already explained, there is no direct conflict between international external agreements of Member States ${ }^{45}$ on the one hand, and Union 'common rules' on the other. A directive or regulation cannot set aside a Member State treaty concluded with a third state under public international law. Therefore, once a Member State treaty has been concluded, the safeguarding of Union interests requires the Member State concerned to renegotiate or denounce its international obligations. ${ }^{46}$ The same limitations to supremacy exist with regard to mixed agreements. Only those parts of a mixed agreement that are concluded by the Union form an integral part of EU law, as also explained later. Should the Member States therefore, in concluding other parts of an agreement under their national competence, enter into obligations that conflict with secondary law, the Union part of the mixed agreement cannot set aside the commitments entered into by the Member States in their relations with third states. ${ }^{47}$ As we have already observed

39 Opinion 1/94 WTO [1994] ECR I-5267, para 108.

40 Opinion 2/91 ILO Convention 170 [1993] ECR I-1061, para 38.

41 Case C-459/03 MOX Plant [2006] ECR I-4635, paras 174-176.

42 Opinion 1/94 WTO [1994] ECR I-5267, para 109.

43 Opinion 2/91 ILO Convention 170 [1993] ECR I-1061, para 37.

44 See Heliskoski, 'Positions', 141, who sees the duty of cooperation as 'an important conceptual framework for analysis of the position of the Union and the Member States under a mixed agreement'.

45 See Chapter 14 for this term.

46 See Chapter 7. See J. Temple Lang, 'The ERTA Judgment and the Court's Case-law on Competence and Conflict', Yearbook of European Law, 6 (1986), 183-218, 197.

47 It is a different case where Member State commitments are in conflict with the parts of a mixed agreement concluded by the Union. Since such parts constitute Union law at the level of primary law, the Member States would be in violation of Union law. Moreover, distinguish the situation when the EU enters into international obligations which conflict with its own secondary law. In such a case, the mixed agreement would have priority over secondary law within the EU. This could only be prevented by a disconnection clause. See, for such clauses, Cremona, 'Disconnection Clauses', 180-181; G. Hafner, 'Entkoppelungsklauseln der EG', in P. Fischer (ed.), Die Welt im Spannungsfeld zwischen Regionalisierung und Globalisierung: Festschrift für Heribert Franz Köck (Vienna: Linde, 2009), 127.

This is an open access version of the publication distributed under the terms of the Creative Commons Attribution-NonCommercial-NoDerivs licence (http://creativecommons.org/licenses/by-nc-nd/3.0/), which permits non-commercial reproduction and distribution of the work, in any medium, provided the original work is not altered or transformed in any way, and that the work is properly cited. For commercial re-use, please contact academic.permissions@oup.com 
with respect to non-exclusive competences, the weaker the role of supremacy, the more important the duties of cooperation are flowing from the principle of loyalty.

The second reason for the importance of loyalty with mixed agreements is that these agreements are by their very nature a threat to uniform action and to the united appearance of the Union and its Member States on the external scene. ${ }^{48}$ This international dimension explains the different import of Article 4 (3) TEU compared to its role in the exercise of competences internally, ${ }^{49}$ and even compared to the exercise of external competences in a non-mixed setting. This specific situation is reflected by the recurrent topos of the 'unity of representation' of the Union on the international plane in the case law on mixity. This concern is not primarily about the difficulty third states have with mixity, ${ }^{50}$ but about safeguarding the effective and coordinated appearance on the international scene by the Union. The relationship between this argument of unity and loyalty is explored next.

\section{Loyalty and the Requirement of Unity}

In Chapter 1, I have argued to see duties of cooperation as a subcategory of a more general duty of loyalty. ${ }^{51}$ Duties of cooperation are often considered as expressing a procedural constraint on Member State action at the external level. ${ }^{52}$ In a number of judgments involving mixed agreements the Court made a connection between such duties of cooperation and the requirement of unity, such as in the following words:

Where it is apparent that the subject-matter of an agreement or convention falls partly within the competence of the Community and partly within that of its Member States, it is essential to ensure close cooperation between the Member States and the Community institutions, both in the process of negotiation and conclusion and in the fulfilment of the commitments entered into. That obligation to cooperate flows from the requirement of unity in the international representation of the Community ... 53

The last part of this statement by the Court has been read as showing that the duty of (close) cooperation has its basis in the requirement of unity. ${ }^{54}$ While this is an apposite

48 See AG Tesauro in Case C-53/96 Hermès International [1998] ECR I-3603, para 21.

49 A good illustration of this is Case C-246/07 PFOS [2005] ECR I-6985, paras 100-102, where the Court explains that the effect of depositing a proposal for the listing of a substance in Annex A to the Stockholm Convention is the adoption of an international legal rule binding on the Union. In contrast, it explains, a national measure of the same content that is more stringent than a minimum Union measure and is permitted by ex Art. 176 (now Art. 193 TFEU) would not be binding on the Union.

50 The Court has repeatedly demonstrated that it cares little for the understanding of third states of the complex division of competences within the Union. This it considered a domestic question in which third parties have no need to intervene. See Ruling 1/78, IAEA [1978] ECR 2151. But see Case C-246/07 PFOS [2005] ECR I-6985, para 99.

51 See also, for the external relations context, R. Frid, The Relations Between the EC and International Organizations: Legal Theory and Practice (The Hague: Kluwer Law International, 1995), 149. Similar Eeckhout, EU External Relations Law, 255.

52 Cremona, 'Defending the Community Interest', 126. See also E. Neframi, 'The Duty of Loyalty: Rethinking its Scope Through its Application in the Field of EU External Relations', Common Market Law Review, 47 (2010), 323-359, 325-331.

53 Case C-246/07 PFOS [2005] ECR I-6985, para 73. Identical wording in Opinion 1/94 WTO [1994] ECR I-5267, para 108; Case 25/94 FAO [1996] ECR I-1469, para 48. Similar wording in Opinion 1/08 Accession to GATS [2009] ECR I-11129, para 136; Opinion 2/00 Cartagena Protocol on Biosafety [2001] ECR I-9713, para 18. But see Case C-45/07 Commission v Greece (IMO) [2009] ECR I-701, where this argument was not applied.

${ }^{54}$ Cremona, 'Defending the Community Interest', 157; P. Koutrakos, 'The Interpretation of Mixed Agreements under the Preliminary Reference Procedure', European Foreign Affairs Review, 7 (2002), 25, 49.

This is an open access version of the publication distributed under the terms of the Creative Commons Attribution-NonCommercial-NoDerivs licence (http://creativecommons.org/licenses/by-nc-nd/3.0/), which permits non-commercial reproduction and distribution of the work, in any medium, provided the original work is not altered or transformed in any way, and that the work is properly cited. For commercial re-use, please contact academic.permissions@oup.com 
observation, it needs to be qualified. The Court made such statement in the Union context for the first time in Opinion 2/91, where it held that the duty of cooperation must also apply in the EEC context 'since it results from the requirement of unity in the international representation of the Community. ${ }^{55}$ A closer look at this statement shows that the Court might have meant that the duty of cooperation originally prescribed in the EURATOM context also applied within the EEC context, not that it is based on the requirement of unity. ${ }^{56}$ However, subsequent case law relying on Opinion 2/91 referred to earlier intimated that the requirement of unity is indeed the basis of cooperation within Union law. ${ }^{57}$ Does this mean that the requirement of unity is a distinct legal principle, possibly even on a par with loyalty? Is there a duty of cooperation flowing from loyalty and, at the same time, a different duty of cooperation based on unity?

I would argue that the missing link for understanding this relation is the Union interest. I have already argued that the basis for the application of the abstention duty that is provided in Article 4 (3) TEU are the interests of the Union when it acts in pursuance of Treaty objectives. The more specifically these interests are expressed, the stronger the restraints are on the Member States. The unity in the international representation of the Union is such an interest, if a very general one. Thus, while loyalty in combination with more specific interests such as those expressed in an act of secondary law can produce duties of abstention for the Member States, loyalty in combination with the interest in unity generates duties of cooperation in the form of coordination and consideration. In this sense, duties of cooperation do flow from the requirement of unity. However, it would be misguided to conceive this requirement as a distinct and binding principle of Union law. The requirement of unity should rather be seen as a cipher for the general interest of the Union in coherence with the management of mixed agreements. ${ }^{58}$

This explains why the unity argument has not been the direct basis of tangible duties for the Member States. This furthermore explains why some lines of case law on mixed agreements have referred to duties of cooperation but not to the requirement of unity. Thus, the case law on the exclusive jurisdiction of the Court to interpret provisions in mixed agreements discussed later invokes duties of cooperation, but does not exhort the unity argument. The reason for this is that in the situations at issue there, the concern is not the coherence of the external action of the Union but the uniformity of Union law, as I will explain later. Similarly, it has been queried why the unity topos did not appear in the MOX Plant case, where the Court invoked ex Article $10 \mathrm{EC}$ and 'an obligation of close cooperation'. ${ }^{59}$ The reason for this perceived omission is that the concern in $M O X$ Plant was an inward-looking notion of uniformity and not an outward-looking notion of unity. Ireland in this case had breached a 'duty of prior information and consultation' intended to protect the Union Court in exercising its jurisdiction in matters falling within Union competence. ${ }^{60}$ Thus, the reliance in MOX Plant on the Dior case law and not on Opinion 2/91 or on the other 'unity' cases mentioned earlier. ${ }^{61}$

55 Opinion 2/91 ILO Convention 170 [1993] ECR I-1061, para 36.

56 See, in this sense, Hillion, 'Mixity and Coherence', 90-91.

57 The argument in Opinion 2/91 ILO Convention 170 [1993] ECR I-1061 was 'judicially altered' according to Hillion, 'Mixity and Coherence', 91.

58 See the link between close cooperation and the coherence and consistency of Union actions and represenation in Case 266/03 Commission v Luxembourg [2005] ECR I-4805, para 60. See, for a more narrow perspective on unity as opposed to consistency and coherence, Hillion, 'Mixity and Coherence', $114-115$.

59 CaseC-459/03 MOXPlant[2006] ECR I-4635, para 175. See Hillion, 'Mixity and Coherence', 92.

60 Case C-459/03 MOX Plant [2006] ECR I-4635, para 180.

61 Case C-459/03 MOX Plant [2006] ECR I-4635, para 175.

This is an open access version of the publication distributed under the terms of the Creative Commons Attribution-NonCommercial-NoDerivs licence (http://creativecommons.org/licenses/by-nc-nd/3.0/), which permits non-commercial reproduction and distribution of the work, in any medium, provided the original work is not altered or transformed in any way, and that the work is properly cited. For commercial re-use, please contact academic.permissions@oup.com 
Hence, while loyalty can be instrumental in safeguarding the attainment of many different Union interests, with mixed agreements this interest lies predominantly in the coherence of its contractual involvement with third states. The unity argument might help us understand why Member States are bound by duties of cooperation when they act within the area of their reserved competences under a mixed agreement. ${ }^{62}$ It might furthermore elucidate why the constraints placed on the Member States based on loyalty have in general been particularly strong in the present context. It could thus be argued that the interest in unity extends the scope of the application of loyalty, and that it reinforces its effect. However, I would submit that by its nature as a very general Union interest it cannot be the basis of specific legal obligations for the Member States throughout the 'life circle' of mixed agreements, discussed in the following section.

\section{Loyalty and the Conclusion of Mixed Agreements}

\subsection{Indications from Case Law}

As explained earlier, mixed agreements can be either mandatory or facultative. In the latter case, the Union may in theory have the choice of exercising its competence fully and conclude the respective agreement alone. The question is whether loyalty might somehow influence this decision by the Union.

A case in the realm of the EURATOM, where Article 192 EAEC was identical to ex Article 10 EC, seemed to have reinforced the cause for mandatory mixity. Despite its competence, it was not certain that the Union would be allowed to become a member to a draft convention in this area. ${ }^{63}$ The Court argued that there can be no doubt that unilateral action by the Member States could affect the Union's 'independent action in external relations'. ${ }^{64}$ The Court continued that the agreement 'can be implemented as regards the Community only by means of a close association between the institutions of the Community and the Member States both in the process of negotiation and conclusion and in the fulfilment of the obligations entered into'. ${ }^{65}$ This argument in favour of mandatory mixity has not resonated in the case law under the EU Treaties.

A case commonly mentioned in connection with the general conditions for mixity is Opinion 1/76 on the conclusion of an agreement on a scheme for the elimination of disturbances for navigation on the Rhine (the European Laying-up Fund for Inland Waterway Vessels). ${ }^{66}$ The Court found it necessary for the Community to enter into the agreement on its own because the planned scheme could not be established by autonomous Community rules, due to the need for the participation of Switzerland. Six (of the then nine) Member States participated in the agreement only because it required the amendment of earlier treaties to which these Member States were already parties. ${ }^{67}$ The Court goes to great lengths to find that mixity here does not 'encroach on

62 On this see also Chapter 1.

63 For a different perspective, see P.-J. Kuijper, 'Re-reading External Relations Cases in the Field of Transport: The Function of Community Loyalty', in J. Bulterman et al. (eds), Views of European Law from the Mountain. Liber Amicorum for Piet-Jan Slot (The Hague: Kluwer Law International, 2009), 291-300, 291, 295.

64 Ruling 1/78 IAEA [1978] ECR 2151, para 33.

65 Ruling 1/78 IAEA [1978] ECR 2151, para 34.

66 Opinion 1/76 European Laying-up Fund [1977] ECR 741. See Chapter 7.

67 Opinion 1/76 European Laying-up Fund [1977] ECR 741, para 6. cf. Eeckhout, EU External Relations Law, 215-216.

This is an open access version of the publication distributed under the terms of the Creative Commons Attribution-NonCommercial-NoDerivs licence (http://creativecommons.org/licenses/by-nc-nd/3.0/), which permits non-commercial reproduction and distribution of the work, in any medium, provided the original work is not altered or transformed in any way, and that the work is properly cited. For commercial re-use, please contact academic.permissions@oup.com 
the external power of the Community'. ${ }^{68}$ It took issue, however, with the result of the participation of these Member States in the negotiations of the agreement. The Court found that the limited role of the Community institutions, particularly in the supervisory board as the controlling organ of the fund, would 'call in question the power of the institutions of the Community and, moreover, alter in a manner inconsistent with the Treaty the relationships between the Member States within the context of the Community as it was at the beginning and when the Community was enlarged'. ${ }^{69}$ This was seen as a threat to 'the requirements of unity and solidarity', ${ }^{70}$ and to the effective 'defence of the interests of the Community'. ${ }^{71}$ Consequently, the agreement was found to be incompatible with the Treaty.

In this decision, the Court thus shows a great concern for the particulars of an institution established under a mixed agreement. The choice of mixity seems less of a problem here, probably because it was owed to the very specific contractual circumstances. Instead, the Member States' participation is considered a problem in view of the pertinent institutional set-up. While this is an important line drawn by the Court with regard to mixed agreements, it arguably does not touch the core of the conditions for mixity as such. ${ }^{72}$

\subsection{Arguments Against Mixity}

To the contrary, as already explained, it is rather common that in the case of facultative mixity the respective agreement nonetheless is concluded jointly by the Union and the Member States. It has even been argued that the choice of mixity in this constellation requires a specific justification and is not simply optional. ${ }^{73}$ Mixity, according to this view, would violate Article 4 (3) TFEU, since by demanding their participation the Member States make it more difficult and cumbersome for the Union to achieve its objectives. A similar argument has been made in the context of ex Article 133 (5) EC (repealed by the Lisbon Treaty) in a case on the competence for deciding on the accession of Vietnam to the WTO. Whereas Article 133 (5) EC prescribed a shared competence for certain matters in the otherwise exclusive Common Commercial Policy, it was proffered that mixed agreements should not be possible because of the problems they cause with ensuring the effective representation of the Union vis-à-vis its trading partners. ${ }^{74}$

Such limitations imposed on facultative mixity would have the benefit of 'depoliticizing' the decision on the participation of the Member States in international agreements. However, this approach would not reflect the treaty-making practice in the EU. Moreover, the Court has explicitly refuted the relevance of the argument that mixity was more cumbersome than agreements concluded only by the Union. ${ }^{75}$ From a

68 Opinion 1/76 European Laying-up Fund [1977] ECR 741, para 7.

69 Opinion 1/76 European Laying-up Fund [1977] ECR 741, para 10.

70 Opinion 1/76 European Laying-up Fund [1977] ECR 741, para 12.

71 Opinion 1/76 European Laying-up Fund [1977] ECR 741, para 14.

72 See also Opinion 1/78, International Agreement on National Rubber [1979] ECR 2871, where mixity was only owed to the application of the agreement to Member State territories not belonging to the Union. cf. Eeckhout, EU External Relations Law, 217.

${ }^{73}$ Eeckhout, EU External Relations Law, 265. See, for a more pronounced view, Eeckhout, External Relations of the European Union: Legal and Constitutional Foundations (Oxford: Oxford Univ. Press, 2004), 194.

74 AG Kokott in Case C-13/07 Commission v Council (Accession of Vietnam to WTO), removed from registry, para 74. This should apply even when the Commission de facto is also the spokesperson for the Member States. See AG Kokott in Case C-13/07 Commission v Council (Accession of Vietnam to WTO), para 72.

75 Opinion 1/94 WTO [1994] ECR I-5267, paras 106-107: 'In response to that concern, which is quite legitimate, it must be stressed, first, that any problems which may arise in implementation of the

This is an open access version of the publication distributed under the terms of the Creative Commons Attribution-NonCommercial-NoDerivs licence (http://creativecommons.org/licenses/by-nc-nd/3.0/), which permits non-commercial reproduction and distribution of the work, in any medium, provided the original work is not altered or transformed in any way, and that the work is properly cited. For commercial re-use, please contact academic.permissions@oup.com 
dogmatic point of view, it is also difficult to find a legal basis for such duty of abstention for the Member States. The only possible basis is the interest in the unity of international representation of the Union and its Member States. ${ }^{76}$ This Union interest, as I have argued, extends the scope of the application of loyalty and reinforces its effects, but it does not provide a sufficient basis for triggering the duties under Article 4 (3) TEU. This might be different if the Member States were to insist on including provisions in an international agreement for the sole purpose of establishing a cause for mixity, and if thereby the fulfilment of the obligations of the Union under the agreement was impaired.

\subsection{Arguments in Favour of Mixity}

Conversely, we might ask whether there are circumstances where Article 4 (3) TEU would bring the Union into an extra-Union legal regime. What do I mean by that? Imagine that the Union passes secondary law in an area, which is, on the international level, governed by an international organization. Imagine further that this organization does allow for the membership of states, but not of the EU. Imagine, finally, that a third state party to the international convention starts a dispute within the organization against the Member States that are a party to the organization for the violation of obligations caused by Union law acts. This scenario took place within the International Civil Aviation Organisation (ICAO) regarding a directive banning certain loud types of aeroplanes from European skies. ${ }^{77}$ The question is whether Article 4 (3) TEU would require the Member States in such a case to actively promote the right of the EU to enter the organization instead of the Member States or, more realistically, alongside them, creating a mixed agreement in the latter case. ${ }^{78}$ One might argue that this is not required when there can be other ways of effectively protecting the interests of the Union to act in matters coming within its (exclusive) competence. Thus, in the case of the ICAO, the EU Member States passed the defence of the organization to the Director-General of the Commission Legal Service, which can be seen as predicated on loyalty. ${ }^{79}$ It has even been claimed that the current situation with regard to organizations such as the ICAO and the IMO adequately serves the interests of the Union. ${ }^{80}$

It would be a different matter if the Member States as parties to an international organization actively prevented the EU from joining, such as by not contributing to the amendments to the statutes required to allow the membership of the EU. I would

WTO Agreement and its annexes as regards the coordination necessary to ensure unity of action where the Community and the Member States participate jointly cannot modify the answer to the question of competence, that being a prior issue. As the Council has pointed out, resolution of the issue of the allocation of competence cannot depend on problems which may possibly arise in administration of the agreements.'

76 See Eeckhout, EU External Relations Law, 265.

77 See P.-J. Kuijper, 'International Responsibility for EU Mixed Agreements', in C. Hillion and P. Koutrakos (eds), Mixed Agreements Revisited: The EU and its Member States in the World (Oxford and Portland, Oregon: Hart Publishing, 2010), 219-220.

78 See, in this sense, Kuijper, 'International Responsibility', 220. See, however, the constellation discussed by M. Cremona, 'Member States as Trustees of the Union Interest: Participating in International Agreements on Behalf of the European Union', in A. Arnull et al. (eds), A Constitutional Order of States?: Essays in EU Law in Honour of Alan Dashwood (Oxford and Portland, Oregon: Hart Publishing, 2011), 435-457, 444, who advocates an obligation of the Member States based on Art. 4 (3) TEU to conclude an agreement if it falls under exclusive Union competence but which it cannot accede to.

79 See Kuijper, 'International Responsibility', 220.

80 I. Smyth, 'Mixity in Practice: A Member State Practioner's Perspective', in C. Hillion and P. Koutrakos (eds), Mixed Agreements Revisited: The EU and its Member States in the World (Oxford and Portland, Oregon: Hart Publishing, 2010), 304, 312-313.

This is an open access version of the publication distributed under the terms of the Creative Commons Attribution-NonCommercial-NoDerivs licence (http://creativecommons.org/licenses/by-nc-nd/3.0/), which permits non-commercial reproduction and distribution of the work, in any medium, provided the original work is not altered or transformed in any way, and that the work is properly cited. For commercial re-use, please contact academic.permissions@oup.com 
submit that this would be contrary to the principle of loyalty, unless the Member States have a valid reason to act in such a manner. In practice, notably, such obligations have been imposed on the Member States by Council decisions. Thus, in the case of the Bunkers Convention on civil liability for oil pollution damage, Member States were required to use their best endeavours to ensure the amendment of the Convention to enable the accession of the Union. ${ }^{81}$

The Bunkers Convention, however, is also a case in point for an obligation on the part of the Member States based on loyalty to accede to conventions, which only very marginally comes under Union competence, and where their participation either goes against their national interests or might even violate their national law. ${ }^{82}$

\section{Loyalty and Declarations of Competence}

In a growing number of international agreements, commitment clauses oblige 'regional economic integration organizations' such as the Union to declare their responsibilities under the respective treaty. ${ }^{83}$ In most of these cases, the Union institutions' reluctance to submit precise and complete statements on the demarcation of competences conflicts with the desire of third states to understand whether the Union or the Member States are their competent counterparts. ${ }^{84}$

This issue of demarcation is closely linked to the question of responsibility under international law. The reason is that such a declaration is decisive for attributing international responsibility for implementing the commitments entered into. ${ }^{85}$ The Union is only responsible for complying with those parts of an agreement which come within its competence. ${ }^{86}$ If this demarcation is not clear because there is no such declaration or it is uninformative, the Union and the Member States are jointly liable. ${ }^{87}$ Despite this detrimental consequence of the lack or the deficiency of declarations of competence, there has always been surprisingly little practice of issuing complete or precise statements. ${ }^{88}$ This may have its foundation in the view expressed also by the ECJ that the distribution of competences is a matter internal to the Union and does not concern third states. ${ }^{89}$

81 See Cremona, 'Member States as Trustees of the Union Interest', 442.

82 See, for such constellations, Kumin and Bittner, 'Die "gemischten" Abkommen', 83-84, who have called this the 'tail wagging the dog'.

${ }^{83}$ Such provisions have, among others, been included in the UN Convention on Biological Diversity, the Cartagena Protocol on Biosafety, the Vienna Convention for the Protection of the Ozone Layer, the UN Framework Convention on Climate Change and the UN Convention on the Law of the Sea. For a full list of mixed agreements with commitment clauses see the Treaties Office Database at $<$ http:// ec.europa.eu/world/agreements/>.

${ }_{84}$ See Olson, 'Mixity from the Outside', 335. cf. the account regarding the accession to the Food and Agriculture Organization (FAO) by Heliskoski, Mixed Agreements, 142 and 144 specifically.

85 See Heliskoski, Mixed Agreements, 147 passim; E. Neframi, 'International Responsibility of the European Community and of the Member States under Mixed Agreements', in E. Cannizzaro (ed.), The European Union as an Actor in International Relations (The Hague: Kluwer Law International, 2002), 193-205.

${ }^{86}$ Case 104/81 Kupferberg [1982] ECR 3641; Case 12/86 Demirel [1987] ECR 3719, para 11. A. Rosas, 'Mixed Union-Mixed Agreements', in J. Koskenniemi (ed.), International Law Aspects of the European Union (The Hague: Kluwer Law International, 1998), 125, 142.

87 See Kuijper, 'International Responsibility', 209-210. cf. C. Tomuschat, 'Liability for Mixed Agreements', in D. O'Keeffe and H. Schermers (eds), Mixed Agreements (Deventer: Kluwer, 1983), 125-132. For a more nuanced view, see Eeckhout, EU External Relations Law, 262-263.

${ }^{88}$ See the similar verdict by Heliskoski, 'Positions', 150. Declarations of competence are less complex when the conclusion on the Union side can be based on one (predominant) legal basis, which is the case with the majority of mixed agreements.

89 See note 13.

This is an open access version of the publication distributed under the terms of the Creative Commons Attribution-NonCommercial-NoDerivs licence (http://creativecommons.org/licenses/by-nc-nd/3.0/), which permits non-commercial reproduction and distribution of the work, in any medium, provided the original work is not altered or transformed in any way, and that the work is properly cited. For commercial re-use, please contact academic.permissions@oup.com 
Thus, declarations of competence tend to be very terse, and if they consist of a list of legislative acts relevant for demarcating the scope of Union competence (qua ERTA), the list in most cases is 'illustrative' (a euphemism for non-exhaustive) and often rather short. ${ }^{90}$ Only a small minority of the declarations submitted in the past did provide for an exhaustive list of pertinent common rules, or linked Union competence to specific treaty provisions, as is required for adequately informing third parties. ${ }^{91}$ The declaration annexed to the Council decision on the conclusion of UNCLOS has been praised as a very elaborate example. ${ }^{92}$ The declaration distinguished the exclusive areas of conservation and management of sea fishing resources, commercial and customs policy from exceptions to this exclusivity. ${ }^{93}$ As areas of shared competence it stated 'matters not directly related to the conservation and management of sea fishing resources, among others'. However, even this declaration required some effort of interpretation on the part of the Court of Justice when it was at issue in the MOX Plant case..$^{94}$

I would argue that the Council is not under an obligation based on Union loyalty to issue a declaration of competences in the first place. Again, the argument of the Union interest in unity by itself does not suffice to impose such specific duty. In a similar vein, it has also been suggested that the EU institutions might be required to conclude inter-institutional agreements on voting rights, especially with important international organizations such as the WTO, or concerning organizations to which the Union cannot become a member such as the ILO. ${ }^{95}$ Again, the underlying rationale of unity does not carry such an obligation in my opinion, especially since such an arrangement might also bind the Member States, as shown by the $F A O$ case. ${ }^{96}$

There is, however, some support from a case under the EURATOM Treaty that once the Council does issue such a declaration, loyalty requires it to be complete and faithfully reflect the current competence situation for the scope of the respective agreement. ${ }^{97}$

90 See M. Klamert, 'Rechtsprobleme gemischter Abkommen der EG illustriert am Beispiel der UNESCO Konvention über den Schutz und die Förderung der Vielfalt kultureller Ausdrucksformen', Zeitschrift für öffentliches Recht, (2009), 217-235, 229 for examples. B. de Witte, 'Too Much Constitutional Law in the European Union's Foreign Relations?', in M. Cremona and B. de Witte (eds), EU Foreign Relations Law: Constitutional Fundamentals (Oxford and Portland, Oregon: Hart Publishing, 2008), 3, 14, notes pointedly whether illustrative examples are really good enough, quipping that this may only be illustrative of the fact that the constitutional law of the EU foreign relations is out of control.

${ }^{91}$ See the case of the UN Convention Against Transnational Organised Crime, mentioned by F. Hoffmeister, 'Curse or Blessing? Mixed Agreements in the Recent Practice of the European Union and its Member States', in C. Hillion and P. Koutrakos (eds), Mixed Agreements Revisited: The EU and its Member States in the World (Oxford and Portland, Oregon: Hart Publishing, 2010), 259. As we have seen, each and every internal legal act of the Community curtails Member State competences. To counter such problems in the case of 'joint' membership of the FAO, a general declaration has been supplemented by the requirement for ad hoc declarations and the right of FAO member states to request information on the distribution of competences for a specific question.

92 Smyth, 'Mixity in Practice', 317.

93 'Measures relating to the exercise of jurisdiction over vessels, flagging and registration of vessels and the enforcement of penal and administrative sanctions.'

${ }^{94}$ Case C-459/03 MOX Plant [2006] ECR I-4635, paras 99-108. See also later in this Chapter and in Chapter 1.

95 Eeckhout, EU External Relations Law, 214.

96 Case C-25/94 FAO [1996] ECR I-1469. Recall that there was a dispute on voting rights in spite of the inter-institutional arrangement on voting in the FAO. The Court found that the Council had breached the duty of cooperation, of which the mentioned arrangement was an expression. It is difficult to generalize from the specifics of the $F A O$ case. In particular, Annex II of the FAO arrangement makes clear that it has no implications regarding other international organizations, including those of the United Nations system.

97 Case C-29/99 Commissionv Council (Nuclear Safety Convention) [2002] ECR I-11221. The Court had already previously endorsed case law under the EAEC as being pertinent also for the EU. See

This is an open access version of the publication distributed under the terms of the Creative Commons Attribution-NonCommercial-NoDerivs licence (http://creativecommons.org/licenses/by-nc-nd/3.0/), which permits non-commercial reproduction and distribution of the work, in any medium, provided the original work is not altered or transformed in any way, and that the work is properly cited. For commercial re-use, please contact academic.permissions@oup.com 
In this case, the Commission had brought an action for annulment against the EAEC's accession to the Nuclear Safety Convention, claiming that the declaration of competences attached to the Council's accession decision had been incorrect. The Court argued that 'it follows from the duty of sincere cooperation between the institutions ...' and from 'Article 30(4)(iii) of the Convention' that 'the Council was, under Community law, required to attach a complete declaration of competences to its decision approving accession to the Convention'. ${ }^{98}$ Loyalty thus transformed an obligation under international law into an obligation under Union law. There is no principled reason why this holding should not also be relevant for the European Union. ${ }^{99}$

This would include the obligation of the Union regularly to update its declarations of competence, even when this is not expressly required by the international agreement concerned. ${ }^{100}$ It would also require declarations to give clause-by-clause, or at least article-by-article, information on which entity is responsible for exercising which rights and performing which obligations. ${ }^{101}$

\section{Loyalty and Common Positions}

\subsection{Introduction}

Article 218 (9) TFEU provides that the Council, on a proposal from the Commission, must adopt a decision 'establishing the positions to be adopted on the Union's behalf in a body set up by an agreement, when that body is called upon to adopt acts having legal effects ...' ${ }^{102}$ This refers to the most common situation in this context, i.e. when common positions are the basis for proposals for acts taken by such an institution. ${ }^{103}$ However, in line with the general reticence of the Treaties on mixed agreements, Article 218 (9) TFEU does not provide for the case of common positions under these agreements. This gap is sometimes compensated by the establishment of rules on the implementation of and the participation in specific mixed agreements. ${ }^{104}$ More and more often, however, it is giving rise to disputes between the Member States and the Union regarding the right to act in bodies set up under an international convention, such as in the PFOS case.

Opinion 2/91 ILO [1993] ECR I-1061. But see Case 327/91 France v Commission (Competition Law Agreement) [1994] ECR I-3641. cf. Kuijper, 'Re-reading', 296.

98 Case C-29/99 Commission v Council (Nuclear Safety Convention) [2002] ECR I-11221, paras 69-71.

99 See also Eeckhout, EU External Relations Law, 258.

100 cf. Smyth, 'Mixity in Practice', 318. This, in practice, is not done by the Union. See Olson, 'Mixity from the Outside', 336.

101 See Olson, 'Mixity from the Outside', 336.

102 cf. Heliskoski, Mixed Agreements, 143.

103 Thus, a common position does not require the participation of the European Parliament, but in general resembles the procedure applying for delegated Union law acts. See T. Müller-Ibold, 'Art. 218 AEUV', in K.-D. Borchardt (ed.), EU-Verträge (Cologne, Vienna: Bundesanzeiger, Linde, 2010), para 19.

104 The best known is the PROBA 20-arrangement between the Council and the Commission on the occasion of negotiations on raw materials under UNCTAD, and the inter-institutional arrangement relating to the FAO, discussed in Chapter 14. cf. Heliskoski, 'Positions', 144-145; Hoffmeister, 'Curse or Blessing?', 261-262, who mentions point 4.4 of the Code for the Codex Alimentarius Commission, which provides that in case of disagreement about competence the Member States and the Union can only vote in matters falling clearly within their respective competence. This entails a duty of abstention for ambigious matters and, thus, a strong incentive to cooperate.

This is an open access version of the publication distributed under the terms of the Creative Commons Attribution-NonCommercial-NoDerivs licence (http://creativecommons.org/licenses/by-nc-nd/3.0/), which permits non-commercial reproduction and distribution of the work, in any medium, provided the original work is not altered or transformed in any way, and that the work is properly cited. For commercial re-use, please contact academic.permissions@oup.com 
As already intimated, the intricacies of the delimitation of competences after the conclusion of mixed agreements fully reflect on the right to adopt a common position under such an agreement. The rights to adopt common positions would be much easier to assign if there were a clear delimitation of competences between the Union and the Member States. However, even when this has been attempted, the results were still not clear enough to bring certainty on this issue. ${ }^{105}$ In the following section, we will discuss the situation concerning common positions against the background of the different competence constellations that I have laid out earlier.

\subsection{Common Positions in Cases of Exclusive Member State Competence}

In general, Member States are not obliged to reach a concerted position in matters coming under their exclusive competence. ${ }^{106}$ However, as mentioned, the Member States are bound by the principle of loyalty even when they act within the realm of their reserved competences in the context of a mixed agreement. The rationale is that within a mixed agreement Union interests may be affected by the action of a Member State even when there is no Union competence involved. A second rationale is the general Union interest of unity, which loyalty requires the Member States to consider in their actions.

\subsection{Common Positions in Cases of Exclusive Union Competence}

When matters on which a decision shall be taken in a body mentioned earlier fall within the exclusive competence of the Union, a common Union position is a necessity for arriving at any position at all. Without agreement in the Council in such a case, there is no position taken. ${ }^{107}$ Member States can only act unilaterally when the Union permits them to do so. ${ }^{108}$ This duty cannot be weighed against a possible breach of loyalty by the Commission, as the Court made clear with the IMO case. In this case, Greece had argued that not putting its proposal on the agenda for a meeting of the Maritime Safety (Marsec) Committee chaired by the Commission's representative constituted a separate breach of loyalty. The Court conceded that 'the Commission could have endeavoured to submit that proposal to the Maritime Safety Committee and allowed a debate on the subject', and that the Commission 'in chairing that committee, may not prevent such an exchange of views on the sole ground that a proposal is of a national nature'. ${ }^{109}$ At the same time, however, it held that a breach by the Commission of ex Article 10 EC does not allow a Member State to undermine exclusivity by adopting unilateral measures. ${ }^{110}$

105 See Heliskoski, 'Positions', 145, who mentions the UNESCO Code of Conduct between the Council, the Member States, and the Commission on negotiations on the draft Convention on the protection of the diversity of cultural contents and artistic expressions, which prescribed a rule of preponderance of competence, but did not clarify whether this referred to the existence of competence or its exercise.

106 See Smyth, 'Mixity in Practice', 310. 107 Heliskoski, 'Positions', 146.

108 M. Cremona, 'External Relations and External Competence of the European Union: The Emergence of an Integrated Policy', in P.P. Craig and G. de Búrca, The Evolution of EU Law, 2nd edn. (Oxford: Oxford Univ. Press, 2011), 225, 251.

109 Case C-45/07 Commission v Greece (IMO) [2009] ECR I-701, para 25.

110 Case C-45/07 IMO [2009] ECR I-701, para 26: ' . . take initiatives likely to affect Community rules promulgated for the attainment of the objectives of the Treaty, in breach of that State's obligations, which, in a case such as the present, arise under Articles 10 EC, 71 EC and 80(2) EC ...'. The reference by the Court to Case C-5/94 Hedley Lomas [1996] ECR I-2553 is hard to understand in this context.

This is an open access version of the publication distributed under the terms of the Creative Commons Attribution-NonCommercial-NoDerivs licence (http://creativecommons.org/licenses/by-nc-nd/3.0/), which permits non-commercial reproduction and distribution of the work, in any medium, provided the original work is not altered or transformed in any way, and that the work is properly cited. For commercial re-use, please contact academic.permissions@oup.com 
The IMO case also shows that the constraints imposed on Member States are irrespective of whether the Union is allowed membership in an international organization. This can also be illustrated by the example of the Convention on International Trade in Endangered Species of Wild Fauna and Flora (CITES). Despite not being a party to CITES, in contrast to all Member States, the Union is very actively involved in voting, which is done by Member States on behalf of the Union. CITES has also been implemented in the EU by a number of Regulations known as the Wildlife Trade Regulations. ${ }^{111}$ By these measures ('common rules'), the Union has activated its (internal) shared competence in the area of environmental protection and Member States are therefore not only precluded from acting at a national level beyond the implementation of the Wildlife Trade Regulations, but are also precluded from acting unilaterally under CITES. Thus, there must be a common position when voting for proposals in the bodies set up under CITES (the Conference of the Parties). If there is none because there is no qualified majority in the Council, or because the proposal based on a common position is rejected at voting, Member States must abstain from voting on any other proposals. Both the fact that the competence for matters under CITES under the Treaty is (partly) shared, as well as the fact that the Union is not a member of the convention, is therefore irrelevant when there is exclusivity qua common rules in conjunction with Article 3 (2) TFEU.

When it has been argued that the proposal by Sweden in the PFOS case would have affected secondary law by the Union, and therefore would have had the same potential to undermine the integrity of common rules as a Member State treaty, ${ }^{112}$ this would only make sense when we assume that the Union was exclusively competent. If a decision taken in a body within an international organization could somehow affect Union law, a unilateral proposal by Member States made in this context would violate exclusivity. Thus, had the decision-based on the Swedish proposal—under the Stockholm Convention to include PFOS in Annex I to the Stockholm Convention obliged the Union to amend its secondary law on POPs, this would have invited a reasoning based on exclusive competence. In the PFOS case, in fact, Sweden's proposal and vote in the organization would have prevented the Union from voting, but would not necessarily have led to the adoption of a decision on PFOS binding on the Union. ${ }^{113}$ This might explain why the Court, instead of relying on ERTA, had to resort to Article 4 (3) TEU in order to constrain Sweden in this case.

However, the constraints imposed on the Member States when acting within international organizations can be even more complex. Take the example of the International Organisation of Vine and Wine (OIV), which, among other things, contributes to the international harmonization of the conditions for producing and marketing vine and

This case concerns a conflict between two Member States over compliance with a harmonizing directive and has nothing to do with loyalty. The Court's analogy, however, works in the sense that also in the Hedley Lomas case there was exclusive competence through full harmonization and Member States were not allowed to act outside the so established Union regime for whatever reason. For a contrasting view see Hillion, 'Mixity and Coherence', 113, who links the case with an alleged necessity to bring an action for failure to act if a Member State wants to address a breach of the duty of cooperation by the Commission.

111 Currently these are Regulation (EC) 338/97 on the protection of species of wild fauna and flora by regulating trade therein [1997] OJ L61/1 (the Basic Regulation), and Commission Regulation (EC) 865/2006 laying down detailed rules concerning the implementation of Council Regulation (EC) $338 / 97$ on the protection of species of wild fauna and flora by regulating trade therein [2006] OJ L166/1 (the Implementing Regulation).

112 See Eeckhout, EU External Relations Law, 254.

113 Case C-246/07 PFOS [2005] ECR I-6985, paras 97-100.

This is an open access version of the publication distributed under the terms of the Creative Commons Attribution-NonCommercial-NoDerivs licence (http://creativecommons.org/licenses/by-nc-nd/3.0/), which permits non-commercial reproduction and distribution of the work, in any medium, provided the original work is not altered or transformed in any way, and that the work is properly cited. For commercial re-use, please contact academic.permissions@oup.com 
wine products. Resolutions in the General Assembly are adopted by consensus. Thus, in order to prevent resolutions from being adopted, Member States have to express their dissent, since mere acquiescence will lead to their adoption. The resolutions taken within the OIV are not binding. However, Council Regulation 479/2008 on the common organization of the market in wine ${ }^{114}$ contained dynamic references to these resolutions, making the rules adopted within the OIV also binding within the EU. In such a constellation, the ERTA principle now codified in Article 3 (2) TFEU would arguably require the Member States to vote against proposals and thus to prevent the adoption of resolutions in the General Assembly of the OIV, unless they are based on a decision pursuant to Article 218 (9) TFEU. Would, for whatever reason, the argument in such a constellation not be based on exclusivity, which is less likely in this area of comprehensive Union regulation than in a context such as the one in the PFOS case, Article 4 (3) TEU might be relied on instead. ${ }^{115}$ The argument in such a case would have to be that the failure by the Member States to prevent a resolution in the OIV would jeopardize the interests of the Union. Only in relation to such an argument, should it be possible to weigh in interests of the Member States being parties to the OIV. In other words, with loyalty, the case by the Union against the Member States may be less absolute and more open to a balancing of interests than when relying on competence.

\subsection{Common Positions in Cases of Shared Competence}

It follows from the earlier discussion that only for such matters that have already been within the exclusive competence of the Union before the conclusion of an agreement, as well as for such matters for which the Member States are precluded because of the act of conclusion itself, the Member States are prohibited from adopting a common position.

In contrast, when matters remain under shared competence after the conclusion of an agreement by the Union, a common position by the Union is not an absolute necessity, and each Member State, as a matter of principle, is free to adopt a negotiating position of its own choosing. ${ }^{116}$ This applies irrespective of the circumstances of the mixed agreement at issue. ${ }^{117}$ However, when a common position is reached according to the procedure under Article 218 (9) TFEU, Member States will be pre-empted. ${ }^{118}$ The reason is that such a common position has the same restraining effects as a common rule within the meaning of ERTA, and legally binds the Member States. This means above all that those Member States that were the minority vote in the Council cannot take unilateral positions when voting within the framework of an international agreement.

114 Council Regulation (EC) 479/2008 on the common organization of the market in wine [2008] OJ L148/1.

${ }_{115}$ See also W. Obwexer, 'Die Vertragsschlusskompetenzen und die vertragsschlussbefugten Organe der Europäischen Union', Europarecht, Beiheft (2012), 49-75, 71-72.

116 I. MacLeod, I.D. Hendry, and S. Hyett, The External Relations of the European Communities (Oxford: Clarendon Press, 1996), 149. For the contrasting view that the Union and the Member States as parties to a mixed agreement should be required to adopt a common negotiating position at all times, see Eeckhout, EU External Relations Law, 216; C. Timmermans, 'Organising Joint Participation of EC and Member States', in A. Dashwood and C. Hillion (eds), The General Law of EC External Relations (London: Sweet \& Maxwell, 2000), 239, 241-243; Anonymous, Editorial comments: 'The Aftermath of Opinion 1/94 or How to Ensure Unity of Representation for Joint Competences', Common Market Law Review, 32 (1995), 385. See also the position of the Commission in C-246/07 PFOS [2005] ECR I-6985, paras 35-36.

117 See Smyth, 'Mixity in Practice', 304. See also the Opinion of AG Tesauro in Case C-53/96 Hermès International [1998] ECR I-3603, para 21, and fn 33.

118 Similar Heliskoski, 'Positions', 152.

This is an open access version of the publication distributed under the terms of the Creative Commons Attribution-NonCommercial-NoDerivs licence (http://creativecommons.org/licenses/by-nc-nd/3.0/), which permits non-commercial reproduction and distribution of the work, in any medium, provided the original work is not altered or transformed in any way, and that the work is properly cited. For commercial re-use, please contact academic.permissions@oup.com 
It entails furthermore that when a common position has been established based on a proposal submitted by the Commission, Member States remain bound by it irrespective of whether or not it has been successful in the body set up by an international agreement.

We cannot infer from case law that even in a 'complex' setting this obligation should be absolute in a sense that no position but a common one may be adopted under shared competence. As explained, while the Union interest in the unity of international representation may determine the force of the duty of cooperation, it cannot fundamentally change its nature, which would be the case if Member States were always required to adopt a common position within the EU. ${ }^{119}$

We would argue that the claim that Member States are free to adopt a unilateral position in areas of shared competence is adumbrated in the PFOS case. Had there not been a concerted strategy at Union level, Sweden arguably would not have been precluded from making its proposal, unless we adopt the ERTA reading discussed earlier. ${ }^{120}$ Were Member States not free to adopt unilateral positions in areas of shared competence in a body set up by a mixed agreement, there would not have been the need to argue for their preclusion for undermining the Union interest in this case.

However, Member States are under an obligation at least to try to reach a common position with the Union in such a situation. ${ }^{121}$ Put in other words, 'the consequence must be that the Member State should engage fully and in good faith in such process' of Union decision-making. ${ }^{122}$ As laid out earlier, this best effort obligation is stronger the more closely the Member State parts of the agreement are interlinked with the Union parts. ${ }^{123}$ The reason is that this increases the likelihood of contradictions and ambiguities proportionally, and thus risks impairing the effectiveness of Union action. ${ }^{124}$ Conversely, if the parts of the agreement concluded by the Union and the Member States, respectively, are easily distinguishable, the nature of this obligation to reach a common position will be less powerful.

If, despite the best efforts of the Member States in an area of shared competence, no common position is adopted, the following must be considered. Since the matters concerned in such a case remain under Union competence even when there is no common position adopted, ${ }^{125}$ loyalty continues to apply to safeguard specific Union interests and the general Union interest in the unity of international representation. This entails that the Member States must take due regard of pertinent interests of the Union, even when they have not been expressed by a Council decision or as a Union strategy. Moreover, loyalty mandates that the Member States inform the Union when they intend to adopt a negotiating position. ${ }^{126}$ Again, this obligation will be more resolute if the competence

119 Similar, Hillion, 'Mixity and Coherence', 104.

120 See the contrasting view by P. Delgado Casteleiro and J. Larik, 'The Duty to Remain Silent: Limitless Loyalty in EU External Relations?', European Law Review, (2011), 524, 539, who claim that if a lack of a clear Union position barred Member States from acting independently, 'then a contrario, in order to act it appears that they would need some sort of Union authorisation to do so notwithstanding intra-Union dissension'. This ignores the fact that the Court emphasized that there was a clear Union position in this case, which was not to act for the time being.

121 See Smyth, 'Mixity in Practice', 310. See also Opinion of AG Tesauro in Case C-53/96 Hermès International [1998] ECR I-3603, para 21, and fn 33.

122 Opinion of AG Poiares Maduro in Case C-246/07 PFOS [2005] ECR I-6985, para 48.

123 See Chapter 12 on the classification of best-effort obligations and obligations of result.

124 Others have advocated that this obligation only applies in cases of intertwined competences, relying on the proposition that the duty of cooperation is 'directly linked by the Court to the requirement of unity in the international representation of the Community'. See Timmermans, 'Organising Joint Participation', 241-243. See also Anonymous, 'The Aftermath of Opinion 1/94', 385.

125 See Cremona, 'External Relations', 257. $\quad 126$ In this sense, Heliskoski, 'Positions', 158.

This is an open access version of the publication distributed under the terms of the Creative Commons Attribution-NonCommercial-NoDerivs licence (http://creativecommons.org/licenses/by-nc-nd/3.0/), which permits non-commercial reproduction and distribution of the work, in any medium, provided the original work is not altered or transformed in any way, and that the work is properly cited. For commercial re-use, please contact academic.permissions@oup.com 
situation or the agreement itself is intertwined/complex. As mentioned, the MOX Plant judgment can be seen as the basis for a general obligation in the field of mixed agreements 'to inform and consult the Community institutions prior to engaging in individual action'. ${ }^{127}$

\section{Loyalty and the Ratification of Mixed Agreements}

Mixed agreements need to be ratified by all participating Member States. ${ }^{128}$ The Union normally will not ratify before all Member States have done so. ${ }^{129}$ This may be a time-consuming process, which is only partly abided by as a possibility to conclude interim agreements or by provisionally applying the agreement concerned. ${ }^{130}$ It has been submitted that both the Union and the Member States must 'refrain from acting in a way that would make the ratification of the agreement more difficult'. ${ }^{131}$ Similarly, it has been argued that Member States should be prohibited from frustrating the entering into force of signed mixed agreements. ${ }^{132}$ For a duty of ratification on the part of the Union based on loyalty, Epiney has mentioned the case that Member States have already ratified trusting in the ratification also by the Union of an agreement that requires the participation of the Union. ${ }^{133}$

With regard to Member State ratification, I would argue that the reason for a delay in ratification by Member States is decisive, as is the interest of the Union in the expeditious entry into force of the agreement concerned. The stronger and more specific such interest is, the stronger will be the obligation imposed on the Member States. ${ }^{134}$ If there is, thus, a clear interest of the Union in the ratification of an agreement or in its ratification without delay, Article 4 (3) TEU only excuses a Member State for delaying or withholding ratification if the Member State has good reasons to do so. ${ }^{135}$ This is certainly not the case

127 Opinion of AG Poiares Maduro in Case C-246/07 PFOS [2005] ECR I-6985, para 48.

128 Maresceau, 'Typology', 12, calls this 'reinforced unanimity'.

129 Eeckhout, EU External Relations Law, 218; Hoffmeister, 'Curse or Blessing?', 256. But see the case of the UNESCO Convention on Cultural Diversity mentioned by Olson, 'Mixity from the Outside', 345 .

130 Eeckhout, EU External Relations Law, 219; Hoffmeister, 'Curse or Blessing?', 257-258; Maresceau, 'Typology', 13. But see J. Czuczai, 'Mixity in Practice', in C. Hillion and P. Koutrakos (eds), Mixed Agreements Revisited: The EU and its Member States in the World (Oxford and Portland, Oregon: Hart Publishing, 2010), 231-248, 244, who points to the problem that provisional application can be terminated by either party without notice or reasons. See also Rosas, 'The Future of Mixity', 367, 368-369, on attempts by Member States to prevent the provisional application of the Union parts of (facultative) mixed agreements.

131 Hillion, 'Mixity and Coherence', 101.

132 C. Durand, 'Le principe de coopération loyale entre les États membres et les institutions: les article 5 et 6 du traité CEE', in Commentaire Megret, Vol. I 2nd edn. (Brussels: Éditions de l'Université de Bruxelles, 1992), 25-42; L. Gormley, 'Some Further Reflections on the Development of General Principles of Law within Article 10 EC', in U. Bernitz, J. Nergelius, and C. Cardner (eds), General Principles of EC Law in a Process of Development (The Hague: Kluwer Law International, 2008), 303, 309. The case law on directives introduced by Case C-129/96 Inter-Environnement Wallonie [1997] ECR I-7411 has been invoked in support of this claim.

133 A. Epiney, 'Zur Tragweite des Art. 10 EGV im Bereich der Außenbeziehungen', in J. Bröhmer and G. Ress (eds), Internationale Gemeinschaft und Menschenrechte: Festschrift für Georg Ress zum 70. Geburtstag am 21. Januar 2005 (Cologne: Heymanns, 2005), 441-459, 447, arguing that this would jeopardize essential obligations under international law of the Member States that have already ratified.

134 The legal uncertainty a delay by either the Member States or the Union would cause, in contrast, is not a relevant interest here. See, for a perhaps contrasting view, Czuczai, 'Mixity in Practice', 231, 233.

135 Compare this situation to the case where a Member State blocks decision-making in the Council on a matter where there is an existing legal obligation to act by a prescribed date. This is discussed by Durand, 'Le Principe de Cooperation Loyale', and by Gormley, 'Some Further Reflections', 309. In this

This is an open access version of the publication distributed under the terms of the Creative Commons Attribution-NonCommercial-NoDerivs licence (http://creativecommons.org/licenses/by-nc-nd/3.0/), which permits non-commercial reproduction and distribution of the work, in any medium, provided the original work is not altered or transformed in any way, and that the work is properly cited. For commercial re-use, please contact academic.permissions@oup.com 
should the delay be due to an attempt of the respective Member State to extract commercial concessions from a third country. ${ }^{136}$ It can be argued in this respect that such duty to ratify is a logical extension of a declaration of competence by the Union and the ensuing allocation of international responsibility. As has been noted, should a Member State not ratify, such effort to cabin the responsibility for the implementation of a mixed agreement would be futile, since the Union would be responsible for those matters coming under shared competence, even though these matters had been assigned to the Member States under the agreement concerned. ${ }^{137}$ We might thus claim that Article 4 (3) TEU protects the interest of the Union in the effectiveness of its declaration of competence. This reasoning adds further support to the call for submitting declarations of competence made earlier.

This means conversely that if there is no such Union interest, Member States are free to postpone ratification or even abstain from it and thus to leave the agreement in a state of partial mixity, in spite of the problems this may cause. ${ }^{138}$ As I have already argued, the Union interest in the unity of its international representation is not a sufficient basis, here for establishing an unconditional and general duty of ratification, even though this interest would undoubtedly be affected by such Member State action. ${ }^{139}$

\section{Loyalty and the Interpretation and Implementation of Mixed Agreements}

\subsection{Introduction}

In a number of cases on its exclusive jurisdiction to interpret provisions in mixed agreements, the Court relied on the Community interest, or on the duty of (close) cooperation. As I will also explain in Chapter 13, this case law is one example showing that loyalty is the foundation of distinct duties under Union law imposed on the Member States. In the following, I will take a closer look at how loyalty precisely works in relation to the interpretation of mixed agreements. We shall see that this principle plays a role both for the jurisdiction of the Court in preliminary reference as well as in enforcement proceedings. It is, however, not always obvious why loyalty has been invoked in some of these cases and not in others.

\subsection{The Role of Loyalty in Preliminary References}

In two preliminary rulings on Article 50 of the Agreement on Trade Related Aspects of Intellectual Property Rights (TRIPS), the Court developed the assertion of its exclusive jurisdiction to interpret procedural, 'neutral' provisions in a mixed agreement. ${ }^{140}$

case, a proceeding for failure to act is suggested as a preferable solution to a claim under ex Art. 10 EC. Such a proceeding is clearly not available for ratification problems.

136 Eeckhout, EU External Relations Law, 219. $\quad 137$ See Rosas, 'The Future of Mixity', 373.

138 Practical problems that may be caused by this are not relevant per se. See Opinion 1/94. But see the account of the ratification process of the Convention on the Physical Protection of Nuclear Material and Nuclear Facilities (CPPNM) by Czuczai, 'Mixity in Practice', 242; and the problems mentioned by Olson, 'Mixity from the Outside', 345.

139 See for a contrasting view, Czuczai, 'Mixity in Practice', 233 and 242.

140 According to Art. 50 TRIPS, the judicial authorities of WTO Members have the authority to order prompt and effective provisional measures either to prevent the infringement of an intellectual property right from occurring, or to preserve relevant evidence for an alleged infringement.

This is an open access version of the publication distributed under the terms of the Creative Commons Attribution-NonCommercial-NoDerivs licence (http://creativecommons.org/licenses/by-nc-nd/3.0/), which permits non-commercial reproduction and distribution of the work, in any medium, provided the original work is not altered or transformed in any way, and that the work is properly cited. For commercial re-use, please contact academic.permissions@oup.com 
In Hermès, the Court affirmed such jurisdiction because Regulation No. 40/94 on Community trademarks had already been in force when the WTO Agreement was signed. ${ }^{141}$ The Court held that "where a provision can apply both to situations falling within the scope of national law and to situations falling within the scope of Community law, it is clearly in the Community interest that, in order to forestall future differences of interpretation, that provision should be interpreted uniformly, whatever the circumstances in which it is to apply'. ${ }^{142}$ This was confirmed and developed in the Dior case on rights to an industrial design, which did not come under the competence of the Union under the scope of TRIPS, in contrast to trademark rights. ${ }^{143}$ The Court distinguished between the applications of Article 50 TRIPS to trademark-related disputes on the one hand, and to disputes under national law on industrial designs on the other. The Court referred to the 'obligation of close cooperation in fulfilling the commitments undertaken by [the Union and the Member States] under joint competence', and continued that for this reason Article 50 of TRIPS must be interpreted uniformly. ${ }^{144}$ Since only the Court, acting in cooperation with the judicial authorities of the Member States, could ensure such uniform interpretation, the Court affirmed its exclusive jurisdiction also with regard to matters outside the area of trademark law. ${ }^{145}$

The rationale both in Hermès and in Dior thus was the uniformity of the Union legal order, which would be at risk if a neutral provision were construed differently depending on the circumstances of its application. This has been criticized for enforcing uniformity for (national) matters, when this should only be relevant for (transnational) situations coming under Union law. ${ }^{146}$ However, it arguably makes sense not to allow Member State courts to interpret a provision in a mixed agreement differently from the Union Court. ${ }^{147}$ A contrasting national assessment such as on the direct effect of Article 50 TRIPS might cast doubts on the judgment of the Union Court. This interest in uniformity is thus less concerned about the external representation of the Union. ${ }^{148}$ I would argue that the duty of cooperation mentioned by the Court in Dior was instead an instrument to protect the specific Union interest mentioned in Hermès. ${ }^{149}$ Both the duty and the interest were required to rationalize why Member State courts should defer to the Court of Justice also with regard to cases that only concerned matters coming under national competence. ${ }^{150}$ Competence alone could not justify that the exclusive jurisdiction of the Court also extends to situations not coming under Union competence.

141 See Case C-53/96 Hermès International [1998] ECR I-3603, para 32.

142 Case C-53/96 Hermès International [1998] ECR I-3603, para 32.

143 Joined cases C-300/98 Christian Dior and C-392/98 Assco Gerüste [2000] ECR I-11307.

144 Joined cases C-300/98 Christian Dior and C-392/98 Assco Gerüste [2000] ECR I-11307, paras 36-37.

145 Joined cases C-300/98 Christian Dior and C-392/98 Assco Gerüste [2000] ECR I-11307, paras 37-39.

146 Critical of this argument, Koutrakos, 'Interpretation', 122-123.

147 In this sense, Hoffmeister, 'Curse or Blessing?', 266.

148 But see AG Tesauro's Opinion in Case C-53/96 Hermès International [1998] ECR I-3603, para 21, who had argued that a common position on the interpretation of Art. 50 TRIPS was required because of the 'obligation of cooperation and the requirement of unity in the international representation of the Community'. AG Tesauro might also have noticed that in Case C-459/03 MOX Plant [2006] ECR I-4635, which he invoked in support of this claim, the unity argument had not played a role, as shown earlier.

149 See Eeckhout, EU External Relations Law, 283.

150 See also Hillion, 'Mixity and Coherence', 96; AG Colomer in Case C-431/05 Merck Genéricos [2007] ECR I-7001, para 41. See also AG Maduro in Case C-459/03 MOX Plant [2006] ECR I-4635, para 21. See J.H.J. Bourgeois, 'The European Court of Justice and the WTO: Problems and Challenges', in J.H.H. Weiler (ed.), The EU, the WTO, and the NAFTA (Oxford: Oxford Univ. Press, 2001), 71, 122,

This is an open access version of the publication distributed under the terms of the Creative Commons Attribution-NonCommercial-NoDerivs licence (http://creativecommons.org/licenses/by-nc-nd/3.0/), which permits non-commercial reproduction and distribution of the work, in any medium, provided the original work is not altered or transformed in any way, and that the work is properly cited. For commercial re-use, please contact academic.permissions@oup.com 
The centrality of loyalty for attributing jurisdiction in the Dior and Hermès constellation is corroborated by the fact that in a more recent case regarding TRIPS, Merck Genéricos, neither the duty of cooperation nor the Community interest played a role in the reasoning of the Court. While Hermès and Dior had concerned a procedural, 'neutral' provision in a mixed agreement, Merck was about the interpretation of Article 33 TRIPS on the term of protection for a specific field, viz. patent rights. In this case, instead of uniformity the decisive argument has been whether that provision has lain in a sphere where the Community had already legislated. ${ }^{151}$

\subsection{The Role of Loyalty in Infringement Proceedings}

This role of loyalty to bind the Member States in their own reserved domain is also visible in another strand of case law on the exclusive jurisdiction of the Court in infringement cases. The Community interest was mentioned in an action against France for polluting a salt-water lake in Provence. In this case, the situation was that the respective provisions in the convention fell within Union competence because 'environmental protection, which is the subject-matter of the Convention and the Protocol, is in very large measure regulated by Community legislation ...' ${ }^{152}$ Responsible for the implementation of these convention rules, however, were the Member States. Thus, while the matter came under exclusive competence, the competence for the implementation of the Convention fell to the Member States. It is submitted that this is the reason why the Court also held that there was a Community interest in compliance by both the Community and its Member States with the commitments entered into under those instruments. ${ }^{153}$

Another infringement case may be referred to as proof that loyalty is required to oblige Member States to exercise their own competences in implementing a mixed agreement. ${ }^{154} \mathrm{~A}$ provision in the mixed EEA Agreement required adherence to the Berne Convention, which, however, lay within the responsibility of the Member States. The Court argued that the provisions of the Berne Convention on the protection of literary and artistic works covered an area falling in large measure within the scope of Community competence. ${ }^{155}$ Since the Berne Convention thus created 'rights and obligations in areas covered by Community law', the Court held that 'there is a Community interest in ensuring that all Contracting Parties to the EEA Agreement adhere to that Convention'. 156

With infringement cases, it is therefore easy to understand why the Court relied on the Community interest as an expression of loyalty. Parts of mixed agreements coming

who has argued that the ECJ could exercise jurisdiction via a broad interpretation of ex Art. 5 that 'could also apply to Member States' courts and imply for them a duty to seek preliminary rulings under Article 177 (new Art. 234) EC'. At 88 he has argued that in cases where the respective parts under a mixed agreement were clearly identified, ex Art. 5 EC would provide a duty for Member States to apply clauses of mixed agreements uniformly.

151 Case C-431/05 Merck Genéricos [2007] ECR I-7001, para 39. See Hoffmeister, 'Curse or Blessing?', 266, who questions the admissibility of the case in view of the fact that the Court denied its jurisdiction for interpreting Art. 33 TRIPS. This, I would argue, confounds the jurisdiction to determine jurisdiction ('jurisdiction-jurisdiction') with the jurisdiction for interpretation of mixed agreements. On this distinction see R. Holdgaard, 'Annotation to Case C-431/05 Merck Genéricos', Common Market Law Review, (2008), 1233, 1239.

152 Case C-239/03 Commission v France (Étang de Berre) [2004] ECR I-9325, para 28.

153 Case C-239/03 Commission v France (Étang de Berre) [2004] ECR I-9325, para 29.

154 See Cremona, 'Defending the Community Interest', 147.

155 Case C-13/00 Commission v Ireland (Bern Convention) [2002] ECR I-2943, para 16.

156 Case C-13/00 Bern Convention [2002] ECR I-2943, para 19.

This is an open access version of the publication distributed under the terms of the Creative Commons Attribution-NonCommercial-NoDerivs licence (http://creativecommons.org/licenses/by-nc-nd/3.0/), which permits non-commercial reproduction and distribution of the work, in any medium, provided the original work is not altered or transformed in any way, and that the work is properly cited. For commercial re-use, please contact academic.permissions@oup.com 
under Union competence are a part of EU law for which the Union has a responsibility for complying. These commitments are thus transformed into Union objectives. Loyalty in this sense requires Member States not to impair the attainment of these objectives. This in turn requires Member States to act in matters coming within their own powers, and it empowers the Court to hold the Member States accountable for the fulfilment of such obligations. This also applies where the Union is competent, but could not accede to the agreement concerned and the Member States became parties on its behalf. In this case, compliance with the agreement and its implementation is required from the Member States qua Union law. ${ }^{157}$

\section{Conclusion}

The regime on mixed agreements shows the full range of duties based on Union loyalty. The strong role of loyalty is owed to the weakness of supremacy as a conflict resolution mechanism in this context and to the interest of the Union to be represented in a coherent and unified manner on the international stage. Loyalty also intervenes in case competence does not police the relationship between the Union and the Member States, such as in the PFOS case. It is thus an additional instrument of conflict prevention where exclusivity does not operate. Loyalty, different from exclusivity, allows room for a balancing of interests and a weighing of the circumstances concerned. Thus, the force of loyalty with mixed agreements increases proportionally with the complexity of the contractual arrangement, as well as with the complexity of the division of competences.

Loyalty pervades all matters of relevance with mixed agreements, without, however, imposing constraints on the Member States comparable to those based on supremacy or exclusivity. Loyalty, in contrast, creates a general duty of coordination between the parties involved, and a general duty of consideration for each other's interests. It can therefore not be the basis of Member State duties to act, such as with declarations of competence or ratification, nor to abstain, such as with the conclusion of mixed agreements per se. The interest in unity is not a sufficiently specific point of reference for triggering the obligations provided under Article 4 (3) TEU.

This interest, on the other hand, explains why Member States are bound also in matters coming within their own competence under a mixed agreement. This is most apparent in the case law assigning exclusive jurisdiction to the Court of Justice, when provisions in mixed agreements can apply both to national law and to Union law (the Dior constellation), or come under EU competence but must be implemented by the Member States (the Étang de Berre constellation).

This is an open access version of the publication distributed under the terms of the Creative Commons Attribution-NonCommercial-NoDerivs licence (http://creativecommons.org/licenses/by-nc-nd/3.0/), which permits non-commercial reproduction and distribution of the work, in any medium, provided the original work is not altered or transformed in any way, and that the work is properly cited. For commercial re-use, please contact academic.permissions@oup.com 


\section{Conclusion of the Part on Cooperation}

This part has discussed various aspects of Union competence. Loyalty is omnipresent here both as the foundation of important principles, such as the ERTA and the ILO principles, as the main rule governing the exercise of irregular and supporting competences, and in the area of mixed agreements.

I have shown that the role of the duty of cooperation is the more important the more intertwined the division of competence is between the Member States and the Union. Note that this reflects a finding made in the Introductory Part on the greater relevance of federal fidelity in states with overlapping spheres of competence. I would also suggest that loyalty's effects are proportional to the extent of the threat to the interests of the Union. This makes loyalty a principle that is more open to a balancing exercise between the interests of the Member States and those of the Union than the principles of supremacy or a resolution based on competence.

This Part has also shown the important role of loyalty as the third conflict prevention instrument besides competence (exclusivity superveniens) and supremacy. Mixed agreements show clearly the importance of loyalty in constellations where conflicting or inconsistent Member State measures cannot easily be set aside. This has also been demonstrated by an analysis of the ERTA effect showing that supremacy could not remove conflicting commitments by Member States entered into with third states. I have, however, stressed that this does not mean that the effects of loyalty have no limits. Case law confirms that it has always been applied to safeguard a specific concretization of a Union interest. The unity of international representation arguably does not carry distinct obligations for the Member States.

This negative correlation between the strength of supremacy and competence on the one hand and the relevance of loyalty on the other I have also discussed with respect to non-exclusive competences. The weaker the separation of the spheres of Member States and Union is with supporting and irregular shared competences, the more need there is for cooperation between the actors. I have in this respect, however, also pointed out that it would be a fallacy to deny any conflict potential in these fields. 
This is an open access version of the publication distributed under the terms of the Creative Commons Attribution-NonCommercial-NoDerivs licence (http://creativecommons.org/licenses/by-nc-nd/3.0/), which permits non-commercial reproduction and distribution of the work, in any medium, provided the original work is not altered or transformed in any way, and that the work is properly cited. For commercial re-use, please contact academic.permissions@oup.com 


\section{PART IV \\ THE CONSTRUCTION OF THE EUROPEAN UNION}

\section{Introduction}

By the Construction of the European Union, I refer to two related roles of loyalty. I will explore how loyalty has driven the process of shaping Union law through principles such as effet utile and effectiveness. ${ }^{1}$ Secondly, I will analyse the role of loyalty in addressing various forms of conflicts between the Union institutions on the one hand, and between the Union system and the Member States on the other. Underpinning this Part is a broader understanding of conflict than the conflicts of legal norms. Recall that I have already shown that conflicts with the regulatory autonomy of Member States that are resolved by loyalty arise because of a collision of Union objectives at different levels of concretization. This ranges from the general primacy of Union law over colliding national law, the priority of Union objectives in the contractual interaction with third states, to the precedence of the objectives of directives over national methods of construction in the case of indirect effect. ${ }^{2}$ Thus, it can be argued that whenever a fundamental conflict between Union and Member State action arose, loyalty was invoked to decide the case in favour of the Union. ${ }^{3}$ Moreover, loyalty plays a role both with the prevention and with the resolution of conflicting claims to jurisdiction within the European Union. Recall that Article 344 TFEU assigns exclusive jurisdiction to the ECJ by prohibiting the Member States from submitting a dispute concerning the interpretation or application of the Treaties 'to any method of settlement other than those provided for therein'. ${ }^{4}$ In Chapter 3 on loyalty and the constitutionalization of Union law I have therefore submitted that Article 4 (3) TFEU, with its insistence on the fulfilment of the objectives of the Treaty and the corresponding duty of abstention, constitutes the adequate and only available Treaty provision for addressing these conflicts. ${ }^{5}$

1 See M. Poiares Maduro, 'Interpreting European Law: Judicial Adjudication in a Context of Constitutional Pluralism', European Journal of Legal Studies, (2007), 1-21, 15 for a similar use of the term construction.

2 See Chapter 5.

3 See A. von Bogdandy, 'Rechtsfortbildung mit Art. 5 EG-Vertrag', in A. Randelzhofer, R. Scholz and D. Wilke (eds), Gedächtnisschrift für Eberhard Grabitz (Munich: Beck, 1995), 17-28, 23-24, in his piece on judicial lawmaking and ex Art. $10 \mathrm{EC}$, who also notes the inherent propensity to collisions and conflicts between the Community and the Member States which must be resolved so as to safeguard the functioning of both parties.

4 See Chapter $1 . \quad 5$ See Chapter 3.

This is an open access version of the publication distributed under the terms of the Creative Commons Attribution-NonCommercial-NoDerivs licence (http://creativecommons.org/licenses/by-nc-nd/3.0/), which permits non-commercial reproduction and distribution of the work, in any medium, provided the original work is not altered or transformed in any way, and that the work is properly cited. For commercial re-use, please contact academic.permissions@oup.com 
In this Part, the role of the Court in the present context will be examined more closely, adopting two distinct perspectives. Firstly, as has become clear so far, Article 4 (3) TEU primarily governs the interrelation between the Member States and the Union. It is in this context that the most controversial developments of the law based on loyalty have taken place. Since the European Union is a polity that is comprised of a multitude of actors, which are not subjected to a clear hierarchy, ${ }^{6}$ we will briefly recapitulate the partly difficult relation between the ECJ and national constitutional courts. This section of the Part will also discuss the preliminary reference procedure as a concretization of the duty of cooperation in general, and its purportedly cooperative nature in particular. These largely cooperative forms of interaction between the courts in the European Union will be distinguished from matters that are essentially conflictive and confrontational. Moreover, I will also discuss ways to frame cases of (institutional) conflict between the Court and the Union legislature, as well as the role of loyalty in managing the relationship between the Union institutions. I will argue that the principle of institutional balance that is important in the latter context is yet another, largely horizontal manifestation of the principle of loyalty.

In the following, I will also take a closer and methodological look at the nature and the various distinct roles of loyalty. This involves discussing whether it can apply as a self-standing legal rule and whether it can be called a (general) principle of Union law, and which implications such characterization would have. Moreover, I will explore whether it is possible to 'deconstruct' loyalty and the different rationales and principles based on it. I would argue that there is a need for such discussion since it is normally not distinguished whether loyalty applies as lex generalis, as the separate basis of obligations under Union law, as a supporting, complementary legal basis, or as the legal basis for seemingly distinct principles of Union law in their own right. In addition to those roles of loyalty, I discuss in this Part what I refer to as the amplification of Union law by virtue of loyalty. This concept of amplification also furnishes a suitable framework for thinking the potential of loyalty for shaping the scope of Union law to its (logical?) end.

${ }^{6}$ See M. Poiares Maduro, We the Court: The European Court of Justice and the European Economic Constitution (Oxford and Portland, Oregon: Hart Publishing, 1998), 15, noting that the relationship between the European Court of Justice and the other Union institutions is not subject to a clear hierarchy.

This is an open access version of the publication distributed under the terms of the Creative Commons Attribution-NonCommercial-NoDerivs licence (http://creativecommons.org/licenses/by-nc-nd/3.0/), which permits non-commercial reproduction and distribution of the work, in any medium, provided the original work is not altered or transformed in any way, and that the work is properly cited. For commercial re-use, please contact academic.permissions@oup.com 


\section{A Primer on Cooperation and Constitutional Conflict in the European Union}

\section{Introduction}

I would submit that we must distinguish between several distinct constellations that might give rise to jurisdictional conflicts in the European Union.

Firstly, there might be conflicts because of the adoption of new Union treaties or because of changes to them. This can cause concerns as to the preservation of a core identity of national constitutional law, such as epitomized by the identity review introduced by the German Constitutional Court (Bundesverfassungsgericht, 'BVerfG') that will be discussed later. Moreover, what is termed ultra vires review can also apply here if the changes to the Treaties are brought about by an act of Union institutions under a simplified amendment procedure. ${ }^{7}$ In this case, the Union institutions could be said to be involved as 'second order masters of the Treaties' ${ }^{8}$

Secondly, the enactment of secondary law can give rise both to claims to the control of such acts relating to their compliance with fundamental rights, and to claims to assess their possible ultra vires nature. In the latter case, the Union lawmaker is accused of overreaching its competences, including a violation of the subsidiarity principle. ${ }^{9}$ In this instance, the Member States as privileged claimants can initiate a procedure for annulment. Alternatively, the national courts can request a preliminary ruling from the ECJ. Unilaterally, Member States could refuse to apply such a Union measure within their territory without taking recourse to an action for annulment. ${ }^{10} \mathrm{With}$ secondary law, there is a potential overlap between ultra vires review and identity control, when the latter is also applied to 'the adoption of a particularly wide-ranging directive on the harmonizing of criminal law'. ${ }^{11}$ The same ambiguity would surround the application of

7 Of course, the BVerfG or any other national constitutional court could have declared their inclusion in the TEU as per se unconstitutional by arguing that they confer Kompetenz-Kompetenz to the Union. This, however, has not been done by the BVerfG, who, instead, de facto transforms them into fully-fledged Treaty amendments with the same consequences as a normal Treaty amendment would have in the German legal order.

8 If the BVerfG moreover were appealed to before such a decision was taken, Germany could seek an opt-out under the emergency brakes the Treaty provides for in the area of criminal law. See Arts. 81 et seq TFEU. See D. Thym, 'In the Name of Sovereign Statehood: A Critical Introduction to the Lisbon judgment of the German Constitutional Court', Common Market Law Review, (2009), 1795-1822, 1809, who has claimed on this basis that identity review could be very similar to ultra vires review. See also M. Payandeh, 'Constitutional Review of EU Law After Honeywell: Contextualizing the Relationship between the German Constitutional Court and the EU Court of Justice', Common Market Law Review, 1 (2011), 9-38, 18.

9 Case 2 BvE 2/08 et al. Lisbon Treaty [2009] BVerfGE 123, 267, para 240 (<http://www.bverfg.de/ entscheidungen/es20090630_2bve000208.html>).

10 Distinguish this from a Union law act adopted based on Art. 352 TFEU, which according to the identity control exercised by the BVerfG is not ultra vires per se, but does require specific approval under German constitutional law.

11 Thym, 'In the Name of Sovereign Statehood', 1806.

This is an open access version of the publication distributed under the terms of the Creative Commons Attribution-NonCommercial-NoDerivs licence (http://creativecommons.org/licenses/by-nc-nd/3.0/), which permits non-commercial reproduction and distribution of the work, in any medium, provided the original work is not altered or transformed in any way, and that the work is properly cited. For commercial re-use, please contact academic.permissions@oup.com 
the new competence on foreign direct investment provided in Article 206 TFEU, which has to be construed narrowly according to the BVerfG. ${ }^{12}$ This could mean that an international agreement concluded by the Union on a broad interpretation of this legal basis would not have binding force for Germany.

Thirdly, judgments by the Court of Justice may be challenged on two accounts. If the Court is accused of overstepping its powers of adjudication and of acting as a quasi-lawmaker, its judgments can only be challenged under the ultra vires count. In other words, a conflict between the ECJ and the Member States (aka 'Masters of the Treaties ${ }^{13}$ ) might lead to an ultra vires review. ${ }^{14}$ The implication here would be that such a judicial act of ultra vires would not be applied by a Member State. ${ }^{15}$ If in contrast the Court assumes the role of a maker of Union law, the conflict arises not between the ECJ and the Member States in their function as the Masters of the Treaties, but between the Court and the Member States as Union legislator in the Council. Whereas for all conflicts involving national constitutional courts the preliminary reference procedure is the designated Union law instrument of inter-court conflict prevention, this is different when the conflict lies in the relation between the ECJ and the Union legislator. There are two conceivable ways how the Court might enter into this sort of conflict with the Union legislator. The first concerns the disregard by the Court of secondary law, the other concerns the disregard by the legislator of settled case law by the Court. I will present examples for both constellations and will discuss approaches to resolving the inherent discrepancy.

The connection with loyalty is perhaps not too obvious in this Chapter, but it is there. With preliminary references, which I will start with as an example of judicial cooperation, I have already pointed to this connection in Chapter 1. In this context, I will also discuss the case of the interaction between the European Court of Justice and the European Court of Human Rights. Conflicts of legal basis, which I will discuss later, in my opinion, should also be seen as the application of institutional loyalty. The ultra vires issue is closely tied to the use by the Court of effet utile and loyalty, and with national identity review the BVerfG at least has referred to Article 4 (3) TEU in support of its stance, as I will show later.

\section{Preliminary References and Other Interactions Between Courts in the EU}

It has correctly been cautioned in the present context that cooperation may be an imprecise term in that it could imply both collaboration (Zusammenarbeit) and interaction (Zusammenwirken). ${ }^{16}$ While cooperation in the sense of collaboration would, among other things, involve inter-personal efforts such as informal meetings, cooperation in the sense of interaction would rather involve cross-references in the decisions of different courts. ${ }^{17}$ This latter form of interaction has been called 'mutual reinforcement

12 Case 2 BvE 2/08 et al. Lisbon Treaty [2009] BVerfGE 123, 267, paras 377-380.

13 See Case 2 BvE 2/08 et al. Lisbon Treaty [2009] BVerfGE 123, 267, para 231.

14 As we will see, this challenge is framed in very narrow terms by the BVerfG. See Case 2 BvE 2/08 et al. Lisbon Treaty [2009] BVerfGE 123, 267, para 340.

15 Claims for annulment or preliminary references are not available in such a case.

16 C. Grabenwarter, 'Die Kooperation zwischen EuGH und EGMR', in C. Grabenwarter and E. Vranes (eds), Kooperation der Gerichte im europäischen Verfassungsverbund: Grundfragen und neueste Entwicklungen (Baden-Baden: Nomos, 2013), 35-44, 36-37.

17 See, both with regard to the ECJ and the ECHR, C. Timmermans, 'The Relationship between the European Court of Justice and the European Court of Human Rights', in A. Arnull et al. (eds), $A$

This is an open access version of the publication distributed under the terms of the Creative Commons Attribution-NonCommercial-NoDerivs licence (http://creativecommons.org/licenses/by-nc-nd/3.0/), which permits non-commercial reproduction and distribution of the work, in any medium, provided the original work is not altered or transformed in any way, and that the work is properly cited. For commercial re-use, please contact academic.permissions@oup.com 
of legimitation' (gegenseitige Legitimationsverstärkung) by Grabenwarter, who has also identified two other forms of interaction, viz. a separation of judicial responsibilities in the sense of the Solange jurisprudence of the BVerfG or the Bosphorus jurisprudence of the European Court of Human Rights (ECHR), and the reinforcement of legal protection as the result of judicial dialogue. ${ }^{18}$ Indeed, this distinction is often not transparent in the literature. In the following, cooperation will primarily refer to what has been called interaction in the classification mentioned earlier.

In Chapter 1, I have shown that the procedure under Article 263 TFEU can be qualified as an instrument of cooperation and thus as a specification of Article 4 (3) TEU. However, de Witte has argued that the preliminary reference procedure should not be called an example of judicial conversations or even constitutional dialogue between the ECJ and the national courts. ${ }^{19}$ This would ignore the fact that preliminary references are mostly made by ordinary courts, that they do not raise constitutional questions, that they are not answered by the ECJ in reference to national constitutional doctrine, and that a real dialogue with a mutual exchange of arguments would therefore require an entirely different institutional setting. ${ }^{20}$ Besides some valid qualifications to these observations, ${ }^{21}$ I would argue in the same vein that while it is true that preliminary references are essentially co-operative, the 'agenda' and the rules of engagement under which this cooperation plays out are set by the ECJ.

Thus, in a judgment where the Court referred to preliminary rulings as an instrument of cooperation, the Court also placed the burden squarely on the national courts to determine the need for a preliminary ruling and the relevance of the questions referred to the Court. ${ }^{22}$ In the Atlanta case, the ECJ reminded the national court that, when deciding on granting interim relief, it 'is obliged under Article 5 of the Treaty to respect what the Community court has decided on the questions at issue before it'. ${ }^{23}$ If no invalidity has been found by the ECJ, it would follow that 'the national court can no longer order interim measures or must revoke existing measures, unless the grounds of illegality put forward before it differ from the pleas in law or grounds of illegality rejected by the Court in its judgment'. ${ }^{24}$ Moreover, when there has not yet been a reference to the Court of

Constitutional Order of States?: Essays in EU Law in Honour of Alan Dashwood (Oxford and Portland, Oregon: Hart Publishing, 2011), 151-160, 156.

18 See Grabenwarter, 'Die Kooperation zwischen EuGH und EGMR', 37-42.

19 B. de Witte, 'The Closest Thing to a Constitutional Conversation in Europe: The Semi-Permanent Treaty Revision Process', in P. Beaumont, S. Lyons, and N. Walker (eds), Convergence and Divergence in European Public Law (Oxford and Portland, Oregon: Hart Publishing, 2002), 39-57, 40. See also K. Alter, Establishing the Supremacy of European Law: The Making of an International Rule of Law in Europe (Oxford: Oxford Univ. Press, 2001), 38.

20 De Witte, 'The Closest Thing', 40-41. Note that the BVerfG has at least paid lip service to the need to make references. In its Honeywell decision, it emphazised that a preliminary reference would have resolved the conflict between national and EU law 'in a co-operative manner and at an early stage'. See Case 2 BvR 2661/06 Honeywell [2010] BVerfGE 126, 286, English version at <http://www.bverfg. de/entscheidungen/rs20100706_2bvr266106en.html>, para 100. This has been claimed to indicate that the BVerfG upholds judicial dialogue between the Union and national courts. T. Konstadinides, 'Constitutional Identity as a Shield and as a Sword: The European Legal Order within the Framework of National Constitutional Settlement', Cambridge Yearbook of European Legal Studies, 13 (2010-2011), 195-218, 215. But see my dicussion later of ultra vires.

21 See, in defence of the framing of the relationship between national courts and the European courts in terms of a dialogue, A. Torres Pérez, Conflicts of Rights in the European Union (Oxford: Oxford Univ. Press, 2009), 97-130.

22 Case C-231/89 Krystyna Gmurzynska-Bscher v Oberfinanzdirektion Köln [1990] ECR I-4003, para 19.

23 Case C-465/93 Atlanta Fruchthandelsgesellschaft [1995] ECR I-3761, para 46.

24 Case C-465/93 Atlanta Fruchthandelsgesellschaft [1995] ECR I-3761, para 46.

This is an open access version of the publication distributed under the terms of the Creative Commons Attribution-NonCommercial-NoDerivs licence (http://creativecommons.org/licenses/by-nc-nd/3.0/), which permits non-commercial reproduction and distribution of the work, in any medium, provided the original work is not altered or transformed in any way, and that the work is properly cited. For commercial re-use, please contact academic.permissions@oup.com 
Justice for a preliminary ruling, but an action for annulment against a Union measure, loyalty requires the national court to stay its proceedings pending final judgment on this issue. ${ }^{25}$

The ambivalent nature of preliminary references is further exacerbated if we consider the 'conversations' between the ECJ and BVerfG. On the one hand, the BVerfG has fostered the development of human rights at the Union level by supervising and encouraging the initiation of requests for preliminary rulings by lower German courts. ${ }^{26}$ The ECJ has also paid attention to national constitutional courts, adapting its findings to their prior decisions. ${ }^{27}$ As such, the preliminary reference instrument has been employed to assist the ECJ in developing its own human rights doctrine and it can indeed be argued that there was a 'normative pull' and a 'synthetic and participatory nature of the resulting norms'. ${ }^{28}$ On the other hand, however, the relationship between the BVerfG and the ECJ on this matter is best described as a conflict on hold, as I will explain at the end of this Chapter. On the issue of ultra vires, also discussed later, the BVerfG has spoken of the necessary 'coordination' on this matter with the ECJ. ${ }^{29}$ However, the mentioning of the preliminary ruling procedure here should be seen only as a matter of courtesy. Hence, when the BVerfG states that 'the Court of Justice is therefore to be afforded the opportunity to interpret the Treaties, as well as to rule on the validity and interpretation of the legal acts in question', ${ }^{30}$ this does not mean to grant the Court a substantive say in the determination of ultra vires acts of Union institutions. While it gives the ECJ a right to be heard in the respective matter, the BVerfG does not subject itself to an ECJ decision or even purport to consider it before it opines on the consequences of an ultra vires act, viz. 'any inapplicability of Union law for Germany'. ${ }^{31}$

This might explain why preliminary rulings are unlikely to be requested by national constitutional courts that claim to have the final authority to decide on the domestic effect of Union law. Any ruling by the ECJ in such a context would create facts that would make it difficult for the national court to ignore. It should thus come as no surprise that until today and in spite of the professions quoted earlier, the BVerfG has not referred for a preliminary ruling to the European Court of Justice. ${ }^{32}$

A new chapter on inter-court 'dialogue' involving the ECJ has been opened by the accession of the EU to the European Charter of Human Rights and the ensuing need to

25 Case C-344/98 Masterfoods [2000] ECR I-11369, para 59.

${ }^{26}$ See Case 1 BvR 1036/99 Teilzeitqualifizierung [2001], Europäische Zeitschrift für Wirtschaftsrecht, (2001), 255.

27 See de Witte, 'The Closest Thing', 39-41, referring to the Banana saga and the BVerfG.

28 T. de la Mare, 'Article 177 in Social and Political Context', in P.P. Craig and G. de Búrca (eds), The Evolution of EU Law (Oxford: Oxford Univ. Press, 1999), 242, adopting a 'compliance or loyalty perspective', claiming this function of dialogue to be one of the strengths of EU law.

${ }_{29}$ Case 2 BvR 2661/06 Honeywell [2010], para 56: 'The obligation incumbent on the Federal Constitutional Court to pursue substantiated complaints of an ultra vires act on the part of the European bodies and institutions is to be coordinated with the task which the Treaties confer on the Court of Justice, namely to interpret and apply the Treaties, and in doing so to safeguard the unity and coherence of Union law (see Article 19.1 (1) sentence 2 TEU and Article 267 TFEU).'

30 Case 2 BvR 2661/06 Honeywell [2010], para 56.

31 Case 2 BvR 2661/06 Honeywell [2010], para 60. See also M. Claes, 'Negotiating Constitutional Identity or Whose Identity is it Anyway?', in M. Claes et al. (eds), Constitutional Conversations in Europe: Actors, Topics and Procedures (Cambridge: Intersentia, 2012), 205-233, 210, who has considered these professions of cooperation and mutual understanding as 'only partially sincere'.

32 It, is, however, expected to do so for the first time in the case on the European Stability Mechanism (ESM). An exception is the Austrian Constitutional Court, which has referred to the Court in four cases so far, most recently on the Data Retention Directive. See Case G 47/12-11 et al., Decision of 28 November 2012.

This is an open access version of the publication distributed under the terms of the Creative Commons Attribution-NonCommercial-NoDerivs licence (http://creativecommons.org/licenses/by-nc-nd/3.0/), which permits non-commercial reproduction and distribution of the work, in any medium, provided the original work is not altered or transformed in any way, and that the work is properly cited. For commercial re-use, please contact academic.permissions@oup.com 
engage more directly with the European Court of Human Rights. Thus, the accession agreement gives the ECJ the opportunity to express its views on an issue of EU law pending before the European Court of Human Rights. ${ }^{33}$

\section{Loyalty, Institutional Balance, and Conflicts of Legal Basis}

In Chapter 1, I have shown that because the obligation of sincere cooperation in Article 4 (3) TEU now frames the entire Union law regime, it is not limited to the relationship between the institutions and the Member States, but also applies to inter-institutional cooperation. ${ }^{34}$ Moreover, I have shown that the role of loyalty in connection with conflicts of legal basis has so far either been neglected or been denied on the basis of a misreading of case law by the ECJ.

I have argued elsewhere that conflicts of legal basis are likely to remain an issue under the Lisbon Treaty due to a number of Union policies applying special procedures and the fact that Article $40 \mathrm{TEU}$ extends the pertinent regime for resolving such conflicts also to the delimitation of the former pillars. ${ }^{35}$ Moreover, I have argued that case law cannot be invoked to claim that the legal basis giving greater rights of participation to the Parliament must be chosen in resolving incompatibility. ${ }^{36}$ I would argue that such a solution to conflicts of legal basis also could not be reconciled with the principle of institutional balance. This, however, firstly requires us to take a closer look at this principle.

According to Opinion 2/00 on the Cartagena Protocol, a Union law measure must be deemed invalid 'where the appropriate legal basis for the measure concluding the agreement lays down a legislative procedure different from that which has in fact been followed by the Community institutions' ${ }^{37}$ Implicit in this focus on procedure is the principle of institutional balance protecting the respective powers of the institutions. ${ }^{38}$ In other cases, institutional balance has been associated with the empowerment of the Parliament vis-à-vis the other players in the Union. ${ }^{39}$ When the Council only foresaw the consultation of the European Parliament instead of a co-decision for drawing up a list of safe third countries for asylum seekers, the Court held that the procedural rules in the Treaty were not at the disposal of the Member States or of the institutions. ${ }^{40}$ If an institution such as the Council could, at will, establish 'secondary legal bases',

33 See G. Gaja, 'Accession to the ECHR', in A. Biondi, P. Eeckhout, and S. Ripley (eds), European Union Law After the Treaty of Lisbon (Oxford: Oxford Univ. Press, 2011), 180-194, 193.

34 See Chapter 1.

35 See M. Klamert, 'Conflicts of Legal Basis: No Legality and No Basis but a Bright Future under the Lisbon Treaty?', European Law Review, (2010), 497-515.

36 Klamert, 'Conflicts of Legal Basis', 497-515. See also E. Sharpston and G. de Baere, 'The Court of Justice as a Constitutional Adjudicator', in A. Arnull et al. (eds), A Constitutional Order of States?: Essays in EU Law in Honour of Alan Dashwood (Oxford and Portland, Oregon: Hart Publishing, 2011), 123-150, 138 passim, who claim that this was the approach by the Court, which would, however, have no basis in the Treaty.

37 Klamert, 'Conflicts of Legal Basis', 497-515.

38 See on this principle, K. Lenaerts and P. Van Nuffel, European Union Law, 3rd edn. (London: Sweet \& Maxwell, 2011), 635-639.

39 See K. St.C. Bradley, 'Maintaining the Balance: the Role of the Court of Justice in Defining the Institutional Position of the European Parliament', Common Market Law Review, 24 (1987), 41-64. But see S. Prechal, 'Institutional Balance: A Fragile Principle with Uncertain Contents', in T. Heukels, N. Blokker, and M. Brus (eds), The European Union after Amsterdam: A Legal Analysis (The Hague: Kluwer Law International, 1998), 273, 276, who notes that there can be a balance in the sense that there is an even division of power, or a fixed structure.

40 Case C-133/06 Parliamentv Council(Delegation of Legislative Power) [2008] ECR I-3189, para 54.

This is an open access version of the publication distributed under the terms of the Creative Commons Attribution-NonCommercial-NoDerivs licence (http://creativecommons.org/licenses/by-nc-nd/3.0/), which permits non-commercial reproduction and distribution of the work, in any medium, provided the original work is not altered or transformed in any way, and that the work is properly cited. For commercial re-use, please contact academic.permissions@oup.com 
this would upset the principle of institutional balance. ${ }^{41}$ In the Chernobyl judgment, institutional balance was the basis for granting the European Parliament the right of legal review of (then) Community acts beyond what was possible under the wording of the Treaty at the time of the case. ${ }^{42}$ However, the Court also stated on this occasion that 'each of the institutions must exercise its powers with due regard for the powers of the other institutions'. ${ }^{43}$

Since the choice of procedure for lawmaking is only a function of the powers of the institutions in the Union, the choice of a legal basis is a politically charged issue causing 'bitter disputes' between the institutions. ${ }^{44}$ By safeguarding the correct application of procedures, the Court is thus realizing the principle of institutional balance, as expressed, among others, in Opinion 2/00. ${ }^{45}$ I would submit that this principle of institutional balance is a manifestation of institutional loyalty, requiring the Union institutions to respect each other's rights of participation in lawmaking. ${ }^{46}$ This principle arguably is not a one-way street solely protecting the rights of the Parliament. ${ }^{47}$ It should also take the interests of the Council and the Commission into account. These, however, would be ignored if conflicts of legal basis would always be decided in favour of the rights of participation of the European Parliament. ${ }^{48}$ Suppose that two applicable provisions require different voting procedures in the Council. Suppose further that one provision does not qualify as a legal basis because it gives less rights of participation to the Parliament than the other provision. Suppose, thirdly, that the former grants shared competence, while the latter provides exclusive competence. ${ }^{49}$ The safeguarding of the institutional interests of the Parliament in this case clearly has adverse effects on the interests of the Council. The Council in this case would have no incentive to claim the invocation of the shared competence; it would do so for considerations of competence, but the result offered would be about the rights of the Parliament. The Council, furthermore, would have to accept the participation of the Parliament in lawmaking for the entire measure, including matters where it is not normally involved. ${ }^{50}$ Thus, it is submitted that always favouring the legal basis granting more rights of participation to the Parliament is not supported by arguments of institutional balance. ${ }^{51}$

41 See P.P. Craig, 'Delegation of Legislative Power', Common Market Law Review, 49 (2009), $1265-1275,1271$.

42 Case C-70/88 Parliament v Council (Chernobyl) [1990] ECR I-2041.

43 Case C-70/88 Parliament v Council (Chernobyl) [1990] ECR I-2041, para 22.

44 AG Mengozzi in Case C-91/05 Commission v Council (Small Arms and Light Weapons) [2008] ECR I-3651, para 84. It is also of constitutional significance. See Opinion 2/00 Cartagena Protocol [2001] ECR I-9713, para 5.

45 See J.-P. Jacqué, 'The Principle of Institutional Balance', Common Market Law Review, 41 (2004), 383-391.

46 See also AG Maduro in C-411/06 Commission v Parliament and Council (Basel Convention) [2009] I-7585.

47 Similar Prechal, 'Institutional Balance', 278: 'However, institutional balance does not entail a kind of one-way traffic in favour of the European Parliament.'

48 See Sharpston and de Baere, 'The Court of Justice as a Constitutional Adjudicator', 139 passim, who make a similar case based on the perspective of the vertical division of competences.

49 This situation would arise for instance with a combination of Art. 192 (2) TFEU and Art. 207 TFEU.

50 See AG Kokott in Case C-155/07 Parliament v Council (European Investment Bank) [2008] ECR I-0, paras 89-90. The Council, in her view, would then 'be deprived of its exclusive legislative competence in this field and would have to share legislative competence with the Parliament' which would 'be contrary to the deliberate decision of the Member States regarding the legislative procedure'. However, she argues this as criteria for establishing incompatibility. Her solution then is to give precedence to the legal basis providing for co-decision because 'with respect to legislative procedure, the Parliament's right of co-decision is the norm'. As explained, this does not strike us as a convincing argument.

51 The interests of the Commission would be affected in the (theoretical) case that the legal basis which has to yield is the one conferring exclusive powers. In this case the solution based on the rights of

This is an open access version of the publication distributed under the terms of the Creative Commons Attribution-NonCommercial-NoDerivs licence (http://creativecommons.org/licenses/by-nc-nd/3.0/), which permits non-commercial reproduction and distribution of the work, in any medium, provided the original work is not altered or transformed in any way, and that the work is properly cited. For commercial re-use, please contact academic.permissions@oup.com 
I would thus argue that Article 4 (3) TEU and Article 13 TEU require both the institutions between themselves and in relation to the Member States to work together in good faith and to ensure that in cases of conflict between incompatible legal bases the solution chosen accommodates all interests involved.

\section{The Relationship Between the ECJ and the Union Legislature}

\subsection{Introduction}

The whole of Chapter 3 is dedicated to case law, which, by reference to the constitutionalization it engendered, can be characterized as quasi-legislative, or even as quasi-constitutional. ${ }^{52}$ This raises the issue of conflicting claims to lawmaking authority in the Union and who should decide on its legitimacy. ${ }^{53}$ Put in other words, it must be examined whether there is a hierarchy between Union law created by the Council and the Parliament on the one hand, and Union law handed down by the Court on the other. ${ }^{54}$ In the following section, I will start by briefly laying out examples for judicial restraint and cooperation between the Union legislature and the Court. I will then mention some examples that could be seen as more confrontational. This will be followed by a discussion of three different approaches to addressing this question of the 'final lawmaker' in the European Union.

\subsection{Judicial Restraint and Cooperation}

Challenges to the lawmaking role of the European Court of Justice can be countered by firstly referring to legal developments that have prompted Treaty amendments, and secondly, to cases where the Court has shown self-restraint vis-à-vis the Union legislature. Examples of the former are the codification of the Court's case law on implied external competences, ${ }^{55}$ the Chernobyl case on the Parliament's locus standi, ${ }^{56}$ and Protocol No. 2 on ex Article 119 annexed to the Maastricht Treaty following the broad interpretation of this provision by the Court in the Barber case. ${ }^{57}$ Moreover, hardly any declaration

the Parliament would lead to an empowerment of the Member States. What the Court would give the Union on the one hand (more democracy) it would take away with the other (less competence). The Commission in this case would have no incentive to claim the invocation of the exclusive competence.

52 F.E. Dowrick, 'A Model of the European Communities' Legal System', Yearbook of European Law, 3:1 (1983), 169-237, 201, has called them 'legislative judgements'.

53 The Court, as a party to such dispute, would hardly be impartial. The situation therefore is different compared to conflicts between other institutions, such as between the Council, the Commission, and the Parliament, which manifest themselves, among other things, in quarrels about the proper legal basis to choose for adopting a certain legal act. As I have explained earlier, these conflicts apply the principles of loyalty and institutional balance that can be enforced before the Court.

54 This relationship has so far mostly escaped the attention of the literature. But see J. Komarek, 'Judicial Lawmaking and Precedent in Supreme Courts: The European Court of Justice Compared to the US Supreme Court and the French Cour de Cassation', Cambridge Yearbook of European Legal Studies, 11 (2008-2009), 399-433.

55 See Chapter 7, where I have argued that this codification of the competence case law still calls for the consideration of the pre-Lisbon case law, which creates a sort of dialectic relation between case law and primary law, and thus implicitly also between the Court and the Member States.

56 Case C-70/88 Parliament v Council (Chernobyl) [1990] ECR I-2041. cf. T. Tridimas, The General Principles of EU Law, 2nd edn. (Oxford: Oxford Univ. Press, 2006), 13. Now in Art. 263 AEUV.

57 Case C-262/88 Barber v Guardian Royal Exchange [1990] ECR 1889. See the critique by T. Harvey, 'Legal Issues Concerning the Barber Protocol', in D. O'Keeffe and P.M. Twomey (eds), Legal Issues of the Maastricht Treaty (London: Chancery Law Publishing, 1994), 329, 334 of the Member

This is an open access version of the publication distributed under the terms of the Creative Commons Attribution-NonCommercial-NoDerivs licence (http://creativecommons.org/licenses/by-nc-nd/3.0/), which permits non-commercial reproduction and distribution of the work, in any medium, provided the original work is not altered or transformed in any way, and that the work is properly cited. For commercial re-use, please contact academic.permissions@oup.com 
from the Council or the Commission has expressed discontent with the Court's rulings. ${ }^{58}$ Examples of judicial restraint are Defrenne, where the Court did not extensively interpret ex Article 119 EC (Article 157 AEUV), ${ }^{59}$ Ruckdeschel, where it referred to the competent organs of the Member States for taking the necessary measures to rectify a case of discrimination, ${ }^{60}$ and $U P A$, where the Court held that the principle of effective judicial protection could not override the condition of individual concern 'expressly laid down in the Treaty, without going beyond the jurisdiction conferred by the Treaty on the [Union] courts'. ${ }^{61}$ Such deference by the Court to the lawmaking prerogative of the Member States can also be seen in references in judgments to the current state of Union law. ${ }^{62}$ Regarding the annulment procedure, the Common Agricultural Policy has been mentioned as an area where the Court defers to the legislative discretion of the Council and correspondingly applies a reduced standard of scrutiny. ${ }^{63}$ Moreover, various forms of the suspension of the effects of judgments, such as concerning the invalidation of secondary law, ${ }^{64}$ can be seen in the context of cooperation between the Council and the Court.

\subsection{Confrontation}

However, while the Court's approach therefore is not always confrontational, various constellations tell a more conflict-prone story. ${ }^{65}$ The first case where the Court acted in defiance of secondary law concerns Regulation 1408/71 on the application of social security schemes to employed persons and their families moving within the (then) Community. ${ }^{66}$ This Regulation provided for limited coordination between the social security and healthcare systems of the Member States. Further harmonization was opposed by the Member States at that time. The Court stepped in and interpreted the Regulation in an extensive manner, thus closing gaps in the scope of application of the Regulation. Thus, the Court applied the Regulation to a pensioner by qualifying him as a worker in the sense of Article 22 of the Regulation. ${ }^{67}$ This in turn prompted the Union legislature to restrict the scope of application of the Regulation to 'employed or self-employed' persons. ${ }^{68}$ Consequently, the Court resorted directly to the Treaty for

States for usurping the judicial function reserved to the Court and thus undermining the separation of powers in the EU.

58 Komarek, 'Judicial Lawmaking and Precedent', 428.

59 Case 149/77 Defrenne [1978] ECR 1365, 1378.

${ }^{60}$ Joined cases $117 / 76$ and 16/77 Ruckdeschel [1977] ECR 1753, 1771.

${ }^{61}$ C-50/00 P. UPA [2002] ECR I-6677, para 44. See also C-263/02 P. Commission v Jégo-Quéré [2004] ECR I-3425, para 36. Critical A. Arnull, 'The Principle of Effective Judicial Protection in EU Law: An Unruly Horse?', European Law Review, (2011), 51-70, 69.

${ }^{62}$ See the cases cited by K.-D. Borchardt, 'Richterrecht durch den Gerichtshof der Europäischen Gemeinschaften', in A. Randelzhofer, R. Scholz, and D. Wilke (eds), Gedächtnisschrift für Eberhard Grabitz (Munich: Beck, 1995), 29, 42 (fn 32).

${ }^{63}$ See F. Mayer, 'Art. 19 EUV', in E. Grabitz, M. Hilf, and M. Nettesheim (eds), Das Recht der Europäischen Union (Munich: Beck, 2011), para 72. But see the examples from the area of competition law at para 74 .

${ }^{64}$ cf. M. Nettesheim, 'Normenhierarchien im EU-Recht', Europarecht, (2006), 737-771, 748-749.

${ }^{65}$ See also the conclusion by P. Syrpis, 'Theorising the Relationship Between the Judiciary and the Legislature in the EU Internal Market', in P. Syrpis (ed.), The Judiciary, the Legislature and the EU Internal Market (Cambridge: Cambridge Univ. Press, 2012), 3-24, 7.

${ }^{66}$ Regulation 1408/71 L 149 of 05.07.1971. $\quad{ }^{67}$ Case 182/78 Pierik II [1979] ECR 1977.

${ }^{68}$ Council Regulation (EEC) 1390/81 extending to self-employed persons and members of their families Regulation (EEC) 1408/71 on the application of social security schemes to employed persons and their families moving within the Community [1981] OJ L143/1.

This is an open access version of the publication distributed under the terms of the Creative Commons Attribution-NonCommercial-NoDerivs licence (http://creativecommons.org/licenses/by-nc-nd/3.0/), which permits non-commercial reproduction and distribution of the work, in any medium, provided the original work is not altered or transformed in any way, and that the work is properly cited. For commercial re-use, please contact academic.permissions@oup.com 
upholding its expansive jurisdiction, thus circumventing the application of Regulation 1408/71. ${ }^{69}$

Another instrument of secondary law sidelined by the Court was Directive 2004/38 on the right of citizens of the Union and their family members to move and reside freely within the territory of the Member States. ${ }^{70}$ The right of jobseekers to social benefits in the host state had already been established by the Court in previous case law. ${ }^{71}$ In its Article 24 (2), the Directive prescribed that the host Member States must not grant jobseekers - that have not yet acquired the status of workers-social benefits during the first three months of residence. In the Vatsouras and Koupatantze cases, the Court however granted such jobseekers access to those social benefits in the host Member State 'intended to facilitate access to employment in the labour market'. ${ }^{72}$ The Court based this decision directly on ex Articles 39, 12, and 18 EC, thus on the free movement of workers, non-discrimination, and citizenship. Similarly, in Bidar, the Court based rights to maintenance grants for students in higher education directly on ex Articles 12 and 18 EC, in defiance of secondary law. ${ }^{73}$

In the final version of the Services Directive, already discussed, Article 16 provides for a general prohibition of restrictions, thus the regulatory model developed by the ECJ in cases such as Säger and Gebhard. ${ }^{74}$ In contrast to the case law regime, however, Article 16 (1) of the Directive only lists public policy, public security, public health, and the protection of the environment as reasons for the justification of national 'requirements'. The Services Directive thus reduces Member State regulatory autonomy by removing most of the imperative reasons in the public interest that the Court has introduced in case law to compensate for the creation of the prohibition of restrictions beyond the strict wording of the Treaty. ${ }^{75}$ The legality of this has not been challenged yet, and it is possible that it never will be. Nonetheless, I will discuss ways in which the Court might still be able to continue its 'old' jurisprudence, allowing the Member States more justifications than now provided in Article 16 of the Directive. Note that if the Court did rule in such a manner, the 'beneficiaries' of such disregard of secondary law would be the Member States, while the case law discussed earlier granted rights to individuals beyond those provided in secondary law. This distinction will prove important in the following discussion of possible lines of demarcation for the interplay between the legislature and the Court in the European Union.

69 See, on this succession of events, V. Hatzopoulos, 'Health Law and Policy: The Impact of the EU', in G. de Búrca (ed.), EU Law and the Welfare State: In Search of Solidarity (Oxford: EUI/Oxford Univ. Press, 2005), 123-160. See, however, for an account of more recent and more deferential case law in this respect by the Court, H. Verschueren, 'The EU Social Security Co-ordination System: A Close Interplay Between the EU Legislature and Judiciary', in P. Syrpis (ed.), The Judiciary, the Legislature and the EU Internal Market (Cambridge: Cambridge Univ. Press, 2012), 177-204, 199-202.

70 Directive 2004/38 (EC) on the right of citizens of the Union and their family members to move and reside freely within the territory of the Member States [2004] OJ L158/77.

71 cf. D. Damjanovic, 'Annotation to Joined Cases C-22/08 \& C-23/08, Athanasios Vatsouras and Josif Koupatantze v Arbeitsgemeinschaft (ARGE) Nürnberg 900', Common Market Law Review, 47 (2010), 847-861, 855.

72 Joined cases C-22/08 and C-23/08 Athanasios Vatsouras and JosifKoupatantze v Arbeitsgemeinschaft (ARGE) Nürnberg 900 [2009] ECR I-4585, para 44.

73 Case C-209/03 Bidar [2005] ECR I-2119, especially paras 44-46.

74 Case C-76/90 Säger [1991] ECR I-4221; Case C-55/94 Gebhard [1995] ECR I-4165.

75 cf., among many others, M. Klamert with S. Griller, Services Liberalisation in the EU and WTO (Cambridge: Cambridge Univ. Press, forthcoming 2014). The number of mandatory requirements that Art. 16 Services Directive actually abolishes depends on the import of the general exceptions in Arts. 1 to 3 Services Directive. For a Member State friendly reading, see S. Griller, "The New Services Directive of the European Union. Hopes and Expectations from the Angle of a (Further) Completion of the Internal Market', in H.F. Köck and M.M. Karollus (eds), The New Services Directive of the European Union, FIDE General Report (Vienna: Congress, 2008), 379-423, 410-412.

This is an open access version of the publication distributed under the terms of the Creative Commons Attribution-NonCommercial-NoDerivs licence (http://creativecommons.org/licenses/by-nc-nd/3.0/), which permits non-commercial reproduction and distribution of the work, in any medium, provided the original work is not altered or transformed in any way, and that the work is properly cited. For commercial re-use, please contact academic.permissions@oup.com 


\subsection{The Functional Approach}

The literature has mostly discussed the lawmaking function of the Court in the context of locating case law within the different sources of Union law. It is hardly surprising that former or current judges at the European Court of Justice have displayed a tendency to recognize case law by the Union courts as a distinct source of law in the European Union legal system. ${ }^{76}$

It has been pointed out that there is mention of the Court in what is now Article 13 (1) TEU in support of its equal rank as one of the Union's institutions with especially the Council. ${ }^{77}$ Against this it can be argued that Article 13 (2) TEU refers each institution to the 'limits of the powers conferred on it in the Treaties'. For the Court this is, according to Article $19 \mathrm{TEU}$, that 'in the interpretation and application of the Treaties the law is observed'. What 'the law' is in this respect is not specified in the Treaties. There is no indication in the wording of Article 19 TEU that the Court is restricted to interpreting and applying primary or secondary law. ${ }^{78}$ When the Court is mandated to ensure that 'the law' is observed this can refer to both unwritten general principles as discussed in Chapter 13 and to case law.

Thus, the Union legislature cannot claim exclusive lawmaking competence; it rather shares this with the judiciary. ${ }^{79}$ The Council and the Parliament may be the designated lawmakers of choice, yet it is a fact that the Court also creates Union law, as explained earlier. ${ }^{80}$ Some have assigned to the Court a residual role in lawmaking, allowing it to step in should the legislator not fulfil its primary responsibility for regulating. ${ }^{81}$ Others see the Court and its case law on the same hierarchical level as primary law, thus above secondary law. ${ }^{82}$ It has also been argued in this vein that there are no Community institutions to compete with the Court, that there is no constitutional voice in the Union other than that of the Court. ${ }^{83}$ It has thus been claimed that, since the Court has been conferred with the power 'to interpret the Treaty in accordance with internationally recognized canons of interpretation', political institutions must 'work within the bounds of that interpretation unless and until the Treaty itself is amended by those who have the power to amend it'. ${ }^{84}$ With respect to the case of the Services Directive, this would mean that if in case law mandatory requirements have been allowed for Member States to be invoked, this cannot be reversed by a directive but only by amending the respective Treaty provisions.

76 See W. Schroeder, Das Gemeinschaftsrechtssystem (Tübingen: Mohr Siebeck, 2002), 315, with further references.

77 Schroeder, Gemeinschaftsrechtssystem, 315.

${ }^{78}$ For a different perspective, see I. Pernice, 'Art. 164 EGV', in E. Grabitz and M. Hilf (eds), Das Recht der EU (Munich: Beck, 1992), para 14.

79 Borchardt, 'Richterrecht', 39: 'konkurrierende Zuständigkeit'.

${ }^{80}$ For a different perspective, see S. Griller, 'The New Services Directive', 411: 'But the Court is no legislator. When it comes to legislation, the Court, in interpreting the law, has to take into account that primary law authorises the legislator to concretise.'

81 Borchardt, 'Richterrecht', 39. See also Nettesheim, 'Normenhierarchien im EU-Recht', 757, who refers to J. Hart Ely, seeing a role for constitutional courts in safeguarding values and interests which are not accounted for in the political process because of substantive or institutional circumstances. This would require restraint by the Court in the face of instruments passed with unanimity in the Council.

82 D. Edward, Editorial Comment, 'Will there be Honey still for Tea?', Common Market Law Review, (2006), 523-527, 627.

${ }^{83}$ See Komarek, 'Judicial Lawmaking and Precedent', 428, arguing also that the Union legislature is not superior to the Court, and thus is unable to monitor or modify the Court's activities.

${ }^{84}$ Edward, 'Will there be Honey still for Tea?', 627.

This is an open access version of the publication distributed under the terms of the Creative Commons Attribution-NonCommercial-NoDerivs licence (http://creativecommons.org/licenses/by-nc-nd/3.0/), which permits non-commercial reproduction and distribution of the work, in any medium, provided the original work is not altered or transformed in any way, and that the work is properly cited. For commercial re-use, please contact academic.permissions@oup.com 
I would argue that both approaches fail to adequately describe the interplay between case law and other sources of Union law. It is more apposite to refer to the competing powers of the Council (and the Parliament) on the one hand and of the Court on the other hand for the concretization of primary law. ${ }^{85}$ It seems even more to the point to speak rather of a right to develop the law and a right to concretize the law, respectively, in this context because the confines for the actions of either branch are not equally set in Union law. While the legislature must remain within the boundaries provided by the Treaty's applicable legal basis, the ECJ is bound by its mandate set out in Article 19 TEU. This mandate, however, is a very broad one when we consider the case law on state liability. It is now an accepted principle of Union law and, at least with hindsight, must be considered as not ultra vires. The principle of state liability, however, could not possibly have been introduced by an act of secondary law, I submit. This shows that the powers of concretization by the ECJ and the legislator are not distributed evenly. ${ }^{86}$ State liability or the prohibition of restrictions in the common market law regime can hardly be conceived as a mere concretization of the law. With the Court, it is thus more apposite to refer to the power to develop the law.

In theory, it would have to follow from this that if we wanted to challenge the Services Directive, the argument would have to be that it is not covered by its legal basis, ex Article 47 EC. ${ }^{87}$ This, however, cannot provide a viable approach here, for the following reason. Held against the Treaty freedom as it was developed by the Court before the passing of the Services Directive, the Directive further liberalizes the common market. It essentially makes it harder for Member States to put up obstacles to trade because they are deprived of reasons to justify them. However, the same argument would be more difficult to make if we assume that the Court had not developed the freedom to provide services and to prohibit restrictions that are not discrimination. In such a case, Article 16 Services Directive would introduce a prohibition of restrictions to a Treaty regime which only provides for a prohibition of discrimination. Thus, in order to qualify the Services Directive as an instrument to further the liberalization of the services market, which is the basic requirement for any legislation in this area, we must understand the Treaty as it was interpreted/developed by the Court. The Union legislature would not have had the mandate to pass the Services Directive without understanding primary law and the way it had been developed by the Court.

Thus, the Court develops the law, and the Council and the Parliament regulate on this basis and within the limits of the powers conferred by the respective legal bases in the Treaty. However, what about the health and social security cases discussed earlier, where the Court disregarded such secondary law? This would be the same as if the ECJ disregarded Article 16 Services Directive and continued ruling based on the 'old' list of justifications. ${ }^{88}$ It would effectively render the Directive pointless, 'dead law'. When both the concretization by the Union legislator (in the form of the Services Directive) and the preceding development by the Court (the prohibition of restrictions) are equally valid and intra vires, the functional approach cannot provide an answer. I thus turn to a perspective more focused on hierarchies in Union law.

85 See Griller, 'The New Services Directive’, 412.

86 See also Griller, arguing that the 'competing' powers of the legislator and the ECJ are different, but going on to defend secondary law against 'amendments' by the Court.

87 See M. Klamert, 'Of Empty Glasses and Double Burdens: Approaches to Regulating the Services Market à propos the Implementation of the Services Directive', Legal Issues of Economic Integration, (2010), 111-132, for such an argument.

88 Klamert, 'Of Empty Glasses and Double Burdens'.

This is an open access version of the publication distributed under the terms of the Creative Commons Attribution-NonCommercial-NoDerivs licence (http://creativecommons.org/licenses/by-nc-nd/3.0/), which permits non-commercial reproduction and distribution of the work, in any medium, provided the original work is not altered or transformed in any way, and that the work is properly cited. For commercial re-use, please contact academic.permissions@oup.com 


\subsection{The Hierarchical Approach}

A provision of secondary law must be annulled if it does not conform to primary law. In order to avoid such an outcome, the former may be interpreted in light of the latter. It has been pointed out that there is no clear boundary between judicial review and 'a strategy based on interpretation', whereby the latter may succeed in hiding the extent of the judiciary's disagreement with the legislature. ${ }^{89}$ In national law, this is reflected by the method of interpreting laws and regulations in conformity with constitutional law. The reason for the obligation to attain the conformity of the lower rank law with the superior norm is normally the latter's higher rank. The Court, however, has argued that 'when interpreting the provisions of a directive account must be taken of the principle of the coherence of the Community legal order which requires secondary Community legislation to be interpreted in accordance with the general principles of Community law' ${ }^{90}$

Whether its legal basis is such principle of coherence, the superiority of primary law or the duty of the judiciary to show restraint in annulling secondary law need not further concern us here. ${ }^{91}$ Important for the present purpose is that such interpretation may also involve the development of secondary law, just as the Court is empowered to develop the Treaties, as discussed repeatedly in this chapter. However, this must not entail an amendment of secondary law by the Court. ${ }^{92}$ Moreover and importantly, the wording of secondary law must be open to interpretation in the first place, by either being unclear on its meaning or being silent on a certain issue it should regulate. ${ }^{93}$ Thus, a provision in a directive or regulation that is clear but not in conformity with primary law must be annulled. ${ }^{94}$

The relationship between secondary law and primary law, however, is a bit more complicated. A hierarchical approach would argue against a 'reverse' influence of secondary law on the interpretation of primary law. ${ }^{95}$ Nevertheless, it has been shown that the Court has repeatedly referred to secondary law for confirming its understanding of Treaty provisions. ${ }^{96}$ In this context, it has been argued that it is relevant for the ECJ whether the legislature has shown an intention to further integrate an area of the law, yet that it does not feel bound by this intent. ${ }^{97}$

When we apply these principles to the cases discussed earlier, no clear picture emerges. The Court could interpret the Services Directive in conformity with primary law as it has been substantiated by previous case law of the Court, but this would require that Article 16 of the Directive is unclear or silent on the reasons of justification available to the Member States. Since this is not the case, it would therefore seem that the Court could not argue the extension of justification beyond the narrow reasons allowed in the Directive. However, this is not what has happened in the Bidar case. The Court did

89 Syrpis, 'Theorising the Relationship', 9.

90 Case C-499/04 Werhof [2006] ECR 2397, para 32.

${ }^{91}$ See the dicussion by S. Leible and R. Domröse, 'Die primärrechtskonforme Auslegung', in K. Riesenhuber (ed.), Europäische Methodenlehre (Berlin: de Gruyter, 2010), 250-284, 262-264, who also mention Art. 4 (3) TEU in this context.

92 See Case C-376/98 Germany v Parliament and Council [2000] ECR I-8419, though with regard to the rejection of partial annulment of Directive 98/43/EC. cf. Leible and Domröse, 'Die primärrechtskonforme Auslegung', 269.

93 See Case 218/82 Commission v Council (Lomé Convention) [1983] ECR 4063, para 12: 'The Court takes the view that when the wording of secondary Community law is open to more than one interpretation, preference should be given to the interpretation which renders the provision consistent with the Treaty rather than the interpretation which leads to its being incompatible with the Treaty.'

94 See Damjanovic, 'Annotation', 857-858.

95 See Nettesheim, 'Normenhierarchien im EU-Recht', 753.

96 See Nettesheim, 'Normenhierarchien im EU-Recht', 754.

97 Nettesheim, 'Normenhierarchien im EU-Recht', 756.

This is an open access version of the publication distributed under the terms of the Creative Commons Attribution-NonCommercial-NoDerivs licence (http://creativecommons.org/licenses/by-nc-nd/3.0/), which permits non-commercial reproduction and distribution of the work, in any medium, provided the original work is not altered or transformed in any way, and that the work is properly cited. For commercial re-use, please contact academic.permissions@oup.com 
undertake a 'reverse' interpretation of primary law in light of the pertinent directive, ${ }^{98}$ but then resorted to primary law for resolving the issue at hand instead of considering secondary law. A hierarchical approach fails to explain why this circumvention of secondary law is possible in the Bidar case, but shall not be possible with respect to the Services Directive.

In the Vatsouras and Koupatantze case, in contrast, the Court did interpret a provision of secondary law, viz. Article 24 (2) of Directive 2004/38, in light of primary law, viz. ex Article 39 (2) EC. Recall that Article 24 (2) derogates from the principle of equal treatment by allowing the host Member State to not confer entitlement to social assistance on certain jobseekers. The Court held that 'in any event, the derogation provided for in Article 24 (2) of Directive 2004/38 must be interpreted in accordance with Article 39 (2) EC' 99 'This therefore ignores the requirement, recognized by the Court itself in other cases referred to earlier, to only interpret secondary law in conformity with primary law when it is unclear, i.e. it is open to more than one interpretation. Consequently, the Court found that '(B)enefits of a financial nature which, independently of their status under national law, are intended to facilitate access to the labour market cannot be regarded as constituting "social assistance" within the meaning of Article 24 (2) of Directive 2004/38'. While this is thus presented as the result of an interpretation in conformity with ex Article $39 \mathrm{EC}$, it has been pointed out that there would have been other results of interpretation which would have been more in line with previous case law and with the literal meaning of Article 24 (2). ${ }^{100}$ It seems that the central argument of the Court here is based on the fact that it wanted to preserve its jurisprudence in cases such as Collins, granting financial benefits intended to facilitate access to employment in the host labour market based on the Treaty provision of Article 39 (2) EC. ${ }^{101}$ In other words, a lack of clarity of the term 'social assistance' could only be argued because there existed case law explicitly granting certain benefits coming within its scope.

Thus, a hierarchical approach to the understanding of the relation between primary law, secondary law, and case law cannot fully explain the cases discussed in this Chapter. A solution based on interpretation would have to consider the fact as to whether secondary law is unclear or silent on a certain issue, which would empower the Court to either clarify the respective issue or come to a result based on other sources of the law. It cannot explain the reach of the mandate of the Court in cases where provisions of secondary law exist and are sufficiently clear. I submit that the solution has to be found in the nature of the matter at hand, which is discussed in the following section.

\subsection{The Subject Matter Related Approach}

In general, primary law may be superior to secondary law and the latter may only concretize the former. ${ }^{102}$ As discussed earlier, this argues for a top-down relation for purposes of

98 Case C-209/03 Bidar [2005] ECR I-2119, para 43, seeking confirmation of a development of Treaty law in Directive 2004/38.

99 Case C-209/03 Bidar [2005] ECR I-2119, para 44. See the Opinion of AG Colomer, paras 51-55.

100 Case C-209/03 Bidar [2005] ECR I-2119, para 45. 'Against this background and given that with its result the ECJ confers a meaning to Art. 24(2) which is anything but obvious and therewith risks overstepping the fine line between interpreting the content of a norm and changing it, one could expect that it at least thoroughly argues what it is doing.'

101 Case C-138/02 Collins [2004] ECR I-2703, para 63. See N. Nic Shuibhne, 'The Third Age of EU Citizenship: Directive 2004/38 in the Case Law of the Court of Justice', in P. Syrpis (ed.), The Judiciary, the Legislature and the EU Internal Market (Cambridge: Cambridge Univ. Press, 2012), 331-362, $352-353$.

102 Nettesheim, 'Normenhierarchien im EU-Recht', 757-758.

This is an open access version of the publication distributed under the terms of the Creative Commons Attribution-NonCommercial-NoDerivs licence (http://creativecommons.org/licenses/by-nc-nd/3.0/), which permits non-commercial reproduction and distribution of the work, in any medium, provided the original work is not altered or transformed in any way, and that the work is properly cited. For commercial re-use, please contact academic.permissions@oup.com 
interpretation. Just as this is not always true, as explained, there are other ways secondary law can influence the application of primary law.

In some areas of Union law there is a direct interplay between acts of secondary law and the application of primary law. Under the fundamental freedoms, secondary law harmonization measures curtail the rights of Member States to put up obstacles to the exercise of the freedoms. This means that there is a direct link between the mandate of the ECJ to enforce the fundamental freedoms and the decision of the Union legislator to regulate a certain matter. ${ }^{103}$ This is ordered expressly for the area of the free movement of products in Article 114 TFEU, according to which harmonization measures replace reasons of justification on grounds of mandatory requirements with the limited reasons provided in Article 114 (4) and (5) TFEU. ${ }^{104}$ In case law, the Court has stated that 'recourse to Article 36 is no longer possible where Community directives provide for harmonization of the measures necessary to achieve the specific objective which would be furthered by reliance upon this provision.' ${ }^{105}$ This means that existing Member State measures can only be maintained by invoking ex Article $30 \mathrm{EC}$ or the protection of the (working) environment, with even stricter limitations applying to new state measures.

Article 20 TFEU grants Union citizens a right of movement and residence subject to 'the conditions and limits defined by the Treaties and by the measures adopted thereunder'. The concretization by the Union legislator with regard to the rights of Union citizens has not explicitly been made subject to the condition that secondary law must have as its objective the furtherance of these rights. However, the case law discussed earlier suggests that a similar condition might apply by implication. When secondary law deprives citizens of rights already granted by the judiciary, case law suggests that such measures will not be considered by the ECJ in the same manner as when they would provide further rights to Union citizens; when they, in other words, would deepen non-market related integration in the European Union. ${ }^{106}$

What I call here the subject matter related approach reflects the debate going back to Waldron on whether outcomes should be valued higher than processes. It has thus been argued that if applying an outcome-oriented criterion of evaluation, most citizenship case law of the Court where processes are sidestepped or ignored for the purpose of satisfying the desire of what is conceived to be a better outcome, would make sense. ${ }^{107}$ It is thus submitted that this may be the explanation why the Court, especially in Bidar, has resorted to primary law in defiance of secondary law, and why it performed an 'interpretation' the way it did in Vatsouras and Koupatantze. ${ }^{108}$ This conceptualization, moreover, explains why it is unlikely that the Court will circumvent Article 16 Services Directive by applying the Treaty based reasons of justification instead. Thus,

${ }_{103}$ Nettesheim, 'Normenhierarchien im EU-Recht', note 83.

104 Interestingly, Art. 16 Services Directive replicates the regime of ex Art. 95 EC.

105 Case C-5/94 Hedley Lomas [1996] ECR I-2553, para 18; Case 227/82 van Bennekom [1983] ECR 3883, para 35; Case 190/87 Moormann [1988] ECR 4689, para 10. For services and establishments see Case C-421/98 Commission v Spain [2000] ECR I-10375, paras 41-45.

106 Nettesheim only speaks of a more flexible interplay with Union citizenship compared to the freedoms.

107 See Nic Shuibhne, 'The Third Age of EU Citizenship', 360-361.

108 See Damjanovic, 'Annotation', 857: 'Here the Court clearly applies another standard. By unconditionally rejecting an interpretation option of Article 24(2) of Directive 2004/38 which contradicts its previous case law (Collins and Ioannidis), the Court makes clear that when it comes to individual rights conferred on Union citizens, there is in principle no space for the secondary legislator to correct its previous case law on the interpretation of a primary law provision. Here, the legislature has no other option than to copy case law.'

This is an open access version of the publication distributed under the terms of the Creative Commons Attribution-NonCommercial-NoDerivs licence (http://creativecommons.org/licenses/by-nc-nd/3.0/), which permits non-commercial reproduction and distribution of the work, in any medium, provided the original work is not altered or transformed in any way, and that the work is properly cited. For commercial re-use, please contact academic.permissions@oup.com 
since Article 16 of the Directive qualifies as a furtherance of the market objective, the Directive can influence the application of primary law. ${ }^{109}$

\section{Constitutional Conflicts Between EU Law and Member State Legal Regimes}

\subsection{Introduction}

Commonly, Member States are divided into those where Union law takes full primacy such as in the Netherlands, Luxembourg, and Finland, ${ }^{110}$ those where Union law is subordinate to national constitutional law such as in France and Greece, and those Member States where supremacy is limited by constitutional law. ${ }^{11}$ In most Member States coming under the latter category, the national constitutional courts have reserved for themselves the authority to review Union law in light of certain national law standards. ${ }^{112}$

Thus, the Italian Corte Costituzionale reserves the right to review Union law in respect of fundamental rights and personal freedoms, which, however, will only be done after a request for a preliminary ruling has not been successful. ${ }^{113}$ Sweden and Ireland claim the power to uphold a certain fundamental rights standard for their territory. ${ }^{114}$ In Austria, the supremacy of Union law over constitutional law is accepted as a matter of principle, but might be subject to qualification with regard to the core constitutional principles. ${ }^{115}$ Similar reservations with regard to the integrity of national constitutional law exist in Spain. ${ }^{116}$ Some of the 'new' Member States have adopted the model of approach of the German BVerfG, discussed in detail later. ${ }^{117}$ The Polish Constitutional Court found the EU arrest warrant to be contrary to the Polish constitution, but instead of declaring it inapplicable, the Polish Constitution was amended in order to eliminate the incompatibility. ${ }^{118}$ In its decision on the legality of the accession of Poland to the Union, however, the primacy of the Polish constitution over Union law was proclaimed. ${ }^{119}$ Similar tendencies can be observed in Hungary. ${ }^{120}$ The Czech Constitutional Court has openly taken cues from the BVerfG in its decisions on the Lisbon Treaty. ${ }^{121}$ In general, however, it can be concluded that there is no open conflict between national constitutional courts and the Union courts, but a certain friction is present in some Member States. ${ }^{122}$

109 It is a different matter as to whether the Directive (EC) 2006/123 on services in the internal market, [2006] OJ L376/36, qualifies as a harmonization measure or a mutual recognition measure, which would make its adoption illegal. See Klamert, 'Of Empty Glasses and Double Burdens'.

110 See also Mayer, 'Art. 19 EUV', para 95.

111 See C. Grabenwarter, 'National Constitutional Law Relating to the European Union', in A. von Bogdandy and J. Bast (eds), Principles of European Constitutional Law (Munich: Beck, 2010), $83-129,85$.

112 See the references at Mayer, 'Art. 19 EUV', para 92 passim.

113 See Grabenwarter, 'National Constitutional Law', 86.

114 Grabenwarter, 'National Constitutional Law', 88-89.

115 cf. A. Posch, Vorrang des Gemeinschaftsrechts vor Verfassungsrecht (Vienna: Jan Sramek, 2010).

116 Grabenwarter, 'National Constitutional Law', 88.

117 For an overview see Mayer, 'Art. 19 EUV', paras 100-101.

118 See J. Komarek, 'European Constitutionalism and the European Arrest Warrant: In Search of Limits of "Contrapunctual Principles"', Common Market Law Review, 44 (2007), 9-40, 19.

119 CaseK18/04, 1 May2005, availableat<http://www.trybunal.gov.pl/eng/summaries/documents/

K_18_04_GB.pdf>.

120 Case 17/2004 (V 25) AB, available at <http://www.mkab.hu/letoltesek/en_0017_2004.pdf>.

121 Case Pl. ÚS 19/08 Lisbon I, 26 November 2008, available at <http://www.usoud.cz/en/decisions/>;

Case Pl. US 29/09 Lisbon II, 3 November 2009, available at <http://www.usoud.cz/en/decisions/>. 122 Mayer, 'Art. 19 EUV', para 104.

This is an open access version of the publication distributed under the terms of the Creative Commons Attribution-NonCommercial-NoDerivs licence (http://creativecommons.org/licenses/by-nc-nd/3.0/), which permits non-commercial reproduction and distribution of the work, in any medium, provided the original work is not altered or transformed in any way, and that the work is properly cited. For commercial re-use, please contact academic.permissions@oup.com 
In the following section, I will briefly discuss the fault lines of the relationship between the legal system of the EU and those of the Member States. As we will see and as I have already adumbrated, it is necessary here to distinguish between ultra vires review, identity review, and conflicts about the prerogative to determine the fundamental rights standard applicable to EU law. I will, however, start by discussing theorems to conceptualize the relationship between the Member States and the European Union. I will show that the prevailing concepts often apply monism and dualism terminology, or are somehow based on them. Another backdrop to the concepts discussed in the following that is especially apparent in the German literature is federalism, which I have already dealt with in Chapter 2.

\subsection{Theorizing the Constitutional Relation Between the EU and the Member States}

There is a dizzying array of theories and monikers for overcoming the perceived inappropriateness of the monism/dualism dichotomy. ${ }^{123}$ As with these two concepts discussed in Chapter 3, it is certainly not my intention to add to this debate in substance beyond setting the scene for the following discussion. Constitutional pluralism is a notion that has been introduced to describe the fact that the Treaties as the constitutional law of the European Union exist alongside the national constitutions of the Member States. ${ }^{124}$ Walker has captured what seems to be the essence of constitutional pluralism with the following words:

Constitutional pluralism, by contrast [to constitutional monism] recognizes that the European order inaugurated by the Treaty of Rome has developed beyond the traditional confines of inter-national law and now makes its own independent constitutional claims, and that these claims exist alongside the continuing claims of states. The relationship between the orders, that is to say, is now horizontal rather than vertical-heterarchical rather than hierarchical. ${ }^{125}$

Pluralism thus focuses on constitutional conflicts of authority, but its connotation is essentially positive, emphasizing constitutional unity in diversity. In the same vein, Poiares Maduro has introduced the metaphor of contrapunctual law, ${ }^{126}$ postulating the necessity to apply 'different mechanisms of recognising the supremacy of EU law that can be perfectly compatible with each another so long as they lead to the same result'. ${ }^{127}$ With constitutional pluralism, communication, dialogue, and cooperation play important roles. ${ }^{128}$ It has thus been argued that it requires forms of reducing or managing the potential conflict

123 See N. Krisch, The Case for Pluralism: Beyond Constitutionalism (Oxford: Oxford Univ. Press, 2011), 71-78, who argues in favour of 'systemic pluralism', where there is no common point of reference within the legal or institutional structure, as opposed to institutional pluralism, where such a reference on a constitutional level does exist.

124 See, among many others, N. Walker, 'The Idea of Constitutional Pluralism', EUI Working Paper Law, 1 (2002). Recall also the concept of twenty-seven legal orders plus one used by Dickson, which I have discussed in Chapter 4 on the unity of the EU legal order.

125 Walker, 'The Idea of Constitutional Pluralism', 27. See also D. Halberstam, 'Constitutional Heterarchy: The Centrality of Conflict in the European Union and the United States', in J. Dunoff and J. Trachtman (eds), Ruling the World? Constitutionalism, International Law and Global Governance (Cambridge: Cambridge Univ. Press, 2009), 326-355.

126 <http://en.wikipedia.org/wiki/Counterpoint>: 'In its most general aspect, counterpoint involves the writing of musical lines that sound very different and move independently from each other but sound harmonious when played simultaneously.'

127 M. Poiares Maduro, 'Interpreting European Law: Judicial Adjudication in a Context of Constitutional Pluralism', European Journal of Legal Studies, (2007), 1-21, 17.

128 See N. Walker, 'Flexibility within a Metaconstitutional Frame: Reflections on the Future of Legal Authority in Europe', in G. de Búrca and J. Scott (eds), Constitutional Change in the EU: From Uniformity to Flexibility? (Oxford and Portland, Oregon: Hart Publishing, 2000), 26-29.

This is an open access version of the publication distributed under the terms of the Creative Commons Attribution-NonCommercial-NoDerivs licence (http://creativecommons.org/licenses/by-nc-nd/3.0/), which permits non-commercial reproduction and distribution of the work, in any medium, provided the original work is not altered or transformed in any way, and that the work is properly cited. For commercial re-use, please contact academic.permissions@oup.com 
between legal orders and promoting communication between them. ${ }^{129}$ One condition of such communication is what has been called 'systemic compatibility', which refers to 'an identity as to the essential values of the two systems'. ${ }^{130}$ Pluralism therefore frames the relationship between the EU and the Member States in terms of cooperation ('communication') and constitutional heterarchy. ${ }^{131}$

While I would certainly join the call for 'cooperation' and 'communication' (i.e. interaction) between legal systems that are claimed to be situated in a heterarchical relationship, the concept of pluralism does not provide a convincing answer regarding the resolution of jurisdictional conflicts in the Union. ${ }^{132}$ Thus, it has been argued that constitutional pluralism implies the recognition of the legitimacy of the constitutional claim of final authority on the part of the European Union. ${ }^{133}$ Recall that dualism refers to the idea that domestic law and international law are independent legal orders, where the international legal order is commonly seen as supreme. ${ }^{134}$ What then is pluralism other than a different expression for dualism with some edges softened by ideals of cooperation and communication? Under the pluralism theorem, the supreme authority of the European Union legal order has also been advanced by the argument that the right of national courts to adopt false decisions is owed to Union law and not to national law, because national courts were part of the EU judicial system. ${ }^{135}$ Moreover, it has been pointed out that national courts also sometimes do not have the means to enforce their decisions without putting their authority into question. ${ }^{136}$ However, as noted by Somek, EU law does not prevent national courts from handing down 'false decisions' that challenge the authority of Union law because of the lack of effective sanctions by the Union, which makes Member State liability the only consequence of such false decisions. ${ }^{137}$

Especially in the German literature, the constitutional relations between the EU and its Member States have been characterized as a composite constitution (Verfassungsverbund). ${ }^{138}$ This equally frames the relation between the courts in the EU in terms of 'heterarchy' and cooperation, and emphasizes the need for a common set of values, a common core identity, that must justify the compromises indispensible for the individual parts. ${ }^{139}$ In the non-German literature, this concept has not gained much

129 Poiares Maduro, 'Interpreting European Law', 17.

130 Poiares Maduro, 'Interpreting European Law', 17.

131 See also M. Kumm, 'The Jurisprudence of Constitutional Conflict: Constitutional Supremacy in Europe before and after the Constitutional Treaty', European Law Journal, 11:3 (2005), 262-307, 273.

132 See also A. Somek, 'Monism: A Tale of the Undead', in M. Avbeljand J. Komárek (eds), Constitutional Pluralism in the European Union and Beyond (Oxford: Hart Publishing, 2012), 343-379, 361.

133 M. Poiares Maduro, 'Three Claims of Constitutional Pluralism', in M. Avbelj and J. Komárek (eds), Constitutional Pluralism in the European Union and Beyond (Oxford and Portland, Oregon: Hart Publishing, 2012); M. Poiares Maduro, 'Contrapunctual Law: Europe’s Constitutional Pluralism in Action', in N. Walker (ed.), Sovereignty in Transition (Oxford and Portland, Oregon: Hart Publishing, 2003), 501.

134 See Chapter $4 . \quad 135$ But see Poiares Maduro, 'Three Claims'.

136 See Poiares Maduro, 'Three Claims', referring to judgments by the Italian Corte Costituzionale, and to a decision by the BVerfG of 1995 on crucifixes in Bavarian classrooms (Case 1 BvR 1087/91).

137 Somek, 'Monism', 17-18.

138 See, among many others, I. Pernice, 'Die Dritte Gewalt im europäischen Verfassungsverbund', Europarecht, (1996), 27-43. This is connected to seeing the EU and the Member States as a composite unit (Verband). Thus, it has been argued that there is a difference between the vertical distribution of competences between the Union and the Member States (Verbandskompetenzen) on the one hand, and the horizontal conferral of competences to the Union institutions (Organkompetenzen) on the other. See A. von Bogdandy and J. Bast, 'The Federal Order of Competences', in A. von Bogdandy and J. Bast, Principles of European Consitutional Law (Oxford and Portland, Oregon: Hart Publishing, Munich: Beck, Baden-Baden: Nomos, 2009), 284. Even in this relation, however, this comparison has been qualified by observing that competence is not conferred upon the Union as an entity, but rather upon its specific organs.

139 Maduro mentions supremacy and direct effect in this respect as core principles also accepted by the national constitutional laws. See Case 2 BvR 2661/06 Honeywell [2010], para 53b.

This is an open access version of the publication distributed under the terms of the Creative Commons Attribution-NonCommercial-NoDerivs licence (http://creativecommons.org/licenses/by-nc-nd/3.0/), which permits non-commercial reproduction and distribution of the work, in any medium, provided the original work is not altered or transformed in any way, and that the work is properly cited. For commercial re-use, please contact academic.permissions@oup.com 
traction, and within Germany, it has been criticized for ignoring the structural differences between the national judiciaries and the European courts. ${ }^{140}$

Multilevel constitutionalism is another concept that has been proposed as being preferable to the idea of a composite constitution when referring to the European Union as a Staatenverbund. ${ }^{141}$ This concept is more evocative and places the focus on the different levels within the EU. However, it has been described as 'largely neutral' in terms of hierarchy or heterarchy, since 'the image of distinct levels is not necessarily linked to superordination, supervision and subordination', and levels 'may also be understood as platforms that may be at equal height in one case and at different heights in another, or even circling freely around each other'. ${ }^{142}$ This is difficult to sustain by the ordinary meaning of 'level' in my opinion. If we speak of several levels or layers of constitutional orders within the European Union, this would rather suggest a hierarchical relationship and is, in any case, not very transparent.

Recall that I have argued in Chapter 4 that the monism/dualism label may be misleading and therefore often does not have much explicatory merit. I would suggest that all the concepts outlined earlier offer more or less convincing narratives for what is perceived to be the status of the interaction between the national and Union levels. However, none of them can fully capture the complexity of this interrelation. When the Netherlands displays monism with a primacy of Union law, the UK practices monism 'with a trigger' in the form of an anticipated general transformation, and other Member States are firmly grounded in dualism, this makes a more comprehensive and not merely descriptive picture difficult to come by. As I have mentioned in Chapter 4 with respect to monism and dualism, that they fail to provide a framework for important characteristics of the EU law regime, the same holds for the concepts discussed earlier that are even less precise. Again, I find the concept of a 'dual constitution' existing in each Member State superior to both (constitutional) pluralism and multilevel constitutionalism. ${ }^{143}$ Besides capturing the interventionist nature of Union law, it also offers a Member State centred focus, which is something I find apposite in view of the mentioned diversity of constitutional 'responses' to the Union 'constitution' in the Member States. Moreover, any theoretical concept on the relationship between the Union and the Member State legal orders that lays the focus on its cooperative sides by evoking images of diversity or a common set of rules conceals the fact that this relationship is partly confrontational and inherently conflict-prone. ${ }^{144}$

140 See F.C. Mayer, 'Multilevel Constitutional Jurisdiction', in A. von Bogdandy and J. Bast, Principles of European Consitutional Law (Oxford and Portland, Oregon: Hart Publishing, Munich: Beck, Baden-Baden: Nomos, 2009), 399-439, 431 passim.

141 Mayer, 'Multilevel Constitutional Jurisdiction', 431 passim. See also I. Pernice, 'Multilevel Constitutionalism in the European Union', European Law Review, (2002), 511-529; N. Walker, 'Multilevel Constitutionalism: Looking Beyond the German Debate', in K. Tuori and S. Sankari (eds), The Many Constitutions of Europe (Farnham: Ashgate, 2010), 143-168; J. Baquero Cruz, 'The Legacy of the Maastricht-Urteil and the Pluralist Movement', European Law Journal, (2008), 389-422, 412 passim.

142 Mayer, 'Multilevel Constitutional Jurisdiction', 429-430.

143 T. Öhlinger, 'Die Verfassung im Schmelztiegel der europäischen Integration: Österreichs neue Doppelverfassung', in T. Öhlinger, Verfassungsfragen einer Mitgliedschaft zur Europäischen Union (Vienna, New York: Springer, 1999), 165 passim.

144 See also J.H.H. Weiler, 'Prologue: Global and Pluralist Constitutionalism: Some Doubts', in G. de Búrca and J.H.H. Weiler (eds), The Worlds of European Constitutionalism (Cambridge: Cambridge Univ. Press, 2012), 8-18, 14: '... in my understanding, constitutional orders, whether national or transnational, inherently contain hierarchical and pluralist features. It is part of their ontology. It cannot be otherwise.'

This is an open access version of the publication distributed under the terms of the Creative Commons Attribution-NonCommercial-NoDerivs licence (http://creativecommons.org/licenses/by-nc-nd/3.0/), which permits non-commercial reproduction and distribution of the work, in any medium, provided the original work is not altered or transformed in any way, and that the work is properly cited. For commercial re-use, please contact academic.permissions@oup.com 
In the following section, I will take a closer look at conflicts, where the German BVerfG and the ECJ play the roles of agonist and antagonist. From the EU law perspective, the foremost issue is the judicial control over acts of ultra vires, as I will explain later by distinguishing this issue from the claims to safeguard national identity and fundamental rights. I will, however, show that also those two latter issues cannot be framed in terms of a cooperative relationship. ${ }^{145}$ Recall that the BVerfG, in connection with its claim to the prerogative to protect Germany's national identity has explicitly referred to the principle of sincere cooperation provided in Article 4 (3) TEU. ${ }^{146}$

\subsection{Ultra Vires, Identity, and Fundamental Rights}

In its Maastricht decision, the BVerfG established the prerogative of the German Bundestag in deciding on all relevant steps of integration, under the threat of a claim of ultra vires by German citizens under Article 38 (1) of the Basic Law. ${ }^{147}$ The Maastricht decision has still used a term that is difficult to translate, viz. ausbrechender Rechtsakt, for denoting acts of ultra vires. ${ }^{148}$ While the ultra vires standard has been applied by lower courts in Germany, only once did a German court qualify a Union act as ultra vires, ${ }^{149}$ and the BVerfG itself rejected all such claims when they were brought before it. ${ }^{150} \mathrm{With}$ the Lisbon judgment, the BVerfG confirmed its Maastricht jurisprudence by adding, however, that the right to decide on this matter was reserved to itself, and by avoiding the notion of ausbrechender Rechtsakt. ${ }^{151}$

In its Honeywell decision, the BVerfG elaborated on what it considers an act of ultra vires on the occasion of the ECJ's Mangold judgment. ${ }^{152}$ Thus, such review can apply to 'acts on the part of the European bodies and institutions with regard to whether they take place on the basis of manifest transgressions of competence', 'and where appropriate to declare the inapplicability of acts for the German legal system which exceed competences'. ${ }^{153}$ A breach of competences in other words must be 'sufficiently qualified'. ${ }^{154}$

145 For a different perspective, see Mayer, 'Art. 19 EUV', para 81.

146 See, critical, Thym, 'In the Name of Sovereign Statehood', 1796. This implies a guarantee of Germany membership in a European Union as an association of sovereign states instead of as a federal state. See at 1799.

147 For the first time, the BVerfG construed this right not only as the right to vote, but also as a right to elect a Parliament having the power to decide all questions of importance for the State, thus clearing the way for judicial review of the Union Treaty. cf. J. Wieland, 'Germany in the European Union: The Maastricht Decision of the Bundesverfassungsgericht', European Journal of International Law, 5 (1994), 263-265, who has criticized this decision for disregarding 'the danger of different interpretations of the law of the Union, and the duty of the European Court of Justice to ensure that, in the interpretation and application of the Treaty, the law is observed'.

148 Case 2 BvR 1877/97 and 2 BvR 50/98 Maastricht Treaty [1998] BVerfGE 97, 350, <http://www. bverfg.de/entscheidungen/rs19980331_2bvr187797en.html>. See Case 2 BvR 687/85 Kloppenburg [1987] BVerfGE 75, 223.

149 See Mayer, 'Art. 19 EUV', para 84.

150 See Case 2 BvR 1210/98 Alcan [2000], Europäische Zeitschrift für Wirtschaftsrecht, (2000), 445; Case 2 BvR 1826/09 Europäischer Haftbefehl [2009], <http://www.bverfg.de/entscheidungen/ rk20090903_2bvr182609.html>, paras 1-52. See however Case No. III ÚS 1021/10 Retired Engine Driver by the Czech Constitutional Court, discussed by P. Molek, 'The Czech Constitutional Court and the Court of Justice: Between Fascination and Securing Autonomy', in M. Claes et al. (eds), Constitutional Conversations in Europe: Actors, Topics and Procedures (Cambridge: Intersentia, 2012), 131-159, 155, where the Czech court declared a judgment of the ECJ ultra vires.

151 Case 2 BvE 2/08 et al. Lisbon Treaty [2009] BVerfGE 123, 267.

152 Case 2 BvR 2661/06 Honeywell [2010].

153 Case 2 BvR 2661/06 Honeywell [2010], para 55.

154 Case 2 BvR 2661/06 Honeywell [2010], para 61.

This is an open access version of the publication distributed under the terms of the Creative Commons Attribution-NonCommercial-NoDerivs licence (http://creativecommons.org/licenses/by-nc-nd/3.0/), which permits non-commercial reproduction and distribution of the work, in any medium, provided the original work is not altered or transformed in any way, and that the work is properly cited. For commercial re-use, please contact academic.permissions@oup.com 
This seems to require that the impugned act is highly significant in the structure of competences between the Member States and the Union with regard to the principle of conferral and to the binding nature of the statute under the rule of law' ${ }^{155}$ A sufficiently qualified breach by the Court of Justice of the principle of conferral, which would be 'a structurally significant shift to the detriment of Member State competences', was therefore not found in the Mangold case, despite misgivings by the BVerfG as to the methodology used by the ECJ in its decision. ${ }^{156}$

However, in a recent judgment, the BVerfG has apparently tried to pre-empt any development by the Court that it could perceive as ultra vires by telling the Court in the spirit of cooperative collaboration' ([I]m Sinne eines kooperativen Miteinanders) how its decision in Case Åkerberg Fransson ${ }^{157}$ would have to be understood. ${ }^{158}$ The pleonasm in professing 'cooperative collaboration' with the ECJ barely conceals the threatening connotation of this argument.

In general, however, there seems to be a high threshold for a finding of ultra vires. ${ }^{159}$ Thus, not all Union measures and decisions by Union courts seem to qualify for an ultra vires review, but only those that would somehow affect the distribution of competences between the Member States and the Union. It is difficult to think of an example where such a seismic effect could be produced by an act of secondary law. ${ }^{160}$ With regard to decisions of Union courts, it is also unlikely that any future judgment of the Court might have such a far-reaching effect. ${ }^{161}$ However, in retrospect, it is intriguing to speculate on the result of such a review, had it been applied to cases such as ERTA, which without doubt fundamentally changed the distribution of competences in the Union. ${ }^{162}$

The high threshold applied here is commendable, because should a national constitutional court claim that the Union acts ultra vires, it thereby claims that it trespasses its competences as conferred by the Treaty. This claim therefore would not only have implications for the respective Member State but it would be a challenge of more general purport. If the decision by the Court of Justice in Mangold had been deemed

155 Case 2 BvR 2661/06 Honeywell [2010], para 61. Möllers has commented that because the BVerfG could not apply its own standards of review, it invented 'meta-standards'. See C. Möllers, 'German Federal Constitutional Court: Constitutional Ultra Vires Review of European Acts Only Under Exceptional Circumstances; Decision of 6 July 2010, 2 BvR 2661/06, Honeywell', European Constitutional Law Review, 7 (2011), 161-167, 166. I shall return to the difficulty of applying national standards for judicial activism to EU law in Chapter 13.

156 Case 2 BvR 2661/06 Honeywell [2010], paras 68 passim. The main scrutiny instead was applied to whether the Court erred in applying the pertinent Directive 2000/78 to the facts of the case in the first place, thus to the scope of application of Union secondary law as determined by the ECJ. Here again the decisive issue for the BVerfG seems to have been that Case C-155/04 Mangold [2005] ECR I-9981 may further expand the effects of directives before their deadline of transposition has expired in the tradition of Inter-Environnement Wallonie, but it does not 'create any new obligations of the Member States violating the principle of conferral'. See Case 2 BvR 2661/06 Honeywell [2010], paras 77-78. Does this mean that because the pertinent Directive itself was valid and regulated a prohibition of discrimination on grounds of age, the awarding of a greater effect of this instrument was not ultra vires?

157 Case C-617/10 Åkerberg Fransson, judgment of 26 February 2013, nyr.

158 Case 1 BvR 1215/07 Antiterrordateigesetz, judgment of 24 April 2013, para 91 (<http://www. bverfg.de/entscheidungen/rs20130424_1bvr121507.html>).

159 Similar Payandeh, 'Constitutional Review', 9-38.

160 This has been called a 'Euro-friendly' approach by T. Konstadinides, 'Constitutional Identity as a Shield and as a Sword: The European Legal Order within the Framework of National Constitutional Settlement', Cambridge Yearbook of European Legal Studies, 13 (2010-2011), 195-218, 215. One could, however, think of a broad understanding of the WTO principle now codified in Art. 3 (2) TFEU, according to which the Union acquires exclusive competence for the conclusion of an international agreement when this is provided for in a legislative act of the Union. I have explained in Chapter 7, however, that there are good reasons for cabining the self-conferring potential of this provision.

161 Similar Payandeh, 'Constitutional Review', $25 . \quad 162$ See Chapter 3.

This is an open access version of the publication distributed under the terms of the Creative Commons Attribution-NonCommercial-NoDerivs licence (http://creativecommons.org/licenses/by-nc-nd/3.0/), which permits non-commercial reproduction and distribution of the work, in any medium, provided the original work is not altered or transformed in any way, and that the work is properly cited. For commercial re-use, please contact academic.permissions@oup.com 
ultra vires, the reproach in such a case would not be merely in relation to Germany but to all Member States, since it would be impossible for the ECJ to rule in a manner that would exclusively affect the competences of Germany alone. ${ }^{163}$

We must therefore conclude that the ultra vires review is targeting Union law and is essentially confrontational in nature, without giving much room for cooperation. ${ }^{164}$ Thus, in the German literature, the ultra vires case law of the BVerfG has been criticized for concealing the fact that assessing the ultra vires nature of an act of Union law means to examine its legality under Union law, which would be contrary to Article 19TEU and the duties of solidarity (sic) flowing from Article 4 (3) TEU. ${ }^{165}$

Under the title of identity control, the BVerfG demarcated core areas of such statehood the control of which must remain at national level. ${ }^{166}$ This was aimed at various procedures foreseen under the Lisbon Treaty to amend primary law deviating from the regular procedure for Treaty amendments provided by Article 24 TEU. ${ }^{167}$ All of these procedures thus concern (simplified) Treaty amendments and require action not by the Union, but require action on the German level. ${ }^{168}$ The only legal basis for the passage of secondary law which is affected by identity control are Union measures based on the so called flexibility clause of Article 352 TFEU, thus measures that also require specific parliamentary approval in Germany. ${ }^{169}$ Despite the fact that identity control by the BVerfG may also result in Union law being declared inapplicable in Germany, ${ }^{170}$ there is an important difference to ultra vires control. With identity control in the Lisbon judgment, the BVerfG reflected on the compatibility of the Lisbon Treaty with the German Grundgesetz, whereas the assessment of a decision such as Mangold by the BVerfG reflected primarily on the powers of the Union itself.

The third fault line in the relation between the BVerfG and the ECJ concerns the protection of fundamental rights. Suffice it to recall here that the BVerfG, on a divided vote, set out in the Solange I decision on a rather confrontational course by emphasizing its constitutional prerogatives against the supremacy of Union law as regards the protection

163 See Mayer, 'Art. 19 EUV', para 90: 'Der Vorwurf eines kompetenzwidrigen Rechtsaktes betrifft zudem auch Geltung bzw. Anwendbarkeit des Unionsrechts in den anderen Mitgliedstaaten.' The underlying finding that these powers are limited because Germany could not confer more powers without violating its Grundgesetz, seem second in line here.

164 See also Mayer, 'Art. 19 EUV', para 90: 'Bei der Frage der Einhaltung sachlicher Kompetenzschranken ist kein Raum für ein Kooperationsverhältnis zwischen BVerfG und EuGH.'

165 See Mayer, 'Art. 19 EUV', para 86: 'Verdoppelung des Prüfungsmaßstabes'. According to the test introduced in the Maastricht and Lisbon judgments, it has been argued that the BVerfG, while professing to assess Union secondary law only against the standard of national law, would in fact apply a 'German version' of Union law. See Mayer, 'Art. 19 EUV', paras 86 and 89: 'Die vorgebliche Selbstbeschränkung, wonach BVerfG und EuGH in unabhängigen Rechtskreisen judizieren, erscheint dabei als Kunstgriff, der die mittelbare Kontrolle von Unionsrecht über die unmittelbare Kontrolle der verfassungsrechtlichen Grenzen einer gesetzlichen Übertragung von Hoheitsrechten nach Art. 23 GG letztlich nur verschleiert.'

166 See Case 2 BvE 2/08 et al. Lisbon Treaty [2009] BVerfGE 123, 267, para 252 lists criminal law, the use of force, fiscal policy, social guarantees, the school and education system, and the status of religious communities. See Chapter 2.

167 See Thym, 'In the Name of Sovereign Statehood', 1802.

168 Such Treaty changes require the approval of the German Parliament before the German Government can consent in the Council.

169 See Case 2 BvE 2/08 et al. Lisbon Treaty [2009] BVerfGE 123, 267.

170 Case 2 BvE 2/08 et al. Lisbon Treaty [2009] BVerfGE 123, 267, para 241: 'To preserve the viability of the legal order of the Community, taking into account the legal concept expressed in Article 100.1 of the Basic Law, an application of constitutional law that is open to European law requires that the ultra vires review as well as the finding of a violation of constitutional identity is incumbent on the Federal Constitutional Court alone.' One is tempted to ask what would apply in a case where German law was not open to European law.

This is an open access version of the publication distributed under the terms of the Creative Commons Attribution-NonCommercial-NoDerivs licence (http://creativecommons.org/licenses/by-nc-nd/3.0/), which permits non-commercial reproduction and distribution of the work, in any medium, provided the original work is not altered or transformed in any way, and that the work is properly cited. For commercial re-use, please contact academic.permissions@oup.com 
of human rights. ${ }^{171}$ Only with the Solange II decision of 1986 did the BVerfG retreat to foregoing its rights of final control in this matter in practice, as long as there was an effective and equivalent protection of human rights at the European level. ${ }^{172}$ Since this time, the BVerfG has only accepted complaints regarding the human rights compatibility of Union secondary law under very strict conditions, which place a heavy burden of reasoning on the complainant. ${ }^{173}$ Similar to identity control and in contrast to the ultra vires review, the $\mathrm{BVerfG}$ here is rather concerned with setting up national constitutional law limits for the conferral of powers to the Union, ${ }^{174}$ while the ultra vires claim attacks Union measures including judgments by the ECJ for being defective in light of Union law itself. However, while the tone might have become more conciliatory on the human rights issue, it remains a conflict 'on hold', placed under the suspending condition of an 'emergency prerogative'. ${ }^{175}$

\section{Conclusion}

Loyalty applies to all relationships within the EU, irrespective of whether they involve only the Union institutions, or whether they also involve Member State institutions. There are, however, no precise rules as to how this requirement of loyalty shall translate in constellations that are conflictive or confrontational. As I have shown, such conflicts can arise in all relationships between different actors in the European Union. Except for conflicts of legal basis as forms of institutional conflict, where the European Court of Justice is the designated arbiter, all other constellations involve the Court as actor. Thus, the Court's case law raises issues both with respect to the lawmaking authority of the Council and the Parliament, as well as with regard to the self-perceptions as final arbiters of national constitutional courts and, above all, the German BVerfG. This Chapter has thus provided the backdrop for a methodological analysis in the remainder of this Part on Construction, where I will discuss why and how exactly the Court's jurisprudence has often been faulted for being respectively activist and ultra vires, and what precisely the role of loyalty is in all of this.

One finding on the role of loyalty, however, may already be made at this point. I have shown that in spite of all attempts to frame the relationship between the various levels in the EU as cooperative and pluralist, there is a confrontational side inherent in the relationship between the constitutional courts of the Member States and the ECJ, which cannot be managed by loyalty.

171 Case Solange I (Internationale Handelsgesellschaft) BVerfGE 37, 271. On this see Mayer, 'Art. 19 EUV', para 80.

172 Case Solange II BVerfGE 73, 339. Confirmed by Case 2 BvR 1877/97 and 2 BvR 50/98

Maastricht Treaty [1998], and Case 2 BvL 1/97 Bananenmarktordnung [2000] BVerfGE 102, 147.

173 See Case 2 BvE 2/08 et al. Lisbon Treaty [2009] BVerfGE 123, 267, para 189. cf. Payandeh,

'Constitutional Review', 13-14.

174 Mayer, 'Art. 19 EUV', para 81 and para 90.

175 Mayer, 'Art. 19 EUV', para 82: 'Notvorbehalt'.

This is an open access version of the publication distributed under the terms of the Creative Commons Attribution-NonCommercial-NoDerivs licence (http://creativecommons.org/licenses/by-nc-nd/3.0/), which permits non-commercial reproduction and distribution of the work, in any medium, provided the original work is not altered or transformed in any way, and that the work is properly cited. For commercial re-use, please contact academic.permissions@oup.com 


\section{2 \\ On the Nature of Loyalty}

\section{Introduction}

Perceptions on loyalty have changed over time as regards the question whether loyalty is capable of producing binding legal obligations on its own. This must be distinguished from the question whether Article 4 (3) TEU is only lex generalis to more specific provisions in the Treaty. As we have seen in Chapter 1, a number of provisions in the Treaty are specifications of the principle now contained in Article 4 (3) TEU. Asking for the stand-alone legal capacity of loyalty means to ask whether it can be legally binding without requiring another provision of the Treaty to apply at the same time. It will be shown that the Court, since its early case law, has continuously expanded the role of loyalty as a source of distinct duties imposed especially on the Member States. In order to demonstrate the autonomous legal force of loyalty, I will take a closer look at two situations that are particularly pertinent to the claim regarding the independent application of loyalty in matters of cooperation between national and EU institutions. The first concerns duties of Member States in relation to infringement procedures; the second relates to mutual duties connected with the implementation of Union law. In this context, I will also discuss whether it is appropriate and useful to distinguish between obligations of result and obligations of conduct.

Hatje has written a book entitled Loyalty as Legal Principle in the European Union (Loyalität als Rechtsprinzip in der Europäischen Union) against the background of the Maastricht Treaty and the need to define loyalty also in relation to the then newly introduced Union pillars. ${ }^{1}$ We are in a different situation today, with far more case law on ex Article 10 EC and Article 4 (3) TEU, and with a Treaty amendment by the Lisbon Treaty, which makes clear that loyalty applies across the entire Union law regime, as discussed in Chapter 4. The feat of concretizing what is today Article 4 (3) TEU has been done by the Court to a degree that, arguably, leaves considerably less room for speculation on its scope and effect than in the days of the Maastricht Treaty. ${ }^{2}$ Since Zwartveld, we also know that the scope and effects of loyalty may transcend the boundaries of the wording of now Article 4 (3) TEU. ${ }^{3}$ The current relevance of exploring the legal nature of loyalty lies not so much in predicting its broader application, but in the fact that the qualification of a rule such as loyalty as a general principle of law might have legal implications beyond the merely semantic affirmation of its importance. Put in other words, qualifying loyalty as a principle could be largely descriptive, or the label of 'principle' could refer to a certain legal quality of loyalty. I will compare loyalty to other general principles of Union law, in order better to understand its basis and functions. I will conclude this Chapter with an overview of the very different roles of loyalty in Union law.

1 A. Hatje, Loyalität als Rechtsprinzip in der Europäischen Union (Baden-Baden: Nomos, 2001).

2 Note that this, at the same time, does not mean that there is not still the need to discuss whether loyalty applies in the Common Foreign and Security Policy (CFSP) and the former third pillar with the same force and to the same effect it has been developed by the Court for the former Community pillar. This I specifically deal with in the Part on Cohesion.

3 See Chapter 1 and later in this Chapter.

This is an open access version of the publication distributed under the terms of the Creative Commons Attribution-NonCommercial-NoDerivs licence (http://creativecommons.org/licenses/by-nc-nd/3.0/), which permits non-commercial reproduction and distribution of the work, in any medium, provided the original work is not altered or transformed in any way, and that the work is properly cited. For commercial re-use, please contact academic.permissions@oup.com 


\section{Loyalty as an Independent Source of Obligations}

\subsection{The Early Case Law and Doubts in the Literature}

In early Community law, the position of then Article 5 EEC at the very beginning of the Treaty and next to the eminently general provision of Article 3 EEC has invited its understanding as a statement of principle and political intent, only providing the backdrop for enforceable provisions stated further in the Treaty. ${ }^{4}$ Its indeterminate wording has also been emphasized in this context. ${ }^{5}$ The Court's judgment in Deutsche Grammophon seemed to support this view. Referring to the second paragraph of ex Article 5 EEC, the Court held:

This provision lays down a general duty for the Member States, the actual tenor of which depends in each individual case on the provisions of the Treaty or on the rules derived from its general scheme. ${ }^{6}$

As late as 1986, no less than AG Lord Slynn rejected a claim based on ex Article 5 EEC by referring to the 'Commission's approach', observing that 'the provisions of Articles 3 and 5 are general statements of more specific principles developed in other Treaty articles and cannot be relied on in isolation ...' ${ }^{7}$ All the while loyalty gained in power as a tool for the Court in a number of landmark cases, the view persisted in the literature that loyalty has never been the sole legal basis, but that all that has been decided based on it required a further basis in the Treaty. ${ }^{8}$ This slightly contradictory position to the effect that loyalty is found highly instrumental but is not deemed to have any legal weight on its own is aptly demonstrated by the following submission:

Article $10 \mathrm{EC}$, has formed perhaps the single most dynamic provision in the Treaty in the hands of the Court. Not so much because of any stand-alone function: it has none; but because of what it can achieve in combination with the specific obligations, which the EC Treaty imposes to deal with sins of omission and commission. ${ }^{9}$

4 See the references at M. Blanquet, L'Article 5 du Traité C.E.E.: Recherche sur les Obligations de Fidélité des États Membres de la Communauté (Paris: LGDJ, 1994), 9. See the references at H. Schermers and P.J. Pearson, 'Some Comments on Article 5 of the EEC Treaty', in J.F. Baur, K.J. Hopt, and K.P. Mailänder (eds), Festschrift für Ernst Steindorff zum 70. Geburtstag am 13. März 1990 (Berlin: de Gruyter, 1990), 1359-1378, 1360.

5 See AG Roemer in Case 14/68 Walt Wilhelm [1969] ECR 1, 27. See Zuleeg, 'Art 10 EGV', in H. von der Groeben and J. Schwarze (eds), Kommentar zum EU-/EG-Vertrag, 6th edn. (Baden-Baden: Nomos, 2003), para 3.

6 Case 78/70 Deutsche Grammophon [1971] ECR 487, para 5. With similar wording Case 2/73 Geddo [1973] ECR 865, para 4.

7 AG Slynn in Case 308/86 Lambert [1988] ECR 4369. See also, more recently still, AG Maduro in Case C-467/98 Commission v Denmark(Open Skies) [2002] ECR I-9519, para 34: '(I)t is in the nature of the duty of loyal cooperation that it cannot be applied on its own but requires other Community norms to come into play.' Note that this diminutive view on the force of loyalty apparently has also been shared by the Commission. This might explain why the Commission, until fairly recently, has not shown a lot of appetite for invoking Art. 4 (3) TEU and its precursors, as I have analysed in Chapter 3.

8 See P.-J. Kuijper, 'Re-reading External Relations Cases in the Field of Transport: The Function of Community Loyalty', in J. Bulterman et al. (eds), Views of European Law from the Mountain. Liber Amicorum for Piet-Jan Slot (The Hague: Kluwer Law International, 2009), 291-300, 293: 'Community loyalty cannot stand on its own; it is invoked as a complement to a Community rule that in a particular situation lacks sufficient effect to compel a Member State (and later also a Community institution) to behave in conformity with it'. See also J. Klabbers, Treaty Conflict and the European Union (Cambridge: Cambridge Univ. Press, 2009), 193, who, in a study written based on a strong public international law perspective, states: 'To paraphrase the ICJ on the related notion of good faith: good faith alone cannot create obligations where otherwise none would exist.'

9 See L. Gormley, 'Some Further Reflections on the Development of General Principles of Law within Article 10 EC', in U. Bernitz, J. Nergelius, and C. Cardner (eds), General Principles of EC Law in a Process of Development (The Hague: Kluwer Law International, 2008), 303-313, 303.

This is an open access version of the publication distributed under the terms of the Creative Commons Attribution-NonCommercial-NoDerivs licence (http://creativecommons.org/licenses/by-nc-nd/3.0/), which permits non-commercial reproduction and distribution of the work, in any medium, provided the original work is not altered or transformed in any way, and that the work is properly cited. For commercial re-use, please contact academic.permissions@oup.com 
It is submitted that whether we can agree with this analysis on the (missing) stand-alone capacity of loyalty largely depends on what we consider are the 'specific obligations' in the Treaty applied in combination with loyalty. Not every Treaty provision that is applied together with loyalty can be deemed to provide a more specific obligation than loyalty, as I will demonstrate later by using the example of Article 17 TEU and Article 259 TFEU. Moreover, it has been argued correctly that the fact that specific rules take precedence over general rules within the limits of their scope (specialia generalibus derogant) does not automatically mean that there is no room for a self-standing application of the general rule. ${ }^{10}$ Finally, the Court has in its case law not invoked a more special norm applicable to violations by the Member States of the duty to cooperate (in a narrow sense) with the Union institutions.

\subsection{Duties to Consult and Inform}

Recall that in the Inland Waterway cases discussed in the Part on Cohesion, loyalty was applied without recourse to further provisions in the Treaty relating to the Member States' failure to cooperate or consult with the Commission after the mandate to negotiate had been given to the Commission. ${ }^{11}$

In the MOX Plant case, the Court found that Ireland violated the exclusive jurisdiction of the Court pursuant to Article 344 TFEU by having started proceedings against the United Kingdom. ${ }^{12}$ In this case, there was however another, separate count on the basis of ex Article 10 EC. ${ }^{13}$ The Commission had challenged Ireland not only for choosing the wrong forum to settle the dispute with the UK, but it had also claimed that Ireland had breached ex Article 10 EC (and Article 192 EA) by engaging the UNCLOS tribunal without having first informed and consulted the competent Community institutions. The Court explicitly qualified this claim as being distinct from the claim that Ireland had acted in disregard of Article 344 TFEU. ${ }^{14}$ The Court recalled ex Article 10 EC and the 'obligation of close cooperation' stated in Dior, discussed in Chapter 10, and continued as follows:

In those circumstances, the obligation of close cooperation within the framework of a mixed agreement involved, on the part of Ireland, a duty to inform and consult the competent Community institutions prior to instituting dispute-settlement proceedings concerning the MOX plant within the framework of the Convention. ${ }^{15}$

The Court, in making the argument for this verdict, strongly emphasized the special circumstances of that case, viz. closely interrelated competences of the Union and the Member States under a mixed agreement. ${ }^{16}$ However, the dictum of the Court on the

10 Opinion by AG Poiares Maduro in Case C-82/03 Commission v Italy [2004] ECR I-6635, para 6.

11 Case C-266/03 Commission v Luxembourg (Inland Waterway) [2005] ECR I-4805, and Case C-433/03, Commission v Germany (Inland Waterway) [2005] ECR I-6985. Had there existed exclusive competence in this case, as AG Tizzano rightly pointed out, the challenge would have to be mounted related to the infringement of that competence and any reference to ex Art. 10 EC would merely have been a corollary. Opinion of AG Tizzano in Case C-433/03 Inland Waterway [2005] ECR I-6985, para 79.

12 Case C-459/03 Commission v Ireland (MOX Plant) [2006] ECR I-4635, paras 169-171.

13 In this sense, J. Heliskoski, 'Adoptions of Positions under Mixed Agreements (Implementation)', in C. Hillion and P. Koutrakos (eds), Mixed Agreements Revisited: The EU and its Member States in the World (Oxford and Portland, Oregon: Hart Publishing, 2010), 158.

14 Case C-459/03 MOX Plant [2006] ECR I-4635, para 173.

15 Case C-459/03 MOX Plant [2006] ECR I-4635, para 179.

16 See Case C-459/03 MOX Plant [2006] ECR I-4635, paras 175-176.

This is an open access version of the publication distributed under the terms of the Creative Commons Attribution-NonCommercial-NoDerivs licence (http://creativecommons.org/licenses/by-nc-nd/3.0/), which permits non-commercial reproduction and distribution of the work, in any medium, provided the original work is not altered or transformed in any way, and that the work is properly cited. For commercial re-use, please contact academic.permissions@oup.com 
obligation to cooperate with the Union institutions arguably can be generalized. When the interests of the Union are in jeopardy, Member States must be careful to work together with its institutions, or at least to give timely information on their own possibly conflicting actions. The failure to do so constituted a distinct breach of Article 4 (3) TEU.

In the $I M O$ case, Greece was accused of undermining the 'principle of a united external representation for the Community', based among others on ex Article 10 EC. ${ }^{17}$ I have discussed this case in Chapter 10 on mixed agreements. What we should add now is that Greece responded by itself invoking ex Article 10 EC to claim that its proposal should have been put on the agenda of a meeting of the Maritime Safety (Marsec) Committee. ${ }^{18}$ This was a committee set up by Regulation 725/2004 on enhancing ship and port facility security, ${ }^{19}$ chaired by the Commission's representative. The Court replied to this counter-argument by Greece in the following manner:

It is true that, in order to fulfil its duty of genuine cooperation under Article $10 \mathrm{EC}$, the Commission could have endeavoured to submit that proposal to the Maritime Safety Committee and allowed a debate on the subject. As is apparent from Article 2(2)(b) of the Standard rules of procedure, such a committee is also a forum enabling exchanges of views between the Commission and the Member States. The Commission, in chairing that committee, may not prevent such an exchange of views on the sole ground that a proposal is of a national nature. ${ }^{20}$

Loyalty may here have been specified by the rules of procedure mentioned by the Court and established by Council Decision 1999/468. ${ }^{21}$ These rules required the Commission's representative in the function as chair to put issues on the agenda on the 'written request of a committee member' such as Greece. However, the sole legal basis identified here was ex Article 10 EC.

\subsection{Loyalty and Infringements}

Article 17 TEU (ex Article 211 EC) assigns to the Commission the task of ensuring that the provisions of the Treaties and the measures taken by the institutions on their basis are applied. Article 4 (3) TEU creates an obligation for the Member States to facilitate the achievement of these tasks. The Court held in that regard:

Member States are therefore required to cooperate bona fide in any inquiry undertaken by the Commission under Article 169 [Article 258 TFEU], and to supply the Commission with all the information requested to that end. ${ }^{22}$

17 Case C-45/07 Commission v Greece (IMO) [2009] ECR I-701.

18 Even had this been affirmed, however, it would not have saved Greece in the area of exclusive competence at play in this case. See Case C-45/07 IMO [2009] ECR I-701, para 26.

19 Regulation (EC) 725/2004 on enhancing ship and port facility security [2004] OJ L129/6.

20 Case C-45/07 IMO [2009] ECR I-701, para 25. Hillion, 'Mixity and Coherence in EU External Relations: The Significance of the "Duty of Cooperation"', CLEER Working Papers, 2 (2009), 28, has pointed to the use of words such as 'could have' and 'may' to make his claim on the quality of the obligation. However, it arguably would not have made a difference had the Court formulated 'must have endeavoured' instead. The Commission would still only be required to make an effort to submit the proposal for debate.

${ }^{21}$ Council Decision (EC) 1999/468 laying down the procedures for the exercise of implementing powers conferred on the Commission [1999] OJ L184/23 (now repealed by Regulation (EU) 182/2011 laying down the rules and general principles concerning mechanisms for control by Member States of the Commission's exercise of implementing powers [2011] OJ L55/13).

22 Case 192/84 Commissionv Greece [1985] ECR 3967, para 19. See also Case C-375/92 Commission v Spain [1994] ECR I-923, paras 24-26; Case C-478/01 Commission v Luxemburg (Patent Agents)

This is an open access version of the publication distributed under the terms of the Creative Commons Attribution-NonCommercial-NoDerivs licence (http://creativecommons.org/licenses/by-nc-nd/3.0/), which permits non-commercial reproduction and distribution of the work, in any medium, provided the original work is not altered or transformed in any way, and that the work is properly cited. For commercial re-use, please contact academic.permissions@oup.com 
This invites the question, not answered in the quoted judgment, whether the mentioned duties applying during an infringement proceeding are of such quality that their violation may constitute a distinct breach of the Treaty, separate from the breach that gave rise to the infringement proceeding in the first place. Only then, it is submitted, would Article 4 (3) TEU alone create legal obligations in this context.

What is clear is that a failure to fulfil specific obligations under an act of secondary law cannot at the same time violate Article 4 (3) TEU. ${ }^{23}$ Article 4 (3) TEU is subsidiary to Article 288 TFEU for directives ${ }^{24}$ and to Article 291 (1) TFEU with respect to all other binding legal acts. ${ }^{25}$ In general, notification duties in secondary law are not always linked to enforcement procedures. Thus, the Court of Justice held that a procedure under Regulation 2679/98, which aims at eliminating such obstacles to trade as put up by private parties in the so-called 'strawberries' case and which provides for national contact points for the transmission of the information under an early warning mechanism, is not a precondition for initiating an Article 260 complaint. $^{26}$

More to the point, an obligation provided in certain regulations for the Member States to 'take all requisite measures' for making available entitlements of the Union to the Commission has been qualified as 'a specific expression of the obligation of genuine cooperation under Article 10 EC, which requires Member States, when they encounter problems in the application of Community law, to submit those problems to the Commission'. ${ }^{27}$ With certain notification obligations of the Member States vis-à-vis the Commission provided by Union directives, the Court found them equally to have a background related to loyalty, but at the same time to justify themselves recourse to the infringement procedure. ${ }^{28}$

Distinct from such enforcement constellations directly connected to the breach of the Treaty or of a directive by a Member State are actions taken by the Commission because of circumstances surrounding the commencement or the non-commencement of infringement proceedings. In an enforcement case, the Court deplored the following action by Belgium:

... the Kingdom of Belgium fulfilled its obligations under the directive only under the direct threat of an application to the Court and that it acted in breach of them as soon as the threat appeared to have passed. In particular, it ceased to forward information as required very soon after the Court ordered the removal from the register of Case 277/86, which the Commission had brought for the same reasons as it brought the present action, and which it withdrew on the

[2003] ECR I-2351, para 24; see also Case C-135/05 Commission v Italy (Waste Management) [2007] ECR I-3475, para 32; Case 240/86 Commission v Greece [1988] ECR 1835; Case C-40/92 Commission $v$ United Kingdom [1994] ECR I-989.

23 Case C-48/89 Commission v Italy [1990] ECR I-2425; Case C-374/89 Commission v Belgium (Directive 76/491/EEC) [1991] ECR I-367, para 13.

24 But note the practice by the Court of taking the 'detailed opinions' pursuant to Notification Directive 83/189/EC, the precursor of Directive 98/34/EC, requesting the Member State to refrain from a measure or to repeal it, as formal notice under the Art. 226 EC procedure. See A. Gil Ibáñez, The Administrative Supervision and Enforcement of EC Law: Powers, Procedures, and Limits (Oxford and Portland, Oregon: Hart Publishing, 1999), 118.

25 M. Ruffert, 'Art. 291 AEUV', in C. Calliess and M. Ruffert (eds), EUVIAEUV: Das Verfassungsrecht der Europäischen Union mit Europäischer Grundrechtecharta, 4th edn. (Munich: Beck, 2011), para 3.

26 See Chapter 11.

27 Case C-105/02 Commission v Germany (TIR Carnets) [2006] ECR I-9659, para 98. See also Case C-499/99 Commission v Spain [2002] ECR I-6031, para 24.

28 Case 96/81 Commission v Netherlands (Bathing Water) [1982] ECR 1791, paras 7-8; Case 97/81 Commission v Netherlands (Drinking Water) [1982] ECR 1819, paras 7-8; Case 274/83 Commission v Italy (Public Works Contracts) [1985] ECR 1077, para 42.

This is an open access version of the publication distributed under the terms of the Creative Commons Attribution-NonCommercial-NoDerivs licence (http://creativecommons.org/licenses/by-nc-nd/3.0/), which permits non-commercial reproduction and distribution of the work, in any medium, provided the original work is not altered or transformed in any way, and that the work is properly cited. For commercial re-use, please contact academic.permissions@oup.com 
ground that in view of the practice adopted for some years the Belgian Government seemed to have brought its failure to a definitive end. ${ }^{29}$

This, in fact, did not raise issues concerning the implementation of directives or even of a failure to provide information to the Commission. Belgium's conduct was considered intentionally obstructive to a degree verging on malevolence. One might say that the reason for the Court to rule against Belgium on the (sole) basis of ex Article $10 \mathrm{EC}$ in this case is that it felt that the Member State had not acted in good faith within the traditional meaning of the term.

I would therefore have hesitated to conclude on the basis of Commission v Belgium that, as a matter of principle, a breach of the obligation to provide information to the Commission is sufficient for establishing a distinct failure by a State to fulfil its obligations under Article 4 (3) TEU. ${ }^{30}$ However, in a subsequent case, Italy had patently refused even to respond to the letters and notices of the Commission preceding the enforcement action, arguing that the Commission's requests lacked detail and did not identify the place of the alleged infringement. ${ }^{31}$ The Court followed the AG's Opinion and held Italy responsible for failure to comply with ex Article $10 \mathrm{EC}$, arguing that it should have sought to clarify the Commission's request. ${ }^{32}$ What this case has in common with the decision against Belgium is that the incriminating behaviour did not lie in a substantive breach of the Treaty or of secondary law, or in the failure to provide information to the Commission. It was crucial that Belgium had manoeuvred the Commission into resting its original case only to continue its infringement once that had happened, and that Italy hindered the Commission from bringing a case in the first place. ${ }^{33}$

Hence, we can see two possible causes for an action of infringement based on Article 4 (3) TEU. First, conduct of a Member State which is not bona fide, displaying an attitude of obstruction and plotting. The second possible cause of action is a manifest and obvious refusal to provide information to the Commission. This, however, does not mean that any sort of failure to cooperate with the Commission violates Article 4 (3) TEU. Case law suggests that a failure must be manifest and fundamental to warrant the invocation of Article 4 (3) TEU.

We can conclude that the Court found both Belgium and Italy guilty of breaching ex Article 10 EC alone, without reference to a breach of what is now Article 17 (1) TEU or Article 258 TFEU in the cases discussed earlier. That it did not apply loyalty in combination with these provisions might of course be explained by the fact that Article 17 TEU is of such generality that we cannot really speak of its application to a specific case, and that Article 258 TFEU can hardly be the basis for a substantive claim of infringement. Nonetheless, this demonstrates the autonomous application of Article 4 (3) TEU, which does not require further support in these situations.

29 Case C-374/89 Commission v Belgium (Directive 76/491/EEC) [1991] ECR I-367, para 14.

30 See the contrasting Opinion by AG Poiares Maduro in Case C-82/03 Commission v Italy [2004] ECR I-6635, para 6: "The Court has clearly recognised that refusal to assist the Commission in the achievement of its tasks may constitute a distinct failure by a State to fulfil its obligations under Article 10 EC'

31 Case C-82/03 Commission v Italy [2004] ECR I-6635.

32 See also Opinion by AG Poiares Maduro in Case C-82/03 Commission v Italy [2004] ECR I-6635, para 8.

33 See also cases where the Court sanctioned the refusal to cooperate by Member States as a 'serious impediment to the administration of justice' and found a violation of Article 10 EC. See Case 272/86 Commission v Greece (Olive Oil) [1988] ECR 4875, paras 30-32; Case C-65/91 Commission v Greece (List D) [1992] ECR I-5245, paras 12-17.

This is an open access version of the publication distributed under the terms of the Creative Commons Attribution-NonCommercial-NoDerivs licence (http://creativecommons.org/licenses/by-nc-nd/3.0/), which permits non-commercial reproduction and distribution of the work, in any medium, provided the original work is not altered or transformed in any way, and that the work is properly cited. For commercial re-use, please contact academic.permissions@oup.com 


\subsection{Loyalty and Implementation}

In an infringement case, Germany had claimed that the implementation of a regulation making distillation notices compulsory encountered unforeseeable difficulties, which made it impossible for Germany to carry out the obligations imposed by that regulation. ${ }^{34}$ The Court held that if such difficulties arose, a Member State must submit those problems to the Commission and suggest to it appropriate solutions.

In such a case, the Commission and the Member State are obliged, by virtue of the reciprocal duties of genuine cooperation imposed on them in particular by Article 5 of the EEC Treaty, to work together in good faith in order to overcome those difficulties while complying in full with the provisions of the Treaty. ${ }^{35}$

The Court concluded that unilateral action without such coordination is a violation of ex Article 5 EEC. ${ }^{36}$ The Court thus accepted that a Member State might find it impossible to comply with its obligations, as long as it cooperates with the Union in resolving them.

While this case concerned a regulation, the same also applies to directives and the time limit they prescribe for implementation. In enforcement proceedings, the Court held that Greece 'must in any event submit the problems linked with such implementation in good time to the appropriate institution for consideration'. ${ }^{37}$ On the implementation of a decision on state aid, the Court not only required a Member State to submit problems for consideration by the Commission, but also held that it must submit proposals for suitable amendments to the decision in question. ${ }^{38}$ In another state aid case, the Court specified that pleading the impossibility of redeeming the capital holding because of domestic legal provisions, and requesting the Commission to clarify what it meant by 'withdrawal of the aid', could not be regarded as conforming with the duty of cooperation. ${ }^{39}$

Obligations for the Commission and the Member States to cooperate in good faith in connection with directives have also been found to apply to the implementation of the notification scheme provided for in ex Article 100a (4) EC.

It is incumbent on Member States under Article 5 of the EC Treaty (now Article 10 EC) to notify as soon as possible the provisions of national law which are incompatible with a harmonisation measure and which they intend to maintain in force. ${ }^{40}$

Notably, the Commission in this case had been admonished for not demonstrating the same degree of diligence and not examining as quickly as possible the provisions of national law submitted to it. However, this did not outweigh the breach of the duty of cooperation by the Member State. ${ }^{41}$ In another case, ex Article $10 \mathrm{EC}$ has also been invoked to justify a failure of timely implementation, arguing that the Commission would have been required to state the reasons for its refusal to grant a request for an

34 Case C-217/88 Commission v Germany (Market in Wine) [1990] ECR I-2879, para 33.

35 Case C-217/88 Commission v Germany (Market in Wine) [1990] ECR I-2879, para 33.

36 Case C-217/88 Commission v Germany (Market in Wine) [1990] ECR I-2879, para 33.

37 Case C-50/94 Greece v Commission (Clearance of EAGGF Accounts) [1996] ECR I-3331, para 39.

38 Case C-404/97 Commission v Portugal [2000] ECR I-4897, para 40; Case C-499/99 Commission v Spain (Magefesa Group) [2002] ECR I-6031, para 24; Case C-278/00 Greece v Commission (State Aid) [2004] ECR 2004 I-3997, para 114.

39 Case 52/84 Commission v Belgium (Holding) [1986] ECR 89, para 16. See also Case 94/87

Commission v Germany (Undertaking Producing Primary Aluminium) [1989] ECR 175, para 9.

40 Case C-319/97 Criminal Proceedings Against Antoine Kortas [1999] ECR I-3143, para 39.

41 Case C-319/97 Kortas [1999] ECR I-3143, paras 35-36.

This is an open access version of the publication distributed under the terms of the Creative Commons Attribution-NonCommercial-NoDerivs licence (http://creativecommons.org/licenses/by-nc-nd/3.0/), which permits non-commercial reproduction and distribution of the work, in any medium, provided the original work is not altered or transformed in any way, and that the work is properly cited. For commercial re-use, please contact academic.permissions@oup.com 
extension of the period provided in the directive. Again, the Court held that this, in any case, could not justify the omission by Belgium. ${ }^{42}$

A more substantive prescription for the Commission based exclusively on ex Article 10 EC has been handed down by the Court in the context of mixed agreements, showing that sometimes loyalty merely produces a duty to make a best effort in considering the interests of another party. This and related categorizations will be discussed in the following section.

\subsection{Obligations of Best Effort, Conduct, or Result}

The MOX Plant, the Dior and the IMO cases have been relied on by Hillion to make an argument on the legal quality of obligations based on loyalty. ${ }^{43}$ Recall that the Court in Dior inferred its exclusive right of interpretation from the obligation of close cooperation and, thus, loyalty. ${ }^{44}$ While Dior was thus about protecting the prerogatives of the Court, in MOX Plant ex Article $10 \mathrm{EC}$ was invoked to impose information obligations on the Member States, as discussed earlier. ${ }^{45}$ In IMO, the Commission had sued Greece because of a unilateral proposal made by Greece within the International Maritime Organisation. ${ }^{46}$

Thus, the Court's finding on exclusive jurisdiction in Dior has been qualified as an obligation of result because it would require the Member States and the Union 'to ensure unity in the implementation of a mixed agreement's provision'. ${ }^{47}$ However, at the same it has been remarked that such qualification is only apposite 'in the specific Dior set of circumstances, when the autonomy of the EC legal order is at stake'. ${ }^{48}$ In contrast, the duties to inform and consult ensuing from ex Article 10 EC in MOX Plant that we have already discussed have been classified as obligations of conduct for the Member States. ${ }^{49}$ At the same time, Hillion has submitted that these obligations may require more than their best efforts. ${ }^{50}$

There are two problems, I suggest, with the distinction between obligations of result and obligations of conduct in the MOX Plant case. First, such distinction implies that obligations of conduct are less binding or less enforceable than obligations of result. This is difficult to accept, considering that the duties to inform and consult such as those prescribed in MOX Plant have been cited in the enforcement action against Ireland. In fact, all the duties based on loyalty previously discussed gave rise to claims of infringement for violations of clear requirements of action or abstention on the part of the Member States. Second, I find the obligation to inform the Commission in general very difficult to conceive as conduct that does not need to lead to a result. What could get in the way

42 Case C-236/99 Commission v Belgium (Directive 91/271/EEC) [2000] ECR I-5657, para 32.

43 C. Hillion, 'Mixity and Coherence'; Case C-45/07 IMO [2009] ECR I-701.

44 See Chapter 10.

45 These prerogatives of the Court were also an important issue in Case C-459/03 MOX Plant [2006] ECR I-4635, yet there they were secured by recourse to Art. 344 TFEU, as explained earlier.

46 Greece had proposed monitoring the compliance of ships and port facilities with the requirements of Chapter XI-2 of the International Convention for the Safety of Life at Sea and the International Ship and Port Facility Security Code.

47 Hillion, 'Mixity and Coherence', $12 . \quad 48$ Hillion, 'Mixity and Coherence', 21.

49 Hillion, 'Mixity and Coherence', 20.

50 Hillion, 'Mixity and Coherence': 'While such procedural obligations constrain the conduct of the parties, they also appear to entail more than an obligation of conduct, in the sense that they require a particular action, if not, as suggested above, a particular abstention. Member States and institutions are not only expected to do their best efforts to inform/consult, they must comply with these procedural obligations.'

This is an open access version of the publication distributed under the terms of the Creative Commons Attribution-NonCommercial-NoDerivs licence (http://creativecommons.org/licenses/by-nc-nd/3.0/), which permits non-commercial reproduction and distribution of the work, in any medium, provided the original work is not altered or transformed in any way, and that the work is properly cited. For commercial re-use, please contact academic.permissions@oup.com 
of Member States actually informing the Commission or anyone else, if required? The fulfilment of this obligation does not depend on any action by the recipient of the information, in casu the Commission. Therefore, it was not the fact that a Member State had to do something that was decisive in the MOX Plant case, but the obligation to achieve a result, viz. the notification.

Arguably, the Dior judgment also cannot be seen in terms of obligations of conduct or obligations of result. The finding by the Court that there must be a uniform interpretation of the provision in the TRIPS Agreement does not impose an obligation of result, neither on the Court nor on the Member States. It is submitted that such a claim would imply that there is a certain benchmark to be achieved against which to measure whether an obligation has been complied with or not. This, obviously, was not the case in Dior. The unity of the Union legal order alone was the reason for the Court to claim jurisdiction in this case. It is difficult to see this as a result actually achieved by the assumption of competence as such, or by the actual interpretation of the Court. In general, duties of interpretation such as those of the Member States in light of primary or secondary law do not fit well into the result/conduct scheme. While the act of interpretation might be seen as conduct, the interpretation of national law could also be seen as a result which national courts have to achieve.

I would suggest that it is more apposite to speak of best-effort obligations in connection with those duties inferred from Article 4 (3) TEU, which do not necessarily require Member States to actually do something. There are, however, only very few examples of such obligations in Union law. One example would arguably be the duty for national authorities to consider the binding objectives of Union directives before the expiry of the implementation deadline. Recall that this duty does not require national authorities to give priority to a result in conformity with a directive. It 'merely' obliges them to take due note of a directive, to consider whether national law can be interpreted in its light, and to provide justification if guidance from the directive is rejected. ${ }^{51}$

The IMO case is also an example of a best-effort obligation. Hillion has pondered on 'the specific action the Commission would be expected to undertake'. ${ }^{52}$ However, a discussion over an action for failure to act is beside the point here. The decision to put the issue on the agenda or not did not give rise to a qualified action under Article 265 TFEU. ${ }^{53}$ If it did, this arguably would have been more than a best-effort obligation.

\section{Loyalty as a General Principle of Union Law}

\subsection{Introduction}

General principles have been defined in the narrow sense as 'fundamental propositions of law which underlie a legal system and from which concrete rules or outcomes may be derived'. ${ }^{54}$ This reflects the seminal distinction between rules and principles advocated by Dworkin. ${ }^{55}$ Based on this distinction, it has been argued that general principles

51 See Chapter 4 and earlier in this Chapter. $\quad 52$ See Hillion, 'Mixity and Coherence', 29.

53 For a different perspective, see Hillion, 'Mixity and Coherence', 29, who argues that 'a clear procedural obligation would most likely need to be invoked'.

54 T. Tridimas, The General Principles of EU Law, 2nd edn. (Oxford: Oxford Univ. Press, 2006), 1.

55 R. Dworkin, Taking Rights Seriously, 2nd edn. (Cambridge: Harvard Univ. Press, 1978), has distinguished rules applicable in an all-or-nothing fashion, and value-maximizing principles. See also R. Dworkin, 'Social Rules and Legal Theory', The Yale Law Journal, 81:5 (1972), 855-890, 876: 'A principle is a principle of law if it figures in the soundest theory of law that can be provided as a justification for the explicit substantive and institutional rules of the jurisdiction in question.'

This is an open access version of the publication distributed under the terms of the Creative Commons Attribution-NonCommercial-NoDerivs licence (http://creativecommons.org/licenses/by-nc-nd/3.0/), which permits non-commercial reproduction and distribution of the work, in any medium, provided the original work is not altered or transformed in any way, and that the work is properly cited. For commercial re-use, please contact academic.permissions@oup.com 
are characterized by not specifying legal consequences that follow automatically in certain defined circumstances and by having a dimension of weight and importance. ${ }^{56}$ Conversely, general principles have been seen as the normative basis for formulating an operable rule in a given case. ${ }^{57}$ Raz has distinguished between substantive principles, which dictate a goal to be pursued or a value to be protected, and principles of discretion, which guide discretion by stipulating what type of goals and values the judge may take into account. ${ }^{58}$ However, Griller, among others, has shown that there is no fundamental difference in nature between rules and principles. ${ }^{59}$

Not only is the legal nature of principles a difficult matter, also, the concept of general principles in EU law is a thorny issue, with inconsistent terminology mystifying both legal literature and case law. ${ }^{60}$ Tridimas has identified general principles deriving from the rule of law, such as fundamental rights, equality, and proportionality, general principles of substantive Union law, such as the fundamental freedoms, and ' $[$ s]ystemic principles which underlie the constitutional structure of the Community and define the Community legal edifice', such as supremacy, the attribution of competences, subsidiarity, and direct effect. ${ }^{61}$ Lenaerts and Van Nuffel have distinguished principles of sound administration, such as legal certainty and legitimate expectations, and constitutional principles, such as fundamental rights, proportionality, subsidiarity and non-discrimination. ${ }^{62}$ Note that in this latter category of constitutional principles direct effect and supremacy are not included. Pernice and Mayer, in turn, have counted the principles of equality, legal certainty, and proportionality as general principles of law, and supremacy and direct and indirect effect as fundamental principles of Union law. ${ }^{63}$ Finally, Groussot and Lidgard have distinguished fundamental provisions of Union law, such as the four freedoms, from genuine general principles, which 'must be detected, understood and recognized', and which 'are not to be found in the statutory provisions. ${ }^{64}$

56 J. Wouters, D. Coppens, and D. Geraets, 'The Influence of General Principles of Law', in S.E. Gaines, B. Egelund Olsen, and K. Engsig Sørensen (eds), Liberalising Trade in the EU and the WTO: A Legal Comparison (Cambridge: Cambridge Univ. Press, 2012), 43-74, 44.

57 M. Herdegen, 'The Origins and Development of the General Principles of Community Law', in U. Bernitz and J. Nergelius (eds), General Principles of European Community Law (The Hague: Kluwer Law International, 2000), 3, 17

58 J. Raz, 'Legal Principles and the Limits of Law', in J. Cohen (ed.), Ronald Dworkin and Contemporary Jurisprudence (London: Duckworth, 1984), 73, 76. In his view: 'Principles evolved by the courts become binding by becoming a judicial custom. They are part of the law because they are accepted by the courts, not because they are valid according to the rule of recognition.' See Raz, 'Legal Principles', 80.

59 S. Griller, 'Der Rechtsbegriff bei Ronald Dworkin', in S. Griller and H.-P. Rill (eds), Rechtstheorie: Rechtsbegriff_Dynamik—Auslegung (Vienna, New York: Springer, 2011), 57-79, 64-70 especially.

${ }_{60}$ This problem is not confined to EU law, as the discussion following the presentation of K. Wellens, 'Revisiting Solidarity as a (Re-)Emerging Constitutional Principle', in R. Wolfrum and C. Kojima (eds), Solidarity: A Structural Principle of International Law (Heidelberg et al.: Springer, 2010), recited at 39-54, shows.

61 Tridimas, General Principles, 4.

${ }^{62}$ K. Lenaerts and P. Van Nuffel, European Union Law, 3rd edn. (London: Sweet \& Maxwell, 2011), 851.

${ }_{63}$ I. Pernice and F.C. Mayer, 'Art. 220', in E. Grabitz and M. Hilf (eds), Das Recht der Europäischen Union (Munich: Beck, 2002), paras 26-29. Similar, Frenz, Handbuch Europarecht: Wirkungen und Rechtsschutz (Heidelberg et al.: Springer, 2010), 182, with further German references.

${ }^{64}$ X. Groussot and H.H. Lidgard, 'Are There General Principles of Community Law Affecting Private Law?', in U. Bernitz, J. Nergelius, and C. Cardner (eds), General Principles of EC Law in a Process of Development (The Hague: Kluwer Law International, 2008), 155-175, 159.

This is an open access version of the publication distributed under the terms of the Creative Commons Attribution-NonCommercial-NoDerivs licence (http://creativecommons.org/licenses/by-nc-nd/3.0/), which permits non-commercial reproduction and distribution of the work, in any medium, provided the original work is not altered or transformed in any way, and that the work is properly cited. For commercial re-use, please contact academic.permissions@oup.com 
When loyalty has been referred to as a (general) principle, this has often been done in a rather non-technical way. Thus, when Gormley examined various 'general principles of conduct affecting the Member States' based on ex Article 10 EC, and identified a general principle of mutual cooperation as a third category of obligations emerging from this provision, he did not expand on the implications of such assessment. ${ }^{65}$ Others have referred to loyalty as a principle when writing before the Lisbon Treaty, in order to claim its application beyond the first pillar, where it was provided for. ${ }^{66}$ Particularly in German literature, it today seems without need of further explanation to qualify loyalty as a general principle of European Union law. ${ }^{67}$ This view seems almost de rigeur once Union loyalty is seen against the background of federal fidelity (Bundestreue) under German law. Thus, Bleckmann assumed extensive notification, reporting, and confidentiality obligations for the Member States derived from this principle, which clearly exceeded the scope of ex Article 5 EEC. ${ }^{68}$ Temple Lang has even claimed that ex Article $10 \mathrm{EC}$ is not only a general principle, but also that it is the most important one, because it would be 'the legal basis of the obligation on all national courts and authorities to comply with all other general principles' ${ }^{69}$

In the following section, I will first explore whether such a view of loyalty finds support in the case law. As a next step, I will analyse what such qualification could actually mean.

\subsection{The Case Law on Loyalty as a Principle of Law}

Hartley has described the sequence of reasoning by the Court as involving two stages: ' . . the first is inductive, in which the Court derives a general principle from specific provisions of the Treaty; the second stage is deductive-here the Court arrives at a solution to the particular issue before it by applying the general principle. ${ }^{70}$ Hartley has stressed 'that when the Court acts in this way, the legal source of its decision is not the Treaty but the general principle'. ${ }^{71}$ Tridimas, however, has shown that Hartley's first stage may involve deduction if general principles are derived from the fundamental objectives of a legal system. ${ }^{72}$ In the latter sense, deduction may either consider only the Union law regime itself as a reference point, or may cast the net wider and look at the constitutional traditions of the Member States. ${ }^{73}$ In other words, general principles of Union law may

65 See Gormley, 'Some Further Reflections', 310 and 312.

${ }^{66}$ Hatje, Loyalität als Rechtsprinzip.

67 Lenz, 'Art. 4 EUV', in C.-O. Lenz and K.-D. Borchardt (eds), EU-Verträge Kommentar (Cologne and Vienna: Bundesanzeiger Verlag, 2010), para 11. But see R. Söllner, Art. 5 EWG-Vertrag in der Rechtsprechung des Europäischen Gerichtshofes (Munich: VVF, 1985), 28, who in 1985 was still arguing that the jurisprudence of the Court did not allow for the assumption of the existence of a general principle of loyalty.

68 A. Bleckmann, 'Art. 5 EWG-Vertrag und die Gemeinschaftstreue: Zugleich ein Beitrag zur Entwicklung des allgemeinen europäischen Verwaltungsrechts', Deutsches Verwaltungsblatt, (1976), 483-487.

69 J. Temple Lang, 'Article 10 EC: The Most Important “General Principle” of Community Law', in U. Bernitz, J. Nergelius, and C. Cardner (eds), General Principles of EC Law in a Process of Development (The Hague: Kluwer Law International, 2008), 75-113, 77.

70 T. Hartley, The Foundations of European Community Law, 5th edn. (Oxford: Oxford Univ. Press, 2003), 134.

${ }_{71}^{71}$ Hartley, Foundations, 134. Recall reverse loyalty discussed in Chapter 1.

72 Tridimas, General Principles, 2, with further references to French literature.

73 Tridimas, General Principles, 4, includes this in his category of 'principles which derive from the rule of law'.

This is an open access version of the publication distributed under the terms of the Creative Commons Attribution-NonCommercial-NoDerivs licence (http://creativecommons.org/licenses/by-nc-nd/3.0/), which permits non-commercial reproduction and distribution of the work, in any medium, provided the original work is not altered or transformed in any way, and that the work is properly cited. For commercial re-use, please contact academic.permissions@oup.com 
be established by looking at the legal regime they should be applied in, or by looking at the laws of the Member States. ${ }^{74}$

As discussed in Chapter 1, there are various specifications of loyalty in the Treaty. ${ }^{75}$ However, if we consider the numerous provisions in the Treaty as leges speciales to what is now Article 4 (3) TEU, this would merely suggest that the rule contained in this provision has a very general application. It would not necessarily imply that there is a principle of loyalty beyond the wording of Article 4 (3) TEU, nor would it tell us anything about its legal quality.

There is no indication in case law that the Court has ever inferred loyalty in Union law from the laws and the constitutional traditions of the Member States. On the contrary, while the Court in Kofisa qualified judicial review and due process as general principles of Union law, and established them by means of constitutional comparison and consideration of the European Convention on Human Rights, its reasoning and wording with regard to the 'principle of cooperation' has been markedly different. ${ }^{76}$

In contrast, there is evidence that loyalty has been deduced from the premises on which the Union law regime is based. Recall that in Brasserie du Pêcheur, the Court qualified both effectiveness and the obligation to cooperate as 'principles inherent in the Community legal order'. ${ }^{77}$ Another case widely quoted in this context is Hurd, which will be discussed in Chapter $13 .{ }^{78}$ In this case, the Court argued with a duty of genuine cooperation and assistance which Member States owe the Community and which finds expression in the obligation laid down in Article 5 of the EEC Treaty'. ${ }^{79}$ Finally, I could also mention case law on 'unforeseen and unforeseeable difficulties' for Member States when implementing Commission decisions relating to state aid, where the Court spoke of a 'principle underlying Article 5 of the Treaty, which imposes a duty of genuine cooperation on the Member States and the Community institutions' ${ }^{80}$ These cases thus

${ }^{74}$ See the discussion and case law cited by M. Herdegen, 'General Principles of EU Law: The Methodological Challenge', in U. Bernitz, J. Nergelius, and C. Cardner (eds), General Principles of EC Law in a Process of Development (The Hague: Kluwer Law International, 2008), 343, 346-349. cf. P.P. Craig and G. de Búrca, EU Law: Text, Cases and Materials, 5th edn. (Oxford: Oxford Univ. Press, 2011), 369-371. When looking at the latter, normally a principle would have to be recognized by a majority of members, thus not necessarily by all of them. Herdegen, 'General Principles', 348. Tridimas, General Principles, 6. See further M. Potacs, Auslegung im öffentlichen Recht (Baden-Baden: Nomos, 1994), 235-239.

75 Similar to loyalty, discrimination is prohibited in provisions throughout the Treaty which are considered specific illustrations of a general principle of equality underlying the Union legal order. See Joined cases 117/76 and 16/77 Ruckdeschel [1977] ECR 1753, para 7. See further Tridimas, General Principles, 62.

76 Contrast Case C-1/99 Kofisa Italia [2001] ECR I-207, para 46 on the one hand, and para 47 on the other: 'The requirement of judicial control of any decision of a national authority reflects a general principle of Community law stemming from the constitutional traditions common to the Member States and enshrined in Articles 6 and 13 of the European Convention for the Protection of Human Rights and Fundamental Freedoms ...' 'In the exercise of their control, it is for the national courts, pursuant to the principle of cooperation laid down in Article 5 of the EC Treaty (now Article 10 EC), to ensure the legal protection which persons derive from the direct effect of provisions of Community law ...' See also Case C-226/99 Siples [2001] ECR I-277, paras 17 and 18.

77 Joined cases C-46/93 and C-48/93 Brasserie du Pêcheur [1996] ECR I-1029.

78 Case 44/84 Hurd [1986] ECR 29. See J. Wuermeling, Kooperatives Gemeinschaftsrecht: Die Rechtsakte der Gesamtheit der EG-Mitgliedstaaten, insbesondere die Gemeinschaftskonvention nach Art. 220 EWG-Vertrag (Cologne: Engel, 1988), 193.

79 Case 44/84 Hurd [1986] ECR 29. See also Case C-6/89 Commission v Belgium [1990] ECR I-1595.

80 See Case C-404/97 Commission v Portugal [2000] ECR I-4897, para 40 (emphasis added). See also Case C-75/97 Belgium v Commission (Maribel Scheme) [1999] ECR I-3671, para 88; Case C-499/99 Commission v Spain (Magefesa Group) [2002] ECR I-6031, para 24; Case C-278/00 Greecev

This is an open access version of the publication distributed under the terms of the Creative Commons Attribution-NonCommercial-NoDerivs licence (http://creativecommons.org/licenses/by-nc-nd/3.0/), which permits non-commercial reproduction and distribution of the work, in any medium, provided the original work is not altered or transformed in any way, and that the work is properly cited. For commercial re-use, please contact academic.permissions@oup.com 
support the existence of some 'higher' principle of Union law, which is expressed by now Article 4 (3) TEU, but which would also apply assuming that this provision did not exist at all. ${ }^{81}$

However, we must also note that all the cases mentioned earlier in one way or another required the Court to claim the existence of an unwritten principle of law applying beyond the wording of the Treaty that had been too narrow to carry the judicial findings handed down in these cases. Recall that the Treaty, before Lisbon, had not prescribed mutual duties of loyalty. Recall further that Francovich had been criticized as lacking any legal foundation, in response to which the Court drew the principle of cooperation out of its 'judicial hat' in Brasserie du Pêcheur. Thus, as far as I can see, case law where the Court suggested such general concept of loyalty is by far the minority. In most cases, the Court arguably used the notion 'principle' only to refer to the duties and obligations contained in what is now Article 4 (3) TEU. ${ }^{82}$ This implies that the Treaty provision was the basis for a rule such as introduced in the respective judgment, rather than that it was an unwritten principle of Union law. ${ }^{83}$

Hence, loyalty has in some controversial cases been qualified as a legal principle by the Court. In most cases, however, it was not so called and, if it was, it was for mainly descriptive reasons. In the following section, I will compare loyalty with other general principles of Union law, in order to find out if this might inform us about its legal nature.

\subsection{Comparing Loyalty with Other General Principles}

\subsubsection{Introduction}

It is submitted that the lowest common denominator that may be derived from the various classifications of general principles mentioned earlier are principles of sound administration deriving from the rule of law, which seem generally accepted as being general principles of Union law. ${ }^{84}$ Fundamental rights must equally be considered central to any debate on general principles in Union law. ${ }^{85}$ These principles have been developed by the Court in order to protect the individual and in order to establish the rule of law in the European Union. ${ }^{86}$ They have been 'children of national law', adopted by the Court to become 'enfants terribles' of Union law. ${ }^{87}$ In the course of Treaty

Commission (State Aid) [2004] ECR I-3997, para 114; Case C-261/99 Commission v France (State Aid) [2001] ECR 2001 I-2537, para 24; Case C-378/98 Commission v Belgium (Maribel Scheme) [2001] ECR I-5107, para 31; Case 52/84 Commission v Belgium (Holding) [1986] ECR 89, para 16. See also Case 94/87 Commission v Germany (Primary Aluminium) [1989] ECR 175, para 9.

81 See P. Pescatore, 'Das Zusammenwirken der Gemeinschaftsrechtsordnung mit den nationalen Rechtsordnungen', Europarecht, (1970), 307-323, 322.

82 See Case 5/79 Procureur Général v Hans Buys et al. [1979] ECR 3203, para 6; Case 61/79 Denkavit [1980] ECR 1205, para 25; Case 811/79 Ariete [1980] ECR 2545, para 12; Case 14/88 Italy $v$ Commission (Clearance of EAGGF Accounts) [1989] ECR 3677, para 20; Case C-213/89 Factortame [1990] ECR I-2433, para 19; Case C-165/91, van Munster [1994] ECR I-4661, para 32; Joined cases C-36/97 and C-37/97 Kellinghusen [1998] ECR I-6337, para 30.

83 See the reference to a 'principle of loyal cooperation' in Case C-105/03 Criminal Proceedings Against Maria Pupino [2005] ECR I-5285, para 42, and to 'the principle of cooperation arising from Article 10 EC' in Case C-453/00 Kühne \& Heitz [2004] ECR I-837, para 28.

84 See also the general principles listed by P. Raitio, 'The Principle of Legal Certainty as a General Principle of EU Law', in U. Bernitz, J. Nergelius, and C. Cardner (eds), General Principles of EC Law in a Process of Development (The Hague: Kluwer Law International, 2008), 47-73, 49-50.

85 See Art. 6 (3) TEU. See Lenaerts and Van Nuffel, European Union Law, 825.

86 Tridimas, General Principles, 7.

87 See for this nice metaphor, Tridimas, General Principles, 6.

This is an open access version of the publication distributed under the terms of the Creative Commons Attribution-NonCommercial-NoDerivs licence (http://creativecommons.org/licenses/by-nc-nd/3.0/), which permits non-commercial reproduction and distribution of the work, in any medium, provided the original work is not altered or transformed in any way, and that the work is properly cited. For commercial re-use, please contact academic.permissions@oup.com 
revision, they have been transformed from unwritten principles of law to being expressly recognized and entrenched in the Treaties. ${ }^{88}$

In contrast, there seems to be much less consensus in the literature on those principles that are (more) specific to the Union legal order, such as supremacy and direct effect. These have been considered systemic, fundamental, or constitutional principles of Union law in most classifications mentioned earlier. ${ }^{89}$ Tridimas has placed the duty of cooperation within the category of 'systemic principles', together with supremacy, direct effect, and the attribution of competences. ${ }^{90}$ Frenz has categorized loyalty together with supremacy and the uniform application of Union law. ${ }^{11}$ Von Bogdandy has claimed that loyal cooperation belongs to the founding principles, as do the principles laid down in Article 6 (1) TEU, the allocation of competences, and structural compatibility. ${ }^{92}$ Lenaerts and Van Nuffel have mentioned 'the principle of sincere cooperation' as an example of a constitutional principle, placing it thus in the same basket as the principle of conferral and non-discrimination, but apparently not supremacy or direct effect. ${ }^{93}$ Pernice and Mayer, in contrast, do not mention loyalty in connection with the 'fundamental principles', respectively the fundamental provisions of Union law. ${ }^{94}$

In the following section, I will refer to fundamental rights and equality as genuine general principles of Union law. I propose that the fact that loyalty does not resemble genuine general principles by the way it is deduced and the manner it is expressed in the Treaty does not mean that there could not be parallels in the purpose loyalty serves in Union law. This requires that we measure loyalty against the common characteristics of genuine general principles of Union law. After comparing loyalty with genuine general principles, we will look for analogies with what I will refer to as systemic principles of Union law.

\subsubsection{Comparing loyalty with genuine general principles}

Already superficially, loyalty is different from general principles such as fundamental rights. Firstly, because it has always been a part of the Treaty, has always been stated in the same exposed position at the beginning of the EC Treaty before Lisbon, and at the beginning of the EU Treaty after Lisbon. It has never been codified or formalized any further, also not by the Lisbon Treaty. Over the years, it has not even substantially changed its wording. In order to assess whether loyalty is also substantially different from genuine

88 See Tridimas, General Principles, 11-12. Strongest witnesses of this are fundamental rights, which have gone from being purely case law based to being stipulated in the Charter of Fundamental Rights.

${ }^{89}$ See the references at Tridimas, General Principles, 11-12, notes 265 and 266. The Court also ruled that supremacy and direct effect form 'essential characteristics of the Community legal order'. See Opinion 1/91 Draft Agreement relating to the creation of the European Economic Area [1991] ECR I-6079, para 21. Wouters, Coppens, and Geraets, 'The Influence of General Principles of Law', 45, would probably qualify them as 'internal principles', being sui generis to the legal regime in which they are constructed.

90 Tridimas, General Principles, 17. Tridimas, at 5, has declared forgoing an exhaustive coverage of the systemic principles. He therefore does not discuss loyalty in the remainder of his otherwise exhaustive study.

${ }_{91}$ Frenz, Handbuch, 536.

92 A. von Bogdandy, 'Founding Principles of EU Law: A Theoretical and Doctrinal Sketch', European Law Journal, 16:2 (2010), 95-111, 106.

93 Lenaerts and Van Nuffel, European Union Law, 853.

${ }^{94}$ I. Pernice and F.C. Mayer, 'Art 220 EGV', in E. Grabitz and M. Hilf (eds), Das Recht der Europäischen Union (Munich: Beck, 2002), paras 26-29. Similar, Frenz, Handbuch, 182, with further German references. Groussot and Lidgard, 'General Principles', 158. Yet, according to their view, neither would proportionality and subsidiarity qualify, since both are expressly provided for in the Treaty.

This is an open access version of the publication distributed under the terms of the Creative Commons Attribution-NonCommercial-NoDerivs licence (http://creativecommons.org/licenses/by-nc-nd/3.0/), which permits non-commercial reproduction and distribution of the work, in any medium, provided the original work is not altered or transformed in any way, and that the work is properly cited. For commercial re-use, please contact academic.permissions@oup.com 
general principles, we need to know the functions such a genuine principle performs in Union law. It would lead too far here to explore this issue comprehensively, and it is also quite futile, because the following will show that loyalty also has very little in common with genuine general principles on account of the way it functions.

Tridimas has suggested that general principles in Union law are applied as aids to the interpretation of written Union and national law and that they have a gap-filling function in Union law. ${ }^{95}$ Thus, on the one hand, Union measures must be interpreted in the light of general principles of Union law because of their hierarchical position on the same tier as primary law. ${ }^{96}$ On the other hand, the function of general principles is to 'resolve the case by deducing from the existing rules a rule which is in conformity with the underlying premises on which the legal system is based'. ${ }^{97}$ Moreover, Tridimas has shown that genuine general principles of Union law are directly applicable and they are grounds for the review of Union measures. ${ }^{98}$

Loyalty does not have direct effect in national law. ${ }^{99}$ In the Schlüter case on monetary policy, the Court found ex Article 5 EEC in combination with ex Article 107 EEC (now Article $130 \mathrm{TFEU}$ ) as not suited to conferring rights on individuals. ${ }^{100}$ However, recall the general principle of effective judicial protection, which is closely related to loyalty, and which has been claimed to have constitutional status and direct effect, at least in the manner it was applied in Mangold. ${ }^{101}$

I am also not aware of any case where the Court has annulled an act of secondary law on grounds of a breach of loyalty. The only example of loyalty applying in the context of the annulment proceedings under Article $263 \mathrm{TFEU}$ is the requirement for national courts, based on ex Article $10 \mathrm{EC}$, to interpret national procedural rules so as to give individuals the right to plead the illegality of Union acts and to ask for a reference for a preliminary ruling on legality. ${ }^{102}$ This, of course, is not an example of the review of Union measures as to their compatibility with loyalty, but rather a case of gap-filling discussed further later. That loyalty is not suitable as a ground for review of Union acts is not surprising in view of the fact that Article 4 (3) TEU prima facie addresses the Member States and does not concern the protection of the individual or the rule of law.

This leaves the function of loyalty as an aid to interpretation and as a basis for gapfilling to be addressed. Besides the fact that loyalty has served as a legal basis for a duty of interpretation in light of Union primary law and directives, as I have explained earlier,

95 See Tridimas, General Principles, 17-19, 29. Tridimas also claims that their breach may give rise to tortuous liability on the part of the Union. As to this third function, a liability of Union institutions for breach of loyalty is difficult to conceive and will not be explored further. Instead, note that loyalty has been one of the grounds invoked by the Court to rationalize state liability itself, as already mentioned.

96 Case 218/82 Commission v Council [1983] ECR 4063, para 15. Principles applied for this purpose are equal treatment, the protection of legitimate expectations, and proportionality. See Tridimas, General Principles, 29, with further references from case law.

97 Tridimas, General Principles, 17.

98 See Tridimas, General Principles, 31-35. The Court normally annuls Union measures when they infringe general principles. The Court does so either by way of proceedings under Art. 263 TFEU or under Art. 267 TFEU. Thus, Union measures have been reviewed against the principles of legal certainty and non-discrimination. See Case C-326/88 Hansen \& Soen [1990] ECR I-2911, para 19.

99 See Hartley, Foundations, 199, who has considered loyalty as a good example of a Treaty provision being 'far too general to be directly effective by itself'. See also Wuermeling, Kooperatives Gemeinschaftsrecht, 188.

100 Case 9/73 Schlüter [1973] ECR 1135, para 39. See also Case 44/84 Hurd [1986] ECR 29, paras 47-48.

101 A. Arnull, 'The Principle of Effective Judicial Protection in EU Law: An Unruly Horse?', European Law Review, (2011), 51-70, 68

102 Case C-362/06 P. Sahlstedt [2009] ECR I-2903, para 43.

This is an open access version of the publication distributed under the terms of the Creative Commons Attribution-NonCommercial-NoDerivs licence (http://creativecommons.org/licenses/by-nc-nd/3.0/), which permits non-commercial reproduction and distribution of the work, in any medium, provided the original work is not altered or transformed in any way, and that the work is properly cited. For commercial re-use, please contact academic.permissions@oup.com 
case law rather suggests that ex Article $10 \mathrm{EC}$ could not be a reference for the interpretation of secondary law. This can be shown by the judgment in the Wood-Trading case on the interpretation of Article 7 (4) of Directive 75/442/EEC on waste, ${ }^{103}$ which provides that the competent Member State authorities of destination and dispatch may raise reasoned objections to a planned shipment. The Court found that the authority of dispatch was entitled to assess the planned recovery of the waste at the place of destination by its own health and environmental requirements, even where these state standards were higher than the standards applicable in the state of destination. ${ }^{104}$ In other words, it was irrelevant that the competent authority of destination may have taken the view that the recovery meets the requirements of its own national standards and consequently raises no objection to an envisaged shipment of waste. The Court held in this context that such divergence in the assessments by the different competent authorities was not contrary to the principle of cooperation expressed in ex Article $10 \mathrm{EC}$, and, therefore, did not require a different interpretation of the mentioned Directive. ${ }^{105}$

I would argue that the only function that loyalty shares with genuine general principles is its role for the filling of gaps in EU law. I will show later that with most legal developments engineered by the Court, gap-filling is not a suitable methodological standard to be applied. There is, however, case law requiring certain sanctions to apply in the Member States in the case of a violation of EU law, which could be qualified as an example of orthodox gap-filling. Thus, the Court ruled, '. . where a Community regulation does not specifically provide any penalty for an infringement or refers for that purpose to national laws, regulations and administrative provisions, Article 5 of the EEC Treaty requires the Member States to take all measures necessary to guarantee the application and effectiveness of Community law' ${ }^{106}$ Loyalty here is not employed to interpret the regulation to ensure that there is no breach of loyalty as a superior rule of law. Instead, loyalty closes a normative gap in such regulation. This gap can be either implicit ('does not specifically provide'), or explicit ('refers for that purpose to national laws, regulations and administrative provisions'), and must be filled by the national authorities. ${ }^{107}$

\subsubsection{Comparing loyalty with systemic principles}

I would argue that there is indeed some logic in comparing loyalty to supremacy and direct effect, as has been implied by Tridimas. ${ }^{108}$ One might argue that if supremacy and direct effect are deemed essential characteristics of the Union legal order, the same should apply to loyalty. However, as I have explained in Chapter 3, supremacy and direct

103 Council Directive (EEC) 75/442 on waste [1975] OJ L194/39.

104 Case C-277/02 EU-Wood-Trading [2004] ECR I-11957.

105 Case C-277/02 EU-Wood-Trading [2004] ECR I-11957, para 48.

106 Case C-326/88 Hansen \& Soen [1990] ECR I-2911, para 17. See also Case C-382/92 Commission $v$ United Kingdom (Employees'Rights) [1994] ECR I-2435, para 55; Case C-383/92 Commission v United Kingdom (Collective Redundancies) [1994] ECR I-2479, para 40; Case C-341/94 Criminal Proceedings Against André Allain et al. [1996] ECR I-4631, para 24; Case C-177/95 Ebony Maritime [1997] ECR I-1111, para 35; Case C-40/04 Criminal Proceedings Against Syuichi Yonemoto [2005] ECR I-7755, para 59.

107 Another angle from which to see such cases, of course, is from the perspective of implementation and the standards the Court has prescribed in this respect. This is a subject I deal with extensively in the Part on Cohesion. Suffice it to note at this point that exigencies on national law due to the need for implementing secondary Union law are also not to be seen as a case of interpretation.

108 See Tridimas, General Principles, 4.

This is an open access version of the publication distributed under the terms of the Creative Commons Attribution-NonCommercial-NoDerivs licence (http://creativecommons.org/licenses/by-nc-nd/3.0/), which permits non-commercial reproduction and distribution of the work, in any medium, provided the original work is not altered or transformed in any way, and that the work is properly cited. For commercial re-use, please contact academic.permissions@oup.com 
effect are themselves partly based on ex Article 5 EEC. Moreover, loyalty is expressly provided for in the Treaty, in obvious and persistent contrast to supremacy in particular. Finally, supremacy and especially direct effect are, as much as they are constitutional principles of Union law, also technical and clearly defined rules, determining the interaction between the Union and national legal orders. The same could be said about the principle of equality, which is not only an abstract principle but, at the same time, a concrete rule that can be applied to facts, is directly effective, and operates by a clear set of (sub)rules, such as with the prohibition of discrimination in Article 18 TFEU. ${ }^{109}$

There is also some logic in Tridimas and von Bogdandy's classification of loyalty together with the principle of the attribution of competences in Union law. ${ }^{110}$ The principle of conferral is as fundamental to the construction of the Union systemic as loyalty. Contrary to supremacy and direct effect, conferral is not a rule that can be applied to facts, or requires a certain set of conditions in order to apply. However, again the analogy does not fit fully. In Chapter 3, I have discussed the dichotomy between gravitational and centrifugal forces in Union law, and have qualified loyalty as perhaps the most important example of the former, having been instrumental in expanding the competences of the Union in cases such as ERTA, among others. Conferral, in contrast, represents the rival force in preserving Member States prerogatives.

Hence, I would conclude that loyalty is a systemic/constitutional principle similar to conferral, supremacy, and direct effect. It can therefore be said that the trajectory of loyalty as a legal principle is by itself evidence of the constitutionalization brought about by the Court over the years. In this vein, Weatherill noted the following in 1994:

The Court's shaping of Article 5 into a general constitutional principle, far beyond its explicit wording, is emblematic of the Court's self-evolution into a general constitutional court possessed of inherent jurisdiction to ensure the observance of the rule of law in the Community, beyond the Treaty structure of enumerated powers. ${ }^{111}$

However, from a methodological perspective, this finding does not get us anywhere. If we reduce the use of the notion of 'general principle' in connection with loyalty to a way of emphasizing its importance in the Union legal order, such reference to loyalty is no more than an 'empty shell'. It does not tell us more about its quality and nature than that it is very important. This modest conclusion may be unsatisfactory, but it should at least provide a note of caution that often the use of the notion of 'principle' serves nothing more than to add legal force to the application of a rule in order to justify far-reaching developments of the law.

\section{Conclusion}

In this Chapter, I have tried to answer the question whether loyalty is a general principle of Union law and whether this assessment has any legal consequences. I have shown that there are some indications in case law that the Court considers loyalty to be a general principle that is not attached to the scope and wording of Article 4 (3) TEU. This is especially true for judgments where the Court has stretched loyalty to establish controversial

109 See Tridimas, General Principles, 118-134.

110 See Tridimas, General Principles, 4; von Bogdandy, 'Founding Principles of EU Law', 106.

111 S. Weatherill, 'Beyond Preemption? Shared Competence and Constitutional Change in the European Community', in D. O'Keeffe and P.M. Twomey (eds), Legal Issues of the Maastricht Treaty (London: Chancery Law Publishing, 1994), 13, 31.

This is an open access version of the publication distributed under the terms of the Creative Commons Attribution-NonCommercial-NoDerivs licence (http://creativecommons.org/licenses/by-nc-nd/3.0/), which permits non-commercial reproduction and distribution of the work, in any medium, provided the original work is not altered or transformed in any way, and that the work is properly cited. For commercial re-use, please contact academic.permissions@oup.com 
principles such as state liability. However, loyalty largely evades common criteria for distinguishing general principles from other sources of Union law. In contrast to fundamental rights, it is neither directly effective nor does it constitute a standard for review of Union legal acts. As opposed to direct effect and supremacy, loyalty has a basis in the Treaty and does not apply by a clear set of rules. This means, however, that while we can thus speak of loyalty as a principle of Union law, expressing this broader scope of application, we should not refer to it as a general principle of Union law without inviting unfounded analogies as to its functions.

Because loyalty serves as a legal basis for direct effect and supremacy, Temple Lang's statement quoted earlier about loyalty being the most important general principle of them all because it is the basis for the requirement of the Member States to comply with all other general principles carries some truth in this respect. ${ }^{12}$ On some accounts, loyalty could be best compared to non-discrimination (as regards its omnipresence in the Treaty), and to conferral (as its antithesis). In any case, whether we consider loyalty a general principle, a genuine general principle or a systemic general principle does not allow us to draw any conclusions other than that it applies beyond the wording of Article 4 (3) TEU and that it is of fundamental importance for Union law. We will see in the next Chapter that effectiveness is the principle more often used by the Court to develop the law, and that this is problematic since effectiveness is nothing more than loyalty in disguise.

\section{Interim Summary of the Roles of Loyalty in EU Law}

At this point, let us briefly recapitulate the roles loyalty can have in Union law and the constellations it can apply within.

In this Chapter, I have discussed loyalty as the separate basis of obligations under Union law. In cases such as MOX Plant, the Court referred to ex Article $10 \mathrm{EC}$ as a stand-alone legal basis for duties of information and coordination, both with regard to Union institutions and binding the Member States. In these cases, therefore, loyalty did not require another provision of the Treaty to create legally binding rules, in contrast to what has been claimed in the literature until quite recently.

In Chapter 1, it has been shown that there are a number of specifications of Article 4 (3) TEU in the Treaty, such as the principle of mutual recognition. In relation to these specifications, loyalty is lex generalis. It is thus not invoked by the Court when provisions that are more specific exist in the Treaty.

In Chapter 3, I have explained that loyalty is the supporting, complementary legal basis for the obligation to interpret national law in light of a directive, with the principal legal basis being Article 288 TFEU. This is an example of the 'auxiliary' function of loyalty in establishing Union law obligations.

In Chapter 6 in the Part on Cohesion, I have explained that Article 4 (3) TEU is closely related to the principle of effectiveness. In this context, as well as in cases such as Zwartveld in particular, establishing 'reverse loyalty' obligations, loyalty thus has been applied as a legal principle in the sense of applying beyond the confines of the wording in the Treaty.

112 Temple Lang, 'The Most Important "General Principle” of Community Law', 77. Loyalty, yet, has no bearing on the binding value of fundamental rights, of subsidiarity, proportionality, or equality.

This is an open access version of the publication distributed under the terms of the Creative Commons Attribution-NonCommercial-NoDerivs licence (http://creativecommons.org/licenses/by-nc-nd/3.0/), which permits non-commercial reproduction and distribution of the work, in any medium, provided the original work is not altered or transformed in any way, and that the work is properly cited. For commercial re-use, please contact academic.permissions@oup.com 


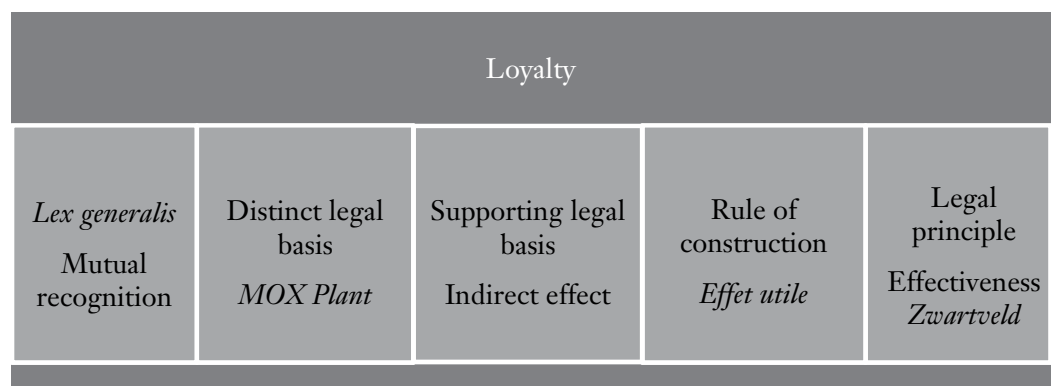

Figure 12.1 The Diverse Roles of Loyalty in Union Law

In Chapter 13 I will show that loyalty can also be understood as a basis for effet utile, and thus as the basis for a rule of construction of Union law.

These diverse applications of loyalty can be summarized in the above picture (see Figure 12.1).

This is an open access version of the publication distributed under the terms of the Creative Commons Attribution-NonCommercial-NoDerivs licence (http://creativecommons.org/licenses/by-nc-nd/3.0/), which permits non-commercial reproduction and distribution of the work, in any medium, provided the original work is not altered or transformed in any way, and that the work is properly cited. For commercial re-use, please contact academic.permissions@oup.com 


\section{Deconstructing Loyalty}

\section{Introduction}

This is not the place to discuss the legal reasoning of the Court of Justice conclusively. ${ }^{1}$ Furthermore, no overall judgement will be cast on whether the Court is legitimate in its activities. ${ }^{2}$ However, it is necessary to provide some background for the ensuing examination of the role of loyalty in the reasoning of the Court. If we wish to analyse the Court's use of loyalty, I would submit that it is essential to know exactly what we are discussing, and what the test is that we apply to assess the reasoning of the Court in this respect. ${ }^{3}$ This, it is submitted, is especially apposite since this study is about a principle, which, as I have shown and will continue to demonstrate, is at the very heart of this legal reasoning. In the following, thus, I will not assess the case law regarding its substantive legitimacy, but rather from the methodological perspective, looking at how the Court, based on loyalty, proceeded to construct the Union law regime as it stands today.

In Chapter 3, I have argued that loyalty is strangely underrepresented in the 'grand' narratives on the constitutionalization of Union law. It is suggested here that the lack of transparency and methodological rigour displayed by the Court in the use of the principles of loyalty, effet utile, and effectiveness may have contributed to this. In the following, I will thus more closely examine the relation between these three principles. The fact that there is a relation between these principles does not dispose of the need for differentiation, for reasons of methodological clarity and predictability. One might question whether this is not futile legal nitpicking. After all, supremacy and direct effect are settled matters and there appears to be little reason dissecting the Court's judgments on them some forty years after their introduction. However, it is arguably crucial to comprehend the way legal concepts such as loyalty, effet utile, and effectiveness have been used. This is because loyalty has been a key, recurring argument in the constitutionalizing jurisprudence of the Court and cases such as ERTA continue to be at the centre of a regime that is ambiguous to this day. Moreover, loyalty and effectiveness, as I have shown, are invoked today rather more than less in case law. ${ }^{4}$

1 See, to name just a few examples from the extensive literature on this, J. Anweiler, Die Auslegungsmethoden des Gerichtshofs der Europäischen Gemeinschaften (Frankfurt et al.: Lang, 1997); A. Bredimas, Methods of Interpretation and Community Law (Amsterdam: North Holland, 1978); G. de Búrca and J.H.H. Weiler (eds), The European Court of Justice (Oxford: Oxford Univ. Press, 2001); M. Potacs, Auslegung im öffentlichen Recht (Baden-Baden: Nomos, 1994); J. Bengoetxea, The Legal Reasoning of the European Court of Justice (Oxford: Clarendon Press, 1993); G. Conway, The Limits of Legal Reasoning and the European Court of Justice (Cambridge: Cambridge Univ. Press, 2012).

${ }_{2}$ For such recent undertaking, see P.P. Craig, 'The ECJ and Ultra Vires Action: A Conceptual Analysis', Common Market Law Review, 48 (2011), 395-437.

3 See S. Weatherill, 'Activism and Restraint in the European Court of Justice', in P. Capps, M. Evans, and S. Konstadinidis (eds), Asserting Jurisdiction: International and European Legal Perspectives (Oxford and Portland, Oregon: Hart Publishing, 2003), 255, 258 (fn 7): 'The question of how to measure due restraint in interpretation is central yet elusive. Criticism of the Court in this vein demands that attention be paid to devising a theory of legal reasoning and interpretation.'

${ }^{4}$ See Chapter 6.

This is an open access version of the publication distributed under the terms of the Creative Commons Attribution-NonCommercial-NoDerivs licence (http://creativecommons.org/licenses/by-nc-nd/3.0/), which permits non-commercial reproduction and distribution of the work, in any medium, provided the original work is not altered or transformed in any way, and that the work is properly cited. For commercial re-use, please contact academic.permissions@oup.com 


\section{Evaluation Criteria for the Reasoning of the Court}

\subsection{Introduction}

When the Treaty provides, now in Article 19 TEU, that the Court 'shall ensure that in the interpretation and application of the Treaties the law is observed', it is contested what this means precisely. The right and the duty of the Court to interpret Union law, most importantly by way of preliminary rulings proceedings, is beyond doubt, as is its competence to resolve conflicts between the Union and its Member States. ${ }^{5}$ There also seems to be agreement that the task of the Court comprises both the concretization of the law and its development. ${ }^{6}$ However, borders are blurred between the interpretation of the law, its concretization, the development of the law, and judicial activism, when the latter can be understood as a more charged synonym for the concept of judicially developing the law. ${ }^{7}$ In other words, it is difficult to determine the point where permissible development of the law becomes undesired judicial activism. ${ }^{8}$ The Court itself does not distinguish methodologically between the interpretation and the development of Union law, whether by disclosing which approach it adopts in a specific case, or by following a certain method in performing either task. ${ }^{9}$

It has thus been argued that the inherence argument in Francovich represented the 'mere interpretation of law' ${ }^{10}$ As I have argued earlier and will continue to show in this Chapter, Francovich in particular is a very difficult case to support such a statement. ${ }^{11}$ At the same time, it has been argued that there is a difference between interpretation on the one hand and legislation or lawmaking on the other, especially in the Anglo-American world. ${ }^{12}$ In this view, courts are confined to identifying the law that has already been

5 A. von Bogdandy, 'Rechtsfortbildung mit Art. 5 EG-Vertrag', in A. Randelzhofer, R. Scholz and R. Wilke (eds), Gedächtnisschrift für Eberhard Grabitz (Munich: Beck, 1995), 17, 24. See also K.-D. Borchardt, 'Richterrecht durch den Gerichtshof der Europäischen Gemeinschaften', in A. Randelzhofer, R. Scholz and D. Wilke (eds), Gedächtnisschrift für Eberhard Grabitz (Munich: Beck, 1995), 29.

6 See F.C. Mayer, 'Art. 19 EUV', in E. Grabitz, M. Hilf, and M. Nettesheim (eds), Das Recht der Europäischen Union (Munich: Beck, 2011), para 30. The German term for the development of the law by the judiciary is 'Rechtsfortbildung', which arguably has a more ponderous connotation. J. Komarek, 'Judicial Lawmaking and Precedent in Supreme Courts: The European Court of Justice Compared to the US Supreme Court and the French Cour de Cassation', Cambridge Yearbook of European Legal Studies, 11 (2008-2009), 399-433, has shown that both the legal system of the US and France acknowledge that judges 'make law' based on their respective foundational documents.

7 Case C-155/04 Mangold [2005] ECR I-9981was a judgment of the Court that has elicited accusations of judicial overreaching in recent times. See Anonymous, Editorial Comments, 'The Court of Justice in the Limelight: Again', Common Market Law Review, 45 (2008), 1571-1579. Mangold also undermines the argument that the Court has, in recent times, shown greater restraint in its constitutionalizing case law. This has been claimed by F.C. Mayer, 'Art. 220 AEUV', in E. Grabitz, M. Hilf and M. Nettesheim (eds), Das Recht der Europäischen Union (Munich: Beck, 2011), para 76.

8 See T. Tridimas, 'The Court of Justice and Judicial Activism', European Law Review, 21 (1996), 199-210, finding the term judicial activism relative and uncertain and arguing that there is no persuasive argument that the Court has exceeded its powers. See now Craig, 'The ECJ and Ultra Vires Action', 396-398, for a delineation of criteria for defining judicial activism.

9 See Borchardt, 'Richterrecht', 37. See also, in the context of the prescriptions of the Court with regard to the duties of national courts to interpret national law in light of Union law, W.-H. Roth, 'Die richtlinienkonforme Auslegung', Europäisches Wirtschafts- und Steuerrecht, 9 (2005), 385-396.

10 See Komarek, 'Judicial Lawmaking and Precedent', 426.

11 Joined cases C-6/90 und C-9/90 Francovich [1991] ECR I-5357. See Chapter 6.

12 See Conway, The Limits of LegalReasoning, 14. On the 'Americanization' of EU law, see T. Öhlinger, 'Gesetz und Richter unter dem Einfluss des Gemeinschaftsrechts: Anmerkungen zu einem Prozess der “Amerikanisierung” des europäischen Rechts', in P. Hänni (ed.), Mensch und Staat: Festgabe für Thomas Fleiner (Freiburg: Universitätsverlag Freiburg Schweiz), 719-735.

This is an open access version of the publication distributed under the terms of the Creative Commons Attribution-NonCommercial-NoDerivs licence (http://creativecommons.org/licenses/by-nc-nd/3.0/), which permits non-commercial reproduction and distribution of the work, in any medium, provided the original work is not altered or transformed in any way, and that the work is properly cited. For commercial re-use, please contact academic.permissions@oup.com 
constituted before. ${ }^{13}$ The case that has been referred to in illustration of this point is Pupino, where the Court held that the duty of consistent interpretation with regard to framework decisions should not entail the duty to construe national law contra legem. ${ }^{14}$ With this, the ECJ without doubt alluded to the demarcation between justified legal development and illegitimate legal development that exists in many legal systems. However, it is difficult to see how this should reflect on the case law of the ECJ, when, as mentioned, it does not make such a distinction itself. ${ }^{15}$

In the following section, I will briefly explore several arguments that have been made in the context of justifying judicial activism by the Court. As we shall see, all of these arguments carry some flaw or have problematic 'side-effects'. After this, I will more closely examine which methodological standards could be applied to assessing judicial activism/ legal development by the Court. I will start, however, by briefly discussing the methodology of the Court and the role of effet utile in particular.

\subsection{Interpretation and Telos}

While the methods of interpretation employed by the Court are largely very similar to those used by national courts, ${ }^{16}$ there are important differences. Thus, the travaux préparatoires to the original Treaties were never used as a guide to interpretation, since they had never been published. ${ }^{17}$ In general, the Court of Justice places comparably little emphasis on the intentions of the legislator when interpreting the Treaties or secondary law. ${ }^{18}$ Moreover, in comparison to courts in other legal regimes, the European Court of Justice places more emphasis on a systematic and teleological interpretation. ${ }^{19}$ Connected to the latter approach to interpretation is the concept of effet utile. The principle of effet utile and its prominent role in the development of Union law, such as with direct effect and state liability, has come to epitomize the mentioned preference of the Court for an (objective) purposive approach to construction. ${ }^{20}$ The relation between

13 Conway, The Limits of Legal Reasoning, 14.

14 See Chapter 6. See Case C-105/03 Criminal Proceedings Against Maria Pupino [2005] ECR I-5285, para 48 .

15 See A. Arnull, 'Judicial Activism and the Court of Justice: How Should Academics Respond?', Maastricht Working Papers, (2012-13), 20, noting that many of the decisions criticized as activist were not reached contra legem. See Case C-161/06 Skoma-Lux [2007] ECR I-10841, para 41 as an example where the Court seems to refer to the concept of contra legem as a limit to the effects of Art. 4 (3) TEU. However, this is not referred to as a methodological tool of interpretation, but in a more substantive manner. See also N. Grosche, Rechtsfortbildung im Unionsrecht (Tübingen: Mohr Siebeck, 2011), 188.

16 See, for a comparison with Austrian supreme courts, Potacs, Auslegung, 297-299; cf. Mayer, 'Art. 19 EUV', para 53.

17 See P.P. Craig and G. de Búrca, EU Law: Text, Cases and Materials, 5th edn. (Oxford: Oxford Univ. Press, 2011), 64. See further, on the interpretation of secondary law, Potacs, Auslegung, 136-142. It, however, seems likely that recourse to the travaux préparatoires will become more compelling now, in view of the availability of documents from the Convention on the Future of the European Union, which is relevant also for the Lisbon Treaty. See Mayer, 'Art. 19 EUV', para 66.

${ }_{18}$ But see the examples for an interpretation of secondary and also primary law in light of the intention of the Union legislator cited by M. Potacs, 'Effet utile als Auslegungsgrundsatz', Europarecht, (2009), 465-488, 471.

19 See, among many others, A. Bleckmann, 'Zu den Auslegungsmethoden des Europäischen Gerichtshofs', Neue Juristische Wochenschrift, (1982), 1177-1182, 1178 passim; J. Bengoetxea, N. MacCormick and L. Moral Soriano, 'Integration and Integrity in the Legal Reasoning of the European Court of Justice', in G. de Búrca and J.H.H. Weiler (eds), The European Court of Justice (Oxford: Oxford Univ. Press, 2001), 43-85, 43 passim. For a comparison to the WTO regime, see Conway, The Limits of Legal Reasoning, 23, with further references.

20 See Potacs, 'Effet utile', 469, on effet utile as a representation of teleological interpretation, and at 475-477 on the importance of effet utile with Treaty provisions pivotal for achieving the objective

This is an open access version of the publication distributed under the terms of the Creative Commons Attribution-NonCommercial-NoDerivs licence (http://creativecommons.org/licenses/by-nc-nd/3.0/), which permits non-commercial reproduction and distribution of the work, in any medium, provided the original work is not altered or transformed in any way, and that the work is properly cited. For commercial re-use, please contact academic.permissions@oup.com 
effet utile and loyalty has also given rise to criticism for alleged judicial activism targeting the invocation of the loyalty principle as an integrationist rationale. ${ }^{21}$

Effet utile refers to the Court's practice of adopting an understanding of a specific provision of Union law, which ensures either that it has any effect at all or that it is most effective. ${ }^{22}$ It thus shows a willingness 'to sidestep the presumptive rule of interpretation typical in international law, that treaties must be interpreted in a manner that minimizes encroachment on state sovereignty'. ${ }^{23}$ This is what an eminent former judge of the Court of Justice had to say in this context:

The Court is not guided so much by what the primary legislator has laid down as by what, in the Court's opinion, he should have laid down. This method of interpretation comes very close to the 'rule of reason' in cases when no law is available... the only difference being that in the present context the Court finds a law which it can apply and uses a rule of reason only as a method of interpreting it. ${ }^{24}$

Potacs has distinguished effet utile in a narrow sense, which aims at ensuring a minimal effect of Union law, from effet utile in a broad sense, seeking to realize the maximum effect of Union law. ${ }^{25}$ In other words, we can distinguish between an approach, which construes Union law so as not to render it futile or a paradox on the one hand, and the reliance on effet utile by the Court to interpret Union rules so that they apply to their fullest effect on the other. ${ }^{26} \mathrm{~A}$ rare example of effet utile in the narrow sense can be observed in the Commission's argument in von Colson, mentioned earlier, where it was submitted that the sanctions prescribed by the pertinent directive should not be of such a nature as to make the prohibition of discrimination at issue in von Colson 'derisory'. ${ }^{27}$

All this, however, shows in my opinion that effet utile must be understood as an interpretatory instrument. It is meant to apply to specific Treaty provisions and to afford them a certain meaning. As I will explain later, this is a fundamentally different approach than with effectiveness and loyalty.

\subsection{Defences of Judicial Activism: Majoritarianism, loi cadre, and Feblerkalkül}

The first point to recall is the fact that the Court in many cases has displayed the opposite to judicial activism, by interpreting Treaty provisions narrowly, or deferring to prerogatives

of the common market such as fundamental rights. See R.M. Chevallier, 'Methods and Reasoning of the European Court in its Interpretation of Community Law', Common Market Law Review, (1964), 21-35, 32-35, on the relevance of effet utile. See further the recent and comprehensive study by Seyr, Der effet utile in der Rechtsprechung des Europäischen Gerichtshofs (Berlin: Duncker \& Humblot, 2008). See D. Edward, 'Judicial Activism: Myth or Reality?', in A. Campell and M. Voyatzi (eds), Legal Reasoning and Judicial Interpretation of European Law (Gosport: Trenton Publishing, 1996), 29-67, 56, on its parallels in common law.

21 See F. Snyder, 'The Effectiveness of European Community Law: Institutions, Processes, Tools and Techniques', Modern Law Review, (1993), 19, 53.

22 See Case 8/55 Fédération charbonnière de Belgique [1955/56] ECR 197; Case 34/62 Germany v Commission [1963] ECR 287; Case 246/80 Broekmeulen [1981] ECR 2311; Case 9/70 Grad [1970] ECR 825; Case 41/74 van Duyn [1974] ECR 1337; Joined cases C-143/88 \& C-92/89 Süderdithmarschen [1991] ECR I-415.

23 J.H.H. Weiler, 'The Transformation of Europe', The Yale Law Journal, (1991), 2403-2483, 2416.

${ }^{24}$ H.G. Schermers, 'The European Court of Justice: Promoter of European Integration', American Journal of Comparative Law, (1974), 444-464, 457.

25 See Potacs, 'Effet utile', 465.

26 See the overview of the literature on effet utile by Seyr, Der effet utile, 102-103.

27 See Chapter 6.

This is an open access version of the publication distributed under the terms of the Creative Commons Attribution-NonCommercial-NoDerivs licence (http://creativecommons.org/licenses/by-nc-nd/3.0/), which permits non-commercial reproduction and distribution of the work, in any medium, provided the original work is not altered or transformed in any way, and that the work is properly cited. For commercial re-use, please contact academic.permissions@oup.com 
of the Member State. ${ }^{28}$ Secondly, as has been pointed out by Craig, criticism of judicial activism levelled at the Court is often not coherent both from the perspective of the literature and from the perspective of national courts, which are themselves habitually engaging in this practice. ${ }^{29}$ Moreover, it has been pointed out that the Member States have, through Treaty revisions, either explicitly or implicitly approved many Court decisions. ${ }^{30}$ However, this last argument is slightly tainted when considering the opposition from the public and partly also in the literature to the envisaged 'codification' of the supremacy principle in the Constitutional Treaty and its subsequent omission from the body of the Lisbon Treaty. ${ }^{31}$

In a more general mould, Poiares Maduro has argued that judicial activism practised by the Court should be understood as 'majoritarian activism', which would further 'the rights and policies of the larger European political community' against the self-interest of the individual Member States. ${ }^{32}$ This has been deemed palatable especially in the case law on ex Article $28 \mathrm{EC}$ concerning national rules on the composition or presentation of products traditional in the respective Member States. ${ }^{33}$ In such cases the Court, it has been submitted, looked at whether the national preference was shared by other Member States and if this was not the case, it was struck down as a measure equivalent to a quantitative restriction. ${ }^{34}$ While this explanation may present an apposite view on common market case law, I would submit that it is less convincing for other areas of Union law. Only with regard to the common market objective, does it make sense to 'enforce' the preferences of the majority of the Member States, since they are unlikely to tolerate preferences of a minority of Member States mounting an obstacle to inter-Union trade. ${ }^{35}$ In contrast, in the cases establishing the principles of supremacy, direct effect, or the ERTA effect, the Court arguably did not proceed in such a manner but rather acted as the custodian of the interest of the citizens of the Member States in enjoying the legal benefits granted to them by Union law. ${ }^{36}$ While one could therefore perhaps speak of a sort of 'democratic activism' on the part of the Court concerning

28 See Chapter 11. See Tridimas, 'The Court of Justice and Judicial Activism', 200-202.

29 Craig, 'The ECJ and Ultra Vires Action', 400-406. On Rechtsfortbildung by the German Constitutional Court, see Grosche, Rechtsfortbildung im Unionsrecht, 48-54.

30 cf. Craig and de Búrca, EU Law, 65

31 See further Mayer, 'Art. 19 EUV', paras 36-37. This might be taken to show that Member States have not felt sufficiently at ease with one of the most central tenets of the Court on the relationship between their own legal systems and EU law to provide for it in the Treaty. Admittedly, it might also merely show that one Member State (here: the UK) can block Treaty amendments on important issues. I am grateful to Stefan Griller for pointing this out to me.

32 M. Poiares Maduro, 'Interpreting European Law: Judicial Adjudication in a Context of Constitutional Pluralism', European Journal of Legal Studies, (2007), 1-21, 11.

33 M. Poiares Maduro, We the Court: The European Court of Justice and the European Economic Constitution (Oxford and Portland, Oregon: Hart Publishing, 1998), 72.

34 Poiares Maduro, We the Court, 72. See the similar story told by M. Nettesheim, 'Grundsatz der Wirksamkeit des Gemeinschaftsrechts', in A. Randelzhofer, R. Scholz, and D. Wilke (eds), Gedächtnisschrift für Eberhard Grabitz (Munich: Beck, 1995), 447-468, 460, apropos the Milchkontor jurisprudence of the ECJ. See, however, the cases mentioned by R. Lang in his annotation to case DocMorris, Common Market Law Review, (2005), 189-204, 195.

35 Even with regard to the human rights case law of the Court, where it looked at national 'preferences', this was not done to impose the preferences of the majority against those of one Member State.

36 See, however, the opinion by AG Lagrange in Case 6/64 Costa v ENEL [1964] ECR 601, 604607, who did compare the different attitudes of incorporating Community law in the States being members at this time and faults the Italian Constitutional Court for the 'disastrous consequences' (605) its jurisprudence might have. The Italian Constitutional Court had applied the lex posterior rule to Italian law enacted after the national law ratifying the EEC Treaty. See also Chapter 3.

This is an open access version of the publication distributed under the terms of the Creative Commons Attribution-NonCommercial-NoDerivs licence (http://creativecommons.org/licenses/by-nc-nd/3.0/), which permits non-commercial reproduction and distribution of the work, in any medium, provided the original work is not altered or transformed in any way, and that the work is properly cited. For commercial re-use, please contact academic.permissions@oup.com 
direct effect, indirect effect, and state liability, this does not really rationalize these developments of Union law. ${ }^{37}$

A second defence emphasizes the nature of Union law as inherently incomplete, which would compel a greater role for the Court. ${ }^{38}$ In this vein, it has been argued that Article 4 (3) TEU would provide the mandate for the judicial development of norms regulating the relationship between the Union and the Member States. ${ }^{39}$ Von Bogdandy has pointed to the vagueness of what is now Article 4 (3) TEU as an appropriate basis for the resolution of conflicts in this relationship, given that their exact nature could not possibly have been foreseen when drafting the Treaty. ${ }^{40}$ However, this should only be done by the Court to the degree required to ensure the functioning of the Union. ${ }^{41} \mathrm{EU}$ law, in this view, constitutes the legal framework which cabins the freedom of the Court to deduce obligations for Member States from Article 4 (3) TEU. ${ }^{42}$ Firstly, this defence of the competence of the Court to develop the law fails to recognize that the Court has not only invoked what is now Article 4 (3) TEU to constitutionalize EU law, but has also relied on a number of other arguments and principles to the same effect, such as effectiveness and effet utile. These are principles, which themselves are closely connected, if not synonymous, to loyalty, which gives rise to further criticism, as I will argue later. Moreover, I would submit that the functioning of the Union as the suggested yardstick for assessing the appropriateness of legal developments brought about by the jurisprudence of the Court is a very malleable one. To determine which form of rules the Union needs to ensure its proper functioning presumes an idea of the kind of Union that is desired. If judicial activism is measured against this standard, it arguably becomes a very opaque means to an ill-defined end.

The third argument related to judicial activism I want to mention is not so much a defence as a pragmatic approach of tolerance. In its Honeywell decision, the German Federal Constitutional Court granted the European Court of Justice the right 'to tolerance of error' with regard to judgments that pass below the threshold of ultra vires in the definition of the BVerfG. ${ }^{43}$ The original concept of tolerance of error-or better the allowance of error (in German: Fehlerkalkül) — is a much wider notion, encompassing all rules that allow ascribing to an entity those measures that do not fulfil the requirements of their coming into existence. ${ }^{44}$ As Wiederin has argued, the concept underlying most positivist legal orders since the Roman times is that errors leading to the invalidity of a legal act are limited to those violating formal requirements such as

37 Whereas 'majoritarian activism' might be seen as legitimizing the Court by expressing the will of the majority of Member States, this works much worse when the point of reference for determining the legitimacy of the Court is a non-defined democratic standard.

38 See T. Tridimas, The General Principles of EU Law, 2nd edn. (Oxford: Oxford Univ. Press, 2006), 17-18, with regard to general principles. Similar A. Dashwood, 'The Limits of European Community Powers', European Law Review, (1996), 113-128: 'Of course, the terms of the argument are unique, because they relate to that unique construct, the constitutional order of States created by the Treaties.'

39 Von Bogdandy, 'Rechtsfortbildung', 20 with references.

40 Von Bogdandy, 'Rechtsfortbildung', 24. $\quad 41$ Borchardt, 'Richterrecht', 34.

42 Von Bogdandy, 'Rechtsfortbildung', 21.

43 Case 2 BvR 2661/06 Honeywell [2010] BVerfGE 126, 286, English version at <http://www. bverfg.de/entscheidungen/rs20100706_2bvr266106en.html>, para H8. This judgment will be discussed in detail later in this chapter. Suffice it to note at this point, however, that the BVerfG acknowledged Art. 4 (3) TEU as being the legal basis of the premature effect of the Union directive in Case C-155/04 Mangold [2005] ECR I-9981. See T. Konstadinides, 'Constitutional Identity as a Shield and as a Sword: The European Legal Order within the Framework of National Constitutional Settlement', Cambridge Yearbook of European Legal Studies, 13 (2010-2011), 195-218, 214-215.

44 See E. Wiederin, 'Die Stufenbaulehre Adolf Julius Merkls', in S. Griller and H.-P. Rill (eds), Rechtstheorie: Rechtsbegriff-Dynamik-Auslegung (Vienna, New York: Springer, 2011), 81-134, 122.

This is an open access version of the publication distributed under the terms of the Creative Commons Attribution-NonCommercial-NoDerivs licence (http://creativecommons.org/licenses/by-nc-nd/3.0/), which permits non-commercial reproduction and distribution of the work, in any medium, provided the original work is not altered or transformed in any way, and that the work is properly cited. For commercial re-use, please contact academic.permissions@oup.com 
publication or signature. ${ }^{45}$ However, in the classic understanding of Fehlerkalkül, other errors often lead not to invalidity but to the possible invalidation of the defective legal act, such as by decision of the constitutional court. ${ }^{46}$ Applying this to the present context, it would mean firstly that legally flawed (erroneous) decisions by the ECJ might be valid even when they are defective for a certain reason. Secondly, however, the BVerfG could declare them inapplicable in Germany. ${ }^{47}$ Alternatively, we might posit that there can be no concept of an allowance of error with the ECJ, because this normally entails that a higher court can decide on the validity/applicability of its judicial acts, and there is no higher court in the EU. I would therefore argue that relying on the concept of the Fehlerkalkül would be a double-edged sword for the ECJ. While accepting that decisions by the ECJ may be defective but remain valid until found non-applicable in Germany, the BVerfG might profess to allow a certain amount of judicial lawmaking on the part of the ECJ. Implicitly, however, the BVerfG with this positions itself as the final arbiter with regard to the legality of EU law.

\subsection{Criteria for Assessing Legal Developments by the Court}

MacCormick has proposed that the Court should start with a textual analysis, followed by systematic, consistency arguments, and finally consequentialist arguments. ${ }^{48} \mathrm{He}$ has argued that in cases where deductive arguments cannot justify judicial decisions, courts should deploy non-deductive arguments based on the ideas of consistency, coherence, and consequences, in fashioning a rule or principle of law to resolve the case; a method that MacCormick has called consequence-based reasoning. ${ }^{49}$ The tendency of the Court and even more so of the Advocate Generals to resort to a meta-purposive, systemic style of reasoning has also been observed by Lasser. ${ }^{50}$ I would suggest that the criterion of consistency, i.e. the assessment whether a certain interpretation of the Treaties conforms to the general system of the Treaties, could also be seen in the context of an interpretation in view of the telos of the Treaties. From this perspective, the theory mentioned earlier does no more than rebrand the effet utile approach professed by the Court.

MacCormick's approach has recently been modified by Conway by asserting the relevance of the lex specialis argument in cases where ordinary meaning does not bear fruit. ${ }^{51}$ According to Conway, this should be followed by an 'originalist' interpretation and a preference for dialectic reasoning. ${ }^{52}$ The general validity of these interpretative methods

45 Wiederin, 'Stufenbaulehre', 123.

46 See Art. 140 of the Austrian Constitution (B-VG). The Fehlerkalkül may therefore only be the legal basis for the temporary validity of the concerned act until the time it is invalidated. Clearly, there is a problem with this concept when it comes to acts of supreme (constitutional) courts themselves. See Wiederin, 'Stufenbaulehre', 126, fn 193.

47 The national law consequence of invalidation would become disapplication in the EU law context. In this case, the BVerfG itself would have to face the question whether its decisions are themselves subject to a temporary or absolute Fehlerkalkül.

48 See N. MacCormick, Legal Reasoning and Legal Theory (London: Clarendon, 1994), 128 passim.

49 MacCormick, Legal Reasoning.

50 See the convincing reading of the case law by M. de S.-O.-l'E. Lasser, Judicial Deliberations: A Comparative Analysis of Judicial Transparency and Legitimacy (Oxford: Oxford Univ. Press, 2009), 206-236.

51 Conway, The Limits of Legal Reasoning, 144. Lex specialis is meant to apply the ordinary meaning of the most specific relevant legal provision or source. See 153-158.

52 Conway, The Limits of Legal Reasoning, 144. 'A judge should decide on the basis of the most specific legal or constitutional provision, as supplemented by originalist interpretation if ordinary meaning is

This is an open access version of the publication distributed under the terms of the Creative Commons Attribution-NonCommercial-NoDerivs licence (http://creativecommons.org/licenses/by-nc-nd/3.0/), which permits non-commercial reproduction and distribution of the work, in any medium, provided the original work is not altered or transformed in any way, and that the work is properly cited. For commercial re-use, please contact academic.permissions@oup.com 
is not in debate here for the narrower purposes of this book. Dialectic reasoning is certainly also to be kept in mind as a methodological value in itself. However, this proposed standard equally fails to provide a suitable foundation for analysing the foundational cases involving loyalty, which are at the centre of our analysis. Thus, it is revealing that the Court's reasoning both in its case law on state liability and in ERTA especially cannot be brought in line with the methodological standards suggested by Conway. ${ }^{53}$

Another pertinent perspective in assessing the methodology of the Court is reasoning by analogy. While this is a perfectly normal method in civil law countries, ${ }^{54}$ with respect to EU law, not surprisingly, the difficulty lies in the details. This can already be demonstrated by looking at gap-filling in national law in a constellation that involves the Union legal order, such as with directives. I have argued elsewhere that two steps are required in this case. ${ }^{55}$ Firstly, the need for an act of gap-filling must be established, i.e. it must be demonstrated that there is a lacuna in the law. Secondly, for actually closing such a lacuna, a similar rule must be applied to the facts of the case at issue. ${ }^{56}$ With directives, I would argue that they should not be taken into consideration in the first act of establishing the existence of a lacuna. Otherwise, the flawed transposition of a directive would always entail a lacuna because the non-implemented parts of national law would be missing by the standard of the directive concerned. With the second step of the actual filling of a gap, in contrast, the directive must be considered because it forms a part of the overall legal order to be considered as the source of rules to be applied in such a case. In other words, if we were to close a gap found to exist by measure of a directive by applying the very same directive, this would bring about direct effect through the backdoor.

While this example shows the complexity of closing gaps in national laws under the impression of Union law, similar intricacies arise with the filling of gaps within the Union legal order. It has been claimed that the filling of gaps is not included in the Court's arsenal, since it does not concern the observance of the law required by Article 19TEU. ${ }^{57}$ In contrast to this view, it has been pointed out that the Treaties contain more lacunae (gaps) than national law, which would explain the propensity of the Court to engage in 'judicial law-making'. ${ }^{58}$ If we look at established methods for closing gaps in national law and try to adapt them to the EU, this proves to be a difficult task. ${ }^{59}$ The main problem is where to draw the line between legitimate reasoning by analogy and judicial activism when discussing EU law. Reasoning by analogy in the civil law tradition is an instrument of interpretation, which goes a step further than purposive interpretation

not decisive, and should explain and justify the extent of choice within that framework.' See Conway, The Limits of Legal Reasoning, 163.

53 See Conway, The Limits of Legal Reasoning, 232-237.

${ }_{44}$ See T. Hartley, The Foundations of European Community Law, 5th edn. (Oxford: Oxford Univ. Press, 2003), 193, for common law.

55 See, on the following, M. Klamert, 'Richtlinienkonforme Auslegung und unmittelbare Wirkung von EG-Richtlinien in der Rechtsprechung der österreichischen Höchstgerichte', Juristische Blätter, $130 / 3$ (2008), 158-170. Three steps are involved if we consider constitutional limits to reasoning by analogy. See K. Langenbucher, 'Argument by Analogy in European Law', Cambridge Law Journal, $57: 3$ (1998), 481, 483.

56 See Langenbucher, 'Argument by Analogy', 483.

57 Mayer, 'Art 19 E.UV', para 31

58 Tridimas, General Principles, 17-18; J. Bengoetxea, Legal Reasoning, 44-45.

59 Exceptions are analogies with secondary law, where the original intent can be ascertained. See the examples given by Langenbucher, 'Argument by Analogy', 510-512, mainly Case 6/78 Union Francaise de Céréales [1978] ECR 1675.

This is an open access version of the publication distributed under the terms of the Creative Commons Attribution-NonCommercial-NoDerivs licence (http://creativecommons.org/licenses/by-nc-nd/3.0/), which permits non-commercial reproduction and distribution of the work, in any medium, provided the original work is not altered or transformed in any way, and that the work is properly cited. For commercial re-use, please contact academic.permissions@oup.com 
in that it extends an enacted rule to cases the legislature had not foreseen. ${ }^{60}$ However, not every lacuna can be closed by such a test. The main criterion, according to the prevailing opinion in German and Austrian legal theory, is legislative intent; there is no gap if the legislator planned for the legal order to be incomplete in a certain respect. ${ }^{61}$ As already discussed, however, in Union law travaux préparatoires have played little role in the interpretation of Treaty provisions. ${ }^{62}$ Thus, if we wanted to assess the case law in this area, we would have to conclude either that there are no gaps at all because the drafters had conceived the Treaties as a frame only, or that there are gaps all over the place for the exact same reason. ${ }^{63}$ Similarly, the apparent conflict between the contra-argument mentioned earlier based on Article 19 TEU on the one hand, and the pro-argument based on general principles on the other could be resolved by considering general principles a part of Union law. In this case, there would be no gap in Union law, and the Court would observe the 'law' when it uses general principles to close gaps in the Treaties. ${ }^{64}$

Langenbucher has referred to the 'principle-based' common law variant of reasoning by analogy, whereby a general principle of law is developed on a case-by-case basis and is applied to individual cases. ${ }^{65}$ According to Langenbucher, an analogy must not violate the constitutional balance struck between the powers of the Member States and those of the Union in an EU law context, nor must it infringe fundamental rights of Union citizens. ${ }^{66}$ In her view, the 'constitutional restriction' for reasoning with analogy is that the Member States' sovereignty must not be impaired. ${ }^{67}$ On this basis, Langenbucher has criticized the Brasserie judgment for extending state liability for a breach of a directive

60 See Langenbucher, 'Argument by Analogy', 482, and on the intricacies of the act of closing the gap by, among other things, establishing the relevant tertium comparationis, 487-490. Langenbucher has called this rule-based reasoning by analogy, where a statutory norm is extended to a different case that it was not originally meant to cover.

61 Langenbucher, 'Argument by Analogy', 482, with illustrations from German law. See T. Hartley, Constitutional Problems of the EU (Oxford and Portland, Oregon: Hart Publishing, 1999), 44: 'However, a true gap exists only where there is a reason to believe that the authors of the text intended a given topic to be covered. This occurs where a provision of the text cannot be applied, or does not make sense, unless a rule is created to cover another question.' See Hartley, Constitutional Problems, 45: 'A gap does not, however, exist simply because a topic is not covered - even if it would be convenient if it were.'

62 See, in this context, W. Dänzer-Vanotti, 'Der Europäische Gerichtshof zwischen Rechtsprechung und Rechtsetzung', in O. Due, M. Lutter, and J. Schwarze (eds), Festschrift für Ulrich Everling, Vol. I (Baden-Baden: Nomos, 1995), 205-221, 220.

63 The argument by Conway, The Limits of Legal Reasoning, 169, that the EU is not complete as a legal system because where it does not regulate the Member States are competent to do so, is not apposite, at least not in the present context. Neither is the concept of non liquet. Take state liability, discussed later. Had the Court not come up with the principle of state liability, there would have been a decision by the Court by ordering indirect effect, and there would have been a claim for infringement. These instruments might not have been as effective for the protection of the rights of the individuals concerned, but it would not have been a non liquet.

64 See the account by Mayer, 'Art. 19 EUV', para 32, on the human rights jurisprudence of the Court and on general principles in general, which follows his statement mentioned earlier on the inadmissibility of gap-filling.

65 Mayer, 'Art. 19 EUV', 502-504, and at 504: 'Argument by analogy is thus used to compare a new case with a precedent in the light of the general legal principle.' Principle-based reasoning by analogy is held to require a similarity between two cases in the light of the value promoted by a norm. See Mayer, 'Art. 19 EUV', 513. cf. C. Sunstein, Legal Reasoning and Political Conflict (Oxford, NY: Oxford Univ. Press, 1996), 71: 'A precedent can serve as either a rule or an analogy.' 'A precedent serves not as a rule but as an analogy to the extent that it is at least plausibly distinguishable from the case at hand, but suggestive of a more general principle or policy that seems relevant to the case.'

66 Langenbucher, 'Argument by Analogy', 502-503.

67 For her, '[t] he sovereignty of the Member States is one of the main boundaries to judicial activism on the European level'. See Langenbucher, 'Argument by Analogy', 518.

This is an open access version of the publication distributed under the terms of the Creative Commons Attribution-NonCommercial-NoDerivs licence (http://creativecommons.org/licenses/by-nc-nd/3.0/), which permits non-commercial reproduction and distribution of the work, in any medium, provided the original work is not altered or transformed in any way, and that the work is properly cited. For commercial re-use, please contact academic.permissions@oup.com 
without direct effect (as in Francovich) to a breach of a directly effective Treaty rule. ${ }^{68}$ In the latter case, she has posited, the Francovich argument, that without state liability the individual could not have enforced its rights, would not apply. I would argue that this is not a convincing line to draw on this issue. In Brasserie, the argument was that effectiveness would be promoted even more if there was an additional remedy of state liability. If state liability was an analogy and if Francovich was legitimate, Brasserie cannot be faulted because state liability there was not strictly necessary to protect private interests. If this were true, Langenbucher would also have to attack indirect effect in cases where direct effect is available.

\subsection{Conclusion}

Hence, the Court cannot be attacked because of its methodology on analogies or the use of general principles to close gaps per se. Attempts at suggesting a method to follow for the Court with regard to using the telos of the Treaties for interpretative purposes have not borne fruit. Moreover, adapting civil law standards for closing gaps in EU law cannot be reconciled with the fact that the intent of the legislator plays little role in EU law. Suggestions on adapting common law standards on reasoning by analogy equally fail to set up clear borders beyond the protection of national sovereignty. This means that no objective standard exists that could be applied to legal developments of EU law engineered by the Court.

However, this interim conclusion does not mean that we cannot formulate a general criticism of the reasoning of the Court in cases involving loyalty or principles related to loyalty. For this, we need as a next step to revisit some of the foundational case law and the legal principles it established.

\section{Loyalty, Effectiveness, and effet utile}

\subsection{Introduction}

In the literature, most seem to make scant difference between loyalty, effet utile, and effectiveness. Those writing on effet utile have not clearly distinguished between this rule and the principle of effectiveness. ${ }^{69}$ Conversely, those discussing effectiveness have not mentioned effet utile. ${ }^{70}$ Supremacy is a good example of this ambiguity. A recent study on effet utile has shown that parts of the German literature have seen the basis of supremacy in the principle of effectiveness; ${ }^{71}$ others have assumed a teleological interpretation of ex Article $10 \mathrm{EC} ;{ }^{72}$ others still have considered supremacy as based on effet

68 Langenbucher, 'Argument by Analogy', 517-518.

69 See R. Streinz, 'Der effet utile in der Rechtsprechung des Gerichtshofs der Europäischen Gemeinschaften', in O. Due, M. Lutter, and J. Schwarze, Festschrift für Ulrich Everling (Munich: Beck, 1995), 1491-1510.

70 M. Ross, 'Effectiveness in the European Union Legal Order(s): Beyond Supremacy to Constitutional Proportionality?', European Law Review, (2006), 476-498. Interestingly, R. Nazzini, 'Potency and Act of the Principle of Effectiveness: The Development of Competition Law Remedies and Procedures in Community Law', in C. Barnard and O. Odudu (eds), The Outer Limits of European Union Law (Oxford: Hart, 2009), 401-435, does not even mention effet utile in his text and only briefly mentions ex Art. 10 EC.

71 Seyr, Der effet utile, 120, with references to Nicolysen, Ipsen, and Streinz ('Prinzip der Funktionsfähigkeit der Gemeinschaft').

72 Seyr, Der effet utile, 121, referring to Grabitz.

This is an open access version of the publication distributed under the terms of the Creative Commons Attribution-NonCommercial-NoDerivs licence (http://creativecommons.org/licenses/by-nc-nd/3.0/), which permits non-commercial reproduction and distribution of the work, in any medium, provided the original work is not altered or transformed in any way, and that the work is properly cited. For commercial re-use, please contact academic.permissions@oup.com 
utile. ${ }^{73}$ While a clear distinction between these concepts is thus shown to be missing, it seems not to have been missed much in the literature.

I would proffer that the alternating use by the Court of seemingly different legal concepts cannot simply be brushed aside as irrelevant or as a 'mask' for pure politics, as it has been put by Burley and Matti. ${ }^{74}$ Instead, I would argue that a legal analysis worthy of its name has to take the law at 'face value'. We have to start with the assumption that the Court had good reasons to frame an argument in this or that wording. That judgments might spur unforeseen developments, as mentioned earlier, is not in contradiction to this. However, a caveat must apply here: At the end of such analysis, we might still arrive at the conclusion that the use of pivotal legal concepts by the Court is confusing, ambiguous, or perhaps indeed only a pseudo-rationale.

Both effectiveness and effet utile are expressions of the idea that Union law must be construed and applied as to enable it to function in the way it has been conceived. Thus, it might be said that ' $\mathrm{t}]$ he origins of the principle [of effectiveness] lie in the interpretative techniques of the Court which, even at an early stage, favoured a liberal construction of Treaty provisions so as to ensure their effet utile $e^{75}$ The close relation between effectiveness and effet utile is clearly visible with the Rewe strand of case law on the enforcement of directly effective Union law rights, discussed earlier. Here, it might actually make no difference from a methodological perspective whether we consider this an application of effectiveness or of effet utile. Requirements for national law ensuing from the need to enforce Union rights can be seen both as an extensive interpretation of Article $288 \mathrm{TFEU}$, or as the application of a distinct principle of effectiveness connected to the principle of supremacy. I have also shown the close relation between the Rewe case law and effectiveness on the one hand, and loyalty on the other. While loyalty is the legal basis for introducing the implementation related side of the principle of effectiveness, the case law on the enforcement related side of effectiveness is also in many respects connected to loyalty. ${ }^{76}$

However, in the following section, the use of these arguments in relation to direct effect can be distinguished from the legal reasoning employed to establish the exclusive external competences formerly implied in the Treaty and now expressly provided for in Articles 3 (2) TFEU and 216 TFEU.

\subsection{Loyalty, effet utile and the Rationale for Direct Effect}

As I have explained, in its case law on direct effect the Court has relied on both effet utile and loyalty. In a long line of cases the Court invoked ex Article $249 \mathrm{EC}$, effet utile, and the principle that Member States should not profit from their own omissions to rationalize the direct effect of directives. ${ }^{77}$ As mentioned, in Moormann the Court changed course to declare that direct effect is based on a combination of ex Article $249 \mathrm{EC}$ and ex Article 10 EC. ${ }^{78}$ This aligned the reasoning on direct effect with that on the obligation of consistent interpretation where the Court, from the beginning of its jurisprudence,

73 Seyr, Der effet utile, referring to Ormand and Bredimas.

74 W. Burley and A.-M. Matti, 'Europe Before the Court: A Political Theory of Legal Integration', International Organization, 47 (1993), 41-76, 72-73.

75 Burley and Matti, 'Europe Before the Court', 72-73.

76 See Chapter 6.

77 See Case 51/76 Verbond van Nederlandse Ondernemingen [1977] ECR 113, para 23; Case 148/78 Ratti [1979] ECR 1629, paras 20-23.

78 Case 190/87 Moormann [1988] ECR 4689.

This is an open access version of the publication distributed under the terms of the Creative Commons Attribution-NonCommercial-NoDerivs licence (http://creativecommons.org/licenses/by-nc-nd/3.0/), which permits non-commercial reproduction and distribution of the work, in any medium, provided the original work is not altered or transformed in any way, and that the work is properly cited. For commercial re-use, please contact academic.permissions@oup.com 
has invoked both Article 288 TFEU and Article 4 (3) TEU, without any mention of effet utile. I submit that there is a small but noteworthy difference between the former and the latter rationale for the following reasons.

Article 288 TFEU arguably does not provide a sufficient basis directly to empower individuals, or to set aside national law. This provision only states the binding nature of the directive's objective and the discretion of Member States in choosing the means to implement it. In contrast, effet utile caters to the idea that without a subjectivist element, Union directives would be toothless in the face of Member State inaction. Thus, Article 288 TFEU is interpreted to comprise such possibility of direct effect as an integral component of the prescription contained in it. In other words, effet utile finds direct effect to be inherent in Article 288 TFEU.

Invoking Article 4 (3) TEU together with Article 288 TFEU, in contrast, emphasizes the obligation of the Member States to step into action in order to make Union directives work effectively. Recall that loyalty addresses the Member States above all and obliges them to ensure that binding Union law, such as the objective of a directive, is fulfilled. It is proposed that here direct effect is not located within Article 288 TFEU proper. ${ }^{79}$ It is rather owed to the combined reading of Article 288 TFEU with its strong element of Member State regulatory autonomy, and Article 4 (3) TEU with its call on Member States to enforce EU law by all appropriate and available means. Hence, the argument here is, if Member States are not able or willing to honour their obligation to transpose a directive, self-executing provisions of a directive must be enforceable before national courts nonetheless.

This may be a small difference, since applying either argument the result is the same. This might also be the reason why the Court so easily jumped from one rationale to the other in its case law on direct effect, as mentioned earlier. However, I submit that, from a legitimacy perspective, it is preferable to invoke loyalty rather than effet utile, especially when it concerns the creation of such far-reaching new rights not expressly foreseen in the Treaty.

\subsection{Loyalty, effet utile, Effectiveness, and the Rationale for External Exclusive Competences}

In the case of the ERTA judgment, I have argued that ex Article 5 EEC was the appropriate argument to infer exclusive external powers, since this could not be derived by way of interpretation of the relevant internal competence. ${ }^{80}$ Recall that I have pointed out with regard to ERTA that there is a difference between assuming implied powers in a general vein, and the finding of exclusive external competence because of the passing of common rules. ${ }^{81}$ The statement by the Court in ERTA on the external capacity of the (then) Community does assume implied external powers to be inherent in the Treaty. However, it does not necessarily require implied exclusive external powers of the Union under certain conditions. The former can be explained by a very general argument of effet utile in light of the general scheme of the Treaty. Here, indeed, effet utile and implied powers are very closely related. The latter finding in ERTA, however, is better understood as predicated by the need to prevent a conflict between the possible international action by a Member State and existing Union measures. This conflict

79 See also A. von Bogdandy and S. Schill, 'Art. 4 EUV', in E. Grabitz, M. Hilf, and M. Nettesheim (eds), Das Recht der Europäische Union, Kommentar, Vol. II (Munich: Beck, 2010), para 62.

80 See Chapter $3 . \quad 81$ See Chapter 3.

This is an open access version of the publication distributed under the terms of the Creative Commons Attribution-NonCommercial-NoDerivs licence (http://creativecommons.org/licenses/by-nc-nd/3.0/), which permits non-commercial reproduction and distribution of the work, in any medium, provided the original work is not altered or transformed in any way, and that the work is properly cited. For commercial re-use, please contact academic.permissions@oup.com 
theme is the explanation for invoking ex Article 5 EEC in ERTA to justify the specific finding of competence because of the passing of common rules.

Therefore, it is apposite to claim that implied powers are a special form of interpretation of a norm of competence in light of its effet utile. ${ }^{82}$ ERTA, in contrast, is a valid example of the relation between effet utile and implied powers only insofar as the general statement on the existence of implied powers in the Treaty as a matter of principle is concerned. This is also confirmed by the leading case on implied powers in Union law. In Fèdèchar, the Court held on account of the European Coal and Steel Community (ECSC):

The Court considers that without having recourse to a wide interpretation it is possible to apply a rule of interpretation generally accepted in both international and national law, according to which the rules laid down by an international treaty or a law presuppose the rules without which that treaty or law would have no meaning or could not be reasonably and usefully applied. ${ }^{83}$

The finding of exclusivity in ERTA, however, is not primarily built on the methodological edifice of effet utile. Rather, it is an example of the competence conferring power of loyalty as a tool for the prevention of conflicts.

While there is, thus, a close rapport between implied powers and effet utile, I submit that it is unnecessarily confusing to argue that implied powers, on the one hand, is a principle of construction more powerful than effet utile proper, and that, on the other hand, implied powers are the result of such interpretation. ${ }^{84}$ Put in other words: It is, if perhaps only on account of terminology, circular to claim that the method applied to construct a provision of the Treaty at the same time constitutes the result thereby reached. It is, I suggest, more transparent and more logical to consider implied powers as a distinct form of competence of the Union to act under certain conditions, and effet utile as the method employed to establish such unwritten competences. ${ }^{85}$

Arguably, an important example of the application of effet utile in the field of external relations is Opinion 1/76. ${ }^{86}$ I would submit that the $1 / 76$ kind of exclusivity is different from ERTA. In this case, the Court finds that the internal competence must be extended to the external sphere in order not to jeopardize its effectiveness. This is inferred directly from the internal competence norm. The Court has never expressly rationalized this award of exclusive external competence in the 1/76 constellation; an omission that has been deplored in the literature. ${ }^{87}$ What seems clear is that justification in this case could not have been to preserve the unity and consistency of Union law such as with the ERTA line of case law. ${ }^{88}$ In the $1 / 76$ constellation, it was not a situation of conflict between Union rules and national law that required a solution. There existed no Union rules that

82 See Seyr, Der effet utile, 110: 'Überzeugender ist der Ansatz, die implied powers als eine besondere Art der Auslegung nach dem effet utile zu betrachten, die nur bei der Interpretation von Kompetenznormen zur Anwendung kommen kann.'

83 Case 8/55 Fédération Charbonnière de Belgique [1956] ECR 292, at 299.

84 Seyr, Der effet utile, 110: 'Diese stellen mit anderen Worten die Rechtsfolge der Auslegung nach dem effet utile dar.'

85 See also M. Cremona, 'EU External Action in the JHA Domain: A Legal Perspective', EUI LAW Working Paper, 24 (2008), 6.

86 Opinion 1/76 European Laying-up Fund [1977] ECR 741.

87 cf. P. Eeckhout, EU External Relations Law: Legal and Constitutional Foundations, 2nd edn. (Oxford: Oxford Univ. Press, 2011); P. Koutrakos, EU International Relations Law (Oxford and Portland, Oregon: Hart Publishing, 2006), 113.

88 cf. J.-V. Louis, 'Editorial: La Cour et les relations extérieures des la Communauté, Cahier de Droit European, (2007), 285-291, 289.

This is an open access version of the publication distributed under the terms of the Creative Commons Attribution-NonCommercial-NoDerivs licence (http://creativecommons.org/licenses/by-nc-nd/3.0/), which permits non-commercial reproduction and distribution of the work, in any medium, provided the original work is not altered or transformed in any way, and that the work is properly cited. For commercial re-use, please contact academic.permissions@oup.com 
had to be protected, in contrast to the ERTA case. This difference, however, is only apparent when the role of loyalty in ERTA is fully acknowledged, as I have argued for earlier. ${ }^{89}$ Instead, the test of necessity in the $1 / 76$ case is rather guided by the effet utile of the internal Union objective, which requires external action in order to be effectively exercised. ${ }^{90}$ Could the Court, in the $1 / 76$ case, have invoked loyalty instead? Without conflict, this would seem less consistent in light of the Court's previous case law in Costa and ERTA.

While this is still not an ordinary exercise in norm interpretation, the link between a specific internal competence norm and the argument of effet utile based on it is convincing. In this case, a competence norm is interpreted to confer further competence in the external sphere by implication. This finding of the Court in Opinion 1/76 can also not be challenged on grounds of proportionality, if we consider this a yardstick for assessing the legitimacy of a reasoning based on effet utile. If an internal competence cannot be properly exercised without concluding an international agreement, which is embodied by the necessity criteria central to the tenet in this Opinion and the case law following it, there is no other choice than to assume exclusive competence for the Union.

\subsection{Loyalty, Effectiveness, effet utile, and State Liability}

I would argue that when state liability was initially only applied in the context of directives in Francovich, this could also have been rationalized with the effet utile of directives. However, when state liability has also been made applicable to other breaches of Union law unrelated to directives, such as the breach of the common market rules in cases such as Brasserie du Pêcheur or because of national court decisions such as Köbler, this rationale is difficult to transfer. It might be argued that effectiveness here actually relates to the useful effect of the Union law regime as a whole, instead of the effect of certain of its legal instruments. This is supported by the argument of the Court in Brasserie du Pêcheur, where, as mentioned, the Court referred to effectiveness and the obligation to cooperate as 'principles inherent in the Community legal order which form the basis for State liability'. ${ }^{91}$ In addition, the fact that state liability in the EU had its precursor in the ECSC points in the same direction.

However, such an all-encompassing view of effet utile would undermine my earlier claim for effet utile to be a rule of interpretation. Even where effet utile had been used in the process of constitutionalization, such as with direct effect and with Opinion 1/76 on exclusivity, it had always referred back to a certain provision of Union law. With state liability, it is not possible to argue that way. Suggestions on regulating the liability of the Member States by amending ex Article 228 EC on the liability of the EU had not been adopted. ${ }^{92}$ Moreover, the Court did not refer to any specific provision of the Treaty in support of its argument, but it plainly asserted the existence of principles inherent in the Treaty mandating such development. Thus, I would claim that the Court applied effectiveness not as a rule of construction, but as a principle of Union law, possessing a

89 But see Weiler, 'Transformation', 2416, who does not mention Art. 10 EC in his account of ERTA but claims that ERTA was a case of purposive interpretation.

90 See R. Kovar, 'Les compétences implicites: jurisprudence de la Cour et pratique communautaire', in P. Demaret (ed.), Relations extérieures de la Communauté européenne et marché intérieur: Aspects juridiques et fonctionnels (Brussels: Story, 1986), 15-36, 20-21.

91 Joined cases C-46/93 and C-48/93 Brasserie du Pêcheur [1996] ECR I-1029 (emphasis added).

92 See the account by D. Chalmers, 'Judicial Preferences and the Community Legal Order', The Modern Law Review, 60 (1997), 164-199.

This is an open access version of the publication distributed under the terms of the Creative Commons Attribution-NonCommercial-NoDerivs licence (http://creativecommons.org/licenses/by-nc-nd/3.0/), which permits non-commercial reproduction and distribution of the work, in any medium, provided the original work is not altered or transformed in any way, and that the work is properly cited. For commercial re-use, please contact academic.permissions@oup.com 
gap-filling function in Union law. Conversely, I would submit that a rule of interpretation such as effet utile could not have created and cannot create a novel institute of Union law such as state liability. ${ }^{93}$

\subsection{Conclusion}

Figure 13.1, by way of summary, illustrates the prototypical relation between loyalty/ Article 4 (3) TEU, supremacy, effectiveness, implied powers, and effet utile. I thus do not claim that this follows necessarily from case law, but it helps in distinguishing concepts that arguably are in need of distinction.

The central position of loyalty reflects it as being the explicit or implicit, single or auxiliary basis for all the other principles and concepts mentioned earlier. However, this relation cannot simply be presented in a clearly hierarchical form, but is more complex, including the application of loyalty in conjunction with other principles and the partial correlation between loyalty and, for instance, effectiveness. Thus, loyalty shares the 'creationist', 'constructivist' side with the principle of effectiveness, illustrated by the fact that both have been invoked as the foundations of state liability. In contrast, in its predominant function of ensuring the effective judicial protection of individuals and the

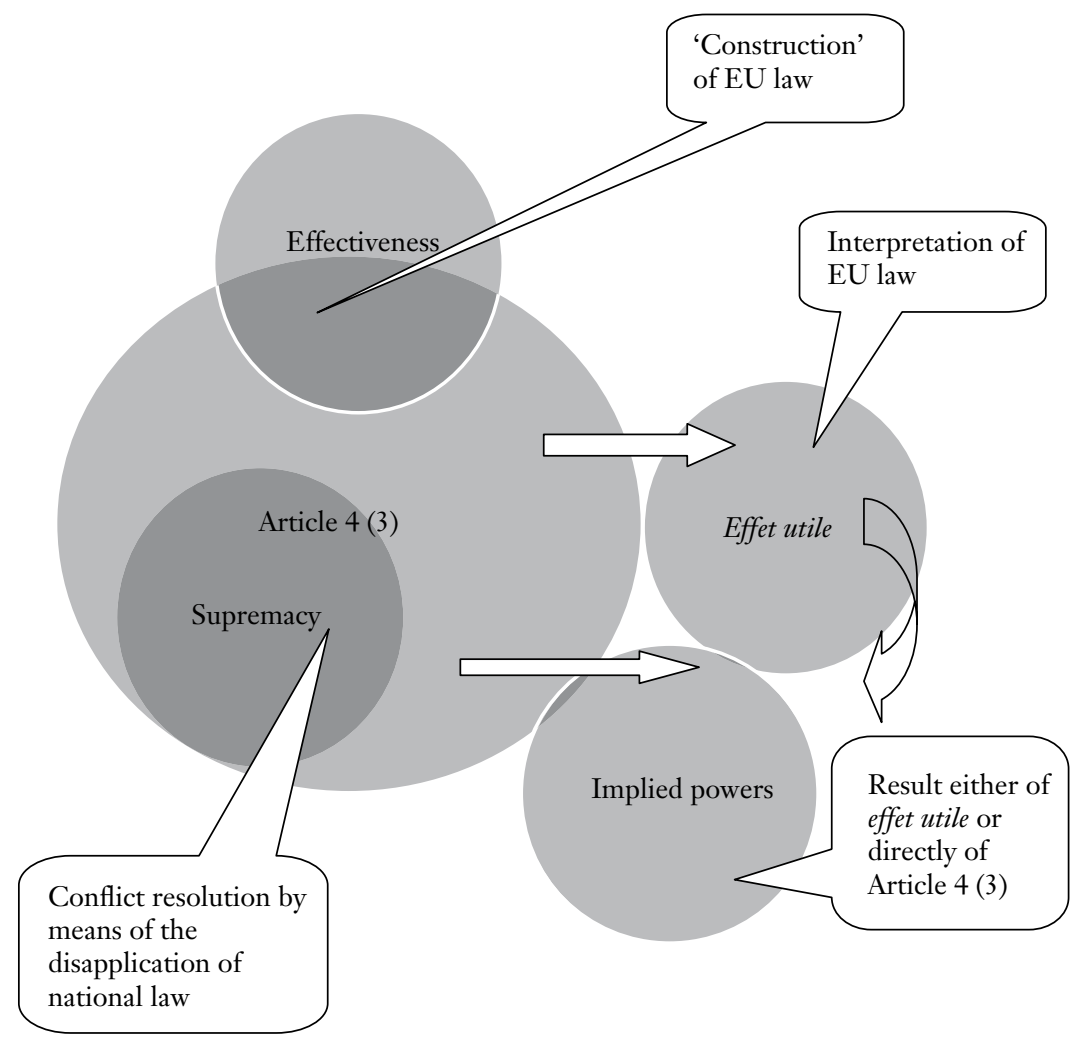

Figure 13.1 The Centrality of Loyalty for the Construction of the Union

${ }^{93}$ But see Seyr, Der effet utile, 153-158, who makes no difference between either principle.

This is an open access version of the publication distributed under the terms of the Creative Commons Attribution-NonCommercial-NoDerivs licence (http://creativecommons.org/licenses/by-nc-nd/3.0/), which permits non-commercial reproduction and distribution of the work, in any medium, provided the original work is not altered or transformed in any way, and that the work is properly cited. For commercial re-use, please contact academic.permissions@oup.com 
enforcement of Union law rights, effectiveness is rather comparable to effet utile. In contrast again to loyalty, effet utile has no inherent constructivist nature. It is a rule of interpretation, which is applied in a non-methodical manner in many foundational judgments. Implied powers are the result of such interpretation, as shown by the Court in Opinion 1/76.

The qualification of effet utile as a method of interpretation makes it ill-suited to constituting the basis of distinct legal obligations of Member States or rights of Union citizens. Loyalty is similar to effet utile since both principles are concerned with the goal of making Union law work in a very general sense. Recall that under Article 4 (3) TEU the Member States shall facilitate the attainment of the Union's objectives and refrain from any measure which could jeopardize this goal. This, in theory, makes loyalty more than the parameter of interpretation that is effet utile. By its wording and its position in the Treaty, it is the basis for distinct obligations and, thus, has a 'legal life of its own'. The main, distinct function of loyalty is as a conflict resolution rule, such as in ERTA. This it has in common with supremacy, of which it is also one important legal basis. However, while supremacy has the sole effect of setting aside national law in the case of a conflict, loyalty has a much broader conflict related function in Union law, as I have explained in the Part on Cohesion.

In the following section, I will now come to the only critique that in my opinion can validly be raised with regard to the reasoning of the Court on methodological grounds.

\section{Loyalty and Self-referential Reasoning}

\subsection{Introduction}

The Court has often been criticized for its reduced and minimalistic style, which has been claimed to be the result of the absence of dissent and a reluctance to commit itself on specific issues when not directly necessary for the decision. ${ }^{94}$ The ambiguity on matters of substance that this has led to may explain why the members of the Court were taken by surprise at what has been read into some of the Court's judgments. ${ }^{95}$ It has been observed in this context that AGs routinely address what has been termed 'micro purposes' to promote a specific Treaty provision's effet utile. ${ }^{96}$ More often, however, they resort to 'meta purposes', i.e. purposes, values, or policies underlying the EU's legal structure as a whole, such as the effectiveness of Union law or the legal protection of individual rights. ${ }^{97}$ It has been argued that because the Union legal order was a 'skeleton' in special need of the closing of gaps and the Treaty lacked any rules on how this should be done properly, this would make a strong case for a more flexible reasoning with general principles. ${ }^{98}$ Tridimas has also presented principles as the solution to the 'skeleton'

94 See Craig and de Búrca, EU Law, 63. cf. Lasser, Judicial Deliberations, 351, who has commented: 'The ECJ's collegial decisions remain distinctly civilian - and especially French (i.e., 'Continental', 'Cartesian', and 'cryptic') - in style, despite their abandonment of the single-sentence syllogism. ECJ decisions continue to be unsigned, univocal, magisterial ('authoritarian'), and largely deductive documents that reveal decidedly less than they might...' There is a strong discrepancy between the terseness of the Court's reasoning and the Advocate Generals' elaborateness, such as is apparent from Joined cases C-6/90 und C-9/90 Francovich [1991] ECR I-5357.

95 U. Everling, 'The Court of Justice as a Decisionmaking Authority', Michigan Law Review, 82 (1984), 1294-1310, 1308: 'The Court of Justice is constantly impressed to find what wide-reaching intentions and ideas are often read into its decisions.'

96 Lasser, Judicial Deliberations, 207-208. $\quad 97$ Lasser, Judicial Deliberations, 207-208.

98 See K.F. Röhl and H.C. Röhl, Allgemeine Rechtslehre (Cologne: Heymanns, 2008), 536-537. In contrast to EU law, German constitutional law opens the German legal order to the closing of lacunae,

This is an open access version of the publication distributed under the terms of the Creative Commons Attribution-NonCommercial-NoDerivs licence (http://creativecommons.org/licenses/by-nc-nd/3.0/), which permits non-commercial reproduction and distribution of the work, in any medium, provided the original work is not altered or transformed in any way, and that the work is properly cited. For commercial re-use, please contact academic.permissions@oup.com 
problem because with their help one might 'resolve the case by deducing from the existing rules a rule which is in conformity with the underlying premises on which the legal system is based'. ${ }^{99}$ This, however, has been criticized as a ploy of judicial lawmaking instead of 'legislative law-making. ${ }^{100}$ Hartley, a reliable critic of the Court, has had the following to say in this respect:

The European Court, on the other hand, has utilized general principles of law to cloak the nakedness of judicial law-making: the idea is that, if a ruling can be shown to be derived from a principle of sufficient generality as to command common assent, a firm legal foundation for the judgement will be provided. ${ }^{101}$

I will show in the following that it is not the use of legal principles by the Court as such which can be faulted. One might well discuss the establishment of general principles of Union law as an act of gap-filling. In this view, the Treaty is incomplete and this gap is filled by general principles such as fundamental rights. However, it is a different matter if the Court considers the Treaty incomplete by the standard set by general principles. In this case, general principles are not invoked to close a gap in Union law, but are employed to find a lacuna in the first place. ${ }^{102}$ This would also not be a problem from the methodological perspective when we consider general principles a part of the Union legal order, and thus a suitable point of reference for the establishment of a gap. There is, however, a methodological blemish if these two ways to use general principles, or even one specific general principle, are mashed together. Thus, it must be deemed as unduly self-referential if a general principle is invoked to find a gap, and then is invoked to close the same gap just found. Similarly, there is a problem with legal logic when a certain general principle is referred to in order to establish another general principle, and when both are consequently applied as if they were distinct from each other.

In the following sections, I will demonstrate why the use of loyalty as the basis for a strongly autopoietic legal reasoning is a major problem by discussing state liability and the Pupino case. Before I do this, let us briefly examine what has been submitted in defence of the specific style of reasoning displayed by the Court.

\subsection{The Defence of 'Formal Reasoning'}

Poiares Maduro has presented the Court's style in a more positive light by claiming that the judicial practice of not explicating the choice between two or more possible interpretations of the Treaty would uphold 'an image of neutrality and impartiality'. ${ }^{103}$ Even if we consider formal reasoning a deliberately chosen approach by the Court and not

and general principles in German law are, thus, rather concretizations of constitutional principles. AG Mazák in Case C-411/05 Palacios de la Villa [2007] ECR I-8531, para 85: 'By formulating general principles of Community law - pursuant to its obligation under Article $220 \mathrm{EC}$ to ensure observance of the law in the interpretation and application of the Treaty - the Court has actually added flesh to the bones of Community law, which otherwise - being a legal order based on a framework treaty - would have remained a mere skeleton of rules, not quite constituting a proper legal "order" ...'. See Joined cases 7/56 and 3-7/57 Algera $v$ Common Assembly [1957-58] ECR 39, at 55.

99 Tridimas, General Principles, 17-18.

100 See W. Buerstedde, Juristische Methodik des Europäischen Gemeinschaftsrechts (Baden-Baden: Nomos, 2006).

101 Hartley, Foundations, 133.

102 This problem is perhaps referred to by Tridimas, General Principles, 19, who mentions the Case C-70/88 Parliament v Council (Chernobyl) [1990] ECR I-2041 as an example of this.

103 Poiares Maduro, 'Interpreting European Law', 20-22.

This is an open access version of the publication distributed under the terms of the Creative Commons Attribution-NonCommercial-NoDerivs licence (http://creativecommons.org/licenses/by-nc-nd/3.0/), which permits non-commercial reproduction and distribution of the work, in any medium, provided the original work is not altered or transformed in any way, and that the work is properly cited. For commercial re-use, please contact academic.permissions@oup.com 
rather the expression of the lowest possible judicial denominator, there are some serious problems with this approach. ${ }^{104}$ Firstly, Conway has insisted correctly that justification is central to legal reasoning. ${ }^{105}$ Dialectic reasoning as the studied consideration of alternative possible interpretations requires that discretion is made explicit. ${ }^{106}$ Thus, already the lack of alternatives disclosed in the Court's judgments may per se fault the outcome of some cases. Moreover, I would submit that this style makes it easier for the Court to present decisions as logical from a legal perspective, when they are in fact conscious choices to meet a certain 'legal-political' objective, such as to protect the autonomy of the Union legal order or to ensure the effectiveness of its instruments. Over the years, this may have had the desired side effect of creating the retrospective impression of the inevitability of the development of EU law. ${ }^{107}$ As it has been put by Temple Lang, 'Article 10 is the legal basis for a number of fundamental 'constitutional' principles of Community law that are now so well established... that nobody looks for their legal basis any longer'. ${ }^{108}$ Indeed, the more we tend to accept the inevitability and quasi-automatism of the development of Union law in this foundational period, the less it matters precisely by which rationale the Court came to its findings. Moreover, it may also disguise a lack of proper methodology or any consistency in employing legal concepts and principles such as loyalty and those principles related to it, as I will explain further later.

Such lack of substantive reasoning is especially deplorable in cases that can be qualified as judicial development of the law, or even as examples of judicial activism. ${ }^{109}$ In performing the exercise of balancing the interest in the functioning of the Union and the uniform and effective application of its legal regime on the one hand, with the interest of the Member States in retaining their regulatory freedom on the other, the Court is not always rationalizing its findings beyond the 'formal reasoning' mentioned earlier. ${ }^{110}$ Take the Mangold case, which has met with strong, sometimes even angry, opposition, especially in Germany, whose national law was found non-applicable as a result. ${ }^{11}$ In this case, the Court held that 'the principle of non-discrimination on grounds of age

${ }^{104}$ I hesitate to see formal reasoning as a method in view of the apparent lack of theoretical underpinning.

105 Conway, The Limits of Legal Reasoning, 161, N. MacCormick, Legal Reasoning, 100-101.

106 Conway, The Limits of Legal Reasoning, 161.

107 See, for this term, N. MacCormick, Questioning Sovereignty (Oxford: Oxford Univ. Press, 2001), 107.

108 J. Temple Lang, 'Article 10 EC: The Most Important "General Principle” of Community Law', in U. Bernitz, J. Nergelius, and C. Cardner (eds), General Principles of EC Law in a Process of Development (The Hague: Kluwer Law International, 2008), 75-113, 76.

109 See Craig and de Búrca, EU Law, 65: 'It is equally important for such judicial decision-making to be fully reasoned.' R. Streinz and C. Herrmann, 'Der Fall Mangold: Eine "kopernikanische Wende im Europarecht"?', Recht der Arbeit, (2007), 165-169, 169: 'Für die Dogmatik des Gemeinschaftsrechts bleibt zunächst das Desiderat nach einer besser nachvollziehbaren Argumentation des EuGH zumindest bei Urteilen, die von ihm selbst offenbar als grundlegend eingeschätzt werden.' (For the analysis of Union law remains the wish for a more transparent reasoning of the ECJ, at least regarding judgments, which itself appears to consider as fundamental.) See also Arnull, 'Judicial Activism and the Court of Justice', 28-29, who rejects 'judicial activism' as an appropriate term, and deplores case law that 'confounds our expectations by overturning apparently settled principles without adequate justification or explanation of their wider implications'.

110 For a different perspective, see von Bogdandy, 'Rechtsfortbildung', 21.

111 Case C-155/04 Mangold [2005] ECR I-9981. See M. Herdegen, 'General Principles of EU Law: The Methodological Challenge', in U. Bernitz, J. Nergelius, and C. Cardner (eds), General Principles of EC Law in a Process of Development (The Hague: Kluwer Law International, 2008), 343, 345; L. Gerken et al., 'Mangold als ausbrechender Rechtsakt (Munich: Sellier, 2009). See the literature cited by Streinz and Herrmann, 'Der Fall Mangold', fn 2. See, however, the apposite reposte by Arnull, 'Judicial Activism and the Court of Justice', 11, that such criticism is rarely based on a developed theory of where the limits of the judicial function are located.

This is an open access version of the publication distributed under the terms of the Creative Commons Attribution-NonCommercial-NoDerivs licence (http://creativecommons.org/licenses/by-nc-nd/3.0/), which permits non-commercial reproduction and distribution of the work, in any medium, provided the original work is not altered or transformed in any way, and that the work is properly cited. For commercial re-use, please contact academic.permissions@oup.com 
must... be regarded as a general principle of Community law', since it exists 'in various international instruments and in the constitutional traditions common to the Member States'. ${ }^{112}$ The Court reasoned the existence of this general principle in two sentences, thereby brushing aside the denial of (full) horizontal direct effect of Union directives, one of the only matters on which it has so far displayed judicial self-restraint. It might have been possible to show that a prohibition of discrimination on grounds of old age was not alien to most Member States, is now included in the Charter of Fundamental Rights, and that the substance of the judgment was thus well grounded. ${ }^{113}$ However, the Court, sitting in Grand Chamber, chose to substitute reasoning for affirmation. ${ }^{114}$ This has prompted the warning that cases such as Mangold and the Court's 'unwillingness or inability' to explain satisfactorily how new developments can be reconciled with established case law 'have made severe legal uncertainty one of the defining characteristics of the modern era'. ${ }^{115}$

Hence, what is called formal reasoning tends to conceal methodological deficiencies, while presenting the outcome in a case as the only logical and legally conceivable option. In other words, a line should be drawn between the competence of the Court to develop the law and the way this is actually done. With loyalty, this is, however, only the starting point. In the following section, we will see how the issues we have discussed, viz. reasoning with general principles, telos, and terseness, all come together when we look at the way the Court has employed the principle of loyalty in the foundational case law.

\subsection{Deconstructing State Liability}

Recall that, initially, the Court founded state liability on effectiveness in Francovich. This rationale has been questioned even by generally friendly voices in the literature. ${ }^{116}$ In later case law, we have observed the same phenomenon with state liability that I have already noted with regard to the jurisprudence on supremacy: The Court at some point no longer legitimized the invocation of the principle of effectiveness by referring to the Treaty. Instead, it simply stated the existence of the pertinent principle without mentioning its legal basis. It is not far-fetched to assume that the fact that the emphasis shifted slightly to the Article 4 (3) TEU rationale in cases following Francovich can be explained as a reaction to this criticism of the doctrine.

Effectiveness in Francovich acquired an independent function that no longer seemed to require a reference to the Treaty as authority. This underpins the observation by Ross that ' $[t]$ his particular technique has a self-legitimating aspect, since the seemingly stable

112 Case C-155/04 Mangold [2005] ECR I-9981, paras 74-75. See M. Ross, 'Effectiveness in the European Union Legal Order(s): Beyond Supremacy to Constitutional Proportionality?', European Law Review, (2006), 476-498, 493-495.

113 See, among others, M. Dougan, 'In Defence of Mangold?', in A. Arnull et al. (eds), A Constitutional Order of States?: Essays in EU Law in Honour of Alan Dashwood (Oxford and Portland, Oregon: Hart Publishing, 2011), 219-244.

114 See Craig, 'The ECJ and Ultra Vires Action', 421-422, showing what a coherent reasoning of the Court could have looked like.

115 A. Arnull, 'The Principle of Effective Judicial Protection in EU Law: An Unruly Horse?', European Law Review, (2011), 51-70, 69. See also Craig, 'The ECJ and Ultra Vires Action', 421.

116 See C. Tomuschat, 'Das Francovich-Urteil des EuGH: Ein Lehrstück zum Europarecht', in O. Due, M. Lutter, and J. Schwarze (eds), Festschrift fuer Ulrich Everling, Vol. II (Baden-Baden: Nomos, 1995), 1585-1609, 1593, who has doubted whether the principle of effectiveness permits compelling deductions (stringente Ableitungen).

This is an open access version of the publication distributed under the terms of the Creative Commons Attribution-NonCommercial-NoDerivs licence (http://creativecommons.org/licenses/by-nc-nd/3.0/), which permits non-commercial reproduction and distribution of the work, in any medium, provided the original work is not altered or transformed in any way, and that the work is properly cited. For commercial re-use, please contact academic.permissions@oup.com 
and entrenched nature of effectiveness can compensate or camouflage the novelty of the development which it is invoked to justify'. ${ }^{117}$ Indeed, if the principle of effectiveness is presented as a legal given, the Court saves one argumentative step in deducing a new institute of law such as state liability. Put differently, with effectiveness being taken for granted, the Court could more easily carry that thought to a higher level. Loyalty, invoked in Brasserie du Pêcheur in the present context as an additional rationale for state liability, shares the constitutionalizing function with this application of effectiveness. What distinguishes loyalty from effectiveness is that the latter is not about conflicts between Union measures and national measures, such as the principle of state liability is not about the prevention or resolution of conflicts, but about nullification.

Recall that effectiveness had been derived neither by induction nor by deduction from the Treaty, but it was presented as being rooted in loyalty in cases such as Rewe. Therefore, when the Court stated in Brasserie du Pêcheur that effectiveness and loyalty are the basis of state liability, it makes three principles of Union law out of one. It could be argued that loyalty gave birth to effectiveness, and that effectiveness gave birth to state liability. If we only consider the Francovich constellation, where state liability was invoked to prop up the effect of directives, in particular where direct effect is wanting, we might furthermore note that loyalty has also been one of the foundations of the direct effect of directives. Finally, only in subsequent cases such as Factortame did the Court refine and put flesh on the principle of state liability. ${ }^{18}$ Thus, we might even say that at the time of Francovich one ambiguous and undefined principle, viz. effectiveness, begot another principle of Union law of a similarly opaque nature, viz. state liability. ${ }^{119}$

This remarkable, double circularity of reasoning that is centred on loyalty is summarized in the following diagram (Figure 13.2):

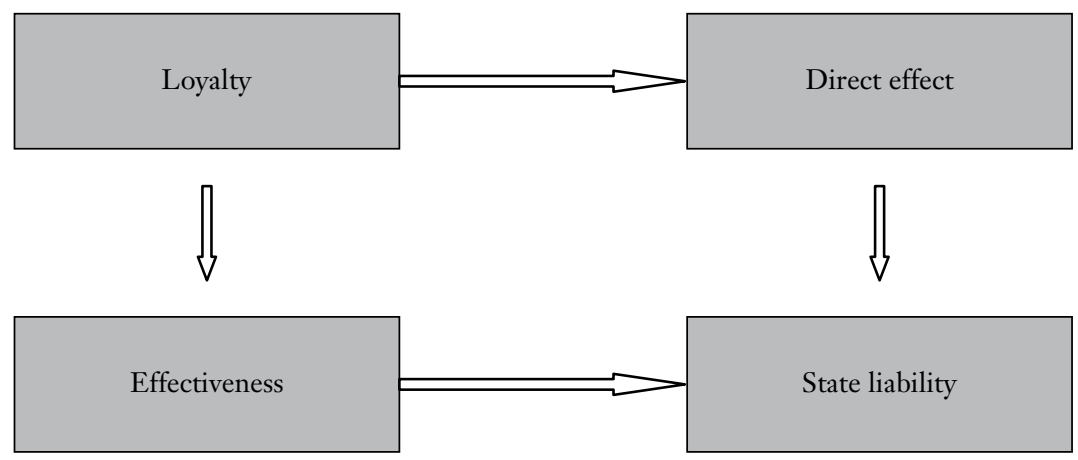

Figure 13.2 Loyalty and Self-reference in Justifying State Liability

117 Ross, 'Effectiveness', 481.

118 R. Nazzini, 'Potency and Act of the Principle of Effectiveness: The Development of Competition Law Remedies and Procedures in Community Law', in C. Barnard and O. Odudu (eds), The Outer Limits of European Union Law (Oxford and Portland, Oregon: Hart Publishing, 2009), 401-435, 416.

119 Lasser, Judicial Deliberations, 210-211, arrives at a similar conclusion with regard to AG Tesauro's Opinion in Brasserie du Pêcheur with his critique on what he calls meta-purposive argumentation, whereby 'one telos is piled upon the next until the debate expressly revolves around the very structure, purpose, and existence of the Community legal order as a whole. What is in question and what drives the analysis is - to use AG Tesauro's terms - 'the system of the treaty'. The argument therefore operates at an utterly fundamental level of systemic debate'.

This is an open access version of the publication distributed under the terms of the Creative Commons Attribution-NonCommercial-NoDerivs licence (http://creativecommons.org/licenses/by-nc-nd/3.0/), which permits non-commercial reproduction and distribution of the work, in any medium, provided the original work is not altered or transformed in any way, and that the work is properly cited. For commercial re-use, please contact academic.permissions@oup.com 


\subsection{Deconstructing Pupino}

In Pupino, considerations of effectiveness played a multifaceted role. Firstly, the Court invoked effet utile to affirm its jurisdiction to hear the case, responding to arguments by some Member States that the reference jurisdiction under ex Article 35 TEU (Nice version) was not as broad as that under ex Article 234 EC. ${ }^{120}$ Secondly, the Court countered the claim that the Nice Treaty contained no provision equivalent to ex Article 10 EC by arguing that it would be difficult for the Union to carry out its task effectively if the principle of loyal cooperation were not also binding in the area of police and judicial cooperation in criminal matters. ${ }^{121}$ With this, as already discussed, the Court exported an obligation incumbent on Member States concerning directives in the former first pillar to framework decisions under the former third pillar. ${ }^{122}$ Let us take a closer look at how precisely the Court arrived at this conclusion.

Recall that the obligation to interpret national law in light of directives had been based on loyalty and on Article 288 TFEU. ${ }^{123}$ In von Colson, the Court mentioned the binding objective of a directive that would require Member States to take all measures necessary 'to ensure the fulfilment of that obligation'. ${ }^{124}$ Hence, the central argument of the Court in justifying indirect effect was contingent on the specific nature of (Union) directives. If this is compared with the reasoning in Pupino, we should note that the Court in this case did not make the connection between the objectives of framework decisions and loyalty. The key to the finding in Pupino was the admissibility of exporting ex Article $10 \mathrm{EC}$ to the former third pillar. Hence, the core of the rationale in von Colson, i.e. the connection between the objective of the legal instrument and loyalty, was not reflected in Рирino and seems to have been taken as a given. This abridged presentation of indirect effect can be seen as a forebear of the statement in Pfeiffer on the inherent nature of indirect effect. ${ }^{125}$

What the Court added in Pupino is a reliance on the effectiveness principle ('It would be difficult for the Union to carry out its task effectively if the principle of loyal cooperation...'). Loyalty was extended to the former third pillar because otherwise the tasks of the Union under this pillar could not be carried out effectively. Put differently, the argument of the Court went as follows: Since effectiveness is inherent in the whole of Union law, loyalty must apply within the former third pillar, and indirect effect must thus apply to framework decisions as well. Arguably, it would have been the same if the Court had claimed that loyalty is inherent in the entirety of Union law. However, this might have come too close to stating that indirect effect itself is an obligation inherent in the whole of Union law. While this was the reasoning later in Pfeiffer, as mentioned, such an argumentative short cut in Pupino would probably have met with even greater protestations than the reasoning actually proffered.

120 Case C-105/03 Pupino [2005] ECR I-5285, para 38: 'That jurisdiction would be deprived of most of its useful effect if individuals were not entitled to invoke framework decisions in order to obtain a conforming interpretation of national law before the courts of the Member States.' On this, see critically, M. Fletcher, 'Extending "Indirect Effect" to the Third Pillar: The Significance of Pupino', European Law Review, 30 (2005), 862-877, 871-872, noting that the reference to merely 'most of its useful effect' alluded to the fact that the preliminary reference procedure has a much wider scope than the interpretation of framework decisions.

121 Case C-105/03 Pupino [2005] ECR I-5285, para 39.

122 See Ross, 'Effectiveness', 483 for the 'export' metaphor. As discussed, the inter-pillar transfer of loyalty is validated by the Lisbon Treaty, which applies the former Community loyalty provision to the entire Union law regime.

123 See Chapter 3. $\quad 124$ Case 14/83 von Colson [1981] ECR 1891, para 26.

125 Joined cases C-397/01 and C-403/01 Pfeiffer [2004] ECR I-8835.

This is an open access version of the publication distributed under the terms of the Creative Commons Attribution-NonCommercial-NoDerivs licence (http://creativecommons.org/licenses/by-nc-nd/3.0/), which permits non-commercial reproduction and distribution of the work, in any medium, provided the original work is not altered or transformed in any way, and that the work is properly cited. For commercial re-use, please contact academic.permissions@oup.com 

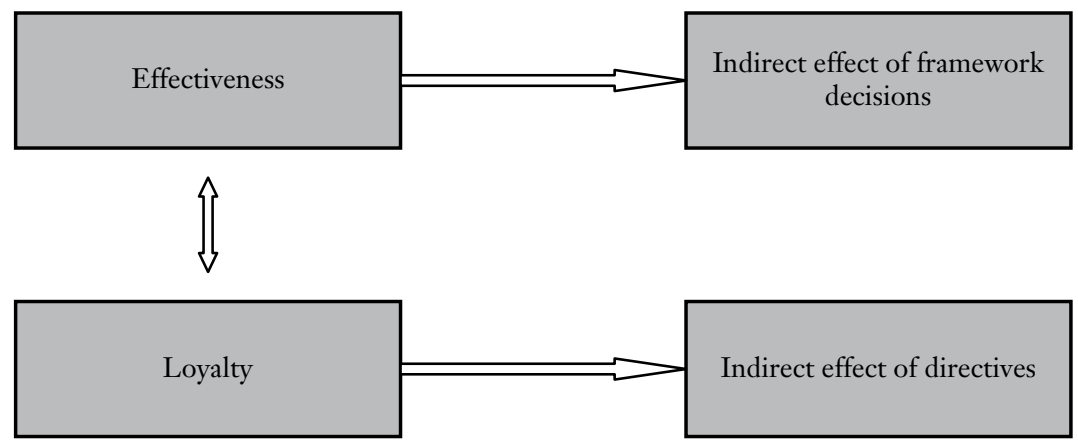

Figure 13.3 Loyalty and Self-reference in Pupino

I would claim that, in fact, effectiveness did not have any additional, specific explanatory merit in this case, for the following reason. If effectiveness was applicable in the former third pillar and effectiveness was based on loyalty, as argued earlier, this means that loyalty must have been applicable in the former third pillar. What then was the reason for the argumentative detour via effectiveness? I would suggest that effectiveness in Pupino provided a strong and nearly irrefutable rationale, which could be presented as being distinct from both loyalty and indirect effect. With this, criticism that such a strong principle of Union law as loyalty was simply exported to another pillar could be avoided. The reliance on effectiveness has therefore adroitly been described as disingenuous by Ross in the present context. ${ }^{126}$

Moreover, if we again consider the connection between loyalty and effectiveness, the reasoning of the Court in Pupino is revealed as highly self-referential. The above illustration (Figure 13.3) summarizes this peculiar line of arguments.

\section{Conclusion}

What is now provided in Article 4 (3) TEU has spawned several other essential principles of Union law of decreasing scope and/or force. I have shown that loyalty works on two levels: First, it creates legal institutes such as direct effect or indirect effect. In a next argumentative step, it props up the enforcement of these instruments under the title of the principle of effectiveness, which, however, is itself closely related to loyalty. We might say that consequently Member States 'suffer' doubly by virtue of a single Treaty provision. ${ }^{127}$

126 Ross, 'Effectiveness', 481: 'There is also, perhaps, a disingenuousness to the appeal of effectiveness as a rationale for development - who, after all, would advocate rules, methods or systems that proclaimed themselves to be ineffective?'

127 See for a contrasting view, Conway, The Limits of Legal Reasoning, 140, who does not see this connection. His claim that the case law on reciprocal duties of the Union institutions to the Member States shows that the loyalty principle cannot be invoked in presumption of favouring intergration in any situation of interpretative doubt, in this light might need to be qualified.

This is an open access version of the publication distributed under the terms of the Creative Commons Attribution-NonCommercial-NoDerivs licence (http://creativecommons.org/licenses/by-nc-nd/3.0/), which permits non-commercial reproduction and distribution of the work, in any medium, provided the original work is not altered or transformed in any way, and that the work is properly cited. For commercial re-use, please contact academic.permissions@oup.com 
The relation of effet utile, effectiveness, but also of supremacy, thus, reminds us a bit of the Russian doll model. The Court, as we have seen, metaphorically either piles loyalty based arguments upon each other, such as in the case law on state liability, or various permutations of loyalty are coalesced to provide a seemingly compelling chain of reasoning such as in the Pupino case. Loyalty resembles a methodological perpetuum mobile in its self-referential usage by the Court. I would suggest that, for want of any other methodological standards that could be applied to feats of judicial lawmaking by the Court, it is this practice that is the most critical and the most questionable, at least when referring to the matters of interest in this study.

This is an open access version of the publication distributed under the terms of the Creative Commons Attribution-NonCommercial-NoDerivs licence (http://creativecommons.org/licenses/by-nc-nd/3.0/), which permits non-commercial reproduction and distribution of the work, in any medium, provided the original work is not altered or transformed in any way, and that the work is properly cited. For commercial re-use, please contact academic.permissions@oup.com 


\section{4}

\section{Amplification and the Limits of Loyalty}

\section{Introduction}

At the end of Chapter 12, I summarized that loyalty serves in Union law as lex generalis, as an independent legal basis for distinct obligations, as a supporting legal basis, as a rule of construction, and as a legal principle. There is, however, another possible form of application of Article 4 (3) TEU, when it is neither a self-sufficient legal basis nor merely has a supporting role. In constellations such as those discussed later, loyalty applies in conjunction with another legal basis to create obligations which could not be established by referring to the 'other' legal basis in isolation. The difference here is that loyalty does not merely reinforce an obligation primarily based on another provision, but that the respective obligation would not exist without combining a certain legal basis with loyalty. ${ }^{1}$

This effect of loyalty to transform Treaty rules into something they alone could not be may also be seen in a much broader context, which I shall discuss in the following under the term 'amplification'. I will show that the loyalty principle can transform the nature of Union law obligations, and that it can extend the scope of the application of Union rules in several distinct areas of Union law. Presumably because of the disparate case law displaying what I call amplification, this issue has so far not received too much attention in the literature or the existence of this effect of loyalty has been denied. ${ }^{2}$

Amplification will be discussed in relation to the following constellations. I will firstly examine loyalty as the basis for extending the application of competition law and the fundamental freedoms to matters originally not covered by the Treaty. This concerns the question of the range of measures that can be attributed to the Member States, and the circle of addressees of Treaty prohibitions. Here it will be shown that the role of loyalty with the fundamental freedoms, although presented as being in line with the cases on competition law, is rather a supporting one and not an amplifying one.

In this context, I will also discuss whether loyalty can help to solve incompatibilities between Union law and treaties between Member States (inter se treaties) by extending the bilaterally agreed benefits to all Member States. Secondly, I will distinguish cases where loyalty serves to transform Union law instruments that are not binding at all or are not binding for the Member States into measures that do constrain the Member States in a certain respect. This part, among other things, will discuss the judgment of the Court in the Hurd case.

I suggest moreover that the concept of amplification furnishes a suitable framework for thinking about the potential of loyalty to shape the scope of Union law to its (logical?) end.

1 Some borders are blurred, however, particularly between amplification and the supporting role, as I will show later in the comparision between the competition rules and the fundamenal freedoms.

2 See the conclusions of the FIDE Congress of 2000, produced in J. Temple Lang, 'The Development by the Court of Justice of the Duties of Cooperation of National Authorities and Community Institutions under Article 10 EC', Fordham International Law Journal, 31 (2008), 1483-1532, 1517, claiming that ex Art. 10 'is not a justification for making Community law rules broader, by analogy, than the relevant rules themselves'.

This is an open access version of the publication distributed under the terms of the Creative Commons Attribution-NonCommercial-NoDerivs licence (http://creativecommons.org/licenses/by-nc-nd/3.0/), which permits non-commercial reproduction and distribution of the work, in any medium, provided the original work is not altered or transformed in any way, and that the work is properly cited. For commercial re-use, please contact academic.permissions@oup.com 
I will therefore discuss in this Chapter whether loyalty could apply in conjunction with mere Treaty objectives and thus create legally binding obligations for the Member States. Furthermore, I will discuss whether loyalty might also apply in conjunction with Treaty principles and thus impose certain actions for the Member States to take or to abstain from. Besides providing an analytical framework for discussing various and seemingly unrelated lines of case law, this Chapter on amplification therefore also leads us to an exploration of the outer limits of loyalty. This of course is not the least of the concerns for the Member States being the main addressees of duties flowing from loyalty, and in light of recent case law emanating from the Court, which has invoked ex Article 10 EC to produce a greatly restraining effect, as we have discussed in the Part on Cohesion.

\section{The Amplification of Provisions of Primary and Secondary Law}

\subsection{Loyalty and Competition Law}

The initial concept laid down in the wording of the Treaty foresees quite clearly that the fundamental freedoms are directed at the Member States, while the competition law rules target the behaviour of natural and legal persons. ${ }^{3}$ In case law, this divide between the public and the private spheres has become increasingly blurred because of the difficulty in assigning certain enterprises either to the state or to the private sector. ${ }^{4}$ Thus, Articles 101 and 102 TFEU were also applied to public authorities engaging in economic activities. Conversely, private enterprises are not caught by the scope of these rules when they exercise powers that are characteristic of public law. ${ }^{5}$

More interestingly for our purposes, the Court has brought provisions of national law and national administrative practices within the scope of the competition rules when they adversely affect the application of the mentioned Treaty rules. ${ }^{6}$ Thus, Article 4 (3) TEU has been invoked in conjunction with ex Article 3 EC and Article 101 TFEU, obliging the Member States 'not to detract, by means of national legislation, from the full and uniform application of Community law or from the effectiveness of its implementing measures; nor may they introduce or maintain in force measures, even of a legislative nature, which may render ineffective the competition rules applicable to undertakings. ${ }^{7}$ This has also been called the INNO doctrine. ${ }^{8}$ It is inapplicable in cases

3 P. Oliver and W.-H. Roth, 'The Internal Market and the Four Freedoms', Common Market Law Review, (2004), 421.

4 S. Prechal and S. de Vries, 'Seamless Web of Judicial Protection in the Internal Market', European Law Review, 34:1 (2009), 5-24.

5 Case C-343/95 Diego Cali [1997] ECR I-1547. The public law powers entail that, in principle, the free movement rules apply.

6 See Case 45/85 Verband der Sachversicherer [1987] ECR 405, para 20.

7 Case C-332/89 Criminal Proceedings Against André Marchandise [1991] ECR I-1027, para 22. See also Case C-35/99 Criminal Proceedings Against Manuele Arduino [2002] ECR I-1529, paras 42 passim; Case C-198/01 Consorzio Industrie Fiammiferi (CIF) [2003] ECR I-8055, paras 45-46; Joined cases C-94/04 and C-202/04 Cipolla [2006] ECR I-11421; Case C-446/05 Criminal Proceedings Against Ioannis Doulamis [2008] ECR I-1377, para 19. Case 229/83 Leclerc [1985] ECR 1, para 20; Case 254/87 Syndicat des libraires de Normandie [1988] ECR 4457, para 15; Case 136/86 Yves Aubert [1987] ECR 4789, para 25; Case 267/86 Van Eycke [1988] ECR 4769, para 20; Case 231/83 Cullet [1985] ECR 305, para 16; Case C-60/91 Criminal Proceedings Against José António Batista Morais [1992] ECR I-2085, para 11 .

8 R. Whish and D. Bailey, Competition Law, 7th edn. (Oxford: Oxford Univ. Press, 2012), 218. See Case 13/77 SA G.B.-INNO-B.M. v Association des détaillants en tabac (ATAB) [1977] ECR 2115, para 31.

This is an open access version of the publication distributed under the terms of the Creative Commons Attribution-NonCommercial-NoDerivs licence (http://creativecommons.org/licenses/by-nc-nd/3.0/), which permits non-commercial reproduction and distribution of the work, in any medium, provided the original work is not altered or transformed in any way, and that the work is properly cited. For commercial re-use, please contact academic.permissions@oup.com 
where the national legislation did not encourage or extend an anti-competitive private agreement that had already existed before. ${ }^{9}$ A breach of Article 4 (3) TEU was affirmed if 'a Member State requires or favours the adoption of agreements, decisions or concerted practices contrary to Article 85 or reinforces their effects or deprives its own legislation of its official character by delegating to private traders responsibility for taking economic decisions affecting the economic sphere...' ${ }^{10}$

I would argue that the Court invoked Article 4 (3) TEU because this application of the competition law regime to governmental activity was never foreseen under the Treaty. Put in other words, loyalty was the requisite connection between the government and acts of private individuals, drawing within the scope of the competition regime that which was outside. ${ }^{11}$ The role of loyalty here arguably is different from its reinforcing function, such as with indirect effect. ${ }^{12}$ Without loyalty, it seems, Articles 101 and 102 TFEU could have never extended their reach to also target measures by the Member States. One can take the view that it is not particularly remarkable to apply Union rules to the Member States, who are the default addressees of obligations deriving from Union law. One might also remark that this case law is in line with the concepts of effet utile and effectiveness, further discussed later. However, I would suggest that loyalty operates differently here compared to when it is the basis for effects of Union law instruments, such as the direct or indirect effect of directives. Article 4 (3) TEU in the cases mentioned earlier prevents the Member States from being accomplices to violations of Union law by natural or legal persons. While this may make a lot of sense from a practical point of view, from a legal perspective it arguably changes nothing less than the scope of core Treaty provisions.

\subsection{Loyalty and the Fundamental Freedoms}

Such as with the competition rules, with the fundamental freedoms the Court adopted an expansive view of what it considers a state activity by attributing private action to the state when the latter controls the private measures. ${ }^{13}$ Moreover, the Court applied the free movement rules to private law entities when they, in place of the Member States, create or maintain obstacles to the functioning of the internal market. ${ }^{14}$ This application of the fundamental freedoms to measures by non-state entities has been referred to as the horizontal direct effect of the freedoms.

While it has been argued that the rationale for this case law was to ensure the effectiveness of the fundamental freedoms, ${ }^{15}$ it could also be said that private measures here are rather caught by their scope because perpetrators acted in lieu of the Member States. The Member States in these cases conferred organizations such as trade unions or sporting

9 Whish and Bailey, Competition Law, 220.

10 Case C-332/89 Marchandise [1991] ECR I-1027, para 22. See also Case C-185/91 Gebrüder Reiff [1993] ECR I-5801, para 14; Case C-153/93 Delta Schiffahrts- und Speditionsgesellschaft [1994] ECR I-2517, para 14. See also Case C-67/96 Albany International [1999] ECR I-5751, para 65; Case C-219/97 Maatschappij Drijvende Bokken [1999] ECR I-6121, para 55.

11 See, for this nice wording, Prechal and de Vries, 'Seamless Web of Judicial Protection', 23.

12 See the overview in Chapter 12.

13 Case C-249/81 Commission v Ireland (Buy Irish) [1982] ECR 4005.

14 See, among others, Case C-36/74 Walrave [1974] ECR 1405. Important examples of this are Case C-341/05 Laval [2007] ECR I-11767, paras 98 and 99, 104, 105, and Case C-438/05 Viking [2007] ECR I-10779, paras 78-79, where the Court qualified collective action by trade unions as restrictions pursuant to ex Art 49 or 56 TFEU. cf. Prechal and de Vries, 'Seamless Web of Judicial Protection', 15-18.

15 See Prechal and de Vries, 'Seamless Web of Judicial Protection', 14.

This is an open access version of the publication distributed under the terms of the Creative Commons Attribution-NonCommercial-NoDerivs licence (http://creativecommons.org/licenses/by-nc-nd/3.0/), which permits non-commercial reproduction and distribution of the work, in any medium, provided the original work is not altered or transformed in any way, and that the work is properly cited. For commercial re-use, please contact academic.permissions@oup.com 
associations with quasi-lawmaking powers. This can thus be compared to extending the meaning of what is the state, such as in the competition law cases assessed earlier. In the case law based on Article 4 (3) TEU that I have discussed, in contrast, Member States were not acting in a private capacity, but were enabling anti-competitive practices by private actors.

Another distinct issue is whether the fundamental freedoms can also cover measures by individuals acting in their private capacity, i.e. when they are not taking over tasks that could also be performed by the state. Loyalty has been suggested as a possible basis for such full horizontal effect, pointing to an obligation of the Member States to guarantee the effectiveness of free movement rules by protecting the rights granted to private individuals by the Treaty freedoms. ${ }^{16}$ This, one might add, also recalls the case law on the requirements to ensure the enforcement of secondary Union law acts, such as by providing for effective sanctions should the Union measure itself fail to do so. ${ }^{17}$

A radical version of full horizontal effect would apply the Treaty freedom in conjunction with Article 4 (3) TEU directly against an individual or against a non-state entity. ${ }^{18}$ This would de facto extend the Viking and Laval case law mentioned earlier to any sort of private measure, irrespective of its connection to state authority. Parts of the literature have expressed their preference for this effect, arguing that direct claims against the alleged perpetrators would promise a more effective way to end measures considered as disruptive for trade. ${ }^{19}$ However, this route has not been taken by the Court until now.

In a succession of judgments, the Court instead invoked Article 4 (3) TEU as the conjunct basis of a claim of infringement brought against Member States for not adequately safeguarding the freedoms against certain private action. ${ }^{20}$ It thus used loyalty to link the conduct of a Member State to qualified acts of individuals. ${ }^{21}$ The first pertinent case was the Spanish Strawberries decision, where the Commission brought a claim of infringement against France on the grounds of ex Article 10 EC in conjunction with ex Article $28 \mathrm{EC}$ (now Article 34TFEU). ${ }^{22}$ France had abstained from taking the necessary measures against French farmers, who agitated against Spanish strawberries and against fruits and vegetables from other Member States by, among other things, the interception of lorries, the destruction of their loads, violence against drivers, threats to wholesalers and retailers, and the damaging of goods on display in shops. ${ }^{23}$ AG Lenz, in his opinion in the case, noted the novelty of the question whether this may cause obligations for the Member State concerned, in light of the fact that ex Article $30 \mathrm{EC}$ is directed only against

16 Prechal and de Vries, 'Seamless Web of Judicial Protection', 20.

17 See Chapter 6.

18 The first case has been referred to as 'Art 10 EC-plus combinations', while the latter case has been labelled direct horizontal effect by Prechal and de Vries, 'Seamless Web of Judicial Protection', 19.

19 See the discussion at Prechal and de Vries, 'Seamless Web of Judicial Protection', 21-23.

20 The debate on the indirect effect of freedom rights has a long history in Germany, where it is run under the title 'mittelbare Drittwirkung der Grundrechte'. See O. Cherdnychenko, 'EU Fundamental Rights, EC Fundamental Freedoms and Private Law', European Review of Private Law, 14:1 (2006), 23-61. See also R. Alexy, Theorie der Grundrechte (Baden-Baden: Nomos, 1994), 484-493.

21 See A. Bleckmann, 'Art. 5 EWG-Vertrag und die Gemeinschaftstreue: Zugleich ein Beitrag zur Entwicklung des allgemeinen europäischen Verwaltungsrechts', Deutsches Verwaltungsblatt, (1976), 483-487, 487; R. Söllner, Art. 5 EWG-Vertrag in der Rechtsprechung des Europäischen Gerichtshofes (Munich: VVF, 1985), 15.

22 See Case C-265/95 Commission v France [1997] ECR I-6959.

23 Case C-265/95 Commission v France [1997] ECR I-6959, para 38. See also K. Mortelmans, 'Towards Convergence in the Application of the Rules on Free Movement and on Competition', Common Market Law Review, (2001), 613-649, at fn 95. cf. Oliver and Roth, 'The Internal Market and the Four Freedoms', 427.

This is an open access version of the publication distributed under the terms of the Creative Commons Attribution-NonCommercial-NoDerivs licence (http://creativecommons.org/licenses/by-nc-nd/3.0/), which permits non-commercial reproduction and distribution of the work, in any medium, provided the original work is not altered or transformed in any way, and that the work is properly cited. For commercial re-use, please contact academic.permissions@oup.com 
measures of Member States. ${ }^{24}$ He distinguished ex Article 5 EC from the corresponding principle of public international law, which attributes the acts of citizens to a state only when the state has not complied with a standard of due diligence. ${ }^{25}$ AG Lenz argued for a specific obligation of the EU Member States actively to safeguard the fundamental freedoms, drawing a parallel with earlier case law in the field of competition law already discussed. ${ }^{26}$ In his opinion, the amplification of the rules of competition law to the Member States would reflect a duty of abstention under what is now Article 4 (3) subparagraph 2 TEU, while the amplification of the fundamental freedoms would reflect a duty of action based on what is now provided in Article 4 (3) subparagraph 1 TEU. ${ }^{27}$

The Court, following the AG's opinion, held as follows:

Article 30 therefore requires the Member States not merely themselves to abstain from adopting measures or engaging in conduct liable to constitute an obstacle to trade but also, when read with Article 5 of the Treaty, to take all necessary and appropriate measures to ensure that that fundamental freedom is respected on their territory. ${ }^{28}$

Consequently, France was found in breach of ex Article 10 in conjunction with ex Article $28 \mathrm{EC}$, in view of the frequency and the seriousness of the incidents giving rise to the case. ${ }^{29}$ At the same time, the Court granted the Member States some discretion in determining the appropriate measures against such private action. ${ }^{30}$ This decision by the Court was confirmed by the case of Schmidberger, which found Austria in breach of what is now Article 4(3) TEU and Article 34TFEU for the blocking of the Brenner motorway as the result of a demonstration by an environmental group. ${ }^{31}$ It has been argued that the link between the state and the private measure was much closer in Schmidberger than in Commission v France and would not have required reliance on loyalty in addition to the freedom. ${ }^{32}$

When comparing the role of loyalty in the field of competition law discussed earlier, besides the distinction between the duty of abstention and the duty of action also emphasized earlier, the amplifying effect of loyalty seems less strong with the fundamental freedoms. While with the former, state action is added to the reach of a rule originally targeted only at private action, with regard to the latter case law the target is state action or state inaction. The inappropriateness of the reaction of the state to a private action gives rise to a claim of infringement, not the private measure itself. For this reason, it is

24 AG Lenz in Case C-265/95 Commission v France [1997] ECR I-6959, paras 7-9. He mentions, however, in para 44 the Case C-16/94 Dubois [1995] ECR I-2421 as a precursor.

25 AG Lenz in Case C-265/95 Commission v France [1997] ECR I-6959, paras 38-39.

26 AG Lenz in Case C-265/95 Commissionv France [1997] ECR I-6959, paras 41-42. As an 'obligation de moyens' and not 'de résultat'. See para 44.

27 AG Lenz in Case C-265/95 Commission v France [1997] ECR I-6959, paras 42-43.

28 AG Lenz in Case C-265/95 Commission v France [1997] ECR I-6959, para 32.

29 AG Lenz in Case C-265/95 Commission v France [1997] ECR I-6959, para 33.

30 AG Lenz in Case C-265/95 Commission v France [1997] ECR I-6959, para 33. Loyalty was also discussed as applying in conjunction with ex Art. 28 EC in Case C-470/03 A.G.M.-COS.MET Srl v Suomen valtio and Tarmo Lehtinen [2007] ECR I-2749, occasioned by statements by a Finnish government official concerning the danger of certain vehicle bridges in spite of their compliance with the safety requirements in the pertinent directive. The Finnish referring court raised the question whether these statements could be attributed to the Finnish state, or whether they should be qualified as private utterances. In the latter case, it asked whether ex Art. $10 \mathrm{EC}$ would have obliged Finland to react to these statements. The Court, however, did not address this second query. In her opinion, AG Kokott, para 126 , considered that no more serious interference on the part of Finland had been necessary in this case.

31 See Case C-112/00 Schmidberger [2003] ECR I-5659.

32 P. Oliver, 'Measures of Equivalent Effect I: General', in P. Oliver (ed.), Oliver on Free Movement of Goods in the European Union, 5th edn. (Oxford and Portland, Oregon: Hart, 2010), 84-156, 155.

This is an open access version of the publication distributed under the terms of the Creative Commons Attribution-NonCommercial-NoDerivs licence (http://creativecommons.org/licenses/by-nc-nd/3.0/), which permits non-commercial reproduction and distribution of the work, in any medium, provided the original work is not altered or transformed in any way, and that the work is properly cited. For commercial re-use, please contact academic.permissions@oup.com 
submitted that loyalty would not be required as a conjunctive legal basis here. It rather seems justified to qualify it merely as a supporting legal basis in this constellation. ${ }^{33}$

\section{Loyalty, the Prohibition of Discrimination, and Inter se Treaties}

\subsection{Introduction}

In this section, I will discuss case law and literature on what can be called the amplification of commitments under public international law treaties between Member States of the European Union. I will show that loyalty plays an important role in this respect, providing for solutions beyond supremacy. At the beginning, let me briefly summarize the law concerning the different constellations involving international agreements, recalling the ubiquitous role of loyalty as discussed so far.

In Chapter 1, I discussed Article 351 TFEU (ex Article 307 EC) on the prevention and resolution of conflicts between 'old' international agreements of Member States with Union law. Above all, this provision requires Member States to 'take all appropriate steps to eliminate the incompatibilities established'. I have mentioned that this conflict rule is a specification of Article 4 (3) TEU, ${ }^{34}$ and may lead to the renegotiation or even the denunciation of the respective Member State agreements. ${ }^{35}$ Thus, the Treaty expressly regulates the fate of Member State treaties with third states that were concluded prior to a certain point in time. ${ }^{36}$

The same principle applies to bilateral agreements with third states concluded by Member States after their accession to the EU, respectively after the date mentioned in Article 351 TFEU. These 'new' international ('external') agreements of EU Member States must also be compatible with Union law, and must at the least be renegotiated if they are not. Inapplicability is no solution in this case, since it does not resolve the public international law side of the conflict. Thus, if commitments undertaken by a Member State towards a third state conflict with Union law, the resolution is not to simply set aside public international law norms. ${ }^{37}$ Should two Member States both be parties to an international agreement, a disconnection clause may at least prevent the Member States from having to choose whether to apply between each other Union law or the public international law norm. As such, disconnection clauses have accurately been identified as an expression of Article 4 (3) TEU within the international law context. ${ }^{38}$

Agreements concluded between two Member States (bilateral inter se) are possible in areas falling outside the scope of Union law. In these areas, they are even sometimes expressly encouraged by the Treaty, such as under ex Article 293 EC with regard

33 For the qualification of the role of loyalty as merely supporting, see, among others, P. Szczekalla, 'GrundfreiheitlicheSchutzpflichten: Eine "neue” Funktion der Grundfreiheiten des Gemeinschaftsrechts', Deutsches Verwaltungsblatt, (1998), 219-224, 220. For a different perspective, see M. Jarvis, 'Case law', Common Market Law Review, 35:6 (1998), 1371-1383, 1378. See also AG Lenz in Case C-265/95 Commission v France [1997] I-6959, paras 8-11.

34 Joined opinion of AG Tizzano in Case C-466/98 Commission v UK [2002] ECR I-9427, para 38.

35 See C-62/98 Commission v Portugal [2000] ECR I-5171, para 49.

36 Case 235/87 Matteucci [1988] ECR 5589, para 21. See J. Klabbers, Treaty Conflict and the European Union (Cambridge: Cambridge Univ. Press, 2009), 120-126.

37 See further discussion on this point in Chapter 7.

38 M. Cremona, 'Disconnection Clauses in EU Law and Practice', in C. Hillion and P. Koutrakos (eds), Mixed Agreements Revisited: The EU and its Member States in the World (Oxford and Portland, Oregon: Hart Publishing, 2010), 160, 172.

This is an open access version of the publication distributed under the terms of the Creative Commons Attribution-NonCommercial-NoDerivs licence (http://creativecommons.org/licenses/by-nc-nd/3.0/), which permits non-commercial reproduction and distribution of the work, in any medium, provided the original work is not altered or transformed in any way, and that the work is properly cited. For commercial re-use, please contact academic.permissions@oup.com 
to the conclusion of double taxation treaties, relevant later. However, once bilateral inter se agreements of Member States come under Union law, supremacy applies as a matter of principle. ${ }^{39}$ This is irrespective of whether the Treaty concerned has been concluded prior to accession (old inter se treaties) or during membership (new inter se treaties). ${ }^{40}$ As such, national inter se agreements are not any different from 'normal' national law in their relation to Union law. ${ }^{41}$ It follows that commitments made by Member States between each other must not be applied to the extent that they conflict with Union law. ${ }^{42}$

In the following section, I will argue that supremacy, i.e. inapplicability, is not always the exclusive or the required solution to a conflict between Union law on the one hand, and an external or an inter se bilateral treaty of Member States on the other. Let me first, however, with the following figure (Figure 14.1) briefly summarize the legal situation with regard to the different possible interactions between international treaties of Member States and EU law.

Old external treaties

- Article 351 TFEU (specification of loyalty)

- Renegotiation/renouncation

Old inter se treaties

- Supremacy (based on loyalty)

- Inapplication with accession

New external treaties

- Supremacy vis-à-vis Member States

- Renegotiation/renouncation vis-à-vis third states

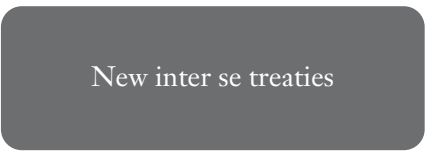

- Supremacy (based on loyalty)

- Other solutions based on loyalty?

Figure 14.1 Member State Treaties and Duties Flowing from Loyalty

39 Case 10/61 Commission v Italy [1962] ECR 1, 23.

40 Case 235/87 Matteucci [1988] ECR 5589, para 22: '... in matters governed by the EEC Treaty, that Treaty takes precedence over agreements concluded between Member States before its entry into force'. See A. Dimopoulos, 'The Validity and Applicability of International Investment Agreements between EU Member States under EU and International Law', 48:1 (2011), Common Market Law Review, 63-93, 70 for bilateral investment treaties (BITs).

41 See B. de Witte, 'Old-fashioned Flexibility: International Agreements between Member States of the European Union', in B. de Witte, D. Hanf and E. Vos (eds), The Many Faces of Differentiation in EU Law (Cambridge: Intersentia, 2001), 32-33.

42 In practice, multilateral inter se agreements, where not only Member States are party to the agreement, but also one or more third states, are the most complex ones. Legally, however, the solution on the external side here as well is renegotiation or denunciation in case of incompatibility with Union law.

This is an open access version of the publication distributed under the terms of the Creative Commons Attribution-NonCommercial-NoDerivs licence (http://creativecommons.org/licenses/by-nc-nd/3.0/), which permits non-commercial reproduction and distribution of the work, in any medium, provided the original work is not altered or transformed in any way, and that the work is properly cited. For commercial re-use, please contact academic.permissions@oup.com 


\subsection{The Matteucci Case}

Belgium had concluded a Cultural Agreement with Germany in 1956 providing that each party 'shall grant to nationals of the other party scholarships to enable them to undertake or continue studies or research in the other country or to complete their scientific, cultural, artistic or technical training. ${ }^{43}$ When Annunziata Matteucci, an Italian national living and working in Belgium, applied for such a scholarship, she was rejected on the grounds of her nationality. Thus, a bilateral agreement on a matter outside the competence of the Union (culture) discriminated against nationals of other Member States except from those of Belgium and Germany. Since the subject matter of the bilateral agreement in Matteucci did not come under the EEC Treaty, a reference to supremacy was not possible. Instead, the Court resorted to ex Article $5 \mathrm{EEC}$ and extended the prohibition of discrimination provided in Article 7 of Regulation 1612/68/EEC also to the field of culture and to the agreement in issue. ${ }^{44}$ The Court held as follows:

Article 5 of the Treaty provides that the Member States must take all appropriate measures, whether general or particular, to ensure fulfilment of the obligations arising out of the Treaty. If, therefore, the application of a provision of Community law is liable to be impeded by a measure adopted pursuant to the implementation of a bilateral agreement, even where the agreement falls outside the field of application of the Treaty, every Member State is under a duty to facilitate the application of the provision and, to that end, to assist every other Member State which is under an obligation under Community law. ${ }^{45}$

The Court considered the right to equal treatment under then Community law superior to a bilateral agreement of two Member States. ${ }^{46}$ What the Court decreed in Matteucci was not the disapplication of the national law of either Belgium or Germany, nor did it demand the disapplication of the bilateral agreement between these countries. Instead, the Court ordered that the benefits granted to nationals of the two Member States had to be extended to nationals from all other Member States. Rights under a bilateral inter se agreement were thus amplified to all Union citizens, they were 'multilateralized', thus putting into effect the rights granted to workers in the mentioned Regulation. The result was the same as if the Court had decided that the provisions in the agreement limiting its benefits to German and Dutch nationals could not be applied. Thus, while the solution in this case de iure was not based on supremacy, it was based on loyalty serving as a sort of replacement basis for the supremacy effect in an area outside of Community law.

It should be stressed that the result here could not have been achieved if there had not been the mentioned Regulation, providing for the right not to be discriminated against. It is therefore not entirely correct to state that the conflict in the Matteucci case was resolved by the 'unilateral extension by a Member State of favourable treatment provided under an agreement with another Member State to all EU nationals'. ${ }^{47}$ It is also not instructive to suggest that Article 4 (3) TEU has been applied in a flexible manner to

43 Case 235/87 Matteucci [1988] ECR 5589, para 19. See C. Durand, 'Le principe de coopération loyale entre les États membres et les institutions: les article 5 et 6 du traité CEE', in Commentaire Megret, Vol. I, 2nd edn. (Brussels: Éditions de l'Université de Bruxelles, 1992), 25-42, 40.

44 This provision states that a worker who is a national of a Member State is to enjoy, in the territory of the other Member States, the same social advantages as national workers; thus the worker must also be given the same advantages facilitating the acquisition of professional qualifications and social advancement. See para 11 of the Regulation.

45 Case 235/87 Matteucci [1988] ECR 5589, para 19.

46 See Case 235/87 Matteucci [1988] ECR 5589, para 21 on ex Art. 234 EC.

47 But see Dimopoulos, 'Validity and Applicability', 71.

This is an open access version of the publication distributed under the terms of the Creative Commons Attribution-NonCommercial-NoDerivs licence (http://creativecommons.org/licenses/by-nc-nd/3.0/), which permits non-commercial reproduction and distribution of the work, in any medium, provided the original work is not altered or transformed in any way, and that the work is properly cited. For commercial re-use, please contact academic.permissions@oup.com 
achieve this result. ${ }^{48}$ In Matteucci, loyalty extended a prohibition of discrimination in an act of secondary law to an area not covered by Union law, and afforded it precedence over a provision in a bilateral treaty limiting benefits to nationals of two Member States. ${ }^{49}$ Matteucci thus shows that loyalty may affect Member States also when they cooperate in an area that per se is outside the scope of Union law, if such cooperation conflicts with Union law obligations.

\subsection{The Question of MFN: Distinguishing Matteucci}

Whereas the Matteucci case has remained a singularity in case law, as far as we can see, it has been invoked in support of the existence of a principle of most favoured nation (MFN) in Union law. ${ }^{50} \mathrm{MFN}$ is a concept prominent especially in WTO law, prescribing that privileges granted by one WTO member to another member must also be granted to all other (member) states. ${ }^{51}$ Transferring MFN to Union law would extend privileges to third states not because a provision of national or Union law is enforced in spite of a more exclusive treaty provision, but because this extension is mandated directly by the MFN obligation. Indeed, the result in Matteucci, forcing Germany and Belgium to abandon the bilateral nature of their agreement, is strongly reminiscent of an MFN obligation. However, the rule that was enforced in this case was a specific non-discrimination rule provided for in a provision of secondary law. Loyalty amplified it to an area not covered by Union law and to a constellation not covered by supremacy. This is not an authority for a general obligation of MFN.

Moreover, other ECJ cases referred to in this context can be distinguished from Matteucci. Thus, the Gottardo case concerned a bilateral agreement on social security between Italy and Switzerland on the mutual taking into account of periods of insurance completed in the respective countries. ${ }^{52}$ The issue was whether this right must equally be granted to nationals of other Member States. ${ }^{53}$ The solution in this case was based directly on the prohibition of discrimination in ex Articles 12 and $39 \mathrm{EC}$ in conjunction with the supremacy principle. As a result, the limitation as regards the nationality of the entitled persons in the international agreement of Italy was not applied to citizens from other Member States. Note that the pertinent agreement did not lose much of its initial value for Italy, since the mutual taking into account of pension entitlements continued to apply in its relation to Switzerland. In the Matteucci case, in contrast, the agreement between Belgium and Germany was largely deprived of its original purpose.

The Open Skies cases concerned bilateral air transport agreements between the US and several Member States individually. ${ }^{54}$ These agreements granted the US the right to refuse or withdraw the licences or authorizations of airlines resident in the respective

48 But see Dimopoulos, 'Validity and Applicability', 71.

49 See Klabbers, Treaty Conflict, 126, who concludes that the Court, while correct in not applying ex Art. 307 EC, 'in case of conflict, it simply places EC law as hierarchically superior, without bothering too add much argument or to analyse the situation in the light of international law'.

50 See K. Eicker, 'EC Tax Scene: Recent Developments Regarding Cross-Border Pensions: Landmark Decision by the ECJ in the Case C-55/00 Gottardo', Intertax, 4 (2002), 156. For a different view, see G. Kofler, 'Most-Favoured-Nation Treatment in Direct Taxation: Does EC Law Provide For Community MFN in Bilateral Double Taxation Treaties?', Houston Business and Tax Law Journal, (2005), 1-89, 36.

51 See Art. I GATT, Art. II GATS, Art. 4 TRIPS.

52 Case C-55/00 Gottardo [2002] ECR I-413.

53 The case fell squarely within the scope of application of Union law.

54 See, e.g., Case C-467/98 Commission v Denmark(Open Skies) [2002] ECR I-9519, para 128.

This is an open access version of the publication distributed under the terms of the Creative Commons Attribution-NonCommercial-NoDerivs licence (http://creativecommons.org/licenses/by-nc-nd/3.0/), which permits non-commercial reproduction and distribution of the work, in any medium, provided the original work is not altered or transformed in any way, and that the work is properly cited. For commercial re-use, please contact academic.permissions@oup.com 
Member State, when a substantial part of the ownership and effective control was not vested in that Member State or in nationals of that Member State or American nationals. The Court decided that such 'nationality clauses' potentially prevented EU airlines of one Member State from establishing in another Member State and offering direct air service from that Member State to the US. ${ }^{55}$ This has been interpreted as showing that a Member State must extend the rights it confers to third states to other Member States, likening it to MFN. ${ }^{56}$ However, in contrast to the Matteucci case, the privileges of the Member States in the Open Skies cases were not extended to the other Member States. Instead, the offending clauses had to be renegotiated, which is the normal implication of an incompatibility of external bilateral treaties with Union law, as explained earlier. In addition, different from Matteucci, the subject matter of the Open Skies cases came within the scope of Union law because of secondary law in force at the time of the conclusion of the agreements. This means that not only was there no MFN treatment decreed by the Court, there was also no comparable amplification as regards the effect of supremacy beyond the scope of Union law, such as in Matteucci.

The MFN analogy, moreover, has been discussed in the context of bilateral treaties for the avoidance of double taxation (DTTs) concluded between various EU Member States. Direct taxation is an area, similar to culture, where competence lies primarily with the Member States. ${ }^{57}$ Bilateral treaties on this matter must not violate Union law, including in particular the free movement of capital, in the same way as the general rule concerning external bilateral agreements, as explained in the beginning of this section. Thus, the Court decided that a Member State party to a DTT must grant the advantages provided by it to permanent establishments of companies resident in another Member State under the same conditions as those applying to its own companies on grounds of Union law non-discrimination. ${ }^{58}$ Beyond this application of the non-discrimination rule, it has been argued for MFN treatment based on ex Article 10 EC, requiring Member States to grant all bilateral concessions agreed upon in an international treaty with a non-Member State to all other Union citizens. ${ }^{59}$

The case law of the Court has so far avoided a clear statement on MFN in these matters. ${ }^{60}$ This has also been the case in the most recent cases of $D^{61}$ and $A C T^{62}$.

55 Case C-467/98 Commission v Denmark (Open Skies) [2002] ECR I-9519, paras 131-132: 'It follows that Community airlines may always be excluded from the benefit of the air transport agreement between the Kingdom of Denmark and the United States of America, while that benefit is assured to Danish airlines. Consequently, Community airlines suffer discrimination which prevents them from benefiting from the treatment which the host Member State, namely the Kingdom of Denmark, accords to its own nationals. Contrary to what the Kingdom of Denmark maintains, the direct source of that discrimination is not the possible conduct of the United States of America but the clause on the ownership and control of airlines, which specifically acknowledges the right of the United States of America to act in that way.'

56 See Kofler, 'Most-Favoured-Nation Treatment in Direct Taxation', 51.

57 See Case C-376/03 D [2005] ECR I-5821, para 32.

58 Case C-307/97 Saint-Gobain [1999] ECR I-6161, paras 57-59; Case C-376/03 D [2005] ECR I-5821, para 32. See, on this, A.P. Dourado, 'From the Saint-Gobain to the Metallgesellschaft Case: the Scope of Non-discrimination of Permanent Establishments in the EC Treaty and the Most-Favoured-Nation Clause in EC Member States Tax Treaties', EC Tax Review, (2002), 147-156.

59 Kofler, 'Most-Favoured-Nation Treatment in Direct Taxation', 34.

60 See Case C-279/93 Schumacker [1995] ECR I-225. By contrast, in his opinion delivered on 22 November 1994, the AG discussed the issue of MFN treatment and found that the denial of MFN treatment would breach EC law.

61 Case C-376/03 D [2005] ECR I-5821. See D. Weber, 'Most-Favoured-Nation Treatment under Tax Treaties Rejected in the European Community: Background and Analysis of the D Case-A Proposal to Include a Most-Favoured-Nation Clause in the EC Treaty', Intertax, (2005), 429-444; J. Schuch,

“"Most-favoured-nation clause" in Tax Treaty Law', EC Tax Review, (1996), 161.

62 Case C-374/04 D [2005] ECR I-5821.

This is an open access version of the publication distributed under the terms of the Creative Commons Attribution-NonCommercial-NoDerivs licence (http://creativecommons.org/licenses/by-nc-nd/3.0/), which permits non-commercial reproduction and distribution of the work, in any medium, provided the original work is not altered or transformed in any way, and that the work is properly cited. For commercial re-use, please contact academic.permissions@oup.com 
The former concerned a German resident complaining about being taxed less favourably under the Netherlands-German DTT compared to other EU residents under Dutch DTTs concluded with other Member States. ${ }^{63}$ In the request for preliminary ruling by the Dutch court in the $D$ case, queries on discrimination and the fundamental freedoms had priority over the issue of MFN. ${ }^{64}$ The Advocate General also argued for MFN treatment only if specific conditions were fulfilled. ${ }^{65}$ The Court referred to the inherent peculiarity of DTTs of granting reciprocal rights and obligations only to persons resident in one of the two contracting Member States. ${ }^{66}$ It also pointed to the fact that the Treaty, as mentioned, explicitly acknowledged their existence before the Lisbon Treaty, and that no unifying or harmonizing measures for the elimination of double taxation, as foreseen by ex Article 293 EC, had been adopted at Union level. ${ }^{67}$ Since the Court found the situation of taxable persons residing in different Member States as not being comparable, it consequently found no grounds for a claim of discrimination. ${ }^{68}$

I would submit that the reason why the Court approached this case and others from the discrimination perspective is that a Union rule was available, which prohibited discriminatory treatment in the field of application concerned. Despite the fact that direct taxation does not fall under Union law, discriminatory treatment in this context comes under the common market rules. To claim that the Court, in $D$ and $A C T$, confirmed the existence of MFN in Union law misses this crucial point. Also in Matteucci, as mentioned, there was discrimination since the only aim of the bilateral agreement on scholarships in Matteucci was to award their own nationals special rights. Even if the Court in $D$ had examined whether residents coming under different DTT regimes were in a comparable position, a rule such as Article 7 of Regulation 1612/68/EEC would still be missing, and with it a rule providing that benefits granted in one Member State must also be granted to citizens from other Member States.

\subsection{Conclusion}

What makes the Matteucci case special is that the area concerned fell outside the scope of Union law. In such a constellation, loyalty may replace supremacy as the legal basis for the inapplicability of national law or of bilateral agreements of a Member State

63 The tax treaty concluded between the Netherlands and Belgium grants residents of Belgium holding property in the Netherlands tax benefits. Comparable benefits, however, are not available under the bilateral treaty between Germany and the Netherlands. This was claimed to cause an impermissible difference in treatment between Belgian and German residents. See Kofler, 'Most-Favoured-Nation Treatment in Direct Taxation', 52-53 for further details of the cases.

64 Whether EU law, 'preclude[s] legislation under which a domestic taxpayer is always entitled to deduction of a tax allowance in respect of wealth tax, whereas a foreign taxpayer has no such entitlement in the case where the assets in question are situated predominantly in the taxpayer's State of residence (in which no wealth tax is levied).' Only the second question asked whether it makes a difference 'that the Netherlands has, under a bilateral treaty, granted to residents of Belgium, who in all other respects are in comparable circumstances, entitlement to the tax allowance (where no wealth tax is levied in Belgium either)'.

65 Opinion of AG Colomer in Case C-376/03 D [2005] ECR I-5821, para 97. See also at para 95: ‘... the object of a bilateral double taxation convention is to prevent income which is taxed in one State from being taxed again in the other, not to confer upon taxpayers the tax status which is most favourable to them in each case'. For a detailed discussion of the AG's conclusions see G. Kofler, 'Generalanwalt zur Kapitalverkehrsfreiheit und Meistbegünstigung bei DBA-Anwendung', Österreichische Steuerzeitung, (2004), 558 passim.

66 Case C-376/03 D [2005] ECR I-5821, para 61.

67 Case C-376/03 D [2005] ECR I-5821, para 50.

68 Case C-376/03 D [2005] ECR I-5821, para 61.

This is an open access version of the publication distributed under the terms of the Creative Commons Attribution-NonCommercial-NoDerivs licence (http://creativecommons.org/licenses/by-nc-nd/3.0/), which permits non-commercial reproduction and distribution of the work, in any medium, provided the original work is not altered or transformed in any way, and that the work is properly cited. For commercial re-use, please contact academic.permissions@oup.com 
conflicting with Union law. However, in Matteucci this 'quasi' MFN could not have applied if there had not been the non-discrimination rule in Regulation 1612/68/EEC. A prohibition of discrimination such as ex Art 12 EGV (now Article 18 TFEU) would not have been a sufficient basis for such an outcome. The other cases discussed earlier can be distinguished from this either because there was no inapplicability, such as in the Open Skies cases, or because the subject matter did not fall outside the application of the Treaty, such as in the Gottardo and DTT cases. There is thus no principle of MFN in Union law, when we understand this as the extension of bilaterally agreed privileges to all Member States, without the application of another rule of Union law causing such extension to the specific case.

In the following section, I will discuss a kind of 'reverse' effect when compared to the effect that loyalty has on bilateral treaties of Member States. Instead of drawing 'extra-Union' legal acts into the scope of Union law, in the cases discussed later loyalty extends the application of internal Union measures to the Member States. With internal Union measures, I will refer to legal acts with initially no binding effect on the Member States.

\section{The Amplification of Internal Union Rules}

\subsection{Staff Regulations}

Recall that the Gottardo case discussed earlier concerned the taking into account of pension entitlements between individual Member States and the discrimination this may entail. There is other case law also dealing with the taking into account of periods of employment for the purpose of entitlements to an early retirement pension. These cases do not concern bilateral agreements between Member States, but national laws discouraging employment within an institution of the European Union by making a citizen lose the right to benefit under the respective national scheme. Thus, the Court found that this 'cannot be accepted in the light of the duty of genuine cooperation and assistance which Member States owe the Community and which finds expression in the obligation laid down in Article $10 \mathrm{EC}$ to facilitate the achievement of the Community's tasks'. ${ }^{69}$ The Court continued:

Consequently, the reply to the question referred must be that Article 10 EC, in conjunction with the Staff Regulations, must be interpreted as meaning that national legislation which does not permit years of employment completed by a Community citizen in the service of a Community institution to be taken into account for the purposes of entitlement to an early retirement pension under the national scheme is contrary to those provisions. ${ }^{70}$

This amplifies staff regulations of the Union to bind the Member States in an area where they are supposed to have regulatory autonomy. The underlying rationale is the concern for the functioning of Union law, or, more precisely, of the Union institutions. I have discussed this rationale in Chapter 1 on reverse loyalty in connection with inter-institutional duties. What is different here is that ex Article $10 \mathrm{EC}$ established binding obligations for the Member States from an internal Regulation containing rules of employment for Union staff.

A similar constraint was imposed in a case against Belgium for enacting legislation that provided for allowances overlapping with those payable under the staff regulations. ${ }^{71}$

69 Case C-293/03 Gregorio My Case [2004] ECR I-12013, para 48.

70 Case C-293/03 Gregorio My Case [2004] ECR I-12013, para 48.

71 Case 186/85 Commission v Belgium (Family Allowances) [1987] ECR 2029.

This is an open access version of the publication distributed under the terms of the Creative Commons Attribution-NonCommercial-NoDerivs licence (http://creativecommons.org/licenses/by-nc-nd/3.0/), which permits non-commercial reproduction and distribution of the work, in any medium, provided the original work is not altered or transformed in any way, and that the work is properly cited. For commercial re-use, please contact academic.permissions@oup.com 
Although the Court held that there is no obligation on the Member States to regulate such a situation, it found that by passing 'provisions affecting the application of the staff regulations and amending an earlier practice consistently followed by it', Belgium had infringed ex Article 5 EEC. ${ }^{72}$

\subsection{Inter-institutional Agreements}

The rules of the United Nations Food and Agriculture Organization (FAO) required the Community and the Member States to indicate their respective competence and right to vote on agenda items. In light of this, the Council and the Commission had concluded an arrangement regarding the preparation for FAO meetings, statements, and voting, setting up a coordination procedure between the Commission and the Member States to decide on the exercise of responsibilities or on statements on a particular point. Among other things, this arrangement provided that the Commission should speak and vote for the Community where an agenda item deals with matters of exclusive Community competence, and that Member States should speak and vote where an agenda item deals with matters of national competence. ${ }^{73}$ The $\mathrm{FAO}$ arrangement continued by providing:

Where an agenda item deals with matters containing elements both of national and of Community competence, the aim will be to achieve a common position by consensus. If a common position can be achieved:

- the Presidency shall express the common position when the thrust of the issue lies in an area outside the exclusive competence of the Community. Member States and the Commission may speak to support and/or to add to the Presidency statement. Member States will vote in accordance with the common position;

- the Commission shall express the common position when the thrust of the issue lies in an area within the exclusive competence of the Community. Member States may speak to support and/or add to the Commission's statement. The Commission will vote in accordance with the common position. ${ }^{74}$

With regard to the FAO Agreement to Promote Compliance with International Conservation and Management Measures by Fishing Vessels on the High Seas, the Commission had proposed a vote by the Community. However, the Committee of Permanent Representatives (Coreper) decided that the Member States should vote on the matter, arguing that the thrust of the agreement fell within the area of conservation and management of fishery resources. ${ }^{75}$ The Commission brought an action for the annulment of this decision by the Fisheries Council. ${ }^{76}$

72 Case 186/85 Commission v Belgium (Family Allowances) [1987] ECR 2029, para 40.

73 See Case C-25/94 Commission v Council (FAO) [1996] ECR I-1469, para 7. cf. P. Eeckhout, EU External Relations Law: Legal and Constitutional Foundations, 2nd edn. (Oxford: Oxford Univ. Press, 2011), 212-214; J. Heliskoski, 'Internal Struggle for International Presence: the Exercise of Voting Rights within the FAO', in A. Dashwood and C. Hillion (eds), The General Law of EC External Relations (Oxford: Oxford Univ. Press, 2000), 79; J. Sack, 'The European Community's Membership of International Organisations', Common Market Law Review, 32 (1995), 1227-1256.

74 See Case C-25/94 Commission v Council (FAO) [1996] ECR I-1469, para 7.

75 See Case C-25/94 FAO [1996] ECR I-1469, paras 9-16. There was another problem for the Commission since the exercise of the voting right in a matter is indication of the distribution of competence between the (then) Community and the Member States according to the FAO rules. See para 36.

76 See AG Jacobs in Case C-25/94 FAO [1996] ECR I-1469, para 2, who considered this case a test with regard to the representation of the (then) Community in international organizations, after

This is an open access version of the publication distributed under the terms of the Creative Commons Attribution-NonCommercial-NoDerivs licence (http://creativecommons.org/licenses/by-nc-nd/3.0/), which permits non-commercial reproduction and distribution of the work, in any medium, provided the original work is not altered or transformed in any way, and that the work is properly cited. For commercial re-use, please contact academic.permissions@oup.com 
In its judgment, the Court recalled the importance of close cooperation between the Member States and the institutions in an area of shared competence. ${ }^{77}$ It continued by stating:

In the present case, section 2.3 of the Arrangement between the Council and the Commission represents fulfilment of that duty of cooperation between the Community and its Member States within the FAO. It is clear, moreover, from the terms of the Arrangement, that the two institutions intended to enter into a binding commitment towards each other. Nor has the Council contested its effect at any moment in the proceedings. ${ }^{78}$

Consequently, the Court found the Council to be in breach of section 2.3 of the arrangement by giving the Member States voting rights, since the pertinent draft agreement concerned an issue the thrust of which did not lie within an area of exclusive competence. ${ }^{79}$ Member States thus were bound by an arrangement between the Commission and the Council which they had not even negotiated in their role as Member States. ${ }^{80}$ The crucial argument for admitting the case in the first place was that, while the Member States were not a party to the arrangement, they were nonetheless affected by it in practice. I would submit that the Court here needed to resort to loyalty in order not only to enforce the spirit of the arrangement as an expression of a general duty to cooperate, but in order to enforce its specific provisions.

Hence, ex Article $10 \mathrm{EC}$ was central for establishing binding and enforceable obligations for the Member States in this case, in spite of the fact that they were not a party to the arrangement between the Commission and the Council. However, I would not argue that the Court derived these obligations directly from ex Article 10 EC. ${ }^{81}$ Instead, what it did was to amplify the scope of application of the inter-institutional agreement to the Member States. Technically, it is submitted, the obligations themselves were not provided by or derived from ex Article $10 \mathrm{EC}$. They were based in the inter-institutional agreement, and were 'merely' extended to the Member States.

\section{The Hurd Case}

The Hurd case concerned two agreements under public international law that were the legal basis for the European schools, which provide schooling for the children of officials and servants of the Union in their mother tongues. ${ }^{82}$ Teachers received a salary paid by

the Commission had deplored during the Opinion 1/94 proceedings the manner in which the (then) Community and the Member States were represented in the FAO.

77 See Case C-25/94 FAO [1996] ECR I-1469, para 48. See, among others, Opinion 1/94 WTO [1994] ECR I-5267, para 108. See further Chapter 10.

78 See Case C-25/94 FAO [1996] ECR I-1469, para 49.

79 Case C-25/94 FAO [1996] ECR I-1469, para 50.

80 AG Jacobs, in his Opinion in Case C-25/94 FAO [1996] ECR I-1469, para 72, referred to the duty of cooperation in such treaty constellations, but argued that 'it is by no means suggested that there was a breach of the obligation of cooperation on the part of any of the Community institutions or on the part of any of the Member States'. This might have been because he saw the terms of the arrangement as fulfilled and the dispute over the exercise of the voting right as less important compared to the fact that a common position was reached. There is, however, the impression that the AG did not consider the arrangement as legally binding in all details as long as the general spirit of cooperation was satisfied.

${ }^{81}$ But see, in this sense, C. Hillion, 'Mixity and Coherence in EU External Relations: The Significance of the "Duty of Cooperation"', 93-94; cf. Eeckhout, External Relations Law, 214.

${ }_{82}$ Case 44/84 Hurd [1986] ECR 29. The one was the statute of the European school, and the second a protocol on the setting up of European schools. These gave the board of governors, composed of national and Union representatives, the right to adopt provisions concerning the rights and obligations of the teaching staff in these schools.

This is an open access version of the publication distributed under the terms of the Creative Commons Attribution-NonCommercial-NoDerivs licence (http://creativecommons.org/licenses/by-nc-nd/3.0/), which permits non-commercial reproduction and distribution of the work, in any medium, provided the original work is not altered or transformed in any way, and that the work is properly cited. For commercial re-use, please contact academic.permissions@oup.com 
their national authorities and a supplement paid by the European school. According to a decision taken before the accession of the UK to one of the agreements, members of the teaching staff should not pay taxes on the European supplement; instead, they should only be taxed on the national salary in their respective state of origin. In addition, the European schools should grant a 'differential' allowance to compensate for this domestic taxation to the extent it exceeds the charges applying to officials of the European community. ${ }^{83}$ Should a Member State tax the European supplement, the school would refund the tax by means of the differential allowance, which may itself be taxed nationally. The crucial point was, however, that the Community paid the difference between the European school's own income and the national salaries of the teachers and, on the other hand, the total budget of the European School. ${ }^{84}$ Any additional payment for the teaching staff therefore fell directly on the Union budget. ${ }^{85}$

The case came before the Court because the UK tried to tax a British teacher in a European school situated in the UK on the European supplement and other allowances. Loyalty had already been the central argument brought forward by the referring national authority as well as by Mr Hurd, in contrast to other landmark cases discussed in Chapter 3. The Court started by stating that the international agreements concerned and the measures adopted on their basis were not an integral part of Community law, that it therefore could interpret their scope, but not do so 'for the purpose of defining Member States' obligations'. ${ }^{86}$ Moreover, it held that the EC Treaty did not apply to the statute of the European school or to decisions adopted on its basis. ${ }^{87}$ For this reason, the Court also refused to apply the mutual duties of cooperation imposed in its case law, since these would only protect the functioning of Union institutions. ${ }^{88}$ Nevertheless, the Court based its argument on loyalty, considering that the UK tax practice reverberated on the Union budget, and because it feared this might set an example for other Member States. According to the Court, ex Article 5 EEC obliges Member States 'to refrain from any unilateral measure that would interfere with the system adopted for financing the Community and apportioning financial burdens between the Member States' ${ }^{89}$ 'The Court even stopped short of finding this obligation to be directly effective. ${ }^{90}$

Hence, although the rules on the European schools could not be interpreted to the detriment of the Member States, the Member States were bound by loyalty in the decisions on their implementation. I would submit that the Hurd case is another example of the importance of the Union interest, discussed in Chapter 5. The Union interest here was the financial system of the (then) Community. Loyalty did not protect the integrity and effectiveness of Union secondary law, but its application was placed in reference to a specific interest of the European Union. This was enough to activate the obligations provided in what is today Article 4 (3) TEU.

I discuss this case under the part on amplification, since there are certain analogies to some other case law discussed earlier. Same as in the Matteucci case, the context in the Hurd case was an agreement under public international law. While in Matteucci loyalty trumped the lack of competence of the Union in the pertinent area, in Hurd it overcame the fact that the agreements regulated an institution entirely outside of the Union framework. In all the cases, loyalty was the only rule that could possibly be applied, with

83 Case 44/84 Hurd [1986] ECR 29, para 41.

85 Case 44/84 Hurd [1986] ECR 29.

87 Case 44/84 Hurd [1986] ECR 29, para 37.

88 Case 44/84 Hurd [1986] ECR 29, paras 38-39. Case 230/81 Luxembourg v European Parliament [1983] ECR 255. See Chapter 1.

89 Case 44/84 Hurd [1986] ECR 29, para 48.
84 Case 44/84 Hurd [1986] ECR 29, para 42. Case 44/84 Hurd [1986] ECR 29, para 20.

90 Case 44/84 Hurd [1986] ECR 29.

This is an open access version of the publication distributed under the terms of the Creative Commons Attribution-NonCommercial-NoDerivs licence (http://creativecommons.org/licenses/by-nc-nd/3.0/), which permits non-commercial reproduction and distribution of the work, in any medium, provided the original work is not altered or transformed in any way, and that the work is properly cited. For commercial re-use, please contact academic.permissions@oup.com 
supremacy not being applicable. In all of these cases, loyalty protected interests of the Union, such as the interest in a united international representation in the FAO case, the interest in the functioning of Union institutions in Gottardo, and the interest in the equal share of the financial burden in Hurd.

However, the Hurd decision is different from the other cases discussed with respect to one detail. In all other cases, loyalty applied in conjunction with other Treaty provisions, secondary law, or other legal acts. Thus, Treaty prohibitions of discrimination were amplified in the fundamental freedoms case law, competition law rules were amplified in the pertinent case law, a Regulation was amplified in the Matteucci case, and in the case law on internal Union rules the specific obligations were derived from staff regulations and an inter-institutional agreement, respectively. In the Hurd case, in contrast, what is now Article 4 (3) TEU was applied by itself as the only legal basis for the prohibition imposed on the UK. Recalling our picture earlier summarizing the different roles of loyalty, the Hurd case must therefore be listed next to MOX Plant as an example of providing a distinct legal basis for Union law obligations.

In the following section, I will discuss whether Article 4 (3) TEU could also provide the basis for prescriptions to safeguard the Treaty objectives, Treaty principles, or even the mere spirit of the Treaty. We will thus also discuss the possible limitations of loyalty in amplifying the Union interest and Treaty provisions.

\section{The Limits to Amplification}

\subsection{Loyalty and the Objectives of the Union}

Recall that the third sentence of Article 4 (3) provides that the Member States 'shall facilitate the achievement of the Union's tasks and refrain from any measure which could jeopardise the attainment of the Union's objectives'. This abstention duty is therefore not linked to specific regulatory powers of the Union; instead, it seems to refer to the objectives listed in Article 3 TEU. ${ }^{91}$ It is true that duties flowing directly from the Treaty objectives are at odds with the commonly held view that these objectives are not capable of producing binding obligations by themselves. ${ }^{92}$ However, I would argue that, at least in one of the foundational cases discussed in this book, the Court has clearly brought the linkage between the Treaty objectives and loyalty to the fore, and seemingly has derived binding obligations for the Member States on this basis.

As I have explained, in ERTA the main argument of the Court was based on a combined reading of ex Article 5 EEC and ex Article 3 EEC on transport policy, in order to rationalize the duty of the Member States to refrain from entering into international agreements when the Union has enacted common rules in a specific matter. ${ }^{93}$ It seems that in the ERTA case no more was needed than a combination of a Treaty objective with the loyalty principle to constrain the Member States in their external capacity. According to this reading, the Treaty objective, for the attainment of which a certain common rule had been enacted, had to be 'protected' against conflicting international commitments

91 See J.-P. Terhechte, 'Art. 3 EUV', in E. Grabitz, M. Hilf, and M. Nettesheim (eds), Das Recht der Europäische Union (Munich: Beck, 2010), para 27.

92 See Terhechte, 'Art. 3 EUV', 28.

93 If these two provisions [Articles 3 and 5] are read in conjunction, it follows that to the extent to which Community rules are promulgated for the attainment of the objectives of the Treaty, the Member States cannot, outside the framework of the Community institutions, assume obligations which might affect those rules or alter their scope. See Terhechte, 'Art. 3 EUV', para 22.

This is an open access version of the publication distributed under the terms of the Creative Commons Attribution-NonCommercial-NoDerivs licence (http://creativecommons.org/licenses/by-nc-nd/3.0/), which permits non-commercial reproduction and distribution of the work, in any medium, provided the original work is not altered or transformed in any way, and that the work is properly cited. For commercial re-use, please contact academic.permissions@oup.com 
by the Member States. While this is not the only way to read this judgment, ${ }^{94}$ as far as I can see, ERTA has remained the only important case to date where the Court has combined ex Article $3 \mathrm{E}(\mathrm{E}) \mathrm{C}$ with what is now Article 4 (3) TEU to arrive at binding obligations for the Member States. The Lisbon Treaty no longer provides for a list of policy objectives in the TFEU. Instead, the TEU provides for a list of very general objectives in Article 3 TEU, which is the successor of the old Article 2 TEU. Still, reference to Treaty objectives is made in many other provisions of the Treaty, such as in Article 5 TEU on conferral, subsidiarity, and proportionality. The Treaties also speak of objectives with regard to the Common Foreign and Security Policy (CFSP) in Article 21 (2) TEU, in Article 19 (1) TFEU on the Union's anti-discrimination policy, and in Article 26 TFEU on the internal market. In fact, most parts of the TFEU on the policies of the Union use the term objectives to refer to the aims the Union must or may pursue in the respective area. For this reason, despite the abolition of ex Article $3 \mathrm{EC}$, we can assume that there would be enough points of reference for the obligation provided in Article 4 (3) TEU to constrain the Member States in virtually all areas of Union law if the only decisive additional element were the existence of policy objectives for the Union. Moreover, the Treaty objectives would be very malleable hooks on which to hang binding obligations for the Member States.

In Chapter 5, I proposed a different understanding of what should be meant by objectives in the context of loyalty and Article 4 (3) TEU. Recall that I argued that Treaty objectives should only produce binding effects on the Member States if they have been concretized by acts of the Union (institutions). ${ }^{95}$ This is also the reason why, before the exercise of a non-exclusive competence by the Union (to achieve Treaty objectives), there can only be constraints on the Member States in exceptional circumstances, as I have proffered in Chapter 7 . This can also be supported by taking a second look at ERTA. Although, as mentioned, it seems that the Court's argument was solely based on ex Article 3 EEC combined with loyalty, the decisive additional element arguably was that a Union regulation existed at that time. ${ }^{96}$ Thus, the Court did not protect the pure, 'naked' Treaty objective of having a common transport policy. Instead, the reason why Member States were pre-empted from entering into international agreements in this field was that this objective had been moulded into a concrete regulation specifying the ways and the means the Union had decided to pursue this objective.

I would therefore argue that the Treaty objectives by themselves cannot provide the point of reference for the duties contained in Article 4 (3) TEU. Thus, in some contradiction to the wording of Article 4 (3) TEU, the mere objectives of Union action as stated in various places in the Treaties are not sufficient to trigger the application of loyalty-based duties for the Member States. Put into other words, loyalty does not amplify the scope or effect of Treaty objectives.

In the following section, I will discuss case law where it is not the objectives provided in the Treaties but the aims stated in specific Treaty provisions that were amplified by loyalty.

94 See Chapter 3.

95 But compare the conclusions of the FIDE Congress of 2000, produced in Temple Lang, 'The Development by the Court of Justice of the Duties of Cooperation', 1517 passim, claiming that ex Art. $10 \mathrm{EC}$ would only create duties together with 'some other rule of Community law, or some principle or objective of Community policy which is to be facilitated or, at least, not jeopardized'.

${ }_{96}$ Regulation EEC No. 543/69 on the harmonization of certain social legislation relating to road transport. See Case 22/70 ERTA [1971] ECR 263, para 28.

This is an open access version of the publication distributed under the terms of the Creative Commons Attribution-NonCommercial-NoDerivs licence (http://creativecommons.org/licenses/by-nc-nd/3.0/), which permits non-commercial reproduction and distribution of the work, in any medium, provided the original work is not altered or transformed in any way, and that the work is properly cited. For commercial re-use, please contact academic.permissions@oup.com 


\subsection{Loyalty and the Aim of Treaty Provisions}

In Commission v Belgium, the Commission had incriminated Belgium for infringing Article 12 (b) of the Protocol on the privileges and immunities of the European Communities, which exempted officials and other servants of the (then) Community from the obligation to register in the population registers of the Member State of residence. ${ }^{97}$ By-laws of Belgian municipalities, while not directly requiring registration, had attached adverse fiscal consequences to a failure to register. The Court held:

It follows from that obligation [ex Article $5 \mathrm{EEC}$ ] that the Member States must refrain from adopting any measure which is incompatible with the provisions of Community law and, consequently, any measure which, contrary to Article 12 (b) of the Protocol, would have the effect of compelling officials and other servants of the Community, whether directly or indirectly, to apply for registration in the population registers. An indirect constraint of that kind is operative in particular where a Member State attaches unfavourable consequences to non-registration by officials and other servants of the Communities. ${ }^{98}$

On the occasion of another case, AG La Pergola has argued based on this decision that loyalty 'provides a sound legal basis for condemning as unlawful any conduct by a Member State which, although complying with the literal requirements of a provision of the Treaty, nevertheless runs counter to the aim pursued by that provision'. ${ }^{99} \mathrm{He}$ furthermore opined that the Court in Commission v Belgium had 'used the second paragraph of Article 5 [which is now the third paragraph]... as a provision dealing with indirect failure to observe tenets or principles implicit in the Treaty'. ${ }^{100}$ Situations that 'are not penalized by more specific provisions but nevertheless go against the aims of the Treaty' should be caught by the abstention duty under ex Article 5 EEC, which would thus apply as a fallback, sweeping up provision. ${ }^{101}$ However, contrary to this very far-reaching assessment by La Pergola, I would suggest that Commission v Belgium should be seen as casting judgment on the attempted circumvention of a Treaty rule rather than as a case about the extension of the scope of a Treaty provision to matters not covered by its literal meaning.

This is supported by other case law showing that there are limits to the amplification of the aims of Treaty rules. Thus, in Leclerc, the Court refrained from examining national legislation on the right to fix the retail prices of books in the light of ex Article 5 EEC in conjunction with ex Articles 3 and 85 EEC. It found that these provisions were not specific enough to preclude the Member States. ${ }^{102}$ In enforcement proceedings against France, the Commission unsuccessfully argued for extending the scope of the Treaty provisions on state aid to cover measures that have an effect on competition equivalent to that of state aid. ${ }^{103}$ French farmers had received a 'solidarity grant' paid by the National Agricultural Credit Fund, which was defended by the French government as

97 Case 85/85 Commission v Belgium [1986] ECR 1149.

98 Case 85/85 Commission v Belgium [1986] ECR 1149, para 22.

99 Opinion of AG La Pergola in Case C-16/94 Dubois and Cargo v Garonor [1995] ECR I-2421, para 12.

100 Opinion of AG La Pergola in Case C-16/94 Dubois [1995] ECR I-2421.

101 Opinion of AG La Pergola in Case C-16/94 Dubois [1995] ECR I-2421, para 11. The Court in Dubois, however, did not deal with the considerations of AG La Pergola with regard to a possible role of loyalty and resolved the pertinent case on the administering of the customs service by applying ex Arts. 9 and 12 EEC. See also AG Mancini in Case 290/83 Commission v France (National Agricultural Credit Fund) [1985] ECR 439.

102 Case 229/83 Association des Centres Distributeurs Édouard Leclerc and Others $v$ SARL 'Au blé vert' and Others [1985] ECR 1, para 20. See also Case 254/87 Syndicat des Libraires de Normandie v L'Aigle Distribution [1988] ECR 4457, para 15.

103 Case 290/83 National Agricultural Credit Fund [1985] ECR 439.

This is an open access version of the publication distributed under the terms of the Creative Commons Attribution-NonCommercial-NoDerivs licence (http://creativecommons.org/licenses/by-nc-nd/3.0/), which permits non-commercial reproduction and distribution of the work, in any medium, provided the original work is not altered or transformed in any way, and that the work is properly cited. For commercial re-use, please contact academic.permissions@oup.com 
not constituting a state measure. After the Commission had initially based its claim of infringement on a violation of ex Article 93 (2) EEC, it abandoned this path and instead started a new procedure based on ex Article 5 EEC, 'having regard to the objectives of the Treaty concerning competition'. ${ }^{104}$ In its decision, the Court emphasized the exclusive nature of the procedure for violations of the provisions on state aid, and concluded that 'Articles 92 and 93 [EEC] leave no scope for a parallel concept of "measures equivalent to aid" which are subject to different rules from those which apply to aid properly so-called'. 105 The Court also refrained from amplifying the scope of the Treaty provisions on state aid in the PreussenElektra case. ${ }^{106}$ The Commission had argued that in order to preserve the effectiveness of the state aid rules read in conjunction with ex Article 5 EC, it would be necessary to interpret the concept of state aid to include support measures decided upon by the state but financed by private undertakings. ${ }^{107}$ The Court responded as follows:

In those circumstances, Article 92 of the Treaty is in itself sufficient to prohibit the conduct by States referred to therein and Article 5 of the Treaty... cannot be used to extend the scope of Article 92 to conduct by States that does not fall within it. ${ }^{108}$

I would argue that the case law discussed earlier shows that when Union law provides a regulation for a certain matter that is complete and comprehensive, loyalty cannot be invoked to amplify its scope. Moreover, if the Treaty provides for a specific procedure such as on state aid, recourse to the general infringement procedure based on Article 4 (3) TEU is unavailable. ${ }^{109}$ This also means that the mere aims of a Treaty provision cannot justify the extension of its scope of application, such as it was not possible to extend the prohibition of state aid measures to measures having an equivalent effect.

This leaves the question of when we can assume that Treaty rules are sufficiently complete and comprehensive to exclude the amplifying application of loyalty. The only guidance on this is the Court's rebuttal of the argument by the Commission in PreussenElektra in favour of an analogy to the case law mentioned earlier on applying the competition rules to state measures. ${ }^{10}$ The ECJ pointed to the fact that, unlike ex Article 85 EC, which concerned only the conduct of undertakings, ex Article 92 EC referred directly to Member State measures. ${ }^{111}$ Indeed, as already argued, it is more 'logical' to apply to the state a Treaty prohibition that exceptionally is directed at individuals, than conversely holding individuals responsible under rules directed at the Member States. Both under the fundamental freedoms and with the competition law regime, the Court shifted the focus to the perpetration of the Member States. In contrast, in the case law the Court would have ordered something akin to full horizontal effect denied under the free movement of goods if it had attributed the pertinent measures to the state under ex Article 85 EC. Thus, one could suspect that Treaty rules might then not be comprehensive if some action by the Member States is not fully covered. This, however, very much limits the potential for amplification of the aims of Treaty provisions by virtue of loyalty.

104 Case 290/83 National Agricultural Credit Fund [1985] ECR 439.

105 Case 290/83 National Agricultural Credit Fund [1985] ECR 439, paras 16-18.

106 Case C-379/98 PreussenElektra [2001] ECR I-2099, para 63.

107 Case C-379/98 PreussenElektra [2001] ECR I-2099, para 63.

108 Case C-379/98 PreussenElektra [2001] ECR I-2099, para 65.

109 Case 290/83 National Agricultural Credit Fund [1985] ECR 439, para 16.

110 The jurisprudence of the Court on the duties of the Member States based on loyalty to introduce sanctions under national law if Union legislation does not do so cannot be argued in support here. This case law is not about the transformation of the scope or the effect of Union law itself. See Chapter 6.

111 Case C-379/98 PreussenElektra [2001] ECR I-2099, para 64.

This is an open access version of the publication distributed under the terms of the Creative Commons Attribution-NonCommercial-NoDerivs licence (http://creativecommons.org/licenses/by-nc-nd/3.0/), which permits non-commercial reproduction and distribution of the work, in any medium, provided the original work is not altered or transformed in any way, and that the work is properly cited. For commercial re-use, please contact academic.permissions@oup.com 


\subsection{Loyalty and the Treaty 'Corset'}

As shown earlier, the Court has ruled out recourse to a general procedure under the Treaty when a more specific procedure exists in the Treaty. ${ }^{112}$ The question is whether this tenet may also apply more generally to choices of Member States to act within the Treaty or to act outside the Treaty's framework. Weatherill predicted in 1994 that the Court may have to make a choice about how far it is prepared to go beyond supervising management of shared competence into the realm of invalidating denial of competence, implying action 'to prevent the fragmentation of the Community structure on which the Member States have unanimously agreed'. ${ }^{113}$ Peers has argued that Article 4 (3) TEU might be the basis of, on the one hand, a prohibition from creating 'competing' institutions in inter se treaties, and on the other, an obligation to use the EU institutions in such treaties. ${ }^{114}$ In his view, a thus created ambitious integration process covering a large part of EU law with competing institutions would necessarily violate Article 4 (3) TEU. ${ }^{115}$

Enhanced cooperation is a mechanism provided in Article $20 \mathrm{TEU}$ that comprises various elements of loyalty. ${ }^{116}$ If the requirements laid down in Articles 326 to 329 TFEU are fulfilled, ${ }^{117}$ enhanced cooperation allows nine Member States or more that 'wish' to enter into closer cooperation on a certain matter, to make use of the institutional infrastructure of the Union. According to Article 327 TFEU, the 'outsiders' must not impede the implementation of the enhanced cooperation by the participating Member States. ${ }^{118}$ This prohibition of frustration applies even though the acts adopted in the framework of enhanced cooperation only bind the participating Member States, and do not form a part of the 'acquis'. ${ }^{119}$ The rationale for this prohibition of frustration has been seen in Article 4 (3) TEU and its protection of the functioning of the Union. ${ }^{120}$ Indeed, as I have shown in Chapter 1, loyalty also protects the functioning of Union institutions. ${ }^{121}$ Loyalty could thus be seen as amplifying the effects of acts that are outside the scope of Union law. Again, loyalty draws something in that is 'outside'. ${ }^{122}$

The set up of enhanced cooperation under the Treaty therefore protects the integrity of the Sonderweg of a number of Member States qua a prohibition of frustration. Could

112 Case 290/83 National Agricultural Credit Fund [1985] ECR 439, para 16; Case C-379/98 PreussenElektra [2001] ECR I-2099.

113 S. Weatherill, 'Beyond Preemption?: Shared Competence and Constitutional Change in the European Community', in D. O'Keeffe and P.M. Twomey (eds), Legal Issues of the Maastricht Treaty (London: Chancery Law Publishing, 1994), 13, 32, referring to the social policy opt-outs of that time.

${ }_{114}$ S. Peers, 'Towards a New Form of EU Law?: The Use of EU Institutions outside the EU Legal Framework', European Constitutional Law Review, 9:1 (2013), 37-72, 70.

115 Peers, 'Towards a New Form of EU Law?', 71.

116 See the repeated references to loyalty by H.-J. Blanke, 'Art. 327 AEUV', in E. Grabitz, M. Hilf, and M. Nettesheim (eds), Das Recht der Europäische Union, Kommentar (Munich: Beck, 2011), paras 1,2 , and 3 .

117 See the references at H.-J. Blanke, 'Art. 20 EUV', in E. Grabitz, M. Hilf, and M. Nettesheim (eds), Das Recht der Europäische Union, Kommentar (Munich: Beck, 2010), para 26. See also Anonymous, 'Editorial Comments, Enhanced Cooperation: A Union à Taille Réduite or à Porte Tournante?', Common Market Law Review, 48 (2011), 317-327.

118 This privilege is not accorded to cooperation of the Member States outside the enhanced cooperation procedure. Thus, in theory, non-participating Member States are not prohibited qua Union law from impeding the implementation of such cooperation.

119 Art. 20 (4) TEU.

120 See M. Zuleeg, 'Art. 5 EGV', in H. v d Groeben, J. Thiesing, and C.-D. Ehlermann, EUVIEGV, 5th edn. (Baden-Baden: Nomos, 1997), para 10; H.-J. Blanke, 'Art 20 EUV', para 47.

121 See Chapter 1. See also Case Gottardo, discussed at note $52 . \quad 122$ See earlier note 11.

This is an open access version of the publication distributed under the terms of the Creative Commons Attribution-NonCommercial-NoDerivs licence (http://creativecommons.org/licenses/by-nc-nd/3.0/), which permits non-commercial reproduction and distribution of the work, in any medium, provided the original work is not altered or transformed in any way, and that the work is properly cited. For commercial re-use, please contact academic.permissions@oup.com 
we then also argue that Article 4 (3) TEU protects the integrity of the Treaty system by prohibiting enhanced cooperation unless it is done by using the mechanism provided in Article 20 TEU? ${ }^{123}$ This would mean that should nine Member States or more want to enter into closer cooperation on a certain matter, Article 4 (3) TEU would force them to use the mechanism for enhanced cooperation in Article 20 TEU. ${ }^{124}$ Conversely, this would bar Member States from cooperating outside the Treaty framework whenever such cooperation could also be done by applying Treaty rules. ${ }^{125}$

I would argue that, for several reasons, this is not convincing as a general proposition. Firstly, I would submit that while loyalty may protect the integrity of enhanced cooperation once this is established, this does not necessarily mean that it should protect the mechanism as such. The very cautious wording of Article 20 TEU does not support such 'exclusivity' of enhanced cooperation. ${ }^{126}$ Secondly, whereas Article 4 (3) TEU protects the objectives of the Union and obliges the Member States to support the realization of Union law, I would deny a relevant Union interest that its rules are applied whenever this is possible. Thus, Union law does not force Member States to orchestrate financial assistance to other Member States within the mechanisms provided for in the Treaties. Member States can provide financial support bilaterally or multilaterally without taking recourse to the instruments available to the European Central Bank (ECB) under the Treaty, as long as this does not violate the Treaty. ${ }^{127}$

Finally, we could also not point to an argument of lex specialis in analogy to the constellation in PreussenElektra, discussed earlier, because the EU Treaty cannot be considered lex specialis to agreements between the Member States under public international law. If multilateral or bilateral inter se treaties between Member States do not violate Union law, such extra-Union cooperation arguably is not per se prohibited. ${ }^{128}$

This conditional freedom of the Member States to conclude bilateral or multilateral inter se agreements is also expressed in Article 2 of the Treaty on Stability, Coordination and Governance in the European Monetary and Economic Union: ${ }^{129}$

1. This Treaty shall be applied and interpreted by the Contracting Parties in conformity with the Treaties on which the European Union is founded, in particular Article 4(3)

123 This must be distinguished from the right of the Member States, in areas which do not fall under the exclusive competence of the Union, to entrust tasks to the institutions, outside the framework of the Union, provided that those tasks do not alter the essential character of the powers conferred on those institutions by the EU and FEU Treaties. See Case C-370/12 Thomas Pringle v Government of Ireland, Ireland and The Attorney General [2012] ECR 00000, para 158.

124 See the references at Blanke, 'Art. 20 EUV', para 26. See also V. Constantinesco, 'Les clauses de coopération renforcée', Revue Trimesterielle de Droit Europeen, 33 (1997), 751, 755.

125 In this sense, B. Martenczuk, 'Die differenzierte Integration nach dem Vertrag von Amsterdam', Zeitschrift für Europarechtliche Studien, (1998), 447-474, 464, who has even argued for the pre-emption of the right of Member States to enter into international agreements to the extent enhanced cooperation is possible.

126 'Member States which wish to establish enhanced cooperation between themselves within the framework of the Union's non-exclusive competences may make use of its institutions and exercise those competences by applying the relevant provisions of the Treaties...' [emphasis added]. See also Blanke, 'Art. 20 EUV', para 26; M. Ruffert, 'Art. 20 EUV', in C. Calliess and M. Ruffert (eds), EUVIAEUV: Das Verfassungsrecht der Europäischen Union mit Europäischer Grundrechtecharta, 4th edn. (Munich: Beck, 2011), para 22.

127 See also the Schengen or the Prüm agreement. cf. Blanke, 'Art. 20 EUV', para 27.

128 But recall the special case of the judgment in Matteucci.

129 More complex is the agreement concluded by twenty-six Member States on 31 January 2012 to address the debt crisis in the European Union, and which conferred certain competences on the Commission and the Council. cf. P.P. Craig, 'The Stability, Coordination and Governance Treaty: Principle, Politics and Pragmatism’, European Law Review, 37 (2012), 231.

This is an open access version of the publication distributed under the terms of the Creative Commons Attribution-NonCommercial-NoDerivs licence (http://creativecommons.org/licenses/by-nc-nd/3.0/), which permits non-commercial reproduction and distribution of the work, in any medium, provided the original work is not altered or transformed in any way, and that the work is properly cited. For commercial re-use, please contact academic.permissions@oup.com 
of the Treaty on European Union, and with European Union law, including procedural law whenever the adoption of secondary legislation is required.

2. The provisions of this Treaty shall apply insofar as they are compatible with the Treaties on which the Union is founded and with European Union law. They shall not encroach upon the competences of the Union to act in the area of the economic union. ${ }^{130}$

While there thus is no general obligation based on Article 4 (3) TEU for the Member States to 'stay within' the Treaty, I would submit that extra-Union cooperation has limits if it is used to circumvent the carefully balanced framework provided by the enhanced cooperation procedure under the EU Treaties. Recall that in the case of Commission $v$ Belgium the decisive factor was Belgium's attempt to circumvent a rule of Union law. ${ }^{131}$

Similarly, I would suggest that cooperation by Member States outside the Treaty structure must not emulate the specific mechanisms provided for under Articles 326 to 334 TFEU. What is more, such cooperation must not assign selective und unevenly balanced roles to Union institutions. This arguably runs counter to the spirit of Article $20 \mathrm{TEU}$ and is caught by Article 4 (3) TEU. In other words, Article 4 (3) TEU prohibits extra-Union cooperation if it is crafted to make use of the Union institutions and the characteristics of Union law, while at the same time avoiding the narrow corset of rules provided for enhanced cooperation in the Treaties. ${ }^{132}$ That this would only apply if such cooperation would foresee the adoption of legal acts of the Union seems a rather narrow criterion. ${ }^{133}$

If it can therefore be shown that the twenty-six Member States that are parties to the Treaty on Stability, Coordination and Governance have in fact pursued enhanced cooperation as foreseen under the Treaty, but have circumvented the application of Article $20 \mathrm{TEU}$, this in my view would challenge the legality of this Treaty. ${ }^{134}$ Recently, the Court has ruled on the legality of the European Stability Mechanism (ESM) Treaty, which allocates various tasks to the Commission and to the ECB. ${ }^{135}$ In this case, the claim that the ESM Treaty would circumvent the rules on enhanced cooperation has been rejected by the Court. Enhanced cooperation would require a competence of the Union in the area concerned with the cooperation, which was not the case with regard to the permanent stability mechanism established with the ESM. ${ }^{136}$

\footnotetext{
130 See also the reference to enhanced cooperation in Art. 10 of the Treaty on Stability, Coordination and Governance in the European Monetary and Economic Union.

131 See note 11. 132 See Blanke, 'Art. 20 EUV', para 26.

133 See AG Kokott in Case C-370/12 Pringle [2012] ECR 00000, para 174, who has argued that Art. 20 (1) TEU would with this qualification allow the conferral of tasks on the institutions, such as tasks of coordination, outside the scope of the Treaties.

134 For a different perspective, see Peers, 'Towards a New Form of EU Law?', 71, who has drawn a line where some or all Member States would 'establish an ambitious European integration process that both covered a broad swathe of the subject-matter of the treaties and created competing institutions'. On the other hand, Peers, at 71, has argued that Art. 4 (3) TEU might even require the participation of Union institutions in an inter se treaty if otherwise consistency between EU law and the thus created regime could not be warranted.

135 Case C-370/12 Pringle [2012] ECR 00000, paras 156-157.

136 Case C-370/12 Pringle [2012] ECR 00000, para 168.
}

This is an open access version of the publication distributed under the terms of the Creative Commons Attribution-NonCommercial-NoDerivs licence (http://creativecommons.org/licenses/by-nc-nd/3.0/), which permits non-commercial reproduction and distribution of the work, in any medium, provided the original work is not altered or transformed in any way, and that the work is properly cited. For commercial re-use, please contact academic.permissions@oup.com 


\section{Conclusion of the Part on Construction}

We have already seen in the Introductory Part that loyalty has a very strong constitutionalizing role to play, not only in the early days of European integration. An important initial finding in this respect is that, in spite of reassuring language and numerous attempts to theorize it away with positively connoted terminology, the relationship between both the final arbiters in the EU and the Member States as well as between the Court and the Union legislator is inherently conflicting. While there is no available solution for conflict resolution with regard to claims of ultra vires besides avoiding escalation, as has happened so far, I have suggested that the resolution of conflicts between the 'lawmaking' prerogatives of Court and Council/Parliament can best be explained by adopting a view considering whether a Union measure confers rights on citizens or aims at furthering the internal market.

We have discussed how difficult it is to assess the jurisprudence of the Court on methodological grounds, because national law standards for policing the outer limits of permissible judicial lawmaking cannot be applied to Union law, and because of how the Treaties were drafted. The Court's case law can, however, be challenged on grounds of the self-referential manner in which loyalty has provided the rationale for the principle of state liability in particular and for the extension of indirect effect to the former third pillar.

I have also explored the role of loyalty in extending the scope of application of Union law rules and in adding binding force to non-binding Union measures. Again, I did not argue in favour of an unbound duty of loyalty that could prop up any rule or objective in the Treaty. What is decisive is that there is a substantiated interest of the Union concretizing objectives provided in the Treaty. However, I have shown that the same reasons that prevent the application of Article 4 (3) TEU from amplifying the state aid rules, could also be invoked to challenge the legality of cooperation outside the Union legal structure.

I would suggest that it is this amplification potential and the sort of judicial 'shell game' the Court has played with loyalty that should be kept in mind in observing future developments of Union law involving loyalty. Conceptual clarity is not a luxury here but a necessity in an edifice that so heavily relies on legal principles of undefined nature. 


\section{Final Remarks}

As already mentioned in this book, loyalty is a coat of many colours, the prevalence of which in Union law is to some extent cyclical. While it was used in most early foundational cases by the European Court of Justice without attracting the requisite attention or criticism in the literature, it became for some time sidelined by the increased reliance on principles such as effet utile and effectiveness. I have argued that the lack of understanding of the relationship of these principles has disguised the level of self-reference that has occurred in the case law of the Court. This autopoiesis in rationalizing developments such as state liability and indirect effect is arguably the only methodological critique that can be raised with regard to the style of reasoning of the Court, besides it being too minimalistic.

Recently, loyalty has been brought back into the limelight in the field of external relations law. I have suggested that this increasing relevance of loyalty is proportional to the complexities bedevilling the delimitation of competences, even after the professed codification by the Lisbon Treaty. It must also be seen against the background of the 'open sore' that is the Union law regime on mixed agreements, which are likely to stay and continue to pose intricate problems of coordination and demarcation. This is also a fertile ground for an increase of legal obligations that are exclusively based on Article 4 (3) TEU; something that parts of the literature have plainly rejected or ignored in the not too distant past.

Loyalty has developed to become a central principle to prevent and resolve conflicts in the European Union, constituting the 'missing link' between rules of competence and supremacy. I have shown that the Union interest in the form of a qualified expression of a concrete interest of one or several Union institutions should be the determining criterion for activating duties of action or abstention. While duties of conduct based on loyalty exist, they have shown to be the exception, while duties of result are the rule. The required interest can be the interest of the Union in the unity of its international representation, or it might be the interest in providing a system of effective judicial protection. Under the latter title, at least, some of the most interventionist developments of recent times involving loyalty could be observed in case law, where diverse established effects of directives and international agreements within national law have been amalgamated to test the limits of direct and indirect effect.

Loyalty also provides the backdrop for the various relations between institutions and actors within the European Union. This concerns its manifestation as the principle of institutional balance, reverse duties of cooperation addressed to the European Commission, as well as informing the relationship between Union and national courts. As I have discussed, however, it is a fallacy to believe that loyalty could play a role in preventing conflicts on the level of the 'Grenzorgane', viz. the national constitutional courts on the one side, and the European Court of Justice on the other. Professions of a spirit of cooperation in this context should be located in the field of diplomacy and not within the legal sphere. The underlying claims of final authority by some national courts and the empirical lack of a culture of 'high-level' judicial conversations via the cooperative instrument of preliminary references both stand in the way of a meaningful role for loyalty in this respect.

I have also argued that we should be aware of the distinction between loyalty and solidarity in Union law. While the former is an enforceable, primarily vertically directed principle, solidarity is rather political, predominant in the Common Foreign and Security

This is an open access version of the publication distributed under the terms of the Creative Commons Attribution-NonCommercial-NoDerivs licence (http://creativecommons.org/licenses/by-nc-nd/3.0/), which permits non-commercial reproduction and distribution of the work, in any medium, provided the original work is not altered or transformed in any way, and that the work is properly cited. For commercial re-use, please contact academic.permissions@oup.com 
Policy, and is mainly the basis for 'moral', political, and sometimes legal duties in the relation between the Member States. Loyalty has been shown to have more in common with the concept of constitutional fidelity in federal systems, while also displaying some remarkable parallels to principles of public international law. Loyalty has proven very difficult to classify within the frame of Union law, and I have settled for a perhaps rather unsatisfactory qualification as sui generis, a systemic principle of Union law which is characterized more by its peculiarities than its communalities with other principles.

The future of loyalty I predict will remain colourful. An 'anti-activist' backlash can be expected after its pervasiveness in recent case law, especially on international relations. Member States will closely watch attempts to use loyalty as 'deus ex machina' to shortcut the inadequacies of Union law. However, the principle of loyalty is not contrived, nor should its application be unexpected. This book has shown that it is the one rule in Union law that has helped to build the foundations of the Union law regime, continues to guarantee the legal cohesion with the national legal orders, and provides the basis for sincere cooperation between all actors involved in the integration process.

This is an open access version of the publication distributed under the terms of the Creative Commons Attribution-NonCommercial-NoDerivs licence (http://creativecommons.org/licenses/by-nc-nd/3.0/), which permits non-commercial reproduction and distribution of the work, in any medium, provided the original work is not altered or transformed in any way, and that the work is properly cited. For commercial re-use, please contact academic.permissions@oup.com 
This is an open access version of the publication distributed under the terms of the Creative Commons Attribution-NonCommercial-NoDerivs licence (http://creativecommons.org/licenses/by-nc-nd/3.0/), which permits non-commercial reproduction and distribution of the work, in any medium, provided the original work is not altered or transformed in any way, and that the work is properly cited. For commercial re-use, please contact academic.permissions@oup.com 


\section{References}

Akande, Dapo, 'International Organizations', in Malcolm Evans (ed.), International Law, 3rd edn. (Oxford: Oxford Univ. Press, 2010), 252-283

Alavi, Amin, 'Negotiating in the Shadow of Good Faith', in Sanford E. Gaines, Birgitte Egelund Olsen, and Karsten Engsig Sørensen (eds), Liberalising Trade in the EU and the WTO: A Legal Comparison (Cambridge: Cambridge Univ. Press, 2012), 21-42

Alen, André, Patrick Peeters, and Wouters Pas, 'Bundestreue im belgischen Verfassungsrecht', Jahrbuch des öffentlichen Rechts, 42 (1994), 439-505

Alexy, Robert, Theorie der Grundrechte (Baden-Baden: Nomos, 1994)

Allott, Philip, 'Adherence to and Withdrawal from Mixed Agreements', in David O'Keeffe and Henry Schermers (eds), Mixed Agreements (Deventer: Kluwer, 1983), 97-121

Alter, Karen J., Establishing the Supremacy of European Law: The Making of an International Rule of Law in Europe (Oxford: Oxford Univ. Press, 2001)

Anonymous, Editorial Comments: 'The Aftermath of Opinion 1/94 or How to Ensure Unity of Representation for Joint Competences', Common Market Law Review, 32 (1995), 385-390

Anonymous, Editorial Comments, 'The Court of Justice in the Limelight: Again', Common Market Law Review, 45 (2008), 1571-1579

Anonymous, 'Editorial Comments, Enhanced Cooperation: A Union à Taille Réduite or à Porte Tournante?', Common Market Law Review, 48 (2011), 317-327

Anonymous, 'Horizontal Direct Effect: A Law of Diminishing Coherence?', Common Market Law Review, 43:1 (2006), 1-8

Anweiler, Jochen, Die Auslegungsmethoden des Gerichtshofs der Europäischen Gemeinschaften (Frankfurt et al.: Lang, 1997)

Armstrong, Kenneth, 'Mutual Recognition', in Catherine Barnard and Joanna Scott (eds), The Law of the Single European Market: Unpacking the Premises (Oxford and Portland, Oregon: Hart Publishing, 2002), 225-267

Arnull, Anthony, 'Annotation to Case C-432/05, Unibet (London) Ltd v Justitiekanslern', Common Market Law Review, 44 (2007), 1763

Arnull, Anthony, The European Union and its Court of Justice (Oxford: Oxford Univ. Press, 1999)

Arnull, Anthony, 'Judicial Activism and the Court of Justice: How Should Academics Respond?', Maastricht Working Papers (2012-13)

Arnull, Anthony, 'The Principle of Effective Judicial Protection in EU Law: An Unruly Horse?', European Law Review, 36:1 (2011), 51-70

Aroney, Nicholas, The Constitution of a Federal Commonwealth: The Making and Meaning of the Australian Constitution (Cambridge: Cambridge Univ. Press, 2009)

Aust, Anthony, 'Pacta Sunt Servanda', Max Planck Encyclopedia of Public International Law (Heidelberg and Oxford: Oxford Univ. Press, 2013) (<http://www.mpepil.com>)

Baquero Cruz, Julio, 'The Legacy of the Maastricht-Urteil and the Pluralist Movement', European Law Journal, 14:4 (2008), 389-422

Barav, Ami, 'The Judicial Power of the European Economic Community', The Southern California Law Review, 53 (1979-80), 461-525

Barav, Ami, 'Omnipotent Courts', in Deidre Curtin and Ton Heukels (eds), Essays in Honour of Henry G. Schermers (Dordrecht: Martinus Nijhoff, 1994), 265-302

Barnard, Christine, 'Unravelling the Services Directive', Common Market Law Review, 45:2 (2008), 323-394

Bayer, Hermann, Die Bundestreue (Tübingen: Mohr, 1961)

Bebr, Gerhard, 'Court of Justice: Judicial Protection and the Rule of Law', in Deidre Curtin and Ton Heukels (eds), Institutional Dynamics of European Integration: Essays in Honour of Henry G. Schermers, Vol. II (Dordrecht/Boston/London: Martinus Nijhoff, 1994), 303-333

This is an open access version of the publication distributed under the terms of the Creative Commons Attribution-NonCommercial-NoDerivs licence (http://creativecommons.org/licenses/by-nc-nd/3.0/), which permits non-commercial reproduction and distribution of the work, in any medium, provided the original work is not altered or transformed in any way, and that the work is properly cited. For commercial re-use, please contact academic.permissions@oup.com 
Bekkedal, Tarjei, 'Article 106 TFEU is Dead: Long Live Article 106TFEU!', in Erika Szyszczak et al. (eds), Developments in Services of General Interest (The Hague: TMC Asser, 2011), 61-102

Benedek, Wolfgang, 'Art. 210 AEUV', in Eberhard Grabitz, Meinhard Hilf, and Martin Nettesheim (eds), Das Recht der Europäischen Union, Kommentar (Munich: Beck, 2011)

Bengoetxea, Joxerramón, The Legal Reasoning of the European Court ofJustice (Oxford: Clarendon Press, 1993)

Bengoetxea, Joxerramón, Neil MacCormick, and Luis Moral Soriano, 'Integration and Integrity in the Legal Reasoning of the European Court of Justice', in Gráinne de Búrca and Joseph H.H. Weiler (eds), The European Court of Justice (Oxford: Oxford Univ. Press, 2001), 43-85

Besselink, Leonard, 'National and Constitutional Identity Before and After Lisbon', Utrecht Law Review, 6:3 (2010), 36-49

Bitterlich, Joachim, 'Art. 24 EUV', in Claus-Otto Lenz and Klaus-Dieter Borchardt (eds), EUVerträge, Kommentar nach dem Vertrag von Lissabon, 5th edn. (Cologne: Bundesanzeiger, Vienna: Linde, 2010)

Blanke, Hermann-Josef, 'Art. 20 EUV', in Eberhard Grabitz, Meinhard Hilf, and Martin Nettesheim (eds), Das Recht der Europäische Union, Kommentar (Munich: Beck, 2010)

Blanke, Hermann-Josef, 'Art. 167 AEUV', in Christian Calliess and Matthias Ruffert (eds), EUVIAEUV: Das Verfassungsrecht der Europäischen Union mit Europäischer Grundrechtecharta, 4th edn. (Munich: Beck, 2011)

Blanke, Hermann-Josef, 'Art. 327 AEUV', in Eberhard Grabitz, Meinhard Hilf, and Martin Nettesheim (eds), Das Recht der Europäische Union, Kommentar (Munich: Beck, 2010)

Blanquet, Marc, L'Article 5 du Traité C.E.E.: Recherche sur les Obligations de Fidélité des États Membres de la Communauté (Paris: LGDJ, 1994)

Bleckmann, Albert, 'Art. 5 EWG-Vertrag und die Gemeinschaftstreue: Zugleich ein Beitrag zur Entwicklung des allgemeinen europäischen Verwaltungsrechts', Deutsches Verwaltungsblatt, (1976), 483-487

Bleckmann, Albert, 'Die Rechtsprechung des Europäischen Gerichtshofes zur Gemeinschaftstreue', Recht der internationalen Wirtschaft, 27 (1981), 653-655

Bleckmann, Albert, 'Zu den Auslegungsmethoden des Europäischen Gerichtshofs', Neue Juristische Wochenschrift, 35:22 (1982), 1177-1182

Bobek, Michel, 'Why there is no Principle of "Procedural Autonomy" of the Member States', in Bruno de Witte and Hans Micklitz (eds), The European Court of Justice and the Autonomy of the Member States (Cambridge: Intersentia, 2011), 305-324

Boeing, Detlev, Elisabeth Kotthaus, and Tim Maxian Rusche, 'Art. 92 AEUV', in Eberhard Grabitz, Meinhard Hilf, and Martin Nettesheim (eds), Das Recht der Europäische Union (Munich: Beck, 2012)

Booker, Kevin and Arthur Glass, 'The Engineers Case', in H.P. Lee and George Winterton (eds), Australian Constitutional Landmarks (Cambridge: Cambridge Univ. Press, 2003), 34-61

Borchardt,Klaus-Dieter, 'RichterrechtdurchdenGerichtshofderEuropäischenGemeinschaften', in Albrecht Randelzhofer, Rupert Scholz, and Dieter Wilke (eds), Gedächtnisschrift für Eberhard Grabitz (Munich: Beck, 1995), 29-43

Bourgeois, Jacques H.J., 'The EC in the WTO and Advisory Opinion 1/94: An Echternach Procession', Common Market Law Review, (1995), 763-787

Bourgeois, Jacques H.J., 'The European Court of Justice and the WTO: Problems and Challenges', in Joseph H.H. Weiler (ed.), The EU, the WTO, and the NAFTA (Oxford: Oxford Univ. Press, 2001), 71-124

Bradley, Kieran St.C., 'Maintaining the Balance: The Role of the Court of Justice in Defining the Institutional Position of the European Parliament', Common Market Law Review, 24 (1987), 41-64

Bredimas, Anna, Methods of Interpretation and Community Law (Amsterdam: North Holland, 1978)

This is an open access version of the publication distributed under the terms of the Creative Commons Attribution-NonCommercial-NoDerivs licence (http://creativecommons.org/licenses/by-nc-nd/3.0/), which permits non-commercial reproduction and distribution of the work, in any medium, provided the original work is not altered or transformed in any way, and that the work is properly cited. For commercial re-use, please contact academic.permissions@oup.com 
Brun, Henri and Guy Tremblay, Droit Constitutionnel, 4th edn. (Montréal: Éditions Yvon Blais, 2002)

Buerstedde, Wolfgang, Juristische Methodik des Europäischen Gemeinschaftsrechts (Baden-Baden: Nomos, 2006)

Burley, Anne-Marie and Walter Matti, 'Europe Before the Court: A Political Theory of Legal Integration', International Organization, 47 (1993), 41-76

Bußjäger, Peter, 'Bundesstaat und Gleichheitsgrundsatz', Juristische Blätter, (2007), 289-298

Calliess, Christian, 'Art. 1 EUV', in Christian Calliess and Matthias Ruffert (eds), EUVIAEUV: Das Verfassungsrecht der Europäischen Union mit Europäischer Grundrechtecharta, 4th edn. (Munich: Beck, 2011)

Calliess, Christian, 'Art. 5 EGV', in Christian Calliess and Matthias Ruffert (eds), EUVIEGV, 3rd edn. (Munich: Beck, 2007)

Calliess, Christian, 'Art. 222 AEUV', in Christian Calliess and Matthias Ruffert (eds), EUV/ AEUV: Das Verfassungsrecht der Europäischen Union mit Europäischer Grundrechtecharta, 4th edn. (Munich: Beck, 2011)

Calliess, Christian, 'Perspektiven des Euro zwischen Solidarität und Recht: Eine rechtliche Analyse der Griechenlandhilfe und des Rettungsschirms', Zeitschrift für europarechtliche Studien, 14:2 (2011), 213-282

Canaris, Claus-Wilhelm, 'Die richtlinienkonforme Auslegung und Rechtsfortbildung im System der juristischen Methodenlehre', in Helmut Koziol and Peter Rummel (eds), Im Dienste der Gerechtigkeit: Festschrift fir Franz Bydlinski (Vienna, New York: Springer, 2002)

Cappelletti, Mauro, The Judicial Process in Comparative Perspective (Oxford: Clarendon Press, 1989)

Cappelletti, Mauro, Monica Seccombe, and Joseph H.H. Weiler, 'Integration Through Law: Europe and the American Federal Experience: A General Introduction', in Fabio Cappelletti, Monica Seccombe, and Joseph H.H.Weiler (eds), Integration Through Law: Europe and the American Federal Experience, Vol. I, Methods, Tools and Institutions, Book I, A Political, Legal and Economic Overview (Berlin: de Gruyter, 1986), 3-68

Carnap, Rudolf, Logical Foundations of Probability (Univ. of Chicago Press, 1950)

Chalmers, Damian, 'Judicial Preferences and the Community Legal Order', The Modern Law Review, 60 (1997), 164-199

Cherdnychenko, Olha, 'EU Fundamental Rights, EC Fundamental Freedoms and Private Law', European Review of Private Law, 14:1 (2006), 23-61

Chevallier, Roger-Michel, 'Methods and Reasoning of the European Court in its Interpretation of Community Law', Common Market Law Review, (1964), 21-35

Cheyne, Ilona, 'Haegeman, Demirel and their Progeny', in Alan Dashwood and Christophe Hillion (eds), The General Law of EC External Relations (London: Sweet \& Maxwell, 2000), $20-41$

Cini, Michelle, 'Intergovernmentalism', in Michelle Cini and Nieves Pérez-Solórzano Borragán (eds), European Union Politics, 3rd edn. (Oxford: Oxford Univ. Press, 2010), 86-103

Claes, Monica, The National Courts'Mandate in the European Constitution (Oxford and Portland, Oregon: Hart Publishing, 2006)

Claes, Monica, 'Negotiating Constitutional Identity or Whose Identity is it Anyway?', in Monica Claes et al. (eds), Constitutional Conversations in Europe: Actors, Topics and Procedures (Cambridge: Intersentia, 2012), 205-233

Cohen, Jonathan and William Varat, Constitutional Law: Cases and Materials, 10th edn. (New York: The Foundation Press, 1997)

Conant, Lisa, Justice Contained: Law and Politics in the European Union (Ithaca: Cornell Univ. Press, 2002)

Constantinesco, Vlad, 'Les clauses de coopération renforcée', Revue Trimesterielle de Droit Europeen, 33 (1997), 751-767

This is an open access version of the publication distributed under the terms of the Creative Commons Attribution-NonCommercial-NoDerivs licence (http://creativecommons.org/licenses/by-nc-nd/3.0/), which permits non-commercial reproduction and distribution of the work, in any medium, provided the original work is not altered or transformed in any way, and that the work is properly cited. For commercial re-use, please contact academic.permissions@oup.com 
Constantinesco, Vlad, 'L'article CEE de la bonne foi à la loyauté communautaire', in Francesco Capotorti et al. (eds), Du Droit International au Droit de l'Intégration: Liber Amicorum Pierre Pescatore (Baden-Baden: Nomos, 1987), 97-114

Conway, Gerard, The Limits of Legal Reasoning and the European Court of Justice (Cambridge: Cambridge Univ. Press, 2012)

Craig, Paul P., 'Competence: Clarity, Conferral, Containment and Consideration', European Law Review, (2004), 323-344

Craig, Paul. P., 'Constitutions, Constitutionalism, and the European Union', European Law Journal, 7:2 (2001), 125-150

Craig, Paul P., 'Delegation of Legislative Power', Common Market Law Review, 49 (2009), $1265-1275$

Craig, Paul P., 'The ECJ and Ultra Vires Action: A Conceptual Analysis', Common Market Law Review, 48 (2011), 395-437

Craig, Paul P., The Lisbon Treaty: Law, Politics and Treaty Reform (Oxford: Oxford Univ. Press, 2010)

Craig, Paul P., 'The Stability, Coordination and Governance Treaty: Principle, Politics and Pragmatism', European Law Review, 37 (2012), 231-248

Craig, Paul P. and Gráinne de Búrca, EU Law: Text, Cases and Materials, 5th edn. (Oxford: Oxford Univ. Press, 2011)

Cremer, Hans-Joachim, 'Art. 14 EUV', in Christian Calliess and Matthias Ruffert (eds), EUV/ $E G V$, 3rd edn. (Munich: Beck, 2007)

Cremer, Hans-Joachim, 'Art. 24 EUV', in Christian Calliess and Matthias Ruffert (eds), EUV/ AEUV: Das Verfassungsrecht der Europäischen Union mit Europäischer Grundrechtecharta, 4th edn. (Munich: Beck, 2011)

Cremona, Marise, 'Annotation to Case C-246/07, Commission v Sweden (PFOS)', Common Market Law Review, 48 (2011), 1693-1666

Cremona, Marise, 'An Assessment of the Provisions on EU External Action in the Constitutional Treaty', EUI Working Paper, 30 (2006)

Cremona, Marise, 'Coherence through Law: What Difference will the Treaty of Lisbon Make?', Hamburg Review of Social Sciences, (2008), 11-36

Cremona, Marise (ed.), Compliance and the Enforcement of EU Law (The Collected Courses of the Academy of European Law; Oxford: Oxford Univ. Press, 2012)

Cremona, Marise, 'Defending the Community Interest: The Duties of Cooperation and Compliance', in Marise Cremona and Bruno de Witte (eds), EU Foreign Relations Law: Constitutional Fundamentals (Oxford and Portland, Oregon: Hart Publishing, 2008), 125-169

Cremona, Marise, 'Defining Competence in EU External Relations: Lessons from the Treaty Reform Process', in Alan Dashwood and Marc Maresceau (eds), Law and Practice of EU External Relations: Salient Features of a Changing Landscape (Cambridge: Cambridge Univ. Press, 2008), 34-69

Cremona, Marise, 'Disconnection Clauses in EU Law and Practice', in Christoph Hillion and Panos Koutrakos (eds), Mixed Agreements Revisited: The EU and its Member States in the World (Oxford and Portland, Oregon: Hart Publishing, 2010), 160-186

Cremona, Marise, 'Extending the Reach of the AETR Principle: Comment on Commission v Greece (C-45/07)', European Law Review, 34 (2009), 754-768

Cremona, Marise, 'External Relations and External Competence of the European Union', in Paul P. Craig and Gráinne de Búrca, The Evolution of EU Law, 2nd edn. (Oxford: Oxford Univ. Press, 2011), 217-268

Cremona, Marise, 'Member States as Trustees of the Union Interest: Participating in International Agreements on Behalf of the European Union', in Anthony Arnull et al. (eds), A Constitutional Order of States?: Essays in EU Law in Honour of Alan Dashwood (Oxford and Portland, Oregon: Hart Publishing, 2011), 435-457

This is an open access version of the publication distributed under the terms of the Creative Commons Attribution-NonCommercial-NoDerivs licence (http://creativecommons.org/licenses/by-nc-nd/3.0/), which permits non-commercial reproduction and distribution of the work, in any medium, provided the original work is not altered or transformed in any way, and that the work is properly cited. For commercial re-use, please contact academic.permissions@oup.com 
Cremona, Marise, 'The Two (or Three) Treaty Solution: The New Treaty Structure of the EU', in Andrea Biondi, Piet Eeckhout, and Stephanie Ripley (eds), European Union Law After the Treaty of Lisbon (Oxford: Oxford Univ. Press, 2011), 40-61

Cross, Eugene D., 'Pre-emption of Member State law in the European Economic Community: A Framework for Analysis', Common Market Law Review, 29 (1992), 447-472

Curtin, Deidre, 'The Decentralised Enforcement of Community Law Rights: Judicial Snakes and Ladders', in Deidre Curtin and David O'Keeffe (eds), Constitutional Adjudication in European Community and National Law (London: Butterworths, 1992), 33-49

Curtin, Deidre and Inge Dekker, 'The Constitutional Structure of the European Union: Some Reflections on Vertical Unity-in-Diversity', in Paul Beaumont, Sue Lyons, and Neil Walker (eds), Convergence and Divergence in European Public Law (Oxford and Portland, Oregon: Hart Publishing, 2002), 59-78

Czuczai, Jenö, 'Mixity in Practice', in Christophe Hillion and Panos Koutrakos (eds), Mixed Agreements Revisited: The EU and its Member States in the World (Oxford and Portland, Oregon: Hart Publishing, 2010), 231-248

Damjanovic, Dragana, 'Annotation to Joined Cases C-22/08 \& C-23/08, Athanasios Vatsouras and Josif Koupatantze v. Arbeitsgemeinschaft (ARGE) Nürnberg', Common Market Law Review, (2010), 847-861

Dänzer-Vanotti, Wolfgang, 'Der Europäische Gerichtshof zwischen Rechtsprechung und Rechtsetzung', in Ole Due, Marcus Lutter, and Jürgen Schwarze (eds), Festschrift für Ulrich Everling, Vol. I (Baden-Baden: Nomos, 1995), 205-221

Dashwood, Alan, 'Annotation to Opinion 2/00 Cartagena Protocol', Common Market Law Review, (2002), 353-368

Dashwood, Alan, 'The Attribution of External Relations Competence', in Alan Dashwood and Christophe Hillion (eds), The General Law of EC External Relations (London: Sweet \& Maxwell, 2000), 115-138

Dashwood, Alan, 'The Limits of European Community Powers', European Law Review, (1996), $113-128$

Davis, Richard and D. Jeffrey Burnham, 'The Role of the Federal Judiciary in the Development of Federalism in West Germany and the United States', Boston College International of Comparative Law Review, 12:1 (1989), 63-88

Davy, Ulrike, 'Zur Bedeutung des bundesstaatlichen Rücksichtnahmegebotes für Normenkonflikte', Österreichische Juristenzeitung, (1986), 225-234

De Almeida, J. C. Moitinho, 'L'effet direct des directives, l'interprétation conforme du droit national et la jurisprudence de la Cour Supreme de Justice portugaise', in Ninon Colneric et al. (eds), Une communauté de droit: Festschrift für Gil Carlos Rodríguez Iglesias (Berlin: Berliner Wissenschafts-Verlag, 2003), 235-244

De Baere, Geert, Constitutional Principles of EU External Relations (Oxford: Oxford Univ. Press, 2008)

De Baere, Geert and Elke Cloots (eds), Federalism and EU Law (Oxford and Portland, Oregon: Hart Publishing, 2012)

De Búrca, Gráinne and Joseph H.H. Weiler (eds), The European Court ofJustice (Oxford: Oxford Univ. Press, 2001)

De la Mare, Thomas, 'Article 177 in Social and Political Context', in Paul P. Craig and Gráinne de Búrca (eds), The Evolution of EU Law (Oxford: Oxford Univ. Press, 1999)

De la Rosa, Stephane, 'The Directive on Cross-border Healthcare or the Art of Codifying Complex Case Law', Common Market Law Review, 49 (2012), 15-46

De Witte, Bruno, 'The Closest Thing to a Constitutional Conversation in Europe: The SemiPermanent Treaty Revision Process', in Paul Beaumont, Sue Lyons, and Neil Walker (eds), Convergence and Divergence in European Public Law (Oxford and Portland, Oregon: Hart Publishing, 2002), 39-57

This is an open access version of the publication distributed under the terms of the Creative Commons Attribution-NonCommercial-NoDerivs licence (http://creativecommons.org/licenses/by-nc-nd/3.0/), which permits non-commercial reproduction and distribution of the work, in any medium, provided the original work is not altered or transformed in any way, and that the work is properly cited. For commercial re-use, please contact academic.permissions@oup.com 
De Witte, Bruno, 'A Competence to Protect: Pursuing Non-Market Aims Through Internal Market Laws', in Phil Syrpis (ed.), The Judiciary, the Legislature and the EU Internal Market (Cambridge: Cambridge Univ. Press, 2012), 25-46

De Witte, Bruno, 'Direct Effect, Primacy and the Nature of the Legal Order', in Paul P. Craig and Gráinne de Búrca, The Evolution of EU Law, 2nd edn. (Oxford: Oxford Univ. Press, 2011), 323-362

De Witte, Bruno, 'Direct Effect, Supremacy, and the Nature of the Legal Order', in Paul P. Craig and Gráinne de Búrca (eds), The Evolution of EU Law (Oxford: Oxford Univ. Press, 1999), $177-213$

De Witte, Bruno, 'The European Union as an International Legal Experiment', in Gráinne de Búrca, and Joseph H.H. Weiler (eds), The Worlds of European Constitutionalism (Cambridge: Cambridge Univ. Press, 2012), 18-56

De Witte, Bruno, 'Interpreting the EC Treaty like a Constitution: The Role of the European Court of Justice in Comparative Perspective', in R.C.L. Bakker, A.W. Heringa, and F.A.M. Stroink (eds), Judicial Control: Comparative Essays on Judicial Review (Antwerp: Apeldoorn, 1995)

De Witte, Bruno, 'Old-fashioned Flexibility: International Agreements between Member States of the European Union', in Bruno de Witte, Dominik Hanf, and Ellen Vos (eds), The Many Faces of Differentiation in EU Law (Cambridge: Intersentia, 2001), 31-58

De Witte, Bruno, 'The Past and Future Role of the European Court of Justice in the Protection of Human Rights', in Philip Alston (ed.), The EU and Human Rights (Oxford: Oxford Univ. Press, 1999), 859-897

De Witte, Bruno, 'The Pillar Structure and the Nature of the European Union: Greek Temple or French Gothic Cathedral?', in Ton Heukels, Niels Blokker, and Marcel Brus (eds), The European Union after Amsterdam: A Legal Analysis (The Hague: Kluwer Law International, 1998), 51-68

De Witte, Bruno, 'Too Much Constitutional Law in the European Union's Foreign Relations?', in Marise Cremona and Bruno de Witte (eds), EU Foreign Relations Law: Constitutional Fundamentals (Oxford and Portland, Oregon: Hart Publishing, 2008), 3-15

Dehousse, Renaud, The European Court of Justice (London: St. Martin's Press, 1998), 133-152

Delgado Casteleiro, Pedro and Joris Larik, 'The Duty to Remain Silent: Limitless Loyalty in EU External Relations?', European Law Review, (2011), 524

Delpérée, Francis, 'Constitutional Law', in Hubert Bocken and Walter de Bondt (eds), Introduction to Belgian Law (The Hague, London, Boston: Kluwer Law International and Brussels: Bruylant, 2001), 60

Denza, Eileen, 'A Note on Intertanko', European Law Review, (2008), 870-879

Dickson, Julie, 'Directives in EU Legal Systems: Whose Norms Are They Anyway?', European Law Journal, 17:2 (2011), 190-212

Dimopoulos, Angelos, 'The Validity and Applicability of International Investment Agreements between EU Member States under EU and International Law', Common Market Law Review, 48:1 (2011), 63-93

Dolmans, Maurits, Problems of Mixed Agreements: Division of Powers within the EEC and the Rights of Third States (The Hague: Kluwer Law International, 1985)

Dougan, Michael, 'In Defence of Mangold?', in A. Arnull et al. (eds), A Constitutional Order of States?: Essays in EU Law in Honour of Alan Dashwood (Oxford and Portland, Oregon: Hart Publishing, 2011), 219-244

Dourado, Ana Paula, 'From the Saint-Gobain to the Metallgesellschaft Case: the Scope of Non-discrimination of Permanent Establishments in the EC Treaty and the Most-FavouredNation Clause in EC Member States Tax Treaties', EC Tax Review, (2002), 147-156

Dowrick, F.E., 'A Model of the European Communities' Legal System', Yearbook of European Law, 3:1 (1983), 169-237

This is an open access version of the publication distributed under the terms of the Creative Commons Attribution-NonCommercial-NoDerivs licence (http://creativecommons.org/licenses/by-nc-nd/3.0/), which permits non-commercial reproduction and distribution of the work, in any medium, provided the original work is not altered or transformed in any way, and that the work is properly cited. For commercial re-use, please contact academic.permissions@oup.com 
Drake, Sara, 'Twenty Years after Von Colson: The Impact of "Indirect Effect" on the Protection of the Individual's Community Rights', European Law Review, 30 (2005), 329-348

Durand, Christine, 'Le principe de coopération loyale entre les États membres et les institutions: les article 5 et 6 du traité CEE', in Commentaire Megret, Vol. I, 2nd edn. (Brussels: Éditions de l'Université de Bruxelles, 1992), 25-42

Durner, Wolfgang, 'Die Unabhängigkeit nationaler Richter im Binnenmarkt: Zu den Loyalitätspflichten nationaler Gerichte gegenüber der EG-Kommission, insbesondere auf dem Gebiet des Kartellrechts', Europarecht, (2004), 547-574

Dworkin, Ronald, 'Social Rules and Legal Theory', The Yale Law Journal, 81:5 (1972), 855-890

Dworkin, Ronald, Taking Rights Seriously, 2nd edn. (Cambridge: Harvard Univ. Press, 1978)

Edward, David, Editorial Comment, 'Will there be Honey still for Tea?', Common Market Law Review, (2006), 523-527

Edward, David, 'Judicial Activism: Myth or Reality?', in Angus Campell and Meropi Voyatzi (eds), Legal Reasoning and Judicial Interpretation of European Law (Gosport: Trenton Publishing, 1996), 29-67

Eeckhout, Piet, EU External Relations Law: Legal and Constitutional Foundations, 2nd edn. (Oxford: Oxford Univ. Press, 2011)

Eeckhout, Piet, External Relations of the European Union: Legal and Constitutional Foundations (Oxford: Oxford Univ. Press, 2004)

Eicker, Klaus, 'EC Tax Scene: Recent Developments Regarding Cross-Border Pensions: Landmark Decision by the ECJ in the Case C-55/00 Gottardo', Intertax, 4 (2002), 156-156

Eleftheriadis, Pavlos, 'Federalism and Jurisdiction', in Geert de Baere and Elke Cloots (eds), Federalism and EU Law (Oxford and Portland, Oregon: Hart Publishing, 2012), 45-64

Eleftheriadis, Pavlos, 'The Structure of European Union Law', Cambridge Yearbook of European Legal Studies, 12 (2010), 121-150

Epiney, Astrid, 'Die Bindung der Europäischen Union an das allgemeine Völkerrecht', Europarecht, Beiheft 2 (2012), 25-49

Epiney, Astrid, 'Gemeinschaftsrecht und Föderalismus: "Landes-Blindheit" und Pflicht zur Berücksichtigung innerstaatlicher Verfassungsstrukturen', Europarecht, (1994), 301-324

Epiney, Astrid, 'Zur Tragweite des Art. 10 EGV im Bereich der Außenbeziehungen', in Jürgen Bröhmer and Georg Ress (eds), Internationale Gemeinschaft und Menschenrechte: Festschrift für Georg Ress zum 70. Geburtstag am 21. Januar 2005 (Cologne: Heymanns, 2005), 441-459

Erk, Can and Alain.-G. Gagnon, 'Constitutional Ambiguity and Federal Trust: Codification of Federalism in Canada, Spain and Belgium', Regional \& Federal Studies, 10:1 (2000), 92-111

Everling, Ulrich, 'The Court of Justice as a Decisionmaking Authority', Michigan Law Review, 82 (1984), 1294-1310

Fabbrini, Sergio (ed.), Democracy and Federalism in the European Union and the United States: Exploring Post-National Governance (London: Routledge, 2005)

Falkner, Gerda, et al., Complying with Europe? The Impact of EU Minimum Harmonisation and Soft Law in the Member States (Cambridge: Cambridge Univ. Press, 2005)

Fitzmaurice, Malgosia, 'The Practical Working of the Law of Treaties', in Malcolm Evans (ed.), International Law, 3rd edn. (Oxford: Oxford Univ. Press, 2010), 172-199

Fletcher, Maria, 'Extending “Indirect Effect" to the Third Pillar: The Significance of Pupino', European Law Review, 30 (2005), 862-877

Frenz, Walter, Handbuch Europarecht: Wirkungen und Rechtsschutz (Heidelberg et al.: Springer, 2010)

Frenz, Walter, 'Rücknahme eines gemeinschaftsrechtswidrigen belastenden VA', Deutsches Verwaltungsblatt, (2004), 373-376

Frid, Rachel, The Relations Between the EC and International Organizations: Legal Theory and Practice (The Hague: Kluwer Law International, 1995)

This is an open access version of the publication distributed under the terms of the Creative Commons Attribution-NonCommercial-NoDerivs licence (http://creativecommons.org/licenses/by-nc-nd/3.0/), which permits non-commercial reproduction and distribution of the work, in any medium, provided the original work is not altered or transformed in any way, and that the work is properly cited. For commercial re-use, please contact academic.permissions@oup.com 
Funk, Bernd-Christian, Das System der bundesstaatlichen Kompetenzverteilung im Lichte der Verfassungsrechtsprechung (Vienna: Wilhelm Braumüller, 1980)

Furrer, Andreas, Die Sperrwirkung des sekundären Gemeinschaftsrechts auf die nationalen Rechtsordnungen (Baden-Baden: Nomos, 1994)

Gaja, Giorgio, 'Accession to the ECHR', in Andrea Biondi, Piet Eeckhout, and Stephanie Ripley (eds), European Union Law After the Treaty of Lisbon (Oxford: Oxford Univ. Press, 2011), 180-194

Gamper, Anna, 'Koordination im Bundesstaat—ein “ungeschriebenes” Verfassungsprinzip?', in Andreas Rosner and Peter Bußjäger (eds), Im Dienste der Länder: Im Interesse des Gesamtstaates: Festschrift 60 Jahre Verbindungsstelle der Bundesländer (Vienna: Braumüller, 2011)

Gamper, Anna, 'On Loyalty and the (Federal) Constitution', International Constitutional Law Journal, 4:2 (2010), 157 (<http://www.icl-journal.com>)

Ganshof van der Meersch, W.J. (ed.), Droit des Communautés européennes (Brussels: Larcier, 1969)

Gerken, Lüder, et al., 'Mangold' als ausbrechender Rechtsakt (Munich: Sellier, 2009)

Gil Ibáñez, Alberto J., The Administrative Supervision and Enforcement of EC Law: Powers, Procedures, and Limits (Oxford and Portland, Oregon: Hart Publishing, 1999)

Gilsdorf, Peter, 'Die Außenkompetenzen der EG im Wandel', Europarecht, (1996), 145

Glander, C. Emory and Addison E. Dewey, 'Municipal Taxation: A Study of the Pre-emption Doctrine', Ohio State Law Journal, (1948), 72-97

Glenn, Garrard, 'Pre-emption in Connection with Unfair Trade', Columbia Law Review, 19 (1919), 29-46

Gormley, Laurence, 'Some Further Reflections on the Development of General Principles of Law within Article 10 EC', in Ulf Bernitz, Joakim Nergelius, and Cecilia Cardner (eds), General Principles of EC Law in a Process of Development (The Hague: Kluwer Law International, 2008), 303-313

Govaere, Ingo, 'Beware of the Trojan Horse: Dispute Settlement in (Mixed) Agreements and the Autonomy of the EU Legal Order', in Christophe Hillion and Panos Koutrakos (eds), Mixed Agreements Revisited: The EU and its Member States in the World (Oxford and Portland, Oregon: Hart Publishing, 2010), 187

Grabenwarter, Christoph, 'Grundrechtsvielfalt und Grundrechtskonflikte im europäischen Mehrebenensystem: Wirkungen von EGMR-Urteilen und der Beurteilungsspielraum der Mitgliedstaaten', Europäische Grundrechte Zeitschrift, 38:8 (2011), 229-232

Grabenwarter, Christoph, 'Die Kooperation zwischen EuGH und EGMR', in Christoph. Grabenwarter and Erich Vranes (eds), Kooperation der Gerichte im europäischen Verfassungsverbund: Grundfragen und neueste Entwicklungen (Baden-Baden: Nomos, 2013), 35-44

Grabenwarter, Christoph, 'National Constitutional Law Relating to the European Union', in Armin von Bogdandy and Jürgen Bast (eds), Principles of European Constitutional Law (Munich: Beck, 2010), 83-129

Grabitz, Eberhard, 'Art. 5 EWGV', in Eberhard Grabitz (ed.), Kommentar zum EWG-Vertrag (Munich: Beck, 1992)

Griller, Stefan, 'The New Services Directive of the European Union: Hopes and Expectations from the Angle of a (Further) Completion of the Internal Market', in Heribert Franz Köck and Margit Maria Karollus (eds), The New Services Directive of the European Union, FIDE General Report (Vienna: Congress, 2008), 379-423

Griller, Stefan, 'Der Rechtsbegriff bei Ronald Dworkin', in Stefan Griller and Heinz-Peter Rill (eds), Rechtstheorie: Rechtsbegriff_Dynamik_Auslegung (Vienna, New York: Springer, 2011), 57-79

Griller, Stefan, Die Übertragung von Hoheitsrechten aufzwischenstaatliche Einrichtungen (Vienna, New York: Springer, 1989)

Griller, Stefan, 'Völkerrecht und Landesrecht: unter Berücksichtigung des Europarechts', in Robert Walter, Clemens Jabloner, and Klaus Zeleny (eds), Hans Kelsen und das Völkerrecht (Vienna: Manz, 2004), 83-120

This is an open access version of the publication distributed under the terms of the Creative Commons Attribution-NonCommercial-NoDerivs licence (http://creativecommons.org/licenses/by-nc-nd/3.0/), which permits non-commercial reproduction and distribution of the work, in any medium, provided the original work is not altered or transformed in any way, and that the work is properly cited. For commercial re-use, please contact academic.permissions@oup.com 
Griller, Stefan and Katharina Gamharter, 'External Trade: Is there a Path through the Maze of Competences?', in Stefan Griller and Birgit Weidel (eds), External Economic Relations and Foreign Policy in the European Union (Vienna, New York: Springer, 2002), 65-112

Griller, Stefan and Marcus Klamert, 'Das Aussenwirtschaftsrecht der EU', in Michael Holoubek and Michael Potacs (eds), Öffentliches Wirtschaftsrecht (Vienna, New York: Springer, 2007)

Griller, Stefan and Andreas Orator, 'Everything Under Control?: The "Way Forward" for European Agencies in the Footsteps of the Meroni Doctrine', European Law Review, (2010), $3-35$

Grosche, Niels, Rechtsfortbildung im Unionsrecht (Tübingen: Mohr Siebeck, 2011)

Groussot, Xavier and Hans Henrik Lidgard, 'Are There General Principles of Community Law Affecting Private Law?', in Ulf Bernitz, Joakim Nergelius, and Cecilia Cardner (eds), General Principles of EC Law in a Process of Development (The Hague: Kluwer Law International, 2008), 155-175

Guzman, Andrew T., How International Law Works: A Rational Choice Theory (Oxford and New York: Oxford Univ. Press, 2007)

Hable, Angelika, 'The European Constitution: Changes in the Reform of Competences with a Particular Focus on the External Dimension', Working Paper of the Research Institute for European Affairs, (2005)

Häde, Ulrich, 'Die europaische Wahrungsunion in der internationalen Finanzkrise: an den Grenzen europaischer Solidarität?', Europarecht, 6 (2010), 854-866

Hafner, Gerhard, 'Entkoppelungsklauseln der EG', in Peter Fischer (ed.), Die Welt im Spannungsfeld zwischen Regionalisierung und Globalisierung: Festschrift für Heribert Franz Köck (Vienna: Linde, 2009)

Haguenau, Catherine, L'application effective du droit communautaire en droit interne (Brussels: Bruylant, 1995)

Halberstam, Daniel, 'Constitutional Heterarchy: The Centrality of Conflict in the European Union and the United States', in Jeffrey L. Dunoff and Joel P. Trachtman (eds), Ruling the World? Constitutionalism, International Law and Global Governance (Cambridge: Cambridge Univ. Press. 2009), 326

Halberstam, Daniel, 'Of Power and Responsibility: The Political Morality of Federal Systems', Virginia Law Review, (2004), 731-834

Hanks, Peter, Constitutional Law in Australia, 2nd edn. (London: Butterworths, 1996)

Hart, H.L.A., 'Kelsen's Doctrine of the Unity of Law', in S.L. Paulson and B. Litschewski Paulson (eds), Normativity and Norms: Critical Perspectives on Kelsenian Themes (Oxford: Oxford Univ. Press, 1998), 560-563

Hartley, Trevor, Constitutional Problems of the EU (Oxford and Portland, Oregon: Hart Publishing, 1999)

Hartley, Trevor, The Foundations of European Community Law, 5th edn. (Oxford: Oxford Univ. Press, 2003)

Hartley, Trevor, 'National Law, International Law and EU Law: How Do They Relate?', in Patrick Capps, Malcolm Evans, and Stratos Konstadinidis (eds), Asserting Jurisdiction: International and European Legal Perspectives (Oxford and Portland, Oregon: Hart Publishing, 2003), 65

Harvey, Tamara, 'Legal Issues Concerning the Barber Protocol', in David O'Keeffe and Patrick M. Twomey (eds), Legal Issues of the Maastricht Treaty (London: Chancery Law Publishing, 1994), 329

Hatje, Armin, Loyalität als Rechtsprinzip in der Europäischen Union (Baden-Baden: Nomos, 2001)

Hatje, Armin, 'Die Rechtskraft und ihre Durchbrechungsmöglichkeiten im Lichte des Gemeinschaftsrechts', in Michael Holoubek and Michael Lang (eds), Das EuGH-Verfahren in Steuersachen (Vienna: Linde, 2000), 133-149

Hatzopoulos, Vassilis, 'Assessing the Services Directive (2006/123/EC)', Cambridge Yearbook of European Legal Studies, (2007-2008), 215-261

This is an open access version of the publication distributed under the terms of the Creative Commons Attribution-NonCommercial-NoDerivs licence (http://creativecommons.org/licenses/by-nc-nd/3.0/), which permits non-commercial reproduction and distribution of the work, in any medium, provided the original work is not altered or transformed in any way, and that the work is properly cited. For commercial re-use, please contact academic.permissions@oup.com 
Hatzopoulos, Vassilis, 'Health Law and Policy: the Impact of the EU', in Gráinne de Búrca (ed.), EU Law and the Welfare State: In Search of Solidarity (Oxford: EUI/Oxford Univ. Press, 2005), 123-160

Hay, Peter, Federalism and Supranational Organizations: Patterns for New Legal Structures (Urbana and London: Univ. of Illinois Press, 1966)

Heliskoski, Joni, 'Adoptions of Positions under Mixed Agreements (Implementation)', in Christoph Hillion and Panos Koutrakos (eds), Mixed Agreements Revisited: The EU and its Member States in the World (Oxford and Portland, Oregon: Hart Publishing, 2010)

Heliskoski, Joni, 'Internal Struggle for International Presence: the Exercise of Voting Rights within the FAO', in Alan Dashwood and Christophe Hillion (eds), The General Law of EC External Relations (London: Sweet \& Maxwell, 2000), 79

Heliskoski, Joni, Mixed Agreements as a Technique for Organizing the International Relations of the European Community and its Member States (The Hague: Kluwer Law International, 2001)

Herdegen, Matthias, 'General Principles of EU Law: the Methodological Challenge', in Ulf Bernitz, Joakim Nergelius, and Cecilia Cardner (eds), General Principles of EC Law in a Process of Development (The Hague: Kluwer Law International, 2008), 343

Herdegen, Matthias, 'The Origins and Development of the General Principles of Community Law', in Ulf Bernitz and Joakim Nergelius (eds), General Principles of European Community Law (The Hague: Kluwer Law International, 2000), 3

Herrmann, Christoph, 'Much Ado about Pluto?', in Marise Cremona and Bruno de Witte (eds), EU Foreign Relations Law: Constitutional Fundamentals (Oxford and Portland, Oregon: Hart Publishing, 2008), 19

Herrmann, Christoph, Wolfgang Weiß, and Christoph Ohler, Welthandelsrecht, 2nd edn. (Munich: Beck, 2007)

Heukels Ton and Jamila Tib, 'Towards Homogeneity in the Field of Legal Remedies: Convergence and Divergence', in Paul Beaumont, Sue Lyons, and Neil Walker (eds), Convergence and Divergence in European Public Law (Oxford and Portland, Oregon: Hart Publishing, 2002), 111

Hillion, Christophe, 'Mixity and Coherence in EU External Relations', in C. Hillion and P. Koutrakos (eds), Mixed Agreements Revisited: The EU and its Member States in the World (Oxford and Portland, Oregon: Hart Publishing, 2010), 87

Hillion, Christophe, 'Tous pour un, un pour tous!: Coherence in the External Relations of the European Union', in Marise Cremona (ed.), Developments in EU External Relations Law, Collected Courses of the Academy of European Law (Oxford: Oxford Univ. Press, 2008), 10

Hillion, Christophe and Ramses Wessel, 'Restraining External Competences of EU Member States', in Marise Cremona and Bruno de Witte (eds), EU Foreign Relations Law: Constitutional Fundamentals (Oxford and Portland, Oregon: Hart Publishing, 2008), 79-121

Hoffmeister, Frank, 'Art. 212 AEUV', in Eberhard Grabitz, Meinhard Hilf, and Martin Nettesheim (eds), Das Recht der Europäischen Union (Munich: Beck, 2011)

Hoffmeister, Frank, 'Curse or Blessing? Mixed Agreements in the Recent Practice of the European Union and its Member States', in Christophe Hillion and Panos Koutrakos (eds), Mixed Agreements Revisited: The EU and its Member States in the World (Oxford and Portland, Oregon: Hart Publishing, 2010), 259-266

Hogg, Peter, Constitutional Law of Canada, 5th edn. Vol. I (Toronto: Thomson \& Carswell, 2011)

Holdgaard, Rass, 'Annotation to Case C-431/05 Merck Genéricos', Common Market Law Review, (2008), 1233

Holoubek, Michael, 'Die Zuständigkeit bei unmittelbarer Anwendung von Gemeinschaftsrecht', in Michael Holoubek and Michael Lang, Abgabenverfahren und Gemeinschaftsrecht (Vienna: Linde, 2006)

This is an open access version of the publication distributed under the terms of the Creative Commons Attribution-NonCommercial-NoDerivs licence (http://creativecommons.org/licenses/by-nc-nd/3.0/), which permits non-commercial reproduction and distribution of the work, in any medium, provided the original work is not altered or transformed in any way, and that the work is properly cited. For commercial re-use, please contact academic.permissions@oup.com 
Howard, Colin, Australian Federal Constitutional Law, 3rd edn. (Sydney: The Law Book Company, 1985)

Jacobs, Francis and Kenneth Karst, "The "Federal" Legal Order: The U.S.A. and Europe Compared: A Juridical Perspective', in Mauro Cappelletti and Monica Seccombe (eds), Integration through Law: Europe and the American Federal Experience (Berlin: Walter de Gruyter, 1986), 169-243

Jacqué, Jean-Paul, 'The Principle Of Institutional Balance', Common Market Law Review, 41 (2004), 383-391

Jarass, Hans and Sasha Beljin, 'Die Bedeutung von Vorrang und Durchführung des EG-Rechts', Neue Zeitschrift für Verwaltungsrecht, (2004), 1

Jarvis, Malcolm A., 'Case law', Common Market Law Review, 35:6 (1998), 1371-1383

Jary, David and Julia Jary (eds), Collins Dictionary of Sociology (Harper Collins, 1991)

Jung, Christian, 'Art. 92 AEUV', in Christian Calliess and Matthias Ruffert (eds), EUVIAEUV: Das Verfassungsrecht der Europäischen Union mit Europäischer Grundrechtecharta, 4th edn. (Munich: Beck, 2011)

Kahl, Wolfgang, 'Art. 4 (3) EUV', in Christian Calliess and Matthias Ruffert, EUVIAEUV: Das Verfassungsrecht der Europäischen Union mit Europäischer Grundrechtecharta, 4th edn. (Munich: Beck, 2011)

Kakouris, Vassilis, 'Do the Member States Possess Judicial Procedural Autonomy?', Common Market Law Review, 34 (1997), 1390

Kaufmann-Bühler, Werner, 'Art. 11 EUV', in Eberhard Grabitz, Meinhard Hilf, and Martin Nettesheim (eds), Das Recht der Europäische Union (Munich: Beck, 2010)

Kaufmann-Bühler, Werner, 'Art. 24 EUV', in Eberhard Grabitz, Meinhard Hilf, and Martin Nettesheim (eds), Das Recht der Europäische Union, Kommentar, Vol. I (Munich: Beck, 2010)

Kaufmann-Bühler, Werner and Nikolaus Meyer-Landrut, 'Art. 31 EUV', in Eberhard Grabitz, Meinhard Hilf, and Martin Nettesheim (eds), Das Recht der Europäische Union (Munich: Beck, 2010)

Kelsen, Hans, Das Problem der Souveränität und die Theorie des Völkerrechts, Beitrag zu einer Reinen Rechtslehre (Tübingen: Mohr, 1920)

Kelsen, Hans, The Pure Theory of Law, 2nd revised edn. (Berkeley: Univ. of California Press, 1967; orig. German publ. 1960)

Kincaid, John, 'Comparative Observations', in John Kincaid and G. Alan Tarr (eds), Constitutional Origins, Structure, and Change in Federal Countries (Montreal \& Kingston/ London/Ithaca: McGill-Queen's Univ. Press, 2005), 409-448

Kingreen, Thorsten, 'Art. 168 TFEU', in Christian Calliess and Matthias Ruffert (eds), EUV/ AEUV: Das Verfassungsrecht der Europäischen Union mit Europäischer Grundrechtecharta, 4th edn. (Munich: Beck, 2011)

Kirchhof, Paul, 'Die Gewaltbalance zwischen staatlichen und europäischen Organen', Juristenzeitung, (1998), 965

Klabbers, Jan, Treaty Conflict and the European Union (Cambridge: Cambridge Univ. Press, 2009)

Klamert, Marcus, 'Art. 205 AEUV', in Heinz Mayer and Karl Stöger (eds), EUVIAEUV Kommentar (Vienna: Manz, 2010)

Klamert, Marcus, 'Art. 209 AEUV', in Heinz Mayer and Karl Stöger (eds), EUVIAEUV Kommentar (Vienna: Manz, 2010)

Klamert, Marcus, 'Conflicts of Legal Basis: No Legality and No Basis but a Bright Future under the Lisbon Treaty?', European Law Review, (2010), 497-515

Klamert, Marcus, 'Dark Matter: Competence, Jurisdiction and "the Area Largely Covered by EU Law”: Comment on Lesoochranárske’, European Law Review, (2012), 340-350

Klamert, Marcus, 'Judicial Implementation of Directives and Anticipatory Indirect Effect: Connecting the Dots', Common Market Law Review, (2006), 1251-1275

This is an open access version of the publication distributed under the terms of the Creative Commons Attribution-NonCommercial-NoDerivs licence (http://creativecommons.org/licenses/by-nc-nd/3.0/), which permits non-commercial reproduction and distribution of the work, in any medium, provided the original work is not altered or transformed in any way, and that the work is properly cited. For commercial re-use, please contact academic.permissions@oup.com 
Klamert, Marcus, 'New Conferral or Old Confusion?: The Perils of Making Implied Competences Explicit and the Example of the Competence for Environmental Policy', CLEER Working Paper, 6 (2011)

Klamert, Marcus, 'Die Notifizierungspflichten der Dienstleistungsrichtlinie: ein Fall für den EuGH?', Deutsches Verwaltungsblatt, (2008), 829-832

Klamert, Marcus, 'Of Empty Glasses and Double Burdens: Approaches to Regulating the Services Market à propos the Implementation of the Services Directive', Legal Issues of Economic Integration, (2010), 111-132

Klamert, Marcus, 'Rechtsprobleme gemischter Abkommen der EG illustriert am Beispiel der UNESCO Konvention über den Schutz und die Förderung der Vielfalt kultureller Ausdrucksformen', Zeitschrift für öffentliches Recht/Journal of Public Law, (2009), 217-235

Klamert, Marcus, 'Review of Guzman, How International Law Works: A Rational Choice Theory', International Constitutional Law Journal, 4/2 (2010), 320-322

Klamert, Marcus, 'Richtlinienkonforme Auslegung und unmittelbare Wirkung von EGRichtlinien in der Rechtsprechung der österreichischen Höchstgerichte', Juristische Blätter, 130:3 (2008), 158-170

Klamert, Marcus, 'Richtlinienkonforme teleologische Reduktion bis zur Gegenstandslosigkeit: Methodologische Anmerkungen zur Zugabenverbot-Entscheidung des OGH $4 \mathrm{Ob}$ 208/10g', Juristische Blätter, 11 (2011), 738-742

Klamert, Marcus and Niklas Maydell, 'Lost in Exclusivity: Implied Non-exclusive External Competences in Community Law', European Foreign Affairs Review, 13 (2008), 493-513

Klamert, Marcus and Niklas Maydell, 'Rechtsfragen der impliziten Außenkompetenz der EG illustriert am Beispiel der Dienstleistungsrichtlinie und der Minimum Platform on Investment', Europarecht, (2008), 589-602

Klamert, Marcus with Stefan Griller, Services Liberalisation in the EU and WTO (Cambridge: Cambridge Univ. Press, forthcoming 2014)

Kofler, Georg, 'Generalanwalt zur Kapitalverkehrsfreiheit und Meistbegünstigung bei DBAAnwendung', Österreichische Steuerzeitung, (2004), 558

Kofler, Georg, 'Most-Favoured-Nation Treatment in Direct Taxation: Does EC Law Provide For Community MFN in Bilateral Double Taxation Treaties?', Houston Business and Tax Law Journal, (2005), 1-89

Komarek, Jan, 'European Constitutionalism and the European Arrest Warrant: In Search of Limits of "Contrapunctual Principles", Common Market Law Review, 44 (2007), 9-40

Komarek, Jan, 'Judicial Lawmaking and Precedent in Supreme Courts: The European Court of Justice Compared to the US Supreme Court and the French Cour de Cassation', Cambridge Yearbook of European Legal Studies, 11 (2008-2009), 399-433

Konstadinides, Theodore, 'Constitutional Identity as a Shield and as a Sword: The European Legal Order within the Framework of National Constitutional Settlement', Cambridge Yearbook of European Legal Studies, 13 (2010-2011), 195-218

Koopmans, T., Guest Editorial: 'Federalism: the Wrong Debate', Common Market Law Review, 29 (1992), 1047-1052

Kotzur, Markus, 'Good Faith (Bona Fides)', Max Planck Encyclopedia of Public International Law (Heidelberg and Oxford: Oxford Univ. Press, 2013) (<http://www.mpepil.com>)

Koutrakos, Panos, 'Annotation to Case C-205/06, Commission v. Austria and Case C-249/06, Commission v. Sweden', Common Market Law Review, (2009), 2059-2076

Koutrakos, Panos, 'Annotation to Case C-94/03 Commission v Council (Rotterdam Convention)', Common Market Law Review, (2007), 171-194

Koutrakos, Panos, EU International Relations Law (Oxford and Portland, Oregon: Hart Publishing, 2006)

Koutrakos, Panos, 'The Interpretation of Mixed Agreements under the Preliminary Reference Procedure', European Foreign Affairs Review, 7 (2002), 25

This is an open access version of the publication distributed under the terms of the Creative Commons Attribution-NonCommercial-NoDerivs licence (http://creativecommons.org/licenses/by-nc-nd/3.0/), which permits non-commercial reproduction and distribution of the work, in any medium, provided the original work is not altered or transformed in any way, and that the work is properly cited. For commercial re-use, please contact academic.permissions@oup.com 
Kovar, Robert, 'Les compétences implicites: jurisprudence de la Cour et pratique communautaire', in Demaret (ed.), Relations extérieures de la Communauté européenne et marché intérieur: aspects juridiques et fonctionnels (Brussels: Story, 1986), 15-36

Krisch, Nico, The Case for Pluralism: Beyond Constitutionalism (Oxford: Oxford Univ. Press, 2011)

Krislov, Samuel, Claus-Dieter Ehlermann, and Joseph H.H.Weiler, 'The Political Organs and the Decision-making Process in the United States and the European Community', in Mauro Cappelletti, Monica Seccombe, and Joseph H.H.Weiler, Integration Through Law: Europe and the American Federal Experience, Vol. I, Methods, Tools and Institutions, Book I, Political Organs, Integration Techniques, and Judicial Process (Berlin: de Gruyter, 1986), 3-112

Kuijper, Pieter-Jan, 'International Responsibility for EU Mixed Agreements', in Christophe Hillion and Panos Koutrakos (eds), Mixed Agreements Revisited: The EU and its Member States in the World (Oxford and Portland, Oregon: Hart Publishing, 2010), 208-227

Kuijper, Pieter-Jan, 'Re-reading External Relations Cases in the Field of Transport: The Function of Community Loyalty', in Bulterman et al. (eds), Views of European Law from the Mountain. Liber Amicorum for Piet-Jan Slot (The Hague: Kluwer Law International, 2009), 291-300

Kumin, Andreas and Philip Bittner, 'Die "gemischten” Abkommen zwischen der Europäischen Union und ihren Mitgliedstaaten einerseits und dritten Völkerrechtssubjekten andererseits', Europarecht, Beiheft, (2012), 75-91

Kumm, Mathias, 'The Jurisprudence of Constitutional Conflict: Constitutional Supremacy in Europe before and after the Constitutional Treaty', European Law Journal, 11:3 (2005), 262-307

Lang, Richard, 'Annotation to Case DocMorris', Common Market Law Review, (2005), 189-204

Langenbucher, Katja, 'Argument by Analogy in European Law', Cambridge Law Journal, 57:3 (1998), 481

Lasok, Paul, The European Court of Justice: Practice and Procedure, 2nd edn. (London: Butterworths, 1994)

Lasser, Mitchel de S.-O.-l'E., Judicial Deliberations: A Comparative Analysis of Judicial Transparency and Legitimacy (Oxford: Oxford Univ. Press, 2009)

Laursen, Finn, 'Federalism: From Classical Theory to Modern Day Practice in the EU and Other Polities', in Finn Laursen (ed.), EU and Federalism: Polities and Policies Compared (Farnham: Ashgate, 2010), 3

Leczykiewicz, Dorota, “Effective Judicial Protection” of Human Rights After Lisbon: Should National Courts be Empowered to Review EU Secondary Law?', European Law Review, 35 (2010), 326

Leible, Stefan and Ronny Domröse, 'Die primärrechtskonformeAuslegung', in Karl Riesenhuber (ed.), Europäische Methodenlehre (Berlin: de Gruyter, 2010), 250-284

Lenaerts, Koen, 'Constitutionalism and the Many Faces of Federalism', American Journal of Comparative Law, 38 (1990), 205-263

Lenaerts, Koen, 'EU Federalism in 3-D', in Elke Cloots, Geert de Baere, and Stefan Scottiaux (eds), Federalism in the European Union (Oxford and Portland, Oregon: Hart Publishing, 2012), 13-44

Lenaerts, Koen and Tim Corthaut, 'Of Birds and Hedges: The Role of Primacy in Invoking Norms of EU Law', European Law Review, 31 (2006), 289-315

Lenaerts, Koen and Piet Van Nuffel with Robert Bray and Nathan Cambien (eds), European Union Law, 3rd edn. (London: Sweet \& Maxwell, 2011)

Lenz, Carl-Otto, 'Art. 4', in Carl-Otto Lenz and Klaus-Dieter Borchardt (eds), EU-Verträge, Kommentar nach dem Vertrag von Lissabon, 5th edn. (Cologne and Vienna: Bundesanzeiger Verlag, 2010)

Lööf, Robin, 'Temporal Aspects of the Duty of Consistent Interpretation in the First and Third Pillars', European Law Review, 32 (2007), 888-895

Lorenzmeier, Stefan, 'Art. 351 AEUV', in Eberhard Grabitz, Meinhard Hilf, and Martin Nettesheim (eds), Das Recht der Europäischen Union (Munich: Beck, 2011)

Louis, Jean-Victor, 'Editorial: La Cour et les relations extérieures des la Communauté, Cahier de Droit European, (2007), 285-291

This is an open access version of the publication distributed under the terms of the Creative Commons Attribution-NonCommercial-NoDerivs licence (http://creativecommons.org/licenses/by-nc-nd/3.0/), which permits non-commercial reproduction and distribution of the work, in any medium, provided the original work is not altered or transformed in any way, and that the work is properly cited. For commercial re-use, please contact academic.permissions@oup.com 
Lück, Michael, Die Gemeinschaftstreue als allgemeines Rechtsprinzip im Recht der Europäischen Gemeinschaft: Ein Vergleich zur Bundestreue im Verfassungsrecht der Bundesrepublik Deutschland (Baden-Baden: Nomos, 1992)

MacCormick, Neil, Legal Reasoning and Legal Theory (Oxford: Clarendon Press, 1994)

MacCormick, Neil, Questioning Sovereignty (Oxford: Oxford Univ. Press, 2001)

MacLeod, Iain, I. D. Hendry, and Stephen Hyett, The External Relations of the European Communities: A Manual of Law and Practice (Oxford: Oxford Univ. Press, 1996)

Madner, Verena, 'Effektiver gerichtlicher Rechtsschutz, Anwendungsvorrang und zuständige gerichtliche Kontrollinstanz', Zeitschrift für Verwaltung, 1 (2011), 1

Magiera, Siegfried, 'Art. 325 AEUV', in Eberhard Grabitz, Meinhard Hilf, and Martin Nettesheim (eds), Das Recht der Europäischen Union, Kommentar (Munich: Beck, 2012)

Mancini, G. Federico, 'The Making of a Constitution for Europe', Common Market Law Review, 26 (1989), 596-599

Maresceau, Marc, 'A Typology of Mixed Bilateral Agreements', in Christoph Hillion and Panos Koutrakos (eds), Mixed Agreements Revisited: The EU and its Member States in the World (Oxford and Portland, Oregon: Hart Publishing, 2010), 11

Martenczuk, Bernd, 'Die differenzierte Integration nach dem Vertrag von Amsterdam', Zeitschrift für Europarechtliche Studien, (1998), 447-474

Mathijsen, Pierre, Le Droit de la Communaute Europeenne du Charbon et de L'Acier: Une Etude des Sources (The Hague: Martinus Nijhoff, 1958)

Maunz, Theodor, 'GG Art. 71', in Theodor Maunz and Günter Dürig (eds), Grundgesetz Kommentar (Munich: Beck, 2011)

Maunz, Theodor, 'GG Art. 72', in Theodor Maunz and Günter Dürig (eds), Grundgesetz Kommentar (Munich: Beck, 2011)

Mavroides, Petros, The General Agreement on Tariffs and Trade: A Commentary (Oxford: Oxford Univ. Press, 2005)

Mayer, Franz C., 'Art. 19 EUV', in Eberhard Grabitz, Meinhard Hilf, and Martin Nettesheim (eds), Das Recht der Europäischen Union, Kommentar (Munich: Beck, 2011)

Mayer, Franz C., 'Art. 220 AEUV', in Eberhard Grabitz, Meinhard Hilf, and Martin Nettesheim (eds), Das Recht der Europäischen Union (Munich: Beck, 2011)

Mayer, Franz C., 'Art. 341 TFEU', in E. Grabitz, M. Hilf, and M. Nettesheim (eds), Das Recht der Europäischen Union (Munich: Beck, 2011)

Mayer, Franz C., 'Multilevel Constitutional Jurisdiction', in Armin von Bogdandy and Jürgen Bast (eds), Principles of European Constitutional Law, 2nd edn. (Oxford and Portland: Hart Publishing; Munich: Beck; Baden-Baden: Nomos, 2010), 399-439

Mayer, Heinz, 'Neue Wege der Kompetenzinterpretation?', Österreichische Juristenzeitung, (1986), 513-520

McMahon, Joseph A., The Development Co-operation Policy of the EC (The Hague: Kluwer Law International, 1998)

Molek, Pavel, 'The Czech Constitutional Court and the Court of Justice: Between Fascination and Securing Autonomy', in Monica Claes et al. (eds), Constitutional Conversations in Europe: Actors, Topics and Procedures (Cambridge: Intersentia, 2012), 131-159

Möllers, Christoph, German Federal Constitutional Court: Constitutional Ultra Vires Review of European Acts Only Under Exceptional Circumstances; Decision of 6 July 2010, 2 BvR 2661/06, Honeywell, European Constitutional Law Review, 7 (2011), 161-167

Mortelmans, Kamiel, 'The Principle of Loyalty to the Community (Article 5 EC) and the Obligations of the Community Institutions', Maastricht Journal of European and Comparative Law, 5:1 (1998), 67-88

Mortelmans, Kamiel, 'Towards Convergence in the Application of the Rules on Free Movement and on Competition', Common Market Law Review, (2001), 613-649

Müller-Graff, Peter-Christian, 'The Common Commercial Policy Enhanced by the Reform Treaty of Lisbon?', in Alan Dashwood and Marc Maresceau (eds), Law and Practice of EU

This is an open access version of the publication distributed under the terms of the Creative Commons Attribution-NonCommercial-NoDerivs licence (http://creativecommons.org/licenses/by-nc-nd/3.0/), which permits non-commercial reproduction and distribution of the work, in any medium, provided the original work is not altered or transformed in any way, and that the work is properly cited. For commercial re-use, please contact academic.permissions@oup.com 
External Relations: Salient Features of a Changing Landscape (Cambridge: Cambridge Univ. Press, 2008), 188-201

Müller-Ibold, Till, 'Art. 218 AEUV', in Klaus-Dieter Borchardt (ed.), EU-Verträge (Cologne, Vienna: Bundesanzeiger, Linde, 2010)

Nazzini, Renato, 'Potency and Act of the Principle of Effectiveness: The Development of Competition Law Remedies and Procedures in Community Law', in Catherine Barnard and Okeoghene Odudu (eds), The Outer Limits of European Union Law (Oxford and Portland, Oregon: Hart Publishing, 2009), 401-435

Nebbia, Paolisa, 'The Double Life of Effectiveness', Cambridge Yearbook of European Legal Studies, 10 (2007/2008), 287-302

Neframi, Eleftheria, 'The Duty of Loyalty: Rethinking its Scope Through its Application in the Field of EU External Relations', Common Market Law Review, 47 (2010), 323-359

Neframi, Eleftheria, 'International Responsibility of the European Community and of the Member States under Mixed Agreements', in Enzo Cannizzaro (ed.), The European Union as an Actor in International Relations (The Hague: Kluwer Law International, 2002), 193-205

Nettesheim, Martin, 'Art. 6 EUV', in Eberhard Grabitz, Meinhard Hilf, and Martin Nettesheim, Das Recht der Europäischen Union (Munich: Beck, 2011)

Nettesheim, Martin, 'Art. 13 AEUV', in Eberhard Grabitz, Meinhard Hilf, and Martin Nettesheim, Das Recht der Europäischen Union (Munich: Beck, 2011)

Nettesheim, Martin, 'Art. 288 AEUV', in Eberhard Grabitz, Meinhard Hilf, and Martin Nettesheim (eds), Das Recht der Europäischen Union (Munich: Beck, 2011)

Nettesheim, Martin, Auslegung und Fortbildung nationalen Rechts im Lichte des Gemeinschaftsrechts', Archiv des öffentlichen Rechts, 119 (1994), 261-293

Nettesheim, Martin, 'Die Kompetenzordnung im Vertrag über eine Verfassung für Europa', Europarecht, (2004), 511-546

Nettesheim, Martin, 'Grundsatz der Wirksamkeit des Gemeinschaftsrechts', in Albrecht Randelzhofer, Rupert Scholz, and Dieter Wilke (eds), Gedächtnisschrift für Eberhard Grabitz (Munich: Beck, 1995), 447-468

Nettesheim, Martin, 'Normenhierarchien im EU-Recht', Europarecht, (2006), 737-771

Neuwahl, Nanette, 'The WTO Opinion and Implied External Powers of the Community: A Hidden Agenda?', in Alan Dashwood and Christophe Hillion (eds), The General Law of EC External Relations (London: Sweet \& Maxwell, 2000), 139-151

Nicolaidis, Kalypso, 'Trusting the Poles?: Towards a Regulatory Peace Theory in the World of Mutual Recognition', in Iannos Lianos and Okeoghene Odudu (eds), Regulating Trade in Services in the EU and the WTO: Trust, Distrust and Economic Integration (Cambridge: Cambridge Univ. Press, 2012), 263-297

Nicolaïdis, Kalypso, 'We, the Peoples of Europe', Foreign Affairs, 83 (2004), 97-110

Nicolaïdis, Kalypso and Robert Howse (eds), The Federal Vision: Legitimacy and Levels of Governance in the United States and the European Union (Oxford: Oxford Univ. Press, 2001)

Nic Shuibhne, Niamh, 'The Third Age of EU Citizenship: Directive 2004/38 in the Case Law of the Court of Justice', in Phil Syrpis (ed.), The Judiciary, the Legislature and the EU Internal Market (Cambridge: Cambridge Univ. Press, 2012), 331-362

Novak, Richard, 'Bundesstaatliche Rücksichtnahme', in Heinz Schäffer et al. (eds), Staat -Verfassung-Verwaltung: FS für Friedrich Koja (Vienna, New York: Springer, 1998), 357

Obwexer, Walter, 'Die Vertragsschlusskompetenzen und die vertragsschlussbefugten Organe der Europäischen Union', Europarecht, Beiheft, (2012), 49-75

O'Connor, John F., Good Faith in International Law (Aldershot: Dortmann, 1991)

Öhlinger, Theo, 'Gesetz und Richter unter dem Einfluss des Gemeinschaftsrechts: Anmerkungen zu einem Prozess der "Amerikanisierung” des europäischen Rechts', in Peter Hänni (ed.), Mensch und Staat: Festgabe für Thomas Fleiner (Freiburg: Universitätsverlag Freiburg Schweiz), 719-735

This is an open access version of the publication distributed under the terms of the Creative Commons Attribution-NonCommercial-NoDerivs licence (http://creativecommons.org/licenses/by-nc-nd/3.0/), which permits non-commercial reproduction and distribution of the work, in any medium, provided the original work is not altered or transformed in any way, and that the work is properly cited. For commercial re-use, please contact academic.permissions@oup.com 
Öhlinger, Theo, 'Die Verfassung im Schmelztiegel der europäischen Integration: Österreichs neue Doppelverfassung', in Theo Öhlinger (ed.), Verfassungsfragen einer Mitgliedschaft zur Europäischen Union (Vienna, New York: Springer, 1999), 165

Oliver, Peter, 'Measures of Equivalent Effect I: General', in Peter Oliver (ed.), Oliver on Free Movement of Goods in the European Union, 5th edn. (Oxford and Portland, Oregon: Hart Publishing, 2010), 84-156

Oliver, Peter and Wulf-Henning Roth, 'The Internal Market and the Four Freedoms', Common Market Law Review, (2004), 421

Olson, Pernille, 'Mixity from the Outside: the Perspective of a Treaty Partner', in Christophe Hillion and Panos Koutrakos (eds), Mixed Agreements Revisited: The EU and its Member States in the World (Oxford and Portland, Oregon: Hart Publishing, 2010), 331

Pawłowski, Tadeusz, Begriffsbildung und Definition (Berlin, New York: de Gruyter, 1980)

Payandeh, Mehrdad, 'Constitutional Review of EU Law After Honeywell: Contextualizing the Relationship between the German Constitutional Court and the EU Court of Justice', Common Market Law Review, 1 (2011), 9-38

Peers, Steve, 'Towards a New Form of EU Law?: The Use of EU Institutions Outside the EU Legal Framework', European Constitutional Law Review, 9:1 (2013), 37-72

Peeters, Patrick, 'Federalism: A Comparative Perspective: Belgium Transforms from a Unitary to a Federal State', in Bertus de Villiers (ed.), Evaluating Federal Systems (Dordrecht, Boston, London: Martinus Nijhoff, 1994), 200

Pelkmans, Jacques, 'Mutual Recognition in Goods: On Promises and Disillusions', Journal of European Public Policy, (2007), 699-716

Pernice, Ingolf, 'Art. 164 EGV', in Eberhard Grabitz and Meinhard Hilf (eds), Das Recht der EU (Munich: Beck, 1992)

Pernice, Ingolf, 'Die Dritte Gewalt im europäischen Verfassungsverbund', Europarecht, (1996), $27-43$

Pernice, Ingolf, 'Einheit und Kooperation', in Albrecht Randelzhofer, Rupert Scholz, and Dieter Wilke (eds), Gedächtnisschrift für Eberhard Grabitz (Munich: Beck, 1995), 523

Pernice, Ingolf, 'Multilevel Constitutionalism in the European Union', European Law Review, (2002), 511-529

Pernice, Ingolf and Franz C. Mayer, 'Art 220 EGV', in Eberhard Grabitz and Meinhard Hilf (eds), Das Recht der Europäischen Union (Munich: Beck, 2002)

Pescatore, Pierre, 'Das Zusammenwirken der Gemeinschaftsrechtsordnung mit den nationalen Rechtsordnungen', Europarecht, (1970), 307-323

Poiares Maduro, Miguel, 'Contrapunctual Law: Europe's Constitutional Pluralism in Action', in Neil Walker (ed.), Sovereignty in Transition (Oxford and Portland, Oregon: Hart Publishing, 2003), 501

Poiares Maduro, Miguel, 'Interpreting European Law: Judicial Adjudication in a Context of Constitutional Pluralism', European Journal of Legal Studies, (2007), 1-21

Poiares Maduro, Miguel, 'Three Claims of Constitutional Pluralism', Matej Avbelj and Jan Komárek (eds), Constitutional Pluralism in the European Union and Beyond (Oxford and Portland, Oregon: Hart Publishing, 2012)

Poiares Maduro, Miguel, We the Court: The European Court of Justice and the European Economic Constitution (Oxford and Portland, Oregon: Hart Publishing, 1998)

Pollack, Mark, 'The Engines of Integration? Supranational Autonomy and Influence in the European Union', in Wayne Sandholtz and Alec Stone Sweet, European Integration and Supranational Governance (Oxford: Oxford Univ. Press, 1998), 217-249

Posch, Albert, Vorrang des Gemeinschaftsrechts vor Verfassungsrecht (Vienna: Jan Sramek, 2010)

Potacs, Michael, Auslegung im öffentlichen Recht (Baden-Baden: Nomos, 1994)

Potacs, Michael, 'Bestandskraft staatlicher Verwaltunsakte oder Effektivität des Gemeinschaftsrechts?: Anmerkung zum Urteil vom 13. Januar, Kühne \& Heitz NV/Productschap voor Pluimvee en Eieren, Rs C-453/00', Europarecht, (2004), 595-603

This is an open access version of the publication distributed under the terms of the Creative Commons Attribution-NonCommercial-NoDerivs licence (http://creativecommons.org/licenses/by-nc-nd/3.0/), which permits non-commercial reproduction and distribution of the work, in any medium, provided the original work is not altered or transformed in any way, and that the work is properly cited. For commercial re-use, please contact academic.permissions@oup.com 
Potacs, Michael, 'Effet utile als Auslegungsgrundsatz', Europarecht, (2009), 465-488

Potacs, Michael, 'Die Europäische Wirtschafts- und Währungsunion und das Solidaritätsprinzip', Europarecht, (2013), 133-146

Prechal, Sacha, 'Annotation to Pfeiffer et al.', Common Market Law Review, 42 (2005), $1445-1463$

Prechal, Sacha, 'Community Law in National Courts: The Lessons From van Schijndel', Common Market Law Review, 35 (1998), 681

Prechal, Sacha, Directives in EC Law (Oxford: Oxford Univ. Press, 2005)

Prechal, Sacha, 'Institutional Balance: A Fragile Principle with Uncertain Contents', in Ton Heukels, Niels Blokker, and Marcel Brus (eds), The European Union after Amsterdam: A Legal Analysis (The Hague: Kluwer Law International, 1998), 273

Prechal, Sacha and Sybe de Vries, 'Seamless Web of Judicial Protection in the Internal Market', European Law Review, 34:1 (2009), 5-24

Rasmussen, Haltje, On Law and Policy in the European Court of Justice: a Comparative Study in Judicial Policymaking (Dordrecht: Martinus Nijhoff, 1986)

Raz, Joseph, 'Legal Principles and the Limits of Law', in Jonathan Cohen (ed.), Ronald Dworkin and Contemporary Jurisprudence (London: Duckworth, 1984), 73

Richter, Dagmar, 'Unfriendly Act', Max Planck Encyclopedia of Public International Law (Heidelberg and Oxford: Oxford Univ. Press, 2013) (<http://www.mpepil.com>)

Riesenhuber, Karl and Ronny Domröse, 'Richtlinienkonforme Rechtsfindung und nationale Methodenlehre', Recht der internationalen Wirtschaft, (2005), 47-54

Raitio, Par J., 'The Principle of Legal Certainty as a General Principle of EU Law', in Ulf Bernitz, Joakim Nergelius, and Cecilia Cardner (eds), General Principles of EC Law in a Process of Development (The Hague: Kluwer Law International, 2008), 47-73

Rodríguez Iglesias, Gil, 'Zu den Grenzen der verfahrensrechtlichen Autonomie der Mitgliedstaaten bei der Anwendung des Gemeinschaftsrechts', Europäische Grundrechte Zeitschrift, (1997), 289

Röhl, Klaus F. and Hans C. Röhl, Allgemeine Rechtslehre (Cologne: Heymanns, 2008)

Rosas, Alan, 'The European Union and Mixed Agreements', in Alan Dashwood and Christophe Hillion (eds), The General Law of EC External Relations (London: Sweet \& Maxwell, 2000), 203

Rosas, Alan, 'The Future of Mixity', in Christophe Hillion and Panos Koutrakos (eds), Mixed Agreements Revisited: The EU and its Member States in the World (Oxford and Portland, Oregon: Hart Publishing, 2010), 367

Rosas, Alan, 'Mixed Union-Mixed Agreements', in Joni Koskenniemi (ed.), International Law Aspects of the European Union (The Hague: Kluwer Law International, 1998), 125

Ross, Malcolm, 'Effectiveness in the European Union Legal Order(s): Beyond Supremacy to Constitutional Proportionality?', European Law Review, (2006), 476-498

Ross, Malcolm, 'Solidarity: A New Constitutional Paradigm for the EU?', in Malcolm Ross and Yuri Borgmann-Prebil (eds), Promoting Solidarity in the European Union (Oxford: Oxford Univ. Press, 2010), 23-45

Ross, Malcolm, 'The Value of Solidarity in European Public Services Law', in Markus Krajewski, Ulla Neergaard, and Johan van de Gronden (eds), The Changing Legal Framework for Services of General Interest in Europe: Between Competition and Solidarity (The Hague: TMC Asser Press, Cambridge Univ. Press, 2009), 81-99

Rossi, Matthias, 'Art. 80 AEUV', in Christian Calliess and Matthias Ruffert (eds), EUVIAEUV: Das Verfassungsrecht der Europäischen Union mit Europäischer Grundrechtecharta, 4th edn. (Munich: Beck, 2011)

Roth, Wulf-Henning, 'Die richtlinienkonforme Auslegung', Europäisches Wirtschafts- und Steuerrecht, 9 (2005), 385-396

Ruffert, Matthias, 'Art. 20 EUV', in Christian Calliess and Matthias Ruffert (eds), EUVIAEUV: Das Verfassungsrecht der Europäischen Union mit Europäischer Grundrechtecharta, 4th edn. (Munich: Beck, 2011)

This is an open access version of the publication distributed under the terms of the Creative Commons Attribution-NonCommercial-NoDerivs licence (http://creativecommons.org/licenses/by-nc-nd/3.0/), which permits non-commercial reproduction and distribution of the work, in any medium, provided the original work is not altered or transformed in any way, and that the work is properly cited. For commercial re-use, please contact academic.permissions@oup.com 
Ruffert, Matthias, 'Art. 291 AEUV', in Christian Calliess and Matthias Ruffert (eds), EUVI AEUV: Das Verfassungsrecht der Europäischen Union mit Europäischer Grundrechtecharta, 4th edn. (Munich: Beck, 2011)

Sack, Jörn, 'The European Community's Membership of International Organisations', Common Market Law Review, 32 (1995), 1227-1256

Schäffer, Heinz, 'Kompetenzverteilung und Rücksichtnahmepflicht im Bundesstaat: Das Erkenntnis "Jagdrecht/Forstrecht" und die Neuorientierung der Kompetenzinterpretation', Zeitschrift für Verwaltung, (1985), 357

Schermers, Henry, 'The European Court of Justice: Promoter of European Integration', American Journal of Comparative Law, (1974), 444-464

Schermers, Henry, 'The Internal Effect of Community Treaty-making', in David O'Keeffe and Henry Schermers (eds), Essays in European Law and Integration (Deventer: Kluwer, 1982), 167

Schermers, Henry and Patrick J. Pearson, 'Some Comments on Article 5 of the EEC Treaty', in Jürgen F. Baur, Klaus J. Hopt, and K. Peter Mailänder (eds), Festschrift für Ernst Steindorffzum 70. Geburtstag am 13. März 1990 (Berlin: de Gruyter, 1990), 1359-1378

Scheuner, Ulrich, 'Die Rechtssetzungsbefugnisse internationaler Gemeinschaften', in Karl Zemanek et al. (eds), Völkerrecht und rechtliches Weltbild: FS für Verdross (Vienna: Springer, 1960), 229

Schliesky, Utz, 'Die Vorwirkung von gemeinschaftsrechtlichen Richtlinien', Deutsches Verwaltungsblatt, (2003), 631-641

Schmalenbach, Kirsten, 'Art. 209 AEUV', in Christian Calliess and Matthias Ruffert (eds), EUVIAEUV: Das Verfassungsrecht der Europäischen Union mit Europäischer Grundrechtecharta, 4th edn. (Munich: Beck, 2011)

Schmalenbach, Kirsten, 'Art. 210 AEUV', in Christian Calliess and Matthias Ruffert (eds), EUVIAEUV: Das Verfassungsrecht der Europäischen Union mit Europäischer Grundrechtecharta, 4th edn. (Munich: Beck, 2011)

Schmalenbach, Kerstin, 'Capacity of States to Conclude Treaties', in Oliver Dörr and Kerstin Schmalenbach (eds), Vienna Convention on the Law of Treaties: A Commentary (Berlin, Heidelberg: Springer), 105-118

Schmidt am Busch, Birgit, 'Art. 168 AEUV', in Eberhard Grabitz, Meinhard Hilf, and Martin Nettesheim (eds), Das Recht der Europäischen Union, Kommentar (Munich: Beck, 2011)

Schmidt-Aßmann, Eberhard, 'Verwaltungskooperation und Verwaltungskooperationsrecht in der Europäischen Gemeinschaft', Europarecht, 3 (1996), 270-301

Schroeder, Werner, Das Gemeinschaftsrechtssystem (Tübingen: Mohr Siebeck, 2002)

Schuch, Josef, “"Most-favoured-nation clause” in Tax Treaty Law', EC Tax Review, (1996), 161

Schütze, Robert, 'Co-operative Federalism Constitutionalised: The Emergence of Complementary Competences in the EC Legal Order', European Law Review, (2006), 167-184

Schütze, Robert, 'Federalism and Foreign Affairs: Mixity as an (Inter)national Phenomenon', in Christophe Hillion and Panos Koutrakos (eds), Mixed Agreements Revisited: The EU and its Member States in the World (Oxford and Portland, Oregon: Hart Publishing, 2010), 57-86

Schütze, Robert, From Dual to Cooperative Federalism: The Changing Structure of European Law (Oxford: Oxford Univ. Press, 2009)

Schütze, Robert, 'Lisbon and the Federal Order of Competences: A Prospective Analysis', European Law Review, (2008), 709-722

Schütze, Robert, 'Parallel External Powers in the European Community: From "Cubist" Perspectives Towards "Naturalist" Constitutional Principles?', Yearbook of European Law, 23 (2004), 225-274

Schütze, Robert, 'Supremacy Without Pre-emption? The Very Slowly Emergent Doctrine of Pre-emption', Common Market Law Review, 43:4 (2006), 1023-1048

Seiler, Christian, 'GG Art. 72', in Volker Epping and Christian Hillgruber (eds), Becksscher Online-Kommentar GG (Munich: Beck, 2011)

This is an open access version of the publication distributed under the terms of the Creative Commons Attribution-NonCommercial-NoDerivs licence (http://creativecommons.org/licenses/by-nc-nd/3.0/), which permits non-commercial reproduction and distribution of the work, in any medium, provided the original work is not altered or transformed in any way, and that the work is properly cited. For commercial re-use, please contact academic.permissions@oup.com 
Seyr, Sybille, Der effet utile in der Rechtsprechung des Europäischen Gerichtshofs (Berlin: Duncker \& Humblot, 2008)

Shapiro, Martin and Alec Stone Sweet, On Law, Politics, and Judicialization (Oxford: Oxford Univ. Press, 2002)

Sharpston, Eleanor, 'Preface', in Elke Cloots, Geert de Baere, and Stefan Scottiaux (eds), Federalism in the European Union (Oxford and Portland, Oregon: Hart Publishing, 2012), v-viii

Sharpston, Eleanor and Geert de Baere, 'The Court of Justice as a Constitutional Adjudicator', in Anthony Arnull et al. (eds), A Constitutional Order of States?: Essays in EU Law in Honour of Alan Dashwood (Oxford and Portland, Oregon: Hart Publishing, 2011), 123-150

Simma, Bruno, The Charter of the United Nations: A Commentary (Oxford: Oxford Univ. Press, 1994)

Slaughter, Anne-Marie, 'A Typology of Transjudicial Communication', University of Richmond Law Review, 29 (1994), 99-132

Slaughter, Anne-Marie and William Burke-White, 'The Future of International Law is Domestic (or, The European Way of Law)', Harvard International Law Review, 47:2 (2006), 327-352

Slaughter, Anne-Marie, Alec Stone Sweet, and Joseph H.H. Weiler (eds), The European Courts and National Courts: Doctrine and Jurisprudence (Oxford and Portland, Oregon: Hart Publishing, 1998)

Sloan, Blaine, 'General Assembly Resolutions Revisited (Forty Years Later)', British Yearbook of International Law, 58 (1987), 39-150

Slot, Pieter J., 'The Application of Articles 3f, 5 and 85', European Law Review, (1987), 179

Smend, Rudolf, Verfassung und Verfassungsrecht (Berlin: Duncker \& Humblot, 1928)

Smyth, Ivan, 'Mixity in Practice: A Member State Practioner's Perspective', in Christophe Hillion and Panos Koutrakos (eds), Mixed Agreements Revisited: The EU and its Member States in the World (Oxford and Portland, Oregon: Hart Publishing, 2010), 304

Snell, Jukka, 'Free Movement of Services and the Services Directive: The Legitimacy of the Case Law', in Johan van de Gronden (ed.), EU and WTO Law on Services (The Hague: Kluwer Law International, 2008), 31-54

Snyder, Francis, 'The Effectiveness of European Community Law: Institutions, Processes, Tools and Techniques', Modern Law Review, (1993), 19

Söllner, Renate, Art. 5 EWG-Vertrag in der Rechtsprechung des Europäischen Gerichtshofes (Munich: VVF, 1985)

Somek, Alexander, 'Kelsen Lives', European Journal of International Law, 18:3 (2007), 409-451

Somek, Alexander, 'Monism: A Tale of the Undead', in Matej Avbelj and Jan Komárek (eds), Constitutional Pluralism in the European Union and Beyond (Oxford and Portland, Oregon: Hart Publishing, 2012), 343-379

Sørensen, Karsten E., 'The Most-Favoured-Nation Principle in the EU', Legal Issues of Economic Integration, (2007), 315

Starke, Joseph G., 'Monism and Dualism in the Theory of International Law', British Yearbook of International Law, 17 (1936)

Stein, Eric, 'Lawyers, Judges, and the Making of a Transnational Constitution', The American Journal of International Law, (1981), 1-27

Stein, Eric, and Peter Hay, 'Legal Remedies of Enterprises in the European Economic Community', The American Journal of Comparative Law, 9 (1960), 375-424

Stjernö, Steinar, Solidarity in Europa: The History of an Idea (Cambridge, Cambridge Univ. Press, 2005)

Stone Sweet, Alec, and James Caporaso, 'From Free Trade to Supranational Polity: The European Court and Integration', in Wayne Sandholtz and Alec Stone Sweet (eds), European Integration and Supranational Governance (Oxford: Oxford Univ. Press, 1998), 102

Streinz, Rudolf, 'Der effet utile in der Rechtsprechung des Gerichtshofs der Europäischen Gemeinschaften', in Ole Due, Marcus Lutter, and Jürgen Schwarze (eds), Festschrift für Ulrich Everling (Munich: Beck, 1995), 1491-1510

This is an open access version of the publication distributed under the terms of the Creative Commons Attribution-NonCommercial-NoDerivs licence (http://creativecommons.org/licenses/by-nc-nd/3.0/), which permits non-commercial reproduction and distribution of the work, in any medium, provided the original work is not altered or transformed in any way, and that the work is properly cited. For commercial re-use, please contact academic.permissions@oup.com 
Streinz, Rudolf and Christoph Herrmann, 'Der Fall Mangold: Eine "kopernikanische Wende im Europarecht”?', Recht der Arbeit, (2007), 165-169

Sullivan, Gerard and Kathleen Gunther, Constitutional Law, 14th edn. (New York: Foundation Press, 2001)

Sunstein, Cass, Legal Reasoning and Political Conflict (Oxford, NY: Oxford Univ. Press, 1996)

Syrpis, Phil, 'Theorising the Relationship Between the Judiciary and the Legislature in the EU Internal Market', in Phil Syrpis (ed.), The Judiciary, the Legislature and the EU Internal Market (Cambridge: Cambridge Univ. Press, 2012), 3-24

Szczekalla, Peter, 'GrundfreiheitlicheSchutzpflichten:Eine “neue” Funktion der Grundfreiheiten des Gemeinschaftsrechts', Deutsches Verwaltungsblatt, (1998), 219-224

Temple Lang, John, 'Article 10 EC: The Most Important "General Principle" of Community Law', in Ulf Bernitz, Joakim Nergelius, and Cecilia Cardner (eds), General Principles of EC Law in a Process of Development (The Hague: Kluwer Law International, 2008), 75-113

Temple Lang, John, 'Community Constitutional Law: Article 5 EEC Treaty', Common Market Law Review, (1990), 645-681

Temple Lang, John, 'The Development by the Court of Justice of the Duties of Cooperation of National Authorities and Community Institutions under Article 10 EC', Fordham International Law Journal, 31 (2008), 1483-1532

Temple Lang, John, 'Developments, Issues and New Remedies: The Duties of National Authorities and Courts under Article 10 of the EC Treaty', Fordham International Law Journal, 27 (2004), 1904-1939

Temple Lang, John, 'The Duties of Cooperation of National Authorities and Courts under Article 10 EC: Two More Reflections', European Law Review, 1 (2001), 84-89

Temple Lang, John, 'The ERTA Judgment and the Court's Case-law on Competence and Conflict', Yearbook of European Law, 6 (1986), 183-218

Terhechte, Jörg Philipp, 'Art. 3 EUV', in Eberhard Grabitz, Meinhard Hilf, and Martin Nettesheim (eds), Das Recht der Europäische Union (Munich: Beck, 2010)

Tesauro, Giuseppe, 'The Effectiveness of Judicial Protection and Co-operation between the Court of Justice and the National Courts', Yearbook of European Law, (1993), 1-17

Thym, Daniel, 'In the Name of Sovereign Statehood: A Critical Introduction to the Lisbon Judgment of the German Constitutional Court', Common Market Law Review, (2009), $1795-1822$

Tietje, Christian, 'Art. 114 AEUV', in Eberhard Grabitz, Meinhard Hilf, and Martin Nettesheim (eds), Das Recht der Europäischen Union, Kommentar (Munich: Beck, 2011)

Timmermans, Christiaan, 'The Constitutionalisation of the European Union', Yearbook of European Law, (2002), 1

Timmermans, Christiaan, 'Organising Joint Participation of EC and Member States', in Alan Dashwood and Christophe Hillion (eds), The General Law of EC External Relations (London: Sweet \& Maxwell, 2000), 239

Timmermans, Christiaan, 'The Relationship between the European Court of Justice and the European Court of Human Rights', in Anthony Arnull et al. (eds), A Constitutional Order of States?: Essays in EU Law in Honour of Alan Dashwood (Oxford and Portland, Oregon: Hart Publishing, 2011), 151-160

Tizzano, Antonio, 'The Role of the ECJ in the Protection of Fundamental Rights', in Anthony Arnull, Piet Eeckhout, and Takis Tridimas, Continuity and Change in EU Law (Oxford: Oxford Univ. Press, 2009), 125

Tomuschat, Christian, 'Discussion Following the Presentation by Karel Wellens', in Rüdiger Wolfrum and Chie Kojima (eds), Solidarity: A Structural Principle of International Law (Heidelberg et al.: Springer, 2010), 39-54

Tomuschat, Christian, 'Das Francovich-Urteil des EuGH: Ein Lehrstueck zum Europarecht', in Ole Due, Marcus Lutter, and Jürgen Schwarze (eds), Festschrift für Ulrich Everling, Vol. II (Baden-Baden: Nomos, 1995), 1585-1609

This is an open access version of the publication distributed under the terms of the Creative Commons Attribution-NonCommercial-NoDerivs licence (http://creativecommons.org/licenses/by-nc-nd/3.0/), which permits non-commercial reproduction and distribution of the work, in any medium, provided the original work is not altered or transformed in any way, and that the work is properly cited. For commercial re-use, please contact academic.permissions@oup.com 
Tomuschat, Christian, 'Liability for Mixed Agreements', in David O'Keeffe and Henry Schermers (eds), Mixed Agreements (Deventer: Kluwer, 1983), 125-132

Torres Pérez, Ana, Conflicts of Rights in the European Union (Oxford: Oxford Univ. Press, 2009)

Tridimas, Takis, 'The Court of Justice and Judicial Activism', European Law Review, 21 (1996), 199-210

Tridimas, Takis, The General Principles of EU Law, 2nd edn. (Oxford: Oxford Univ. Press, 2006)

Tridimas, Takis, 'The WTO and OECD Opinions', in Alan Dashwood and Christophe Hillion (eds), The General Law of EC External Relations (London: Sweet \& Maxwell, 2000), 48-60

Trömmel, Ingeborg, 'The European Union: A Federation Sui Generis?', in Finn Laursen (ed.), EU and Federalism: Polities and Policies Compared (Farnham: Ashgate, 2010), 44

Tushnet, Mark, 'What Then Is the American?', Arizona Law Review, (1996), 873

Unruh, Peter, 'Die Unionstreue: Anmerkungen zu einem Rechtsgrundsatz der Europäischen Union', Europarecht, (2002), 41-66

Uyttendaele, Marc, Précis de Droit Constitutionnel Belge: Regards sur un systeme institutionnel paradoxal, 3rd edn. (Brussels: Bruylant, 2005)

Van Cleynenbreugel, Pieter, 'Judge-Made Standards of National Procedure in the Post-Lisbon Constitutional Framework', European Law Review, 37:1 (2012), 90-100

Van Gerven, Walter, 'Of Rights, Remedies and Procedures', Common Market Law Review, 37 (2000), 502

Vedder, Christoph, 'Artikel I-5', in Christoph Vedder and Heintschell von Heinegg (eds), Europäischer Verfassungsvertrag (Baden-Baden: Nomos, 2007)

Verschueren, Herwig, 'The EU Social Security Co-ordination System: A Close Interplay Between the EU Legislature and Judiciary', in Phil Syrpis (ed.), The Judiciary, the Legislature and the EU Internal Market (Cambridge: Cambridge Univ. Press, 2012), 177-204

Viellechner, Lars, 'Berücksichtigungspflicht als Kollisionsregel', Europäische Grundrechte Zeitschrift, (2011), 203-207

Virally, Michel, 'Review Essay: Good Faith in Public International Law', American Journal of International Law, 77 (1983), 130-134

Von Bogdandy, Armin, 'Europäische Prinzipienlehre', in Armin von Bogdandy (ed.), Europäisches Verfassungsrecht: Theoretische und dogmatische Grundzüge (Heidelberg: Springer, 2003), 149-203

Von Bogdandy, Armin, 'The European Union as a Human Rights Organization? Human Rights and the Core of the European Union', Common Market Law Review, (2000), $1307-1338$

Von Bogdandy, Armin, 'Founding Principles', in Armin von Bogdandy and Jürgen Bast (eds), Principles of European Constitutional Law (Oxford and Portland, Oregon: Hart Publishing, Munich: Beck, 2010)

Von Bogdandy, Armin, 'Founding Principles of EU Law: A Theoretical and Doctrinal Sketch', European Law Journal, 16:2 (2010), 95-111

Von Bogdandy, Armin, 'The Legal Case for Unity: The European Union as a Single Organization with a Single Legal System', Common Market Law Review, 36 (1999), 887-910

Von Bogdandy, Armin, 'Rechtsfortbildung mit Art. 5 EG-Vertrag', in Albrecht Randelzhofer, Rupert Scholz, and Dieter Wilke (eds), Gedächtnisschrift für Eberhard Grabitz (Munich: Beck, 1995), 17-28

Von Bogdandy, Armin and Jürgen Bast, 'Art 5. EGV', in Eberhard Grabitz and Meinhard Hilf (eds), Das Recht der Europäischen Union (Munich: Beck, 2005)

Von Bogdandy, Armin and Jürgen Bast, 'The Federal Order of Competences', in Armin von Bogdandy and Jürgen Bast, Principles of European Constitutional Law (Oxford and Portland, Oregon: Hart Publishing; Munich: Beck; Baden-Baden: Nomos, 2009)

Von Bogdandy, Armin and Martin Nettesheim, 'Ex Pluribus Unum: Fusion of the European Communities into the European Union', European Law Journal, 2 (1996), 267

This is an open access version of the publication distributed under the terms of the Creative Commons Attribution-NonCommercial-NoDerivs licence (http://creativecommons.org/licenses/by-nc-nd/3.0/), which permits non-commercial reproduction and distribution of the work, in any medium, provided the original work is not altered or transformed in any way, and that the work is properly cited. For commercial re-use, please contact academic.permissions@oup.com 
Von Bogdandy, Armin and Stephan Schill, 'Art. 4 EUV', in Eberhard Grabitz, Meinhard Hilf, and Martin Nettesheim (eds), Das Recht der Europäische Union, Kommentar, Vol. II (Munich: Beck, 2010)

Vranes, Erich, "The Definition of "Norm Conflict" in International Law and Legal Theory', The European Journal of International Law, 17:2 (2006), 395-418

Waelbroeck, Michel, 'The Emergent Doctrine of Community Pre-emption: Consent and Redelegation', in Wayne Sandelow and Eric Stein (eds), Courts and Free Markets: Perspectives from the United States and Europe, Vol. II (Oxford: Oxford Univ. Press, 1982), 548-580

Walker, Neil, 'Flexibility within a Metaconstitutional Frame: Reflections on the Future of Legal Authority in Europe', in Gráinne de Búrca and Joanna Scott (eds), Constitutional Change in the EU: From Uniformity to Flexibility? (2000), 26-29

Walker, Neil, 'The Idea of Constitutional Pluralism', EUI Working Paper Law, 1 (2002)

Walker, Neil, 'Multilevel Constitutionalism: Looking Beyond the German Debate', in Kaarlo Tuori and Suvi Sankari (eds), The Many Constitutions of Europe (Farnham: Ashgate, 2010), $143-168$

Walter, Robert, Heinz Mayer, and Gabriele Kucsko-Stadlmayer, Grundriss des österreichischen Bundesverfassungsrechts (Vienna: Manz, 2007)

Wank, Rolf, Die juristische Begriffsbildung (Munich: Beck, 1985)

Watts, Ronald L., 'Federalism, Federal Political Systems, and Federation', Annual Review of Political Science, 1 (1998), 117-137

Watts, Ronald L., 'Comparative Conclusions', in Akhtar Majeed, Ronald L. Watts, and Douglas M. Brown (eds), Distribution of Powers and Responsibilities in Federal Countries (Montreal \& Kingston/London/Ithaca: McGill-Queen's Univ. Press, 2006), 322

Watts, Ronald L., Comparing Federal Systems, 3rd edn. (Montreal \& Kingston/London/Ithaca: Institute of Intergovernmental Relations, McGill-Queen's Univ. Press, 2008)

Weatherill, Stephen, 'Activism and Restraint in the European Court of Justice', in Patrick Capps, Malcolm Evans, and Stratos Konstadinidis (eds), Asserting Jurisdiction: International and European Legal Perspectives (Oxford and Portland, Oregon: Hart Publishing, 2003), 255-281

Weatherill, Stephen, 'Beyond Preemption? Shared Competence and Constitutional Change in the European Community', in David O'Keeffe and Patrick M. Twomey (eds), Legal Issues of the Maastricht Treaty (London: Chancery Law Publishing, 1994), 13-33

Weber, Dennis, 'Most-Favoured-Nation Treatment under Tax Treaties Rejected in the European Community: Background and Analysis of the D Case-A Proposal to Include a Most-Favoured-Nation Clause in the EC Treaty', Intertax, (2005), 429-444

Weiler, Joseph H.H., 'The Community System: the Dual Character of Supranationalism', Yearbook of European Law, (1981), 267-280

Weiler, Joseph H.H., The Constitution of Europe (Cambridge: Cambridge Univ. Press, 1999)

Weiler, Joseph H.H., 'Prologue: Global and Pluralist Constitutionalism-Some Doubts', in Gráinne de Búrca and Joseph H.H. Weiler (eds), The Worlds of European Constitutionalism (Cambridge: Cambridge Univ. Press, 2012), 8-18

Weiler, Joseph H.H., 'A Quiet Revolution: The European Court of Justice and its Interlocutors', Comparative Political Studies, 26:4 (1994), 523

Weiler, Joseph H.H., 'Review of Law and Policy in the European Court of Justice, by. H. Rasmussen', Common Market Law Review, 24 (1987), 555-589

Weiler, Joseph H.H., 'The Transformation of Europe', The Yale Law Journal, (1991), 2403-2483

Wellens, Karel, 'Revisiting Solidarity as a (Re-)Emerging Consitutional Principle: Some Further Reflections', in Rüdiger Wolfrum and Chie Kojima (eds), Solidarity: A Structural Principle of International Law (Heidelberg et al.: Springer, 2010), 2-38

Wheare, Kenneth C., Federal Government, 4th edn. (London, New York, Toronto: Oxford Univ. Press, 1967)

Whish, Richard and David Bailey, Competition Law, 7th edn. (Oxford: Oxford Univ. Press, 2012)

This is an open access version of the publication distributed under the terms of the Creative Commons Attribution-NonCommercial-NoDerivs licence (http://creativecommons.org/licenses/by-nc-nd/3.0/), which permits non-commercial reproduction and distribution of the work, in any medium, provided the original work is not altered or transformed in any way, and that the work is properly cited. For commercial re-use, please contact academic.permissions@oup.com 
White, Gillian, 'The Principle of Good Faith', in Vaughan Lowe and Colin Warbrick (eds), The United Nations and the Principles of International Law: Essays in Memory of Micheal Akehurst (London and New York: Routledge, 1994), 230

Wiederin, Ewald, 'Die Stufenbaulehre Adolf Julius Merkls', in Stefan Griller and Heinz-Peter Rill (eds), Rechtstheorie: Rechtsbegriff-Dynamik-Auslegung (Vienna, New York: Springer, 2011), 81-134

Wieland, Joachim, 'Germany in the European Union: The Maastricht Decision of the Bundesverfassungsgericht', European Journal of International Law, 5 (1994), 259-266

Wille, Angelo, Die Pflicht der Organe der Europäischen Gemeinschaftzur loyalen Zusammenarbeit mit den Mitgliedstaaten (Baden-Baden: Nomos, 2003)

Winterton, George et al., Australian Federal Constitutional Law: Commentary and Materials, 2nd edn. (Sydney: Law Book Company, 2007)

Wolinetz, Steven B., 'Comparing the Incomparable: Treating the EU in Comparative Context', in Finn Laursen (ed.), EU and Federalism: Polities and Policies Compared (Farnham: Ashgate, 2010), 27

Wouters, Jan, Dominic Coppens, and Bart de Meester, 'The European Union's External Relations after the Lisbon Treaty', in Stefan Griller and Jacques Ziller (eds), The Lisbon Treaty: EU Constitutionalism without a Constitutional Treaty (Vienna, New York: Springer, 2008), 143-203

Wouters, Jan, Dominic Coppens, and Dylan Geraets, 'The Influence of General Principles of Law', in Sanford E. Gaines, Birgitte Egelund Olsen, and Karsten Engsig Sørensen (eds), Liberalising Trade in the EU and the WTO: A Legal Comparison (Cambridge: Cambridge Univ. Press, 2012), 43-74

Wuermeling, Joachim, Kooperatives Gemeinschaftsrecht: Die Rechtsakte der Gesamtheit der EG-Mitgliedstaaten, insbesondere die Gemeinschaftskonvention nach Art. 220 EWG-Vertrag (Cologne: Engel, 1988)

Zuleeg, Manfred, 'A Community of Law: Legal Cohesion in the European Union', Fordham International Law Journal, 20:3 (1996), 623-637

Zuleeg, Manfred, 'Art. 5 EGV', in Hans v d Groeben, Jochen Thiesing, and Claus-Dieter Ehlermann (eds), EUVIEGV, 5th edn. (Baden-Baden: Nomos, 1997)

Zuleeg, Manfred, 'Art. 10 EGV', in Hans von der Groeben and Jürgen Schwarze (eds), Kommentar zum EU-/EG-Vertrag, 6th edn. (Baden-Baden: Nomos, 2003)

This is an open access version of the publication distributed under the terms of the Creative Commons Attribution-NonCommercial-NoDerivs licence (http://creativecommons.org/licenses/by-nc-nd/3.0/), which permits non-commercial reproduction and distribution of the work, in any medium, provided the original work is not altered or transformed in any way, and that the work is properly cited. For commercial re-use, please contact academic.permissions@oup.com 
This is an open access version of the publication distributed under the terms of the Creative Commons Attribution-NonCommercial-NoDerivs licence (http://creativecommons.org/licenses/by-nc-nd/3.0/), which permits non-commercial reproduction and distribution of the work, in any medium, provided the original work is not altered or transformed in any way, and that the work is properly cited. For commercial re-use, please contact academic.permissions@oup.com 


\section{Index}

air transport 156, 179, 283

analogy $32,111,149,162-163,249,259-261$, 284,295

anticipatory effect of directives 76 , 107-109, 123

autopoiesis 268, 298

bona fides see good faith

Bundestreue 32, 56-57, 59-61, 64, 243

Bundesverfassungsgericht see $\mathrm{BVerfG}$

BVerfG 21, 49, 51, 56-57, 60, 88-90, 92, 211-214, 225, 229-232, 257-258

CFSP see Common Foreign and Security Policy choice of legal basis 29, 216

CITES 199

codification $6,11-12,44,105,120,141$, 143-145, 149-150, 153-159, 200, 217, 246, 256, 298

Common Agricultural Policy 118, 187, 218

Common Commercial Policy 17, 117, 145, 156, 185-186, 193

Common Foreign and Security Policy 11, 36, 38-41, 87, 92-93, 95-100, 291

common position $95,141,151,176,188$, 197-201, 287

common rules $74-75,82,102,105-107,110$, 113, 144-153, 156-157, 166, 171-172, 186-187, 189, 196, 199, 263-264, 290

Common Transport Policy 16, 79, 154, 180,291

competing competence $55,57,59,149$

competition law 130, 173, 275-279, 290, 293

compliance 1-2, 38, 53-54, 74, 95, 97-99, $122,125,131,139,175,177,182$, 205-206, 211

composite constitution 227-228

concurrency 54,58

concurrent competence 52, 54, 149-150

concurrent power see concurrent competence

confederalism 48-49

conferral $10,19,21,58,144,153,159-160$, 230, 232, 246, 249-250, 291

conflict prevention $116,122,188,206-207$, 209, 212, 264, 271, 280

consequence-based reasoning 259

consistency 3, 31, 38, 53-54, 83, 111, 113, 123-124, 258, 264, 269

constitutional principles 48, 89, 137, 225, 242, 246, 249, 269

constitutionalisation $5,63-83,209,217,249$, 252,265

contra legem 104, 135, 254

contrapunctual law 226

Council mandate 98, 111-112, 115, 163, 180,235

cultural policy $170-171$ development policy $6,17,161,163-167$, 170-171

dialectic reasoning 258-259, 269

direct effect $1,6,63,68-71,75-76,78,82$, 86, 90-91, 93-94, 96, 105, 108-109, $116,125-128,131-139,175-176,182$, 204, 242, 246-250, 254, 256-257, 259, $261-263,265,271,273,298$

dual constitution 89,228

dualism 86-92, 226-228

duties of abstention $32-34,39,57,60,68$, $72-73,75,92,101-102,106-115,120$, 122-124, 136-139, 141, 156, 162-163, 166-167, 171, 174, 178-180, 185, 187 , 191, 194, 209, 240, 279, 290, 292, 298

duties of standstill 16, 114-115, 141, 174-179, 182

effectiveness 5-6, 58, 60, 64, 69, 71, 73, 77, 79-80, 82-83, 86, 97-98, 107, 125-139, $141,165,168,171,173,201,203,209$, 244, 248, 250-252, 255, 257, 261-274, 276-278, 289, 293, 298

effet utile 6, 46, 70-72, 76, 83, 209, 212, 252, 254-255, 257-258, 261-267, 272, 274, 277,298

enforcement procedure see infringement procedure 237

enhanced cooperation 294-296

environmental policy $145,149,185-186$

equality 37-39, 57, 242, 246, 249

European Coal and Steel Community 9-10, 41, 80, 264-265

European Commission 2, 10-11, 14-15, 17, 26-30, 42, 67, 77, 81-82, 97, 110-115, $123,154,163,165,169-182,187,194$, 197-201, 216, 218, 234, 235-241, 244, 278, 287-288, 292-293, 296, 298

European Convention of Human Rights 76, 244

European Court of Human Rights 213

European Parliament 24, 26, 30, 182, 215-216

exclusive competence $3,17,54-56,68,73-75$, $81,99,102,105,110,112,115,117$, $119,121,144-160,180-181,183-188$, $194-200,205,216,262-265,287-288$

exclusive jurisdiction $15,24,85,191,203-206$, 209, 235, 240

exclusivity superveniens $102,109,116-118$, 122-123, 147-149, 152, 155-156, $161-162,171,207$

explication 3

federal fidelity 5, 9, 34, 84, 207, 243

federal states $5,47-49,51,59,63$

Fehlerkalkül 255, 257-258

field largely covered 121, 144, 155-156, 205

This is an open access version of the publication distributed under the terms of the Creative Commons Attribution-NonCommercial-NoDerivs licence (http://creativecommons.org/licenses/by-nc-nd/3.0/), which permits non-commercial reproduction and distribution of the work, in any medium, provided the original work is not altered or transformed in any way, and that the work is properly cited. For commercial re-use, please contact academic.permissions@oup.com 
final arbiter 6, 232, 258, 297

Food and Agriculture Organization 196, 287-288

formal reasoning 268-270

fundamental freedoms $22,35,125,224,242$, 275-279, 285, 290, 293

fundamental rights $211,225-226,229,231$, $242,246,250,260,268$

gap-filling 44, 46, 247-248, 259, 266, 268 general principles 220, 222, 233, 241-250, 260-261, 267-268, 270

good faith $2-3,29,31,41-46,51,84,95,132$, 201, 217, 238-239

health policy $22,169-171,183$

heterarchy $227-228$

implementation 2, 4-5, 13, 32, 41, 60, 64, 76-77, $82,85,90-93,96,101,108-109,112$, $123,133,136-137,144,166,173,175$, $178,180,185,197,199,203,205-206$, 233, 238-241, 262, 282, 289, 294

implied competence 73-74, 82, 144, 155, 159-160, 263-266, 263-267

implied powers see implied competence inconsistency see consistency

indirect effect $6,63,71,76-78,81,91,94-95$, 103-104, 109, 126, 133-135, 209, 242, $257,261,272-273,277,297-298$

infringement procedure $16,77,137,233$, 237, 293

institutional balance $13,28-29,210$, 215-217, 298

inter-institutional agreement 196, 288, 290 International Maritime Organisation 189, 194 interpretation obligation see indirect effect invalidation $55,59,102,218,258$

joint action 98, 167

judicial activism 6, 138, 253-260, 269

judicial protection $86,95-96,125,127,131$, 133-139, 218, 247, 266, 298

lex specialis $13,18,78,98,258,295$

majoritarian activism 256

Marpol 43

Marsec 198, 236

monism 86-92, 226-228

most favoured nation 283-285

multilevel constitutionalism 228

mutual recognition 3, 13, 18, 22-23, 51, 94, $250-251$

national identities $19-21,50,84$

non-contradiction 46,62

non-discrimination $93,177,219,242,246$, 250, 269, 283-284, 286

non-violation $45-46$

notification $6,33,92,141,172-182,237,239$, 241,243

nullification 131-132, 134, 139, 271 obligations of conduct $233,240-241$

obligations of result $233,240-241$

pacta sunt servanda 4-5, 9, 41-46, 61, 69, 84

paramountcy 52,54

pluralism 226-228

political exception 25

pre-emption 3-5, 54, 57, 69-70, 86, 101, 116-127, 139, 153, 179

preliminary reference $14-15,27,60,81,96$, 203, 210, 212-214, 253, 272, 298

preliminary ruling see preliminary reference

principle-based reasoning 260

procedural supremacy 104,109

prohibition of frustration $109,133,136$, 178-179, 294

proportionality $20,28,177,242,265,291$

ratification $44,46,111-112,185,189$, 202-203, 206

rectification 131,133

sanctions $18,25,29,38,82,129,137,163$, $174,177,178,227,248,255,278$

screening $174,177-178,182$

Services Directive 156-157, 174, 176-178, 219,224

shared competence $6,17,54-55,102,109$, $111-112,117,122-123,141,145$, 147-152, 156-168, 171-172, 180, 184 , 186-187, 193, 196, 199-203, 207, 216, 288,294

Solange 88, 213, 231-232

solidarity $3,5,11,15,19,31-32,35-41,61$, $84,87,96-97,193,231,292,298$

state aid 37, 239, 244, 292-293, 297

state liability $1,6,63,71,79-82,126$, 131-133, 139, 221, 227, 250, 254, 257, 259-261, 265-266, 268, 270-271, 274, 297-298

subsidiarity 20, 35, 183, 211, 242, 291

substantive supremacy 104,109

supervision 129, 174-176, 178, 182, 228

supporting competence $6,141,144,146,157$, 161, 167-172, 183, 207

supremacy $5,12,20,31,52,55,59-60,63$, 68-73, 78, 81, 85-89, 93, 100-127, 131-139, 141, 149, 156, 162, 189-190, 206-207, 225-226, 231, 242, 246, 248-252, 256, 261-262, 266-267, 270, 274, 280-285, 290, 298

telos 254, 258, 261, 270

tolerance of error see Fehlerkalkül

transformation 91-92, 94, 228

travaux préparatoires 103, 143, 254, 260

trust $3,40,59$

ultra vires 54, 90-92, 211-214, 221, 226, 229-232, 257, 297

UNCLOS 15, 188, 196, 235

uniformity $67-69,72,105,107,191,204-205$

Union citizenship 21, 35, 219, 224

This is an open access version of the publication distributed under the terms of the Creative Commons Attribution-NonCommercial-NoDerivs licence (http://creativecommons.org/licenses/by-nc-nd/3.0/), which permits non-commercial reproduction and distribution of the work, in any medium, provided the original work is not altered or transformed in any way, and that the work is properly cited. For commercial re-use, please contact academic.permissions@oup.com 
Union interest $5,18,20,30,61,67,85-86$,

$101,111,113,115,122-124,138-139$,

161-163, 191-192, 196, 198, 201,

203-204, 207, 289-290, 295, 298

Union strategy 113-115, 122-123, 201 unity of international representation 113-114,

$123,139,141,190-194,201,203-207,298$

unity of the legal order 5, 58, 87, 92-100, 241

WTO 29, 45-46, 75, 186, 189, 193, 196, 283

This is an open access version of the publication distributed under the terms of the Creative Commons Attribution-NonCommercial-NoDerivs licence (http://creativecommons.org/licenses/by-nc-nd/3.0/), which permits non-commercial reproduction and distribution of the work, in any medium, provided the original work is not altered or transformed in any way, and that the work is properly cited. For commercial re-use, please contact academic.permissions@oup.com 
This is an open access version of the publication distributed under the terms of the Creative Commons Attribution-NonCommercial-NoDerivs licence (http://creativecommons.org/licenses/by-nc-nd/3.0/), which permits non-commercial reproduction and distribution of the work, in any medium, provided the original work is not altered or transformed in any way, and that the work is properly cited. For commercial re-use, please contact academic.permissions@oup.com 
This is an open access version of the publication distributed under the terms of the Creative Commons Attribution-NonCommercial-NoDerivs licence (http://creativecommons.org/licenses/by-nc-nd/3.0/), which permits non-commercial reproduction and distribution of the work, in any medium, provided the original work is not altered or transformed in any way, and that the work is properly cited. For commercial re-use, please contact academic.permissions@oup.com 
This is an open access version of the publication distributed under the terms of the Creative Commons Attribution-NonCommercial-NoDerivs licence (http://creativecommons.org/licenses/by-nc-nd/3.0/), which permits non-commercial reproduction and distribution of the work, in any medium, provided the original work is not altered or transformed in any way, and that the work is properly cited. For commercial re-use, please contact academic.permissions@oup.com 